\title{
Directory of Wetlands of International Importance
}





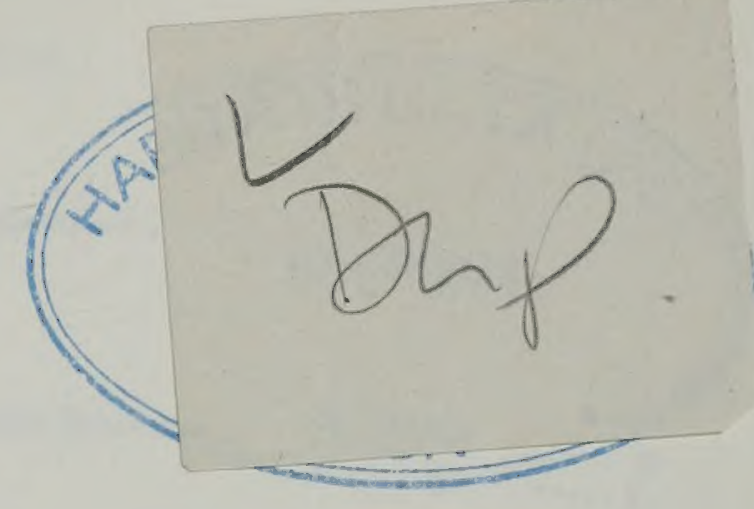

\section{Directory of Wetlands of International Importance}

Sites designated under the Convention on Wetlands of International Importance especially as Waterfowl Habitat

Prepared by the

IUCN Conservation Monitoring Centre

for the

Third Conference of Contracting Parties to the Convention on Wetlands of International Importance especially as Waterfowl Habitat

Regina, Canada, May-June 1987

International Union for Conservation of Nature and Natural Resources

Gland, Switzerland and Cambridge, UK

May 1987 
Published by:

Copyright:

Citation:

ISBN:

Printed by:

Cover design:

Available from:
IUCN, Gland, Switzerland and Cambridge, UK

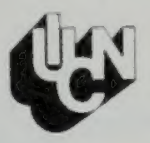

1987 International Union for Conservation of Nature and

Natural Resources

Reproduction of this publication for educational or other non-commercial purposes is authorised without prior permission from the copyright holder.

Reproduction for resale or other commercial purposes is prohibited without the prior written permission of the copyright holder.

Directory of Wetlands of International importance. IUCN, Gland, Switzerland and Cambridge, UK. 1987. $460 \mathrm{pp}$.

2-88032-918-3

Page Bros (Norwich) Limited, UK

James Butler

RAMSAR logo designed by Wildlife Habitat Canada

Publications Services,

IUCN Conservation Monitoring Centre

219c Huntingdon Road, Cambridge CB3 ODL, UK

The designations of geographical entities in this book, and the presentation of the material, do not imply the expression of any opinion whatsoever on the part of IUCN concerning the legal status of any country, territory, or area, or of its authorities, or concerning the delimitation of its frontiers or boundaries. 


\section{CONTENTS}

Algeria

Lac Oubeïra 2

Lac Tonga

Australia

Cobourg Peninsula Aboriginal Land and Wildlife Sanctuary $\quad 8$

Stage I of the Kakadu National Park 9

Moulting Lagoon 11

Logan Lagoon Conservation Area $\quad 12$

Sea Elephant Conservation Area $\quad 12$

Pittwater-Orielton Lagoon $\quad 13$

Apsley Marshes $\quad 14$

East Coast Cape Barren Island Lagoons $\quad 14$

Flood Plain Lower Ringarooma River $\quad 15$

Jocks Lagoon $\quad 15$

Northwestern Corner of Lake Crescent $\quad 16$

Little Waterhouse Lake 16

$\begin{array}{ll}\text { Corner Inlet } & 17\end{array}$

Barmah Forest 18

Gunbower Forest 19

Hattah-Kulkyne Lakes 19

Kerang Wetlands $\quad 20$

Port Phillip Bay (western shoreline) \& Bellarine Peninsula 21

Western Port $\quad 22$

Western District Lakes $\quad 23$

Gippsland Lakes $\quad 24$

Lake Albacutya $\quad 25$

Towra Point Nature Reserve $\quad 25$

Kooragang Nature Reserve $\quad 26$

The Coorong and Lakes Alexandrina and Albert $\quad 27$

Bool and Hacks Lagoons 29

Macquarie Marshes Nature Reserve 29

Austria 31

The Neusiedlersee region, including the lakes in Seewinkel 32

Donau-March-Auen $\quad 33$

Untere Lobau $\quad 34$

Stauseen am Unteren Inn $\quad 35$

Rheindelta, Bodensee $\quad 36$

Belgium $\quad 37$

Les Vlaamse Banken dans les eaux côtières 38

Les Schorren de l'Escaut à Doel et à Zandvliet 39

Le Zwin $\quad 40$

Le Blankaart $\quad 41$

Kalmthoutse Heide $\quad 42$

Le Marais d'Harchies $\quad 43$

Bulgaria $\quad 45$

Srébarna Waterfowl Reserve $\quad 46$

Arkoutino Waterfowl Reserve $\quad 47$

Atanassovo Lake Nature Reserve

Durankulak Lake Natural Landmark 
Cap Tourmente NWA $\quad 51$

Mary's Point NWA $\quad 53$

Long Point NWA $\quad 54$

Delta Marsh $\quad 56$

Last Mountain Lake $\quad 58$

Whooping Crane Summer Range $\quad 59$

Peace-Athabaska Delta $\quad 60$

Hay-Zama Lakes $\quad 62$

$\begin{array}{ll}\text { Alaksen NWA } & 63\end{array}$

\begin{tabular}{ll} 
Old Crow Flats & 64 \\
\hline
\end{tabular}

Polar Bear Pass NWA $\quad 65$

Queen Maud Gulf MBS 66

Rasmussen Lowlands $\quad 67$

McConnell River MBS $\quad 68$

Dewey Soper MBS $\quad 69$

St Clair NWA $\quad 70$

$\begin{array}{ll}\text { Chignecto NWA } & 72\end{array}$

Chile

Carlos Anwandter Nature and Scientific Investigation Sanctuary 75

\section{Denmark}

Fiilso 78

Ringkobing Fiord $\quad 79$

Stadil and Vestastadil Fiords $\quad 80$

Nissum Fiord $\quad 81$

Nissum Bredning with Harboore and Agger peninsulas $\quad 82$

Vejlerne and Logstor Bredning $\quad 83$

Ulvedybet and Nibe Bredning $\quad 84$

Hirsholmene $\quad 85$

Nordre Ronner $\quad 86$

Laeso $\quad 86$

Parts of Randers and Mariager Fiords, etc $\quad 87$

Sea area north of Anholt Island $\quad 88$

Horsens Fiord and Endelave $\quad 89$

Stavns Fiord and adjacent waters 90

Lillebaelt 91

Naereaa Coast and Aebelo area $\quad 92$

South Funen Archipelago $\quad 92$

Sejero Bugt $\quad 93$

Waters off Skaelskor Nor and Glaeno $\quad 94$

Karrebaek, Dybso and Avno Fiords $\quad 95$

Waters south-east of Fejo and Femo Isles 96

Praesto Fiord, Jungshoved Nor, Ulfshale and Nyord 96

Nakskov Fiord and Inner Fiord $\quad 97$

The Maribo Lakes $\quad 98$

Waters between Lolland and Falster $\quad 98$

Ertholmene Islands east of Bornholm $\quad 99$

$\begin{array}{ll}\text { Finland } & 101\end{array}$

$\begin{array}{ll}\text { Aspskär Nature Reserve } & 102\end{array}$

Söderskär Bird Sanctuary and Langoren Nature Reserve $\quad 103$

Björkör Nature Reserve and Lagskär Bird Sanctuary $\quad 103$

$\begin{array}{ll}\text { Signilskär Bird Sanctuary } & 104\end{array}$

Valassaaret Bird Sanctuary and Björkögrunden Bird Sanctuary 104

$\begin{array}{ll}\text { Krunnit Nature Reserve } & 105\end{array}$

Ruskis Nature Reserve $\quad 106$

$\begin{array}{ll}\text { Viikki Nature Reserve } & 106\end{array}$ 
Maartimoaapa - Lumiaapa 108

$\begin{array}{ll}\text { Koitilaiskaira } & 108\end{array}$

France $\quad 110$

La Camargue $\quad 112$

Gabon $\quad 115$

Réserve nationale de Wongha-Wonghé 116

Parc national du Petit Loango 117

Réserve de Sétté Cama $\quad 117$

German Democratic Republic $\quad 118$

Lagoon waters of Ruegen/Hiddensee and part of Zingst Peninsular 119

$\begin{array}{ll}\text { Krakower Obersee } & 120\end{array}$

$\begin{array}{ll}\text { Eastern Shore of Müritz See } & 120\end{array}$

Lower Havel River and Gülper See $\quad 121$

Oder Valley near Schwedt $\quad 122$

Pond areas near Peitz $\quad 122$

Berga-Kelbra Storage Lake 123

Galenbecker See $\quad 124$

Germany, Federal Republic of 125

Wattenmeer, Elbe-Weser-Dreieck 127

Wattenmeer, Jadebusen and Western Weser Mouth 128

Ostf riesisches Wattenmeer \& Dollart 129

Lower Elbe, Barnkrug - Otterndorf 130

Elbe water-meadows between Schnackenburg and Lauenburg 131

Dümmersee $\quad 132$

Diepholzer Lowland Marsh and Peat Bogs 133

Steinhuder Meer $\quad 135$

Rhine between Eltville and Bingen 136

$\begin{array}{ll}\text { Bodensee } & 137\end{array}$

Water-meadows and peat-bogs of Donau 138

Lech-Donau Winkel 139

Ismaning Reservoir and fish-ponds 140

Ammersee 141

Starnberger See $\quad 142$

Chiemsee 143

Lower Inn between Haiming and Neuhaus $\quad 144$

Rieselfelder Münster $\quad 145$

Weserstaustufe Schlüsselburg 146

$\begin{array}{ll}\text { Unterer Niederrhein } & 147\end{array}$

Greece $\quad 148$

Amvrakikos Gulf 149

Evros Delta $\quad 150$

Lake Visthonis and adjoining lakes $\quad 152$

Lake Kerkinitis 153

The Lakes Volvis and Langada 155

National Park Mikra Prespa 156

Axios - Aliakmon - Loudias Delta 158

Nestos Delta 159

Lagoon of Gumburnou $\quad 159$

Gulf of Mesolonghion $\quad 160$

Lagoon of Kotichi 161 
Szaporca Reserve

Velence - Dinnyés Reserve

Kardoskut Reserve

Kisbalaton (Little-Balaton) Reserve

Martély Landscape Protection Area

Kiskunsag National Park

Pusztaszer Landscape Protection Area 169

Hortobàgy National Park

Iceland

Part of Myvatn-Laxa Region

India

Chilka lake

Keoladeo National Park

Iran

Miankaleh Peninsula, Gorgan Bay and Lapoo-Zargmarz Ab-Bandans 182

Lake Parishan and Dasht-e-Arjan

Lake Oroomiyeh (ex Lake Rezaiyeh)

Neiriz Lakes and Kamjan Marshes

Anzali (ex Pahlavi) Mordab Complex

Shadegan Marshes and tidal mud-flats of Khor-al Amaya and Khor Musa 188

Hamoun-e-Saberi

Lake Kobi

South end of Hamoun-e-Puzak

Shur Gol, Yadegarlu \& Dorgeh Sangi Lakes

Bandar Kiashahr (ex Farahnaz) Lagoon and mouth of Sefid Rud

Amirkelayeh Lake

Lake Gori

Alagol, Ulmagol and Ajigol Lakes

Khuran Straits (Bandar Abbas)

Deltas of Rud-e-Shur, Rud-e-Shirin and Rud-e-Minab 198

Deltas of Rud-e-Gaz and Rud-e-Hara 199

Gavkhouni Lake and marshes of the lower Zaindeh Rud 200

\section{Ireland}

Wexford Wildlife Reserve

The Raven Nature Reserve

Pettigo Plateau Nature Reserve 205

Slieve Bloom Mountains Nature Reserve 205

The Owenduff Catchment 206

Italy

Lago di Mezzola - Pian di Spagna

Vincheto di Cellarda

Sacca di Bellochio

Valle Santa

Punte Alberete

Palude di Colfiorito

Palude di Bolgheri

Laguna di Orbetello (Northern part) 
Stagno S'Ena Arrubia

Stagno di Molentargius

Stagno di Cagliari

Le Cesine

Valle Cavanata

Stagno di Cabras and adjacent territory

Corru S'Ittiri Fishery with salt-pan, etc

Stagno di Pauli Maiori and adjacent territory $\quad 227$

Valle Campotto e Bassarone

Marano Lagunare - Mouth of the Stella $\quad 229$

Salina di Margherita di Savoia $\quad 229$

Lago di Tovel

Torre Guaceto, adjacent territory and sea area

Valle di Gorino and adjacent territories

Valle Bertuzzi and adjacent water surfaces

Valli residue del Comprensorio di Comacchio (see under Sacca di 210

Bellochio)

Pialassa della Baiona and adjacent territories

Ortazzo and adjacent territories 233

$\begin{array}{ll}\text { Saline di Cervia } & 234\end{array}$

Stagno di Sale Porcus $\quad 234$

Stagno di Mistras and adjacent territory $\quad 235$

Valli del Mincio

Torbiere d'Iseo $\quad 237$

$\begin{array}{ll}\text { Palude Brabbia } & 237\end{array}$

$\begin{array}{ll}\text { Paludi di Ostiglia } & 238\end{array}$

Japan 239

Kushiro-Shitsugen $\quad 240$

Izu-numa and Uchi-numa 241

Jordan 243

Azraq Oasis $\quad 243$

Mauritania $\quad 246$

Banc d'Arguin $\quad 246$

Mexico 249

Rio Lagartos, Yucatan $\quad 250$

Morocco 252

Merja Zerga $\quad 252$

Douiya Sidi-Bou-Rhaba $\quad 254$

Lac d'Affennourir $\quad 254$

Khnifiss Bay or Puerto Cansado $\quad 255$

Netherlands $\quad 256$

De Groote Peel $\quad 257$

De Weerribben $\quad 258$

Het Naardermeer 260

De Boschplaat $\quad 261$

De Griend $\quad 262$

Part of De Biesbosch

Het Lac (Bonaire) 264

Het Pekelmeer (Bonaire) 265

Klein Bonaire Island and part of the adjacent sea (Bonaire) 266

Het Gotomeer (Bonaire) $\quad 266$

De Slagbaai (Bonaire) $\quad 267$

Het Spaans Lagoen (Aruba) 268

Dutch section of the Wadden Sea $\quad 268$ 
Waituna Lagoon Wetlands Management Reserve

Farewell Spit

Norway

Akersvika Nature Reserve $\quad 276$

Ora Nature Reserve $\quad 276$

Kurefjorden Nature Reserve $\quad 277$

Nordre Oyeren Nature Reserve $\quad 278$

Ilene and Presterodkilen Wetland System $\quad 279$

Jaeren Wetland System $\quad 280$

Orlandet Wetland System $\quad 281$

Tautra and Svaet Nature Reserve $\quad 281$

Stabbursneset Nature Reserve $\quad 282$

Forlandsoyane Bird Sanctuary $\quad 283$

Dunoyane Bird Sanctuary (Spitsbergen) 283

Kongsf jorden Bird Sanctuary (Spitsbergen) 284

Isoyane Bird Sanctuary (Spitsbergen) 284

Gasoyane Bird Sanctuary (Spitsbergen) 285

\section{Pakistan}

Thanadarwala Game Reserve $\quad 287$

Malugul Dhand Wetland $\quad 288$

Kandar Dam Wetland $\quad 289$

Tanda Dam Wetland $\quad 289$

Kheshki Reservoir Wetland $\quad 290$

Khabbaki Lake Wildlife Sanctuary $\quad 290$

Kinjhar Lake Wildlife Sanctuary 291

Drigh Lake Wildlife Sanctuary $\quad 292$

Haleji Lake Wildlife Sanctuary 293

Poland $\quad 296$

Luknajno Lake Nature Reseve 297

Slonsk Reserve $\quad 299$

Swidwie Lake $\quad 299$

Karas Lake $\quad 300$

Siedem Wysp (Seven Islands) Reserve $\quad 301$

$\begin{array}{ll}\text { Portugal } & 303\end{array}$

$\begin{array}{ll}\text { Natural Reserve of the Tagus Estuary } & 304\end{array}$

Natural Reserve of Formosa Sound 305

$\begin{array}{ll}\text { Senegal } & 307\end{array}$

Parc national des Oiseaux du Djoudj 308

Bassin de la Réserve spéciale de faune du Ndiaë! 309

Le Delta du Saloum $\quad 310$

Réserve spéciale de faune de Gueumbeul 311

$\begin{array}{ll}\text { South Africa } & 313\end{array}$

$\begin{array}{ll}\text { De Hoop Vlei } & 314\end{array}$

$\begin{array}{ll}\text { Barberspan } & 315\end{array}$

De Mond State Forest (Heuningnes Estuary) 316

$\begin{array}{ll}\text { Blesbokspruit } & 318\end{array}$

$\begin{array}{ll}\text { Turtle Beaches/Coral Reefs of Tongaland } & 319\end{array}$

$\begin{array}{ll}\text { St Lucia System } & 321\end{array}$

Spain 323

Donana National Park $\quad 324$

Las Tablas de Daimiel National Park $\quad 326$

Refuge National de Chasse de la Lagune de Fuentapiedra $\quad 327$ 


\section{Suriname}

\section{Sweden}

Falsterbo-Bay of Foteviken $\quad 333$

Klingavälsan-Krankesjön $\quad 334$

Helga River $\quad 335$

Ottenby 336

Södviken $\quad 337$

Getterön 338

Store Mosse and Kävsjön $\quad 339$

Isles off Götland $\quad 340$

Hornborgasjön 341

Täkern 342

K vismaren $\quad 343$

Hjälstaviken $\quad 344$

Annsjön $\quad 345$

Gammelstadsviken $\quad 346$

$\begin{array}{ll}\text { Persöfjärden } & 347\end{array}$

$\begin{array}{ll}\text { Tärnasjön } & 347\end{array}$

Tjalmejaure-Laisdalen $\quad 348$

$\begin{array}{ll}\text { Laidaure } & 349\end{array}$

Sjaunja-Kaitum $\quad 350$

Taavavuoma 351

Switzerland 352

Fanel Bay and le Chablais $\quad 353$

Bolle di Magadino $\quad 354$

Tunisia

Ichkeul Wetland 356

Union of Soviet Socialist Republics $\quad 359$

Kandalaksha Bay $\quad 360$

Matsalu Bay 361

Volga Delta 362

Kirov Bays 364

Krasnovodsk and North-Cheleken Bays 365

Sivash Bay $\quad 366$

Karkinitski Bay $\quad 367$

Intertidal Areas of the Dounai/Yagorlits and Tendrov Bays 369

Kourgal'dzhin and Tengiz Lakes 369

Lakes of the lower Turgay and Irgiz 370

Issyk-kul Lake 371

Lake Khanka 372

United Kingdom

Cors Fochno and Dyfi 376

Bridgwater Bay $\quad 377$

Bure Marshes 378

Hickling Broad and Horsey Mere 380

Lindisfarne 381

Lochs Druidibeg, a'Machair and Stilligary 382

Loch Leven 383

Loch Lomond 385

Lough Neagh and Lough Beg $\quad 386$

Minsmere - Walberswick 388

North Norfolk Coast $\quad 390$

Ouse Washes 392

Rannoch Moor 393 
Cairngorm Lochs

Loch of Lintrathen

Claish Moss

396

Silver Flowe

396

Abberton Reservoir

397

Rostherne Mere

The Dee Estuary

400

The Swale

Chesil Beach and the Fleet $\quad 403$

Derwent Ings

405

Holburn Moss

406

Irthinghead Mires

407

Leighton Moss

410

Martin Mere

411

Alt Estuary

412

Loch of Skene

413

Loch Eye

413

Rockcliffe Marshes

414

United States of America $\quad 416$

Ash Meadows NWR $\quad 417$

Edwin B. Forsythe NWR $\quad 420$

Izembek NWR and State Game Refuge $\quad 422$

Okefenokee NWR $\quad 424$

Uruguay

427

Banados del Este y Franja Costera $\quad 427$

Yugoslavia

429

Nature Reserve Obedska Bara

430

Nature Reserve Ludasko Lake

431 


\section{INTRODUCTION}

During preparation for the Second meeting of the Contracting Parties to the Convention on Wetlands of International Importance especially as Waterfowl Habitat, the preparatory committee considered that it would be useful to gather together in a standard format information on each of the sites listed by States party to the Convention. This decision lead to the preparation of a Draft Directory of Wetlands of International Importance by the IUCN Conservation Monitoring Centre. The information presented in this draft was based largely on the information supplied to IUCN by the Contracting Parties when designating sites, national reports prepared for the First Conference of the Contracting Parties (Cagliari, 24-29 November 1980), and on information available from a number of other publications and reports dealing with wetlands. Additional information was also incorporated from data already held by the IUCN Conservation Monitoring Centre on protected areas and protected areas systems.

This draft directory was presented to the Second Meeting of the Contracting Parties (Groningen, 7-12 May 1984) as an information document (INF C2.4), and delegates were asked to provide comments, corrections, and additional information.

Subsequently, at the end of 1985 the IUCN Conservation Monitoring Centre was asked to prepare a more complete directory for publication and presentation at the Third Meeting of Contracting Parties (Regina, 27 May - 5 June 1987). All material available at that time, including the previous draft, comments and corrections received since preparation of the draft, the national reports prepared for the Second Meeting of the Contracting Parties, and material subsequently received by Centre was incorporated. Sections were also drafted covering sites designated since the previous draft had been prepared.

Revised sections covering each country were then communicated to the government bodies designated by each Contracting Party as being responsible for implementation of the Convention. At the same time, State Parties were informed by Notification $86 / 4$ that the directory was being reviewed with a view to publication, and were asked to check the accuracy of the accounts and pass on further comment. Direct contact was also made with a number of individuals within the government bodies responsible for implementation (usually with one or more of those present at the Groningen meeting), to inform them directly of this work.

All corrections were then incorporated into the text when it was reviewed again in early 1987. Comments from the International Wildfowl Research Bureau were also incorporated. Sections were also drafted at this time for the three countries which had become party to the Convention since June 1987, France, Gabon and the United States. Unfortunately, the accounts for these countries, and for sites added to the Convention since this time, could not be made available for review because of shortage of time.

The directory has been produced with a fairly limited budget, and as a result is only available in the English language. This is recognised by IUCN as a shortcoming, but it is hoped that future editions will be produced in each of the working languages of the Convention.

As with all publications of this kind, the accounts for each country and each site are unlikely to be complete. Nor are they likely to be completely accurate. The editors take full responsibility for any error of fact or ommission, but would encourage anyone using this directory to inform IUCN of any changes or additions that might be necessary. In this way we can ensure that the information held by IUCN on designated sites is as accurate as possible.

Protected Areas Data Unit

IUCN Conservation Monitoring Centre

$219 \mathrm{c}$ Huntingdon Road

Cambridge CB3 ODA

United Kingdom 
Within each country section information is clearly laid out under a number of standard headings. First there are a series of headings giving brief details about the country and its protected areas systems. In developing these accounts, extensive use has been made of three books not otherwise credited in the text. These are Poore and Gryn-Ambroes (1980) Nature Conservation in Northern and Western Europe, Carp (1980) Directory of Wetlands of International Importance in the Western Palearctic, and Scott and Carbonell (1986) A Directory of Neotropical Wetlands. The headings describing each country are as follows:

Summary of Wetland Situation Basic information is given on the wetlands of the country, indicating the topography and location of the major areas of interest. The account is not intended to be comprehensive, but rather to provide a brief introductory overview of the types of wetlands to be found in the country, and the types of species associated with them.

Protected Areas Legislation The aim of both this and the next section is to provide background material on protected area conservation measures in general within each Contracting Party. In this section, information is provided to explain the processes by which protected areas are established and managed, and the range of protected areas identified within the national legislation.

Protected Areas Administration This section includes brief information on the actual implementation of protected areas legislation, and who is responsible for administration and management.

Sites Designated under the Convention This section provides a short reference to national activities under the convention, indicating the date of signature and deposition of relevant instruments, and noting when sites were designated. This is followed by a list of the designated sites in their order of designation.

This is followed by the address of the government body responsible for the administration of the Convention. This introduction is then followed by a page or so describing each designated site in turn, in order of designation. Information is provided under the following headings:

Location Details such as latitude and longitude coordinates, and perhaps nearby features, settlements, and so on, are provided.

Area The total area of the designated site, including, where available and relevant, information on terrestrial and aquatic components, and on seperate sections in sites that are split.

Degree of Protection This section includes information on how the area is classified in terms of the national protected areas system, and indicates activities which are controlled/prohibited in the area. Land ownership and the body responsible for local administration are also noted. Finally, if the site has been accorded any other international recognition this is also mentioned.

Site Description This section includes both a physical and biological description of the site. The physical description includes details of geomorphology, hydrology and climate, while the biological section includes a brief review of habitat types, with details of both typical and noteworthy fauna.

Criteria for Inclusion The specific criteria for inclusion as adopted at the First Meeting of the Contracting Parties. Where this information has not been provided by the Contracting Party, this section is dropped.

International and National Importance This section underlines those factors for which the site is considered to be of particular importance, and which are presumably the main factors leading to its designation. 
Changes in Ecological Character The Contracting Parties are obliged to inform the Bureau to the Convention of any change or likely change in the ecological character of designated sites. This section provides the information available on threats and potential threats, as well as actual changes.

Management Practices The key management practices for each area are indicated. Traditional activities such as reed cutting are also noted here.

Scientific Research and Facilities The Convention encourages scientific research and training. The purpose of this section is to highlight such work already underway in each area, and to indicate facilities that might be available.

Principal Reference Material This final section lists the key references referred to in compiling the information, and lists other major works. It is by no means intended to be comprehensive.

\section{Acknowledgements}

The text that follows has been prepared by staff of the Protected Areas Data Unit at the IUCN Conservation Monitoring Centre $(\mathrm{CMC})$. In particular Louise Henson prepared the new draft accounts sent out in early 1986, and Hilary Tye incorporated the returned comments (and drew up new accounts as necessary) in early 1987. Both Hilary Tye and Louise Henson were supported in their work by other staff of the Protected Areas Data Unit - Jeremy Harrison, Zbigniew Karpowicz, Michael Green and Clare Billington. Final copy was prepared for publication by Jeremy Harrison and Barbara Lambert, with the assistance of Duncan Mackinder of CMC's Computer Services Unit, Barbara Brown and Joanne Robinson. The 1984 draft was prepared by Kathy Manson, with the assistance of Sally Ward, Jeremy Harrison and Anthea McKinlay.

Daniel Navid, Head of International Relations for IUCN, and the IUCN officer responsible for the Convention Bureau, was instrumental in the development of this project, and has been involved in all stages of its preparation. Further help and support has been provided by Michael Smart, Assistant Director (Conservation) of the International Waterfowl Research Bureau, and by staff of the International Council for Bird Preservation (who share accomodation with $\mathrm{CMC}$ ). Financial support has been provided by contributions from contracting parties. 



\section{ALGERIA}

Area $2,381,731$ sq.km

Population $21,436,500(1984)$

Summary of Wetland Situation The varied group of fresh or brackish lakes and marshes situated in the extreme north-eastern corner of Algeria between 'Annaba and the Tunisian frontier, near the small coastal town of El Kala, are among the most interesting wetland areas of the Maghreb. The lakes are of exceptional value because of their rich and diverse flora and fauna, which includes several rare and threatened species. They also provide valuable habitat for large numbers of migratory and wintering waterfowl. Their conservation is vitaily important in maintaining the existence of characteristic North African wetland ecosystems, most of which have been drained for agricultural purposes.

In Western Algeria, the only wetlands in the coastal region considered to be of international importance are the mainly brackish Marais de la Macta, south-west of Mostaganem and the salt lake Grande Sebkha d'Oran. The Marais de la Macta was drained in the 1960s, but became flooded again by 1972 and should certainly be kept in that condition as it serves a most useful purpose both for soil and general environmental protection and also as a refuge for wintering and migrating waterfowl.

The vast hinterland includes several large wetland areas of an ephemeral and usually very saline character. They depend for their existence on winter rainfall and may in favourable years offer excellent seasonal feeding grounds for flamingos and a great assortment of wintering and migrating waterfowl including waders or shore birds, herons and crane.

Protected Areas Legislation Parks were previously governed by long-standing decrees, some of which went back more than half a century (1925). The Forest Code was utilized and hunting was regulated on an annual basis by application of the Hunting Laws. In 1979 a study was instigated to establish a new legal framework intended to cover all aspects of nature conservation and the creation of parks and reserves. In 1982-83 major changes became apparent with a proposal being put forward for three new laws. One on the protection of the environment passed on 5 February 1983, one on hunting passed on 21 August 1982 and one on the general management of forests passed on 23 June 1984. These would include new statutes for national park and nature reserve creation and management, pollution control, and the protection of non-domestic species. Simultaneously a new Council of Hunting is directed to create Hunting Reserves and construct a list of wild animals. These measures are intended to be part of a National Strategy for the Conservation of Fauna.

Protected Areas Administration In the 1970s the Ministère de l'Hydraulique, de la Mise en Valeur des Terres et de la Protection de l'Environnment was established. At one stage a separate Secretariat of State for "Forêts et Mise en Valeurs des Terres" was established but later was re-incorporated into the renamed M.H.E.F. At present overall responsiblity rests with the Ministry but changes are predicted. Below the Minister for H.E.F. there is a vice-Minister with responsibility for the environment and forests. Under the vice-Minister there are six 'directions', including the Direction de la Sauvegard et de la Promotion de la Nature (DSPN), the Direction des Forets, Mise en Valeur des Terres, and the office of Amenagement et Grands Projects (Reboisement) Etudes et Administration. The DSPN (in 1984) may be split into two divisions, one for the protection of the environment and one for the protection of nature. The Director of the DSPN has three Deputy Directors responsible for "Parcs Nationaux et Réserves Naturelles", for "Loisirs et Forêts" (hunting) and for "Environnment". The "Sous-Direction des Parcs Nationaux et des Reserves Naturelles" is divided into three 'Bureaux' namely "Parcs nationaux", "Réserves naturelles" and "Faune et Flore en Disparition". 
Algeria

Sites designated under the Convention

Accession 4 November 1983, with 2 sites listed at accession.

Lac Oubeïra

Lac Tonga

Government body responsible for administration of the Convention

Direction de la Sauvegarde et de la Promotion de la Nature, Sécretariat d'Etat aux Forêts et à la Mise en Valeur des Terres, Petit Atlas, El Mouradia, Algiers.

\section{Lac Oubeïra}

Location $36^{\circ} 50^{\prime} \mathrm{N}, 8^{\circ} 23^{\prime} \mathrm{E}$. Situated about $50 \mathrm{~km}$ east of Annaba and just west of Tonga Lake (Ramsar site) in Wilaya d'Annaba on the northeast (Mediterranean) coast of Algeria.

Area 2,400ha

Degree of Protection State owned. The designated area is unprotected except for Ramsar status. A national park has been proposed which would include the lake and four other lakes and associated marshes of the El Kala complex. Designated as a Ramsar site at the time of accession on 4 November 1983.

Site Description Oubeïra Lake is a closed permanent freshwater basin (2-3m depth) surrounded on three sides by wooded hills with the north side open to the dunelands on the coast. The lake is eutrophic with much of the surface overgrown by pondweed Polamogeton sp. and it is fringed by a narrow belt of reeds. The site is part of the extensive El Kala coastal wetland complex (flanked to the south by the Medierda Mountains) which extends some $50 \mathrm{~km}$ along the Mediterranean coast and includes Tonga Lake (Ramsar site), Mellah, Garaet Mekhada (floodplain) and Cheffia dam. The lake supports an abundant fish fauna.

International and National Importance The lake is part of the extensive El Kala wetland complex (comparable in importance for waterfowl with Ichkeul World Heritage Site in Tunisia). Oubeira and Mellah Lake constitute the main wintering site in Africa for tufted duck Aythy'a fuligula (9,000 1982). In January 1984, 60,000 waterfowl were estimated here (Skinner and Smart 1984). Other winter visitors include mallard Anas platyhynchos, teal $A$. crecca, gadwall $A$. strepera, wigeon $A$. penelope $(14,000$ 1982), pintail $A$. acula, northern shoveler A. clypeata, common pochard Aythya ferina $(26,700$ 1982), coot Fulica atra, lapwing Vanellus vanellus, great crested grebe Podiceps cristalus, black-necked grebe $P$. nigricollis (850 1982), little grebe Tachybaptus ruficollis $(2,300$ 1982), cormorants Phalacrocorax spp., sandwich tern Sterna sandvicensis and common kingfisher Alcedo atthis. The small breeding population can include great crested grebe, little grebe, coot and moorhen Gallinula chloropus.

Changes in Ecological Character The lake is potentially threatened by a water resources scheme which proposes to use Lac Oubeïra as a balancing lake in providing water for two towns, Annaba and El Kala (M.Smart \& G.E.Hollis in litt. 1984). There have also been proposals to introduce, for commercial fishing, alien fish species that could destroy the aquatic vegetation and alter the invertebrate fauna (Morgan, 1982). Hunting pressure is described as moderate to heavy (IUCN, 1984).

\section{Management Practices No information}

Scientific Research and Facilities Staff of the Tour du Valat Biological Station in the Camargue have carried out winter waterfowl counts for the IWRB. It has been recommended that a study be made to determine whether there are sufficient food supplies present or whether the large numbers of waterfowl that occur here are feeding elsewhere (Skinner and Smart, 1984). 
Principal Reference Material The above information is taken from:

- Carp, E. (1980). A Directory of Western Palearctic Wellands. IUCN, Gland, Switzerland.

- Morgan, N.C. (1982). An ecological survey of standing waters in Northwest Africa: II. Site descriptions for Tunisia and Algeria. Biol. Cons. 24(2): 83-114.

- Scott, D.A. (1980). A preliminary inventory of wetlands of international importance for waterfowl in west Europe and northwest Africa. IWRB Special Publication No. 2.

- Sécretariat d'Etat aux Forêts et à la Mise en Valeur des Terres (1983). Document submitted at the time of accession to the Ramsar Convention.

- Skinner, J. and Smart, M. (1984). The El Kala wetlands of Algeria and their use by waterfowl. Wild fowl 35:106-118.

\section{Lac Tonga}

Location $36^{\circ} 51^{\prime} \mathrm{N}, 8^{\circ} 30^{\prime} \mathrm{E}$. Situated about $60 \mathrm{~km}$ east of Annaba and $5 \mathrm{~km}$ west of the Tunisia frontier in Wilaya d'Annaba on the northeast (Mediterranean) coast of Algeria.

Area 6,000ha (Sécretariat d'Etat aux Forêts et à la Mise en Valeur des Terres). Carp 1980 lists a lake surface area of $3,000 \mathrm{ha}$.

Degree of Protection State owned. The designated area is unprotected except for Ramsar status. A national park has been proposed which will include the lake and four other lakes and associated marshes of the El Kala complex. Designated as a Ramsar site at the time of accession on 4 November 1983.

Site Description Tonga Lake is a closed freshwater basin, which is dry between August and November, (maximum $2.8 \mathrm{~m}$ depth, average depth $0.5-1 \mathrm{~m}$ ) surrounded by wooded hills. It is part of the extensive El Kala coastal wetland complex (flanked to the south by the Medjerda Mountains) which extends some $50 \mathrm{~km}$ along the Mediterranean coast and includes Oubeïra (Ramsar site), Mellah, Garaet Mekhada (floodplain) and Cheffia dam. The shallow lake is covered with dense aquatic vegetation (reeds, bulrushes, rushes) typical for Mediterranean coastal wetland and only a small area of open water remains. The invertebrate fauna is reported to be unusual.

International and National Importance The lake is part of the extensive E1 Kala wetland complex (comparable in importance for waterfowl with Ichkeul World Heritage Site in Tunisia) and there is considerable interchange of waterfowl between the five wetland areas in the complex. The site is of great importance to wintering, migrating and nesting waterfowl. Winter visitors include mallard Anas platyrhynchos, teal A. crecca, gadwall $A$. strepera, European wigeon $A$. penelope, coot Fulica atra, black-winged stilt Himantopus himantopus, lapwing Vanellus vanellus, common snipe Gallinago gallinago, little grebe Tachybaptus ruficollis, moorhen Gallinula chloropus, black-headed gull Larus ridibundus and common kingfisher Alcedo atthis. Breeding species include black-crowned night heron Nycticorax nycticorax, squacco heron Ardeola ralloides, purple heron Ardea purpurea, marbled teal Anas angustirostris, white-headed duck Oxyura leucocephala (uncommon), common pochard Aythya ferina and purple swamphen Porphyrio porphyrio. (However, in December 1983 and January 1984 no more than 100 duck were recorded by Skinner and Smart (1984).

Changes in Ecological Character Shooting pressure is high.

Management Practices Hunting is prohibited except on certain days.

Scientific Research and Facilities The dune vegetation of the El Kala complex was studied in 1975. Waterfowl counts have been carried out each year since 1971. 
Principal Reference Material The above information is taken from:

- Carp, E. (1980). A Directory of Western Palearctic Wellands. IUCN, Gland, Switzerland.

- Morgan, N.C. (1982). An ecological survey of standing waters in Northwest Africa: II. Site descriptions for Tunisia and Algeria. Biol. Cons. 24(2): 83-114.

- Scott, D.A. (1980). A preliminary inventory of wetlands of international importance for waterfowl in west Europe and northwest Africa. IWRB Special Publication No. 2.

- Sécretariat d'Etat aux Forêts et à la Mise en Valeur des Terres (1983). Document submitted at the time of accession to the Ramsar Convention.

- Skinner, J. and Smart, M. (1984). The El Kala wetlands of Algeria and their use by waterfowl. Wildfowl 35:106-118. 
Area $7,686,855 \mathrm{sq} . \mathrm{km}$

Population $15,450,000(1983)$

Summary of Wetland Situation The vast, dry Australian continent contains a wide variety of wetland types. Because of the climate, many of these areas are ephemeral undergoing irregular sequences of flood and drought. This results in most of the waterfowl being highly nomadic, and boundaries of wetlands tend to fluctuate over time. For example, in north-eastern Australia monsoons, troughs, tropical cyclones and south-easterly air streams deposit more than $90 \%$ of the regions rainfall between November and April, and much of that falls on the coast. Queensland has many wetlands scattered throughout the state, but few of them have never been known to dry out. Inland swamps are vast in wet years, providing habitat for enormous populations of waterbirds, but can disappear completely during dry periods. In this part of the country the more predictable wetlands are the coastal swamps.

Many of the rivers are also ephemeral in parts of the country, and where they are not, they tend to be fairly intensively used, particularly in the south. For example, in the whole of southern Australia there is only one undisturbed river remaining with no settlement on its banks and no damming. This is the Franklin River of western Tasmania.

Over the country as a whole, the habitats range from these tropical freshwater swamps of north-east Queensland; the floodplains of inland eastern Australia; the limited but most reliable drought refuges in South Australia; the temperate lowland and upland wetlands of Tasmania; mangroves, estuaries, open tidal mud-flats and coastal lagoons such as those in the Northern Territory and NSW; permanent lakes as in NSW, Victoria, and Western Australia; and intermittent and dry lakes throughout the country.

The Commonwealth Scientific and Industrial Research Organisation, (CSIRO), Institute of Earth Resources, Division of Land Use Research has established a Wetland library and has produced a map $(1: 2,500,000)$ to give an overview of the distribution of wetlands, nine categories of which are distinguished: permanent lake, intermittent lake, dry lake, permanent swamp, intermittent swamp, land subject to inundation, mangrove, open tidal flat, and tidal river and coastal lagoon.

Protected Areas Legislation Restricted to states and territories with designated sites. Information derived from Hinchey (1982) Nature Conservation Reserves in Australia.

Australian Government The National Parks and Wildlife Conservation Act 1975 provides for the establishment of parks or reserves over land or sea areas where there is constitutionally a basis for Commonwealth action. These areas may be designated as national parks or some other designation and may only be revoked by a resolution of both Houses of Parliament. Kakadu National Park and Uluru National Park in the Northern Territory are proclaimed under the Act.

Northern Territory The Conservation Commission Act 1980 established the Conservation Commission of the Northern Territory to promote the conservation and protection of the natural environment and establish environmental conservation. Land is reserved under the provisions of the Territory Parks and Wildlife Conservation Act by the Administrator of the Northern Territory following receipt of a report from the Conservation Commission. This Act refers only to the creation of "parks and reserves", allowing considerable flexibility in the interpretation of these terms. Accordingly, areas declared may range from small sites of specific interest to major national parks. All land is held by the Conservation Land Corporation as constituted under the Conservation Commission Act. Revocation of reserved land is by declaration by the Administrator following a resolution by the Northern Territory Legislative Assembly. Wildlife sanctuaries may be declared under the Territory Parks and Wildlife Conservation Act for the conservation of wildlife and habitat. However, all 
sanctuaries previously declared under this Act have now been transferred to Aboriginal control and with the exceptions of Cobourg Peninsula and Woolwonga, no longer have legal conservation status. The Cobourg Peninsula Aboriginal Land and Sanctuary Act passed in 1981 established a major Aboriginal controlled and owned national park on Cobourg Peninsula.

Tasmania The National Parks and Wildlife Act 1970, provides for the establishment of conservation areas by Governor's proclamation. Conservation areas may include privately owned lands subject to the consent of the owners. Conservation areas that are Crown land may be declared State reserves by Governor's proclamation but may not be revoked unless the Governor's draft proclamation is first approved by each House of Parliament. Conservation areas may be named wildlife sanctuaries; wildlife is protected in such areas but its habitat is not, unless there is specific provision in a management plan. National parks are generally outstanding natural areas greater than 4,000 ha in conservation and scientific study whereas game reserves are managed to produce native or introduced game species. Crown land conservation areas may also be declared game reserves, in which areas the hunting of wildlife may be permitted in season.

Victoria Under the National Parks Act 1975, provision is made for the establishment of national parks and other parks for the preservation and protection of the environment including indigenous flora and fauna and features of scenic, archaeological, geological, historical or scientific interest. National parks and other parks may be zoned by publication of the Governor's proclamation to that effect. New national parks and other parks may be established by parliamentary amendment of the appropriate schedules to the National Parks Act to include the name and description of the lands included in the park. Provision is also made in the Act for the National Parks Service to manage land not reserved under the Act. Under the Crown (Land) Reserves Act 1978, State wildlife reserves may be established for the preservation or management of wildlife or wildlife habitat. State wildlife reserves may be further classified as game reserves, State game refuges, State faunal reserves, game management stations, nature reserves and other classifications, such as State parks, by order of the Governor. Any proclamation or order made by the Governor may be similarly revoked or varied. State game reserves and State game refuges are specifically managed for waterbird conservation with State game refuges providing a refuge for birds during the open season and State game reserves catering for hunting. State faunal reserves are managed for non-game wildlife species and shooting is prohibited. As part of the reorganisation that has lead to the establishment of the Department of Conservation, Forests and Lands a thorough review of relevant legislation, including that concerned with protected areas, is being conducted.

New South Wales The National Parks and Wildlife Act 1974 provides for national parks and nature reserves to be created by proclamation. The Act establishes a National Parks and Wildlife Adivsory Council to advise the Minister on the control and management of national parks and nature reserves. Advisory Committees may also be established for each national park to make recommendations to the above Council, the Director or Superintendent of the respective national park.

South Australia The National Parks and Wildlife Act, 1972-81 provides for the establishment and management of reserves for public benefit and for the conservation of wildlife in a natural environment. The reserves comprise national parks, conservation parks, game reserves and recreation parks. They may be abolished or their boundaries altered by a proclamation of the Governor, subject to a resolutuion passed by both Houses of Parliament. Management plans for each reserve are prepared by the Minister in conjunction with comments and suggestions of the National Parks and Wildlife Reserves Advisory Committee and representations from the public. Objectives in the management of reserves include the preservation and management of wildlife, the preservation of features of geographical, natural or scenic interest and the encouragement of public use and enjoyment of reserves. The management plan may also provide for the division of a reserve into zones which shall be kept and maintained under the conditions declared by the plan. The National Parks and Wildlife Reserves Advisory Committee, at the request of the Minister, can investigate and advise the Minister upon any matter referred to the Committee for advice. The Committee may also refer any matter affecting the administration of the Act to the Minister for consideration. Five members are appointed to the Committee by the Governor. 
Protected Areas Administration Restricted to states and territories with designated sites. Information derived from Hinchey (1982) Nature Conservation Reserves in Australia.

Australian Government The Director of National Parks and Wildlife is responsible for the areas proclaimed under the National Parks and Wildlife Conservation Act 1975.

Northern Territory A Director of Conservation, his Deputy and staff are public servants employed for the purposes of carrying out the functions of the Commission. The Commission administers the Territory Parks and Wildlife Conservation Act as well as legislation relating to forestry, bushfires and soil conservation.

Tasmania State reserves, game reserves and conservation areas are administered by the Tasmanian National Parks and Wildlife Service established under the Act. Whereas some conservation areas are administered by the Service as wildlife sanctuaries, there are in addition approximately thirty-five conservation areas proclaimed where other government authorities or the owner of the lands are the managing authorities.

Victoria Although the Directors of the National Parks Service and Fisheries and Wildlife Service are empowered by respective acts of parliament to manage National Parks or Wildife Reserves, the recent reorganisation of crownland management in Victoria has altered this role. The National Parks Service and Fisheries and Wildlife Service now have an advisory and management policy formulation role in the Department of Conservation, Forests and Lands. Management works on all parks, reserves, state forests and crownland are conducted by the Regional Management Division of the Department from 18 regional centres in the state.

New South Wales Both national parks and nature reserves are managed by the National Parks and Wildlife Service established under the Act and responsible to the Minister for Planning and Environment.

South Australia The Director of the National Parks and Wildlife Service is responsible to the Director General of the Department of Environment and Planning. Both are responsible to the Minister for the management of reserves. The National Parks and Wildlife Service constitutes a division of the Department of Environment and Planning. All staff, including the Director, are public servants employed to carry out the functions of the National Parks and Wildlife Act.

Sites designated under the Convention Signature without reservation as to ratification 8 May 1974. One site in the Northern Territory listed at signature, and another added 12 June 1980. 10 sites in Tasmania added 16 November 1982, another 10 in Victoria 15 December 1982, 2 in New South Wales 21 February 1984, 2 in South Australia November 1984 and one in New South Wales in August 1986.

Northern Territory

Cobourg Peninsula Aboriginal Land and Wildlife Sanctuary

Stage I of the Kakadu National Park

\section{Tasmania}

Moulting Lagoon

Logan Lagoon Conservation Area

Sea Elephant Conservation Area

Pittwater-Orielton Lagoon

Apsley Marshes

East Coast Cape Barren Island Lagoons

Flood Plain Lower Ringarooma River

Jocks Lagoon

Northwestern Corner of Lake Crescent

Little Waterhouse Lake 


\title{
Victoria
}

Corner Inlet

Barmah Forest

Gunbower Forest

Hattah-Kulkyne Lakes

Kerang Wetlands

Port Phillip Bay (Western Shoreline) \& Bellarine Peninsula

Western Port

Western District Lakes

Gippsland Lakes

Lake Albacutya

New South Wales

Towra Point Nature Reserve

Kooragang Nature Reserve

\section{South Australia}

The Coorang and Lakes Alexandria and Albert Wetland

Bool and Hacks Lagoons

\author{
New South Wales \\ Macquarie Marshes Nature Reserve
}

Government body responsible for administration of the Convention

Australian National Parks and Wildlife Service, GPO Box 636, Canberra ACT 2601; Construction House, 217 Northbourne Avenue, Turner ACT 2601.

\section{Cobourg Peninsula Aboriginal Land and Wildlife Sanctuary}

Location $11^{\circ} 22^{\prime} \mathrm{S}, 131^{\circ} 46^{\prime}-132^{\circ} 35^{\prime} \mathrm{E}$. Situated about $200 \mathrm{~km}$ northeast of Darwin in the Northern Territory.

\section{Area $191,660 \mathrm{ha}$}

Degree of Protection Cobourg Peninsula Flora and Fauna Reserve was created in 1924 and designated as a Ramsar site in 1974 as Cobourg Peninsula Wildlife Sanctuary and Flora and Fauna Reserve. The area has since been renamed as the Cobourg Peninsula Aboriginal Land and Wildlife Sanctuary. The Cobourg Peninsula Aboriginal Land and Sanctuary Act of 1981 established the area as a major Aboriginal controlled and owned national park. Administered by the Conservation Commission of the Northern Territory (Gap Road, PO Box 1046, Alice Springs, Northern Territory 5750).

Site Description The site comprises a gently undulating peninsula about $80 \mathrm{~km}$ long, joined to the mainland by a narrow neck of $10 \mathrm{~km}$ width, which has a long indented coastline with large estuaries dominated by saltflats and mangroves. The area is characterised by a monsoonal climate with distinct dry season from April to October. A tall forest association of Eucalyptus $\mathrm{sp}$. is the dominant vegetation type over much of the peninsula, replaced in some areas by the palm Kentia ramsayi. On sandier soils there are some pure stands of the northern cypress pine Callitris collumellaris. There are a few small areas of monsoon forests, principally as a thin fringe near freshwater streams and along lagoons, as well as behind beach dunes. The latter support prostrate spreading species. Dry stream courses and the sandy deltas of freshwater streams which do not flow throughout the year support Pandanus sp., Melaleuca sp., Banksia dentata and Tristanian lactiflua. Grevillea pteridifolia is dominant as a dense tall shrub in swampy areas. On more open sandy sites associated with stream lines, the sedge Leptocarpus spathaceus occurs in almost pure communities. Near the mouths of tidal rivers and on some protected areas of coastline, mangrove associations are common. Behind the mangroves are salt flats which are flooded at high tides. 
There are not many species of native mammal fauna, with one monotreme, seven marsupials, thirteen bats and five rodents being recorded. The reason for the small number of species is probably a lack of habitat diversity. But there is usually a large number of individuals of each species, perhaps because of the absence of the feral cat from the area. Among the most common species are the agile wallaby Macropus agilis agilis, fawn antechinus Antechinus bellus, black flying fox Pteropus alecto gouldii and hoary bat Chalinolobus nigrogriseus rogersi.

International and National Importance Surveys have illustrated the great value of the area for birds with over 164 recorded species. The tidal mudflats and mangrove swamps are breeding and wintering sites for several migratory waterfowl species, and the site is a breeding and refuge ground for many indigenous waterfowl including the endemic magpie goose Anseranas semipalmata. Known threatened fauna in the waters around the peninsula include dugong Dugong dugon, green turtle Chelonia mydas, leatherback turtle Dermochelys coriacea, olive ridley turtle Lepidochelys olivacea, hawksbill turtle Eretmochelys imbricata and estuarine crocodile Crocodylus porosus.

Changes in Ecological Character Some habitat degradation has been caused by feral animals descended from the livestock introduced by early settlers, including pigs, Timor ponies, Bali cattle, buffalo and Sambar deer. Generally though, the area has remained relatively unaffected by man due to the difficulty of access by land.

Management Practices The area is actively managed for the conservation of wetlands and wildlife. A permit from the board of management is required for entry.

\section{Scientific Research and Facilities No information}

Principal Reference Material The above information is taken from the documents supplied by the Government of the Northern Territory at the time of designation in 1974 and for the Groningen Meeting in 1984.

Supplemented by:

- International Waterfowl Research Bureau Bulletin No. 47 1981. Slimbridge, Glos., England. Additional reference:

- Frith, H.J. and Calaby, J.H. (eds) (1974). Fauna survey of the Port Essington District, Cobourg Peninsula, Northern Territory of Australia. C.S.I.R.O. Division of Wildlife Research Technical Paper No. 28.

- Higgs, H.J. (1975). Cobourg Peninsula Wildlife Sanctuary and Flora and Fauna Reserve. Unpublished report. 3 pages.

- Ivanovici, A.M. (ed.) (1984). Inventory of declared marine and estuarine protected areas in Australian waters. Australian National Parks and Wildlife Service. Special Publications No.12 Vol.2: 419-420.

\section{Stage I of Kakadu National Park}

Location $12^{\circ} 05^{\circ}-13^{\circ} 30^{\prime} \mathrm{S}, 132^{\circ} 22^{\prime}-133^{\circ} 00^{\prime} \mathrm{E}$. Situated about $220 \mathrm{~km}$ east of Darwin in the Northern Territory.

Area 667,000 ha

Degree of Protection Kakadu (Stage I) was declared a National Park in April 1979 under the provisions of the National Parks and Wildlife Conservation Act 1975. Ownership of most of that stage of the park is vested in the Kakadu Aboriginal Land Trust (The Manager, Northern Land Council, P.O. Box 3046, Darwin, N.T. 5794) representing traditional Aboriginal landowners. The land was leased in 1978 for 100 years to the Director of National Parks and Wildlife to be managed as a national park. The remaining park areas are vested in the Director of National Parks and Wildlife (PO Box 636, Canberra 2601). Accepted as a World Heritage Site in May 1981. Designated as a Ramsar site in June 1980. 
Site Description The designated site is Stage I of Kakadu National Park which comprises a major area covering the catchments of the South and East Alligator Rivers and a much smaller triangular area covering the East Alligator River up to and including its outlet into Van Diemen Gulf. The park contains a diversity of wetland habitats which are subject to wide seasonal and between-year variation. It is therefore impossible to provide a meaningful estimate for the area of wetlands and thus the whole park area has been designated. The area has a monsoon climate with wet season from December to April when intense rains flood the vast lowland plains of the park (sometimes up to 136,000 ha are inundated). From April/May the area begins to dry out with the water retreating into the lagoons, billabongs and rivers. Mean rainfall of $338 \mathrm{~mm}$ in January contrasts dramatically with only $2 \mathrm{~mm}$ in June. The water resources of Kakadu are at their lowest in August through October. The vegetation of the tidal mudflats consists of a salt tolerant association of samphire Salicorna spp., sedges and grasses with mangrove forest along the coast and estuarine banks. Vegetation on the floodplains consists of sedges and the freshwater mangrove Barringtonia acutangula occurs in swampy areas along stream and lagoon edges and paperbark Melaleuca spp. elsewhere. Plants such as lilies and fern Azolla sp. occur in deep more permanent waters. The remaining area comprises forest, woodland, savanna grassland or heath-scrubland communities and there is some scattered monsoon rainforest. The fauna is varied with at least 50 native mammal, 275 bird, 75 reptile, $25 \mathrm{frog}, 55 \mathrm{fish}$ and 4,500 insect species recorded. Most important areas to waterfowl are the eastern bank of the South Alligator river and its tributaries particularly Nourlangie Creek and the west bank of the East Alligator River and its tributary Magela Creek.

International and National Importance One third of Australia's waterfowl species occur in the park. During the wet season Magela floodplain supports large concentrations of waterfowl including magpie goose Anseranas semipalmata, jabiru Xenorhynchus asiaticus, whistling tree-duck Dendrocygna arcuata, green pygmy goose Nettapus pulchellus, Burdekin duck Tadorna radjah and pied heron Ardea pictata. During the wet season Nourlangia Creek provides ideal resting, feeding and breeding grounds for waterfowl particularly magpie geese. 35 species of wader have been recorded including many winter migrants from the sub-Arctic, whose first contact with the Australian Continent is in the Kakadu area. The wetlands of the park also contain one quarter of all recorded Australian freshwater fish species and provide habitat for the vulnerable estuarine crocodile Crocodylus porosus.

Changes in Ecological Character One of the major threats to the park environment is the large number of feral animals particularly buffalo Bubalus bubalis, pig Sus scrofa and cattle Bos taurus. The buffalo have damaged the natural levees by wallowing near tidal rivers and creeks thereby allowing saltwater into freshwater swamps. They have also increased the turbidity of many billabongs and damaged vegetation by trampling and selective grazing. Pigs also cause extensive damage in parts and in some rainforest patches few regrowth shoots survive to maturity. Major uranium deposits in the park are being exploited and other mineral deposits such as gold, tin and copper are or could become economically viable for exploitation.

Management Practices Control measures are implemented to eradicate or reduce the numbers of feral animals. Recovery of wetland vegetation has been dramatic following substantial reduction in buffalo populations. Hunting is prohibited except by Aborigines and park staff and there are strict controls on the introduction of exotic animals and plants. Recreational fishing is by permit only. The new plan of management, currently before Parliament, will close part of the park to recreational fishing to protect dry season refuges of many fish species, particularly the clear pools of the escarpment. Controlled burning is practised to maintain the diversity of the grasslands. Comprehensive measures are taken by the government to minimise the environmental damage caused by mining.

Scientific Research and Facilities Many papers were written on the area before it became a national park. A continuing research programme is being carried out to assess the environmental impact of: human activities including traditional Aboriginal activities, past introduction of domestic and feral animals and exotic plants, mining activities and visitor use. Fundamental ecological research on the relationship between living organisms and their relationship with their environments is encouraged. 
Principal Reference Material The above information is taken from the documents supplied by the Government of Australia at the time of designation in 1980.

Supplemented by:

- Australian National Parks and Wildlife Service (1980). Kakadu National Park Plan of Management (contains an extensive reference section). Canberra.

- Australian National Parks and Wildlife Service (May 1980). Nomination of Kakadu National Park for inclusion in the World Heritage List. Canberra.

Additional references:

- Barnett, L. (1980). A checklist of the birds of Kakadu National Park and the Alligator River region of the Northern Territory. Unpublished manuscript.

- Ivanovici, A.M. (ed.) (1984). Inventory of declared marine and estuarine protected areas in Australian waters. Australian National Parks and Wildlife Service. Special Publications No.12 Vol.2: 421-423.

- Ovington, J.D. (1986). Kakadu: A World Heritage of Unsurpassed Beauty. Australian Government Publishing Service, Canberra.

\section{Moulting Lagoon}

Location $42^{\circ} 05^{\prime} \mathrm{S}, 148^{\circ} 10^{\prime} \mathrm{E}$. Situated on the east coast of Tasmania. Contiguous with Apsley Marshes (Ramsar site).

Area $3,930 \mathrm{ha}$

Degree of Protection 511 ha of the area is a wildlife sanctuary administered since April 1959 by the Tasmanian National Parks and Wildlife Service (P.O.Box 210, Sandy Bay, Tasmania 7005). The remainder of the lagoon is crown land administered by the Tasmanian Lands Department. Designated as a Ramsar site in April 1983.

Site Description Moulting Lagoon is a large sanctuary dividing the Apsley and Swan Rivers. Waterfowl include coots, black swan Cygnus atratus, five species of duck and nine wader species. Seasonal fluctuation of numbers depending on the rainfall.

\section{Criteria for inclusion $1(\mathrm{a})$}

International and National Importance $80 \%$ of the black swan breeding population in Tasmania occurs in Moulting Lagoon. The lagoon regularly supports 10,000 black swan and the largest known Tasmanian flocks of greenshank Tringa nebularia and sharp-tailed sandpiper Calidris acuminata.

Changes in Ecological Character None reported (up to January 1984)

Management Practices A draft management plan has been prepared for the wetland. The plan includes a proposal for the setting aside of the lagoon as a Game Resrve under the Tasmanian National Parks and Wildlife Act 1970.

Scientific Research and Facilities No information

Principal Reference Material The above information is taken from the document 'Tasmanian wetlands nominated for inclusion on the List of Wetlands of International Importance' April 1983 and from the Revised Draft Plan for Moulting Lagoon by S.A. Blackhall, August 1986. 
Location $40^{\circ} 10^{\circ} \mathrm{S}, 148^{\circ} 17^{\prime} \mathrm{E}$. Situated in the south-eastern corner of Flinders Island which lies off the north-eastern coast of Tasmania in the Bass Strait.

Area 2,320 ha

Degree of Protection The area has been administered since 6 August 1968 by the Tasmanian National Parks and Wildlife Service (P.O.Box 210, Sandy Bay, Tasmania 7005). Small areas previously under private ownership were recently purchased by the government preparatory to upgrading the status of the wetland to nature reserve. Designated as a Ramsar site in April 1983.

Site Description The site comprises a landlocked system of coastal lagoons enclosed within the Logan Lagoon Wildlife Sanctuary. Waterfowl include coot, waders, ducks and black swan Cygnus Atratus.

Criteria for inclusion 1 (a)

International and National Importance The lagoon is an important resource for waterfowl migrating between the Australian mainland and Tasmania and regularly supports some 10,000 black swan, 5 duck species, 2,000 coots and 2,000 waders.

Changes in Ecological Character None reported (up to January 1984)

Management Practices No information

Scientific Research and Facilities No information

Principal Reference Material The above information is taken from the document 'Tasmanian wetlands nominated for inclusion on the List of Wetlands of International Importance' April 1983.

\section{Sea Elephant Conservation Area}

Location $39^{\circ} 45^{\prime} \mathrm{S}, 144^{\circ} 05^{\prime} \mathrm{E}$. Situated on the east coast of King Island which lies to the north-west of Tasmania in the Bass Strait.

Area 1,730ha

Degree of Protection Small areas previously under private ownership have recently been purchased by the government preparatory to upgrading the status of the wetland to nature reserve. The site is administered by the Tasmanian National Parks and Wildlife Service (P.O.Box 210, Sandy Bay, Tasmania 7005). Designated as a Ramsar site in April 1983.

Site Description The area consists of a small estuary and associated samphire mud flats.

Criteria for inclusion 2(a)

International and National Importance The area is a critical feeding ground for the orange-bellied parrot Neophema chrysogaster during its annual migration between southeast Australia and Tasmania. The orange-bellied parrot is an endangered species whose total population is 100-200 individuals. Flocks of up to 40 juveniles are entirely dependent on the samphire plants for food during migration and they roost in the trees surrounding the estuary.

Changes in Ecological Character None reported (up to January 1984) 
Management Practices No information

Scientific Research and Facilities No information

Principal Reference Material The above information is taken from the document 'Tasmanian wetlands nominated for inclusion on the List of Wetlands of International Importance' April 1983.

Additional reference:

- Ivanovici, A.M. (ed.) (1984). Inventory of declared marine and estuarine protected areas in Australian waters. Australian National Parks and Wildlife Service. Special Publications No.12 Vol.2: 320-321.

\section{Pittwater-Orielton Lagoon}

Location $42^{\circ} 47^{\prime} \mathrm{S}, 147^{\circ} 30^{\prime} \mathrm{E}$. Situated at the mouth of the River Coal near the city of Hobart, Tasmania.

Area 2,920ha

Degree of Protection The area is at present crown land under the jurisdiction of the Lands Department. Recently proposed as a Nature Reserve by the Tasmanian National Parks and Wildlife Service (P.O.Box 210, Sandy Bay, Tasmania 7005). Designated as a Ramsar site in April 1983.

Site Description The lagoon comprises an estuarine system with a larger area of saltmarsh and is an extensive and diverse wetland with abundant birdlife. The area of ten contains large populations of waterfowl and is considered to be a significant refuge in time of drought. The proposed nature reserve will greatly improve the protection of the saltmarsh plants and the communities in which they live.

Criteria for inclusion 2(a), 2(b), 2(d) and 3

International and National Importance The area is of world importance being the major summer feeding ground in Tasmania for migratory birds from as far as the Arctic Tundra. The area is one of the most important wader habitats in Tasmania particularly for eastern curlew Numenius madagascariensis and lesser golden plover Pluvialis dominica. It has been estimated that the proposed reserve area holds about $15 \%$ of the non-breeding wading birds that spend the north hemisphere winter in Tasmania. Grey teal Anas gibberifrons and hoary-headed grebe Podiceps poliocephalus are nomadic species which are sometimes almost absent from Tasmania but following periods of mainland drought subsequent to good breeding seasons, hundreds of both species have been noted on Orielton Lagoon. The lagoon is also the only location in the Hobart area where mountain duck Tadorna tadornoides and great crested grebe Podiceps cristatus are regularly seen. Other fauna in the area include the largest concentration of the small endemic sea star Patiriella vivipara, one of the few viviparous sea stars known. Important plants include the beautiful silky wilsonia Wilsonia humilis which is not reserved elsewhere in Tasmania and is uncommon except near the mouth of the Coal River.

Changes in Ecological Character None reported (up to January 1984)

Management Practices No information

Scientific Research and Facilities No information

Principal Reference Material The above information is taken from the document 'Tasmanian wetlands nominated for inclusion on the List of Wetlands of International Importance' April 1983. 


\section{Apsley Marshes}

Location $41^{\prime \prime} 56^{\prime} \mathrm{S}, 148^{\circ} 12^{\prime} \mathrm{E}$. Situated in the east coast of Tasmania at the mouth of the Apsley River. Contiguous with Moulting Lagoon (Ramsar site).

Area 940 ha

Degree of Protection Apsley Marshes are privately owned. Designated as a Ramsar site in April 1983.

Site Description The marsh is one of the most floristically rich in Tasmania. Water from the marsh drains into the Wildlife Sanctuary area of Moulting Lagoon.

Criteria for inclusion 2(a) and 2(b)

International and National Importance The marsh is an important feeding and nesting area for black swan Cygnus atratus. It also contains four plant species not yet reserved in Tasmania: Glyceria australis, Junais holoschoenus, Lythrum salicaria and Polygonum strigosum.

Changes in Ecological Character Drainage ditches constructed throughout the marsh have not been successful in preventing accumulation of standing water.

Management Practices No information

Scientific Research and Facilities No information

\section{Principal Reference Material}

The above information is taken from the document 'Tasmanian wetlands nominated for inclusion on the List of Wetlands of International Importance' April 1983.

Additional References:

- Blackhall, S.A. (1986). A survey to determine waterbird usage and conservation significance of selected Tasmanian wetlands. National Parks and Wildlife Service Tasmania, Occasional Paper No.14.

\section{East Coast Cape Barren Island Lagoons}

Location $40^{\circ} 22^{\prime} \mathrm{S}, 148^{\circ} 23^{\prime} \mathrm{E}$. Situated on the east coast of Cape Barren Island which is in the Bass Strait off the north-east coast of Tasmania.

Area The 37 lagoons lie within an area of approximately $4,230 \mathrm{ha}$.

Degree of Protection The area is owned by the Crown. Designated as a Ramsar site in April 1983.

Site Description The site comprises mainly shallow saline lagoons in a sand dune system. The lagoons are free from invasion by exotic species and are in an area which has been described as a wilderness.

Criteria for inclusion 2(b) and 2(d)

International and National Importance The lagoons are largely undisturbed and contain populations of Centrolepis puluinata, C. aristata, Scirpus pungens, Myriophyllum muelleri, Wilsonia rotundifolia and Aphelia sp. Some of these plant species do not occur in any other Tasmanian State Reserve. Large numbers of ducks Anatidae have been recorded. 
Management Practices No information

Scientific Research and Facilities Preliminary surveys of waterbirds have been carried out.

Principal Reference Material The above information is taken from the document 'Tasmanian wetlands nominated for inclusion on the List of Wetlands of International Importance' April 1983.

Supplemented by:

- Blackhall, S.A. (1986). A survey to determine waterbird usage an d conservation sigificance of selected Tasmanian wetlands. National Parks and Wildlife Service, Tasmania. Occasional Paper No. 14.

- Kirkpatrick, J.B. and Harwood, C.E. (1983). Conservation of Tasmanian macrophytic wetland vegetation. Papers and proceedings of the Royal Society of Tasmania 117: 5-20.

Flood Plain Lower Ringarooma River

Location $41^{\circ} 54^{\prime} \mathrm{S}, 147^{\circ} 56^{\prime} \mathrm{E}$. Situated in the north-eastern corner of Tasmania.

Area $1,650 \mathrm{ha}$

Degree of Protection The area is privately owned. Designated as a Ramsar site in April 1983.

Site Description The wetland area is situated on the sandy flood plain of the Lower Ringarooma River and is surrounded by woodland used for rough grazing.

Criteria for inclusion 2(a) and 2(b)

International and National Importance The flood plain contains populations of the plant species Centipeda minima, Polygonum strigosum, Lythrum salicaria and Villarsia exaltata.

Changes in Ecological Character None reported (up to January 1984)

Management Practices No information

Scientific Research and Facilities No information

Principal Reference Material The above information is taken from the document 'Tasmanian wetlands nominated for inclusion on the List of Wetlands of International Importance' April 1983.

\section{Jocks Lagoon}

Location $41^{\circ} 21^{\prime} S, 148^{\circ} 18^{\prime} E$. Situated on the east coast of Tasmania near St Helens.

Area 70ha

Degree of Protection Part of the lagoon lies within a state Recreation Area and part is private freehold. Designated as a Ramsar site in April 1983.

Site Description The wetland has developed in a swale behind coastal dunes. The catchment and wetland are unmodified.

Criteria for inclusion 2 (b) 
International and National Importance Jocks Lagoon is one of the few wetlands in Tasmania containing the spectacular sedge Baumea articulata.

Changes in Ecological Character None reported (up to January 1984)

Management Practices No information

Scientific Research and Facilities No information

Principal Reference Material The above information is taken from the document 'Tasmanian wetlands nominated for inclusion on the List of Wetlands of International Importance' April 1983.

\section{Northwestern corner of Lake Crescent}

Location $42^{\circ} 09^{\prime} \mathrm{S}, 147^{\circ} 10^{\prime} \mathrm{E}$. Tasmania.

Area 270 ha

Degree of Protection The area is privately owned. Designated as a Ramsar site in April 1983.

Site Description The wetland comprises a Triglochin procera-Baumera arthrophylla marsh.

Criteria for inclusion 2(a) and 2(b)

International and National Importance The area is one of the three known localities of Scirpus montiuagus in Tasmania. Also present is Amphibromus neesii which is known from only three wetlands in the centre of the state. The area is also an important feeding and roosting area for waterfowl.

Changes in Ecological Character When the edges of the marsh are dry they are used for grazing.

Management Practices No information

Scientific Research and Facilities A preliminary survey of waterbird usage has been carried out.

Principal Reference Material The above information is taken from the document 'Tasmanian wetlands nominated for inclusion on the List of Wetlands of International Importance' April 1983 and from A Survey to Determine Waterbird Usage and Conservation Significance of Selected Tasmanian Wetlands by S.A. Blackhall, August 1986.

\section{Little Waterhouse Lake}

Location $40^{\circ} 52^{\prime} \mathrm{S}, 147^{\circ} 37^{\circ} \mathrm{E}$. Situated in the north-eastern corner of Tasmania.

Area 90 ha

Degree of Protection The lake is on Crown Land administered by the National Parks and Wildlife Service (P.O.Box 210, Sandy Bay, Tasmania 7005). Designated as a Ramsar site in April 1983.

Site Description The wetland is a result of blocked drainage caused by the development of still mobile coastal dunes. 
Criteria for inclusion 3

International and National Importance The lake has dense aquatic growth and a high species diversity.

Changes in Ecological Character None reported (up to January 1984)

Management Practices No information

Scientific Research and Facilities No information

Principal Reference Material The above information is taken from the document 'Tasmanian wetlands nominated for inclusion on the List of Wetlands of International Importance' April 1983.

\section{Corner Inlet}

Location $38^{\circ} 36^{\prime}-38^{\circ} 55^{\prime} \mathrm{S}, 146^{\circ} 11^{\prime}-146^{\circ} 53^{\prime} \mathrm{E}$. Situated in southern Victoria between Wilsons Promontory and Yarram.

Area $51,500 \mathrm{ha}$

Degree of Protection Most of the site is in either Corner Inlet Marine and Coastal Park or in Nooramunga Marine and Coastal Park. Both are managed by the Department of Conservation, Forests and Lands, primarily for wildlife conseivation. The area between these two parks $(13,500 \mathrm{ha})$ which provides access to port facilities is to be managed cooperatively by the Department and the Ports and Harbours Division so that wildlife values are considered. Designated as a Ramsar site on 5 April 1983.

Site Description The inlet is bounded to the west and north by saltmarsh, farmland, mangrove, native woodland and heathland and to the south by a chain of barrier islands and the northern shores of Wilsons Promontory National Park. At low tide, extensive areas of intertidal mudflats are exposed.

Criteria for inclusion $1(\mathrm{a}), 1(\mathrm{~b}), 1(\mathrm{c}), 2(\mathrm{~b})$ and 3

International and National Importance Corner Inlet regularly supports an estimated 29,000 waders (migratory and non-migratory) which represents $21.5 \%$ of the total wader population of Victoria and includes the majority of Victoria's population of less abundant wader species. The inlet's population of grey plover Pluvialis squatarola, bar-tailed godwit Limosa lapponica, red knot Calidris canutus and great knot $C$. tenuirostris represent the largest in southern Australia (greater than $1 \%$ of the flyway or biogeographical region according to the Royal Australasian Ornithologists (Union, RAOU). The inlet also supports an estimated $50 \%$ of the overwintering migratory waders in Victoria, breeding colonies of fairy tern Sterna nereis, crested tern S. bergii, caspian tern S. caspia and short-tailed shearwaters Puffinus tenuirostris and the largest populations yet found in Australia of eastern curlew Numenius madagascariensis. The southern area periodically supports up to 2,000 chestnut teal Anas castanea estimated by RAOU to be $12-15 \%$ of Victoria's population. The area is an important part of the flyway for birds moving between the mainland and Tasmania.

Changes in Ecological Character Part of the inlet is currently used as a port and servicing facility for offshore oil and natural gas exploration. The nearby Gelliondale Brown coal deposit may also require port facilities although the future utilisation of this coal resource has not been determined.

Management Practices Amateur and commercial fishing are permitted. 
Scientific Research and Facilities A study of the roost sites and feeding areas for migratory waders has been completed. There is a laboratory in Wilsons Promontory National Park.

Principal Reference Material The above information is taken from the document 'Wetlands nominated by the State of Victoria, Australia for inclusion on the List of Wetlands of International Importance' April 1983.

\section{Barmah Forest}

Location $35^{\circ} 50-^{\prime} 36^{\circ} 07^{\prime} \mathrm{S}, 144^{\circ} 56^{\prime}-145^{\circ} 20^{\prime} \mathrm{E}$. On the Murray River flood plain between Barmah and Tocumwal in northern Victoria.

\section{Area 28,500 ha}

Degree of Protection Currently reserved as state forest and managed by the Department of Conservation, Forests and Lands. Designated as a Ramsar site on 5 April 1983.

Site Description Barmah Forest has evolved on lands which were flooded under natural conditions in the spring months of most years but rarely flooded in the summer months. The dominant woodland is red gum Eucalyptus camaldulensis, and giant rush Juncus ingens and moira grass Pseudoraphis spinescens are dominant in untimbered areas.

\section{Criteria for inclusion $1(a), 2(b)$ and 3}

International and National Importance After flood periods the forest is one of Victoria's largest waterfowl breeding areas. Sections of the area periodically support large breeding colonies of sacred ibis Threskiornis aethiopica and straw-necked ibis $T$. spinicollis and smaller breeding colonies of white egret Egretta alba and yellow spoonbill Platalea flavipes.

Changes in Ecological Character Since the construction of the first major upstream storage on the Murray River in 1934 (Hume Reservoir) the river flow has been increasingly regulated for water supply purposes. Consequently there has been a reduction in the frequency of spring flooding due to the retention of natural flow in storage and an increase in summer flooding due to the release of stored water for supply to river off-takes downstream of the forest. With the recent completion of another major storage scheme (Dartmouth Reservoir) it is expected that effective spring flooding of Barmah Forest will occur on average about two years in five as against four years in five under natural conditions, meaning a $50 \%$ reduction in flooding frequency. More importantly, without modification to the existing management regime, the intervals between successive forest floodings could be as long as 10 years during severe protracted droughts. Grazing by stock and rabbits combined with changes in water regime have considerably altered the extent and species composition of reedbeds since settlement.

Management Practices The forest is managed for timber production. Shooting of waterfowl is permitted during hunting seasons.

\section{Scientific Research and Facilities No information}

Principal Reference Material The above information is taken from the document 'Wetlands nominated by the State of Victoria, Australia for inclusion on the List of Wetlands of International Importance' A pril 1983.

Additional reference:

- Chesterfield, E.A. (1986). Changes in the vegetation of the river red gum forest at Barmah, Victoria. Aust. For. 49: 4-15. 


\section{Gunbower Forest}

Location $35^{\circ} 39^{\prime}-36^{\circ} 00^{\prime} \mathrm{S}, 144^{\circ} 08^{\prime}-144^{\circ} 30^{\prime} \mathrm{E}$. Situated in northern Victoria on the Murray River flood plain between Torrumbarry and Koondrook.

Area 19,450 ha

Degree of Protection Currently reserved as state forest and managed by the Department of Conservation, Forests and Lands. The eastern area $(9,712 \mathrm{ha})$ is a proclaimed wildlife sanctuary. Designated as a Ramsar site on 5 April 1983.

Site Description Gunbower Forest is dominated by red gum Eucalyptus camaldulensis with mainly grassy understorey, and contains some small creeks and swamps mainly associated with old courses of the Murray River. Floodwaters of the Murray River extend through almost the entire forest.

\section{Criteria for inclusion $2(\mathrm{~b})$ and 3}

International and National Importance After flood periods the forest becomes a large waterfowl breeding area. Sections of the forest support breeding colonies of rufous night heron Nycticorax caledonicus and plumed egret.

Changes in Ecological Character Since the construction of the first major upstream storage on the Murray River in 1934 (Hume Reservoir) the river flow has been increasingly regulated for water supply purposes. Consequently there has been a reduction in the frequency of spring flooding due to the retention of natural flow in storage and an increase in summer flooding due to the release of stored water for supply to river off-takes downstream of the forest. Thus this area is subject to the same hydrological interference as Barmah Forest but the degree of interference is less well known.

Management Practices The forest is managed for timber production and grazing is allowed. In the hunting season shooting is permitted.

\section{Scientific Research and Facilities No information}

Principal Reference Material The above information is taken from the document 'Wetlands nominated by the State of Victoria, Australia for inclusion on the List of Wetlands of International Importance' April 1983.

\section{Hattah-Kulkyne Lakes}

Location $34^{\circ} 38^{\prime} 34^{\circ} 45^{\prime} \mathrm{S}, 142^{\circ} 29^{\prime} \mathrm{E}$. A system of lakes on the Chalka Creek system, an anabranch of the Murray River in the Hattah-Kulkyne National Park, north-western Victoria.

Area $1,018 \mathrm{ha}$

Degree of Protection The lakes are in Hattah-Kulkyne National Park, managed by the Department of Conservation, Forests and Lands (240 Victoria Parade, East Melbourne, Victoria 3002). Designated as a Ramsar site in April 1983.

Site Description The lakes are freshwater lakes linked to the Murray River by Chalka Creek. The system comprises: Lake Arawak 40ha, Lake Bitterang 73ha, Lake Brockie 28ha, Lake Bulla 40ha, Lake Cantala 101 ha, Lake Hattah 61 ha, Lake Konardin 121 ha, Lake Kramen 24 ha, Lake Lockie 141 ha, Lake Moyrnpall 243ha, Lake Yelwell 81 ha and Lake Yerang 65 ha. Mean annual temperature is $23.5^{\circ} \mathrm{C}$ maximum and $9.6^{\circ} \mathrm{C}$ minimum. Mean annual rainfall $300 \mathrm{~mm}$. The riparion woodland surrounding the lakes is periodically flooded and is dominated by Eucalyptus camaldulensis or E. largiflorens. 
Criteria for inclusion 2 (b) and 3

International and National Importance After a flood period the lake system becomes a large breeding area for waterfowl including herons, egrets and spoonbills.

Changes in Ecological Character The flooding frequency along the Murray River has been reduced as a result of water regulation for irrigation. In the past the area was heavily grazed by sheep and cattle and is still grazed by rabbits. Feral cats and foxes are present and troublesome. Considerable timber extraction has occurred.

Management Practices All livestock are now excluded from the area.

Scientific Research and Facilities Current research includes projects on effects of feral cats on wildlife, effects of rabbits and kangaroos on vegetation regeneration, and a recent study of the effects of fire.

Principal Reference Material The above information is taken from the document 'Wetlands nominated by the State of Victoria, Australia for inclusion on the List of Wetlands of International Importance' April 1983.

\section{Kerang Wetlands}

Location $35^{\circ} 30^{\prime}-35^{\circ} 50^{\prime} \mathrm{S}, 143^{\circ} 42^{\prime}-144^{\circ} 10^{\prime} \mathrm{E}$. Situated in nortinern Victoria on the lower reaches of the Avoca River, Loddon River and Pyramid Creek near Kerang.

Area $9,172 \mathrm{ha}$

Degree of Protection Some sections are reserved (or awaiting reservation) as state wildlife reserves, water supply reserves or salinity disposal reserves. The remaining area is Crown Land without specific reservation. Designated as a Ramsar site in April 1983.

Site Description Kerang Wetlands form a system of lakes and swamps ranging in salinity from freshwater marshes to highly saline lakes. They therefore support varied vegetation associations on the margins and beds from river red gum and black box woodlands to canegrass, reedbeds and saltmarshes. The wetlands are adjacent to Gunbower Ramsar site. The system consists of: On the Lower Avoca River four State Wildlife Reserves: First Marsh, Second Marsh and Third Marsh with a total area of 2,405ha, and Lake Bael Bael 435ha; on the Lower Loddon River Town Swamp 294ha, Back Swamp 21 ha, eight Water Supply Reserves, Kangaroo Lake Racecourse Lake 1,140ha, Lake Cullen 760 ha, Middle Lake, Reedy Lake and Third Lake 680ha, Lake Charm 545ha, Little Lake Charm 160ha, Salinity Disposal Reserves, Lake Tutchewop 920ha, Lake Kelly 142 ha and Lake William 120ha, and one State Wildlife Reserve, Stevenson Swamp 90ha; and on Lower Pyramid Creek four State Wildlife Reserves, Johnson Swamp 485ha, Hird Swamp 405ha, Cemetry Swamp 300ha and Foster Swamp 270 ha.

Criteria for inclusion $1(\mathrm{a}), 1(\mathrm{~b}), 2(\mathrm{~b})$ and 3

International and National Importance When most of the swamps and lakes are carrying water, the wetland system supports extremely large numbers of waterfowl, estimates ranging from 'hundreds of thousands' to 'in excess of 1 million' birds. Lake Cullen and Lake Tutchewop periodically support large numbers of the freckled duck Stictonetta naevosa and, together with Kangaroo Lake, regularly support large numbers of blue-billed duck Oxyura australis with recorded flocks of up to 1,000. The largest colonies in Victoria of sacred ibis Threskiornis aethiopica and straw-necked ibis $T$. spinicollis currently occur in Kerang Wetlands, with Hird Swamp supporting an estimated 10,000 sacred ibis and 20,000 straw-necked ibis in 1979-80 and Middle Lake supporting an estimated 15,000 sacred ibis and 
15,000 straw-necked ibis. These accounted for $73 \%$ of the breeding sacred ibis and $45 \%$ of the breeding straw-necked ibis in Victoria. The Kerang Wetlands are an important wader habitat with an estimated population in 1982 of 11,000 comprising $9 \%$ of Victoria's estimated total, with over 9,000 occurring at Lake Tutchewop.

Changes in Ecological Character The lakes have been affected to varying degrees by the development of extensive water supply and drainage disposal systems which have generally resulted in more stable water levels than would occur under natural conditions. The effect on water quality has been beneficial for the lakes that are incorporated into water systems with continual through flow (eg. Kangaroo and Racecourse) but adverse for lakes used for drainage disposal (eg. Lake Tutchewop) or now isolated from flushing by natural flood flows (eg. Cullen). Adjacent irrigation development has raised saline water tables on some wetlands (eg. Second Marsh) causing the death of trees. The modification of natural water courses for irrigation and drainage has interfered with some of the wetlands (eg. Hird and Johnson Swamps) and created the management problem of achieving an alternative water supply to this wetland site.

\section{Management Practices No information}

\section{Scientific Research and Facilities No information}

Principal Reference Material The above information is taken from the document 'Wetlands nominated by the State of Victoria, Australia for inclusion on the List of Wetlands of International Importance' April 1983.

\section{Port Phillip Bay (western shoreliue) and Bellarine Peninsula}

Location $37^{\circ} 53^{\prime}-38^{\circ} 15^{\prime} \mathrm{S}, 144^{\circ} 24^{\prime}-144^{\circ} 48^{\prime} \mathrm{E}$. Situated to the south-west of Melbourne, southern Victoria.

Area 7,000 ha (minimum)

Degree of Protection The site includes over $18 \mathrm{~km}$ of the western shoreline of Port Phillip Bay. The Melbourne Metropolitan Board of Works Werribee Sewage Farm (MMBW) is a proclaimed wildlife sanctuary, and part of the Point Cook coastline is managed by the MMBW as a metropolitan park. The spit is a state wildlife reserve. Most of the remaining western shoreline of Port Phillip Bay is coastal reserve administered by the Department of Conservation, Forests and Lands. On the Bellarine Peninsula, Lake Connewarre and Mud Islands are state wildlife reserves, and Swan Bay and an area of water surrounding Mud Islands are marine reserves. Designated as a Ramsar site on 5 April 1983.

Site Description The Ramsar site includes two areas: Port Phillip Bay (western shoreline) with coastline from Point Wilson to Lime Burners Bay $(13 \mathrm{~km})$, coastline from Skeleton Creek to Point Cook $(5 \mathrm{~km})$, the spit State Wildlife Reserve (380ha) and Melbourne Metropolitan Board of Works Sewage Farm (retention ponds including Lake Borrie); and Bellarine Peninsula with Lake Connevarre State Wildlife Reserve (3,100ha), Swan Bay Marine Reserve (2,800ha) and Mud Island Marine Reserve and State Wildlife Reserve (656ha).

Criteria for inclusion $1(\mathrm{a}), 1(\mathrm{~b}), 2(\mathrm{a}), 2(\mathrm{~b})$ and 3

International and National Importance The Werribee Sewage Farm has a complex of sewage lagoons and irrigated paddocks adjoined by areas of intertidal mudflats, and periodically supports tens of thousands of ducks, coots and swans. In 1982 the number of pink-eared duck Malacorhynchus membranaceus on the farm was estimated at over 15,000. Surveys of wader populations indicate that the western portion of Port Phillip Bay and Bellarine Peninsula support about $47 \%$ (approximately 38,500) of Victoria's wader population. The dead trees in Lake Borrie are important as nocturnal roosting sites for a large number of straw-necked 
ibis Threskiornis spinicollis and sacred ibis $T$. aethiopica, and also support the largest known breeding colony of pied cormorant Phalacrocorax uarius (260 active nests). In winter the spit and Swan Island support over $75 \%$ of the known world population of orange-bellied parrot Neophema chrysogaster.

Changes in Ecological Character Some adjacent areas are used for recreation and industry including an oil refinery.

Management Practices Hunting is permitted during open seasons in Lake Connevarre reserve. Amateur fishing and other water-based recreation occurs along suitable and accessible shorelines.

\section{Scientific Research and Facilities No information}

Principal Reference Material The above information is taken from the document 'Wetlands nominated by the State of Victoria, Australia for inclusion on the List of Wetlands of International Importance' April 1983.

Supplemented by:

- Corrick, A.H. (1981). Wetlands of Victoria III; wetlands and waterbirds between Port Phillip Bay and Mount Emu Creek. Proc. Roy. Soc. Vict. 94(2): 69-87.

- Lane, B.A., Schulz, M. and Wood, K.L. (1984). Birds of Port Phillip Bay. Coastal Unit Technical Report No.1. Ministry for planning and Environment.

\section{Western Port}

Location $38^{\circ} 12^{\prime}-38^{\circ} 31^{\prime} S, 145^{\circ} 02^{\prime}-145^{\circ} 32^{\prime} \mathrm{E}$. Southern Victoria, east of Port Phillip Bay Ramsar site.

Area 52,325ha

Degree of Protection Approximately 31,600 ha has been recommended by the government as a wildlife management co-operative area under the Wildlife Act 1975 and this is awaiting proclamation. This area will be jointly managed by the Ports and Harbours Division and the Department of Conservation, Forests and Lands (250 Victoria Parade, P.O.Box 41, East Melbourne, Victoria 3002). A further 2,050ha of shoreline and small islands is reserved as a state wildlife reserve. Designated as a Ramsar site in April 1983.

Site Description Western Port is a coastal bay.

Criteria for inclusion 1(a), 1(b) and 3

International and National Importance Wader surveys indicate that Western Port supports about 10,000 waders, some $12 \%$ of Victoria's wader population. It is also estimated that Western Port periodically supports over 10,000 ducks and black swan Cygnus atratus.

Changes in Ecological Character Changes in the catchments inland, particularly associated with the drainage of extensive swamps immediately to the north of the bay have increased sedimentation in the bay.

Management Practices The western channel of Western Port is the major shipping channel servicing the port development in the Hastings-Crib Point area. The bay and many sections of the coastline are popular for water-sports. Commercial and amateur fishing are allowed.

Scientific Research and Facilities No information 
Principal Reference Material The above information is taken from the document 'Wetlands nominated by the State of Victoria, Australia for inclusion on the List of Wetlands of International Importance' April 1983.

Additional reference:

- Ivanovici, A.M. (ed.) (1984). Inventory of declared marine and estuarine protected areas in Australian waters. Australian National Parks and Wildlife Service. Special Publications No.12 Vol.2: 304.

\section{Western District Lakes}

Location $38^{\circ} 00^{\prime}-38^{\circ} 20^{\prime} \mathrm{S}, 143^{\circ} 07^{\prime}-143^{\circ} 55^{\prime} \mathrm{E}$. Situated on the basalt plains of Western Victoria between Wichelsea and Camperdown.

\section{Area $30,182 \mathrm{ha}$}

Degree of Protection Six of the lakes are state wildlife reserves (or awaiting proclamation as such) and are managed by the Department of Conservation, Forests and Lands (250 Victoria Parade, P.O.Box 41, East Melbourne, Victoria 3002). These are Lake Beeac (647ha), Lake Bookar (490ha), Lake Cundare (395ha), Lake Malingil (125ha), Lake Murdeduke (1500ha) and Lake Terangpom (275ha). The other three lakes, Lake Colongulac (1400ha), Lake Corangamite $(23,000 \mathrm{ha})$ and Lake Gnarpurt $(2,350 \mathrm{ha})$ are awaiting proclamation as lake reserves and are managed by the Department of Crown Lands and Survey. Designated as a Ramsar site on 5 April 1983.

Site Description The lakes range from fresh (Terangpom and Colongulac) to highly saline (Beeac and Cundare). Although generally shallow $(5 \mathrm{~m})$ they have little emergent vegetation but submerged aquatic vegetation is of ten abundant. They show considerable annual and seasonal changes in extent because of limited catchment areas and natural rainfall variation.

\section{Criteria for inclusion $1(a)$ and 3}

International and National Importance The lake system periodically supports tens of thousands of ducks, swans and coots, and is considered to be an important drought refuge for waterfowl. Lakes Beeac and Cundare support large numbers of banded stilt Cladorhynchus leucocephalus. Lake Murdeduke supports large numbers of migratory waders and several lakes are used by flocks of blue-billed duck Oxyura australis, musk duck Biziura lobata and grebe during winter. Lake Carangamite has an island used by breeding ibis, pelican and cormorant.

Changes in Ecological Character The land adjacent to the lakes is used for grazing and cropping. Inflows to Lake Corangamite have been limited by a diversion system.

Management Practices Hunting of game during open season is permitted on all but lakes Teramngpom and Malingil. Commercial put and take eel fisheries operate on Lakes Murdeduke, Gnarpurt and Colongulac. Water-based recreation including fishing takes place at certain sites.

\section{Scientific Research and Facilities No information}

Principal Reference Material The above information is taken from the document 'Wetlands nominated by the State of Victoria, Australia for inclusion on the List of Wetlands of International Importance' April 1983.

Supplemented by:

- Corrick, A.H. (1981). Wetlands of Victoria III; wetlands and waterbirds between Port Phillip Bay and Mount Emu Creek. Proc. Roy. Soc. Vict. 94(2): 69-87. 


\section{Gippsland Lakes}

Location $37^{\circ} 49^{\prime}-38^{\circ} 12^{\prime} \mathrm{S}, 147^{\circ} 04^{\prime}-148^{\circ} 08^{\prime} \mathrm{E}$. Located in eastern Victoria, extending from the town of Sale eastwards to their sea outlet.

Area 43,046 ha

Degree of Protection The entire site is at present under some sort of protection (as defined in 'Site Description'). About 10,200ha have been recommended to be jointly managed by the Department of Conservation, Forests and Lands as a conservation area (exact nomenclature not yet clarified) which will include all existing state wildlife reserves and several additional areas of Crown Land wetlands and foreshore. The Victorian Government has accepted and commenced implementation of this recommendation although permanent reservation may take some time to be enacted. The remaining 32,800 ha (approximately), although part of the Wetland of International Importance, will not be specifically reserved primarily for nature conservation. Cooperative management between the Department of onservation and Lands and the Ports and Harbours Division will continue to promote conservation and protection of the aquatic ecosystems in this portion of the site. Designated as a Ramsar site on 5 April 1983.

Site Description Gippsland Lakes, with their associated swamps and morasses, are in contact with the sea and are bordered on the landward side by areas of National and Coastal Park, agricultural land, military firing range and urban areas. The site includes seven State Wildlife Reserves: Blond Bay $812 \mathrm{ha}$, Clydebank Morass 640ha, Dowd Morass 1,500ha, Heart Morass 300 ha, Jones Bay 110 ha, Macleod Morass 520 ha and Sale Common 308 ha; five Crown Land Reserves: Lake Bunga, Lake King, Lake Tyers, Lake Victoria and Lake Wellington: (total area 34,000ha), and Lake Reeve 4,856ha (part of Gippsland Lakes Coastal Park).

\section{Criteria for inclusion $1(a)$ and 3}

International and National Importance The site supports an estimated 40-50,000 waterfowl including ducks, swans and coots. Tucker Swamp on the edge of Lake Wellington supports one of only two regular breeding colonies in Victoria of pied cormorant Phalacrocorax varius. The lakes support an estimated $4 \%$ of Victoria's wader population. The permanence of the main lakes and the relatively regular flooding of the adjacent wetlands mean that this system is an important drought refuge.

Changes in Ecological Character Major man made changes to this wetland system include: alteration to the ocean outlet (in 1899) with considerable alteration of the salinity regime and gradient of the lakes; reduction of flood frequencies and flooding duration of the major tributary rivers through water storage developments and water extraction; changes to water quality by pollution and catchment erosion; grazing; land drainage; and residental development and recreational pressures.

Management Practices Commercial and amateur fishing, power boating and sailing and hunting of game during open seasons are permitted although restrictions on power boating and hunting apply only in some areas.

\section{Scientific Research and Facilities No information}

\section{Principal Reference Material}

The above information is taken from the document 'Wetlands nominated by the State of Victoria, Australia for inclusion on the List of Wetlands of International Importance' April 1983.

Supplemented by:

- Corrick, A.H. and Norman, F.I. (1980). Wetlands of Victoria I; wetlands and waterbirds of the Snowy River and Gippsland Lakes catchment. Proc. Roy. Soc. Vict. 91(1): 1-15.

- Corrick, A.H. (1981). Wetlands of Victoria II; wetlands and waterbirds of South Gippsland. Proc. Roy. Soc. Vict. 92(2): 187-200. 
- Ivanovici, A.M. (ed.) (1984). Inventory of declared marine and estuarine protected areas in Australian waters. Australian National Parks and Wildlife Service. Special Publications No.12 Vol.2: 267-268.

- Kinhill Stearns (1984). Gippsland Regional Environmental Study Overview report. Environmental Studies Series No.407. Ministry for Conservation, Victoria.

- Poore, C.C.B., Corrick, A.H. and Norman, F.I. (1979). Food of three waders in Lake Reeve, Victoria. Emu

\section{Lake Albacutya}

Location $35^{\circ} 46^{\prime} \mathrm{S}, 141^{\circ} 58^{\prime} \mathrm{E}$. On the Wimmera River near Rainbow in north-west Victoria.

Area 10,700 ha

Degree of Protection Reserved as a regional park and managed by the Department of Conservation, Forests and Lands (240 Victoria Parade, East Melbourne, Victoria 3002). Designated as a Ramsar site in April 1983.

Site Description Intermittently filled by extreme floods of the Wimmera River. Once filled, water remains for several years. The lake bed is fringed by red gum Eucalyptus camaldulensis and areas of the bed are colonised by Acacia spp. which are killed on reflooding. Wyperfield National Park is adjacent to the north-west boundary.

Criteria for inclusion $1(a), 1(b)$ and 3

International and National Importance Periodically supports over 10,000 ducks and swans and 10,000 coots. The lake has supported over $10 \%(300-400)$ of Victoria's population of the freckled duck Stictonetta naevosa during the migration of this species into Victoria.

Changes in Ecological Character A long term reduction in flooding frequency has been caused by water storage development and water extraction along the Wimmera River and tributaries.

Management Practices Hunting of legal game species during open seasons and fishing are permitted.

Scientific Research and Facilities No information

Principal Reference Material The above information is taken from the document 'Wetlands nominated by the State of Victoria, Australia for inclusion on the List of Wetlands of International Importance' April 1983.

\section{Towra Point Nature Reserve}

Location $34^{\circ} 00^{\prime} \mathrm{S}, 151^{\circ} 10^{\prime} \mathrm{E}$. Situated about $17 \mathrm{~km}$ south of Sydney in New South Wales.

Area 281 ha

Degree of Protection Towra Point Nature Reserve was established in 1982 under the New South Wales National Parks and Wildlife Act 1974. It is owned by the Crown and administered by the National Parks and Wildlife Service of New South Wales (PO Box N189, Grosvenor Street, Sydney NSW 2000). The marine habitat and tidal areas adjacent to the Nature Reserve are currently being considered for proclamation as an Aquatic Reserve by the Department of Agriculture, Division of Fisheries. Close collaboration has been established between the two authorities responsible for the Nature Reserve and Aquatic Reserve to ensure a uniform management approach. Designated as a Ramsar site in March 1984. 
Site Description The site comprises a low-lying promontory of Holocene sandy sediments on the northern side of Kurnell Peninsula in Botany Bay, and contains sandspits, sandbars, dunes, beaches and mudflats. It has a variety of habitats from seagrass beds, mangroves and saltmarshes to dune woodlands, Casuarina forest, small patches of littoral rainforest and sand dune grasslands. The wetland supports many invertebrates and birds and is a source of nutrients for fish nurseries.

\section{Criteria for inclusion 1(a), 2(a), 2(b) and 3}

International and National Importance The site is one of the few remaining areas of estuarine wetland in the Sydney region and is important for the survival of many bird species in this area. Particularly significant is the occurrence of 31 of the 66 species presently listed in the Japan-Australia Migratory Birds Agreement including $6.1 \%$ of the total population of the American golden plover Pluvialis dominica and $1.1 \%$ of the total population of ruddy turnstone Arenaria interpres. Large populations of migratory waders stop to feed and rest here on their way to large summer feeding grounds in the south.

Changes in Ecological Character Present problems are litter, introduced animal and plant species, and open access to the reserve for trail bike riders, horseback riders and day visitors from boats. Some of the mangroves are dying back because of oil polution. Future possible threats are proposed sandmining and marina construction adjacent to the reserve, and dredging and revetment wall construction which may alter wave movement in the bay (thus affecting the seagrass meadows adjacent to the reserve).

\section{Management Practices No information}

Scientific Research and Facilities Periodic counts of waterfowl by the National Parks and Wildlife Serivce.

Principal Reference Material The above information is taken from the document 'Wetlands nominated by the State of New South Wales, Australia for inclusion on the List of Wetlands of International Importance' and from the National Report of Australia to the Groningen Meeting 1984.

Supplemented by:

- Australian Littoral Society (1977). An investigation of management options for Towra Point. Botany Bay. Australian National Parks and Wildlife Service, Canbera.

- National Parks and Wildlife Service (1983). Results of the 1983 Summer National Wader Counts. Internal report.

- Wetlands (1983). Journal of the Coast and Wetlands Society Vol. 3 No. 1.

- Ivanovici, A.M. (ed.) (1984). Inventory of declared marine and estuarine protected areas in Australian waters. Australian National Parks and Wildlife Service. Special Publications No.12 Vol.2: 255-256.

\section{Kooragang Nature Reserve}

Location $32^{\circ} 51^{\prime} \mathrm{S}, 151^{\circ} 46^{\prime} \mathrm{E}$. Situated in the Hunter River catchment area about $7 \mathrm{~km}$ north of Stockton in New South Wales.

Area 2,206ha

Degree of Protection Kooragang Nature Reserve was established in 1983 under the New South Wales National Parks and Wildlife Act 1974. It is owned by the Crown and administered by the National Parks and Wildlife Service of New South Wales (PO Box N189, Grosvenor Street, Sydney NSW 2000). Designated as a Ramsar site in March 1984. 
Site Description The site comprises Fullerton Cove, the lower part of the Hunter River (North Channel) and part of the Hunter River Estuary including some surrounding land. The area is essentially a delta with islands and creeks. The vegetation consists of estuarine wetland communities including mangroves, saltmarshes, brackish and freshwater swamps and tidal mudflats.

Criteria for inclusion $1(\mathrm{~b}), 2(\mathrm{a}), 2(\mathrm{~b})$ and 3

International and National Importance 190 bird species have been recorded in the site area, representing $25 \%$ of the known species for Australia. The site is particularly important for migratory waders with $86 \%(5,020)$ of the total waders in the entire Hunter River wetland $(5,816)$ counted here in 1983 . 38 of the 66 species of migratory waders presently listed in the Japan-Australia Migratory Birds Agreement occur in the wetland including $14.6 \%$ of the total observed population of American golden plover Pluvialis dominica and $5.9 \%$ of the eastern curlew Numenius madagascariensis. Several uncommon waders have been recorded here including ringed plover Charadrius hiaticula, greater sand plover Charadrius leschenaultii, little curlew Numenius minutus, pectoral sandpiper Calidris melanotos and ruff Philomachus pugnax. The site is a productive estuarine wetland which represents a significant genetic pool for wetland species in the region and is also an important contributor of nutrients to the lower Hunter estuarine system.

Changes in Ecological Character The delta has already been extensively modified by man in parts. Present problems are introduced plants and animals and rubbish dumping. Future problems may arise if the water levels in the area west of Fullerton Cove are not actively managed.

\section{Management Practices No information}

Scientific Research and Facilities Periodic counts of waterfowl by the National Parks and Wildlife Service.

Principal Reference Material The above information is taken from the document 'Wetlands nominated by the State of New South Wales, Australia for inclusion on the List of Wetlands of International Importance' and from the National Report of Australia to the Groningen Meeting 1984.

Additional references:

- Hodges, S.L. (1980). Kooragang Island/Fullerton Cove Proposed Nature Reserve Investigation Report. Australian National Parks and Wildlife Service, Canberra.

- National Parks and Wildlife Service (1983). Results of the 1983 Summer National Wader Counts. Internal report.

- Ivanovici, A.M. (ed.) (1984). Inventory of declared marine and estuarine protected areas in Australian waters. Australian National Parks and Wildlife Service. Special Publications No.12 Vol.2: 255-256.

The Coorong and Lakes Alexandrina and Albert Wetland

Location $35^{\circ} 18^{\prime}-36^{\circ} 33^{\prime} \mathrm{S}, 138^{\circ} 46^{\circ}-139^{\circ} 50^{\prime} \mathrm{E}$. Situated in upper south-east South Australia, near the Murray River Mouth.

Area 140,500 ha

Degree of Protection The area covers mostly Crown Lands (water), a national park, and game reserves. Lakes Alexandrina and Albert are surrounded mainly by private property. The Coorong is surrounded mainly by a National Park and Game Reserve established in 1966. Wetlands specifically included in the Ramsar site are: Lake Alexandrina including Tolderol, Mud Islands and Currencey Creek Game Reserves, otherwise mainly Crown lands $(76,000 \mathrm{ha})$; Lake Albert - mainly Crown Lands (16,800ha); and Coorang - mainly covering Coorang National Park and Game Reserve, otherwise mainly Crown Lands (47,700ha). 


\section{Australia}

Site Description The wetland consists of ocean beach with a spectacular coastal dune complex (Younghusband Peninsula), together with the mouth of the River Murray and associated lakes and estuaries. This combination provides a wide range of habitats from freshwater to hypersaline. Dunes east of the lagoons are covered by Mallee open-scrub/tall shrublands while Chenopod low shrubland, paperbark teatree open-scrub and herbland (sedges and rushes) occupy the mudflats ringing the Coorong. Mobile dunes and open scrub/heath are the principal features of Younghusband Peninsula. Several rare plants have been recorded including Helichrysum paralium. Hydrocotyle medicaginoides, H. pterocarpa, Melaleuca oraria, Sebaea albidiflora and Wilsonia backhousei.

\section{Criteria for inclusion $1(\mathrm{a}), 1(\mathrm{~b}), 1(\mathrm{c}), 2(\mathrm{a}), 2(\mathrm{~b}), 2(\mathrm{c}), 2$ (d) and 3}

International and National Importance There is a diversity of species with waders and waterfowl predominating. The 1981 count of the Australasian Wader Studies Group of the Royal Australasian Ornithologists Union estimated the summer population of waders for the area at 122,000, compared with a South Australian population of 200,000 and an Australian population of 403,000 . In 1982 it was estimated that there were 45,000 ducks in the area. Spectacular numbers of black swan Cygnus atratus are present at times and H.J. Frith estimated 50,000 in the Coorong in 1957. Typical numbers for the whole wetland would be in excess of 5,000. Approximately 2,000 Cape barren geese Cereopsis novachollandiae normally summer within $1 \mathrm{~km}$ of the wetland. The area also supports large numbers of grey teal Anas gibberifrons, Pacific black duck A. superciliosa, Australian shelduck Tadorna tadornoides and many other common species. Four species rare to South Australia have been recorded in the park: orange-bellied parrot Neophema chrysogaster, painted snipe Rostratula benghalensis, Terek sandpiper Tringa terek and grey-crowned babbler Pomatostomus temporalis. The Coorong is an important breeding area for the pelican Pelecanus conspicillatus, crested tern Sterna bergii and fairy tern S. nereis, and Lake Alexandrina for egrets Egretta spp., ibises (Threskiornithinae), cormorants (Phalacrocoracidae) and the rufous night heron Nycticorax caledonicus. It is also important as a feeding, breeding, spawning and nursery area for fish species of recreational and commercial interest. Whales have been sighted offshore from Younghusband Peninsula.

Changes in Ecological Character Most of the edge of the Lakes Alexandrina and Albert is used for farming, with tourist development in several areas. Development is otherwise resticted under the State Planning and other Acts, and most of the area is in its natural state. The natural water flow of the Coorong has been altered by drainage channels in the south-east of South Australia and by barrages on the River Murray.

Management Practices Recreational line and net fishing and boating are permitted activities; commercial net fishing under licence from the South Australia Department of Fisheries.

Scientific Research and Facilities In 1981 the Australasian Wader Studies Group of the Royal Australasian Ornithologists Union carried out a bird count for the area.

Principal Reference Material The above information is taken from the document 'Wetlands nominated by the State of South Australia, Australia for inclusion on the List of Wetlands of International Importance' November 1984.

Supplemented by:

- Ivanovici, A.M. (ed.) (1984). Inventory of Declared Marine and Estuarine Protected Areas in Australian Waters. Australian National Parks and Wildlife Service Special Publication No. 12, vol. 2: 382-382.

Additional references:

- CSIRO Division of Land Use Research (1977). Environments of South Australia. Province 1, South East. Canberra, pp.28-31.

- CSIRO Division of Land Use Research (1977). Environments of South Australia, Province 2, Murray Mallee. Canberra, pp.24-27.

- Gilbertson, D,D, and Foale, M.R. (Eds) (1977). The Southern Coorong and lower Younghusband Peninsula of South Australia. Nature Conservation Society of South Australia Report, Adelaide, SA. 
- Nature Conservation Society of S.A. Inc. (1977). The Southern Coorong and Lower Younghusbans Peninsula of South Australia. N.C.S., South Australia.

- Noye, J. (Ed.) (1975). The Coorong. Dept. of Adult Education, University of Adelaide Publication No. 39.

- Paton, P. (1982). Biota of the Coorong - a Study for the Cardwell

Buckingham Committee. SA Dept. Environment and Planning Publ. No. 55, 68pp.

\section{Bool and Hacks Lagoon}

Location $37^{\circ} 06^{\prime}-37^{\circ} 10^{\prime} \mathrm{S}, 140^{\circ} 39^{\prime}-140^{\circ} 44^{\prime} \mathrm{E}$. Situated in lower south-east South Australia

Area 3,200 ha

Degree of Protection The area is a permanent reserve within the Bool Lagoon Game Reserve (3,022ha) and the Hacks Lagoon Conservation Park (249ha).

\section{Site Description}

Criteria for inclusion 1(a), 1(b), 1(c), 2(a), 2(b), 2(c) and 3

International and National Importance The Lagoon is an outstanding area for a wide range of waterbirds. 79 species of waterbirds have been recorded with 48 of these known to have bred there. It is particularly important for waterfowl, and common species include Pacific black duck Anas superciliosa and grey teal A. gibberifrons. Population counts have proven difficult because of vegetation cover, however, typical duck numbers are believed to commonly vary between 15,000 and 50,000, and black swan numbers between 1,000 and 5,000. Straw-necked ibis Threskiornis spinicollis and sacred ibis $T$. aethiopicus are common in the nesting season and numbers of ten exceed 50,000. A wide range of waders and nine rare species including the intermediate egret Egretta internedia and little bittern Ixobrychus minutus, also occur in the area.

Changes in Ecological Character The land immediately surrounding the Lagoons is permanent reserve, and this in turn is bordered by sheep and creal growing areas. The Bool Lagoon Game Reserve is usually opened for duck hunting on several mornings each year, but this is dependent upon suitable seasonal conditions. The presence of rare or nesting birds may also affect the decision to open the reserve to hunters.

Management Practices The wetland is artificially manipulated to act as an equalisation basin for the control of flood waters draining off surrounding farmland.

\section{Scientific Research and Facilities No information}

Principal Reference Material The above information is taken from the document 'Wetlands nominated by the state of South Australia, Australia for inclusion on the List of Wetlands of International Importance' November 1984.

\section{Macquarie Marshes Nature Reserve}

Location $30^{\circ} 40^{\prime} \mathrm{S}, 147^{\circ} 33^{\prime} \mathrm{E}$. On the lower Macquarie River between $85 \mathrm{~km}$ and $125 \mathrm{~km}$ north of Warren, New South Wales.

Area $18,200 \mathrm{ha}$ 
Degree of Protection The marshes have long been recognised as a major wildlife habitat and designated a Bird and Animal Sanctuary before 1955 when they became a Faunal Reserve. An area of 18,000 ha was established as a Nature Reserve on 22 January 1971 and dedicated under the New South Wales National Parks and Wildlife Act 1974 with by-laws under section 155 . It is government owned and managed by the National Parks and Wildlife Service of New South Wales. Designated a Ramsar site in August 1986.

Site Description The Macquarie Marshes as a whole cover 148,000ha and consist of two areas of wetland. The part within the Ramsar site is a shallow wetland seasonally inundated by flood flows in the Macquarie River, which are now artificially controlled. Wetland habitat types include red gum woodland, lignum shrubland, reedswamp and meadow grassland typical of wetlands of the semi-arid zone of Australia.

Criteria for inclusion 1(a), 2(b) and 3.

International and National Importance The area contains a large sample of wetland types of the semi-arid zone of Australia and is the largest reserved area of this type in New South Wales. It is particularly important as a breeding site for colonially nesting herons, egrets, ibises and spoonbills, and is notable for large numbers of breeding straw-necked ibis Threskiornis spinicollis and significant numbers of breeding intermediate egret Egretta intermedia, rufous night heron Nycticorax caledonicus and glossy ibis Plegadis falcinellus. Other species occurring include pacific heron Ardea pacifica, white-faced heron $A$. novaehollandiae, great white egret Egretta alba, little egret E. garzetta, sacred ibis Threskiornis spinicollis, royal spoonbill Platalea regia, yellow-billed spoonbill $P$. flavipes, black swan Cygnus atratus, black duck Anas superciliosa, grey teal A. gibberifrons, shoveler A. rhynchotis and whiskered tern Chlidonias hybrida.

\section{Changes in Ecological Character No information}

Management Practices Management of flows into the Macquarie River, a regulated stream, ensures that the area receives an adequate and appropriate water regime. This is now satisfactorily set out in a water regulation plan. An irrigation area, supplied by the Burrendong Dam, extends almost to the marshes and there are individual irrigation blocks near and downstream of the reserve. Because of potential conflict between agriculture and nature conservation, in 1983 the Water Resources Commission and National Parks and Wildlife Service jointly prepared a draft plan of management for works in the marshes. Public submissions on the plan were considered by a review committee representing both irrigation and conservation interests as well as the Service and the Commission. The New South Wales government subsequently decided not to proceed with proposed irrigation works which may have had a deleterious effect on the wetland habitat and wildlife. Work was proceeding in 1984 towards the final Plan of Management. There is also control of feral pigs, noxious plants and of agricultural development, particularly irrigation, on surrounding lands. Cattle grazing is presently permitted on the reserve, the surrounding areas being used for cattle and sheep grazing and cropping.

\section{Scientific Research and Facilities No information}

Principal Reference Material Documents supplied by the Government of New South Wales at the time of designation. 


\section{AUSTRIA}

Area $83,848 \mathrm{sq} . \mathrm{km}$

\section{Population $7,555,338$ ( 1981 census)}

Summary of Wetland Situation Much of Austria is mountainous, the Alps gradually getting lower to the east till they meet the Pannonian plains south of Vienna, where one of the most interesting wetlands of Central Europe is located, comprising the Neusiedler See and the adjacent pond area of Seewinkel. The waters of both are alkaline and extremely rich in animal and plant species. The wetlands form one of the most important breeding and moulting areas for waterfowl in Central Europe, while huge concentrations of ducks and waders can be encountered during the migration season. Both the Neusiedler See and the Seewinkel lakes have been the subject of a considerable number of limnological studies.

The river March along the border with Czechoslovakia has large stretches of intact riverine forest and wet meadows. A large WWF reserve is situated near Marchegg, protecting the breeding colony of the eastern race of cormorant Phalacrocorax carbo, and night heron Nycticorax nycticorax. Conservation measures should maintain the original character of this unique area although they do not exclude limited hunting and fishing.

A small reserve, the Hagenauer Bucht - now extended, is situated in the valley of the Lower Inn, on the border with the Federal Republic of Germany. It forms an entity with the reservoirs protected by West German territory.

A fourth site of international importance is situated in the Rhine Delta near Bregenz, where the river enters the Bodensee. An area of 1,400ha was set aside as a reserve as long ago as 1942. It has now been given the status of a Nature Reserve and it is hoped that it will be enlarged.

A number of mountain lakes and peat-bogs are clearly of more than national interest while several others are of major limnological interest and in several cases provide excellent examples of successive stages of eutrophication.

Protected Areas Legislation The Federal Parliament and Federal Government are responsible for water and forestry but the governments of the Länder (states) are responsible for nature conservation, hunting, fishing and physical planning. A special ordinance is issued by the state governments for the establishment of each protected area which designates boundaries and restrictions on the use of the area. Nature conservation in Austria is very similar to that in Germany, and the principal legal categories of protected area include landscape protection areas, national parks and nature parks. However there are wide differences in the way different states use the categories.

Protected Areas Administration The state governments are responsible for protected area administration but expert advice and assistance is available from government funded institutes and museums. The Austrian Association for Nature Conservation (Österreichischer Naturschutzbund) also forms a vital national link and has an impotant role in the 'well-being' of reserves. WWF-Austria also owns reserves, some in the Neusiedlersee area.

\section{Sites designated under the Convention}

Accession 16 December 1982, with five sites listed at accession.

The Neusiedlersee region, including the lakes in Seewinkel

Donau-March-Auen

Untere Lobau

Stauseen am Unteren Inn

Rheindelta, Bodensee 
Bundesministerium für Gesundheit und Umweltschutz, Bundesamtsgebände, Radetzkystrasse 2, 1030 Wien.

\section{The Neusiedlersee region, including the lakes in Seewinkel}

Location $47^{\circ} 45^{\prime} \mathrm{N}, 16^{\circ} 50^{\circ} \mathrm{E}$. Situated about $50 \mathrm{~km}$ southeast of Vienna in the state of Burgenland.

Area 57,000-62,500ha. The area can be divided as follows: Neusiedlersee (Austrian part) about 25,000-30,000ha; Seewinkel about 30,000ha (including: Unterer Stinkersee, Illmitzer Kirchsee, Oberer Stinkersee and Illmitzer Zicksee 447ha, Lange Lacke 312 ha, Wörthen Lacke 150ha, Fuchslochlacke $82 \mathrm{ha}$ and Neubruchlacke 47ha; and Hansag about 2,500ha).

Degree of Protection Most of the site is privately owned. The whole area is a Landscape Protection Area and includes a number of nature reserves $(1,000 \mathrm{ha}), 440 \mathrm{ha}$ of which is leased by WWF Austrian Appeal (expiring June 1985). The Austrian part of the site was accepted as a Biosphere Reserve $(25,000 \mathrm{ha})$ in January 1977. Designated as a Ramsar site in December 1982.

Site Description Neusiedlersee is the largest saltlake in Europe and the most western of a series of lakes extending through Hungary to the Soviet Union. It is alkaline and mesotrophic with an average depth of $1 \mathrm{~m}$ and low transparency. About half the lake is covered by reedbeds of Phragmites australis extending $6 \mathrm{~km}$ in places into the lake. Vegetation of the open water includes spiked water milfoil Myriophyllum spicatum and fennel pondweed Potomogeton pectinatus. Much of surrounding land is cultivated. The adjacent area of Seewinkel contains several smaller mostly alkaline lakes which lie in the western extremity of the puszta - dry grasslands thought to have evolved from the original forest cover subsequently destroyed by grazing. Alkalinity in the area is due to carbonates and sulphates in the groundwater which rises to the surface through fissures. The smaller lakes frequently dry out in summer (Neusiedlersee dried out in 1865 and 1872). The water table still fluctuates but levels are now regulated by sluices in the Einser Canal. The area is limited in the northwest by the Leitha Mountains with broadleaf forest and in the southeast by the boggy 'hansag' with acid meadows. The site contains a mosaic of many of the typical habitats of southeast Europe.

International and National Importance The site has a rich birdlife with 300 recorded species including 130 nesting. Species nesting in the reedbeds of Neusiedlersee are purple heron Ardea purpurea, great white egret Egretta alba, spoonbill Platalea leucorodia, bittern Botanus stellaris, blue throat Luscinia svecica, bearded tit Panurus biarmicus and penduline tit Remiz pendulinus. Breeding species in the Seewinkel area include white stork Ciconia ciconia, great bustard Otis tarda, avocet Recurvirostrata avosetta, curlew Numenius arquata, stone curlew Burhinus oedicnemus, black-tailed godwit Limosa limosa, greylag goose Anser anser, garganey Anas querquedula and ferruginous duck Aythya nyroca. It is an important moulting ground for greylag goose and some duck species. Large numbers of visiting migrant waterfowl in autumn and spring include 10,000 bean goose Anser fabalis, up to 30,000 white fronted goose $A$. albifrons, 60,000 greylag goose and 10,000 ducks. Birds of prey such as white-tailed eagle Haliaeetus albicilla, Imperial eagle Aquila heliaca and lesser spotted eagle A. pomarina occur here more regularly than elsewhere in Europe.

Changes in Ecological Character There is increasing disturbance from agriculture, hunting and tourism. In the Seewinkel area there is some ploughing and establishment of vineyards with extension of some existing vineyards to the edge of the ponds, and intensive use of pesticides on the vineyards. An intensive carp breeding enterprise in the reserve is disturbing the ecological balance of the pools. In only two relatively small areas is there no shooting - a small area on the Neusiedlersee and the water area of Lange Lacke with buffer zone. Many areas have been developed for tourism and the area of buildings in and near the reedbeds has doubled in the last decade. The population of great bustard is decreasing. 
Management Practices Hunting is permitted over much of the area and where prohibited, compensation is paid to owners. A subsidy from WWF Austria has recently been introduced to encourage maintenance of cattle on the puszta grasslands as the ecology of this area is dependent on grazing.

Scientific Research and Facilities Ecological and systematic research in Neusiedlersee and Seewinkel have included studies of the macrophytes, plankton and bottom fauna. There is a biological station near Illmitz.

Principal Reference Material The above information is taken from documents supplied by the Government of Austria at the time of designation in 1982.

Supplemented by:

- Carp, E. (1980). A Directory of Western Palearctic Wetlands. IUCN, Gland, Switzerland.

- Duffey, E. (1982). National Parks and Reserves of Western Europe. Macdonald and Co., London.

- Scott, D.A. (1980). A preliminary inventory of wetlands of international importance for waterfowl in west Europe and northwest Africa. IWRB Special Publication No. 2.

Additional references:

- Festetics, A. and Leisler, B. (1970). Ökologische Probleme der Vögel des Neusiedlerseegebietes, besonders des WWF Reservates Seewinkel. (III Teil: Möwen und Watvogel IV. Teil Sumpf- und Feldvogel).

- Guglia, O. and Festetics, A. (1969). Pflanzen und Tiere des Burgenlandes. Österreichischer Bundesverlag, Wien.

- Koenig, O. (1961). Das Buch von Neusiedlersee. Vienna.

- Löffler, H. (1974). Der Neusiedlersee, Naturgeschichte eines Steppensees. Verlag Fritz Wolden, Wien. (Includes large bibliography)

- Löffler, H. (1959). Zur limnologie des Seewinkelgebietes. Sitz. ber. Öster. Ak. Wiss. math. nat. Kl(1) 168: 315-362.

- Zimmerman, R. (1944). Beiträge zur Kenntnis der Vogelwelt des Neusiedlergebiet. (Sonderdruck aus dem I. teil des Bd. 54 der Annalen der Naturhistorischen Museum in Wien, 1943.) Selbstverlag der Wiss. Staatmuseen.

\section{Donau-March-Auen}

Location $48^{\circ} 27^{\prime} \mathrm{N}, 16^{\circ} 50^{\prime} \mathrm{E}$. Situated east of Vienna on the Austrian/Czechoslovakian border in the state of Niederösterreich.

\section{Area 38,500 ha}

Degree of Protection The site is partly protected within an area of six nature reserves, totalling $2213 \mathrm{ha}$, including the Marchauen-Marchegg Nature Reserve (1,150ha) with $50 \%$ WWF Austria ownership and $50 \%$ private ownership. Designated as a Ramsar site in December 1982.

Site Description The site comprises a strip of land either side of the River Danube between the state of Vienna and the Czechoslovakian border; a strip of land along the River March from its confluence with the Danube to south of the Czeckoslovakian town of Breclav; and a strip along the Thaya from Bernhardsthal to its confluence with the March. It contains riverine marshes, ponds, oxbow lakes and meadows with vegetation including alder Alnus sp. and original woodland.

International and National Importance The site comprises one of the last areas of relatively undisturbed habitat of its type in Central Europe which supports about 245 vertebrate species and at least another 100 non-breeding or wintering bird species. There are important breeding colonies of cormorant Phalacrocorax carbo sinensis, grey heron Ardea cinerea and night heron Nycticorax nycticorax. Other breeding birds include black stork Ciconia nigra, white stork Ciconia ciconia, greylag goose Anser anser and several duck species. The site is also important for migrant ducks and geese. 
Changes in Ecological Character Artificial drainage has damaged some important feeding grounds and the proposed Danube-Oder canal may threaten the area. There were plans for the construction of an hydroelectric power station at Hainburg, which faced strong opposition particularly from national and international conservation bodies. This resulted in an injunction on 3 January 1985, preventing construction for a one year period. In early 1986 a decision was taken to abandon the project. The scheme essentially consisted of an hydroelectric dam (the 10th in a series along the Austrian section of the Danube), positioned at the eastern end of two retaining walls which were to have extended some $20 \mathrm{~km}$ upstream - effectively creating a funnel some $16 \mathrm{~m}$ high into which the waters of the Danube would have flowed. The Austria Danube Power Corporation (DOWK), partly owned by the Federal Government, put in successfully for planning permission. The diversion of the Danube into this concrete funnel would have directly destroyed some 800 ha of prime riverine forest (out of a total of some $8000 \mathrm{ha}$ ) and would have prevented the forests from being flooded. It is likely that this would have caused irreparable ecological damage both downstream and upstream, affecting the contiguous forest areas of the Untere Lobau in Vienna and the March/Thaya system to the north.

\section{Management Practices No information}

\section{Scientific Research and Facilities No information}

Principal Reference Material The above information is taken from documents supplied by the Government of Austria at the time of designation in 1982.

Supplemented by:

- Carp, E. (1980). A Directory of Western Palearctic Wetlands. IUCN, Gland, Switzerland.

- Duffey, E. (1982). National Parks and Reserves of Western Europe. Macdonald and Co., London.

- IWRB Bulletin No. 47 (1981). Slimbridge, Glos., England.

- Scott, D.A. (1980). A preliminary inventory of wetlands of international importance for waterfowl in west Europe and northwest Africa. IWRB Special Publication No. 2.

\section{Untere Lobau}

Location $48^{\circ} 10^{\prime} \mathrm{N}, 16^{\circ} 30^{\prime} \mathrm{E}$. Situated in the south-east of the state of Vienna.

\section{Area 1,039ha}

Degree of Protection The site is owned by the state of Vienna and is part of a nature reserve and landscape protection area $(2,000 \mathrm{ha})$, protected by Lobauverordnung LGBI für Wien $\mathrm{Nr}$. 32/1978. The Ramsar site has full nature reserve status on the basis of legislation LGB1 für Wien Nr. 6/1985. Accepted as a Biosphere Reserve in October 1977. Designated as a Ramsar site in December 1982.

Site Description The site is an alluvial riverside landscape with a wide range of habitats including original woodland, thorn-scrub, reedswamp, pools, oxbow lakes, gravel deposits and dry grassland. It is bounded to the west by the Donau-Oder canals and to the south by Hubertus dam. The eastern edge is contiguous with Donau-March-Auen (Ramsar site).

International and National Importance The site combines with the adjoining Danube water meadows to the east to constitute the largest surviving area of its type in Europe. Birds include kingfisher Alcedo atthis, herons Ardea sp., storks Ciconia sp., penduline tit Remiz pendulinus, black woodpecker Dryocopus martius and white-tailed eagle Haliaeetus albicilla.

Changes in Ecological Character There were plans for the construction of an hydroelectric power station scheme at Hainburg, which could have had serious affects on the riverine habitats both upstream and downstream of the dam site. This is discussed further in the description of the site Donau-March-Auen. A dam on the Danube within Vienna has been suggested as an alternative to Hainburg which may affect this site. 
Management Practices There are two core zones surrounded by a buffer zone. Some agriculture and logging is allowed in the buffer zone.

Scientific Research and Facilities Research includes vegetation mapping including investigation of aquatic and semiaquatic communities and limnological studies of the backwaters and oxbow lakes. It is planned to establish a research centre near the buffer zone in the near future.

Principal Reference Material The above information is taken from documents supplied by the Government of Austria at the time of designation in 1982.

Supplemented by:

- Documents submitted to the Man and Biosphere Bureau by the Government of Austria.

- Duffey, E. (1982). National Parks and Reserves of Western Europe. Macdonald and Co., London.

Additional reference:

- Naturgeschichte (1972), Verl Jugend u Volk. Wiens

\section{Stauseen am Unteren Inn}

Location $48^{\circ} 16^{\prime}-22^{\prime} \mathrm{N}, 13^{\circ} 04^{\prime}-23^{\prime} \mathrm{E}$. Situated on the border with the Federal Republic of Germany, west of the city of Linz in the state of Oberosterreich.

Area 870ha

Degree of Protection The site includes Hagenauer Bucht Nature Reserve (166ha). Designated as a Ramsar site in December 1982.

Site Description The site comprises three sections of the River Inn: from Braunau to Frauenstein including the nature reserve at Hagenau; from Obersunzing to Obernberg; and from Reichersberg to just before Gerau. These sections are contiguous with parts of the Unterer Inn zwischen Haiming und Neuhaus Ramsar site in the Federal Republic of Germany. The site includes sandbanks, mudbanks, shallow bays and meadow woodland at the river edge.

International and National Importance The habitat of the site provides an important breeding area for waterfowl. The site is also important for large numbers of migrant and wintering waterfowl. There is an estimated 40,000 waterfowl at the site in autumn.

Changes in Ecological Character None reported (up to December 1982)

Management Practices No information

Scientific Research and Facilities No information

Principal Reference Material The above information is taken from documents supplied by the government of Austria at the time of designation in 1982.

Supplemented by:

- Duffey, E. (1982). National Parks and Reserves of Western Europe. Macdonald and Co., London.

- Scott, D.A. (1980). A preliminary inventory of wetlands of international importance for waterfowl in west Europe and northwest Africa. IWRB Special Publication No. 2. 


\section{Rheindelta Bodensee}

Location $47^{\circ} 30^{\prime} \mathrm{N}, 9^{\circ} 45^{\prime} \mathrm{E}$. Situated near the border with Switzerland and the Federal Republic of Germany in the state of Vorarlberg.

Area 1,960 ha

Degree of Protection Most of the site is protected in a nature reserve established in 1942 (1400ha) and renewed in 1976. Designated as a Ramsar site in December 1982.

Site Description The site comprises the freshwater delta marshes of the Rhine River where it enters the Bodensee; the adjacent lake area; and about $250 \mathrm{ha}$ landward of the nature reserve in the area of the Fussach pumpworks. The landward boundary of the nature reserve runs $8 \mathrm{~km}$ eastwards from the old mouth of the Rhine along embankments to just beyond the present river mouth. The boundary is about $1 \mathrm{~km}$ into the lake.

International and National Importance The site is one of the most important areas in central Europe for migrant waders and is also important for breeding and passage waterfowl including garganey Anas querquedula, shoveler A. clypeata and red-crested pochard Nelia rufina.

Changes in Ecological Character None reported (up to December 1982)

Management Practices No information

Scientific Research and Facilities No information

Principal Reference Material The above information is taken from documents supplied by the Government of Austria at the time of designation in 1982.

Supplemented by:

- Scott, D.A. (1980). A preliminary inventory of wetlands of international importance for waterfowl in west Europe and northwest Africa. IWRB Special Publication No. 2. 


\section{BELGIUM}

Area $9,860,000(1982)$

Population 30,512 sq. $\mathrm{km}$

Summary of Wetland Situation In Belgium most of the wetlands of international importance to waterfowl are situated in the flat low-lying coastlands, along the north-western borders of the country. Thousands of sea-duck also winter in off-shore territorial waters (for example, 8,500 scoters Melanitta nigra were observed on the Vlaamse Banken in February 1972). The Zwin reserve, located in dunes just south of the Dutch border, includes a brackish lake complex that is a habitat for many species of Anatidae, as well as large numbers of Laridae and Limicolae. The reserve is of special educational value and has up to 400,000 visitors a year. The Yser Estuary has been given 'classified landscape' status and is the site of various field courses organized annually by the University of Ghent. Traditional goose wintering grounds near Damme harboured up to 8,750 white-fronted geese Anser albifrons and a maximum of 1,500 pink-footed goose $A$. brachyrhynchus in the winter of 1973/74. Buffer zones and secondary reserves in the polders north and west of Bruges (Moene in Meetkerke) seem essential for the effective protection of these wintering flocks.

Blankaart Lake and the Broeken grasslands are situated in a distinctive wetland area formed by the floodplain of the Yser. Although since the construction of a large reservoir in the area, the Broeken polder has been less often flooded in recent years, the total numbers of waterfowl have not declined, though there has been some loss of breeding habitat.

The polders on the left bank of the River Schelde, which include amongst others the Doel, Kallo and Verrebroek, form a wetland unit with the Verdronken Land of Saeftinge beyond the Netherlands border downstream, many duck such as teal Anas crecca and wigeon $A$. penelope moving freely between the two sites. The area is also an important wintering ground for geese, numbers of bean goose Anser fabalis and white-fronted goose $A$. albifrons being up to 4,000 and 2,500 respectively. Kalmthout Heath and the associated heathland of

Brecht and Wuustwezel, $30 \mathrm{~km}$ north-east of Antwerp are a classified landscape part of which has been made into a state reserve of $850 \mathrm{ha}$. There are several oligotrophic fens of scientific interest in the area, such as Putse Moer and Stappens Ven, though they have to some extent been adversely affected by pumping for the local drinking water supplies. Up to 3,500 whimbrel Numenius phaeopus have their winter roost in the area.

Apart from the flat low-lying coastlands, the Harchies marshes $70 \mathrm{~km}$ south-west of Brussels are a part of a wetland unit that extends beyond the French border. This area is an important habitat for many reedbed birds, including bluethroat Luscina svecica and bittern Botaurus stellaris, and is of value as a wintering ground for a wide variety of waterfowl. Not far from there, the lake of Virelles, now a private protected area, displays similar characteristics.

Located $50 \mathrm{~km}$ south-east of Liege within the Ardennes mountains, the nature park of the Hautes-Fagnes and its nature reserve contain extensive areas of peatlands that are of speial interest for their flora and fauna. In the southernmost part of the country the marshes of the upper Semois river are also of considerable interest. Near St. Lenaarts some abandoned clay-pits have recently become of considerable value for waterfowl.

Protected Areas Legislation According to the law of institutional reforms of 8 August 1980 the Belgian regions are now individually vested with responsibility for nature conservation. However, the principal act remains the law on nature conservation of 12 July 1973 . Another important act for the Walloon region is the decree related to nature parks of 16 July 1985 . The nature conservation act provides for the creation of nature reserves forest reserves and nature parks. Nature reserves are either state-owned reserves or privately-owned approved reserves, the latter subject to an agreement between the regional Minister responsible for nature conservation and the landowner. In the Walloon region, nature parks are multiple use areas, 
which may include villages and local industries; human activities are allowed to continue with some restrictions. Their main objectives are the conservation of the character, diversity and scientific values of the environment and of the natural flora and fauna without forgetting their importance for recreation and tourism.

Protected Areas Administration Responsibility for administering the Nature Conservation Act is vested in the regional authorities. In the Flemish region the Directorate for Nature Conservation is a part of the Administration for Land Management and Environment. The "Institut voor Natuurbehoud" (Nature Conservation Institute) has been created within this administration to do special research and give scientific advice. In the Walloon region the Directorate for Nature Conservation is a part of the Administration of Natural Resources and Environment. These authorities are responsible for all matters of nature conservation including drafting new decrees, coordination of the advisory committees and the Regional Nature Conservation Councils, all matters relating to purchase of reserves and public relations. A number of private conservation organisations also own nature reserves or have taken over the management of reserves.

Sites designated under the Convention Signature without reservation as to ratification 4 March 1986, with six sites listed.

Les Vlaamse Banken dans les eaux côtières

Les Schorren de l'Escaut à Doel et à Zandvliet

Le Zwin

Le Blankaart

Kalmthoutse Heide

Le Marais l'Harchies

Government body responsible for administration of the Convention

Ministère de l'Agriculture, Administration de la Recherche Agronomique, Manhattan Center 7 ème étage, Avenue du Boulevard 21, B 1210 Brussels.

\section{Les Vlaamse Banken dans les eaux côtières}

Location $51^{\circ} 20^{\prime} \mathrm{N}, 3^{\circ} 00^{\circ} \mathrm{E}$. Parts of the North Sea within Belgian territorial waters between Dunkerque and Ostend, where depth is less than $6 \mathrm{~m}$.

Area 1,900 ha

Degree of Protection Designated as a Ramsar site on 27 September 1984, although Belgium did not actually ratify until March 1986.

Site Description The site includes the lowest zone of the beach, extending up to several kilometres offshore and including a series of shallows. Some parts have a rich benthic fauna.

International and National Importance The site is on part of the Belgian coast which is of international importance for migratory waterbirds in particular. Passage birds include Mediterranean gull Larus melanocephalus, little gull L. minutus, sandwich tern Sterna sandvichensis, common tern S. hirundo and little tern $S$. albifrons. Birds wintering in the area include sanderling Calidris alba (450 January average), common scoter Melanitta nigra (4000 January average, maximum 85000), turnstone Arenaria interpres (maximum 400), great crested grebe Podiceps cristatus and eider Somateria mollissima.

Changes in Ecological Character Sand extraction occurs at sea with consequent lowering of the water-table. Extraction of drinking water. An atomic power station is also apparently planned for the area.

Management Practices All hunting is prohibited along the beach and up to $1852 \mathrm{~m}$ off shore. 


\section{Principal Reference Material}

- Kuikjen, E. (1972). Belgian wetlands of international importance for waterfowl. Proc. Int. Cong. Conserv. of Wetlands and Waterfowl,Ramsar 1971: 179-188.

- Kuijken, E. (1976). Belgium national report on wetlands. Proc. Int Congr. Conserv. of Wetlands and Waterfowl, Heiligenhafen, 1974: 81-83.

- Scott, D.A. (1980). A preliminary inventory of wetlands of international importance for waterfowl in West Europe and Northwest Africa. IWRB Special Publication No. 2, 127pp.

\section{Les Schorren de l'Escaut à Doel et à Zandvliet}

Location $51^{\circ} 19^{\prime} \mathrm{N}, 4^{\circ} 15^{\prime} \mathrm{E}$. Along the lower Scheldt river, north of Antwerp. The site includes Schorren at Doel (Beveren), Galgenschoor at Lillo (Anvers) and Groot Buitenschoor at Zandvliet (Anvers)

Area Total 445ha; Schorren at Doel 115ha; Galgenschoor 155ha; Groot Buitenschoor 175 ha.

Degree of Protection All three sites are classified as Protected Landscapes on rural planning maps and proposed as Nature Reserves. Groot Buitenschoor and Galgenschoor are defined as private nature reserves, as officially agreed by the Flemish government. They are now state owned and managed by De Belgische Natuur- en Vogelreservaten. Designated a Ramsar site on 27 September 1984, although Belgium did not actually ratify until March 1986.

Site Description These sites are the last brackish tidal marshes and mud flats along the lower Scheldt river. The marshes have characteristic plant species including Scirpus maximus, Cochlearia officinalis, Aster tripolium, Atriplex hastata. Puccinellia sp., Elytrigia pungens, Triloglochin maritima and Glaux maritima. There is a larger area of such habitat on adjacent Dutch territory, covering $3000 \mathrm{ha}$.

International and National Importance This site is an important area for wintering and migratory water birds, particularly as feeding grounds. These include great crested grebe Podiceps cristatus (maximum 85), cormorant Phalacrocorax carbo (maximum 35), mute swan Cygnus olor (max 10), whistling swan Cygnus columbianus (maximum 30), bean goose Anser fabalis (maximum 800), white-fronted goose A. albifrons (maximum 2000), greylag goose $A$. anser (maximum 270), common shelduck Tadorna tadorna (maximum 2860), wigeon Anas penelope (maximum 3000), A. strepera (maximum 85), green-winged teal A. crecca (maximum 2830), mallard $A$. platyrhynchos (maximum 6230), pintail $A$. acuta (maximum 200), shoveler $A$. clypeata (maximum 1080), pochard Aythya ferina (maximum 165), tufted duck A. fuligula (maximum 830), eider Somateria mollissima (maximum 45), avocet Recurvirostra avosetta (maximum 1800), golden plover Pluvialis apricaria (maximum 2000), dunlin Calidris alpina (maximum 2900), black-tailed godwit Limosa limosa (maximum 800 ) and ruff Philomachus pugnax (maximum 1400). It is also a breeding arera for marsh harrier Circus aeruginosus.

Changes in Ecological Character Pollution of the Galgenschoor by chemical industries is occurring. The building of a large container terminal, connected with the port of Antwerp, is planned which would reduce the area of mudflat at low tide.

Management Practices Reed mowing is carried out.

Scientific Research and Facilities There has been ornithological research including censuses, and guided educational visits are conducted. 


\section{Principal Reference Material}

- Kuijken, E. (1972). Belgian wetlands of international importance for waterfowl. Proc. Int. Congr. Conserv. of Wetlands and Waterfowl, Ramsar, 1971: 179-181.

- Kuijken, E. (1976). Belgian national report on wetlands. Proc. Int. Congr. Conserv. of Wellands and Waterfowl, Heiligenhafen,1974: 81-83.

- Scott, D.A. (1980). A Preliminary Inventory of Wetlands of International Importance for Waterfowl in West Europe and Northwest Africa. IWRB Special Publication no.2; pp. 127.

\section{Le Zwin}

Location $51^{\circ} 21^{\prime} \mathrm{N}, 3^{\circ} 22^{\prime} \mathrm{E}$. Located near Knokke-Heist, on the Netherlands border, $18 \mathrm{~km}$ north-east of Bruges.

\section{Area 550ha}

Degree of Protection The site is designated a Classified Landscape and Nature Reserve on rural planning maps. It is privately-owned, managed by the Réserves Naturelles et Ornithologiques de Belgique. 125ha of the Nature Reserve is in Belgium and it extends a further 25 ha into the Netherlands, with a further 1,500ha of buffer zone. It was designated a Ramsar site on 27 September 1984, although Belgium did not actually ratify until March 1986.

Site Description The reserve consists mainly of a tidal salt marsh including mudflats, creeks and ponds, in the area of the Schelde-Meuse-Rhine delta. The site is the southernmost remainder of a late mediaeval estuary. It is enclosed by $1.5 \mathrm{~km}$ of dunes to the north and by dykes to the south and west. An open connection to the North Sea is formed by a shallow creek at the eastern end which feeds a system of four brackish lagoons, the whole area of ten flooding during winter and at spring tides. Lower areas have salt marsh vegetation in various stages of colonisation, including glasswort Salicornia europaea, seablite Suaeda maritima and sea lavender Limonium vulgare. The variety in microrelief and variation in salinity between saltwater and fresh create a variety of habitats, particularly good for invertebrates. The buffer zone includes sandy grasslands on a former airfield, wet and dry dunes with shrubs and polder areas which have clay soils and consist of ploughed fields.

International and National Importance The site has large populations of migrant, wintering and breeding birds. Breeding birds include grey heron Ardea cinerea (70 pairs), shelduck Tadorna tadorna (60 pairs), avocet Recurvirostra avosetta (40-60 pairs), black-headed gull Larus ridibundus (3400 pairs), common tern Sterna hirundo (370 pairs), mallard Anas platyrhynchos, garganey A. querquedula, oystercatcher Haematopus ostralegus, kentish plover Charadrius alexandrinus and, rarely, ringed plover $C$. hiaticula and mediterranean gull Larus melanocephalus (1-6 pairs). Migrant and wintering birds include little grebe Tachybaptus ruficollis (maximum 20), avocet (maximum 540), bean goose Anser fabalis (average 1000). Large numbers of waders include curlew Numenius arquata (January average 1200, maximum 1700) and whimbrel (maximum 950). There are thousands of migrant and wintering ducks Anatidae and more than 20,000 gulls Larus spp. roost.

Changes in Ecological Character There is some grazing and shooting in the buffer zone where there are also plans to develop recreation.

Management Practices In 1960, three large lagoons connected with tidal creeks were created, as part of works meant to improve the dykes, and have encouraged waterfowl to remain and breed. There is some feeding of birds to attract them for educational and ringing purposes and some are kept in aviaries or semi-confined in enclosures. In the wildlife park, adjacent to the reserve, feral populations of greylag geese Anser anser, night heron Nycticorax nycticorax and white stork Ciconia ciconia have been built up, starting with wounded birds which could not fly, which are not confined. The water level in one of the salt marsh ponds can be regulated. Some of the saltings are grazed by sheep. The influx of over 300,000 visitors a year is properly controlled. 
Scientific Research and Facilities Experimental reintroduction of geese, night heron and white stork has occurred. The $\mathrm{Zwin}$ is important for ornithological and botanical studies and is well-established as an educational centre.

\section{Principal Reference Material}

- Carp, E. (Ed.) (1980). A Directory of Palearctic Wetlands. IUCN, Gland, Switzerland.

- Duffey, E. (1982). National Parks and Reserves of Western Europe. Macdonald and Co., London.

- Kuijken, E. (1972). Belgian wetlands of international importance. In Proc. Internat. Conf. on Conservation of Wetlands and Waterfowl, Ramsar, Iran, 1971, Slimbridge. IVRB publication. Pp. 179-188.

- Kuijken, E. (1976). Belgian wetlands of international importance for waterfowl. Proc. Int. Congr. Conserv. of Wetlands and Waterfowl, Ramsar, 1971: 179-188.

- Kuijken, E. (1980). Belgium national report on wetlands. Proc. Int Congr Conserv. of Wetlands and Water fowl, Heiligenhafen, 1974: 81-83.

- Noirfalise, A., Huble, J. and Delvingt, W. (1970). Les Réserves Naturelles de la Belgique. Ministère de l'Agriculture, Bruxelles, Belgium.

- Scott, D.A. (1980). A Preliminary Inventory of Wetlands of Internationa l Importance for Waterfowl in West Europe and Northwest Africa. IWRB Special Publication no. 2, pp. $12 i$.

- Scott, D.A. (1980). A preliminary inventory of wetlands of international importance for waterfowl in West Europe and Northwest Africa. IWRB Special Publication No. 2.

\section{Le Blankaart}

Location $50^{\circ} 59^{\prime} \mathrm{N}, 02^{\circ} 51^{\prime} \mathrm{E}$. Located in the municipality of Woumen (Dixmude), to the south-east of the River Yser.

Area 160ha

Degree of Protection 81 ha are protected as a reserve, included in a non-shooting area of $400 \mathrm{ha} ; 71 \mathrm{ha}$ of the reserve are owned by the Réserves Naturelles et Ornithologiques de Belgique and 10 ha by the state. On rural planning maps the reserve proper is designated a Nature Reserve and the buffer zone an Ecologically Important Agricultural Landscape. Designated as a Ramsar site on 27 September 1984, although Belgium did not ratify until March 1986.

Site Description The site includes a shallow freshwater lake of about 70 ha with about 50 ha of open water lying on the edge of a sandy-loam region in the plain of the River Yser. The lake originated from earlier exploitation of peat in the valley of the Yzer river and has gradually been silting up, resulting in wide expanses of reedbeds Phragmites australis and fringing willow Salix sp. Other typical plants include marsh vetches Lathyrus palustris, sea milkwort Glaux maritima and marsh marigold Caltha palustris. The surrounding areas include hay fields and grasslands with a network of ditches supporting a variety of plants. Within the reserve is an abandoned duck decoy.

International and National Importance The lake is an important breeding site for little grebe Tachybaptus ruficollis and great crested grebe Podiceps cristatus (maximum 20), reintroduced grey heron Ardea cinerea (maximum 30), bittern Botaurus stellaris, little bittern Ixobrychus minutus, water rail Rallus aquaticus, mallard Anas platyrhynchos, shoveler $A$. clypeata, pintail A. acuta, garganey A. querquedula, cetti's warbler Cettia cetti and marsh harrier Circus aeruginosus. It is also of great importance for the overwintering of some 20,000 Anatidae, 20-30,000 Limicolae and an increasing number of swans. Cormorant Phalacrocorax carbo and white stork Ciconia ciconia have been reintroduced. Otter Lutra lutra also breed in the reserve and ermine Mustela erminea is abundant. The site is also of botanical value with rare species such as Lathyrus palustris and Ranunculus lingua. 
Changes in Ecological Character The lowering of the watertable for agricultural development which is part of the policy of the polder authorities could seriously affect the reserve. Natural silting up and eutrophication is causing extension of the Phragmiles beds which are subsequently colonised by willow. Peat extraction occurs in part of the buffer zone.

Management Practices Shooting is now prohibited over the whole reserve. Access is restricted to guided visits except to the adjacent park and no fishing is allowed. A number of new nesting-places have been created and a breeding colony of 90 pairs of grey heron established. Efforts are being made to encourage cormorant to breed although so far only wintering flocks are present. Reed mowing is allowed.

Scientific Research and Facilities Several thousand birds are ringed annually. Intensive botanical and entomological research is continuing. In general the scientific and educational value of the site is well recognized.

\section{Principal Reference Material}

- Carp, E. (Ed.) (1980). A Directory of Palearctic Wellands. IUCN, Gland, Switzerland.

- Duffey, E. (1982). National Parks and Reserves of Western Europe. Macdonald and Co., London.

- Kuijken, E. (1972). Belgian wetlands of international importance. In Proc. Internat. Conf. on Conservation of Wetlands and Waterfowl, Ramsar, 1971. pp. 179-188.

- Noirfalise, A., Huble, J. and Delvingt, W. (1970). Les Réserves Naturelles de la Belgique. Ministère de l'Agriculture, Bruxelles, Belgium.

- Scott, D.A. (1980). A preliminary inventory of wetlands of international importance for waterfowl in West Europe and Northwest Africa. IWRB Special Publication No. 2.

\section{Kalm thoutse Heide}

Location $51^{\circ} 23^{\prime} \mathrm{N}, 4^{\circ} 28^{\prime} \mathrm{E}$. Located north-east of Antwerp in the municipalities of Kalmthout and Essen in the province of Anvers.

Area 4,045ha

Degree of Protection An area of wetlands covering 850 ha has had the status of a State Nature Reserve since 24 September 1968 but the area as a whole has the status of a Landscape Reserve. $80 \mathrm{ha}$ are State owned and $732 \mathrm{ha}$ municipal territory. Designated as a Ramsar site on 27 September 1984, although Belgium did not ratify until March 1986.

Site Description An area of marsh, heath, old dunes and woodlands, partly bordering the delta of the river Schelde. Vegetation includes dune grasslands of marram Ammophila arenaria, dry heath dominated by ling Calluna vulgaris, and wet heath with bog heather Erica tetralix and willows Salix sp. The oligotrophic marshes are of great interest being the southernmost examples of the type and the only examples in Belgium. The scattered tree cover includes stands of oak Quercus, birch Betula and fir Abies species. The reserve has great entomological interest and over $90 \%$ of the dragonflies (Odonata) known in Belgium can be found there.

International and National Importance The Kalmthout wetlands are important for breeding and wintering water birds. Breeding birds include mallard Anas platyrhynchos, gadwall A. strepera, pochard Aythya ferina and common shelduck Tadorna tadorna. Wintering and migrant birds include black-necked grebe Podiceps nigricollis, pintail Anas acuta (maximum 170), shoveler A. clypeata (maximum 300), tufted duck Aythya fuligula (maximum 110 ), pochard A. ferina (maximum 130), spotted crake Porzana porzana and curlew Numenius arquata (over 3000). It is also an important roosting area for large numbers of other waders like whimbrel Numenius phaeopus (3000-6000) and black-tailed godwit Limosa limosa (maximum 900). The rare bog orchid Hammarbya paludosa occurs in the marshes. 
Changes in Ecological Character None reported in the reserve itself but the surrounding buffer areas suffer somewhat from pumping of groundwater for drinking and increasing agricultural demands.

Management Practices Private properties within the area are fenced and closed and the Nature Reserve is generally inaccessible to the public, particularly in the breeding season. Authorised visitors, several tens of thousands each year, are encouraged to keep strictly to paths. Prohibitions on human activities include habitation, cultivation, hunting, fishing, pasturing and woodcutting (except from limited forestry permitted on private holdings). Rabbits are limited and some gull colonies on oligotrophic fens are controlled to minimise guano accumulation. The heathland is grazed by a local breed of sheep, which prevent trees from becoming established. An important part of the wet heathland is managed in order to maintain optimal water level by small dams.

Scientific Research and Facilities There is a well-established centre for research and education set up by the University of Antwerp. Its Department of Biology has carried out research on terrestrial ecology and published a number of reports between 1977 and 1980 .

\section{Principal Reference Material}

- Carp, E. (Ed.) (1980). A Directory of Palearctic Wetlands. IUCN, Gland, Switzerland.

- Duffey, E. (1982). National Parks and Reserves of Western Europe. Macdonald and Co., London.

- Kuijken, E. (1972). Belgian wetlands of international importance. In Proc. Internat. Conf. on Conservation of Wetlands and Waterfowl, Ramsar, Iran, 1971, Slimbridge. IWRB publication. Pp. 179-188.

- Noirfalise, A., Huble, J. and Delvingt, W. (1970). Les Réserves Naturelles de la Belgique. Ministère de l'Agriculture, Bruxelles, Belgium.

\section{Les Marais d'Harchies}

Location $50^{\circ} 30^{\prime} \mathrm{N}, 3^{\circ} 40^{\prime} \mathrm{E}$. Between Mons and Tournai in the municipalities of Bernissart and Hensies.

\section{Area 535ha}

Degree of Protection An important part of the site (385ha) is protected as a Strict Nature Reserve, owned by the Institut royal des Sciences naturelles de Belgique, les Réserves naturelles et ornithologiques de Belgique. Designated a Ramsar site on 27 September 1984, although Belgium did not actually ratify until March 1986.

Site Description It includes 90 ha of open fresh-water pools and ponds with reedbeds of Phragmites australis, Typha latifolia, T. augustifolia and areas of sedges Carex spp., rushes Juncus spp., willows Salix spp. and wet meadows.

International and National Importance This site contains significant areas of reedbeds (which are becoming rare in Belgium), and is an important area for birds associated with them, as well as being used by many wintering and migrant waterbirds. More than 90 bird species nest in the area, the most notable being great bittern Bolaurus stellaris, little bittern Ixobrychus minutus, night heron Nycticorax nycticorax, bluethroat Luscina svecica, great reed warbler Acrocephalus arundinaceus and marsh harrier Circus aeruginosus. The main wintering birds include teal Anas crecca, tufted duck Aythya fuligula, pochard A. ferina and migrants include gadwall Anas strepera and waders. Rare plants include Thelipteris palustris, Dryopteris cristala, Dactylorhiza incarnata, Epipactis palustris, Utricularia vulgaris, Samolus valerandi, Cyperus fuscus and Scirpus tabernaemontani.

Changes in Ecological Character Water quality has been improved recently and the area of reedbeds increased. 
Belgium

Management Practices Water quality has been improved by not using fertiliser on the meadows. Water level stabilisation and the harvesting and burning of old reedbeds has allowed their area to extend. Fishing and hunting are prohibited.

Scientific Research and Facilities Research is carried out on water chemistry, macrophyte productivity, and reedbed structures; and bird populations are censused regularly. There is an educational centre for visitors, and accomodation for scientists may be available.

\section{Principal Reference Material}

- Dendal, A. and Verhaegen, J.P. (1985). Quelques observations d'orchidées dans le bassin de la Haine. Nat. belg. 66: 163-172.

- Verhaegen, J.P. (1981). Deux ans de gestion au Centre de Recherches biologiques d'Harchies. Bull. Inst. roy. Sciences nat. Belgique 53:1-14.

- Verhaegen, J.P. and Anrys, P. (1984). Rapport ornithologique du Centre de Recherches biologiques d'Harchies pour l'année 1983. Gerfaut 74 


\section{BULGARIA}

Area $110,911 \mathrm{sq} . \mathrm{km}$

\section{Population $8,929,332$ (1983 census)}

Summary of Wetland Situation Many Bulgarian coastal lakes and marshlands have been drained or modified since 1944 , to an extent that the area has become notably less attractive as habitat for breeding and migratory waterfowl. Recently there have been reports of a number of measures being taken to conserve what remains of a once very rich waterfowl habitat.

Lake Srébarna is one of the most important inland lakes in the country and notable amongst other things as a traditional breeding site of the dalmation pelican Pelecanus crispus, a species which has declined seriously in recent years and now rates as 'vulnerable' in the Red Data Book. A number of recent changes affecting the fauna and flora of Srébarna have followed the separation of the lake from the Danube by the construction of a dam. The pelicans now do most of their feeding in the nearby Romanian marshes.

The former nesting place of the white pelican Pelecanus onocrotalus in the marshes of Lake Mandra near Burgas has become so altered as to make it unsuitable, but four reserves have been established which may encourage it to breed again in Bulgaria. Precise information is lacking about what are probably still important wetland sites in the black Sea coastlands near Shabla and Varna, as well as in the Burgas-Pomorie complex. The same applies to a number of other Bulgarian wetlands, including Lake Zrebcevo near Stara Zagora, the Danube islands of Wardim and Belene, where breeding colonies of herons and cormorants have been recorded, the Balabana swamp forest near Elcheve, and the mouths of the rivers Kamchiya and Batova, south of Varna.

In 1978 the Committee for Reservation of Natural Environment developed a programme to reduce and remove pollution, and to close water consumption cycles. Much of the programme has been successfully fulfilled.

Protected Areas Legislation In Bulgaria, preservation of nature is an integral part of the Unified Plan for social and economic development, and is covered by a number of legislative and government acts. Particularly important are the law for Proteciton of the Air, Waters and Soil from Pollution (1963), the Law on Nature Protection (1967), the law on Water Resources (1969) and the law on Conservation of Arable land and Pastures (1973). The Guidelines for the Protection and Reproduction of the Natural Environment in Bulgaria were approved by State Council in 1977. Reserves are by definition strict nature resrves. This law is regulated by the 1969 Code of Application. Proposals for new sites can be submitted by any interested party, and may be declared by the Committee for Preservation of Natural Environment after consultation with the Academy of Sciences and other interested departments.

Protected Areas Administration The Ministry of Forests and Environmental Protection was set up in 1971, and has concentrated its attention on the protection of natural sites. The Committee for Preservation of Natural Environment at the Council of Ministers (set up in 1967) controls, coordinates and implements the policy and decisions of the national government and legislature on questions of environmental protection and reclamation, and the comprehensive utilization of water resources. Detailed checks were made in 1977 of the state of the reserves, and statements of violation drawn up. This led to improvements in the network over the following years, and the checks have continued. 
Sites designated under the Convention

Signature without reservation as to ratification 24 September 1975, with two sites listed at signature, and another two added 28 November 1984

Srébarna Waterfowl Reserve

Arkoutino Waterfowl Reserve

Atanassovo Lake Nature Reserve

Durankulak Lake Natural Landmark

Government body responsible for administration of the Convention

Scientific Research Centre for the Protection of Natural Environment and Water Resources, 1202 Sovia, UL Industrialna 7

\section{Srébarna Waterfowl Reserve}

Location $44^{\circ} 05^{\prime} \mathrm{N}, 27^{\circ} 07^{\prime} \mathrm{E}$. Srébarna Lake is $19 \mathrm{~km}$ west of the town of Silistra and $1 \mathrm{~km}$ south of the Danube (which forms the border with Romania) in Silistra province, northeast Bulgaria.

\section{Area 600 ha}

Degree of Protection State owned. The Committee for Preservation of Natural Environment at the Council of Ministers of Bulgaria is responsible for the implementation of the Ramsar Convention. The reserve is administered in collaboration with the Research and Coordination Centre for the Protection and Restoration of the Environment. The lake area was declared a Wildfowl Refuge in 1942 and upgraded to a Nature Reserve by the Ministry of Agricuiture and Foods on 20 September 1948 by Decree No. 2-11-931. The area is the only sizable natural area protected in northeast Bulgaria. All economic and tourist activities are prohibited under the law for the Protection of Nature of 1967. Access only by scientific staff with research permits (obtainable from the Committee for Preservation of Natural Environment). Shooting and disturbance of nesting birds strictly prohibited. The area was approved as a Biosphere Reserve in January 1977, and accepted as a World Heritage site in 1983. Designated as a Ramsar site at the time of signature in September 1975.

Site Description Srebarna is a typical freshwater Danubian lake on the river flood terrace formed after the drainage of the marshland along the Danube. The marshes are overlooked by hills which lie just outside the reserve boundary. Until 1949, when a dam was built, the lake was linked with the Danube, but since then its openwater area has decreased with reedbeds invading the shallows (maximum depth $2.5 \mathrm{~m}$ ). For some years the dam prevented annual flooding of the area by the river but the lake was reconnected to the river in 1978 . The reserve is in the Ukraine-Kazakh floristic region but the marsh vegetation is dominated by reed Phragmites australis (occupying two thirds of the reserve) with some Typha sp. Other species include pondweed Potamogeton pectinatus, water lily Nymphaea alba, duckweed Lemna $\mathrm{sp}$. and some uncommon marsh plants. The reserve is well fenced and surrounded by forests, vineyards, arable lands and stretches of steppe (to be included in to the reserve).

International and National Importance The site supports a very rich birdlife of some 180 species (half the Bulgarian avifauna). There are 80 migratory and 99 breeding recorded species including the only Bulgarian colony of Dalmatian pelican Pelecanus crispus (50-100 pairs), white-tailed eagle Haliaeetus albicilla (1 pair), glossy ibis Plegadis falcinellus (50-5,000 pairs), spoonbill Platalea leucorodia (3-10 pairs) and little cormorant Phalacrocorax pygmaeus (20 pairs). The site is the only nesting place in Bulgaria for white egret Egretta alba (10-15 pairs) and there are five other species of heron with some 1,000 nests. Other species recorded at the lake include mute swan Cygnus olor, greylag goose Anser anser, lesser white-fronted goose $A$. erythropus, red-breasted goose Branta ruficollis, gadwall Anas strepera, mallard $A$. platyrhynchos, ruddy shelduck Tadorna ferruginea, white-eyed pochard Aythya nyroca, red-crested pochard Netta rufina, red-necked grebe Podiceps griseigena, bluethroat Luscinia svecica, bearded tit Panurus biarmicus, coot Fulica atra, moorhen Gallinula chloropus, grey 
heron Ardea cinerea, purple heron $A$. purpurea, squacco heron Ardeola ralloides, little egret Egretta garzetta, black-crowned night-heron Nycticorax nycticorax, little bittern Ixobrychus minutus, great reed warbler Acrocephalus arundinaceus, common kingfisher Alcedo atthis, marsh harrier Circus aeruginosus and two of the three European species of marsh tern: black tern Chlidonias nigra and whiskered tern C. hybrida. Otter Lutra lutra (V) occasionally occurs.

Changes in Ecological Character Muskrat Ondatra zibethica introduced from central Europe became naturalised in the lake area in 1956. Economic activities around the reserve do not disturb the wildlife within it.

Management Practices A decree for Management of Srébarna Reserve was issued in 1962 concerning the preservation of nature in the wetland zone. A project has been discussed regarding the establishment of a joint nature reserve with Romania to incorporate both banks and the islands of the Danube. A buffer zone is being developed around the reserve. Reserve staff include two biologists, technical staff and two guards.

Scientific Research and Facilities Only carefully controlled scientific research allowed. There is continuous research mainly to establish numbers of the different species and the ecological conditions necessary for their long-term preservation. The site contains a natural history museum and the Bulgarian Academy of Sciences field ecological station.

Principal Reference Material The above information is taken from the document submitted by the Government of Bulgaria at the time of designation in 1975, supplemented by the documents submitted to the Man and Biosphere Bureau, and to the World Heritage Secretariat, and by the National Report of the Peoples Republic of Bulgaria prepared for the Conference on the Conservation of Wetlands of International Importance especially as Waterfowl Habitat held in Cagliari, Italy (November 1980).

Additional information:

- Bulgurkov, K. (1958). Particularités hydrologiques de la réserve - le lac Srébarna et la composition de sa faune piscicole. Izvestija na Zoologischeskija institut s musej pri BAN. Vol. VII. Bulgarian Academy of Sciences.

- Hodek, R. (1982). Der Wanderer Heim. Mitt. Orn. Ver. Wien. 6.

- Micev, T. (1958). La réserve Srébarna. Nachi rezervati i prirodni zabelejitelnosti. Vol. I.

- Paspaleva-Antonova, M. (1961). Contribution à l'ornithofaune de la réserve Srébarna, région de Silistra. Izvestija na Zoologischeskija institut s musej pri ban. Vol. XV. Bulgarian Academy of Sciences.

\section{Arkoutino Waterfowl Reserve}

Location $42^{\circ} 18^{\prime} \mathrm{N}, 27^{\circ} 45^{\prime} \mathrm{E}$. Situated to the south of Burgas on the shore of the Black Sea in southeast Bulgaria. Near the Turkish border.

Area 97ha (within Ropotamo Park 850ha).

Degree of Protection State owned. The Committee for Preservation of Natural Environment at the Council of Ministers of Bulgaria is responsible for the implementation of the Ramsar Convention and the administration of the park. The site is within Ropotamo Park protected under the law for the Protection of Nature (1967). All hunting, tourist and economic activities prohibited in the wetland area. Designated as a Ramsar site at the time of signature in September 1975.

Site Description The site comprises a small freshwater lagoon and associated marshlands situated among the dunes to the northeast of the Ropotamo river mouth. The shallow lagoon $(0.5 \mathrm{~m})$ is fed mainly by rainfall. It is fringed with reedbeds of Phragmites australis and Typha $\mathrm{sp}$. with patches of undisturbed woodland. The open water is covered by floating waterlily Nymphaea alba. A road runs along the east side of the lagoon separating it from the Black Sea shoreline. 
International and National Importance The lagoon is an important resting station for migratory waterfowl including coot Fulica atra and great crested grebe Podiceps cristatus. Other recorded species include black-winged stilt Himantopus himantopus, glossy ibis Plegadis falcinellus, black-crowned night-heron Nycticorax nycticorax, white stork Ciconia ciconia, mallard Anas platyrhynchos and marsh harrier Circus aeruginosus.

Changes in Ecological Character None reported (1980).

Management Practices Tourism to some popular areas near the wetland has been stopped by the Committee for Preservation of Natural Environment to minimise water pollution and improve the ecological conditions for waterfowl and other game species.

\section{Scientific Research and Facilities None reported (1980).}

Principal Reference Material The above information is taken from the document submitted by the Government of Bulgaria at the time of designation in 1975, supplemented by the National Report of the Peoples Republic of Bulgaria prepared for the Conference on the Conservation of Wetlands of International Importance especially as Waterfowl Habitat held in Cagliari, Italy (November 1980).

\section{Atanassovo Lake Natural Reserve}

Location $42^{\circ} 30^{\prime} \mathrm{N}, 27^{\circ} 29^{\prime} \mathrm{E}$. Situated $5 \mathrm{~km}$ north of Burgas

Area 1,050ha.

Degree of Protection The northern part of the lake 1050ha has been designated a nature reserve (Order No 601, of July 12th 1980). All human activities in it - fishing, dumping of industrial waste and effluent is banned. Not included in recultivation plans. Designated as a Ramsar site in November 1984.

Site Description A hypersaline lake which is cut by the Burgas-Varna road into a southern part, 6 sq.km and a northern part 10.9 sq. km. It is the habitat for 14 species of algae with Phragmites australis, Typha latifolia, Artemisia maritima predominant. A large population of invertebrates ( 15 principal species) forms a realiable food base for the abundant and varied bird fauna, with over 202 bird species, most of them forming large colonies or nesting separately. Owing to the high salinity of the lake (50-60\%) it rarely freezes and hence is an important stopping point for birds on their migration in particular wintering waterfowl.

Criteria for inclusion $1(a)$ and $1(e)$.

International and National Importance The lake is the only breeding ground in Bulgaria of gull-billed tern Gelochelidon nilotica, and one of the few locations of avocet Recurvirostra avoselta (1000 pairs), black-winged stilt Himantopus himantopus (100 pairs), shelduck Tadorna tadorna (30 pairs), stone curlew Burhinus oedicnemus, pratincole Glareola pratincola, oystercatcher Haematopus ostralegus, common tern Sterna hirundo and little tern S. albifrons. Also listed as breeding: teal Anas crecca, mallard Anas platyrhynchos, white-eyed pochard Aythya nyroca, purple heron Ardea purpurea, lapwing Vanellus vanellus, redshank Tringa totanus, Kentish plover Charadrius alexandrinus, little ringed plover $C$. dubius, moorhen Gallinula chloropus and common coot Fulica atra. Migratory birds include: Dalmatian pelican Pelecanus crispus, (an average of 189 individuals for the autumn period of 1979-1981), eastern white pelican P. onocrotalus, white stork Ciconia ciconia, black stork $C$. nigra, spoonbill Platalea leucorodia, grey heron Ardea cinerea, marsh harrier Circus aeruginosus, Montagu's harrier $C$. pygarus, hen harrier $C$. cyaneus, pallid harrier $C$. macrourus and osprey Pandion haliaetus. Total average mid-winter numbers of waterfowl 9,700 individuals and 24 species (minimum 6,071 of 21 species; maximum 18,182 of 29 species). 
Changes in Ecological Character

Salt and lye have been produced in the vicinity for pharmaceutical purposes since 1922. Illegal small holdings have been set up within the reserve boundary, prior to the declaration of the site and these are now being moved. Illegal trespass and grazing takes place.

\section{Management Practices No information}

Scientific Research and Facilities No information

Principal Reference Material The above information is taken from the document submitted by the Government of Bulgaria at the time of designation in 1984.

\section{Durankulak Lake Natural Landmark}

Location $43^{\circ} 42^{\prime} \mathrm{N}, 28^{\circ} 30^{\prime} \mathrm{E}$. The most northern of Bulgarian coastal lakes, situated northeast of Vaklino, Tolbouhin District.

Area 350 ha

Degree of Protection State owned. The Committee for Preservation of Natural Environment at the Council of Ministers of Bulgaria is responsible for the implementation of the Ramsar Convention and the administration of the park. Designated as a protected territory (protected landscape) by Order No. 123/21st February, 1980, (State Gazzette No. 23/1980). Designated as a Ramsar site on the 28 November 1984.

Site Description Average depth $1.4 \mathrm{~m}$, maximum depth $4 \mathrm{~m}$. Brakish coastal lake, with low salinity, freezing below freezing point. Fed by two springs at its southwest bank. Over 20 species of plants have been established including Phragmites communis, Iris pseudocoris, Ranunculus aquatilis, the Pteridophyta Equisetum palustris, Cyanophyta (17 species), Euglenophyta (10 species), Chlorophyta ( 47 species). It is the habitat of 4 species of Crustacea, 20 species Insecta, rare and endemic species of Gobiidae, Clupeidae, and Gasterosteidae.

Criteria for inclusion $1(\mathrm{a}), 1(\mathrm{~b})$ and $1(\mathrm{c})$.

International and National Importance It is the habitat of rare and endangered breeding and migratory wintering waterfowl species. Known breeding species include:: great crested grebe Podiceps cristatus, little bittern Ixobrychus minutus, Eurasian bittern Botaurus stellaris, mute swan Cyngus olor, greylag goose Anser anser, mallard Anas platyrhynchos, marsh harrier Circus aeruginosus, common coot Fulica atra and pratincole Glareola pratincola. The wintering waterfowl include: white-fronted goose Anser albifrons, red-breasted goose Branta ruficollis, curlew sandpiper Calidris ferruginea, black-throated diver Gavia arctica, black-necked grebe Podiceps nigricollis, red-necked grebe P. grisegena, common cormorant Phalacrocorax carbo and pygmy cormorant Haliëlor pygmeus. Average winter numbers 32,600 individuals of 19 species, (minimum 14,300 of 13 species, maximum 71,000 of 24 species).

Changes in Ecological Character Anthropogenic activity limited, no industrial or other pollution, not included in reclamation plans, no hunting.

Management Practices A $500 \mathrm{~m}$ buffer zone has been established where hunting and the application of pesticides is banned. Fishing is allowed only when the bird colony is not disturbed.

\section{Scientific Research and Facilities No information}

Principal Reference Material The above information is taken from the document submitted by the Government of Bulgaria at the time of designation in 1984. 


\section{CANADA}

Area $9,976,147$ sq. $\mathrm{km}$

\section{Population $25,127,900(1984)$}

Summary of Wetland Situation Canada has the largest area of land that was covered by glaciers during the last ice age of any country in the world. This has led to the creation of hundreds of thousands of lakes, and the changing of the water flow pattern of a number of major rivers. The Canadian Shield, a nucleus of ancient Pre-cambrian rocks which covers some 2 million sq. miles, was particularly affected by this glaciation which led to considerable erosion of the surface and the subsequent development of an area with thousands of lakes, and a fairly irregular drainage pattern. The edge of the shield is marked by a series of large lakes from Athabasca, Winnipeg, Great Slave and Bear in the west, to the Great Lakes of Superior and Huron (North Channel and Georgia Bay) in the south, with the St Lawrence to the south east.

Several major rivers drain the country, from the St Lawrence in the south-east to the Mackenzie in the north-west. The St Lawrence ends in a wide estuary on the Gulf of St Lawrence, the Mackenzie in a large delta. The Peace-Athabasca delta in northern Alberta, one of the largest inland freshwater deltas in the world, is relatively little disturbed by man. In British Columbia sea fiords and many small islands line the coast. The Bay of Fundy on the Atlantic coast has a large tidal range; at Mary's Point the area is shallow and much of the bottom is uncovered at low tide.

With the largest coastline of any country in the world $(243,000 \mathrm{~km}$ excluding the Great Lakes) and $15 \%$ of the worlds freshwater, Canada has a massive heritage of wetlands.

The rarest bird using the wetlands of Canada is the endangered whooping crane Grus americana, which breeds only in and around the northern edge of Wood Buffalo National Park. Protection of the area is therefore vital to the survival of the Crane. Over 80 million waterbirds use the wetlands of Canada, particularly for breeding and on migration, and many nearctic waders breed in the north.

Protected Areas Legislation National (federal) parks are set up and maintained under the National Parks Act as amended in 1974, Migratory Bird Sanctuaries under the Migratory Birds Convention Act, 1917, and National Wildlife Areas under the Canada Wildlife Act, 1973. Each province also has its own protected areas legislation. In general, natural resources in Canada are under provincial jurisdiction. As a result, provincial governments have a key role in conservation. Federal parks, reserves and sanctuaries have been established on federal lands or through negotiation with provinces.

Protected Areas Administration Responsiblitiy for the Migratory Birds Conservation Act and the Candada Wildlife Act is vested in the Minister of the Environment and undertaken by the Canadian Wildlife Service, which manages National Wildlife Areas (on federal crown land) and supervises Migratory Bird Sanctuaries (some of which are on provincial crown land or land in private ownership) in accordence with the legislation and relevant regulations. Public access to National Wildlife Areas and Migratory Bird Sanctuaries is generally permitted though some ares may be closed to the public seasonally or throughout the year to reduce risks of damage. Scientific collecting of specimens is allowed only by permit. Research in National Wildlife Areas and Migratory Bird Sanctuaries is conducted by the Canadian Wildlife Service, by universities or by other organizations under contract. Where appropriate, the Canadian Wildlife Service provides facilities for the public on National Wildlife Areas, including interpretation programmes. 
Responsibility for the National Parks Act is vested in the Minister of the Environment and undertaken by Parks Canada, which is headed by an Assistant Deputy Minister. Parks Canada headquarters is responsible for policy direction while five regional offices direct the operations of the 28 natioanl parks. Parks Canada's objective is the protection and management, for all time, of representative natural areas of Canadian significance in a system of national parks. Scientific research in National Parks, related primarily to the study of natural resources and their management, is conducted by scientists of the Canadian Wildlife Service; other resource studies, inventory programmes and recreational research are carried out by Parks Canada staff. Research is also undertaken by the universities, subject to the Director General's approval. Special licensing is required for any collecting necessary for scientific purposes. Facilities for park visitors are rated second in administration priority after protection of outstanding natural landscapes. Public use is encouraged (over 19 million park visitors in 1978/79) through interpertative programmes, personal experience, and publications for developing an understanding and knowledge of the values of natural communities and landscapes while enjoying outdoor recreation in natural surroundings. The "FeJeral-Provincial Parks Conference" (FPPC) coordinates activities related to national and provincial parks, and a classification system has been devised for the 2,442 parks listed by the FPPC.

\section{Sites designated under the Convention}

Accession 15 January 1981 with one site listed at accession, 14 sites added 24 May 1982 and another two added 16 October 1985.

Cap Toumente National Wildlife Area (Quebec)

Mary's Point NWA (New Brunswick)

Long Point NWA (Ontario)

Delta Marsh (Manitoba)

Last Mountain Lake (Saskatchewan)

Whooping Crane Summer Range (Alberta and Northwest Territories)

Peace-Athabaska Delta (Alberta)

Hay-Zama Lakes (Alberta)

Alaksen NWA (British Columbia)

Old Crow Flats (Yukon Territory)

Polar Bear Pass NWA, Bathurst Island (Northwest Territories)

Queen Maud Gulf MBS, Keewatin and Mackenzie (Northwest Territories)

Rasmussen Lowlands, Keewatin (Northwest Territories)

McConnell River MBS, Keewatin (Norhtwest Territories)

Dewey Soper MBS, Franklin (Northwest Territories)

St Clair NWA (Ontario)

Chignecto NWA (Nova Scotia)

Government body responsible for administration of the Convention

Canadian Wildlife Service, Environment Canada, Ottwa, Ontario, K1A OE7

\section{Cap Tourmente National Wildlife Area}

Location $47^{\circ} 05^{\prime} \mathrm{N}, 70^{\circ} 45^{\prime} \mathrm{W}$. Situated on the north shore of the St Lawrence River, Montmorency county, Province of Quebec, $50 \mathrm{~km}$ north-east of Quebec city.

Area 2,200 ha

Degree of Protection Cap Tourmente is owned by the government of Canada and was established as a National Wildlife Area under the Canada Wildlife Act of 1973 . It is administered by the Quebec Region, Canadian Wildlife Service. Designated as a Ramsar site in January 1981 when Canada ratified the Ramsar Convention. 
Site Description The site has a wide range of habitats from the summit of Cap Tourmente at $600 \mathrm{~m}$ to the tidal flats of the St Lawrence at 2.5 to $5.0 \mathrm{~m}$ and comprises 400 ha tidal marsh, 100 ha coastal meadow, 500 ha agricultural land and 1,200ha forest. Habitats include coniferous and deciduous forests, ponds and ditches, coastal meadows and tidal marsh. The Cap Tourmente marshes are situated on broad tidal flats subjected to heavy tidal flooding by fresh waters. The tidal amplitude is $4.1 \mathrm{~m}$ at mean tides and $5.8 \mathrm{~m}$ at large tides. The dominant plant is Scirpus americanus and secondary species include Zizania palustris, Sagittaria cuneata and $S$. latifolia. The Scirpus americanus marshes of the St Lawrence are natural wetlands restricted to the freshwater tidal portion of the river with under 4,000 ha remaining, of which only 1,200 ha are situated on the deep $13 \mathrm{~m}$ sediments capable of supporting dense luxuriant plant growth. The coastal meadow which forms the inland border of the tidal marsh is a broad expanse of land flooded only by extreme tides greater than $5.5 \mathrm{~m}$. Extensive mowing and grazing of these meadows in the past has ceased and various stages of plant succession are now present with various sedges and shrubs dominating in many areas. Management of drainage ditches, the construction of artificial ponds and protection of beaver Coster canadensis has improved the area for breeding ducks over the past decade.

International and National Importance The area includes one third (400ha) of the high quality Scirpus americanus marsh remaining in the St Lawrence. These marshes are vital to greater snow geese Anser caerulescens allanticus which stage in the St Lawrence in spring and fall. About $30 \%$ of the goose usage by the entire world's stock of greater snow geese during migration occurs at this site. Their diet here is composed mainly of underground parts of Scirpus americanus although in recent years other marsh plants and agricultural grasses have been consumed. These marshes also serve as important staging areas for large numbers of surface feeding ducks, mainly black duck Anas rubripes, green-winged teal Anas crecca carolinensis, blue-winged teal Anas discors and pintail Anas acuta. Small numbers of these species breed locally raising their young in the tidal marsh. Common snipe Capella galinago is common on the coastal meadow and this area is also used by nesting dabbling ducks and moulting green-winged teal. On the ponds and ditches increased numbers of black duck, green-winged and blue-winged teal and pintail have made use of the new habitats and shoveler Anas clypeata and wood duck Aix sponsa, which did not previously breed in the area, are now present.

Changes in Ecological Character The site is situated just downstream from the heavily industrialised portion of the St Lawrence (extending from Quebec city to the Great Lakes) and therefore remains vulnerable to the effects of toxic substances. Pollution from oil spills would be difficult to control due to the high tides. Increasing numbers of greater snow geese have led to a depletion of Scirpus rhizomes which may eventually cause a deterioration of the marsh at Cap Tourmente.

Management Practices Attempts to alleviate overgrazing of the marsh by greater snow geese are aimed mainly at encouraging use of nearby tidal marshes by larger numbers of geese. Plans are presently being made to manage portions of the coastal meadow to provide supplementary feeding sites within the national wildlife area. Maintenance of the existing managed areas the ponds and ditches - will be required to maintain the attraction of those areas to breeding ducks. Some hunting is allowed based on certain traditional methods such as the use of pit-blinds and horse-drawn mud sleds.

Scientific Research and Facilities Research has been carried out on the greater snow geese and its habitats at Cap Tourmente since the mid 1950s. There is a museum illustrating the interactions of man the hunter and his environment and a reference library.

Principal Reference Material The above information is taken from the list of Canadian Wetlands Designated as of International Importance, May 1982.

Additional information:

- Bouchard, L. (1976). Le Cap Tourmente et la chasse aux oies blanches Fides. Montreal. $160 \mathrm{pp}$.

- Bourget, A. (1974). Migrations de la sauvagine dans la région de Quebec. In Boyd, H. (Ed.) Waterfowl studies. Canadian Wildlife Service Report Series No. 29. Ottawa. 
- Doran, Marie-Andrée (1977). Etude sur la régénération de Scirpus americanus sur les battures de la Réserve Nationale de la Faune à Cap Tormente. Unpublished report to the Canadian Wildlife Service, Quebec.

- Lemieux, L. (1959). Histoire naturelle et aménagement de la Grande Oie blanche, Chen hyperborea atlantica. Naturaliste Canadien 86: 133-192.

- Lemieux, S. (1978). Les oiseaux de la Réserve nationale de faune du cap Tourmente. Naturaliste Canadien 105: 177-193.

- Reed, A. (1980). A greater snow goose management plan: A Canadian perspective. Canadian Wildlife Service. Unpublished draft.

- Reed, A. (in press). The feeding ecology of the greater snow goose on a staging haunt in the St. Lawrence estuary: a progress report. Orn. Ges. Bayern.

- Scherrer, B. (1975). Enquête sur la chasse à la Grande Oie blanche, les aspects bio-socio-économiques. Unpublished report. University of Quebec, Montreal. 187pp.

- Serodes, J. (1978). Qualité des sédiments fins de l'estuaire moyen supérieur. Environment Canada, Inland Waters Directorate. Unpublished report $8 \mathrm{pp}$.

\section{Mary's Point (a unit of Shepody National Wildlife Area)}

Location $45^{\circ} 44^{\prime} \mathrm{N}, 64^{\circ} 45^{\prime} \mathrm{W}$. Situated at the head of the Bay of Fundy, $40 \mathrm{~km}$ south of the city of Moncton in the Province of New Brunswick.

Area 1,200 ha

Degree of Protection The government of Canada owns 107 ha which includes the most critical sites used by the large roosting flocks of shorebirds during high tide and is administered by the Canadian Wildlife Service (Atlantic Region, P.O. Box 1550, Sackville, New Brunswick E0A $3 \mathrm{C} 0$ ). Most of the $150 \mathrm{ha}$ of saltmarsh remain under private ownership as poor land titles have prevented purchase by the federal government. The remaining 940 hat of mudflats are intertidal land with no known ownership. The area is scheduled under and controlled by the Wildlife Area Regulations. Designated as a Ramsar site in May 1982.

Site Description The area encompasses a large tidal Spartina marsh, expanses of intertidal mudflats and a peninsula protruding into Shepody Bay. The peninsula was formed from glacial outwash gravel overlying sandstone bedrock and consists of 2 forested 'islands' joined by salt marsh, rock cliffs and intertidal ledges, gravel beaches and a small ridge of sand dunes. The extensive intertidal mudf lats are over $1.5 \mathrm{~km}$ wide in places and occur to the north and south of the point. They consist of fine marine silts built up over time through deposition from muddy tidal waters. Altitude is -2 to $10 \mathrm{~m}$.

Criteria for inclusion 1(a), 1(b) and 2(c)

International and National Importance The intertidal mudflats support the principal forage species of shorebirds Corophium volutator, an amphipod which in North America occurs only in the Bay of Fundy in recorded densities exceeding 60,000 per sq $\mathrm{m}$ which are the highest densities in the world. The wetland supports the largest numbers of mixed species of shoreline birds during fall migration in all of North America. Several million semi-palmated sandpipers Calidris pusilla, thousands of least sandpipers Calidris minutilla, short-billed dowitcher Limnodromus griseus, white-rumped sandpiper Calidris fuscicollis, semi-palmated plover Charadrius semipalmatus, black-bellied plover Pluvialis squatarola and red knot Calidris canutus feed and roost at the site from late July to September. Small numbers of black duck Anas rubripes, blue-winged teal Anas discors and ring-necked duck Aythya collaris breed in a 20 ha freshwater impoundment adjacent to the 150 ha salt marsh. 
Changes in Ecological Character The possibility of a major alteration at the site due to the installation of a tidal barrage for power generation is potentially a grave threat. The Mary's Point area is considered the least economic of the three prime sites being studied for tidal power installation in the Bay of Fundy. Development may still go ahead though probably not in the next decade. The recreational use of all-terrain vehicles along the beach occasionally causes disturbance to the roosting flocks and the number of visitors needs to be regulated to keep disturbance to a minimum.

Management Practices A 20 ha controlled waterfowl impoundment was constructed by Ducks Unlimited Canada in 1979 at a site adjacent to the salt marsh. Future management of the impoundment may involve vegetation control via tidal flooding and possible maintenance of slightly brackish conditions within the impoundment. The portion of the site presently designated as a National Wildlife Area is posted with identification signs and there is an observation deck overlooking the beach. A seasonal naturalist is needed to advise visitors on the biological values of the area and its sensitivity.

Scientific Research and Facilities Research activities have been aimed at understanding the upper bay of Fundy in general. In particular, shorebird research programmes conducted from 1974-1981 have documented the feeding ecology of the birds and illustrated the importance of the Mary's Point site for feeding and roosting.

Principal Reference Material The above information is taken from the list of Canadian Wetlands Designated as of International Importance May 1982.

Additional information:

- Harrington, B.A. and Morrison, R.I.G. (1979). Semipalmated sandpiper migration in North America. Studies in Avian Biology 2: 83-100. Cooper Ornithological Society, Los Angeles, California.

- Majka, M. (1978). Wings over Fundy. Nature Canada 7(3). Canada.

- Morrison, R.I.G. (1974 to 1978). Annual reports of the Maritime Shorebird Survey, Canadian Wildlife Service, Ottawa.

- Morrison, R.I.G. (1976). Use of the Bay of Fundy by shorebirds. In Daborn, G.R. (Ed.) Proceedings of a workshop of Fundy Tidal Power and the Environment. Acadia University, Wolf ville, Nova Scotia.

\section{Long Point National Wildlife Area}

Location $42^{\circ} 35^{\circ} \mathrm{N}, 80^{\circ} 15^{\prime} \mathrm{W}$. Situated on the north shore of Lake Erie in the regional municipality of Haldimand-Norfolk near the town of Port Rowan, Ontario.

Area 13,730 ha

Degree of Protection Ownership is divided between a number of organisations and the government. Federal Government - Ontario Region: Canadian Wildlife Service (1725 Woodward Drive, Ottawa, Ontario KIA 0E7) 2,440ha and Department of Transport 30 ha. Provincial Government: Ontario Ministry of Natural Resources 820 ha and Long Point Region Conservation Authority 220ha. Navigable water inner bay 7,280 ha, private waterfowl hunt clubs 2,900 ha and other private ownership 40ha. Lands administered by the Canadian Wildife Service have been designated as National Wildlife Areas under the Canada Wildlife Act 1973. Lands administered by the Ontario Ministry of Natural Resources are designated either as provincial park or controlled through the Public Lands Act. The Long Point Region Conservation Authority owns and administers its property under the Conservation Authorities Act. The lands owned by the private waterfowl clubs are managed for waterfowl hunting and are not at present considered in danger of loss. Escalating land costs, however, could materially affect their status. The Canadian Wildlife Service and Nature Conservancy have the right of first refusal to those lands still owned by the Long Point Company. The marshlands and Long Point are zoned as environmental protection areas under the official plan for the Regional Municipality of Haldimand-Norfolk but this does not assure perpetual protection. 
Site Description Long Point is a long slender sandspit extending $32 \mathrm{~km}$ into the deepest part of Lake Erie. The peninsula was formed primarily by easterly longshore currents transporting sand from the eroding cliffs further west. Along the north shore of Long Point, erosion and deposition occur in a westerly direction. A verage altitude is $174 \mathrm{~m}$ rising to $183 \mathrm{~m}$ in the sand dunes. The climate of Long Point is influenced by the moderating effects of Lake Erie meaning that spring and summer temperatures are lower than the adjacent mainland, and fall and winter temperatures higher. Mean summer temperature is $22^{\circ} \mathrm{C}$ and winter $1^{\circ} \mathrm{C}$. Annual precipitation is $860 \mathrm{~mm}$. The thermal moderation caused by the lake, combined with the southern geographic location of the point, allows a number of plants and animals to survive at the northern fringe of their range. The wetlands at the base of the point represent an older more stable successional stage compared to those on the peninsula and include wooded swamp, shrub carr, grassy and cattail marsh. The peninsula is a series of alternating ridges separated by ponds and swales. Water depth between the ridges is greatly influenced by lake levels. Long Point is thus a unique combination of habitats: beach, sand dunes, grass-covered ridges, savannas, woodlands, wet meadows, rush swales, wooded swamp, tamarack-cedar ponds and deep shallow marshes.

\section{Criteria for inclusion 1(a), 1(b), 2(a), 2(b), 2(c) and 3}

International and National Importance The wetlands and associated sand dune ecosystems of Long Point are the best remaining examples of their type in the Great Lakes basin. The whole spectrum of dune and wetland succession is easily discernible along the region's length. The area is renowned as a staging area for waterfowl in spring and fall and is one of the most important areas of waterfowl concentration in Ontario. The marshes and adjacent waters of Long Point Bay can contain at one time during peak migration 100,000 or $11 \%$ of the total population of redheads Aythya americana and at least 43,000 or $14 \%$ of all canvasbacks Aythya valisineria. Whistling swan Cygnus c. columbianus traditionally use the marshes extensively during spring migration with about $50 \%$ of the population east of the Rocky Mountains passing through the area in spring and a lesser number in autumn. Puddle ducks and other species of divers use the region in large numbers. The area is of national significance to many other migrating birds and since the establishment of Long Point Bird Observatory in 1960, 237 species or $75 \%$ of all species recorded for Ontario have been observed. A total of 115 bird species are believed to have nested on Long Point including bald eagle Haliaeetus leucocephalus and piping plover Charadrius melodus (both endangered in Ontario), king rail Rallus elegans, Forster's tern Sterna forsteri and the rare prothonotary warbler Protonotaria citrea. There are 31 recorded species of mammal, 26 species of reptiles and amphibians including five species considered threatened in Canada and 114 species of fish native to Lake Erie, many utilising the waters in and around Long Point at some time in their life-cycle. At least 60 species have been recorded on Canadian Wildlife Service property alone. A variety of invertebrates occur including the meadow crayfish Cambarus diogenes which is one of Canada's rarest invertebrate. The area is also on a migration route for bats and monarch butterflies Danaus plexippus.

Changes in Ecological Character Long Point receives a high degree of acid precipitation and a $\mathrm{pH}$ of around 4.0 is common in places. Environmental pollution from industry is a constant concern. Direct threats to the non-protected wetlands are primarily proposals to convert the marshes to agriculture or recreation. Marina developments to service the large boating public are a constant threat and the construction of channels to service private cottages requires rigid control. Fertiliser and herbicide runoff from increased agricultural use of the marshes could affect water quality. The water of the inner bay already tends towards a eutrophic state. Other threats include possible off-site developments which could interfere with the littoral drift and transport of sand that forms Long Point or by artificial manipulation of the water level of the Great Lakes. Severe storms can overwash the barrier beach damaging the wetland, and high water levels accelerate erosion.

Management Practices The area administered by the Canadian Wildlife Service (CWS) is managed as a wilderness area with little interference in the dynamic forces of nature and limited public use. Some restorative measures may be undertaken to rectify adverse impacts caused by past human activities. The Big Creek Marsh has been historically managed to facilitate waterfowl hunting and muskrat harvesting. Permitted management activities include 
water level control and creation of channels to facilitate waterfowl brood movement and waterflows. Muskrat harvesting is permitted under a CWS permit and waterfowl hunting is permitted in certain areas. Sport fishing, canoeing and wildlife viewing are also permitted. A management plan for Big Creek complex has been agreed to by the government agencies and private owners involved. The marsh areas owned by other government agencies and private owners are generally managed for waterfowl hunting purposes.

Scientific Research and Facilities A permanent research station has been operated by the Long Point Bird Observatory to monitor migratory birds since 1960 and the Canadian Wildlife Service surveys waterfowl populations annually. A number of graduate theses and other studies have been undertaken on a variety of biological topics.

Principal Reference Material The above information is taken from the list of Canadian Wetlands Designated as of International Importance May 1982.

Additional information:

- Barrett, H.B. (1977). Lore and legends of Long Point. Burns and MacEachern Ltd., Don Mills, Ontario. $240 \mathrm{pp}$.

- Bradstreet, M.S.W. (1977). The biological environment of Long Point, Lake Erie: an overview. Unpubl. report for The Nature Conservancy of Canada.

- Bradstreet, M.S.W., McKeating, G. and Parsons, J. (Eds) (1980). Seasons (special issue on Long Point) 21(1). Federation of Ontario Naturalists, Don Mills, Ontario. $63 \mathrm{pp}$.

- Campbell, C.A. (1979). Preliminary herpetological survey and evaluation of proposed habitat alterations at Big Creek National Wildlife Area, Port Rowan, Ontario. Unpubl. report to CWS.

- Catling, P.M. and Reznicek, A. (1979). A list of plants from Long Point. Unpubl. report to CWS. $30 \mathrm{pp}$.

- Deyne, G.A. (1977). Summer resources inventory of the Lee Brown Waterfowl Management Area. Report for the L.P.R.C.A. 102 pp.

- Nelson, J.G. and Needham, R.D. (1979). The Lake Eire peninsulas: management issues and directions. Contact 11(1). Faculty of Environmental Studies, University of Waterloo, Ontario.

- Nelson, J.G. and Jessen, S. (Eds) (1980). Coastal resources and environmental management: the case of the Long Point area, Lake Erie, Ontario. Contact 12(3). Faculty of Environmental Studies, University of Waterloo, Ontario.

\section{Delta Marsh}

Location $50^{\circ} 05^{\prime} \mathrm{N}, 98^{\circ} 00^{\prime} \mathrm{W}$. Situated in the Lake Agassiz Basin at the southern edge of Lake Manitoba in the Province of Manitoba, $22 \mathrm{~km}$ north of Portage la Prairie.

Area 23,000 ha

Degree of Protection About 16,600 ha are in public ownership as provincial Crown land administered by the Wildlife Branch of the Manitoba Department of Natural Resources (P.O. Box 24, 1495 St James Street, Winnipeg, Manitoba). 2,000ha of this area are protected as a game bird refuge and 7,700 ha as public shooting grounds. The Delta Waterfowl Research Station controls a further 1,600 ha of the marsh. The remaining land is under private ownership. Designated as a Ramsar site in May 1982.

Site Description Delta Marsh consists of large basins and small sloughs connected to Lake Manitoba by several natural beaches. The area is subject to low level natural fluctuations caused by wind tides from Lake Manitoba. Average water depth is $1.2 \mathrm{~m}$ and maximum depth $4 \mathrm{~m}$. The altitude of the area is $248 \mathrm{~m}$. The vegetation consists of Phragmites communis and Scolochloa festucacea meadows which grade into wet prairie vegetation at slightly higher elevations. Sand ridges extending into the marsh contain considerable mossy-cup oak Quercus macrocarpa. The beach ridge is dominated by box-elder Acer negundo and red alder Fraxinus pennsylvanica. 
International and National Importance The area is particularly important as a staging marsh for waterfowl now averaging over 50,000 Anatidae during the fall, with past peak populations of ducks and geese over 2 million. Some 285 species of birds have been recorded of which 37 are of accidental occurrence and 1 has been extirpated.

Changes in Ecological Character There is pressure to develop additional cottage sites and recreational facilities on Lake Manitoba beach. The privately owned west portion of the marsh is periodically flooded by the Portage Floodway, causing excessive siltation and vegetational growth.

Management Practices Parts of the area are cut annually for hay and the marsh provides valuable fur and fish harvests. Hay and waterfowl harvests are regulated and the use of motorised boats is restricted. Management plans have been recently proposed by the province in the Delta Marsh Plan 1978 and by Ducks Unlimited Canada which include water level control and development of a public-private cooperative marsh management district.

Scientific Research and Facilities Permanent research programmes have been conducted sirce 1938 by the Delta Waterfowl Research Station, dealing mainly with waterfowl ecology and behaviour. Over 100 publications in journals have resulted. The University of Manitoba opened a field station in the western portion of the marsh in 1967 where research has concentrated on plant ecology, hydrology and local history.

Principal Reference Material The above information is taken from the list of Canadian Wetlands Designated as of International Importance May 1982.

Additional information:

- Bailey, R.O. (1979). Wild mallard stocking in a large marsh habitat. Canadian Field-Naturalist 93: 55-62.

- Bartonek, J.C. and Hickey, J.J. (1969). Selective feeding by juvenile diving ducks in summer. Auk 86: 443-457.

- Batt, B.D.J. (1979). Individual variation and the analysis of mallard populations. In Bookhout, T.A. (ed.) Waterfowl and Wetlands: an integrated review. La Crosse Printing Co. Inc. pp. 95-102.

- Bergman, R.D. (1973). Use of southern boreal lakes by postbreeding canvasbacks and redheads. J. Wildl. Manage. 37: 160-170.

- Bossenmaier, E.F. and Marshall, W.H. (1958). Field-feeding by waterfowl in southwestern Manitoba. Wild. Monog. 1: 32 pages.

- Bossenmaier, E.F. Cober, W.G., Leitch, W.G., MacKay, G.H., Miller, W.R., Moore, D.D., Walker, J.M. and Ward, P. (1968). The Delta Marsh: its values, problems and potentialities. Tech. Commit. for Develop. of the Delta Marsh, Man. Dept. of Mines and Nat. Res. 75pp.

- Brakhage, G.K. (1953). Migration and mortality of ducks hand-reared and wild-trapped at Delta Manitoba. J. Wild. Manage. 17: 465-477.

- Cooper, J.A. (1977). The history and breeding biology of the Canada geese of Marshy Point, Manitoba. Wildl. Managt 61: 87pp.

- Hochbaum, H.A. (1967). Contemporary drainage within the true prairies of the Glacial Lake Agassiz Basin. Life, Land and Water. Proc. 1966 Conference on Environmental Studies, Glacial Lake Agassiz Region. University of Manitoba Press, Winnipeg. pp 197-204.

- Hochbaum, P.W. (1970). The Delta Marsh. Dept. of Mines, Resources and Environmental Management, Conservation Extension Branch, Winnipeg. 52pp.

- Kaminski, R.M. and Prince, H.H. (1981). Dabbling duck and aquatic macro- invertebrate responses to manipulated wetland habitat. J. Wildl. Management 45: 1-15.

- Kiel, W.H. Jr, Hawkins, A.S. and Perret, N.G. (1972). Waterfowl habitat trends in the aspen parkland of Manitoba. Canadian Wild. Serv. Report Series 18, $61 \mathrm{pp}$.

- Ward, P. (1968). Fire in relation to waterfowl habitat of the Delta Marshes. Proc. Ann. Tall Timbers Fire Ecology Conf. 8: 243-267.

- Ward, P. and Batt, B.D.J. (1973). Propogaton of captive waterfowl - the Delta Waterfowl Research Station system. Delta Waterfowl Research Station and Wildlife Management Institute, Washington. 64pp. 
Location $51^{\circ} 20^{\prime} \mathrm{N}, 105^{\circ} 15^{\prime} \mathrm{W}$. Last Mountain Lake is part of the Upper Qu'Appelle River system in south central Saskatchewan, $150 \mathrm{~km}$ south-east of Saskatoon.

Area $15,600 \mathrm{ha}$

Degree of Protection 7,039ha are owned by the federal government and 8,563 ha by the provincial government. The area has been protected and administered cooperatively since 1968 and the governments are now seeking an agreement for long-term uniform management and administration. The federal area is protected under the Migratory Bird Sanctuary Regulations which stem from the Migratory Birds Convention Act. Designated as a Ramsar site in May 1982.

Site Description The sanctuary is situated at the northern end of Last Mountain Lake and comprises shallow marshy bays and inlets separated by points and numerous islands. The lake within the sanctuary has a maximum depth of $6.3 \mathrm{~m}$ and average depth of $0.5-4 \mathrm{~m}$ depending on seasonal variations. The surrounding uplands contain potholes and other fresh and saline wetlands, some with water levels held artificially high by low dams. Soils are light in texture with sandy saline loams near the lake. Altitude is about $425 \mathrm{~m}$. A wide variety of native grasses Agropyron, Distichlis, Stipa and Hordeum, forbs Astragalus, Aster, Thermopsis and Solidago and shrubs Rosa, Symphoricarpos and Elaeagnus occur in complex patterns in the Aspen parkland transition zone between grassland and forest.

Criteria for inclusion $1(\mathrm{a}), 1(\mathrm{~b}), 2(\mathrm{a}), 2$ (c) and 3

International and National Importance The area is an important breeding and staging area for waterfowl and large numbers of other migratory birds. More than 220 species have been recorded including 90 breeding ducks, geese and sandhill crane Grus canadensis. Waterfowl concentrations are greatest from mid-August to November. The endangered whooping crane Grus americana occurs in the area during spring and fall migration.

Changes in Ecological Character A steady rise in public use in the surrounding area and on Last Management Lake is causing increasing disturbance to wildlife throughout the year. Breeding success of double-crested cormorant Phalacrocorax auritus, and perhaps other birds, has declined, and white pelican Pelecanus erythorhynchos only irregularly breeds here. Increasing amounts of toxic chemicals from surrounding agricultural land are carried into the area by runoff water. Natural fluctuations of the lake level have been controlled thereby reducing return of nutrients to some marshlands.

Management Practices The area is managed for the conservation of migratory birds, their habitats, and for other wildlife species, and to help reduce crop damage of cereal grain by influencing the local distribution of waterfowl. Economic activies such as hay cutting and grazing are normally restricted to lands outside the sanctuary. Boating and recreational fishing are permitted with public access restricted in August and September to minimise disturbance of birds feeding on lure crops.

Scientific Research and Facilities Intensive research programmes have been conducted since 1959 by the Canadian Wildlife Service, and in cooperation with the Universities of Saskatchewan and Regina and the province. The Saskatchewan Wildlife and Fisheries Division has conducted studies since the 1950s. There is much interest in continuing research programmes on the area.

Principal Reference Material The above information is taken from the list of Canadian Wetlands Designated as of International Importance May 1982.

Additional information:

- Fawson, D.S. and Moore, J.E. (1944). The saline lakes of Saskatchewan. Canadian Journal Research D.22: 141-201. 
- Johnson, R.P. (1963). Studies on the life history and ecology of the bigmouth buffalo Ictiobus cyprinellus. Journal Fish. Res. Bd. Canada 20(b): 1397-1429.

- Stephen, W.J.D. (1967). Bionomics of the sandhill crane. Canadian Wildlife Service Report Series No.2, 46pp.

\section{Whooping Crane Summer Range}

Location $60^{\circ} 15^{\prime} \mathrm{N}, 113^{\circ} 15^{\prime} \mathrm{W}$. Situated in north-eastern Alberta and in the adjoining southern portion of the district of MacKenzie, Northwest Territories. The town of Fort Smith in NWT lies $80 \mathrm{~km}$ south-east of the area.

Area $1,689,500$ ha

Degree of Protection Most of Whooping Crane Summer Range lies within the Crown-owned Wood Buffalo National Park, which is protected under the National Parks Act and administered by Parks Canada (Prairie Region, 391 York Avenue, Winnipeg, Manitoba). Wood Buffalo Park is a World Heritage Site. Some 230,000 ha of the range lie outside the park in the North vest Territories. The range includes the International Biological Programme (IBP) sites 12 and 13, and the Whooping Crane Nesting Area. Designated as a Ramsar site in May 1982.

Site Description Whooping Crane Summer Range is a natural area comprising a complex of marshes, shallow ponds, streams, lakes and bogs located near the northern extent of the Boreal Forest Region and west of the Canadian Shield. The thousands of water bodies in the area vary in depth from several centimetres to about a metre, with the average depth of the nesting ponds of the whooping crane $26 \mathrm{~cm}$. The area has a boreal continental climate characterised by long cold winters and short warm summers. Mean daily temperatures are $17.8^{\circ} \mathrm{C}-23.3^{\circ} \mathrm{C}$ in January and $15.6^{\circ} \mathrm{C}-18.3^{\circ} \mathrm{C}$ in July. Annual precipitation is about $310 \mathrm{~mm}$ but annual evaporation is $410 \mathrm{~mm}$. This moisture deficit together with some 40 thunderstorms per season creates an extreme forest-fire weather zone in the area. Seasonal drought in some years also greatly affects water levels in the nesting ponds. The brief frost-free period extends from early June to early September, but much of the area is permanently underlain with discontinuous permafrost. Daylight period is short in winter but in mid-summer is over 20 hours. Most of the bedrock in the area is Devonian or Cretaceous limestones, sandstones, shales, and evaporites such as gypsum and halite which were deposited during many periods of marine inundation of the region throughout the past 400 million years. The area is therefore influenced by saline groundwater. Altitude is $150-250 \mathrm{~m}$. The marshland vegetation is dominated by bulrush Scirpus validus, sedge Carex aquatilis and cattail Typha latifolia. Dominant coniferous species include white spruce Picea glauca, black spruce $P$. mariana, tamarack Larix laricina and jack pine Pinus banksiana. Deciduous species include white birch Betula papyrifera, quaking aspen Populus tremuloides and balsam poplar P. balsamifera. Understory species include dwarf birch Betula glandulosa, buffalo berry Shepherdia canadensis, willows Salix spp., Labrador tea Ledum groenlandicum and sphagnum moss. The area contains 47 species of mammal including wolf Canis lupus, moose Alces aces, lynx Lynx canadensis, snowshoe hare Lepus americanus, black bear Ursus americanus, muskrat Ondatra zibethica, beaver Castor canadensis, mink Mustela vison, woodland caribou Rangifer tarandus caribou and wood and plains buffalo Bison bison athabascae and B.bison bison. Reptiles and amphibians, which are limited in numbers by the boreal climate, include boreal chorus frog and wood frog, and at the northern limit of their ranges, Canadian toad, leopard frog Rana pipiens and red-sided garter snake. The fish of the area are not well known but preliminary information suggests that pearl dace, fathead minnow and Iowa darter are at their northern limit. A circumpolar species, the inconnu, spawns in Buffalo Lake at the western edge of the Whooping Crane Summer Range. Bird species include those characteristic of all boreal forest habitats and less common birds include whooping crane Grus americana, peregrine falcon Falco peregrinus and bald eagle Haliaeetus leucocephalus.

Criteria for inclusion $1(\mathrm{a}), 2(\mathrm{a}), 2(\mathrm{~b})$ and $2(\mathrm{c})$ 
International and National Importance The wetland contains the only known nesting locality of the endangered whooping crane. In 1982 there were 19 breeding pairs and this area is critical to its survival. The vulnerable peregrine falcon also occurs in the region.

Changes in Ecological Character Current feasibility study to examine positive and negative aspects of a proposed hydro-electric dam across the Slave River near Fort Smith. It is possible that a dam could change or disrupt water levels and/or drainage patterns in Whooping Crane Summer Range. An extra-heavy voltage powerline running parallel to Highway 5 is a constant danger to low flying birds and electrical power transmission lines from the dam site to the Fort Murray area would pose a serious hazard to migratory birds including whooping crane. It is likely that traffic along Highway 5 north and west of Fort Smith will increase, particularly if there is large scale industrial development near Fort Smith. Highway 5 is the only road access from the west to Whooping Crane Summer Range. It bisects the whooping crane nesting area and runs within $5 \mathrm{~km}$ of a known nesting site.

Management Practices The area is in the management scheme of Parks Canada, which is currently evaluating and planning future management requirements. Recreational activities are minimal due to the remoteness and limited access. All fires in the area are acted on, with Whooping Crane nesting area as one of the main priorities. Hunting and trapping of fur bearers by native inhabitants is permitted. Ground access and aerial traffic under $600 \mathrm{~m}$ is prohibited in the whooping crane nesting area. Excess whooping crane eggs are removed by the Canadian Wildlife Service for a 'foster parent' programme in Idaho conducted as part of a whooping crane recovery plan. A long range management plan for Wood Buffalo National Park has been produced by Parks Canada.

Scientific Research and Facilities The Canadian Wildlife Service carries out aerial whooping crane breeding pair and production surveys annually.

Principal Reference Material The above information is taken from the List of Canadian Wetlands Designated as of International Importance (May 1982).

Additional references:

- Airphoto Analysis Associate Consultants Ltd. (1979). The biophysical resource inventory, Wood Buffalo National Park. Volume I-IV.

- Beckel, D.K.B. (Ed.). IBP Ecological sites in subarctic Canada. Contribution of the Canadian Committee of the Int. Biol. Programme, Region 10 Panel. University of Lethbridge Production Services, Alberta.

- Kienzle, B. (1972). The Wood Buffalo National Park area: a bibliography. Calgary, Alberta.

- Scace, R.A. (1974). An initial bibliography of Wood Buffalo National Park. Scace and Associates, Calgary, Alberta.

- Scace and Associates (1974). Wood Buffalo National Park: a literature review. Ottawa Parks Canada.

Peace-Athabaska Delta (Wood Buffalo National Park section)

Location $58^{\circ} 42^{\circ} \mathrm{N}, 111^{\circ} 08^{\circ} \mathrm{W}$. Situated in the south-east corner of Wood Buffalo National Park in north-east Alberta. The town of Fort Chipewyan is about $20 \mathrm{~km}$ to the east.

Area 321,300 ha

Degree of Protection This site comprises about $80 \%$ of the total area of the delta. It is owned by the Government of Canada and managed and protected under the regulations of the National Parks Act and National Parks Policy by Parks Canada (Prairie Region, 391 York Avenue, Winnipeg, Manitoba). Wood Buffalo National Park is a World Heritage Site. Designated as a Ramsar site in May 1982. 
Site Description Peace-Athabasca Delta is one of the largest freshwater deltas in the world comprising 3 deltas: Athabasca 1,970 sq.km, Peace 1,684 sq. km and Birch 168 sq. $\mathrm{km}$. The major lakes Claire, Baril, Mamawi and Richardson are very shallow $(0.6-3.0 \mathrm{~m})$; and are characterised by a thick growth of submerged and emergent vegetation. The area has a dry continental climate with long cold winters and short warm summers. Mean temperatures are about $16^{\circ} \mathrm{C}$ in July and $-25^{\circ} \mathrm{C}$ in January. The brief frost-free period extends from early June to early September but much of the area is permanently underlain with discontinuous permafrost. Daylight period is short in winter but in mid summer is over 20 hours. The area has much sunshine because of its northern latitude. Altitude is 204-210m. The topography of the delta consists of very large flat areas of sediment with outcropping islands of Canadian Shield scattered in the north-east region. Active and inactive river channels meander across the delta joining major lakes to Lake Athabasca and draining upland areas around the delta. The large open grasslands are interspersed with hundreds of shallow perched basins which are filled with water only during spring floods. The site contains 11 major habitat types: Aspen Water $(130,630 \mathrm{ha})$; emergents - inundated area with erect living vegetation rooted to the substrata (779ha); mud flats - above water level with little or no vegetation (13,593ha); immature fen (meadow) - the community occurring on a mud flat after one year exposure, and represented by seedling stages of Carex spp., Calamagrostis spp. or shrubs $(18,478 \mathrm{ha})$ : sedge meadow-area dominated by sedge $(18,813 \mathrm{ha})$; grass meadow dominated by Calamagrostis canadensis (12,186ha); tall shrub - woody shrub vegetation over 6 feet tall $(26,809 \mathrm{ha})$; deciduous - mainly Balsam poplar Populus balsamifera and birch Betula spp. (7,372ha): coniferous - mainly white and black spruce Picea glauca and P. mariana $(13,157 \mathrm{ha})$; and rock outcrop $(23,473 \mathrm{ha})$. These habitats contain over 250 species of vascular plants, 215 species of birds, 44 species of mammals, 18 species of fish and thousands of species of insects and invertebrates. Reptiles and amphibians include Canadian toad, leopard frog Rana pipiens, the boreal chorus frog, the woodfrog and red-sided garter snake.

\section{Criteria for inclusion $1(\mathrm{a}), 1(\mathrm{~b}), 2(\mathrm{a}), 2(\mathrm{~b}), 2(\mathrm{c})$ and 3}

International and National Importance The Peace-Athabasca Delta is the largest boreal delta in the world and is relatively undisturbed by civilisation. It is one of the most important waterfowl nesting and staging areas in North America and is the staging area for breeding duck and geese on their way to the MacKenzie River lowlands, Arctic river deltas and Arctic islands. Due to the shallow water, high fertility and relatively long growing season, the area is an abundant foodsource of particular importance during drought years on the prairies when a large proportion of the continental duck population is forced to spend the summer in northern habitats. This function will become increasingly important as continual attrition gradually decreases the potholes and marshes of the prairie habitat. All four major North American flyways cross the delta, though it is probably of most significance to the Mississippi and Central flyways. Species recorded in the delta area include lesser snow goose Anser caerulescens, white-fronted goose A. albifrons, Canada goose Branta canadensis, whistling swan Cygnus c. columbianus, all 4 species of loon Gavia, all 7 species of North American grebe (Podicipedidae) and 25 species of duck (Anatidae). The world's entire population of the endangered whooping crane Grus americana $(100+)$ which nest in the northern part of the park, are known to migrate through the site. The only known breeding population in central Canada of the vulnerable peregrine falcon Falco peregrinus nests in the delta area. The site also contains the largest undisturbed grass and sedge meadows in North America which are the prime range in the park for an estimated 10,000 wood and plains buffalo Bison bison athabascae and B.bison bison constituting $71 \%$ of the park's population. The delta is an important fish spawning area for regional populations of goldeneye and walleye.

Changes in Ecological Character At present the only major threat to the delta is the Bennett Dam located upstream on the Peace River in British Columbia which was constructed in 1967. The dam caused a significant drop in water flow to the delta resulting in insufficient water levels to fill the numerous perched basins in the area. Any further dam construction or river diversion on the Peace River could result in more damage to the delta. 
Management Practices Studies in the early 1970s identified that water levels on the delta required regulating to mitigate the effects of the Bennett Dam, and weirs were subsequently constructed at Rivière des Rochers and Revillon Coupé. There is careful monitoring and management of the hunting and trapping activities of the native Indian population. Bison are specifically protected under park game regulations from native domestic hunting. It is possible however, that some form of intensive manipulation of the bison herd may be required in the future due to the presence of anthrax, brucellosis and bovine tuberculosis on the bison range. Outbreak control measures for anthrax are carried out and will be continued. A long range management plan for Wood Buffalo National Park has been produced by Parks Canada.

Scientific Research and Facilities The governments of Canada, Alberta and Saskatechwan established the Peace-Athabasca Delta Project Group in January 1971 to conduct a detailed investigation into the problem of low water levels in Lake Athabasca and their cause and effect on the delta flora, fauna and local people. The investigation followed 3 consecutive years of low water levels in the delta after the construction of Bennett Dam.

Principal Reference Material The above information is taken from the List of Canadian Wetlands Designated as of International Importance in May 1982, supplemented by information from the World Heritage Nomination. The findings of the Peace-Athabasca Delta Project project were published as a summary report and technical report. The summary report, based on the technical report, is aimed for general public readership and was issued in January 1973 as 'The Peace-Athabasca: A Canadian Resource.' The technical report was published in 1973 as 'Peace-Athabasca Delta Project - Technical Report.'

\section{Hay-Zama Lakes}

Location $58^{\circ} 30^{\circ} \mathrm{N}, 119^{\circ} 00^{\prime} \mathrm{W}$. Located in north-eastern Alberta, $100 \mathrm{~km}$ west-northwest of High Level.

\section{Area 50,000 ha}

Degree of Protection Hay-Zama Lakes are an Alberta Fish and Wildlife Crown Reservation owned by the government of Alberta and administered by the Alberta Fish and Wildife Division. Designated as a Ramsar site in May 1982.

Site Description The wetland comprises freshwater eutrophic lakes and the floodplains and interior deltas of a lowland river. The area is about $320 \mathrm{~m}$ above sea level.

\section{Criteria for inclusion $1(\mathrm{a})$ and 3}

International and National Importance The wetland is of continental importance to spring and fall migrating ducks and geese. Waterfowl from three of the four North American flyways (Pacific, central and Mississippi) utilise the complex. Up to 130,000 lesser snow geese Anser $c$. caerulescens, 47,000 Canada geese Branta canadensis and over 200,000 ducks (up to 90\% dabblers) have been known to use this wetland in the fall.

Changes in Ecological Character The wetland is somewhat isolated from major developments, but a potential threat is future expansion of oil and gas activity.

Management Practices There is no active management practised specifically for waterfowl at present but future management may include the control of water levels. Fluctuations in levels and the resultant goose behaviour seem to determine the degree of waterfowl use in the fall. The existing oil and gas activity on the wetland is strictly controlled by 'shut down' dates in spring and fall, and any further expansion will be restricted. 
Principal Reference Material The above information is taken from the list of Canadian Wetlands Designated as of International Importance May 1982.

Additional information:

- Hennan E. and A.J. Macaulay (1974). Hay-Zama Lakes Project, waterfowl habitat assessment. Ducks Unlimited (Canada), Special Report No. 1503, 55p.

- Kelland C.D. (1967). Summarization of goose, vegetation and water level data collected during the summer of 1967 for Hay-Zama Lakes Goose Project. Unpublished progress report, Project 82-4-5-27, Canadian Wildlife Service, Edmonton, 70p.

- Environmental Research Associates (1979). Waterfowl use of the Hay Zama Lakes in relation to oil pumping operations. LGL Ltd., Edmonton, Alberta

- Macaulay A.J. (1969). Job completion report, Hay-Zama Lakes Goose Project. Project No. 82-4-5-78. Unpublished report to Canadian Wildlife Service, Edmonton. 30p.

- Macaulay A.J. (1969). Hay-Zama Lakes Project, summer 1969. Unpublished report of Ducks Unlimited (Canada), Winnipeg $34 p+$ plates.

\section{Alaksen National Wildlife Area}

Location $49^{\circ} 05^{\prime} \mathrm{N}, 123^{\circ} 15^{\prime} \mathrm{W}$. Located in the Municipality of Delta, British Colombia, $40 \mathrm{~km}$ south of Vancouver.

Area 520ha

Degree of Protection Owned by the Government of Canada and protected under the Canada Wildlife and Migratory Birds Convention Acts. Administered by the Canadian Wildlife Service, P.O. Box 340, Delta, British Colombia V4K 3Y3. Designated as a Ramsar site in May 1982.

Site Description The site lies at -1 to $5 \mathrm{~m}$ altitude, and comprises $280 \mathrm{ha}$ of freshwater and farmland, and 240 ha of tidal zone wetlands which include brackish and freshwater marsh and intertidal sand and mudflats. The salinity of the intertidal zone is low owing to the influence of the freshwaters of the Fraser River which flows into the area. The three main vegetational types on the intertidal zone are the cattail, sedge and bulrush communities. The cattail community comprises cattail Typha spp., Lyngbye's sedge Carex lyngbyei and water plantain Alisma plantago-agriatica. The sedge community comprises Lyngbye's sedge in association with reed fescue Festuca anindinaceae, bent grasses Agrostis spp. and round-stemmed bulrush Scirpus americanus valious. The bulrush community which is completely submerged at high tide is dominated by three-square bulrush Scirpus americanus with some round-stem bulrush. The farmland portion is protected by dykes and produces crops of potatoes, 'Indian' corn, peas, beans, cabbage and turnips. The soils are saline gleysols which have developed from the medium deltaic deposits. In addition to the commerical crops there are grasses such as bent grasses Agrostis spp., velvet grass Holcus lanatus, Canada blue grass Poa compressa and smart weeds Polygonum spp. These grasslands and the remnants of the crops provide food for waterfowl especially in winter when the fields are semi-flooded. On higher and well-drained sites there are red alder Alnus rubra, willow Salix spp. and black cottonwood, with shrub communities of snowberry Symphoricarpis albus, salmon berry Rubus spectabilis and blackberry Rubus ursimus. These thickets provide good habitat for pheasants and passerines. The freshwater bodies in the farmland are about $2-3 \mathrm{~m}$ deep and are valuable wintering areas which seldom freeze over for more than three weeks.

\section{Criteria for inclusion $1(\mathrm{a})$ and 3}

International and National Importance The area provides winter staging, feeding and breeding habitat for many species of western North American waterfowl, and supports one of the largest wintering waterfowl populations in Canada comprising 40 species of ducks, geese and swans. The most common species are Canada goose Branta canadensis, mallard Anas platyrhynchos and American wigeon Anas americana. About 25,000 ducks, 25,000 geese (15,000 Canada geese and 10,000 lesser snow geese Anser c. caerulescens that breed on Wrangle Island, USSR) and 100,000 shorebirds winter in the delta. 
Changes in Ecological Character The ownership by the federal government removes the threat of landfill, but pollution by toxic substances from adjacent areas is a potential threat.

Management Practices Control of water levels, agricultural practices, public access and hunting is carried out by Alaksen National Wildlife Area staff. Crops are grown for waterfowl use.

Scientific Research and Facilities Studies are in progress of the use birds make of different parts of the site.

Principal Reference Material The above information is taken from the list of Canadian Wetlands Designated as of International Importance May 1982.

Additional information:

- The Habitat Group (1978). Fraser River Estuary Study - Habitat report. Prepared for the Fraser River Estuary Study steering committee of the Government of Canada and the province of British Columbia. $181 \mathrm{pp}$.

- Hoos, L.M. and G.A. Packman (1974). The Fraser River Estuary - status of environmental knowledge to 1974. Estuary working group Req. Brd. Pac. Reg. Canada Dept. Environ., Spec. Est. Ser. Rept.(1), 518pp.

- Ministry of Environment (1982). A living river by the door; a proposed management program for the Fraser River Sanctuary. Ministry of Environment, Surrey, British Columbia $62 \mathrm{pp}$.

\section{Old Crow Flats}

Location $67^{\circ} 34^{\prime} \mathrm{N}, 139^{\circ} 50^{\prime} \mathrm{W}$. Part of a plain bordered in the north by the British Mountains, in the east by the Driftwood Hills of the Richardson Mountains and in the south by Old Crow and Keele Ranges. About $60 \mathrm{~km}$ north of Old Crow in Yukon Territory, $110 \mathrm{~km}$ south of the Beaufort Sea (Arctic Ocean) and $120 \mathrm{~km}$ north of the Arctic Circle.

Area 617,000 ha

Degree of Protection Federal Crown land administered by the Department of Indian and Northern Affairs subject to the Territorial Lands Act and Territorial Land Use Regulations. Current protection for wildlife species is under the Yukon Wildlife Ordinance and Migratory Birds Convention Act. Designated as a Ramsar site in May 1982.

Site Description Old Crow Flats is a lacustrine plain pocked by over 2,000 shallow freshwater lakes which were presumably formed by the melting of ice blocks in the substrate. The lakes vary in size from 0.5 ha to 4,700 ha with average depth of 0.5 to $1 \mathrm{~m}$ and maximum depth $4.0 \mathrm{~m}$. Permafrost underlies the area and forms the lake margins. The area is traversed by the meandering Old Crow River valley, which is down-cut well below the plain leaving most of the lakes 'hanging.' Altitude of the area is $260-300 \mathrm{~m}$. Several species of Potamogeton dominate the aquatic systems, and the associated invertebrate fauna is unusually varied and productive. When ice-rich margins erode causing sudden changes in water level, a marsh habitat dominated by sedge develops. The sedge first forms floating mats and then eventually shore-fast wet sedge beach, and provides nesting habitat for waterfowl. The dynamics of this process are poorly understood. Scattered stunted black spruce Picea mariana dominate the areas between the lakes, poorly drained sites develop peatlands, and better drained sites develop scattered forest stands with an understory of dwarf birch Betula spp. and willow Salix spp. Mammals include muskrat Ondatra zihethicus and a relatively dense population of moose Alces alces. The deep alluvial substrate underlying the area has been identified as an extremely important palaeontological and archaeological study area containing a rich assortment of pleistocene material.

Criteria for inclusion 1(a), 2(a) and 3 
International and National Importance The highly productive lakes and marshes are exceptional at such a high latitude. The area is important to some 500,000 waterbirds including 60,000 scoter Melanitta spp., 30,000 common goldeneye Bucephala clangula, 150,000 pintail Anas acuta and 75,000 American wigeon Anas americana, and also supports whistling swan Cygnus c. columbianus, sea ducks, loons and grebes. The primary function of the area is seen as a safe moulting and pre-migrational staging area. It is also a haven in years when there is drought in the prairies for ducks that move north after abandoning any attempt at breeding. It provides a nesting and hunting habitat for an important population of peregrine falcon Falco peregrinus.

Changes in Ecological Character Oil exploration is pending for the area, and some seismic line construction has occurred. Heavy machinery would possibly damage the ice-retention properties of the shoreline and could lead to draining of the lakes. There are also proposals for the construction of roads, and at least one gas pipeline near the area. Disturbance to wildlife may also be caused by the major archaeological and palaeontological field programmes being carried out or planned. The future security of the area figures highly in native land claim negotiations between Canada and the native people of Old Crow Band.

Management Practices Issuance of permits to regulate access for exploration and development under the Territorial Land Use Regulations.

Scientific Research and Facilities Surveys of waterfowl were conducted by the Canadian Wildife Service in the 1950s and aerial surveys of breeding ducks in early May have been made annually by the US Fish and Wildife Service since 1957. The Yukon Wildlife Branch began a long-term study in 1974 of the wetland ecology of the flats. The initial phase addressing waterbird use is complete but unpublished. Additional work on fur bearers and large mammals is planned. Archaeological and palaeontological research has been conducted in the area for several decades, and major programmes are planned. This work has produced many scientific and popular publications. Leading agencies are the National Museums of Canada in Ottawa and the University of Toronto.

Principal Reference Material The above information is taken from the list of Canadian Wetlands Designated as of International Importance, May 1982.

Additional information:

- Publications of the Gas Arctic Consortium contain several papers on birds and furbearers. Government reports primarily those of Yukon Territory contain the majority of material available on the biological systems of the area.

- Wiken, E.B., Welch, D.M., Ironside, G.R. and Taylor, D.G. (1981). The northern Yukon: an ecological land survey. Ecological Land Classification Series No. 6. Lands Directorate, Canada. $147 \mathrm{pp}$.

\section{Polar Bear Pass National Wildlife Area}

Location $75^{\circ} 45^{\prime} \mathrm{N}, 98^{\circ} 40^{\prime} \mathrm{W}$. Situated on Bathurst Island, Queen Elizabeth Islands, Northwest Territories.

Area 262,400 ha

Degree of Protection The area is federal Crown land administered by the federal Department of Indian and Northern Affairs under the territorial and land use regulations. Designated as a Ramsar site in May 1982.

Site Description Wetland habitats in the site are small inlets, lowland rivers, brooks, fresh oligotrophic lakes, peat bogs and temporary waters from snowmelt. Maximum water depth is $2.0 \mathrm{~m}$. The marshes, meadows and adjacent slopes provide feeding sites for at least 53 species of birds, 30 nesting in the region. The area contains 8 species of mammals, the most numerous 
being lemming Lemmus and Synaptomys spp., Arctic fox Alopex lagopus, musk-ox Oxibos moschatus and Peary caribou Rangifer pearyi. Polar bear Ursus maritmus regularly use the area in the spring and summer, and occasionally den there. Altitudinal range is from sea level to $60 \mathrm{~m}$.

\section{Criteria for inclusion $2(\mathrm{c})$ and 3}

International and National Importance Important populations of king eider Somateria spectabilis, greater snow goose Anser caerulescens atlanticus, gulls, jaegers and shorebirds, particularly sanderlings Crocethia alba. Atlantic brent Branta bernicla that breed here, winter in Ireland after staging in Iceland.

Changes in Ecological Character Mining, oil exploration and drilling permits were issued many years ago. Surface and subsurface rights to exploration and development were withdrawn prior to the area being created as a National Wildlife Area.

Management Practices A management plan is being developed for the area.

Scientific Research and Facilities The National Museum of Natural Science in Ottawa, with the assistance of the Polar Continental Shelf Project, has operated a research station in the area since 1968 to study the life histories and behavioural adaptations of Arctic animals. Over 100 publications on the research of the area have been published.

Principal Reference Material The above information is taken from the list of Canadian Wetlands Designated as of International Importance, May 1982.

Additional information:

- Nettleship, D.H. and Smith, P.A. (1975). Ecological siles in Northern Canada. Canadian Committee for the International Biological Programme, Conservation Terrestrial Panels. $330 p$.

- Sutton, G.M. (1971). High Arctic. Fitzhenry and Whiteside, Don Mills, Ontario. 119pp.

\section{Queen Maud Gulf Bird Sanctuary}

Location $67^{\circ} 00^{\prime} \mathrm{N}, 102^{\circ} 00^{\circ} \mathrm{W}$. Situated on the south coast of Queen Maud Gulf, Northwest Territories.

Area $6,200,000$ ha

Degree of Protection Established as a bird sanctuary in 1961 and protected under the Migratory Bird Sanctuary Regulations which stem from the Migratory Birds Convention Act. The sanctuary is federal Crown land. Designated as a Ramsar site in May 1982.

Site Description The sanctuary contains a wide range of wetland habitats including permanent shallow waters in open sea and bays, intertidal zones, tidal estuaries, deltas, lowland rivers and fresh oligotrophic lakes. Maximum altitude $100 \mathrm{~m}$. The vegetation is marsh tundra and consists of well vegetated hummocky tussocks, much of which flood during the spring. Mosses Aulacomnium turigidum. Drepanocladus revolvens, Meesea triataria and Tetraplodon urceolatus occur on the wet ground between hummocks. The hummocks support cotton grass Eriophorum vaginatum and sedge Carex chordorhiza. Emergent species include sedge Carex stans and mare's tail Hippuris vulgaris. 46 species of bird and six species of mammal have been recorded in the sanctuary.

Criteria for inclusion $1(\mathrm{a}), \mathrm{l}(\mathrm{b}), \mathrm{l}(\mathrm{c}), 2(\mathrm{~b})$ and $2(\mathrm{c})$ 
International and National Importance The sanctuary contains the largest variety of geese of any nesting area in North America, and is one of the few nesting areas with both the Atlantic and Pacific brent Brant bernicla hrola and B. bernicla nigricans. Almost the entire population of Ross' goose Anser rossii nest here. Their population has increased ten-fold in 35 years to at least 125,000 in 1981. Lesser snow goose Anser caerulescens have recently moved westward into the area, with about 80,000 in the summer of 1982. There are at least two nesting groups of Canada goose Branta canadensis, known as the tall grass prairie and short grass prairie populations. The latter is further west than the former at all times of the year.

\section{Changes in Ecological Character None}

Management Practices Issuance of restrictive permits to explore or develop other renewable and non-renewable resources.

Scientific Research and Facilities The numbers and distribution of waterfowl are recorded at intervals of no more than 5 years. Research has included a study of the breeding biology of Ross' goose.

Principal Reference Material The above information is taken from the list of Canadian Wetlands Designated as of International Importance, May 1982.

Additional information:

- Barry, T.W. (1958). Waterfowl investigations and wildlife surveys of the western arctic and some of the central arctic islands. Unpublished report of the CWS. Pp.42-58.

- Hanson, H.C., Queneau, P. and Scott, P. (1956). The geography, birds and mammals of the Perry River region. Arctic Institute of North America Special Publication No.1, 96pp.

- Kerbes, R.H. (1975). The nesting population of lesser snow geese in the eastern Canadian Arctic: a photographic inventory of June 1973. Can. Wild. Serv. Rep. Ser. No. 35, 47pp.

- Nettleship, D.N. and Smith, P. (1975). Ecological sites in northern Canada. Canadian Committee for the International Biological Programme Conservation Terrestrial Panel 9. $330 \mathrm{pp}$.

- Ryder, J.P. (1967). The breeding biology of Ross' goose in the Perry River region, Northwest Territories. CWS Report Series No. 3, 56pp.

- Ryder, J.P. (1969). Nesting colonies of Ross' goose. Auk. 82(2): 282-292.

- Ryder, J.P. (1969). Timing and spacing of nests and breeding biology of Ross' goose. Unpub. PhD Thesis, University of Saskatchewan, Saskatoon. 239pp.

\section{Rasmussen Lowlands}

Location $68^{\circ} 00^{\prime} \mathrm{N}, 93^{\circ} 30^{\circ} \mathrm{W}$. East of Rasmussen Basin about $100 \mathrm{~km}$ south of Spence Bay in Northwest Territories.

Area 300,000 ha

Degree of Protection The area is federal Crown land administered by the federal Department of Indian and Northern Affairs under Territorial Land Use Regulations. Designated as a Ramsar site in May 1982.

Site Description The southern area of the lowland is flat, poorly-drained, and covered in marine silts and sands with occasional esker or rock outcrops. About $10 \mathrm{~km}$ north of Inglis River, glacial moraine outcrops through the marine sediments forming the gently rolling Ross Hills. Numerous fresh oligotrophic lakes, peat bogs and temporary waters from snow melt are scattered throughout the lowlands. The escarpment of the Wager Highlands is on the eastern border of the area. Maximum altitude is $50 \mathrm{~m}$.

Criteria for inclusion $1(\mathrm{a}), 1(\mathrm{~b}), 1(\mathrm{c}), 2(\mathrm{~b})$ and $2(\mathrm{c})$ 
International and National Importance About 6,000 tundra swans Cygnus c. columbianus summered in the Rasmussen lowlands in 1976. About $90 \%$ of the population is known to nest in the eastern Arctic. An estimated 13,000 white-fronted geese Anser albifrons, comprising $6.5 \%$ of the total North American population, summered in the area during 1977 . The area also contains three small lesser snow goose Anser c. caerulescens nesting colonies totalling 4-6,000 birds, 10-15,000 old squaw Clangula hyemalis, 30-35,000 king eider Somateria spectabilis, raptors nesting along the eastern escarpment, and some 500,000 shorebirds.

Changes in Ecological Character A polar gas pipeline could cross the area.

Management Practices Land use permits are issued under the Territorial Land Use Regulations limiting human activity on certain areas and at certain times of the year.

Scientific Research and Facilities See references.

Principal Reference Material The above information is taken from the List of Canadian Wetlands Designated as of International Importance in May 1982.

Additional references:

- Adan, R.W. and Brackett, D.B. (1976). Migratory bird populations survey in the district of Keewatin and Somerset Island. Environmental Social Program, Northern Pipelines, Escom Repÿrt No.A, 1-18.

- Allen, D.L. and Hogg, T.H. (1978). Bird studies in the district of Keewatin: patterns of distribution, habitat preferences and potential impact of a pipeline. Final report, Arctic Islands Pipeline Project.

- McLaren M.A., McLaren, P.L. and Alliston, W.G. (1977). Bird populations in the Rasmussen Basin lowlands, NWT. June-September 1976. L.G.L. Environmental Research Associates for Polar Gas Project.

\section{McConnell River Bird Sanctuary}

Location $61^{\circ} 07^{\prime} \mathrm{N}, 94^{\circ} 03^{\prime} \mathrm{W}$. Located about $27 \mathrm{~km}$ south of Eskimo Point on the west coast at Hudson Bay in the district of Keewatin, Northwest Territories.

Area 32,800 ha

Degree of Protection The sanctuary was established in 1960 and is federally owned. Protected under the Migratory Bird Sanctuary Regulations which stem from the Migratory Birds Convention Act. Designated as a Ramsar site in May 1982.

Site Description The area consists primarily of coastal marsh flats which extend $3-8 \mathrm{~km}$ inland. The flat low-lying poorly-drained plain is dotted with shallow ponds and lakes with an average depth of $1 \mathrm{~m}$ and is typical of much of the west Husdon Bay coastline. Maximum altitude $20 \mathrm{~m}$.

\section{Criteria for inclusion $1(\mathrm{a}), 2(\mathrm{c})$ and 3}

International and National Importance The colony of lesser snow goose Anser c. caerulescens in the area has undergone rapid growth. The first report of nesting in the area was in 1941 and by 1973 the number had increased to over 163,000 nesting pairs. The colony has now spread beyond the boundaries of the sanctuary. Substantial numbers of the tall grass prairie population of Canada goose Branta canadensis also nest in the sanctuary.

Changes in Ecological Character There are no immediate threats from development, but ownership, land use and hunting rights may be affected by the outcome of land claim negotiations between the Inuit Tapirisat and the Government of Canada.

Management Practices Issuance of permits under the Migratory Bird Sanctuary Regulations and the Territorial Land Use Regulations. 
Scientific Research and Facilities McConnell River has been the site of extensive studies on the biology of geese and other Arctic species during the past two decades. Population levels of breeding lesser snow geese are regularly monitored.

Principal Reference Material The above information is taken from the list of Canadian Wetlands Designated as of International Importance in May 1982.

Additional references:

- Ankney, C.D. (1974). The importance of nutrient reserves to breeding blue geese Anser caerulescens. Unpublished Ph.D Thesis, University of Western Ontario. $213 \mathrm{pp}$.

- Cooch, F.G. (1958). The breeding biology and management of the blue goose Chel caerulescens. Unpublished Ph.D Thesis, Cornel University. 235pp.

- Davis, R.A. (1972). A comparative study of the use of habitat by Arctic loons and red-throated loons. Unpublished Ph.D Thesis, University of Western Ontario. 290pp.

- Harwood, J. (1974). The grazing strategies of blue geese Anser caerulescens. Unpublished Ph.D Thesis, University of Western Ontario. 186pp.

- Kerbes R.A. (1975). The nesting population of lesser snow geese in the eastern Canadian Arctic: A photographic inventory of June 1983. Can. Wild. Serv. Rep. Ser. No.35, 46pp.

- Lieff B.C. (1973). The summer feeding ecology of blue and Canada geese at the McConnell River, NWT. Unpublished Ph.D Thesis, University of Western Ontario. 203pp.

\section{Dewey Soper Bird Sanctuary}

Location $64^{\circ} 14^{\prime} \mathrm{N}, 76^{\circ} 32^{\prime} \mathrm{W}$. Located on Baffin Island about $275 \mathrm{~km}$ north-east of Cape Dorset in the district of Franklin, Northwest Territories.

Area $815,900 \mathrm{ha}$

Degree of Protection The sanctuary was established in 1957 and is federally owned and controlled. Protected under the Migratory Bird Sanctuary Regulation which stems from the Migratory Birds Convention Act. Designated as a Ramsar site in May 1982.

Site Description The sanctuary includes about $250 \mathrm{~km}$ of the coastal section of the Great Plain of the Koukdjuak. Much of the area is covered with a mat of mosses and the sedge Carex stans. Other common plants include Alopecurus alpinus, Salix spp., Cochlearia officinalis and Saxifraga caespitosa. Lack of relief on the plain, and high tides in Foxe Basin, combine to form a tidal zone which may extend up to $15 \mathrm{~km}$ inland. The wide marshy plain is dotted with shallow round lakes and circular swamps, and is drained by innumerable small sluggish streams. Maximum altitude $60 \mathrm{~m}$.

Criteria for inclusion 1(a), 1(b), 1(c), 2(c) and 3

International and National Importance The most abundant waterfowl in the sanctuary is lesser snow goose Anser c. caerulescens, with about 450,000 nesting individuals in three major colonies recorded in 1973 and 1979 (though distribution differed). Other numerous species are small Canada goose Branta canadensis of the tall grass prairie population, Atlantic brent Branta bernicla hrota, old squaw Clangula hyemalis, eiders Somateria mollissima borealis and $S$. spectabilis and several species of shore birds. Cape Dominion seems to be the most important nesting area in the eastern Arctic for Atlantic brent.

Changes in Ecological Character There are no imminent threats.

Management Practices Issuance of Migratory Birds Sanctuary Permits and Territorial Land Use Permits to control access to the area.

Scientific Research and Facilities Population levels of breeding lesser snow goose are regularly monitored. 
Principal Reference Material The above information is taken from the List of Canadian Wetlands Designated as of International Importance in May 1982.

Additional references:

- Kerbes, R.H. (1969). Biology and distribution of nesting blue geese on Koukdjuak Plain, NWT. Unpublished M.Sc. Thesis. University of Western Ontario.

- Kerbes, R.H. (1975). The nesting population of lesser snow geese in the eastern Canadian Arctic: A photographic inventory of June 1983. Can. Wild. Serv. Rep. Ser. No.35, 47pp.

- Soper, J.D. (1946). Ornithological results of the Baffin Island expeditions of 1928-29 and 1930-31; together with more recent records. Auk. 63:1-24, 224-239 and 418-427.

\section{St Clair National Wildlife Area}

Location $42^{\circ} 22^{\prime} \mathrm{N}, 82^{\circ} 22^{\prime} \mathrm{W}$. On the east shore of Lake St Clair in Dover Township, County Kent. Chatham city is $30 \mathrm{~km}$ to the east.

Area 244 ha

Degree of Protection Federal Crown land. Administered by the Canadian Wildlife Service and designated as a National Wildlife Area under the Canada Wildlife Act. Designated as a Ramsar site in October 1985.

Site Description A shallow, mesotrophic link in the Great Lakes system. Waters from Lake Huron flow in via the St Clair River and out via the Detroit River to Lake Erie. The shallow channel of the Thames River (a major tributary) has been extensively dyked to control the frequent spring flood waters, and little natural wetland habitat remains along the river flood plain. The lakeshore marshes lie on stratified clay plains which are among the most fertile in Canada. The St Clair NWA contains examples of the three major habitat types: i) Continuous emergent marsh, predominately stands of cattail Typha sp., with rare plants found on the wet meadows occuring on slightly higher ground such as freshwater cord grass Spartina pectinata, yellow star grass Hypoxis hirsula, Culver's root Veronicastrum virginicum, tickseed sunflower Bidens coronata and tall ironweed Veronica altissima. ii) Emergent marshes interspersed with small ponds which cover about $40 \%$ of St Clair NWA., the principal elements being pickerelweed Pontederia cordata, hardstem bulrush Scirpus acutus, softstem bulrush Scirpus validus, burreed Sparganium spp. and tuberous water lily Nymphaea tuberosa. The rare species green water arum Peltandra virginica, cow lily Nuphar edvena and American lotus Nelumbo lutea are also found here. iii) Marsh zones that are open to Lake St Clair vary in character as lake levels change. In some areas, large increases in the amount of quality waterfowl foods such as sago pondweed Potamogeton pectinatus and wild celery occurred when high lake levels killed extensive beds of emergent vegetation, largely cattails. Some extensive submerged beds of muskgrass occur and some small areas of open water marsh.

Muskrats Ondatra zibethicus play a major ecological role in the marsh. Other mammals of importance in the marshes are raccoons Procyon lotor, striped skunks Mephitis mephitis and mink Mustela vison. The reptiles and amphibians of the area include several species that have not been officially designated but that are considered by experts to be rare or threatened in Canada. The eastern fox snake Elaphe vulpina gloydi, considered threatened in Canada, is abundant in St Clair marsh edges. Among the five species of turtles that have been found are the spotted turtle Clemmy's guttata, blanding's turtle Emydoidea blandingi and eastern spiny softshell Trionyx s. spiniferus, all considered rare in Canada.

Criteria for inclusion $1(\mathrm{a}), 1(\mathrm{~b}), 2(\mathrm{a}), 2(\mathrm{~b}), 2(\mathrm{c})$ and 3

International and National Importance Large numbers of waterfowl use Lake St Clair and adjacent wetlands, which constitute one of the most important staging regions for waterfowl in Ontario south of James Bay. At the height of migrations in spring and fall, tens of thousands of ducks, geese and swans congregate in the marshes and shallow waters of the east shore of the lake. 
During spring and fall migrations, there are frequent periods when more than 100,000 waterfowl are present in the lake and adjacent region. In spring, peak numbers have been as high as 60,000 birds. In autumn, nearly 150,000 ducks, geese and swans have been present at one time. Over half of the eastern population of the tundra swan Cygnus c. columbianus passes through the region in early spring; this is $23 \%$ of the entire North American population. The region in autumn supports significant proportions of waterfowl populations: $15 \%$ of the Tennessee Valley population of Canada geese Branta canadensis; $18 \%$ of world populations of canvas-backs Aythya valisineria, $8 \%$ of world populations of redheads A. americana and $4 \%$ of world populations of ring-necked ducks $A$. collaris and 3\% of North American populations of ruddy ducks Oxyura jamaicensis.

Other marsh-dependent birds found include: grebes, herons, rails and waders. Feeding shorebirds are especially abundant when mud flats are exposed. Among the more uncommon species recorded are king rail Rallus elegans, glossy ibis Plegadis falcinellus and snowy egret Egretta thula. Breeding waterfowl include: pied-billed grebe Podilymbus podiceps, least bittern Ixobrychus exilis, American bittern Botaurus lentiginosus, mallard, American coot Fulica americana and black tern Chlidonias niger. Other nesters are blue-winged teal Anas discors, redhead, virginia rail Rallus limicola, sora Poezana carolina, common moorhen Gallinula chloropus, killdeer Charadrius vociferus, spotted sandpiper Actitis macularia, and snipe Gallinago gallinago. In addition many species use the area for feeding or loafing; great blue herons Ardea herodias, great egrets Casmerodius albus, black-crowned night herons Nycticorax nycticorax and common terns Sterna hirundo feed in the marsh.

Changes in Ecological Character Of the marshes remaining along Lake St Clair's east shore, only the St Clair NWA is protected against development. There has been major wetland loss of privately owned wetlands due to drainage for agriculture, development for recreational uses and cottage development. The lakeshore marshes are vulnerable to impacts from off-site development. Spills of oil or other toxic chemicals from Great Lakes shipping are a constant threat. Manipulations of lake levels or impacts of an extended navigation season on the Great Lakes could cause wetland losses and detrimental changes. St Clair NWA is dyked and somewhat protected from, but not invulnerable to, such impacts. The recently increased dense concentrations of mallards and black ducks tend to discourage the use of the area by other dabblers.

Management Practices In 1940 the area was dyked, strips ploughed to encourage establishment of marsh plants, and flooded. Water levels were kept low in summer to encourage aquatic plant growth and some species were introduced. Water levels were raised in fall to attract ducks and were kept high during muskrat trapping seasons. Since its acquisition by CWS, a variety of wildlife management techniques have been employed. Constructed nesting islands and existing dykes, spoil piles, and meadow areas provide nest sites. Cut channels provide brood habitat and loafing or resting areas. Water circulation throughout the marsh has been improved by pumping; water level manipulations and cattail control measures have improved interspersion of open water and emergent vegetation. These measures have improved growth of submergent aquatic plants and the associated invertebrates that provide food for waterfowl species. Muskrat harvesting has taken place under CWS permits, and minimizes damage to dykes from muskrat tunnels. Moreover, trapping encourages maintenance of healthy populations of muskrats which, by using cattails as a major food source and for lodge-building materials, limit the encroachment of cattail in the marsh ponds and channels.

Scientific Research and Facilities Canadian Wildlife Service has monitored waterfowl numbers and wetland habitats at Lake St Clair for many years. Waterfowl surveys during migration, censuses of wintering waterfowl, and brood surveys are aspects of ongoing programmes. Research on cattail control, waterfowl ecology, breeding bird surveys, weekly bird censuses, vegetation monitoring and a variety of other baseline biological data collections are conducted by CWS staff and other researchers. Water quality is monitored on a regular basis. 
Principal Reference Material The above information is taken from the document submitted at the designation of the St. Clair National Wildlife Area to the List of Wetlands of International Importance October 1985

Additional references:

- Dennis, D.G. and North, N.R. (1981). Waterfowl use of the Lake St. Clair marshes during migration in 1976-77 versus 1968-69. Can. Wildl. Serv. Rep.

- Dennis, D.G., McCullough, G.B., North, N.R., and Ross, R.K. (1983). An updated assessment of migrant waterfowl use of the Ontario shorelines of the southern Great Lakes. Can. Wildl. Serv. Rep.

- McCullough, G.B. (1981). Wetland loss in Lake St. Clair and Lake Ontario. Ontario Wetlands Conf. Proc. 18-19: 81-89.

- McKeating, G., Gow, D. and Madore, P. (1982). Management plan: St. Clair National Wildlife Area. Can. Wildl. Serv. Rep. London, Ontario.

\section{Chignecto National Wildlife Area}

Location $45^{\circ} 47^{\prime} \mathrm{N}, 64^{\circ} 20^{\prime} \mathrm{W}$. Located on Cumberland Basin at the head of the Bay of Fundy $5 \mathrm{~km}$ southwest of the town of Amherst, Cumberland County, Nova Scotia.

Area 1,020 ha

Degree of Protection Federal Crown land. Designated as a National Wildlife Area under the Wildlife Area Regualtions of the Canada Wildlife Act. Additionally, the Amherst Point section is scheduled as a Migratory Bird Sanctuary under the Sanctuary Regulations of the Migratory Birds Convention Act.

Site Description The Wildlife Area consists of the John Lusby Salt Marsh and the Amherst Point Bird Sanctuary, two very different wetlands, and separated by a narrow $(1 \mathrm{~km})$ upland ridge. The 600 ha John Lusby section is principally a Spartina dominated intertidal salt marsh (tide range up to $12 \mathrm{~m}$ ) built up on alluvial silt and intersected by numerous tidal creeks and channels. Small saline ponds (with depths from $15-30 \mathrm{~cm}$ ) are interspersed throughout the marsh, and two brackish impoundments (20ha with average depths of $45 \mathrm{~cm}$ ) have been developed along the upland edge. The Amherst Point Sanctuary section is a mosaic of freshwater wetlands of several natural types ranging from sink hole ponds to small lakes (with average depths of $60 \mathrm{~cm}$, with the exception of a sink hole depression in one of the lakes that decends to $11 \mathrm{~m}$ ), bogs and cattail Typha marshes. However, shallow controlled water level impoundments (with depths from $30-60 \mathrm{~cm}$ ) comprise nearly half of the wetland area. Wetlands at the site are the most productive in the province, and derive this fertility from the gypsum-limestone bedrock and from marine silt deposits. Cattails and burreeds Sparganium are the most common emergent plants, with water milfoil Myriophyllum and pondweeds Polomogeton common throughout.

Criteria for inclusion $1,4,6$ and 7

International and National Importance The salt marsh supports flocks of up to 6,000 Canada geese Branta canadensis during spring migration and lesser numbers of black duck Anas rubripes, green-winged teal $A$. crecca and northern pintail $A$. acuta. In summer broods of black duck are common on the impoundments and on the salt marsh ponds, where greater yellowlegs Tringa melanoleuca are frequently observed. Throughout fall the wetland supports flocks of mixed waterfowl species (numbering in the hundreds). Waterfowl and other marsh birds are abundant in the freshwater wetlands and include most species commonly found in the region, along with the regular occurrence of regionally rare species such as gadwall Anas strepera, redhead Aythy'a americana, ruddy duck Oxyura jamaicensis, virginia rail Rallus limicola, common moorhen Gallinula chloropus, American coot Fulica americana and black tern Chlidonias niger. Over 200 species of birds have been recorded at the sanctuary. 
Changes in Ecological Character Urban expansion around the town of Amherst will increase recreational use pressures on the site, but should not cause serious damage if it is properly regulated and enforced by CWS. The possibility of eventually developing a major tidal power installation on Cumberland Basin is potentially a serious threat to the salt marsh section of the wildlife area. Should a tidal barrage ever be developed across Cumberland Basin, tidal amplitudes will be reduced greatly changing the ecology of the John Lusby Salt Marsh.

Management Practices The site is managed by the Canadian Wildlife Service in cooperation with the province of Nova Scotia (and with development assistance from Ducks Unlimited Canada). Ongoing management is designed to protect the unique ecological and aesthetic features of the area, and to maintain habitat diversity. Nature trails and interpretation signage and facilities are presently being installed and may be gradually more fully developed as the area becomes better known to the public in the region.

Scientific Research and Facilities Research studies have been conducted on the ecology and productivity of the John Lusby Salt Marsh and on a unique limnmological phenomenon that occurs at Layton's Lake within the Amherst Point Bird Sanctuary. A recent study on pied-billed grebes at one of the artificial impoundments has revealed nesting densities unparalleled elsewhere in North America.

Principal Reference Material The above information is taken from the document submitted at the designation of the Chignecto National Wildlife Area to the List of Wetlands of International Importance October 1985.

Additional references:

- Forbes, M.R.L. (1982). The Nesting Ecology and Breeding Behaviour of the Pied-billed Grebe (Podilymbus podiceps) at a National Wildlife Area in Nova Scotia. Honours Thesis, Acadia Univ., Wolfville, N.S.

- Foshay, G.M. (1974). The Limnology of Layton's Lake, N.S. B.Sc. Thesis, Mount Allison Univ., Sackville, N.B.

- Monartz, D.L. (1976). Productivity and export from a marsh with $15 \mathrm{~m}$ tidal range, and the effects of impoundment of selected areas. M.Sc. Thesis, Dalhousie Univ., Halifax, N.S.

- Van Zoost, J.R. (1970). The ecology and waterfowl utilization of the John Lusby National Wildlife Area. M.Sc. Thesis, Acadia Univ., Wolfville, N.S. 


\section{CHILE}

\section{Area 756,943 sq. $\mathrm{km}$}

\section{Population $11,682,260(1983)$}

Summary of Wetland Situation In Southern Chile there are countless fresh-water lakes, marshes, bogs, estuaries, fiords and offshore islands which are of prime importance for breeding Anatidae. Most species are to some extent migratory, but large numbers remain through the winter in sheltered fiords and bays. The most important sites of the region include the freshwater marshes along the Rio Cruces north of Valdivia where the Carlos Anwandter Sanctuary has been established; the freshwater lakes and marshes, and tidal estuaries and salt marshes around Ancud, Isla de Chiloé - particularly important for wintering Anatidae and shorebirds; and the Torres del Paine National Park and Puerto Natales area - another important breeding and wintering area for Anatidae. In the north, along the coast, conditions are extremely arid and there are few wetlands of any significance on the coastal plain. However, the coast itself, with its long sandy beaches and stretches of rocky shore, is of great importance for a variety of shorebirds, gulls and terns. There are many small estuaries with tidal mud-flats and permanent fresh to brackish marshes which are collectively fairly important but there are few large areas which regularly contain high numbers of waterfowl.

Further inland within the Andes there is a chain of freshwater lakes, salt lakes and highland bogs which present some of the finest waterfowl spectacles on the continent. Within Chile particular note should be taken of the marshes, lakes and salt lakes of Lauca National Park (an outstanding area with a wide variety of habitats and almost a full complement of Andean waterfowl); the Salar de Atacama, which is particularly important for flamingos, the Maricunga Salt Lake and Santa Rose Lake.

Protected Areas Legislation The Law of Woodlands, Supreme Decree 4363 of 1931, and the Forest Law, Decree 656 of 1925, enabled the government to establish national parks and other reserves with the purpose of protecting certain species of tree, and conserving scenic beauty. Supreme Decree 531 of 1967 (of the Ministerio de Relaciones Exteriores) subsequently defined National Parks and other reserves and specified their roles. Chilean conservation units have undergone a recent reorganisation and consolidation. The government has set into force law No.18.362 (27.12.1984) of the Ministry of Agriculture which establishes a National System of Protected Wild Areas of the State. This key conservation and environmental law covers all previous types of protected areas in National Parks, Natural Monuments and National Reserves. It is hoped that in future, wetlands and marine habitat can be included in a greater proportion within this legal framework.

Protected Areas Administration Legal responsibility for the protected areas is vested in the Agricola y Ganadero of the Ministerio de Agricultura. Nevertheless this organisation, through a 1971 agreement, delegates administration to the Corporacion Nacional Forestal (CONAF). National Parks are large areas protected by the highest competent authority which have not been significantly altered by exploitation, and in which animal and plant species, geomorphological sites, or habitats are of special scientific, educational and/or recreational interest. They may also contain areas of high landscape value. Natural Monuments are regions, objects or living species of either historic or scientific value, or of aesthetic interest, which are protected absolutely. Scientific Reserves are areas specifically established for their natural resources research potential. There are also National Fauna Refuges and Forest Reserves.

Sites designated under the Convention Accession 27 July 1981, one site listed at accession.

Carlos Anwandter Nature and Scientific Investigation Sanctuary 
Government body responsible for administration of the Convention

Dr Roberto P. Schlatter, Instituto de Zoologia, Universidad Austral de Chile, Casilla 567, Valdiva

\section{Carlos Anwandter Nature and Scientific Investigation Sanctuary}

Location $39^{\circ} 35^{\prime}-39^{\circ} 47^{\prime} \mathrm{S}, 7^{\circ} 07^{\prime}-73^{\circ} 16^{\prime} \mathrm{W}$. Situated along the Rio Cruces to the north of Valdivia city and inland from the central west Chile coast in Valdivia Province.

Area 4,877 ha including a $100 \mathrm{~m}$ wide buffer strip around the entire sanctuary boundary.

Degree of Protection The sanctuary was established under law 17.288 (National Monument) and is the responsibility of the state. It comprises numerous privately owned plots of land including some owned by the Southern University of Chile. The Servicio Agricola y Ganadero (SAG) and Corporacion Nacional Forestal (CONAF) cooperate with the state in administration and there are strict regulations on hunting and trapping. Designated as a Ramsar site at the time of accession on 27 July 1981.

Site Description The designated site comprises the braided section of the Cruce River north of Valdivia with sandbars and river islands and the associated marshlands and swampy ground where numerous tributaries join the Cruce. This part of the river is tidal, being near the Pacific Ocean. The freshwater wetland developed following earthquake subsidence in 1960 and the relatively young ecosystem supports a distinctive vegetation of rooted aquatic plants such as Sagittaria chilensis, Scirpus californicus and Hydrocolyle volksmanni, and a diversity of marsh plants such as Typha angustifolia, Senecio spp., Juncus spp. and sedges (Cyperaceae) on the areas submerged only at high tide or in floods. The sanctuary is demarcated to the north by the swamps just east of the Cruce-San Jose river confluence and follows the course of the Cruce River southwest to the edge of Valdivia city. It is flanked to the west by the coastal range of hills and to the east by the main road from Valdivia to Temuco.

\section{Criteria for inclusion 2(b) and 3(a).}

International and National Importance The wetland attracts large numbers of nesting and migratory birds including black-necked swan Cygnus melancoryphus (threatened in Chile). A document on wetlands in Valdivia Province by Schlatter (1975) contains species lists of birds, mammals, amphibians and fish recorded in the region.

Changes in Ecological Character The soils covering $98 \%$ of the sanctuary are too poor to support commercial agriculture and the area is therefore unlikely to be developed in the near future. The run-off of pesticides from nearby agricultural land could be harmful. River traffic has increased in recent years. Clandestine hunting and nutria capture is undertaken periodically. Rialejo island (private property) within the sanctuary has been logged of its older timber. Much of the property around the area has changed owners. Monterey pine plantations on surrounding hills which delimit the area have increased significantly and may adversely affect the site when the timber comes to be transported towards the sawmills at Valdivia.

Management Practices The wetland is managed as a field study area for the Southern University of Chile. Hunting and trapping are strictly controlled. To try and counter the threats from surrounding pine plantations, there have been plans to change the protective status of the area, mark the boundaries more clearly with signs, and locate high fire-watching posts which would also be used for observing animals and human activity within the sanctuary. From 1984 there has been a faunal guard equipped with binoculars and a rubber dinghy who makes regular surveys and animal censuses which are reported to the local office of CONAF in Valdivia. 


\section{Chile}

Scientific Research and Facilities The Southern University of Chile plans to survey the flora and fauna of this newly developed aquatic ecosystem. There are plans to investigate the potential rational and intensive agricultural use of the area through nutrient supplement experiments.

Principal Reference Material The above information is taken from:

- IUCN/IWRB (1986). Directory of Neotropical Wetlands. IUCN, Gland, Switzerland and Cambridge, England.

- Schlatter, R.P. (1975). Santuarios de la Naturaleza e Investigacion cientifica en las regiones pantanosas e inundadas de los alrededores de la Ciudad de Valdivia. Proyecto. Southern University of Chile, Valdivia.

- Scott, D.A. (1982). Wetlands and waterfowl in South America: a continental perspective. Paper prepared for the IWRB 28th Annual Meeting, Edmonton, Canada. 


\section{DENMARK}

Area 43,030 sq. $\mathrm{km}$

Population $5,112,130$ (1984 census)

Summary of Wetland Situation Denmark has a large number of wetlands of international importance thanks to a long and mostly flat coastline, with numerous fiordlike inlets and archipelagos. In the south-west it shares the biggest, and one of the most important wetlands in Europe, the Waddensea (Vadehavet), with the Federal Republic of Germany and the Netherlands. Sites with excellent habitat for breeding waterfowl are situated along the coast and in the interior of North Jutland, in particular the Lim fiord area which extends right across Northern Jutland from the North Sea to the Kattegat. These sites are also of exceptional importance for wintering and migrating ducks and geese. Vast concentrations of diving ducks and sea-ducks are found in the shallow waters of the Kattegat, the Lillebaelt, the South Funen Archipelago, the Storebaelt, Oresund, South Sealand, Lolland, Falster and Mon.

Detailed information on waterfowl concentrations in the various wetlands can be found in the Danish Review of Game Biology Vol. 9 no. 1 (Waterfowl Populations in Denmark 1965-1973, a survey of the non-breeding populations of duck, swan and coot and their shooting utilization by A.H. Joensen). Conservation of the freshwater wetlands has improved since the 1969 Conservation Act was modified in 1972. It is no longer possible to reclaim fresh or saltwater wetlands without the permission of the Conservation Planning Committee, nor can changes be made affecting the flow of watercourses (unless they are wholly privately owned). The Ministry of the Environment, created in 1973, deals with conservation measures, physical planning and pollution control.

The Nature Protection Council and the Natural History Museum in Aarhus have been very active in promoting public awareness of wetlands. A number of management projects for their improvement as breeding sites for waterfowl have been carried out by the Viltbiologisk Station (Game Biology Station) at Kalo. The wintering populations together with the relative importance of individual wetlands, have been studied by the Viltbiologisk Station.

General conservation of wetlands differs both practically and administratively depending on whether the areas are freshwater or salt. In most cases salt and brackish areas are subject to state control administered by the Ministry of Public Works, while fresh waters are normally placed under local authorities (and are usually a private property).

Protected Areas Legislation Conservation is based on a broad philosphy of long term planning and protection. The principle laws are the Environment Protection Act (1973), the Act on National and Regional Planning (1973), the Urban and Rural Zones Act (1969, amended 1978) and a further act ordered for recreational, scientific, educational or historic reasons. Each area is protected on a case by case basis, and the degree of protection varies widely, both between areas and within them. Regulations are drawn up specifically for each area but in general existing uses including farming, forestry and hunting may well continue. There are two defined types of reserve, scientific reserves, and game reserves (though the latter does not imply biotype protection), while woodlands and forests are protected under the forest legislation, and nature parks controlled through town and country planning.

Protected Areas Administration All matters concerning nature conservation have, since October 1973, come under the Ministry of the Environment. The ministry has two consultative organs, the Nature Conservation Council, and the Government Advisor for Nature Conservation (which also acts as the secretariat for the NCC). The Conservation Planning committees set up in each county make local conservation and planning decisions. They comprise a board of political authorities and a secretary with some technical assistants. The secretary is the actual manager of all issues, Conservation Boards and Chief Conservation Boards. The second is equivalent to a high court of justice. There are no general mangement guidelines, and most areas have no management plan. 
Sites designated under the Convention

Accession 2 September 1977, with 26 sites listed at accession

Fiilso

Ringkobing Fiord

Stadil and Vestastadil Fiords

Nissum Fiord

Nissum Bredning with Harboore and Agger Peninsulas

Vejlerne and Logstor Bredning

Ulvedybet and Nibe Bredning

Hirsholmene

Nordre Ronner

Laeso

Parts of Randers and Mariagwer Fiords, and the sea adjoining them

Sea area north of Anholt Island

Horsens Fiord and EndelaveStavns Fiord and adjacent waters

Lillebaelt

Naereaa Coast and Aebelo area

South Funen Archipelago

Sejero Bay

Waters off Skaelskor Nor and Glaeno

Karresbaek, Dybso and Avno Fiords

Waters south-east of Fejo and Femo Islands

Praesto Fiord, Jungshoved Nor, Ulfshale and Nyord

Nakskov Fiord and Inner Fiord

The Maribo Lakes

Waters between Lolland and Falster, including Rodsand, Guldborgsund and Boto Nor

Ertholmene Islands east of Bornholm

Government body responsible for administration of the Convention

Ministry of the Environment, National Agency for the Protection of Nature, Monuments and Sites, 13 Amaliegade, DK-1256 Kobenhavn K

Fiilso

Location $55^{\circ} 42^{\prime} \mathrm{N}, 8^{\circ} 15^{\prime} \mathrm{E}$. Situated in the county of Ribe, north of Wadden Sea on the west coast.

\section{Area $4,320 \mathrm{ha}$}

Degree of Protection The area is privately owned with the state represented by the Ministry of Defence and Ministry of the Environment. 400ha around Fiilso is a nature conservation area protected under the 1969 Nature Conservation Act (as amended 1972, 1975 and 1978). There are no wildlife reserves. Designated as a Ramsar site in September 1977.

Site Description The site comprises $96.9 \%$ (4,188ha) small plantations and agricultural land, with mainly large fields and few buildings, and $3.1 \%$ (132ha) consisting of two shallow freshwater lakes surrounded by marsh. The vegetation at Fiilso is of scientific interest. The site is a resting and feeding area for waterfowl.

International and National Importance This site is of international importance for 18,000 pink-footed geese Anser brachyrhynchus, 5,000 pintail Anas acuta, 500 Bewick's swan Cygnus columbianus bewickii and 300 whooper swan C. cygnus, and also supports 5,000 mallard Anas platyrhynchos. Fiilso and Vest Stadil Fiord (Ramsar site) are the most important areas in Denmark for the pink-footed goose.

Changes in Ecological Character The area covered by tree plantations is increasing, and the marshes and lakes are becoming overgrown. 
Management Practices Hunting of geese and other waterfowl is restricted. Management practices on the land include reduced ploughing of stubble fields and the maintenance of green fields.

\section{Scientific Research and Facilities No information}

Principal Reference Material The above information is taken from the Danish National Report to the Cagliari Conference in 1980.

Supplemented by:

- Scott, D.A. (1980). A preliminary inventory of wetlands of international importance for waterfowl in west Europe and north-west Africa. IWRB Special Publication No. 2.

\section{Ringkobing Fiord}

Location $56^{\circ} 00^{\prime} \mathrm{N}, 8^{\circ} 15^{\prime} \mathrm{E}$. Located on the west coast in the counties of Ringkobing and Ribe.

Area 27,240 ha

Degree of Protection Ownership is part private and part state, with the state represented by the Ministry of the Environment. Areas protected for nature conservation include the Vaern Meadows, Nymindestrmmen, Tipperne and Klaegbanken totalling 6,000ha protected under the Conservation of Nature Act 1969 (as amended 1972, 1975 and 1978). Tipperne and Klaegbanken are scientific sanctuaries. $60 \mathrm{ha}$ including the outlet of the Skjerna stream is a wildlife reserve protected under the Game Act 1967 (amended 1969 and 1972). Designated as a Ramsar site in September 1977.

Site Description The wetland consists of a shallow brackish-water fiord connected to the North Sea by sluices, and adjacent low-lying meadows and reed swamps in the south. The site includes some small islands. About 300 years ago Ringkobing Fiord was completely open to the sea, but a coastal sandbar has since formed, cutting off the entrance. Sand continuing to drift over the bar into the southern part of the fiord has formed the peninsulas of Tippersande and Vaernsande, which are now vegetated and valuable grazing meadows. The dominant vegetation on Tipperne when Ringkobing was open to the sea was saltmarsh with glasswort Salicornia spp., mud rush Juncus gerardii, sea aster Aster tripolium and sea milkwort Glaux maritima. After the formation of the sandbar Ringkobing Fiord became a freshwater lake, but an inlet has now been cut through the sandbar to allow passage of fishing boats. This has allowed small amounts of salt water into the fiord creating brackish conditions. However the vegetation remains nearer to that of a freshwater marsh than a saltmarsh. The wetland comprises $82.7 \%$ salt and brackish water and $17.3 \%$ land. The site is used by waterfowl for resting, feeding, breeding and moulting.

International and National Importance This site is of international importance as a resting and feeding ground for 15,000 mallard Anas platyrhynchos, 11,000 teal A. crecca, 18,000 pintail A. acuta, 30,000 wigeon A. penelope, 1,000 shoveler A. clypeata, 3,200 goldeneye Bucephala clangula, 5,000 goosander Mergus merganser, 4,000 dark-bellied brent goose Branta bernicla, 7,000 pink-footed goose $A$. brachyrhynchus, 500 grey lag goose $A$. anser, 2,000 shelduck Tadorna tadorna, 4,300 mute swan Cygnus olor, 600 whooper swan $C$. cygnus, 1,100 Berwick's swan C. columbianus bewickii, 25,000 coot Fulica atra, 800 avocet Recurvirostra avosetta and 3,500 bar-tailed godwit Limosa lapponica. Also feeding and resting here are dunlin Calidris alpina. Waterfowl using the area as a moulting site are 500 mallard, 400 goldeneye and 3,000 mute swan. The site is a breeding area for mute swan, black-tailed godwit Limosa limosa, ruff Philomachus pugnax, avocet, sandwich tern Sterna sandvicensis, black-headed gull Larus ridibundus and the marsh harrier Circus aeroginosus. The site is the most important locality in Denmark for Bewick's swan and shoveler, and supports the biggest colony in the world of mute swan. Excluding Vadehavet (the Danish Wadden Sea) the area is the most important locality in Denmark for surface feeding ducks. 
Changes in Ecological Character The major cause for concern in Ringkobing Fiord has been the complete disappearance of submerged macrophytes. There has also been a mass occurrence of blue-green algae. As macrophytes are an important food resource for waterfowl, these changes are potentially disastrous. The causes are unknown, although pollution by agricultural chemicals, and climatic change have been suggested. There is increased sedimentation in the southern part of the fiord since the regulation of Skjerna stream. In areas where hay was cut annually until 1950, much of the nutrient salts have been washed out and the soil has become acid so that cross-leaved heath Erica tetralix, crowberry Empetrum nigrum, common cotton-grass Eriophorum angustifolium and many sedges Carex spp. occur. Hay making had been adandoned on the scientific reserves resulting in the disappearance of some colonial nesting birds such as avocet, but it was reintroduced in 1972. A common problem in dammed wetlands such as Ringkobing Fiord is declining salinity. The sluice has been in operation since December 1979 between the fiord and the North Sea and this experiment has already resulted in improvements of the flora and fauna of the wetland.

Management Practices Klaegbanken and Tipperne are managed on experimental lines (including hay harvesting and grazing) to provide optimum conditions for waterfowl throughout the year. Haymaking was reintroduced in 1972 and the shorter grass is encouraging some of the birds to return, particularly the pink-footed goose. Planning permission for the establishment of an airport for commercial sight-seeing flights over the site area has been refused.

Scientific Research and Facilities The southern part of Ringkobing Fiord, especially Tipperne and Klaegbanken is a scientific reference area which has been studied for over 50 years with particular reference to breeding and resting populations of waterfowl. There are current studies on the ecology of the pink-footed goose and on the disturbance effects on waterfowl of different kinds of boats. A field station has been established on Tipperne.

Principal Reference Material The above information is taken from the Danish National Report to the Cagliari Conference in 1980.

Supplemented by:

- Carp, E. (1980). A Directory of Western Palearctic Wetlands. IUCN, Gland, Switzerland.

- Duffey, E. (1982). National Parks and Reserves of Western Europe. Macdonald and Co., London.

- IWRB Bulletin No. 47. Slimbridge, Glos, England.

- Scott, D.A. (1980). A preliminary inventory of Wetlands of International Importance for waterfowl in west Europe and north-west Africa. IWRB Special Publication No. 2.

Additional references:

- Joensen, A.H. (1974). Waterfowl populations in Denmark 1965-1973. A survey of the non-breeding populations of ducks, swans and coot and their shooting utilisation. Communication 20. Viltbiologisk Station, Denmark.

- Johansen A.C. and Blegaud H. (1933-36). Ringkobing Fiords. Naturhistorie $i$ Brakvandsperioden 1915-1931. Copenhagen. 252pp.

\section{Stadil and Vest Stadil Fiords}

Location $56^{\circ} 11^{\prime} \mathrm{N}, 8^{\circ} 09^{\prime} \mathrm{E}$. Situated on the west coast of Denmark, north of Ringkobing Fiord in the County of Ringkobing.

Area $7,184 \mathrm{ha}$

Degree of Protection Ownership is part state and part private. 1,300ha including Sonderdyb is protected for nature conservation under the 1969 Conservation of Nature Act (amended 1972, 1975 and 1978). There are no wildlife reserves. Designated as a Ramsar site in September 1977. 
Site Description The site consists of shallow fiord areas with reed swamps, meadows and hinter-land comprising $32.3 \%(2,320 \mathrm{ha})$ salt and brackish water, $1.2 \%$ (85ha) fresh water and $66.5 \%(4,779 \mathrm{ha})$ land. The wetland is a feeding, resting and breeding site for waterfowl.

International and National Importance As a breeding area it is mainly used by surface feeding ducks. As a feeding and resting area it is internationally important for 16,000 pink-footed geese Anser brachyrhynchus, 900 Bewick's swan Cygnus columbianus bewickii, 500 whooper swan $C$. cygnus and 10,000 surface feeding ducks. Other species feeding and nesting here include 300 goosander Mergus merganser, 5,000 teal Anas crecca, 11,000 mallard $A$. platyrhynchos, 11,000 pintail $A$. acuta and 300 shoveler $A$. clypeata. This site and Fiilso (Ramsar site) are the most important resting areas in Denmark for pink-footed goose.

Changes in Ecological Character None reported (November 1980)

\section{Management Practices No information}

Scientific Research and Facilities The situation of the pink-footed goose is closely watched by the Game Biology Station, which acts in an advisory capacity on field damage and hunting. The station provides food for migrating pink-footed geese on their way to Svalbard in spring, to keep them away from agricultural crops.

Principal Reference Material The above information is taken from the Danish National Report to the Cagliari Conference in 1980.

Supplemented by:

- Scott, D.A. (1980). A preliminary inventory of wetlands of international importance for waterfowl in west Europe and north-west Africa. IVRB Special Publication No. 2.

\section{Nissum Fiord}

Location $56^{\circ} 21^{\prime} \mathrm{N}, 08^{\circ} 14^{\prime} \mathrm{E}$. Situated on the west coast, north of Stadil and Veststadil fiords in the county of Ringkobing.

Area $11,600 \mathrm{ha}$

Degree of Protection Ownership is part private and part state, with the state represented by the Ministry of Agriculture and the Ministry of Public Works. Protected areas include 380 ha at Bouling Fiord and Krogshede Enge for nature conservation, protected under the 1969 Conservation of Nature Act (amended in 1972, 1975 and 1978), and three wildlife reserves at Bouling Fiord, Fjando and Felsted Kog totalling 3,335ha, protected under the 1.967 Game Act (amended 1969 and 1972). There was a proposal in 1981 for the nature conservation of a further 200 ha of saltmarsh. Designated as a Ramsar site in September 1977.

Site Description Shallow brackish-water fiord connected by sluices to the North Sea and including salt marshes, reed swamps and heathland vegetation on Fjando Island. The site comprises $59 \%(6,840 \mathrm{ha})$ salt and brackish water, $0.6 \%$ (65ha) fresh water and $40.4 \%(4,695 \mathrm{ha})$ land. Nissum Fiord is a breeding, resting and feeding area for waterfowl.

International and National Importance This site is of international importance as a resting and feeding ground for 4,000 pink-footed goose Anser brachyrhynchus, 1,000 pintail Anas acuta, 11,000 mallard A. platyrhynchos, 300 shoveler $A$. clypeata, 5,000 teal A. crecca, 1,800 Bewick's swan Cygnus columbianus bewickii, 2,200 mute swan $C$. olor, 2,000 light-bellied brent geese Branta b. bernicla, 12,000 wigeon Anas penclope, 2,200 shelduck Tadorna tadorna, 4,000 goosander Mergus merganser, 2,000 red-brested merganser $M$. serrator, 3,000 bar-tailed godwit Limosa lapponica and 3,000 goldeneye Bucephala clangula. The site is used as a breeding area for 100 pairs of avocet Recurvirostra avosetta and a few hundred pairs of sandwich tern Sterna sandvicensis. In the spring this site is the most important resting area in the country for Svalbard's population of light-bellied brent goose. 
Changes in Ecological Character Marsh products are no longer harvested, resulting in some marsh areas becoming overgrown. An estimated $40-50 \%$ of the salt marshes of Bovling Kilt are being cultivated.

Management Practices In the wildlife reserves, 230ha are protected from hunting and there is restriction of public access on 1,400 ha. Since 1972 various experiments have been carried out at Felsted Kog such as on agricultural methods and water levels to provide optimum conditions for breeding and resting waterfowl. The reed harvest in this wildlife reserve is planned in consultation with the Wildlife Administration of the Ministry of Agriculture, to cause minimum disturbance to waterfowl. Planning permission for the establishment of an airfield for commercial sight-seeing flights over the site area has been refused.

Scientific Research and Facilities No information

Principal Reference Material The above information is taken from the Danish National Report to the Cagliari Conference in 1980.

Supplemented by:

- Scott, D.A. (1980). A preliminary inventory of wetlands of international importance for waterfowl in west Europe and north-west Africa. IWRB

Special Publication No. 2.

\section{Nissum Bredning with Harboore and Agger Peninsulas}

Location $56^{\circ} 38^{\prime} \mathrm{N}, 8^{\circ} 15^{\prime} \mathrm{E}$. Situated in the west coast, north of Nissum Fiord in the counties of Ringkobing and Viborg.

Area $13,280 \mathrm{ha}$

Degree of Protection Ownership is part private and part state with the state represented by the Ministry of Public Works. $90 \mathrm{ha}$ at Gjeller Odde is a nature conservation area, protected under the 1969 Conservation of Nature Act (amended in 1972, 1975 and 1978), and there are two wildlife reserves at Fiord Holmene and Ronland Sandoer totalling $28 \mathrm{ha}$, protected under the 1967 Game Act (amended 1969 and 1972). There was a proposal in 1981 for the nature conservation of a further 200 ha of saltmarsh. Designated as a Ramsar site in September 1977.

Site Description The site includes a shallow fiord area with shoals and banks, a tidal area and saltmarshes, brackish lagoons with grazing meadows and high shore vegetation, a lake area with reed beds, and cultivated areas with scattered buildings. The site comprises $76.1 \%(10,110 \mathrm{ha})$ salt and brackish water, $22.9 \%(3,040 \mathrm{ha})$ land, and $1.0 \%$ (130ha) freshwater. Nissum Bredning is in direct contact with the North Sea. The site is important for waterfowl and the fiord area is used as a breeding site by 40 common seal Phoca vitulina.

International and National Importance This site is of international importance as a resting and feeding ground for 3,000 pink-footed goose Anser brachyrhynchus, 1,200 pintail Anas acuta, 250 Bewick's swan Cygnus columbianus bewickii, 200 whooper swan C. cygnus, 600 light-bellied brent geese Branta b. bernicla, 11,000 wigeon Anas penelope, 3,000 teal A. crecca, 2,200 shelduck Tadorna tadorna, 4,000 goosander Mergus merganser, 2,000 red-breasted merganser $M$. serrator, 20,000 goldeneye Bucephala clangula, 18,000 dunlin Calidris alpina, 3,800 bar-tailed godwit Limosa lapponica and 1,000 avocet Recurvirostra avosella. The site is a feeding and resting area for 500 curlew Numenius arquata and some velvet scoter Melanitta fusca and is particularly important for the light-bellied brent goose. The site is a breeding area of international importance especially for waders and gulls. The vegetation of the Agger and Harboorge peninsulas is worthy of preservation. 
Changes in Ecological Character The large lagoons of the Agger and Harboore peninsulas were isolated from the Lim Fiord by a dam in the mid 1950s. As a result there has been gradual reduction in salinity and a change of the plant community in and around the lagoons. There has been some pollution by mercury and organic phosphorus compounds fom a chemical factory.

Management Practices Advanced negotiations are being conducted about nature conservation in the Agger and Harboore Peninsulas. The proposals include prohibition of recreational activities in the brackish-water lagoons, and possible preservation measures. Various agricultural methods and water level changes have been experimented with to find the best conditions for breeding and resting waterfowl. Public access to the wildlife reserves is controlled. Planning permission for a campsite at Agger Peninsula has been refused. More efficient sewage purification has been implemented at Harboore Peninsula, and a major dump has been abolished.

\section{Scientific Research and Facilities No information}

Principal Reference Material The above information is taken from the Danish National Report to the Cagliari Conference in 1980.

Supplemented by:

- Scott, D.A. (1980). A preliminary inventory of wetlands of international importance for waterfowl in west Europe and north-west Africa. IWRB Special Publication No. 2.

\section{Vejlerne and Logstor Bredning}

Location $57^{\circ} 07^{\prime} \mathrm{N}, 9^{\circ} 00^{\prime} \mathrm{E}$. Situated in the counties of Viborg and Northern Jutland.

\section{Area 45,280 ha}

Degree of Protection Ownership is part state and part private. $6,800 \mathrm{ha}$ is protected for nature conservation (including Vejlerne, Skarup-Holm Fange, Feggeklit, Livo and Logstor) under the 1969 Nature Conservation Act and amendments. Vejlerne was established as a scientific sanctuary in 1958. Other protected sites include wildlife reserves at Lonnerup Fiord, Livo Bredning and Aggersborggard totalling 1,400ha, protected under the 1967 Game Act and amendments. Designated as a Ramsar site in September 1977.

Site Description The wetland is the result of unsuccessful reclamation work in the late 1800s, and includes a shallow salt fiord area with shoals and islands in the central region of Lim fiord, coastal areas with saltmarshes and agricultural land, partly drained fiords with lakes, reed swamps and salt marshes and the Vejlerne area and Lonnerup fiord. The site comprises $82.0 \%$ brackish water, $17.9 \%$ land and $0.1 \%$ fresh water, and is a feeding, resting, breeding and moulting area for waterfowl. Seals are also found here.

International and National Importance This site is of international importance as a feeding and resting ground for 700 whooper swan Cygnus cygnus, 500 Bewick's swan C. columbianus bewickii, 1,000 grey lag geese Anser anser, 900 bean geese $A$. fabalis, 500 pink-footed geese $A$. brachyrhynchus, 13,000 mallard Anas platyrhynchos, 9,000 wigeon $A$. penelope, 300 shoveler $A$. clydeata, 1,500 shelduck Tadorna tadorna, goldeneye Bucephala clangula, 18,000 scaup Aythya marila, velvet scoter Melanitta fusca, 10,000 golden plover Pluvialis apricaria, 18,000 dunlin Calidris alpina and 500 avocet Recurvirostra avosetta. Other species using the area for feeding and resting are mute swan Cygnus olor, 1,000 teal Anas creca, 2,000 red-breasted merganser Mergus serrater, ruff Philomachus pugnax and pochard Anthya ferina. Vejlerne and fiord areas are moulting refuges for greylag goose, teal, mallard, goldeneye, coot Fulica atra, velvet scoter and red-breasted merganser. This site is the best breeding area in Denmark for greylag goose, and the only permanent locality for the little gull Larus minutus. Excluding Fondermarsken, it is the best Danish breeding area for bittern Botaurus stellaris, marsh harrier Circus aeruginosus and spotted crake Porzana porzana. 
Changes in Ecological Character As a result of lowered water levels and slower circulation of water, the vegetation and animal life of the Vejlerne area are gradually changing.

Management Practices Hunting is prohibited on 370 ha of the wildlife reserves, and on $695 \mathrm{ha}$ (Bygholm Vejle) of the nature conservation areas. There are hunting restrictions on some 5,000 ha of the Vejlerne scientific sanctuary. The water level at Bygholm Vejle has been experimentally raised since 1979 , and a working group is preparing a proposal for water level control in other parts of the wetland.

Scientific Research and Facilities The Ministry of the Environment is carrying out waterfowl counts in Vejlerne scientific sanctuary. There is a marine biology station at Lim fiorden (Livovej 141, Ronbjerg, DK 9681, Ranum) which is open all year. The laboratories are well equipped for terrestrial, freshwater and marine work.

Principal Reference Material The above information is taken from the Danish National Report to the Cagliari Conference in 1980.

Supplemented by:

- Scott, D.A. (1980). A preliminary inventory of Wetlands of International Importance for waterfowl in west Europe and north-west Africa. IWRB Special Publication No. 2.

\section{Ulvedybet and Nibe Bredning}

Location $57^{\circ} 02^{\prime} \mathrm{N}, 9^{\circ} 35^{\prime} \mathrm{E}$. Situated in the county of Northern Jutland.

Area 20,304 ha

Degree of Protection Ownership is part state and part private. The state is represented by the Ministry of Agriculture. The protected sites include a nature conservation area of 23 ha at Skt. Nikolaj Bjerg and three game reserves totalling 1,126ha at Ulvedybet, Nibe and Nibe Bredning. Protection is under the 1969 Nature Conservation Act and the 1967 Game Act and their amendments. Designated as a Ramsar site in September 1977.

Site Description The site includes part of Lim Fiord and adjacent lakes, saltmarshes, reed swamps and agricultural land. The Ulvedybet area is isolated from the fiord by a dam, and contains a brackish-water lake. The area comprises $63.1 \%(12,815 \mathrm{ha})$ salt and brackish water, $0.2 \%$ (35ha) freshwater and $36.7 \%(7,454 \mathrm{ha})$ land. Ulvedybet and Nibe Bredning is used by waterfowl for resting, feeding, breeding and moulting.

International and National Importance This site is of international importance as a feeding and resting ground for 5,000 teal Anas crecca, 11,000 wigeon A. penelope, 7,000 pochard Aythya ferina, 1,500 goosander Mergus merganser, 750 red-breasted merganser $M$. serrator, 800 whooper swan Cygnus cygnus, 1,500 mute swan C. olor, 18,000 golden plover Pluvialis apricaria and 10,000 coot Fulica atra and also supports mallard $A$. platyrhynchos, 1,100 pintail A. acuta, 250 shoveler $A$. clypeata, goldeneye Bucephala clangula, 9,000 tufted duck Aythya fuligula, 1,000 shelduck Tadorna tadorna, 450 pink-footed geese Anser brachyrhynchus and 1,000 greylag geese $A$. anser. Total population of surface feeding duck is 30,000 and of diving duck is 25,000 . The site is the most important area in Northern Jutland for pochard and is the moulting refuge for goldeneye, mute swan and pochard. Breeding ducks, waders and gulls including 50 pairs of avocet Recurvirostra avosetta use the site, especially the Ulvedybet area and the small islands.

Changes in Ecological Character Marsh products are no longer being cropped, resulting in some marsh areas such as the islands becoming overgrown. The meadows along the fiords are being cultivated. An exemption, limited in time, has been granted for two experimental windmills $(60 \mathrm{~m} \mathrm{high})$ at Nibe for investigation into wind energy. 
Management Practices Management practices in the Ulvedybet area specifically for waterfowl include the construction of islands, and cattle grazing to prevent marshes becoming overgrown. Public access is forbidden on some of the islands during the breeding season. Hunting is prohibited on 900 ha of the game reserves.

Scientific Research and Facilities The Game Biology Station in the Ulvedybet game reserve is carrying out experiments in wetland management including monitoring of water levels in the breeding season. Kliim field station (DK 9690 Fjerritslev) lies to the north-west of the site.

Principal Reference Material The above information is taken from the Danish National Report to the Cagliari Conference in 1980.

Supplemented by:

- Scott, D.A. (1980). A preliminary inventory of wetlands of international importance for waterfowl in west Europe and north-west Africa. IWRB Special Publication No. 2.

\section{Hirsholmene}

Location $57^{\circ} 29^{\prime} \mathrm{N}, 10^{\circ} 38^{\prime} \mathrm{E}$. Located off the north-east coast in Northern Jutland.

Area 480 ha

Degree of Protection State ownership represented by the Ministry of Defence. Established as a protected area in 1938 and revised as a scientific reserve in 1948. Negotiations are advanced to renew and extend the current conservation regulations by way of a new Executive Order in accordance with the Conservation of Nature Act 1969 (amended 1972, 1975 and 1978). The Deget area will be included. Designated as a Ramsar site in September 1977.

Site Description The site is a sea area with stony banks and ten islands, only one being inhabited. The vegetation on the islands consists of salt and guano loving plants, and includes some interesting lichens. The site comprises $88.5 \%$ (425ha) salt and brackish water, and $11.5 \%$ (55ha) land. The site is a feeding, resting and breeding area for waterfowl.

International and National Importance The islands are a breeding area of international importance for 1,500 pairs of herring gull Larus argentatus, 15,000 pairs of black-headed gull $L$. ridibundus, 100 pairs of lesser black-backed gull L. fuscus, 1,100 pairs of sandwich tern Sterna sandvicensis, 100 pairs of black guillemot Cepphus grylle, 230 pairs of kittiwake Rissa tridactyla. The site is also one of the most important breeding areas in Denmark for the sandwich tern, black guillemot and Scandinavian rock pipit Anthus spinoletta littoralis. The islands are a resting and feeding area for a number of waterfowl particularly diving ducks such as eider duck Somateria mollissima, common scoter Melanitta nigra and red-breasted merganser Mergus serrator. It is the most important resting site in Denmark for purple sandpiper Calidris maritima.

Changes in Ecological Character There has been a change in the vegetation and to some extent in the bird life as a result of three factors: the extermination of rats Rattus norvegicus which occurred on all the islands from 1949-1975; a drastic decline in 1978 of the numbers of introduced rabbits Oryctololagus cuniculus; and an experimental reduction since 1973 in the herring gull breeding population.

Management Practices Measures have been taken since 1973 to reduce the breeding population of herring gull and rats were exterminated on all the islands by 1975 . Public access is permitted to all the site excluding $30 \mathrm{ha}$. Hunting is prohibited over the entire area.

Scientific Research and Facilities Hirsholmene is a scientific sanctuary and has been an important research and reference area for over 50 years. There is a marine biology station on the mainland at Frederikshavn from which the sea area and reefs between Frederikshavn and Hirsholmene have been intensively studied. 


\section{Denmark}

Principal Reference Material The above information is taken from the Danish National Report to the Cagliari Conference in 1980.

Supplemented by:

- Scott, D.A. (1980). A preliminary inventory of wetlands of international importance for waterfowl in west Europe and north-west Africa. IWRB Special Publication No. 2.

\section{Nordre Ronner}

Location $57^{\circ} 22^{\prime} \mathrm{N}, 10^{\circ} 56^{\prime} \mathrm{E}$. Located off the north-east coast in Northern Jutland.

Area 2,923ha

Degree of Protection Nordre Ronner is in territorial waters in the Municipality of Laeso and is owned by the state represented by the Ministry of Defence. It is a nature conservation area currently protected by voluntary agreements with the Ministry of Defence and the Municipality of Laeso. Negotiations are being conducted with these parties on the future conservation of the area. Designated as a Ramsar site in September 1977.

Site Description The site comprises $99.6 \%$ sea, which includes stony banks and stony uninhabited islands, and $0.4 \%$ land. Waterfowl use the area for resting, feeding and breeding. It is a breeding area and haunt for 50-100 common seal Phoca vitulina.

International and National Importance The islands are a breeding area of international importance for eider duck Somateria mollissima, great black-backed gull Larus marinus, lesser black-backed gull L. fuscus, sandwich tern Sterna sandvicensis, 120 pairs of black guillemot Cepphus grylle and 100 pairs of kittiwake Rissa tridactyla. Also breeding here are 3,000 pairs of black-headed gull Larus ridibundus. The site is the most important breeding area in Denmark for black guillemot and kittiwake. Some 5,000 eider duck also use the area for resting and feeding.

Changes in Ecological Character Conditions for breeding birds have been changed by the gradual growth of bushes and grasses on the islands.

Management Practices There are voluntary agreements with the Ministry of Defence, and in some cases with the Laeso Municipality, on rules governing recreational activities and the gathering of eggs in the breeding season.

Scientific Research and Facilities The field station in the old lighthouse building is rented by the National Agency for the Protection of Nature, Monuments and Sites, and is used for observation and special studies. The islands have been a scientific sanctuary since 1965 .

Principal Reference Material The above information is taken from the Danish National Report to the Cagliari Conference in 1980.

Supplemented by:

- Scott, D.A. (1980). A preliminary inventory of wetlands of international importance for waterfowl in west Europe and north-west Africa. IWRB Special Publication No. 2.

\section{Laeso}

Location $57^{\circ} 12^{\prime} \mathrm{N}, 11^{\circ} 10^{\prime} \mathrm{E}$. Located off the north-east coast in the county of Northern Jutland. 
Degree of Protection Ownership is part private and part state, with the state represented by the Ministry of the Environment. 2,000ha, including Vester and Sonder Nyland, Laesos Sydlige Ronner, Bovet and Syrodde-Knotterne is protected for nature conservation under the Conservation of Nature Act 1969 (amended 1972, 1975 and 1978). Conservation of the Ron areas was completed in 1980. There are no wildlife reserves. Designated as a Ramsar site in September 1977.

Site Description Laeso is mainly a sea area with banks, shallow shoals and tidal areas, and also includes small islands, inlets, salt marshes, near-shore heathland, and occasional cultivated land (including plantations) with some buildings. The land is gradually rising and this is influenced by the development of the vegetation. The area is of great botanical interest and is the largest Danish tidal and saltmarsh area outside the Vadehavet (Danish Wadden Sea). The site comprises $92.7 \%$ salt and brackish water, and $7.3 \%$ land. It is a resting, feeding, breeding and moulting area for waterfowl, and is a breeding area and haunt for 300 common seal Phoce vilulina.

International and National Importance This site is of international importance as a resting and feeding ground for 1,200 dark-bellied brent geese Branta b. bernicla, 11,000 velvet scoter Melanilta fusca, 80,000 eider duck Somateria mollissima, 2,000 red-breasted merganser Mergus serrator, 45,000 dunlin Calidris alpina and 600 avocet Recurvirostra avoselta. Also resting and feeding here are bar-tailed godwit Limosa lapponica. The site is a moulting area for 50,000 diving ducks including eider duck and common scoter. It is also an internationally important breeding area for waterfowl with 170 pairs of avocet, 200 pairs of Arctic tern Sterna paradisaea, 15 pairs of turnstone Arenaria interpres and 1-2 pairs of golden plover Pluvialis apricaria.

Changes in Ecological Character Some areas are becoming overgrown with natural and introduced trees and bushes.

Management Practices The local conservation board has complied with a request fom the National Agency for the Protection of Nature, Monuments and Sites that Knotten be closed to the public for an experimental period 1980-1983.

Scientific Research and Facilities There is a field station in the south-eastern part of the island. Current research is mainly ornithological, botanical and entomological. A laboratory is available.

Principal Reference Material The above information is taken from the Danish National Report to the Cagliari Conference in 1980.

Supplemented by:

- Scott, D.A. (1980). A preliminary inventory of wetlands of international importance for waterfowl in west Europe and north-west Africa. IWRB Special Publication No. 2.

\section{Parts of Randers and Mariager Fiords and the sea adjoining them}

Location $56^{\circ} 59^{\prime} \mathrm{N}, 10^{\circ} 10^{\prime} \mathrm{E}$. Located off the north-east coast in Northern Jutland and Aarhus.

Area $41,440 \mathrm{ha}$

Degree of Protection Ownership is part state and part private. 76 ha at Treskelbakkeholm is a wildlife reserve protected by the 1967 Game Act (amended 1967 and 1972). Designated as a Ramsar site in September 1977.

Site Description Mainly shallow sea and fiord areas with small islands and also salt marshes, and cultivated land including large reclaimed areas near Overgard. The site comprises $84.9 \%$ $(35,200 \mathrm{ha})$ salt and brackish water and $15.1 \%(6,240 \mathrm{ha})$ land. Resting, feeding and breeding area for waterfowl. 
International and National Importance The site is of international importance as a resting and feeding area for 2,000 whooper swan Cygnus cygnus, 5,000 mute swan C. olor, 1,900 light-bellied brent geese Brant b. bernicla, 12,000 mallard Anas platyrhynchos, 10,000 common scoter Melanilta nigra, 20,000 velvet scoter $M$. fusca, 47,000 eider duck Somateria mollissima, 1,000 goosander Mergus merganser, some red-breasted merganser $M$. serrator, 3,000 scaup Aythya marila and 4,000 shelduck Tadorna tadorna. Also resting and feeding here are wigeon Anas penelope and goldeneye Bucephala clangula. From November to February this is the only Danish locality where Svalbard's population of light-bellied brent goose occur. Breeding waterfowl include 300-400 pairs of sandwich tern Sterna sandvicensis, 40 pairs of common tern S. hirundo and 400-600 pairs of black-headed gull Larus ridibundus.

Changes in Ecological Character Parts of the shallow tidal areas in the Mariager Fiord and Alborg Bay belonging to the Overgard Estate have been reclaimed and cultivated. This has resulted in a change in the hydrographic conditions. There may be further erosion as a result of the extraction of raw materials near the coast.

Management Practices Public access to the wildlife reserve at Treskelbakkeholm is prohibited during the breeding season. Planning permission for a major extension to an existing airfield in the area has been refused.

\section{Scientific Research and Facilities No information}

Principal Reference Material The above information is taken from the Danish National Report to the Cagliari Conference in 1980.

Supplemented by:

- Scott, D.A. (1980). A preliminary inventory of wetlands of international importance for waterfowl in west Europe and north-west Africa. IWRB Special Publication No. 2.

\section{Sea area north of Anholt Island}

Location $56^{\circ} 42^{\prime} \mathrm{N}, 11^{\circ} 34^{\prime} \mathrm{E}$. Located off the north-east coast in the county of Aarhus.

\section{Area 12,720 ha}

Degree of Protection Ownership is part private and part state, with the state represented by the Ministry of Defence. The beaches and eastern point of Anholt Island (Totten) are a nature conservaion area of 100 ha protected under the Conservation of Nature Act 1969 (amended 1972, 1975 and 1978). There are no wildlife reserves. Designated as a Ramsar site in September 1977.

Site Description The site is mainly sea with shallow shoals and banks, but also includes the eastern point and the shores of the north coast of Anholt Island. The site comprises $99.3 \%$ salt and brackish water; and $0.7 \%$ land. It is a resting and feeding area for waterfowl, and a breeding site and haunt of both the common seal Phoca vitulina and the grey seal Halichoerus grypus.

International and National Importance This site is of international importance as a resting and feeding ground for 80,000 eider duck Somateria mollissima and 20,000 common scoter Melanitta nigra. Also resting and feeding here are razorbill Alca torda and black-throated diver Gavia arctica.

Changes in Ecological Character At Nordvestrevet and Osterrevet raw materials are being extracted on a large scale and this is thought to have contributed to the erosion of Anholt and in particular the eastern point at Totten. 
Principal Reference Material The above information is taken from the Danish National Report to the Cagliari Conference in 1980.

\section{Horsens Fiord and Endelave}

Location $55^{\circ} 51^{\prime} \mathrm{N}, 10^{\circ} 10^{\prime} \mathrm{E}$. Located on the east coast in the counties of Aarhus and Vejle.

Area 43,200 ha

Degree of Protection Ownership is part private and part state, with the state represented by the Ministry of the Environment. Ownership of Vorso, a small island in the fiord, is by a foundation in association with the University of Copenhagen. Some $900 \mathrm{ha}$ including Vorso, Brigsted-Amstrup, Gesdorfslund and Endelave are protected for nature conservation under the Nature Act 1969 (amended 1972, 1975 and 1978). Areas near Lerdrup Bugt are proposed for nature conservation. Vorso was established as a scientific reserve in 1934. Wildlife areas include Alro Polder, Soby Reo and Mollegrunden totalling 210 ha protected under the Game Act 1967 (amended 1969 and 1972). Designated as a Ramsar site in September 1977.

Site Description The site consists of a shallow fiord and sea areas with shoals, banks, salt marshes and lagoons, and includes three fairly large islands with cultivated land and scattered buildings. It comprises $91.0 \%$ salt and brackish water, and $9.0 \%$ land. The island of Vosro is mainly farmland abandoned in the 1930s and gradually colonised by woody species to a kind of 'virgin forest'. The site is an important resting, feeding, breeding and moulting area for waterfowl. Mollegrunden is the most important locality for seals in the southern part of the Kattegat.

International and National Importance This site is of international importance as a resting and feeding ground for 80,000 eider duck Somateria mollissima, 8,000 common scoter Melanitta nigra, 3,000 velvet scoter $M$. fusca, 1,000 goosander Mergus merganser, 1,000 red-breasted merganser $M$. serrator, 3,000 bar-tailed godwit Limosa lapponica and goldeneye Bucephala clangula. Also resting and feeding here are 400 mute swan Cygnus olor, 300 dark-bellied brent goose Brant b. bernicla and 3,000 surface feeding duck including mallard Anas platyrhynchos and wigeon $A$. penelope. The islands and salt marshes are breeding areas of international importance for waterfowl including 900 pairs of cormorant Phalacrocorax carbo sinensis, 100 pairs of grey heron Ardea cinerea, 4,000 pairs of common gull Larus canus, oystercatcher Haematopus ostralegus, avocet Recurvirostra avosetta and a few hundred pairs of sandwich tern Sterna sandvicensis. Vorso has one of the biggest and most stable colonies of cormorant in Europe. The site is a moulting area for 20,000 diving ducks including eider duck and velvet scoter.

Changes in Ecological Character There has been increased sedimentation around the islands since the 1930s due to the disappearance of grasswrack Zostera sp. Increased silting north of Alro has resulted from a closed dam connecting the island with the mainland. Future potential disturbances to the area include the construction of a traffic link between Jutland and Zealand, and the construction of a nuclear power station at Gyllingnaes.

Management Practices Vorso and the surrounding area is totally protected against hunting, and access is by special permission only. Public access to the wildlife reserves is prohibited in the breeding season.

Scientific Research and Facilities The National Agency for the Protection of Nature, Monuments and Sites has a field station with a small laboratory on Vorso Island. The laboratory has electricity and running water but no equipment. The agency monitors waterfowl and environmental conditions. 
Principal Reference Material The above information is taken from the Danish National Report to the Cagliari Conference in 1980.

Supplemented by:

- Jessen, Knud (1968). Flora og vegetation pa reservatet Vorso i Horsens Fiord (Flora and vegetation on the Vorso reserve in Horsens Fiord). Danish with English summary. Botanisk Tidsskrift 63: 1-2 (Kobenhavn).

- Scott, D.A. (1980). A preliminary inventory of wetlands of international importance for waterfowl in west Europe and north-west Africa. IWRB Special Publication No. 2.

\section{Stavns Fiord and adjacent waters}

Location $55^{\circ} 54^{\prime} \mathrm{N}, 10^{\circ} 40^{\prime} \mathrm{E}$. Located off the north-east coast of the island of Samso in the county of Aarhus.

Area 16,320 ha

Degree of Protection Ownership is part private and part state with the state represented by the Ministry of the Environment. Protected areas include a nature conservation area at Kanhave Kanal (30ha) protected under the Conservation of Nature Act 1969 (amended 1972, 1975 and 1978) and a wildlife reserve at Stavns Fiord (1,650ha) protected under the Game Act 1967 (amended 1969 and 1972). There are proposals for the conservation of areas of land around Stavns Fiord, and an amendment of the Executive Order on Reserves is being prepared. The Ramsar site is part of a larger area known as Nordsamsoog Stavns Fiord Nature Reserve and Bird Sanctuary. Designated as a Ramsar site in Septernber 1977.

Site Description Sea and fiord areas with shallow shoals, uninhabited islands, saltmarshes and grasslands. The fiord is brackish with an average depth of 1 metre. The many islands are formed from the top of a drowned moraine and have mainly low shrub thicket vegetation. There is some small scale farming on a few of the islands - primarily cattle grazing with some cultivation. The site comprises $94.6 \%$ salt and brackish water, and $5.4 \%$ land. It is a resting, feeding, moulting and breeding ground for waterfowl. The common seal Phoca vitulina also occurs here.

International and National Importance This site is of international importance as a resting and feeding ground for waterfowl including: 200 whooper swan Cygnus cygnus, 1,200 mute swan C. olor, 200 dark-bellied brent geese Branta b. bernicla, 9,000 velvet scoter Melanitta fusca, common scoter M. nigra, scaup Aythy'a marila, 62,000 eider duck Somateria mollissima, 1,000 goosander Mergus merganser and 500 cormorant Phalacrocorax carbo sinensis. It is one of the most important breeding areas in Europe for eider duck with 2,000 pairs using this site. The site is internationally important as a breeding area for common gull Larus canus (450 pairs), herring gull $L$. argentatus (2,000 pairs), great black-backed gull $L$. marinus, little tern Sterna albifrons (10 pairs), Arctic tern S. paradisaea, avocet Recurvirostra avosetta (25-50 pairs), grey lag goose Anser anser, mallard Anas platyrhynchos, shelduck Tadorna tadorna, oystercatcher Haematopus ostralegus and black guillemot Cepphus grylle. The site is a moulting area for 10,000 duck including eider duck and common scoter.

Changes in Ecological Character There has been improvement in the water quality after altering a sewage outflow in the south-east corner of the area. There is a potential risk of oil pollution at Hatter Rev.

Management Practices During the waterfowl breeding season in Stavns Fiord wildlife reserve there are hunting restrictions and public access is prohibited. The fox Vulpes vulpes population on the islands is regularly controlled. 
Scientific Research and Facilities There is a field station with accommodation and some labratory facilities at Hjortholm Reserve, a small island in Stavns Fiord. This island has been used for cattle grazing but has never been ploughed so the soil profile is intact. It is used mainly for archaeological, pedological and botanical research, but is available for ecological projects. The main species of waterfowl studied in the Ramsar site is the eider duck.

Principal Reference Material The above information is taken from the Danish National Report to the Cagliari Conference in 1980.

Supplemented by:

- Scott, D.A. (1980). A preliminary inventory of wetlands of international importance for waterfowl in west Europe and north-west Africa. IWRB Special Publication No. 2.

\section{Lillebaelt}

Location $55^{\circ} 21^{\prime} \mathrm{N}, 9^{\circ} 43^{\prime} \mathrm{E}$. Located in the counties of Vejle, North Slesvig and Funen.

Area 37,344 ha

Degree of Protection Ownership is part private and part state. Stenderup Hage ( $30 \mathrm{ha}$ ) is a nature conservation area protected under the Conservation of Nature Act 1969 (amended 1972 , 1975 and 1978). Gamborg Inddaemning (85ha) and Hejlsminde Nor (274ha) are wildlife reserves protected under the Game Act 1967 (amended 1969 and 1972). Designated as a Ramsar site in September 1977.

Site Description Narrow sea area with islands, peninsulas, coves, lagoons, salt marshes and reed swamps. Two of the islands have some cultivated land and scattered habitation. The site comprises $76.2 \%(28,463 \mathrm{ha})$ salt and brackish water, $0.2 \%$ (60ha) freshwater and $23.6 \%$ $(8,821 \mathrm{ha})$ land. It is a resting, feeding and breeding area for waterfowl.

International and National Importance This site is of international importance as a resting and feeding ground for 1,000 whooper swan Cygnus cygnus, 10,000 tufted duck Aythya fuligula, 40,000 scaup A. marila, 1,000 pintail Anas acuta, 40,000 eider duck Somateria mollissima and 5,000 common scoter Melanitta nigra. The site seems to be one of the most important localities in northern Europe for scaup. Also resting and feeding here are 100 bean goose Anser fabalis, 100 white-fronted goose A. albifrons, 1,000 wigeon Anas penelope, 1,000 goldeneye Bucephala clangula, 1,000 pochard Aythya ferina and 5,000 coot Fulica atra. The site is a breeding area for greylag goose Anser anser, red-breasted merganser Mergus serrator, avocet Recurvirostra avosetta, several species of gulls Larus spp. and several species of terns Sterna spp.

Changes in Ecological Character The site receives effluent (calcium sulphate) which may increase in the future.

Management Practices Hunting is totally prohibited in the two wildlife reserves.

\section{Scientific Research and Facilities No information}

Principal Reference Material The above information is taken from the Danish National Report to the Cagliari Conference in 1980.

Supplemented by:

- Scott, D.A. (1980). A preliminary inventory of wetlands of international importance for waterfowl in west Europe and north-west Africa. IWRB Special Publication No. 2. 


\section{Naera Coast and Aebelo Area}

Location $55^{\circ} 36^{\prime} \mathrm{N}, 10^{\circ} 13^{\prime} \mathrm{E}$. Located in the county of Funen.

Area 13,800 ha

Degree of Protection Ownership is part private and part state. Small areas on Aebelo, Kissebjerg-Norreby Hals and Flyvesandet-Fuglsanggard totalling 100 ha are nature conservation areas protected under the Conservation of Nature Act 1969 (amended 1972, 1975 and 1978). Wildlife reserves are Fogense Enge (97ha) and Mageoerne near Bogense protected under the Game Act 1967 (amended 1969 and 1972). Designated as a Ramsar site in September 1977.

Site Description Shallow coastal site with islets and islands, saltmarshes, and drained and cultivated areas. Aebelo Island is wooded and inhabited. The site comprises $73.6 \%$ salt and brackish water, and $26.4 \%$ land. The site is a feeding, resting and breeding area for waterfowl.

International and National Importance This site is of international importance as a resting and feeding ground for 2,000 mute swan Cygnus olor, 2,000 bar-tailed godwit Limosa lapponica, 20,000 eider duck Somateria mollissima, 4,200 common scoter Melanitta nigra and 2,000 velvet scoter $M$. fusca. Also resting and feeding in the area are 100 bean goose Anser fabalis, 2,000 white-fronted goose $A$. albifrons, 300 dark-bellied brent goose Branta $b$. bernicla, 2,000 wigeon Anas penelope, 2,000 golden plover Pluvialis apricaria and 3,000 dunlin Calidris alpina. The only permanent resing area in Denmark for the white-fronted goose is on Gyloensteen's Land. The site is a breeding area for greylag goose Anser anser, red-breasted merganser Mergus serrator, eider duck, several species of gull Larus spp. and several species of tern including over 100 pairs of Arctic tern Sterna paradisaea, over 25 pairs of little tern S. albifrons and a few hundred pairs of sandwich tern S. sandvicensis.

Changes in Ecological Character Population growth and increased planting are causing increasing disturbance to this wetland.

Management Practices Hunting is totally prohibited in the Fogense Enge wildlife reserve. Access is prohibited to Mageoerne in the breeding season.

Scientific Research and Facilities No information

Principal Reference Material The above information is taken from the Danish National Report to the Cagliari Conference in 1980.

Supplemented by:

- Scott, D.A. (1980). A preliminary inventory of wetlands of international importance for waterfowl in west Europe and north-west Africa. IVRB Special Publication No. 2.

\section{South Funen Archipelago}

Location $55^{\circ} 00^{\prime} \mathrm{N}, 10^{\circ} 20^{\prime} \mathrm{E}$. Situated in the county of Funen.

Area 39,200 ha

Degree of Protection Ownership is part private and part state, with the state represented by the Ministry of the Environment. On Tasinge there is one established nature conservation area at Vejlen (50ha) protected under the Conservation of Nature Act 1969 (amended 1972, 1975 and 1978), and one proposed at Monnet. Hjaelmshoved, Aeroskobing, Bredholm and Storeholm are wildlife reserves totalling 161 ha protected under the Game Act 1967 (amended 1969 and 1972). Designated as a Ramsar site in September 1977. 
Site Description The wetland habitats of this site include small lakes, reed swamps, and salt marshes, and sea areas with shallow shoals and many islands. Most of the islands are uninhabited, but some have a scattered population with some cultivated land. The site comprises $82.6 \%(37,378 \mathrm{ha})$ salt and brackish water, and $17.4 \%(6,822 \mathrm{ha})$ land. The archipelago is a resting, feeding, breeding and moulting area for waterfowl.

International and National Importance This site is of international importance as a resting and feeding ground for 2,000 dark-bellied brent geese Branta b. bernicla, 600 whooper swan Cygnus cygnus, 6,000 mute swan C. olor, 45,000 eider duck Somateria mollissima, 23,000 tufted duck Aythya fuligula, 19,000 scaup A. marila, 4,000 goldeneye Bucephala clangula, 6,000 long-tailed duck Clangula hyemalis, 1,000 red-breasted merganser Mergus serrator and 30,000 coot Fulica atra. Also resting and feeding at the site are 4,000 common scoter Melanitta nigra, oystercatcher Haematopus ostralegus and 15,000 surface feeding duck including mallard Anas platyrhynchos. The site is a breeding area of international importance for greylag goose Anser anser, dunlin Calidris alpina, ruff Philomachus pugnax, 60-100 pairs avocet Recurvirostra avosetta, 1-2 pairs of turnstone Arenaria interpres, and several species of gull Larus spp. and tern Sterna spp. 5,000 mute swan use the archipelago for moulting, and this site is one of their most important moulting refuges in Denmark. The area is relatively unusual in Europe being drowned moraine country.

Changes in Ecological Character Since the turn of the century disturbances to the breeding waterfowl have included cattle grazing, land drainage and cultivation.

Management Practices Public access to the four wildlife reserves is prohibited during the waterfowl breeding season, and hunting is prohibited in Aeroskobing (61 ha).

Scientific Research and Facilities No information

Principal Reference Material The above information is taken from the Danish National Report to the Cagliari Conference in 1980.

Supplemented by:

- Scott, D.A. (1980). A preliminary inventory of wetlands of international importance for waterfowl in west Europe and north-west Africa. IWRB Special Publication No. 2.

\section{Sejero Bugt, Nekselo Bugt and Saltbaek Vig}

Location $55^{\circ} 47^{\prime} \mathrm{N}, 11^{\circ} 18^{\prime} \mathrm{E}$. Situated in Western Zealand.

Area 42,560 ha

Degree of Protection Ownership is part private and part state, with the state represented by the Ministry of Defence and the Ministry of the Environment. 600 ha including Overby Lyng, Korevlen, Ordrup Naes, Nekselo and Vesterling are protected for nature conservation under the 1969 Conservation of Nature Act (amended in 1972, 1975 and 1978), and Saltbaekvig is a proposed nature conservation area. There are no wildlife reserves. Designated as a Ramsar site in September 1977.

Site Description The wetland comprises a sea area with shallow bays, cultivated islands with scattered buildings, peninsulas and coastal slopes with saltmarshes and lagoons, and a fiord area with meadows and reed swamps. $91 \%$ salt and brackish water and $9 \%$ island. Nekelso Island conservation area is a relic of a marginal glacial moraine. The site is a moulting, breeding, feeding and resting area for waterfowl.

International and National Importance This site is of internaticnal importance as a resting and feeding ground for 150 whooper swan Cygnus cygnus, 3,000 greylag goose Anser anser, 800 bean goose $A$. fabalis, 30,000 eider duck Somateria mollissima, 15,000 common scoter Melanitta nigra, 12,000 velvet scoter $M$. fusca, teal Anas crecca and ringed 
plover Charadrius hiaticula. Also resting and feeding here are 2,000 mallard Anas platyrhynchos, 3,000 wigeon $A$. penelope, 4,000 scaup Aythya marila, 3,000 golden plover Pluvialis apricaria and 300 pairs of greylag goose. Breeding species include 30 pairs of grey lag goose, 15-25 pairs of avocet Recurvirostra avosetta, oystercatcher Haematopus ostralegus, 2,000-3,000 pairs of black-headed gull Larus ridibundus and 10-15 pairs of little tern Sterna albifrons. The site is used as a moulting area by velvet scoter, and is the most important moulting locality in Denmark for greylag goose $(4,000)$. Nekelso Island has many plant species that are rare in Denmark and also has a rich insect fauna.

Changes in Ecological Character Increasing disturbance due to planting and building along the coast has made this area less suitable for breeding waterfowl.

Management Practices There is restricted public access to the area but a limited amount of hunting is allowed in Saltbaekvig and Store Vroj.

\section{Scientific Research and Facilities No information}

Principal Reference Material The above information is taken from the Danish National Report to the Cagliari Conference in 1980.

Supplemented by:

- Duffey, E. (1982). National Parks and Reserves of Western Europe. Macdonald and Co., London.

- Scott, D.A. (1980). A preliminary inventory of wetlands of international importance for waterfowl in west Europe and north-west Africa. IWRB Special Publication No. 2.

\section{Waters off Skaelskor Nor and Glaeno, and adjacent wetlands}

Location $55^{\circ} 10^{\prime} \mathrm{N}, 11^{\circ} 30^{\prime} \mathrm{E}$. Located in Western Zealand.

\section{Area 17,120 ha}

Degree of Protection Ownership is part private and part state with the state represented by the Ministry of the Environment. Protected sites include two nature conservation areas at Borreby Estate and Osterhovedgard totalling 2,000ha protected since 1978 under the Conservation of Nature Act 1969 (amended 1972, 1975 and 1978), and one wildlife reserve at Basnaes Nor of 1,055ha protected under the Game Act 1967 (amended 1969 and 1972). There are plans in preparation for the conservation of other areas. Designated as a Ramsar site in September 1977.

Site Description The Ramsar site consists of a sea area with shallow shoals and coves, islands with cultivated land and scattered buildings, saltmarshes, uncultivated coastal slopes and grassland, lakes and marshes and reed swamps. Some areas are enclosed by dams. The site comprises $76.4 \%$ salt and brackish water, $23.4 \%$ land and $0.2 \%$ freshwater. The area is regarded as of considerable cultural and historical value. It supports many species of waterfowl.

International and National Importance This site is of international importance as a resting and feeding ground for 700 whooper swan Cygnus cygnus, 3,000 mute swan $C$. olor, 24,000 tufted duck Aythya fuligula, 11,000 coot Fulica atra, 1,000 bar-tailed godwit Limosa lapponica, 5,000 mallard Anas platyrhynchos, 650 shoveler A. clypeata, 1,500 pintail A. acuta, 10,000 eider duck Somateria mollissima, 9,000 common scoter Melanilta nigra, 3,000 velvet scoter $M$. fusca and teal $A$. crecca. The site is a breeding area of international importance for several species of waterfowl and for 300 pairs of cormorant Phalacrocorax carbo sinensis. 
Changes in Ecological Character The increased planting and cultivation of grasslands and saltings has made these areas less suitable for breeding waterfowl. A potential threat is the proposed expansion of the petro-chemical industry at Stignes which may increase pollution in the area.

Management Practices Public access to the wildlife reserve at Basnaes Nor is prohibited during the breeding season, and hunting of waterfowl in the reserve is prohibited.

\section{Scientific Research and Facilities No information}

Principal Reference Material The above information is taken from the Danish National Report to the Cagliari Conference in 1980.

Supplemented by:

- Scott, D.A. (1980). A preliminary inventory of wetlands of international importance for waterfowl in west Europe and north-west Africa. IWRB Special Publication No. 2.

\section{Karrebaek, Dybso and Avno Fiords}

Location $55^{\circ} 10^{\prime} \mathrm{N}, 11^{\circ} 45^{\prime} \mathrm{E}$. Located in the county of Storstrom.

Area 19,200 ha

Degree of Protection Ownership is part private and part state, with the state represented by the Ministry of the Environment. Protected sites include four nature conservation areas at Eno, Dybso, Knudshoved and Stejlebanken totalling 300 ha protected under the Conservation of Nature Act 1969 (amended 1972, 1975 and 1978). There are two wildlife reserves at Karrebaeksminde and Guano totalling 1,010ha protected under the Game Act 1967 (amended 1969 and 1972). Designated as a Ramsar site in September 1977.

Site Description The wetland consists of a sea area with shallow shoals and banks, islands (several having cultivated land and scattered buildings), the peninsula of Knudshoved Odde which has cultivated land and buildings, commons saltmarshes and reed swamps. The site comprises $72.1 \%$ salt and brackish water, $27.7 \%$ land and $0.2 \%$ freshwater. Large tracts which were originally commons have rare plants and animals and the site is of considerable cultural and historical value. Many species of waterfowl use the area for feeding, resting and breeding. The common seal Phoca vitulina breeds in Avno Fiord.

International and National Importance This site is of international importance as a resting and feeding ground for 500 whooper swan Cygnus cygnus, 3,000 mute swan $C$. olor, 12,000 coot Fulica atra and 3,000 bar-tailed godwit Limosa lapponica. The site is one of the most important localities in Denmark for tufted duck Aythya fuligula $(25,000)$. Other species resting and feeding at the site include 5,000 mallard Anas platyrhynchos, 300 shoveler A. clypeata and some overwintering white-tailed eagle Haliaetus albicilla. The site is a breeding area for surface feeding ducks Anas spp., 50-100 pairs of avocet Recurvirostra avosetta, several species of gulls Larus spp., 50-100 pairs of Arctic tern Sterna paradisaea and 25-50 pairs of little tern $S$. albifrons.

Changes in Ecological Character The commons especially at Knudshoved and Dybso have become overgrown.

Management Practices Hunting is prohibited in the nature conservation area at Dybso (132ha) and in the wildlife reserve at Guano (343ha). Public access is prohibited to the wildlife reserves in the waterfowl breeding season.

Scientific Research and Facilities No information 
Principal Reference Material The above information is taken from the Danish National Report to the Cagliari Conference in 1980.

Supplemented by:

- Scott, D.A. (1980). A preliminary inventory of wetlands of international importance for waterfowl in west Europe and north-west Africa. IWRB Special Publication No. 2.

\section{Waters southeast of Fejo and Femo Islands}

Location $54^{\circ} 54^{\prime} \mathrm{N}, 11^{\circ} 30^{\prime} \mathrm{E}$. Situated in the county of Storstrom.

Area $32,640 \mathrm{ha}$

Degree of Protection Ownership is part private and part state. There is a wildlife reserve of 71 ha at Fladet protected under the 1967 Game Act (amended 1969 and 1972). There are no nature conservation areas. Designated as a Ramsar site in September 1977.

Site Description The site consists of sea area with shallow shoals and banks, uninhabited islets, saltmarshes and reed swamps, and contains the shallowest area in Smalandshavet. One island has cultivated land and scattered habitation. The site comprises $89.5 \%$ salt and brackish water, and $10.5 \%$ land. It is a feeding, resting, breeding and moulting area for waterfowl.

International and National Importance This site is of international importance as a resting and feeding ground for 2,000 gosander Mergus merganser, 4,000 red-breasted merganser $M$. serrator, 700 whooper swan Cygnus cygnus, 6,000 mute swan C. olor, 20,000 coot Fulica atra, 5,000 goldeneye Bucephala clangula. Also resting and feeding here are 3,000 mallard Anas platyrhynchos, 1,500 teal A. crecca and 3,000 tufted duck Aythya fuligula. It is a breeding area for several species of surface feeding duck Anas spp. and waders (Charadridae) and an important wintering and moulting area for mute swan.

Changes in Ecological Character The waterfowl breeding on uninhabited islets have been affected by the reduction in grazing of these areas. A proposed project to enclose the southern third of the area by a dam has been abandoned after an analysis of the economic consequences.

Management Practices Hunting prohibited in Fladet wildlife reserve.

\section{Scientific Research and Facilities No information}

Principal Reference Material The above information is taken from the Danish National Report to the Cagliari Conference in 1980.

Supplemented by:

- Scott, D.A. (1980). A preliminary inventory of wetlands of international importance for waterfowl in west Europe and north-west Africa. IWRB Special Publication No. 2.

Praesto Fiord, Jungshoved Nor, Ulfshale and Nyord

Location $55^{\circ} 05^{\prime} \mathrm{N}, 12^{\circ} 15^{\prime} \mathrm{E}$. Situated in the county of Storstrom.

Area 25,960 ha

Degree of Protection Ownership is part private and part state with the state represented by the Ministry of the Environment. The island of Aegholm is owned by the Danish Ornithologists Union. Six nature conservation areas were established prior to 1980 at Praestofed, Roneklint, Jungshoved, Aegholm, Nyord and Ulfshale, and a further 125 ha of saltmarsh was protected for nature conservation in 1980. These areas are protected under the Conservation of Nature Act 1969 (amended 1972, 1975 and 1978). Designated as a Ramsar site in September 1977. 
Site Description Most of the site is sea area with shallow shoals and banks, islets and small islands, but also includes saltmarshes, reed swamps and cultivated land with scattered buildings. The site comprises $85.5 \%(22,200 \mathrm{ha})$ salt and brackish water, $0.2 \%$ (45ha) freshwater and $14.3 \%(3,715 \mathrm{ha})$ land. It is a feeding, resting, breeding and moulting area for waterfowl.

International and National Importance This site is of international importance as a resting and feeding ground for 10,000 tufted duck Aythya fuligula, 2,000 goosander Mergus merganser, 500 red-breasted merganser $M$. serrator, 1,600 whooper swan Cygnus cygnus, 5,000 mute swan $C$. olor, 1,700 coot Fulica atra, 300 wigeon Anas penelope, 1,500 scaup Aythya marila and 2,000 goldeneye Bucephala clangula. Also resting and feeding here are mallard Anas platyrhynchos. The site is a breeding area for surface feeding duck Anas spp., 50 pairs of avocet Recurvirosira avocetta and 150 pairs of sandwich tern Sterna sandvicensis and a moulting refuge for mute swan. It is one of the most important wintering areas in Denmark for whooper swan and the most important breeding locality in Denmark for goosander. The site contains the largest saltmarshes in southeast Denmark.

Changes in Ecological Character The traditional uses of the saltmarshes for grazing and hay harvesting were gradually abandoned during the 1950s and 1960 s resulting in the marshes becoming overgrown. This has made the area less suitable for breeding waterfowl.

Management Practices Small areas are totally protected against hunting by the Foundation for the Protection of Danish Bird Localities.

Scientific Research and Facilities No information

Principal Reference Material The above information is taken from the Danish National Report to the Cagliari Conference in 1980.

Supplemented by:

- Scott, D.A. (1980). A preliminary inventory of wetlands of international importance for waterfowl in west Europe and north-west Africa. IWRB Special Publication No. 2.

\section{Nakskov Fiord and Inner Fiord}

Location $54^{\circ} 50^{\prime} \mathrm{N}, 11^{\circ} 02^{\prime} \mathrm{E}$. Located in the county of Storstrom.

Area 8,960 ha

Degree of Protection Ownership is part private and part state. There are three wildlife reserves totalling $188 \mathrm{ha}$ at Nakskov Indrefjord, Dueholm and Smedeholm protected under the Game Act 1967 (amended 1969 and 1972), but no nature conservation areas. Designated as a Ramsar site in September 1977.

Site Description The site consists of a fiord area with shallow shoals and banks, islands (some inhabited), salt marshes and reed swamps. It comprises $87.2 \%$ salt and brackish water, and $12.8 \%$ land. The site is an important resting, feeding, breeding and moulting area for waterfowl.

International and National Importance This site is of international importance as a resting and feeding ground for 5,000 mute swan Cygnus olor, 200 whooper swan C. cygnus, 200 shoveler Anas clypeata, 5,000 tufted duck Aythya fuligula, 500 red-breasted merganser Mergus serrator and 200 cormorant Phalacrocorax carbo sinensis. Also resting and feeding here are 400 dark-bellied brent goose Branta b. bernicla, mallard Anas platyrhynchos and teal A. crecca. The site is a moulting refuge for mute swan and a breeding area for waterfowl including several species of surface feeding duck.

Changes in Ecological Character There is heavy pollution in Nakskov Indref jord which has adversely affected the flora and fauna, and in certain years creates conditions for severe outbreaks of bird botulism. 
Management Practices Public access to the islands is prohibited during the breeding season and hunting is prohibited at all times in the wildlife reserve at Nakskov Indrefjord.

\section{Scientific Research and Facilities No information}

Principal Reference Material The above information is taken from the Danish National Report to the Cagliari Conference in 1980.

Supplemented by:

- Scott, D.A. (1980). A preliminary inventory of wetlands of international importance for waterfowl in west Europe and north-west Africa. IWRB Special Publication No. 2.

\section{The Maribo Lakes}

Location $54^{\circ} 46^{\prime} \mathrm{N}, 11^{\circ} 31^{\prime} \mathrm{E}$. Situated in the county of Storstrom.

Area 4,400ha

Degree of Protection Private ownership. Some 1,200ha, surrounding and including the lakes, is a nature conservation area protected under the Conservation of Nature Act 1969 (amended 1972, 1975 and 1978). There are no wildlife reserves. Designated as a Ramsar site in September 1977.

Site Description The Maribo Lakes are freshwater lakes with wooded islands and peninsulas. Along the shores are parks, reed swamps, deciduous forests, meadows and fields with scattered buildings. The site comprises $29.1 \%$ (1,280ha) freshwater and $70.9 \%(3,120 \mathrm{ha})$ land. It is a feeding, resting and breeding area for waterfowl.

International and National Importance This site is of international importance as a resting and feeding ground for 2,000 grey lag goose Anser anser, 5,000 pochard Aythya ferina and 5,000 tufted duck Althya fuligula. Also feeding and resting here are smew Mergus albellus and mallard Anas platyrhynchos. The site is a breeding area for 30-40 pairs of greylag goose, several species of surface feeding duck Anas spp. and the marsh harrier Cicrus aeruginosus. The lakes are a regular locality for the smew and white-tailed eagle Haliatus albicilla. The Maribo Lakes is one of the Danish Ramsar sites with a significant proportion of the site area protected for nature conservation.

Changes in Ecological Character The increased use of fertilisers in farming during the past decades has resulted in increased eutrophication of the lakes.

\section{Management Practices No information}

\section{Scientific Research and Facilities No information}

Principal Reference Material The above information is taken from the Danish National Report to the Cagliari Conference in 1980.

Supplemented by:

- Scott, D.A. (1980). A preliminary inventory of wetlands of international importance for waterfowl in west Europe and north-west Africa. IWRB Special Publication No. 2.

The waters between Lolland and Falster including Rodsand, Guldborgsund and Boto Nor

Location $54^{\circ} 14^{\prime} \mathrm{N}, 11^{\circ} 45^{\prime} \mathrm{E}$. Situated in the county of Storstrom. 
Degree of Protection Ownership is part private and part state, with the state represented by the Ministry of the Environment. There are nature conservation areas at Hasselo-Kalvo, Skejten-Frejslev-Boget and Boto Nor totalling 363ha, protected under the Nature Act 1969 (amended 1972, 1975 and 1978), and wildlife reserves at Frejlev Vig, Nysted Nor, Tjorneholm, Hylleholm and Rodsand totalling 812ha, protected under the Game Act 1967 (amended 1969 and 1972). Designated as a Ramsar site in September 1977.

Site Description The site consists of a sea area with shallow shoals and banks, coastal slopes, salt marshes and reedswamps. Some areas are enclosed by dams. The site comprises $29,920 \mathrm{ha}$ salt and brackish water and 6,880 ha land. The site supports a wide variety of waterfowl. Common seal Phoca vilulina breed at Rodsand.

International and National Importance This site is of international importance as a resting and feeding ground for 1,000 bean geese Anser fabalis, 2,000 dark-bellied brent geese Branta b. bernicla, 11,000 tufted duck Aythya fuligula, 2,000 goosander Mergus merganser, 1,500 whooper swan Cygnus cygnus, 2,000 mute swan $C$. olor and 15,000 coot Fulica atra, and is one of the few internationally important areas in Denmark for bean goose. Other species resting and feeding here include 300 greylag goose Anser anser, 200 Canada goose Branta canadensis, 2,000 goldeneye Bucephala clangula, mallard Anas platyrhynchos, wigeon $A$. penelope, teal A. crecca, scaup Aythya marila, bar-tailed godwit Limosa lapponica, dunlin Calidris alpina, knot $C$. canutus, ruff Philomachus pugnax and golden plover Pluvialis apricaria. The site is also a moulting area for mute swan and a breeding area of international importance for several species of waterfowl including 1-2 pairs of turnstone Arenaria intepres and 200-300 pairs Arctic tern Sterna paradisaeae.

\section{Changes in Ecological Character None reported (November 1980)}

Management Practices Public access prohibited to the islands and Rodsand during the waterfowl breeding period. Hunting is prohibited in 174 ha at Boto Nor and 178 ha at Frejslev Vig. An application for a rifle range for the Home Guard at Hyllerrog has been refused.

\section{Scientific Research and Facilities No information}

Principal Reference Material The above information is taken from the Danish National Report to the Cagliari Conference in 1980.

Supplemented by:

- Scott, D.A. (1980). A preliminary inventory of wetlands of international importance for waterfowl in west Europe and north-west Africa. IWRB Special Publication No. 2.

\section{Ertholmene Islands east of Bornholm}

Location $55^{\circ} 19^{\prime} \mathrm{N}, 15^{\circ} 11^{\prime} \mathrm{E}$. Situated east of Bornholm Island.

\section{Area 1,257 ha}

Degree of Protection State ownership with the state represented by the Ministry of Defence. 11 ha at Graesholmene is a nature conservation area protected under the Nature Act 1969 (amended 1972, 1975 and 1978). There are no wildlife reserves. Designated as a Ramsar site in September 1977.

Site Description A sea area containing islands with cliffs. Two islands are inhabited. The site comprises $97.1 \%$ salt and brackish water, and $2.9 \%$ land, and supports several species of waterfowl. 
International and National Importance The site is a breeding area of international importance to 2,000 pairs of eider duck Somateria mollissima, 25 pairs of lesser black-backed gull Larus fuscus, 6,400 pairs of herring gull L. argentatus, 80 pairs of razorbill Alca torda and 1,100 pairs of guillemot Uria aalge. This is the only breeding locality in Denmark for razorbill and guillemot, and one of the most important sites for eider duck. This site is the type locality for the nominate form of lesser black-backed gull. The long-tailed duck Clangula hyemalis also occurs here.

Changes in Ecological Character There have been changes in the bird life and vegetation at Graesholmene since measures were introduced in 1974 to control the herring gull population.

Management Practices Herring gull numbers have been actively controlled since 1974 when the population reached 10,000 pairs. Hunting is prohibited in the conservation area at Graesholmene.

Scientific Research and Facilities There is a small station near Akirkeby on the island of Bornholm (Address: Vasegardsvej, Akirkeby DK3720). Research includes the observation of bird migration and ringing.

Principal Reference Material The above information is taken from the Danish National Report to the Cagliari Conference in 1980. 
Population $4,869,858$ ( 1983 census)

Summary of Wetland Situation Finland with its long irregular coastline, its archipelagos comprising over 30,000 islands and islets, and its lakes which number approximately 62,000 , is extremely rich in waterfowl habitats. Most of them provide suitable breeding sites for Anatidae and waders but some are typical resting and feeding places during the autumn migration (for example the coastal marshes of Bölsvik, Preiviikki and the lake Höystiäinen). The density of breeding pairs of waterfowl is highest on or around small eutrophic lakes but rather lower over the vast peatland areas. It is therefore necessary for effective and successful conservation to protect enough of both kinds of wetland complex, those which consist of large numbers of small lakes, and some much larger ones typical of peatland areas.

The section dealing with the Finnish wetlands in the List of Wetlands of Nordic Importance published in 1973, included 42 sites. Of these, thirteen were designated by Finland for listing when it ratified the Ramsar Convention in 1974. They comprise eight sites in the archiptlagos in the Gulf of Bothnia and Krunnit also in the Gulf of Bothnia; two coastal marshes (Ruskis and Viikki); and three peatland complexes (Suomijärvi-Patvinsuo, Martimoaapa-Lumiaapa and Loitilaiskaira).

An official working group on peatland preservation has published two reports, the first of which is being acted on by the government. A further working group has made proposals on nationally important eutrophic lakes and sea bays. The Bureau of Natural Resources (Ministry of Agriculture and Forestry) is responsible for making inventories of important wetlands.

Protected Areas Legislation The arrangement of nature reserves in Finland is based on the Nature Protection Act (Decree No. 71/23 February 1923) though new legislation is under preparation. This law allows establishment of general and special nature reserves on state-owned land, of which reserves greater than 50 ha are established by law and smaller reserves by a statute. Nature reserves can be established on private land subject to a decision by the provincial government. General nature reserves established by law are called strict reserves (in Finnish: luonnonpuisto), and have been reserved mainly for research work. These will be conserved in their virgin state, and public access is striclty limited. Special nature reserves established by law (national parks or kansallispuisto), have been reserved as public sights of nature, and represent the most valuable and typical natural landscapes. National parks are for education and recreation besides research and nature protection, and the general public usually has free access. Regulations concerning protection in the strict reserves and national parks have been given by the nature protection law, and by the statutes and rules and regulations of each park. Nature reserves established by a statute on state-owned or private land vary in size and in their aims of protection. Besides the nature reserves established by the nature protection law, there are other protected areas on state-owned land established by decisions taken by the National Board of Forestry and the Finnish Forest Research Institute. These reserves are: primaeval forests (considered as representative examples of virgin nature); special conservation forests (established on grounds of social, scenic or biological values, and which may include fully protected parts, lightly managed parts and normally managed parts); peatlands protected from drainage.

Protected Areas Administration Administration and mangement of parks and reserves is the responsibility of two Departments, the National Board of Forestry (Metsähallitus), and the Finnish Forest Research Institute (Metsäntutkimuslaitos). These two Departments are working under the Ministry of Agriculture and Forestry. Although the Forest Research Institute still administers a number of parks and reserves, the main chain of responsibility operates from the Ministry through the National Board of Forestry. The Bureau of National Resources (within the same Ministry) has a key position in ensuring cooperation between the various bodies with responsibility for environment and land-use decisions. 
Sites designated under the Convention

Signature subject to ratification 19 April 1973 with ratification 28 May 1974. 11 sites were listed at ratification.

\author{
Aspskär Nature Reserve \\ Söderskär Bird Sanctuary and Langoren Nature Reserve \\ Björkör Nature Reserve and Lagskär Bird Sanctuary \\ Signilskär Bird Sanctuary \\ Valassaart Bird Sanctuary and Björkögrunden Bird Sanctuary \\ Krunnit Nature Reserve \\ Ruskis Nature Reserve \\ Viikki Nature Reserve \\ Patvinsuo National Park \\ Maartimoaapa - Lumiaapa \\ Koitilaiskaira
}

Government body responsible for administration of the Convention

Ministry of Agriculture and Forestry, Halituskatu 3, 00170 Helsinki 17

\title{
Aspskär Nature Reserve
}

Location $60^{\circ} 16^{\prime} \mathrm{N}, 26^{\circ} 25^{\prime} \mathrm{E}$. Situated offshore in the Gulf of Finland (Baltic Sea), west of Helsinki in southern Finland.

Area 369 ha comprising 27 ha land (islands) and 342 ha water.

Degree of Protection Privately owned and protected as a nature reserve. The Ministry of Agriculture and Forestry in Helsinki is the administrative authority responsible for the implementation of the Ramsar Convention. Designated as a Ramsar site at the time of ratification after 28 May 1974.

Site Description The site comprises a small of fshore archipelago centred on Aspskar Island. The islands are mostly treeless with occasional stands of alder Alnus glutinosa.

International and National Importance The islands support a rich breeding population of birds including common eider Somateria mollissima (45 pairs), tufted duck Aythya fuligula (8 pairs), redshank Tringa totanus (9 pairs), ruddy turnstone Arenaria interpres (12 pairs), great black-backed gull Larus marinus (2 pairs), lesser black-backed gull L. fuscus (70 pairs), herring gull L. argentatus (294 pairs), common gull L. canus (370 pairs), Arctic tern Sterna paridisaea (62 pairs), razorbill Alca torda (350 pairs), common murre Uria aalge (20 pairs) and black guillemot Cepphus grylle (257 pairs). (1979 figures).

\section{Changes in Ecological Character None reported (1980)}

\section{Management Practices No information}

\section{Scientific Research and Facilities No information}

Principal Reference Material The above information is taken from:

- Haapanen, A. and Rassi, P. (April 1980). Finland National Report. Prepared for the Conference on the conservation of wetlands of international importance especially as waterfowl habitat held at Cagliari, Italy in November 1980. Ministry of Agriculture and Forestry, Helsinki. 
Location Soderskar $60^{\circ} 07^{\prime} \mathrm{N}, 25^{\circ} 25^{\prime} \mathrm{E}$. Langoren $60^{\circ} 08^{\prime} \mathrm{N}, 25^{\circ} 30^{\prime} \mathrm{E}$. Situated of fshore in the Gulf of Finland (Baltic Sea), west of Helsinki in southern Finland. Just east of Aspskar Nature Reserve (Ramsar site).

Area 9,632ha: Soderskar 1,382ha and Langoren 8,250ha.

Degree of Protection Privately owned. The site comprises the protected sanctuary and nature reserve. Designated as a Ramsar site at the time of ratification after 28 May 1974.

Site Description The two disjunct but jointly designated areas comprise an outer archipelago of islets centred on Soderskar Island, and the Langoren archipelago of 62 islands and islets. The area freezes over in winter, but the Soderskar archipelago is one of the first areas to thaw, making it an important site for large numbers of early spring migrants.

International and National Importance Langoren is the only breeding site in the Gulf of Finland for greater scaup Aythya marila. Large numbers of migrants pass through Soderskar in early spring when the winter ice has thawed. Breeding birds recorded in the area in 1979 include common eider Somateria mollissima (1,592 pairs), tufted duck Aythya fuligula (17 pairs), red-breasted merganser Mergus serrator (19 pairs), other Anatidae (42 pairs), oystercatcher Haematopus ostralegus (5 pairs), ruddy turnstone Arenaria interpres (17 pairs), redshank Tringa totanus (6 pairs), ringed plover Charadrius hiaticula (2 pairs), great black-backed gull Larus marinus (9 pairs), lesser black-backed gull L. fuscus (207 pairs), herring gull L. argentatus (394 pairs), common gull L. canus (204 pairs), Arctic tern Sterna paridisaea (88 pairs), common tern $S$. hirundo ( 9 pairs), Caspian tern $S$. caspia (1 pair), black guillemot Cepphus grylle (231 pairs) and 8 species of Passeriformes (95 pairs).

\section{Changes in Ecological Character None reported (1980)}

\section{Management Practices No information}

\section{Scientific Research and Facilities No information}

Principal Reference Material The above information is taken from:

- Haapanen, A. and Rassi, P. (1980). Finland National Report. Prepared for the Conference on the conservation of wetlands of international importance especially as waterfowl habitat held at Cagliari, Italy in November 1980. Ministry of Agriculture and Forestry, Helsinki.

Additional references:

- Paavolainen, E.P. (1957). Die Vogelfauna des ausseren Scharenhofes im ostlichen Teil des Finnischen Meerbusens. Ann. Zool. Soc. 18(5): 1-51.

- Suomalainen, E. (1979). The Lepidopteran fauna of an isolated island in the outermost archipelago of the Gulf of Finland. Notulae Entomologicae 59: 79-88

\section{Björkör Nature Reserve and Lagskär Bird Sanctuary}

Location Bjorkor $59^{\circ} 56^{\prime} \mathrm{N}, 20^{\circ} 10^{\prime} \mathrm{E}$. Lagskar $59^{\circ} 50^{\prime} \mathrm{N}, 19^{\circ} 50^{\prime} \mathrm{E}$. Situated to the south of Aland Island archipelago in the Gulf of Bothnia (Baltic Sea) between Sweden and southwest Finland.

Area 5,760ha: Bjorkor 5,300ha and Lagskar 460ha. The designated site is $243 \mathrm{ha}$ land and 5,500ha sea.

Degree of Protection Privately owned. The site comprises the protected nature reserve and sanctuary. Designated as a Ramsar site at the time of ratification after 28 May 1974. 
Site Description The two disjunct but jointly designated areas comprise two wooded islands with freshwater pools, over 150 islets (mostly treeless) and the surrounding sea area. The outer archipelago of Bjorkor Reserve supports a particularly rich fauna.

International and National Importance The islands (particularly the outer Bjorkor archipelago) are an important area for common eider Somateria mollissima (500-700 pairs). Other recorded waterfowl include mute swan Cygnus olor, greylag goose Anser anser, mallard Anas platyrhynchos, tufted duck Aythya fuligula, greater scaup A. marila, and gulls and terns (Laridae).

\section{Changes in Ecological Character None reported (1980)}

\section{Management Practices No information}

Scientific Research and Facilities There is a bird-ringing station and sanctuary within Lagskar Bird Sanctuary.

Principal Reference Material The above information is taken from:

- Haapanen, A. and Rassi, P. (1980). Finland National Report. Prepared for the Conference on the conservation of wetlands of international importance especially as waterfowl habitat held at Cagliari, Italy in November 1980. Ministry of Agriculture and Forestry, Helsinki.

\section{Signilskär Bird Sanctuary}

Location $60^{\circ} 09^{\prime} \mathrm{N}, 19^{\circ} 20^{\prime}-25^{\prime} \mathrm{E}$. The archipelago is situated close to the international frontier between southwest Finland and Sweden in the Gulf of Bothnia.

Area $11,600 \mathrm{ha}$

Degree of Protection Privately owned and protected as a reserve since 1927. Designated as a Ramsar site at the time of ratification after 28 May 1974.

Site Description The site comprises an offshore archipelago and surrounding sea centred on Signilskär Island $(1.5 \mathrm{~km}$ long). Most of the 50 islands and islets are treeless.

International and National Importance The islands support a rich waterfowl fauna including large numbers of common eider Somateria mollissima, razorbill Alca torda, black guillemot Cepphus grylle and gulls (Laridae).

Changes in Ecological Character None reported (1980)

Management Practices Managed as a bird sanctuary.

Scientific Research and Facilities The most active bird ringing station in Finland is on Signilskar Island.

Principal Reference Material The above information is taken from:

- Haapanen, A. and Rassi, P. (1980). Finland National Report. Prepared for the Conference on the conservation of wetlands of international importance especially as waterfowl habitat held at Cagliari, Italy in November 1980. Ministry of Agriculture and Forestry, Helsinki.

\section{Valassaaret and Björkögrunden Bird Sanctuaries}

Location Valassaaret $63^{\circ} 25^{\prime}-28^{\prime} \mathrm{N}, 21^{\circ} 01^{\prime}-08^{\prime} \mathrm{E}$. Bjorkogrunden $63^{\circ} 21^{\prime}-23^{\prime} \mathrm{N}, 21^{\circ} 02^{\prime}-09^{\prime} \mathrm{E}$. Situated in the Gulf of Bothnia (Baltic Sea) off the northwest coast of Vassa Province, western Finland. Near the international frontier with Sweden. 
Area 17,700ha comprising the adjacent sanctuaries of Valassaaret $11,800 \mathrm{ha}$ and Bjorkogrunden 5,900ha.

Degree of Protection Privately owned and protected as bird sanctuaries. Designated as a Ramsar site at the time of ratification after 28 May 1974.

Site Description The site comprises two adjacent island groups separated by shallow open sea. Storskar (the largest island) and numerous islets in the Valassaaret group are gradually increasing in size as the land in the shallow water rises. There are two small settlements on Storskar linked by a track. Björkögrunden comprises a group of small stony islands lying south of Valassaaret.

International and National Importance The sanctuaries are focal points on the migration route through the Gulf of Bothnia. They also support a large breeding population of birds with over 3,300 pairs of 30 species recorded in 1962 in Valassaaret sanctuary, including tufted duck Aythya fuligula, greater scaup A. marila, white-winged scoter Melanitta fusca, red-breasted merganser Mergus serrator, ruddy turnstone Arenaria interpres, redshank Tringa totanus, lesser black-backed gull Larus fuscus and common gull L. canus.

\section{Changes in Ecological Character None reported (1980)}

Management Practices Managed as bird sanctuaries.

Scientific Research and Facilities No information

Principal Reference Material The above information is taken from:

- Haapanen, A. and Rassi, P. (1980). Finland National Report. Prepared for the Conference on the conservation of wetlands of international importance especially as waterfowl habitat held at Cagliari, Italy in November 1980. Ministry of Agriculture and Forestry, Helsinki.

Additional references:

- Hildén, O. (1964). Ecology of duck populations in the island group of Valassaaret, Gulf of Bothnia. Ann. Zool. Fenn. 1: 153-277.

- Hildén, O. (1966). Changes in bird fauna of Valassaaret, Gulf of Bothnia during recent decades. Ann. Zool. Fenn.

\section{Krunnit Nature Reserve}

Location $65^{\circ} 21^{\prime}-26^{\prime} \mathrm{N}, 24^{\circ} 25^{\prime}-25^{\circ} 09^{\prime} \mathrm{E}$. Situated in the extreme northeast of the Gulf of Bothnia (Baltic Sea) off the northwest coast of Oulu Province, west central Finland.

Area 4,600 ha comprising 4 disjunct island groups.

Degree of Protection Privately owned and protected as a nature reserve. Designated as a Ramsar site at the time of ratification after 28 May 1974.

Site Description The site comprises four disjunct offshore island groups with 7 large islands including Mcakrunni, Ristikori and Ulkokrunni and numerous small islets.

International and National Importance The islands support an abundant population of breeding waterfowl with 1,100 pairs of 33 species in 1963 including greylag goose Anser anser, mallard Anas platyrhynchos, tufted duck Aythya fuligula, greater scaup A. marila, red-breasted merganser Mergus serrator, ringed plover Charadrius hiaticula, Temminck's stint Calidris temminckii, redshank Tringa totanus, lesser black-backed gull Larus fuscus, common gull $L$. canus, Caspian tern Sterna caspia, common tern S. hirundo and Arctic tern S. paradisaea.

Changes in Ecological Character None reported (1980)

Management Practices Managed as a nature reserve. 
Scientific Research and Facilities Several research projects on the waterfowl population have been conducted in the reserve.

Principal Reference Material The above information is taken from:

- Haapanen, A. and Rassi, P. (1980). Finland National Report. Prepared for the Conference on the conservation of wetlands of international importance especially as waterfowl habitat held at Cagliari, Italy in November 1980. Ministry of Agriculture and Forestry, Helsinki.

Additional references:

- Vaisanen, R.A. and Jarvinen, O. (1977a). Quantitative structure and primary succession of bird communities in a Finnish archipelago. Ornis Scand. 8: 47-60.

- Vaisanen, R.A. and Jarvinen, O. (1977b). Dynamics of protected bird communities in a Finnish archipelago. J. Anim. Ecol. 46: 891-908.

\section{Ruskis Nature Reserve}

Location $60^{\circ} 22^{\prime} \mathrm{N}, 25^{\circ} 40^{\prime} \mathrm{E}$. Situated in a river estuary on the Gulf of Finland (Baltic Sea), east of Helsinki, in Uusimaa Province, southern Finland.

Area 235 ha

Degree of Protection Privately owned and protected as a nature reserve. Designated as a Ramsar site at the time of ratification after 28 May 1974.

Site Description The site comprises the inshore island of Svino and surrounding marshlands in the mouth of the river. The coastal marsh is predominantly reedbeds of Phragmites communis. The island is linked by a road causeway to Borga and there are several settlments on the mainland estuary shore near the reserve.

International and National Importance The island and marshes are an important resting station for migrating waterfowl. Breeding birds include great-crested grebe Podiceps cristatus (50 pairs), Eurasian bittern Botaurus stellaris, mallard Anas platyrhynchos (30-35 pairs), common pochard Aythya ferina (22-24 pairs), tufted duck A. fuligula (25 pairs), coot Fulica atra (30-35 pairs), black-headed gull Larus ridibundus and marsh harrier Circus aeruginosus.

\section{Changes in Ecological Character None reported (1980)}

\section{Management Practices Managed as a nature reserve.}

\section{Scientific Research and Facilities No information}

Principal Reference Material The above information is taken from:

- Haapanen, A. and Rassi, P. (1980). Finland National Report. Prepared for the Conference on the conservation of wetlands of international importance especially as waterfowl habitat held at Cagliari, Italy in November 1980. Ministry of Agriculture and Forestry, Helsinki.

\section{Viikki Nature Reserve}

Location $60^{\circ} 13^{\prime} \mathrm{N}, 25^{\circ} 00^{\prime} \mathrm{E}$. Situated just northeast of Helsinki in the Vantaa river mouth on the Gulf of Finland (Baltic Sea), southern Uusimma Province.

Area 247 ha

Degree of Protection Privately owned and protected as a nature reserve. Designated as a Ramsar site at the time of ratification after 28 May 1974. 
Site Description The site comprises a small island (Lammassaari Farholmen), associated marshlands, and the shallow estuarine waters of the coastal inlet. The marshlands are supplied with freshwater by the Vantaa and another river, and are dominated by reedbeds Phragmites communis. The northwest boundary is defined by a major motorway.

International and National Importance The coastal wetland supports a large population of breeding birds with 4,663 pairs of 21 species in 1964, including black-headed gull Larus ridibundus (4,200 pairs in 1964: the largest colony in Finland), great crested grebe Podiceps cristatus, mallard Anas platyrhynchos and sedge warbler Acrocephalus schoenobaenus.

Changes in Ecological Character The reserve is surrounded by the densely populated suburbs of Helsinki along the shoreline, and there is a possible threat of water pollution in the wetland resulting from inflow of polluted water from the two major rivers.

\section{Management Practices Managed as a nature reserve.}

Scientific Research and Facilities There is a scientific station on the island.

Principal Reference Material The above information is taken from:

- Haapanen, A. and Rassi, P. (1980). Finland National Report. Prepared for the Conference on the conservation of wetlands of international importance especially as waterfowl habitat held at Cagliari, Italy in November 1980. Ministry of Agriculture and Forestry, Helsinki. Additional references:

- Eriksson, K. (1966). Gammelstadviken och des fagelfauna under den senaste tiden. Nordenskioldsamfundets tidskrift 26: 27-39.

\section{Patvinsuo National Park}

Location $63^{\circ} 05^{\prime} \mathrm{N}, 30^{\circ} 35^{\prime} \mathrm{E}$. Situated on the north shore of Koitere Lake which is part of the inland lake complex in Pohjois-Karjala Province, southwest Finaland. Near the USSR frontier.

Area 9,400 ha

Degree of Protection Privately owned. The designated site includes Patvinsuo State Nature Reserve $(8,800 \mathrm{ha})$ established in 1966 . Designated as a Ramsar site at the time of ratification after 28 May 1974.

Site Description The site comprises a large peatland area with fenlands, raised bogs and small brackish pools, centred around the oligotrophic Suomujarvi Lake. A river runs through the area draining into the larger Koitere Lake.

International and National Importance The wetland is an importnat breeding site for waterfowl including whooper swan Cygnus cygnus, bean goose Anser fabalis, pintail Anas acuta, smew Mergus albellus, crane Grus grus, broad-billed sandpiper Limicola falcinellus and jack snipe Lymnocryptes minimus. Other breeding birds include osprey Pandion haliaetus, golden eagle Aquila chrysaetos and great eagle owl Bubo bubo. Large numbers of stopover migrants include white-fronted goose Anser albifrons, barnacle goose Branta leucopsis and brent goose $B$. bernicla.

Changes in Ecological Character None reported (1980)

Management Practices 8,800 ha managed as a nature reserve.

Scientific Research and Facilities No information 
Principal Reference Material The above information is taken from:

- Haapanen, A. and Rassi, P. (1980). Finland National Report. Prepared for the Conference on the conservation of wetlands of international importance especially as waterfowl habitat held at Cagliari, Italy in November 1980. Ministry of Agriculture and Forestry, Helsinki.

\section{Martimoaapa-Lumiaapa}

Location $65^{\circ} 49^{\prime} \mathrm{N}, 25^{\circ} 15^{\prime} \mathrm{E}$. Situated north of the road from Alaniema to the coastal town of Simo in southern Lappi Province. Alaneima is located near the western boundary.

Area 7,400 ha

Degree of Protection State owned and protected as a nature reserve. Designated as a Ramsar site at the time of ratification after 28 May 1974.

Site Description The site comprises fenland interspersed with small lakes, pools and streams.

International and National Importance The site is an important breeding site for birds with 500 pairs of 21 species recorded in 1977, including red-throated loon Gavia stellata, Arctic loon G. arctica, horned grebe Pociceps auritus, bean goose Anser fabalis (well-established population), pintail Anas acuta, garganey $A$. querquedula, broad-billed sandpiper Limicola falcinellus, spotted redshank Tringa erythropus, Jack snipe Lymnocryptes minimus, northern phalarope Phalaropus lobatus, herring gull Larus argentatus and great black-backed gull $L$. marinus. The peregrine falcon Falco peregrinus is also reported as breeding in the area.

Changes in Ecological Character None reported (1980)

Management Practices No information

Scientific Research and Facilities Population dynamics of breeding birds were studied in 1976/77.

Principal Reference Material The above information is taken from:

- Haapanen, A. and Rassi, P. (1980). Finland National Report. Prepared for the Conference on the conservation of wetlands of international importance especially as waterfowl habitat held at Cagliari, Italy in November 1980. Ministry of Agriculture and Forestry, Helsinki. Additional references:

- Vaisanen, R.A. and Jarvinen, O. (1977). Structure and fluctuation of breeding fauna of a north Finnish peatland area. Ornis Fennica 54: 143-153.

\section{Koitilaiskaira}

Location $67^{\circ} 40^{\prime}-50^{\circ} \mathrm{N}, 26^{\circ} 50^{\prime}-27^{\circ} 41^{\prime} \mathrm{E}$. Situated southwest of Lake Tekojarvi in Lappi Province, northeast Finland. Near the USSR frontier.

Area 34,400 ha

Degree of Protection State owned. The wetland was defined in 1980 as a temporary reserve with plans to upgrade to strict nature reserve status. Designated as a Ramsar site at the time of ratification after 28 May 1974.

Site Description Over $60 \%$ of the site is covered with peatlands, interspersed with small streams and ponds. The remaining area is covered with developed forest with subalpine birch Betula sp. stands on higher ground. The site is drained by the Luiro River to the south, tributaries of the Kemijoki to the west and numerous small channels flowing into nearby Tekojarvi Lake. 
International and National Importance The site is an important breeding site for waterfowl with 5,000-6,000 pairs of 39 species recorded in 1979, including whooper swan Cygnus cygnus, bean goose Anser fabalis, black scoter Melanilla nigra, white-winged scoter $M$. fusca, smew Mergus albellus, ruff Philomachus pugnax, spotted redshank Tringa erythropus, wood sandpiper $T$. glareola, Jack snipe Lymnocryptes minimus, northern phalarope Phalaropus lobatus and black-headed gull Larus ridibundus (perhaps the northern-most colony in Finland).

\section{Changes in Ecological Character None reported (1980)}

Management Practices Managed as a temporary reserve.

Scientific Research and Facilities Several bird population studies have been carried out in the wetland.

Principal Reference Material The above information is taken from:

- Haapanen, A. and Rassi, P. (1980). Finland National Report. Prepared for the Conference on the conservation of wetlands of international importance especially as waterfowl habitat held at Cagliari, Italy in November 1980. Ministry of Agriculture and Forestry, Helsinki. Additional references:

- Haapanen, A., Ulmanen, I. and Valste, J. (1966). Observations on the bird fauna in Koitilaiskaira. Ornis Fenn 43: 45-54.

- Haapanen, A. and Nilsson, L. (1977). Breeding waterfowl populations in northern Fennoscandia. Ornis Scand. 10: 145-219. 


\section{FRANCE}

Area 543,965 sq. $\mathrm{km}$

\section{Population $54,540,000(1984)$}

Summary of Wetland Situation The wetlands of the Atlantic coast are on one of the main migration routes of Palaearctic waterfowl. The shallow bays and estuaries, with extensive mudflats exposed at high tide, offer excellent feeding and roosting sites for large numbers of wildfowl and waders, and the marshes which often occur inland of these estuaries provide essential night feeding areas for the surface feeding ducks, which roost on the sea or mudflats during the day. Along the Pas de Calais and Normandy coasts the Baies de l'Authie, de la Canche and de Veys have lost much of their importance over recent decades as a result of dyke building, sand sedimentation and drainage of most of the inland marshes, as well as heavy hunting pressure. However, in the Baie de la Somme the creation of a reserve has caused the wintering population of several species to increase. The Baie de Mont St Michel supports substantial numbers of waders (January counts average about 140,000). The Baie de St Brieuc is also of international importance since at times it supports over 20,000 waders. Another site, the Rade de Brest, is apparently the major wintering area for red-breasted merganser Mergus serrator (500-900) in France.

In the Bay of Biscay, the Golfe de Morbihan is of exceptional value as it harbours about $70 \%$ of the population of brent goose Branta bernicla wintering in France (about $25 \%$ of the world population). Most of the bays and estuaries in the north and west support flocks of brent geese in smaller numbers, and the total number wintering in France is estimated to be about 40,000. The Golfe de Morbihan is also of major importance for wintering wigeon Anas penelope $(1,200-35,000)$ and pintail $A$. acuta $(500-2,000)$, and in January the average number of wader is around 45,700 . Several sites in the Loire estuary are important day roosting sites for ducks Anas and Aythya spp., and the Lac de Lieu at the upper end of the estuary, which is privately owned, contains the largest breeding colony in France of grey heron Ardea cinerea (although numbers were considerably reduced in 1974 to 300 pairs from a former total of about 1000). This area is now under serious threat from plans for industrial and port development.

Further south the Marais d'Olonne has the only colony of avocet Recurvirostra avosetta in western France, and the Baie de l'Aiguillon and Marais de Vendeee, form one of the most important wintering areas on the Atlantic coast for several species of Anatidae. The associated mudflats offer excellent feeding grounds for thousands of waders including 3000-4000 avocet. The mudflats of the Fier d'Ars and the Anse de Fouras near the Ile de Ré are important for brent geese and several Anas species, but the large estuary of the Gironde provides little suitable wader habitat as there are no high tide roosting sites and hunting pressure is reported to be very high. Numbers of wintering waterfowl have increased considerably in the Bassin d'Arachon with the creation of several reserves. Dunlin Calidris alpina occur in large numbers (up to 220,000) and some 2500 brent geese winter. Since becoming a reserve, the Banc d'Arguin at the mouth of the Bassin has become the site of a colony of 3000 pairs of sandwich tern Sterna sandvicensis.

On the Mediterranean coast, the Camargue is of major importance for breeding, migrating and wintering waterfowl and waders, and is largely contained in a natural park with some areas included in nature reserves. Inland, the most important areas for waterfowl are in the Rhine valley, along the shores of Lake Geneva, in pond areas of the Sologne region, la Brenne and les Dombes, the latter being important for breeding Ardeidae and for migrating birds of many kinds. On Corsica, the Etang de Biguglia harbours internationally important numbers of waterfowl and waders in winter, and the rare Audouin's gull Larus audouinii nests on several islets of $\mathrm{f}$ the coast. 
Protected Areas Legislation

The general framework for establishing national parks is provided by Act No. 60.708 of 22 July 1960 and its enforcement order, No. 61.1195 of 31 October 1961. Article 2 of the 1960 Law was vaguely worded which resulted in flexible application of its protective measures from one national park to another. Each national park is created by a special law which is a long and complex process. Protection is a priority criterion in the creation of national parks, which by definition "safeguard a finite part of the national territory from human interference, in order to preserve its original beauty and conserve its biological assets".

Numerous laws dating back a long time are applicable to the creation of nature reserves. The first text to provide a real definition of a nature reserve was the Nature Conservation Act of 10 July 1976 Act No. 76 629. The enabling decree followed on 25 November 1977. The 1976 law allowed the establishment of new categories of nature reserves (geological, minerological, marine and botanical gardens) and covered seven aspects of their application. Areas declared before 1976 are covered by the Act of 7 July 1957, and 'reserves' can also be created on orders of the Ministry of Transport, but these need renewing every two years. Voluntary nature reserves are covered by Article 24 of the 1976 law, and regulated by Articles 17-25 of the Decree No. 77-1298 of 25 November 1977. Nature reserves are sometimes established on local initiatives, with the Ministry of the Environment giving approval and thus creating an agreement of a contractual nature.

The idea of regional natural parks was advanced in the early 1960 s by DATAR, an agency responsible for establishing regional planning policy. The criteria for establishment and designation of areas was set out in Decree No. 67-158 of 1 March 1967 and updated by Decree No. $75-983$ of 24 October 1975. Since administrative 'regions' had not yet been set up between 1967 and 1975, regional natural park creation depended upon a ministerial decree, although the state assumed less than half of the operating and investment costs. Post 1975 they are created on the initiative of the local population, the local authorities, trade and industry, and regional associations.

Other protection types include hunting reserves, where shooting may or may not be permitted; game reserves, where hunting is considerably reduced; biogenetic reserves; buffer zones, existing around national parks, and a number of large towns and reserves to preserve terrains against building and exploitation; and scenic zones, where there are restrictions on buildings for aesthetic and architectural reasons. The Nature Conservation Act 1976 protects all rare, endangered, noteworthy or declining plant and animal species, and in addition all large game animals are also protected in national hunting reserves.

Special and specific legislation governing marine reserves and parks does not exist. Marine environmental protection relies on a whole series of legal instruments governing the occupation and utilization of the maritime public domain (for fishing, mining, sea transport, industrial pollutant discharge, etc.). Protective fisheries can be set up by permit or lease of occupation of the marine public domain on the basis of Decrees of 9 January 1852 and 21 December 1915. They are renewable every 25 years (non-mobile establishment) and five years (mobile establishment); fishery preserves are governed by Ministerial Decree of 4 June 1963, and their establishment or abolition is decided by the Maritime Affairs Department, usually taking into account users opinions. Marine nature parks may be created by a legal management body which can be a foundation, a departmental administration, a joint syndicate, or an association subject to the 1901 Act. The Decree of 24 October 1975 has no provision for including a marine element, and where this is included it is only covered by a general law. In such cases nature reserves have to be created under the $1976 \mathrm{Act}$. Coastland protection is possible under the Act of 10 July 1976, whilst the Coastland and Lake Shore Conservancy exist mainly for the purchase of natural coastland areas, whilst hunting in coastal zones is authorized by the Navy.

Protected Areas Administration Administrative responsibility for nature conservation rests with the Ministry of the Environment, in which there are a number of 'Directions' advised by a National Nature Conservation Council and by the Ministry's General Secretariat of the Environment Committee. The Direction of Nature Conservation is divided into three offices dealing with Hunting, Fisheries and Hydrobiology, and Parks and Reserves. 
The office dealing with parks and reserves acts as a coordinating body for the establishment and management of national parks and nature reserves. It is responsible for all decisions not taken locally, for the supervision of reserves, for implementing agreements concluded between the Ministry and the managing body and for producing reports on new areas. By a Decree of 25 November 1977 concerning the National Council for the Protection of Nature, its powers were increased and its composition was modified to reflect its more important role. It is advised by the National Nature Conservation Council which meets four times a year on average at the request of the Direction of Nature Conservation. Each national park has a Board of Directors with the total membership fixed by decree.

Responsibility for administering Regional Nature Parks, and for other rural development issues, rests with another Direction at the Ministry, while the Ministry of Regional Planning has responsibility for land-use planning and is closely concerned in the elaboration of the 'zone peripherique' of national parks. In other areas, the 'Conservatoire du littoral français', a public institution, works to safeguard sea and lake shores from urbanization through acquisition. The management of Coastland and Lakeshore Conservancy lands is mainly a prohibitive activity, whilst protective fisheries management is entrusted to a private body, such as a fisherman's guild or an association founded in accordance with the 1901 Act.

Sites designated under the Convention

Entry into force (ratification) on 1 October 1986 with one site listed at ratification.

\section{La Camargue}

Government bodies responsible for the administration of the Convention

Direction de la Protection de la Nature, Ministère chargé de l'Environment, 14, Boulevard du Général Leclerc, 92524 Neuilly-sur-Seine Cedex.

\section{La Camargue}

Location $43^{\circ} 16^{\prime}-43^{\circ} 44^{\prime} \mathrm{N}, 4^{\circ} 14^{\prime}-4^{\circ} 50^{\prime} \mathrm{E}$. In the delta of the river Rhone, which divides just north of Arles into the Grand Rhône and Petit Rhône, between which lies the Camargue; bounded to the south by the Mediterranean Sea, in the Département of Bouches-du-Rhone.

\section{Area 85,000 ha}

Degree of Protection The Réserve Nationale de Camargue on the Etang de Vaccarès $(13,117 \mathrm{ha})$ was formed in 1928; it is state owned and financed but managed by a private organisation, the Sociéte Nationale de Protection de la Nature. This reserve was accepted as a Biosphere Reserve in January 1977. The Réserve des Impériaux (2,777ha) is a departemental reserve, bought from the state in 1964 by the commune of Les Saintes-Maries-de-la-Mer. Tour du Valat (1070ha) has been a private reserve since the early 1950s, managed since 1978 by the 'Fondation Sansouire', a public service foundation under French law. The Parc Naturel Régional $(85,000 \mathrm{ha})$ which was created in 1972 to preserve the equilibrium between human activities and the natural environment, includes the above three reserves. Much of the area outside the reserves is privately owned. The whole area was listed as a Ramsar site on ratification in October 1986.

Along the coastline of the Imperiaux and Etang de Vaccarès reserves there is a hunting reserve including waters up to $2 \mathrm{~km}$ from the shore, and the perimeter of the Parc Naturel Régional includes French territorial waters up to about $22 \mathrm{~km}$ offshore. This area is not however included in the Ramsar site. There is integral protection for all native flora and fauna within the Etang de Vaccarès reserve and in two small areas adjoining it to the east. 
Site Description The site includes an extensive area of delta between the two main distributaries of the Rhóne, which is extremely flat and low-lying $(0-4.5 \mathrm{~m})$, and includes a variety of natural and man-made habitats. Much of the delta is composed of very fine alluvial deposits, although there is a remnant of former coastal dunes of marine origin, the Bois de Rièges, just to the south of the Etang de Vaccarès. The whole coastline is lined by nearly $100 \mathrm{~km}$ of sand dunes, broken only in a few places. The central part of the delta consists of a network of lagoons, the largest being the Etang de Vaccarès, which is only slightly brackish. Between these lagoons and the sea, the water is brackish, while the lagoons along the coastline are saltwater, becoming more saline than the Mediterranean itself in summer (or even drying out completely), due to high evaporation rates. In the south-east, about 10,000 ha of pans have been turned to commercial salt production. Water levels in the lagoons vary considerably throughout the year and in winter about $95 \%$ of the Réserve Nationale is flooded but in summer this falls to $60 \%$ due to high evaporation rates and low summer rainfall. The mean monthly temperature varies from $23^{\circ} \mathrm{C}$ in July to $6^{\circ} \mathrm{C}$ in January, and average annual rainfall is only $500 \mathrm{~mm}$. Most months are very windy, and for six months of the year are dominated by the Mistral, a dry wind from the north-east which increases evaporation rates considerably.

Salt pans which dry out completely are unvegetated but in other areas there is a complete range of plant successions with much of the vegetation in areas nearer the coast being salt tolerant to some degree. The dominant sand dune vegetation is marram grass Ammophila arenaria and sea medick Medicago marina. Behind these is low-lying salt steppe or 'sansouire' sparsely covered with glasswort Arthrocnemum glaucum interspersed with brackish lakes which, apart from algae, only support submerged tassel pondweed Ruppia maritima. Further inland the steppes have a denser cover of the glasswort Salicornia fruticosa, and these areas are often flooded in winter. This area is important for a variety of nesting birds including greater flamingo Phoenicopterus ruber. In the slightly saline waters of the northern part of the Etang de Vaccarès grow plants such as pondweeds Potamogeton spp., reeds Phragmites communis, bulrushes Scirpus spp. and water buttercups. On the Bois de Rièges juniper Juniperus phoenicia and Pistacia lentiscus predominate.

The upper sansouire is much dryer and has a dry grass community dominated by sea lavender Limonium spp., a false-brome grass Brachypodium phoenicoides and mock privet Phillyrea angustifolia. This is the chief area where cattle and semi-wild horses are grazed, plus sheep in winter on higher ground. Much of the land has been converted to rice-growing which involves flooding it in summer, and the area is covered with a dense network of canals. However, the habitat is of greatest importance for waterfowl as there are a number of freshwater lakes and marshes with submerged vegetation of water milfoil Myriophyllum spicatum, fennel pondweed Potamogeton pectinatus and tassel pondweed Ruppia spiralis in more brackish waters. Many of these are fringed with rushes Scirpus spp. and reeds Phragmites spp. which are important for a number of nesting birds. Along the banks of the Rhone there is a strip of luxuriant deciduous forest, frequently flooded, made up of species such as willows Salix alba, white poplar Populus alba, elm Ulmus sp., alder Alnus glutinosa and ash Fraxinus oxycarpa. Along some of the drainage canals, particularly those which follow former courses of the Rhône, are lesser strips of woodland. A number of interesting non-wetland species are also found here, including European bee-eater Merops apiaster, common roller Coracias garrulus, and great spotted cuckoo Clamator glandarius, all three of which breed and usually have a more southerly range in Europe; also breeding are penduline tit Remiz pendulinus, beaver Castor fiber and wild boar Sus scrofa.

Criteria for inclusion $1 \mathrm{a}, 1 \mathrm{~b}, 1 \mathrm{c}, 2 \mathrm{a}, 2 \mathrm{~b}, 2 \mathrm{c}$

International and National Importance The Camargue is important for thousands of wintering, breeding and migrating birds as it is on the migration route between Europe and North Africa of many species, and has a relatively mild climate due to its sotherly position. It is the only regular breeding place in Europe and North Africa for greater flamingo Phoenicopterus ruber (up to 6,000 pairs), and the only breeding place in France for several other species: gull-billed tern Gelochelidon nilotica (250-300 pairs), pratincole Glareola pratincola (150-200 pairs), cattle egret Bulbulcus ibis (100 pairs) and squacco heron Ardeola ralloides. Other nesting birds include several hundred pairs of avocet Recurvirostra avosetta, of 
which a few overwinter. At least 30 species of Anatidae occur; about 200,000 ducks overwinter including over 50,000 mallard Anas platyrhynchos (of which some also breed), gadwall A. strepera (1973 maximum: 13,500), wigeon A. penelope (1976 maximum: 26,500), pintail $A$. acuta (up to 10,000 ) and shoveler $A$. clypeata $(10,000)$. Large numbers of waterfowl pass through on autumn and spring migration, including thousands of garganey $A$. querquedula and many ringed plover Charadrius hiaticula and little ringed plover $C$. dubius. Eight species of gull occur, including thousands of pairs of breeding black-headed gull Larus ridibundus and hundreds of pairs of breeding herring gull $L$. argentatus. Ten species of tern include six which breed, particularly on islands in the lagoons. Common crane Grus grus visit occasionally in winter.

Changes in Ecological Character Changes to the natural and semi-natural environment are continuing, despite the policy to limit agricultural intensification and preserve traditional land uses. Traditional farming has become unprofitable, and alternative land uses do not of ten benefit wildlife; altering water levels has destroyed shoreline habitat and fish farming has made some pools too deep for many birds to feed in; shooting continues to be a problem and the closed season is not respected. Unexplained changes in bird numbers may be due to increases in pollution; although the waters of the Rhone do not directly enter the Camargue except through irrigation channels and the wild part of the Camargue is mainly rain-fed, some areas have high sulphate levels. Tourism is increasing and the coastal areas in particular are of concern.

Management Practices Access to the Etang de Vaccarès reserve is prohibited except by permit to persons proving membership of a scientific research or nature preservation body. The only habitations are the two wardens' lodges. Shooting, grazing and salt extraction are not allowed. In the Impériaux reserve access is generally prohibited and no hunting occurs. A few professional fishermen from Les-Saintes-Maries are allowed to fish. The 25,000ha surrounding these reserves is intended to be maintained, by agreements with landowners, as a buffer between the inner areas (which are most important for waterfowl breeding), and the peripheral agricultural lands. There is also emphasis on protecting the coastline. In the park as a whole policies include limiting the spread of commercial salt pans and rice-growing, subsidising traditional land uses such as horse and cattle open grazing, diverting drainage from agricultural lands into the Rhône rather than into the Etang de Vaccarès, controlling shooting (only allowed from 15 August till the end of February), and organising tourism so as to cause minimum damage to the environment. Special management has been necessary since a dry winter in North Africa (1977) caused many more flamingoes to winter here; farmers at first shot them, but now bird scaring devices are set off throughout the evening to discourage night feeding in the ricefields (the main conflict). The carrying capacity for breeding flamingoes has also been increased by creating artificial nesting islands from clay and mud; previously many nest-islands had suffered from erosion since the birds remove the vegetation before nesting. In the whole area covered by the park, as well as in an area to the north-west enclosed by the Canal du Rhone à Sète, four months' notification must be given to the administration of any modification to the landscape.

Scientific Research and Facilities Research has been carried out since 1954 by the Station Biologique de la Tour du Valat, at first privately, but now organised by the Centre Nationale de la Récherche Scientifique (CNRS) who have also run the Centre d'Ecologie de la Camargue since 1970. There are two main branches of research: pure analysis of the functioning of ecosystems; and applied studies, investigating the effects of human modification and comparing this with the most natural environments.

Principal Reference Material The above was taken from documents supplied by the French Government at the time of designation and the following:

- Carp, E. (1980). A Directory of Western Palearctic Wetlands. IUCN: Gland, Switzerland.

- IUCN (1984). Study and management in Camargue Nature Reserve. Parks 9(3/4):4-7.

- Weber, K. and Hoffman, L. (1970). Camargue. Kümmerley and Frey, Berne.

Supplemented by:

- Britton, R.H. and Podlejski, V.D. (1981). Inventory and classification of the Wetlands of the Camargue (France). Aquatic Botany 10:195-228.

- Hoffmann, L. (1958). An ecological sketch of the Camargue. British Birds 51:321-349. 
Area 267,667 sq. $\mathrm{km}$

Population $1,370,000(1984)$

Summary of Wetland Situation The major wetlands of Gabon are coastal, where the climate is more humid (and rainfall varies between $3500 \mathrm{~mm}$ in the north, and $1750 \mathrm{~mm}$ in the south). Inland, three main river systems drain the country, the Ogooue, the N'Gounie and the Nyanga. Various wetland habitats are found along these rivers and their tributaries, in particular swamp forest.

The Mitemboni River marks the northern boundary of the country, and is joined just before its mouth by the Noya. Tidal swamps lie along the lower stretches of both rivers. South of here the coast is sandy, and many small streams arising in the low coastal hills flow across the narrow coastal plain, giving rise to a diffuse pattern of channels which support a tidal swamp some $1.5 \mathrm{~km}$ wide. Some $17,400 \mathrm{ha}$ of mangrove forest occupy the shores of the Bay of Monda, in a wide belt that extends some $18-22 \mathrm{~km}$ inland up the estuaries of rivers such as the Ayondo. Mangrove forests also fringe the entire shoreline of the Gabon estuary, forming a $1-2 \mathrm{~km}$ belt on the northern shore, but reaching inland for up to $21 \mathrm{~km}$ on the southern shore in areas watered by tributary streams. This tidal forest covers some 45,200 ha, while the coastline between the estuary and Cape Lopez support a further $61,600 \mathrm{ha}$ of tidal forest. In this latter region (where the Wongha-Wonghe reserve is to be found) the coastal plain is also dotted with little lakes enclosed by permanent swamplands.

Most of the central and southern coast is sandy, and river mouths have been deflected northwards behind long sandspits - each of which subtends a large sheltered lagoon, the principal ones being N'Komi, Iguela, N'Dogo and M'Banio. Down this coast there is an extensive area covered by tidal and freshwater swamps, and by lakes and lagoons (varying from fresh water to salt), and large areas are regularly flooded by a combination of tides and freshwater floods. The Petit Loango and Sétte Cama reserves are both located within this part of the coast, and include two of the largest lagoons, Iguela and N'Dogo.

Protected Areas Legislation Parks and reserves are declared by the President of the Republic, after a proposal has been made by the Ministry of Agriculture, Water and Forestry and Rural Development (Ministère de l'agriculture, de l'élevage et du développement rural). The principal terms used are réserve de chasse, domaine de chasse, réserves intégrale and parc national, though according to these terms apparently not well defined in the existing legislation. One of the main acts is the decree fixing the forestry regime, and its modifying acts (notably the Deliberation 33 of 16 October 1957).

Protected Areas Administration This is now primarily the responsibility of the Department of Hunting and Fauna (Départment de chasse et de la faune) within the Ministry of Agriculture, Water and Forestry and Rural Development (Ministère de l'agriculture, de l'élevage et du développement rural). Previously faunal reserves, hunting reserves and integral reserves were controlled by this department, while national parks come under the Ministry of Tourism. Forestry is the responsibility of the Départment des eaux et forêts.

Sites designated under the Convention

Signature without reservation as to ratification 30 December 1986, with three sites listed at ratification.

Réserve nationale de Wongha-Wonghé

Parc national du Petit Loango

Réserve de Sétté Cama

Government body responsible for administration of the Convention

No information 


\section{Réserve nationale de Wongha-Wonghé}

Location $0^{\circ} 30^{\circ}-1^{\circ} 00^{\prime} \mathrm{S}, 9^{\circ} 10-9^{\circ} 40^{\circ} \mathrm{E}$. In the coastal region of Gabon, between Libreville and Port Gentil, $99 \mathrm{~km}$ south of the equator.

\section{Area 380,000 ha}

Degree of Protection The area was designated a National Park 30 March 1967 by Order No. 362/MEF/DEF/CHPP (confirmed by Decree No. 172/PR/MEF title 1, article 5 of 13 April 1971). Earlier, Order No. 1488/SF-5225 of 17 November 1962 set up the Domaines de chasse of Wonga-Wongué (25,000ha), Grand Bam-Bam (20,000ha) and Petit Bam-Bam (35,000ha), and Decree No. 7329 of July 1966, and a provisional order of 30 November 1966 also dealt with protection of the area. The flora and fauna are totally protected, and cultivation prohibited. Access within the reserve is strictly limited to those invited by the president.

Site Description Much of the area is flat, comprising parts of the plains, gently rolling hills and plateaux of the coastal plain. Soils are principally pramitic and ferralitic. With the Atlantic coast to the west, the site is bounded by the Aouagne and Pambo-Nyango rivers to the north, by Lake Azingo to the south-east, and by the Gongoué, Oranga, Wanga, Bembelié and Mpogoué rivers, and the Inyongo and Nguéliee lakes to the south. A number of small coastal rivers cross the area, some giving rise to erosion features such as the amphitheatre of the Cirque du Grand Bam-Bam. The coastline is flat and straight. Average temperature is $26^{\circ} \mathrm{C}$, and annual rainfall varies between $2000 \mathrm{~mm}$ and $2200 \mathrm{~mm}$, with two dry seasons each year. During the longer dry season (June - September) there is almost continuous cloud cover. The vegetation varies from humid tropical forest to stunted woodland savanna, covered in grass species during the rains, with thickets of stunted Aucoumea klaineana and other ligneous species.

International and National Importance The two most notable mammal species in the park are the chimpanzee Pan troglodytes, and the western race of the gorilla Gorilla gorilla gorilla, both threatened species. Elephant Loxodonta africana also occur. Birds include white pelican Pelecanus onocrotalus.

Changes in Ecological Character Intensive poaching has been reported in the past, though poaching control instigated by the present guide de chasse is apparently very effective. Forestry exploitation has occured within the reserve. There have been a number of introductions of exotic species to the area, including Burchell's zebra Equus burchelli, black-tailed gnu Connochaetus taurinus, peccary Tayassu sp., wild boar Sus scrofa, and pony Equus caballus. All but the zebra have established themselves within the park.

Management Practices There were three basic sections within the area now covered by the parc national, but there is now no zoning. The area is essentially managed as a Presidential reserve, where hunting parties are organized for guests of the president. Access is therefore strictly limited (and only really possible by light aircraft from outside the area). Anti-poaching activity is undertaken.

\section{Scientific Research and Facilities Virtually none}

Principal Reference Material As this account was prepared only shortly after ratification of the convention by Gabon it has not been possible to prepare a full text. The material presented here has been adapted from the IUCN Directory of Afrotropical Protected Areas (IUCN/UNEP, 1987). Major references are:

- Nicoll, M and Langrand, O. (1986). The Conservation of Forest Ecosystems in Gabon. IUCN/WWF Project 3247, Systems review of protected areas in Gabon.

- Tutin, C. and Fernandez, M. (1983). Recensement des Gorilles et des Chimpanzés du Gabon. CIRMF, Gabon. 


\section{Parc national du Petit Loango and Réserve de Sétté Cama}

Location $2^{\circ} 15^{\prime} \mathrm{S}, 9^{\circ} 56^{\prime} \mathrm{E}$. Coastal zone of south-west Gabon to the north and south of the lagoon behind Sétté Cama and Gamba.

Area Total area of 700,000 ha. The Petit Loango Ramsar site consists of the Réserve de faune d'Iguela Petit Loanda of $(80,000 \mathrm{ha})$, the Domaine de chasse d'Iguela (150,000ha), and the Domaine de chasse Ngoué-Ndogo $(250,000 \mathrm{ha})$. The Sétté Cama Ramsar site consists of the Réserve de faune de la plaine d'Ouanga $(20,000 \mathrm{ha})$, and the Domaine de chasse de Sétté-Cama $(200,000 \mathrm{ha})$

Degree of Protection Decree No. 1571 of 29 December 1966 includes the domaine de chasse de Iguéla, the réserve de faune du Petit-Louango, the domaine de chasse de Nbove-Ndogo, and the domaine de chasse de Sétté-Cama. Protection of the whole 'Aire d'exploitation rationelle de faune de Sétté-Cama' dates from Arrête 1487/SF-5225 of 17 November 1962.

Site Description The reserve is a weakly undulating, sandy plain, penetrated by an extensive lagoon and several lakes. The small rivers that cross the area mainly spring from the low Mayombe hills to the east of the reserve. The soils are largely a mosaic of hydromorphic clay-sand and sand-clay mixtures. Average temperature is $26^{\circ} \mathrm{C}$, and rainfall varies between $2200 \mathrm{~mm}$ and $2400 \mathrm{~mm}$. There are two dry seasons, though during the long dry season (July September) there is persistent cloud cover. The vegetation consists largely of open savanna with thickets along the littoral zone, but with rain forest covering the majority of the reserve. Most of the forest was exploited some 20 years ago. Several of the forest areas are subject to regular flooding.

International and National Importance There are large populations of elephant Loxodonta africana, and the reserve is reported to be particularly important for the African manatee Trichechus senegalensis. Chimpanzee Pan troglodytes, gorilla Gorilla gorilla gorilla and leopard Panthera pardus also occur.

Changes in Ecological Character There is oil exploration in the region, despite the fact that this is illegal, and this is causing a number of problems. There are guides de chasse in both the Iguela and Sétte-Cama areas, but otherwise there is no organized protection. There are no representatives of the Ministère des eaux et forets at Gamba, the only town within the reserve.

Management Practices There is a permanent presence in both the Sétté-Cama and Iguela areas, but otherwise management and protection would appear to be minimal. Several recommendations on management are made by Nicoll and Langrand (1986). Although the area is remote, several safaris are organized each year for foreign non-resident clients.

\section{Scientific Research and Facilities Virtually none}

Principal Reference Material As this account was prepared only shortly after ratification of the convention by Gabon it has not been possible to prepare a full text. The material presented here has been adapted from the IUCN Directory of Afrotropical Protected Areas (IUCN/UNEP, 1987). Major references are:

- Nicoll, M and Langrand, O. (1986). The Conservation of Forest Ecosystems in Gabon. IUCN/WWF Project 3247, Systems review of protected areas in Gabon.

- Tutin, C. and Fernandez, M. (1983). Recensement des Gorilles et des Chimpanzés du Gabon. CIRMF, Gabon. 


\section{GERMAN DEMOCRATIC REPUBLIC}

Area $107,860 \mathrm{sq} . \mathrm{km}$

\section{Population $16,701,500(1985)$}

Summary of Wetland Situation The Baltic coast from the Wismarbucht to Stralsund and the island of Rügen is of great importance to breeding, migrating and wintering waterfowl. Apart from the Wismarbucht itself, the areas of special interest are the peninsula and islands of Dierhagen, Darss and Zingst, the bays of Saaler Bodden and Der Grabow which they enclose, the vicinity of Stralsund, and the waters around Rügen and Hiddensee islands, including parts of the Greifswalder Bodden to the south-east.

Inland, the many lake complexes in the Schwerin and Neubrandenburg districts have suitable breeding conditions for Anatidae, and also support considerable autumn and winter concentrations of white-fronted goose Anser albifrons and bean goose A. fabalis. Other outstanding wetlands in these districts include the Müritz-See, Lewitz Fishponds, the Krakower Obersee and Plauer See, Tollense See and the Galenbecker See.

The long and complex waterway of the Havel River and Lakes in the Potsdam district are important for wintering ducks, and are frequented by flocks of geese in autumn and later winter. On the western border of the district one of the main research centres of the Zentrale für Wasservogelforschung is the Niederung der Unteren Havel including Gülper See. To the east of Berlin the two most valuable wetlands of the Frankfurt district are the Untere Odertal and Odervorland, both of which have some excellent breeding habitat for waterfowl and provide wintering grounds for geese.

Of the more southerly districts, Halle is of importance for wintering geese and for mallard Anas platyrhynchos. The margins of the Berga-Kelbra reservoir, to the south of the Harz mountains, offer some suitable habitats for migrating waders. In the neighbouring Leipzig district, Wildenhainer Bruch and Zadlitzbruch support breeding populations of several species. Still further to the north-east, in the Cottbus district, the ponds known as the Peitzer Teiche are reported to be much used as staging posts by migrating waders.

Many of the inland wetlands of the German Democratic Republic are of economic importance for fish-culture. The consequent increased eutrophication of such sites and its ecological effects are currently under study.

Protected Areas Legislation Conservation receives legal backing from the Constitution (1968), the State Culture Law (1970) and the Environmental Policy Act (1970). Three types of protected area are defined, natural protected areas (or nature reserves), natural landmarks, and landscape protection areas.

Protected Areas Administration Two ministries in the German Democratic Republic cover environmental issues, the Ministry for Agriculture, Forests and Food (which was established in 1965), and the Ministry of Environmental Protection and Water Management. The Centre for Protection and Improvement of Environment comes under the second of these ministries.

\section{Sites designated under the Convention}

Accession 31 July 1978 with 8 sites listed at accession

Baltic Sea lagoon waters of Rügen/Hiddensee and eastern part of Zingst Peninsula Krakower Obersee

Eastern Shore of Müritz See

Lower Havel River and Gülper See

Oder Valley near Schwedt 
Pond areas near Peitz

Berga-Kelbra Storage Lake

Galenbecker See

Government body responsible for administration of the Convention

Ministerium für Land-, Forst- und Nahrungsgüterwirtschaft, Köpernicker Allee 39-57, Berlin, DDR-1157.

\section{Baltic sea lagoon waters of Rügen/Hiddensee and eastern part of Zingst Peninsula}

Location $54^{\circ} 23^{\prime}-54^{\circ} 36^{\prime} \mathrm{N}, 12^{\circ} 54^{\prime}-13^{\circ} 16^{\prime} \mathrm{E}$. Situated on the Baltic Sea, north of Stralsund in the District of Rostock.

Area $25,800 \mathrm{ha}$

Degree of Protection Some parts of the area, totalling 3,491 ha, are nature reserves. Designated as a Ramsar site on 31 July 1978.

Site Description The site comprises an area of the Baltic Sea between the islands of Rügen and Hiddensee, the western part of Rügen and the whole of Hiddensee and the Isle of Ummanz; also, the sea between the west coast of Hiddensee ( $4 \mathrm{~km}$ north of Neuendorf) and the Zingst Peninsula near Pramort including Wadden See, with the islands of Bock and Grosser Werder. The southern boundary follows the mainland coast from Kinnbackenhagen to the Parower Haken (near Prohn) and the southern coast of the Kubitzer Bodden.

International and National Importance The site is of great importance for breeding, migrating and wintering waterfowl. Wintering species include mallard Anas platyrhynchos, tufted duck Aythya fuligula, scaup A. marila, long-tailed duck Clangula hyemalis, goldeneye Bucephala clangula, sawbill Mergus serrator, coot Fulica atra, mute swan Cygnus olor and whooper swan C. cygnus.

Changes in Ecological Character None reported (up to end of 1986).

Management Practices A management plan entered into force in 1985.

Scientific Research and Facilities There is a bird observatory and ringing station at Hiddensee. A new biological station is planned.

Principal Reference Material The above information is taken from documents supplied by the Government of the German Democratic Republic for designation in 1978 and for the Cagliari Conference in November 1980.

Supplemented by:

- Carp, E. (1980). A Directory of Western Palearctic Wetlands. IUCN, Gland, Switzerland.

- Rutschke, E. (1982). Die Feuchtgebiete von internationaler und nationaler Bedeutung in der DDR. Beitr. Vogelkd. 28: 2-15.

- Weinitschke, H. (Ed.) (1980). Handbuch der Naturschutzgebiete der Deutsche

Demokratischen Republik. Leipzig-Jena-Berlin, Vol.1. 


\section{Krakower Obersee}

Location $53^{\circ} 37^{\prime} \mathrm{N}, 12^{\circ} 18^{\prime} \mathrm{E}$. Situated south-east of the town of Krakow in the District of Schwerin.

\section{Area 870ha}

Degree of Protection The site is a nature reserve. Designated as a Ramsar site on 31 July 1978.

Site Description The site comprises the entire southern part of Krakower Lake (south of the Krakow-Linstow road) including the shoreline.

International and National Importance The site is of importance for breeding, moulting and migrating waterfowl, especially Anatidae. Breeding species include goldeneye Bucephala clangula, tufted duck Aythya fuligula, red-crested pochard Nella rufina, gadwall Anas strepera, garganey $A$. querquedula, bittern Botaurus stellaris, redshank Tringa totanus and common tern Sterna hirundo. The main species which stopover on migration are tufted duck (which also use the area as a moulting refuge), goosander Mergus merganser, Bewick's swan Cygnus columbianus bewickii and various geese Anser spp.

\section{Changes in Ecological Character Increased eutrophication}

Management Practices A management plan came into force in 1983.

Scientific Research and Facilities Studies have been made of population dynamics of gadwall and common tern, including ecological parameters for breeding populations.

Principal Reference Material The above information is taken from documents supplied by the Government of the German Democratic Republic for designation in 1978 and for the Cagliari Conference in November 1980.

Supplemented by:

- Carp, E. (1980). A Directory of Western Palearctic Wetlands. IUCN, Gland, Switzerland.

- Neubauer, W. (1982). Wasservogelschutz, Landwirtschaft, Fischerei und Erholungswesen im NSG Krakower Obersee (Feuchtgebiet von internationaler Bedeutung). Beitr.Vogelkd. 28: $35-40$.

- Rutschke, E. (1982). Feuchtgebiete von internationaler und nationaler Bedeutung in der DDR. Beitr. Vogelkd. 28: 2-15

\section{Eastern shore of Müritz See}

Location $53^{\circ} 27^{\prime} \mathrm{N}, 12^{\circ} 49^{\prime} \mathrm{E}$. Situated immediately south of the town of Waren in the District of Neubrandenburg.

Area 4,830 ha

Degree of Protection The site is a nature reserve. Designated as a Ramsar site on 31 July 1978.

Site Description The site comprises a water area about $800 \mathrm{~m}$ wide on the north-east shore of Lake Müritz and the adjacent strip of land, $2.5 \mathrm{~km}$ wide (at Feisneck Lake) to $4 \mathrm{~km}$ wide (at Speck) and includes a number of small lakes. Müritz See is the largest inland lake in northern Germany and occupies a glacial basin in ground moraine deposited during the Weichsel Period. It is a eutrophic lake with maximum depth $20 \mathrm{~m}$.

International and National Importance The site is very important for many species of breeding and migrating waterfowl including crane Grus grus. 
Changes in Ecological Character Eutrophication in Lake Müritz is increasing due to sewage effluent.

Management Practices A new management plan is being prepared.

Scientific Research and Facilities Research on crane migration has been carried out by several biological stations in the vicinity.

Principal Reference Material The above information is taken from documents supplied by the Government of the German Democratic Republic for designation in 1978 and for the Cagliari Conference in November 1980.

Supplemented by:

- Carp, E. (1980). A Directory of Western Palearctic Wetlands. IUCN, Gland, Switzerland.

- Rutschke, E. (1982). Die Feuchtgebiete von internationaler und nationaler Bedeutung in der DDR. Beitr. Vogelkd. 28: 2-15.

- Weinitschke, H. (Ed.) (1980). Handbuch der Naturschulzgebiete der Deutschen Demokratischen Republik. Leipzig-Jena-Berlin, Vol.1.

\section{Lower Havel River and Gülper See}

Location $52^{\circ} 39^{\prime}-52^{\circ} 49^{\prime} \mathrm{N}, 12^{\circ} 04^{\prime}-12^{\circ} 20^{\prime} \mathrm{E}$. Situated between Rathenow in the district of Potsdam, and Havelberg in the district of Magdeburg.

\section{Area $5,792 \mathrm{ha}$}

Degree of Protection Two parts of the site are a nature reserve. Designated as a Ramsar site on 31 July 1978.

Site Description The site includes a lake, the Gülpersee, and part of the Lower Havel River. Boundaries are marked by dykes along the valley edges between Hohennauen, Parey, Guelpe, Strodehne and Vehlgast on the right bank and Rehberg, Warnau, Kuhlhausen and Jederitz on the left bank. The Gülpersee is a eutrophic, shallow lake through which the Rhin river flows.

International and National Importance The area is important for breeding waders, greylag goose Anser anser, several duck species and rails. The site is one of the largest inland stopover places for geese Anser spp., dabbling ducks, whooper swan Cygnus cygnus and crane Grus grus.

Changes in Ecological Character Lake Gülpe had become eutrophic by 1980.

Management Practices Measures to prevent further eutrophication of Lake Gülpe were carried out from 1980-1983. A management plan is being prepared.

Scientific Research and Facilities Research on population dynamics and ecology of geese Anser spp. and the social structure and behaviour of the greylag goose Anser anser has been carried out, as well as ecological studies of birds other than waterfowl and other animals. There is a scientific station of the Zentrale für die Wasservogelforschung der DDR and the Teachers Training College at Potsdam.

Principal Reference Material The above information is taken from documents supplied by the Government of the German Democratic Republic for designation in 1978 and for the Cagliari Conference in November 1980.

Supplemented by:

- Rutschke, E. (1981). Report from the German Democratic Republic, Debrecen. IWRB Bulletin 47: 41-42.

- Rutschke, E. (1982). Die Feuchtgebiete von internationaler und nationaler Bedeutung in der DDR. Beitr. Vogelkd. 28: 2-15. 


\section{German Democratic Republic}

- Rutschke, E. and Kalbe, L. (1978). Das Gewässergebiet Untere Havel - ein Wasservogelreservat von internationaler Bedeutung. Arch. Naturschutz $u$. Landschaftsforsch. Berlin 18: 1-18.

- Weinitschke, H. (Ed.) (1982). Handbuch der Naturschutzgebiete der Deutschen Demokratischen Republik. Leipzig-Jena-Berlin. Vol.2.

\section{Oder Valley near Schwedt}

Location $53^{\circ} 39^{\prime}-53^{\circ} 10^{\prime} \mathrm{N}, 14^{\circ} 20^{\prime} \mathrm{E}$. Situated near the town of Schwedt in the Frankfurt/Oder District.

\section{Area $5,400 \mathrm{ha}$}

Degree of Protection Part of the site (400ha) is a nature reserve. Designated as a Ramsar site on 31 July 1978.

Site Description The site comprises the Oder valley between the Oder River and the canal known as the 'Hohensaaten-Friedrichsthaler Wasserstrasse' from the village of Stützkow in the south to the village of Friedrichsthal in the north. There are two polders including numerous permanent pools and creeks and agricultural areas, seasonally influenced by floods in winter and spring.

International and National Importance The site is important for breeding ducks including garganey Anas querquedula, shoveler A. clypeata and mallard A. platyrhynchos, and rails and waders, depending on the water level. It is also an important stopover for dabbling ducks, especially shoveler, pintail $A$. acuta, wigeon $A$. penelope, sawbill Mergus serrator, whooper swan Cygnus cygnus, and various geese Anser spp. and waders.

Changes in Ecological Character None reported (up to the end of 1986)

Management Practices A management plan entered into force in 1980.

\section{Scientific Research and Facilities No information}

Principal Reference Material The above information is taken from documents supplied by the Government of the German Democratic Republic for designation in 1978 and for the Cagliari Conference in November 1980.

- Dittberner, H.a.W. (1975). Die ornithologische Bedeutung der Oderauer bei Swedt (Bez. Frankfurt/O.). Naturschutzarb. Berlin Brandenburg 11: 45-47.

- Rutscke, E. (1982). Die Feuchtgebiete von internationaler und nationaler Bedeutung in der Deutschen Demokratischen Republik. Beitr. Vogelkd. 28: 2-15.

\section{Pond areas near Peitz}

Location $51^{\circ} 51^{\prime} \mathrm{N}, 14^{\circ} 25^{\prime} \mathrm{E}$. Situated to the north of the town of Cottbus in the District of Cottbus.

Area 1,060 ha

Degree of Protection Designated as a Ramsar site on July 1978.

Site Description The site contains a number of fish ponds. The eastern boundary is the railway between Cottbus and Wilhelm-Pieck-Stadt-Guben (from Neuendorf to Peitz-Ost station). The northern boundary follows approximately the course of the Hammerstrom to the village of Maiberg. The western boundary is along the road between Peitz and Cottbus, and the southern boundary roughly follows a line between the villages of Maüst and Neuendorf. 
International and National Importance The site is very important for breeding ducks. In autumn and spring it is a stopover site for many waterfowl and waders.

Changes in Ecological Character None reported (until the end of 1986).

Management Practices A management plan came into force in 1984. The fish ponds are being restored.

Scientific Research and Facilities Ecological studies on breeding size of pochard Aythya ferina and other ducks have been made, and the nutrition of swans and waders investigated.

Principal Reference Material The above information is taken from documents supplied by the Government of the German Democratic Republic for designation in 1978 and for the Cagliari Conference in November 1980.

Supplemented by:

- Rutschke, E. (1981). Report from the German Democratic Republic, Debrecen. IWRB Bulletin 47: 41-42.

- Rutschke, E. (1981). Die Feuchtgebiete von internationaler und nationaler Bedeutung in der DDR. Beitr. Vogelkd. 28: 2-15.

\section{Berga-Kelbra Storage Lake}

Location $51^{\circ} 27^{\prime} \mathrm{N}, 10^{\circ} 56^{\prime} \mathrm{E}$. Situated between the towns of Nordhausen in the district of Erfurt and Sangerhausen in the district of Halle.

Area $1,360 \mathrm{ha}$

Degree of Protection Designated as a Ramsar site in 31 July 1978.

Site Description The site comprises a shallow flood protection reservoir at the foot of the western slope of the Kyffhäuser Range, bounded by the villages of Berga, Kelbra and Auleben.

International and National Importance The site is the largest water area in the Thuringian Plain. Its importance as a stopover for large numbers of migrating waterfowl and waders has steadily increased in the last ten years.

Changes in Ecological Character None reported (up to 1986)

Management Practices A management plan entered into force in 1985.

Scientific Research and Facilities Studies have been made of the dependence of waterfowl populations on several ecological factors. There is an ornithological observation station.

Principal Reference Material The above information is taken from documents supplied by the Government of the German Democratic Republic for designation in 1978 and for the Cagliari Conference in November 1980.

Supplemented by:

- Görner, M. et al. (1983). Das Feuchtgebiet von internationaler Bedeutung 'Stausee Berga-Kelbra' und seine Vogelwelt. Landschafts-pflege Naturschutz Thuer. Jena 20: 30-54.

- Rutschke, E. (1982). Die Feuchtgebiete von internationaler und nationaler Bedeutung in der DDR. Beitr. Vogelkd. 28: 2-15. 
German Democratic Republic

\section{Galenbecker See}

Location $53^{\circ} 38^{\prime} \mathrm{N}, 13^{\circ} 44^{\prime} \mathrm{E}$. Situated north-east of the town of Neubrandenburg in the district of Neubrandenburg.

Area 1,015ha

Degree of Protection The area is a nature reserve. Designated as a Ramsar site on 31 July 1978.

Site Description Galenbecker See lies south-west of Friedlaender marsh and is bounded by the villages of Kotelow, Galenbeck and Heinrichswalde. The lake waters are shallow (mean depth $1 \mathrm{~m}$ ) and eutrophic and the lake is being filled by natural succession. It contains carp Cyprinus carpio.

International and National Importance The nature reserve is an outstanding bird sanctuary noted for its breeding populations of gadwall Anas strepera and rails, and as a stopover area for migrants.

Changes in Ecological Character Natural succession is leading to changes in biotic communities and there has been increased eutrophication since 1982.

Management Practices A new management plan was being prepared in 1986.

Scientific Research and Facilities Ornithological, limnological and vegetation studies are continuing. There are bird observation facilities, and a nature reserve station.

Principal Reference Material The above information is taken from documents supplied by the Government of the German Democratic Republic for designation in 1978 and for the Cagliari Conference in November 1980.

Supplemented by:

- Carp, E. (1980). A Directory of Western Palearctic Wetlands. IUCN, Gland, Switzerland.

- Rutschke, E. (1982). Die Feuchtgebiete von internationaler und nationaler Bedeutung in der DDR. Beitr. Vogelkd. 28: 2-15.

- Weinitschke, H. (Ed). (1980). Handbuch der Naturschutzgebiete der Deutschen Demokratischen Republik. Leipzig-Jena-Berlin, Vol.1 


\section{FEDERAL REPUBLIC OF GERMANY}

\section{Area 248,528 sq.km}

Population $61,420,700(1983)$

Summary of Wetland Situation More than 30 wetlands in the Federal Republic have been identified as being of international importance as waterfowl habitat to be found in FRG, and a number of these sites are of great interest. This is particularly so in the northern part of the country along the shores of the North Sea and the Baltic, which are on the main migration route of waterfowl wintering in the Netherlands, Great Britain, Ireland. The Waddensea (Wattenmeer), which West Germany shares with the Netherlands and Denmark, is the biggest and probably the single most important wetland for migrating waterfowl in western Europe. In the FRG sector, fairly extensive areas have been set aside as nature reserves, including some small islands and parts of some larger ones. Parts of the area are now protected withiin two Wattenmeer national parks.

Along the lower course of the Elbe River (Niederelbe) several sites are of value to migrating and roosting Bewick's swans, barnacle geese and white-fronted geese which, in mild wint?rs, of ten prolong their stay. These sites are greatly threatened by industrial development which is tending to spread along the river downstream from Hamburg.

Several sites in the north are important for waterfowl moulting. The best known is Knechtsand, where tens of thousands of Shelduck concentrate in August. The Selenter See on the Ostholsteinische Seenplatte is a traditional moulting area for tufted duck and great-crested grebe. The Dümmer and Diepholzer Moorniederung, although greatly modified by peat digging and farming, are of considerable geological interest and still offer suitable nesting and feeding sites for waders and waterfowl. The Rieselfelder (sewage farms) near Munster attract large numbers of migrant waders, while the reservoirs on the rivers Rhur and Mohne provide winter quarters for diving ducks and coots. The Rhine Valley as a whole has favourable conditions in winter and spring for wintering and migrating waterfowl; flocks of bean geese frequent areas near the border with the Netherlands and, in its upper reaches from Kehl south to Lörrach, great numbers of duck can be found wintering.

The Bodensee is not only of great limnological interest but also attracts huge numbers of wintering waterfowl, since it only partly freezes over in winter when up to 200,000 ducks alone can be present. The lake is also used extensively by moulting pochard and red-crested pochard. Another important wintering and moulting area for waterfowl is the Ismaninger Reservoir just north-east of München. All the reservoirs along the Inn valley and the lakes to the east and south of München, to the border with Austria, attract increasing numbers of breeding and wintering waterfowl.

A few other sites calling for special mention because of their combination of geological, botanical and waterfowl interest are NSG Heiliges Meer (Nordrhein-Westphalen), Mohrweiher am Moorhof (Bayern) and the Wurzacher Ried and Federsee (Baden-Würtemberg). Finally, the Donauauen and Donaustauseen (Bayern and Baden-Würtemberg), comprising the complex of Danubian reservoirs, provide many ducks, grebes and other waterfowl with suitable feeding grounds in winter.

Protected Areas Legislation All categories of protected areas and the procedure of setting them up are defined in the nature conservation legislation, but this is applied at state (Länder), not federal level. The eleven German Federal States are individually vested with responsibility for nature conservation under the constitution. However, under the general provisions of conservation law, despite differences in detail, there are five main types of protected areas: Nature Reserves, National Parks, Natural Monuments/Sites, Protected Landscapes, and Nature 
Parks. Creation of reserves under the Nature Conservation Laws does not exclude hunting, and separate declaration of controlled hunting areas or non-hunting areas must be made under the Hunting Laws. The authority responsible for the establishment or cancellation of reserves differs from state to state.

Protected Areas Administration Nearly all nature reserves are established on private land and in most some form of land use continues. Relatively few of the sites (mostly bird reserves) have staff specifically employed for nature conservation purposes. Expenses tend to be paid from a general budget. There is no one body entirely responsible for protected areas. At the state level a ministry is responsible for adminstration of nature conservation, with a scientific and technical agency. Administration and management of nature reserves also has an important place in the work of the "councils for nature conservation and landscape management" which work at local, regional and state administrative levels, advising the governments concerned. The Federal Institute for Vegetation Research, Nature Conservation and Landscape Management with its Department of Nature Conservation is responsible for research, and provision of advice to federal bodies. Councils for Nature Conservation are established as consultative bodies at all four national adminstrative levels, federal, state, region and country. A number of private conservation organisations also own nature reserves, or parts of nature reserves, or have taken over management or wardening of reserves (especially bird reserves).

\title{
Sites designated under the Convention
}

Signature subject to ratification 28 November 1974 with Ratification on 26 February 1976.17 sites listed at ratification with a further 3 sites added 28 October 1983

\author{
Niedersachsen \\ Wattenmeer, Elbe-Weser-Dreieck \\ Wattenmeer, Jabebusen and Westlich Weser Mundung \\ Ostfriesisches Wattenmeer and Dollart \\ Lower Elbe, Barnkrug-Otterndorf \\ Elbe water-meadows between Schnackenburg and Lauenburg \\ - Elbe water-meadow near Schnacken-burg \\ - Seege Lowland with Lake of Laasche \\ - Elbe water-meadow near Damnatz \\ - Elbe water-meadow near Hitzacker \\ - Elbe water-meadow from Katemin to Vielher Berge \\ - Elbe water-meadow between Alt Garge and Lauenburg \\ Dümmersee \\ Diepholzer Lowland Marsh and Peat Bogs \\ - Geest Marsh \\ - Neustadt Marsh, Great Renzel Marsh, Hespeloh Marsh, Great Marsh near Uchte \\ Steinhuder Meer
}

Hessen and Rheinland-Pfalz

Rhine zwischen Eltville und Bingen

Baden-Württemberg

Bodensee

- Wollmatingen reed-bed with north-eastern part of Ermatingen Basin

- Giehren with Bay of Hegne on the Gnadensee

- Mindelsee near Radolfzell

\section{Bayern}

Donauauen und Donaumoos

- Peat-bog of Danube (western part)

- Peat-bog of Danube (eastern part)

- Water-meadow of Danube 
Lech-Danube Winkel

- Reservoir of Feldheim on the Lech

- Reservoir of Bertoldsheim on the Danube

Ismaninger Speichersee mit fischteichen

Ammersee

Starnberger See

Chiemsee

Unterer Inn zwischen Haiming und Neuhaus

Nordrhein-Westfalen

Rieselfelder Münster

Weserstaustufe Schlüsselburg

Unterer Niederrhein

Government body responsible for administration of the Convention

Bundesministerium fÜr Naturschutz und Reaktorsicherheit, Abteilung Naturschutz, Umwelt und Gesundheit, Postfach 1206 29, D-5300 Bonn 1.

Wattenmeer, Elbe-Weser-Dreieck

Location $53^{\circ} 50^{\prime} \mathrm{N}, 8^{\circ} 25^{\prime} \mathrm{E}$. Situated on the North Sea coast between the estuaries of the Weser and Elbe rivers in the Federal State of Niedersachsen.

Area $38,460 \mathrm{ha}$

Degree of Protection The site includes the Knechtsand-Eversand Nature Conservation Area $(30,200 \mathrm{ha})$. Designated as a Ramsar site in November 1974 with ratification after February 1976.

Site Description The site comprises a coastal area with extensive mudflats and salt marshes. Fauna includes mussels, crabs and numerous fish species.

Criteria for inclusion 1(a), 1(b) and 2(c)

International and National Importance The site is part of the Waddensee and is therefore part of the most important habitat for waterfowl in the Federal Republic of Germany. Passage and wintering waterfowl include 80,000-100,000 moulting shelduck Tadorna tadorna (majority of the European population), eider duck Somateria mollissima (average maximum 20,000), 14,000 oystercatcher Haematopus ostralegus (passage), 10,000-16,000 grey plover Pluvialis squatarola (passage), 50,000 knot Calidris canutus (passage), 1,000 sanderling C. alba (passage), 60,000 dunlin C. alpina (passage) and 10,000-30,000 bar-tailed godwit Limosa lapponica (passage). Breeding species include cormorant Phalacrocorax carbo sinensis (60 pairs), sandwich tern Sterna sandvicensis (maximum 1,000 pairs) and common tern Sterna hirundo (390-470 pairs).

Changes in Ecological Character Since designation, the site area has increased from $33,600 \mathrm{ha}$. This has involved some loss of designated area, but also inclusion of new areas. $\mathrm{Knech}$ tsand Island is being slowly eroded by the sea.

Management Practices Hunting is strictly controlled.

Scientific Research and Facilities Zoological, botanical, ecological, geographical, geological and hygrographical studies are being carried out by various institutes and universities.

Principal Reference Material The above information is taken from documents supplied by the Government of the Federal Republic of Germany for designation in 1978, and for the Cagliari Conference in November 1980. 
Supplemented by:

- Carp, E. (1980). A Directory of Western Palearctic Wetlands. IUCN, Gland, Switzerland.

- Scott, D.A. (1980). A preliminary inventory of wetlands of international importance for waterfowl in west Europe and northwest Africa. IWRB Special Publication No. 2.

Additional references:

- Haarmann, K. (1978). Erster Bericht über den Zustand der Feuchtgebiete internationaler Bedeutung in der Bundesrepublik Deutschland. Biol. Abh. Nr. 36, 28 pages.

- Haarmann, K. and Pretscher, P. (1976). Die Feuchtgebiete inernationaler Bedeutung in der Bundesrepublik Deutschland. Vogelkdl. Bibliothek Band 4, Greven: Kilda-Verlag, 102 pages.

- Haarmann, K. (1984). Feuchtgebiete internationaler Bedeutung und Europareservate in der Bundesrepublik Deutschland. Zweiter Zustandbericht (Stand: Januar 1983). Ottendorf: Niederelbe-Verlag, 12 pages. (Fordsand Buch No. 3.)

\section{Wattenmeer, Jadebusen und Westliche Weser Mundung}

Location $53^{\circ} 30^{\prime} \mathrm{N}, 8^{\circ} 10^{\prime} \mathrm{E}$. Situated on the North Sea coast between the ports of Bremerhaven and Wilhelmshaven in the Federal State of Niedersachsen.

Area 49,490 ha

Degree of Protection The site includes three Nature Conservation Areas: Jadebusen (16,600ha), Mellum (3,500ha) and Süderkleihörne (15.8ha) and a Game Protection Area (GPA): Jadebusen $(2,000 \mathrm{ha})$. The GPA has been extended and there is a new Landscape Protection Area for breeding birds. Designated as a Ramsar site in November 1974 with ratification after February 1976.

Site Description Jadebusen is a large sea bay southeast of the port of Wilhelmshaven. There is little water movement in the bay and much silt is therefore deposited causing gradual reduction in the area of open water and increasing the exterit of sand and mudflats. The remainder of the designated site comprises sand and mudflats, and the island of Mellum ( $35 \mathrm{ha}$ ). The island has three zones: a dune complex in the north (near where sand is rapidly accreting by a sea wall) with sand couch Agropyron junceiforme and lyme grass Elymus arenarius; the central area with seablite Suaeda spp; and the southern area of saltmarsh/grassland with sandwort Minuartia spp. and saltwort Salsola kali, and an increasing area of cord grass Spartina townsendii.

Criteria for inclusion 1(a), 1(b) and 2(c)

International and National Importance The site is part of the Waddensee and is therefore part of the most important habitat for waterfowl in the Federal Republic of Germany. Passage waterfowl include 2,000-3,000 pink-footed goose Anser brachyrhynchus, 3,000-3,500 Brent goose Branta bernicla, up to 14,000 shelduck Tadorna tadorna, 18,000 oystercatcher Haematopus ostralegus, 1,000-3,000 avocet Recurvirostra avosetta, 2,000 grey plover Pluvialis squatarola, 10,000-15,000 knot Calidris canutus, 1,000-8,000 sanderling $C$. alba, 20,000-50,000 dunlin $C$. alpina, 6,000 curlew Numenius arquata, 700 ringed plover Charadrius hiaticula, 1,500 bar-tailed godwit Limosa lapponica and 1,500 redshank Tringa totanus. Breeding species include avocet (60 pairs) and herring gull Larus argentatus (3,500 pairs).

Changes in Ecological Character Since designation, the site area has increased from $45,560 \mathrm{ha}$. This has involved some loss of designated area, but also inclusion of new areas. There is some industrial pollution from Wilhelmshaven.

Management Practices Shooting of waterfowl is limited or prohibited in the Game Protection Area. There is a summer bird warden. 
Scientific Research and Facilities Zoological, botanical, ecological, geographical, geological and hygrographical studies are being carried out by various institutes and universities, some of which have field stations in the area.

Principal Reference Material The above information is taken from documents supplied by the Government of the Ferderal Republic of Germany for designation in 1978, and for the Cagliari Conference in November 1980.

Supplemented by:

- Carp, E. (1980). A Directory of Western Palearctic Wetlands. IUCN, Gland, Switzerland.

- Duffey, E. (1982). National Parks and Reserves of Western Europe. Macdonald and Co., London.

- Scott, D.A. (1980). A preliminary inventory of wetlands of international importance for waterfowl in west Europe and northwest Africa. IWRB Special Publication No. 2.

Additional references:

- Bloem, D. and Steffen, L. (1977). Vogelschutz am Jadebusen. Orn. AG Oldenburg Jahresbericht 1977: 20-22.

- Haarmann, K. (1978). Erster Bericht über den Zustand der Feuchtgebiete internationaler Bedeutung in der Bundesrepublik Deutschland. Biol. Abh. Nr. 36, 28 pages.

- Haarmann, K. and Pretscher, P. (1976). Die Feuchtgebiete inernationaler Bedeutung in der Bundesrepublik Deutschland. Vogelkdl. Bibliothek Band 4, Greven: Kilda-Verlag, 102 pages.

- Haarmann, K. (1984). Feuchtgebiete internationaler Bedeutung und Europareservate in der Bundesrepublik Deutschland. Zweiter Zustandbericht (Stand: Januar 1983). Ottendorf: Niederelbe-Verlag, 12 pages. (Fordsand Buch No. 3.)

\section{Ostf riesisches Wattenmeer and Dollart}

Location $53^{\circ} 45^{\prime} \mathrm{N}, 7^{\circ} 20^{\prime} \mathrm{E}$. Situated on the North Sea coast between Jade Bay and the Netherlands border in the Federal State of Niedersachsen.

Area $121,620 \mathrm{ha}$

Degree of Protection The site is partially protected containing 12 Nature Conservation Areas totalling $10 \%$ of site area. It is within one of the new Wattenmeer national parks. Designated as a Ramsar site in November 1974 with ratification after February 1976.

Site Description The site comprises two sectors: 117,640 ha including some areas of the East Fresian island and an area of saltmarsh, sand and mudflats separating the islands from the mainland; and the Dollart (3,980ha) separated from the islands and situated in the River Ems estuary where extensive banks of very fine mud have formed. The mudflats are rich feeding grounds for birds, and also provide a shelter, being separated from the mainland by a broad band of reeds Phragmites sp. and other plants.

Criteria for inclusion 1(a), 1(b), 2(a), 2(c) and 3

International and National Importance The site is part of the Waddensee and is therefore part of the most important habitat for waterfowl in the Federal Republic of Germany. Passage waterfowl in the Dollart area are bean goose Anser fabilis $(1,000-8,000)$, white-fronted goose Anser albifrons (5,000-8,000), greylag goose Anser anser (1,000-1,600), shelduck Tadorna tadorna (2,000-2,800), teal Anas crecca (5,000-20,000), avocet Recurvirostra avosetta (10,000-20,000), grey plover Pluvialis squatarola (1,000-7,000), dunlin Calidris alpina (50,000-100,000), black-tailed godwit Limosa limosa (2,500-4,600), bar-tailed godwit L. lapponica $(5,000-9,000)$, spotted redshank Tringa erythropus $(1,000-1,700)$, redshank $T$. totanus $(2,000)$ and curlew Numenius arquata $(1,200)$. Breeding species include black-tailed godwit (65 pairs) and redshank (250 pairs). Passage and wintering waterfowl in the East Fresian area are bean goose $(1,000)$, pink-footed goose Anser brachyrhynchus $(500)$, greylag goose $(1,000-2,000)$, barnacle goose Branta leucopsis $(2,000-6,000)$, brent goose $B$. bernicla $(6,00-8,000)$, shelduck $(5,000-20,000)$, wigeon Anas penelope $(6,000)$, teal $A$. crecca 
(2,500), pintail A. acuta $(5,000)$, eider duck Somateria mollissima $(60,000)$, oystercatcher Haemotopus ostralegus (10,000-60,000), avocet $(10,000)$, ringed plover Charadrius hiaticula (2,500), Kentish plover C. alexandrinus (500), grey plover (5,000-9,000), knot Calidris canutus (25,000-80,000), dunlin (100,000-200,000), bar-tailed godwit $(5,000-13,000)$, curlew $(10,000-12,000)$, redshank $(700)$ and turnstone Arenaria interpres (800). Breeding species are avocet (1,200 pairs), Kentish plover (185 pairs), sandwich tern Sterna sandvicensis (1,500-1,600 pairs), common tern $S$. hirundo (1,000-1,300 pairs), little tern S. albifrons (75-100 pairs), oystercatcher (2,000 pairs), black-tailed godwit (100+ pairs), redshank (480 pairs) and shelduck ( $800+$ pairs).

Changes in Ecological Character Since designation there have been some boundary changes with loss of some areas, but there has been a general increase in area from 96,500ha. There are plans to dyke parts of the Leybucht (saltmarsh and wadden areas), and to construct a new harbour at Emden. There is considerable recreation pressure, and the waters are very vulnerable to possible oil spillage from tankers using the adjacent waters.

Management Practices In some parts hunting is strictly controlled. There are summer bird wrdens.

\section{Scientific Research and Facilities No information}

Principal Reference Material The above information is taken from documents supplied by the Government of the Federal Republic of Germany for designation in 1978, and for the Cagliari Conference in November 1980.

Supplemented by:

- Carp, E. (1980). A Directory of Western Palearctic Wetlands. IUCN, Gland, Switzerland.

- Duffey, E. (1982). National Parks and Reserves in Western Europe. Macdonald, and Co., London.

- Scott, D.A. (1980). A preliminary inventory of wetlands of international importance for waterfowl in west Europe and northwest Africa. IWRB Special Publication No. 2.

Additional references:

- Haarmann, K. (1978). Erster Bericht über den Zustand der Feuchtgebiete internationaler Bedeutung in der Bundesrepublik Deutschland. Biol. Abh. Nr. 36, 28 pages.

- Haarmann, K. and Pretscher, P. (1976). Die Feuchtgebiete inernationaler Bedeutung in der Bundesrepublik Deutschland. Vogelkdl. Bibliothek Band 4, Greven: Kilda-Verlag, 102 pages.

- Haarmann, K. (1984). Feuchtgebiete internationaler Bedeutung und Europareservate in der Bundesrepublik Deutschland. Zweiter Zustandbericht (Stand: Januar 1983). Ottendorf: Niederelbe-Verlag, 12 pages. (Fordsand Buch No. 3.)

- Schoennagel, E. (1978). Naturschutzgebiet Lutje Horn. Orn. Mitt. 29(1): 22.

\section{Lower Elbe, Barnkrug - Otterndorf}

Location $53^{\circ} 52^{\prime} \mathrm{N}, 09^{\circ} 07^{\prime} \mathrm{E}$. Situated on the left bank of the River Elbe between the towns of Barnkrug and Otterndorf in the Federal State of Niedersachsen.

Area 11,760 ha

Degree of Protection Ownership is part state and part private. The site is partially protected in four Nature Conservation Areas: Hullen (489ha), Aussendeich Nordkehdingen (900ha), Allwordener Aussendeich/ Brammer Sand (6,525ha) and Ostemündung (160ha), and also contains a Game Protection Area. New Nature Conservation Areas are planned. Designated as a Ramsar site in November 1974 with ratification after February 1976.

Site Description The site comprises a narrow section of the left bank of the River Elbe with conditions ranging from estuarine (17\% salinity) at Otterndorf to freshwater at Barnkrug (although the river here is still tidal). There is a sharp change in salinity where the river flows between Glückstadt on the right bank and Wischafen on the left. Habitats include sandbanks, 
islands and mudflats (up to $1 \mathrm{~km}$ wide at low tide). The shores are fringed with rushes Scirpus spp., Schoenoplectus spp. and reeds Phragmites sp. Short grass meadows intersected by ditches lie behind the dykes and are used for grazing. The riverine marshes are gradually being reclaimed for crop growing. Aussendeich Nordkehdingen reserve is an undyked marsh area with wet pastures, remnants of a saltmarsh plant community and river mudflats (approximately $400 \mathrm{~m}$ wide). Extensive sedge and reedbeds occur in the transition area from marsh and meadow to mudflats.

\section{Criteria for inclusion $1(\mathrm{a}), 1(\mathrm{~b})$ and $2(\mathrm{c})$}

International and National Importance Passage and wintering waterfowl include 1,000 Bewick's swan Cygnus columbianus, 3,000 white-fronted goose Anser albifrons, 2,500 greylag goose $A$. anser, 6,000-11,500 barnacle goose Branta leucopsis, 3,500 teal Anas crecca, 2,300 wigeon $A$. penelope and golden plover Pluvialis apricaria (maximum 4,000). Breeding species include avocet Recurvirostra avosetta (200 pairs), little tern Sterna albifrons (50 pairs), common tern S. hirundo (200-250) gull-billed tern Gelochelidon nilotica (5 pairs), black tern Chlidonias nigra (10 pairs), black-headed gull Larus ridibundus (2,500 pairs), black-tailed godwit Limosa limosa (40 pairs) and ruff Philomachus pugnax (100 pairs).

Changes in Ecological Character Since designation the site area has increased by 2,600ha, despite the fact that there has been some loss of designated area. Threats include industrialisation, pollution, heavy boat traffic on the river, dyke building and dredging of the river. Some areas are particularly vulnerable to disturbance due to their small size.

\section{Management Practices The area has a warden.}

Scientific Research and Facilities Several institutes of the University of Hamburg have studied the hydrological, limnological and ecological problems of the wetland. Avifaunal studies are carried out mainly by private organisations.

Principal Reference Material The above information is taken from documents supplied by the Government of the Federal Republic of Germany for designation in 1978, and for the Cagliari Conference in November 1980.

Supplemented by:

- Carp, E. (1980). A Directory of Western Palearctic Wetlands. IUCN, Gland, Switzerland.

- Duffey, E. (1982). National Parks and Reserves of Western Europe. Macdonald and Co., London.

- Scott, D.A. (1980). A preliminary inventory of wetlands of international importance for waterfowl in west Europe and northwest Africa. IWRB Special Publication No. 2.

Additional references:

- Haarmann, K. (1978). Erster Bericht über den Zustand der Feuchtgebiete internationaler Bedeutung in der Bundesrepublik Deutschland. Biol. Abh. Nr. 36, 28 pages.

- Haarmann, K. and Pretscher, P. (1976). Die Feuchtgebiete inernationaler Bedeutung in der Bundesrepublik Deutschland. Vogelkdl. Bibliothek Band 4, Greven: Kilda-Verlag, 102 pages.

- Haarmann, K. (1984). Feuchtgebiete internationaler Bedeutung und Europareservate in der Bundesrepublik Deutschland. Zweiter Zustandbericht (Stand: Januar 1983). Ottendorf: Niederelbe-Verlag, 12 pages. (Fordsand Buch No. 3.)

\section{Elbaue zwischen Schnackenburg und Lauenburg}

Location $53^{\circ} 03^{\prime} \mathrm{N}, 11^{\circ} 35^{\prime} \mathrm{E}$. Situated on the River Elbe in the north of the Federal State of Niedersachsen, between Schrackenburg and Lauenburg. 
Degree of Protection The site is partially protected in four Nature Conservation Areas: Altwasser Bei Brackede (122ha), Penkefitzer See mit Umgebung (177ha), Bracks bei Predohlsau $(64,7 \mathrm{ha})$ and Habekost (25ha). Designated as a Ramsar site in November 1974 with ratification after February 1976.

Site Description The site comprises a number of separate areas along the floodplain of the middle reaches of the River Elbe.

Criteria for inclusion $1(\mathrm{a})$ and $1(\mathrm{~b})$

International and National Importance Passage waterfowl include 800-1,000 Bewick's swan Cygnus columbianus bewickii, 800 whooper swan Cygnus cygnus, 1,000 bean goose $A$. albifrons, 500 greylag goose $A$. anser, up to 100 smew Mergus albellus and up to 650 pintail Anas acuta. Breeding species include crane Grus grus (3 pairs), black-tailed godwit Limosa limosa (60 pairs) and black tern Chlidonias nigra (50 pairs).

Changes in Ecological Character Since designation there has been a change in area, with loss of some of the original designated site, but generally an increase in site area from 4,165 ha. There are plans for a nuclear fuel processing plant at Gorleben nearby. Much of the wetland will probably be disturbed by drainage schemes and there is recreation pressure.

Management Practices The Hamburg group of the German Bird Preservation Society is managing some areas to protect habitat for nesting cranes and amphibians.

\section{Scientific Research and Facilities University of Hamburg}

Principal Reference Material The above information is taken from documents supplied by the Government of the Federal Republic of Germany for designation in 1978 and for the Cagliari Conference in November 1980.

Supplemented by:

- Scott, D.A. (1980). A preliminary inventory of wetland of international importance for waterfowl in west Europe and northwest Africa. IWRB Special Publication No. 2.

Additional references include:

- Haarmann, K. (1978). Erster Bericht über den Zustand der Feuchtgebiete internationaler Bedeutung in der Bundesrepublik Deutschland. Biol. Abh. Nr. 36, 28 pages.

- Haarmann, K. and Pretscher, P. (1976). Die Feuchtgebiete inernationaler Bedeutung in der Bundesrepublik Deutschland. Vogelkdl. Bibliothek Band 4, Greven: Kilda-Verlag, 102 pages.

- Haarmann, K. (1984). Feuchtgebiete internationaler Bedeutung und Europareservate in der Bundesrepublik Deutschland. Zweiter Zustandbericht (Stand: Januar 1983). Ottendorf: Niederelbe-Verlag, 12 pages. (Fordsand Buch No. 3.)

\section{Dümmersee}

Location $52^{\circ} 32^{\circ} \mathrm{N}, 8^{\circ} 23^{\circ} \mathrm{E}$. Situated about $65 \mathrm{~km}$ south-southwest of Bremen and $85 \mathrm{~km}$ due west of Hannover in the Federal State of Niedersachsen.

Area 3,600ha

Degree of Protection The lake is owned by the state and the surrounding area comprises private and state properties. The site is partly protected in three Nature Conservation Areas including Dümmer (745ha) and Hohe Sieben (75ha). 1,778ha is included in Dümmer Game Protection Area. The site also contains two Landscape Protection Areas. All are included in Dümmer Nature Park. Designated as a Ramsar site in November 1974 with ratification after February 1976. 
Site Description The site contains a large shallow lake ( $1.5 \mathrm{~m}$ depth) in a glaciated valley, with raised bogs, peatbogs, inland sand dunes and moraines. The original vegetation has been substantially modified by man; for example the bogs which were once used intensively as farmland but have now been abandoned since the drainage failed. The original submerged plants of the lake including pondweed Potomogeton spp. and stoneworts Chara spp. have mostly disappeared. There are still some thick belts (up to $800 \mathrm{~m}$ ) of waterlily, reeds Phragmites sp. and reedmace Typha spp. on the lake shore, and some relict patches of alder bogs and sedge meadows.

Criteria for inclusion $1(\mathrm{a})$ and $1(\mathrm{~b})$

International and National Importance Despite the considerable alteration of habitat Dümmer is still important for waterfowl. Passage and wintering species include garganey Anas querquedula (2,000-3,000 passage), smew Mergus albellus (500 maximum), crane Grus grus (3,000 maximum), Bewick's swan Cygnus columbianus bewickii (100 maximum). Breeding species include bittern Botaurus stellaris (10 pairs), spotted crake Porzana porzana (20 pairs), black-headed gull Larus ridibundus (600 pairs) and black tern Chlidonias nigra (30-50 pairs).

Changes in Ecological Character Problems include pollution from sewage causing eutrophication, fluctuating water levels due to use of the lake as a storage reservoir, disturbance by boats, overfishing and construction of weekend houses. Numbers of some bird species such as black tern and crane have declined considerably.

Management Practices A number of restoration measures are being implemented, including sediment removal from the lake, re-establishment of temporary flooding in the Dümmer Nature Conservation Area, and control of fishing and hunting.

\section{Scientific Research and Facilities No information}

Principal Reference Material The above information is taken from documents supplied by the Government of the Federal Republic of Germany for designation in 1978, and for the Cagliari Conference in November 1980.

Supplemented by:

- Carp, E. (1980). A Directory of Western Palearctic Wetlands. IUCN, Gland, Switzerland.

- Duffey, E. (1982). National Parks and Reserves in Western Europe. Macdonald and Co., London.

- Scott, D.A. (1980). A preliminary inventory of wetlands of international importance for waterfowl in west Europe and northwest Africa. IWRB Special Publication No. 2.

Additional references:

- Haarmann, K. (1978). Erster Bericht über den Zustand der Feuchtgebiete internationaler Bedeutung in der Bundesrepublik Deutschland. Biol. Abh. Nr. 36, 28 pages.

- Haarmann, K. and Pretscher, P. (1976). Die Feuchtgebiete inernationaler Bedeutung in der Bundesrepublik Deutschland. Vogelkdl. Bibliothek Band 4, Greven: Kilda-Verlag, 102 pages.

- Haarmann, K. (1984). Feuchtgebiete internationaler Bedeutung und Europareservate in der Bundesrepublik Deutschland. Zweiter Zustandbericht (Stand: Januar 1983). Ottendorf: Niederelbe-Verlag, 12 pages. (Fordsand Buch No. 3.)

\section{Diepholzer Moorniederung}

Location $52^{\circ} 33^{\prime} \mathrm{N}, 8^{\circ} 42^{\prime} \mathrm{E}$. Situated about $37 \mathrm{~km}$ northeast of the town of Osnabrück in the Federal State of Niedersachsen.

Area 15,060 ha 
Degree of Protection Ownership is part state and part private. The site is partially protected in two Nature Conservation Areas: Neustädter Moor (200ha) and Grosses Renzeler Moor (232ha). WWF Federal Republic of Germany owns part of the former reserve. A further 1,000 ha has been purchased since 1979 for nature conservation. Designated as a Ramsar site in November 1974 with ratification after February 1976.

Site Description The site is a region of moor and peat bog on the glacial sands of the north German plain, and comprises two sectors separated by the village of Wagenfeld: Geestmoor to the west and Neustädter Moor, Grosses Renzeler Moor, Hespelohmoor and Grosses Moor bei Uchte to the east. Over the centuries the peat deposits have been and are still exploited by man causing considerable changes in vegetation. Current vegetaton of the moors tends to be dominated by birch Betula sp., cross-leaved heath Erica tetralix, ling Calluna vulgaris and purple moor grass Molina caerulea. The original bog flora survives only in some pools or basins and includes sphagnum moss, sweet gale Myrica gale and cotton grass Eriophorum spp. The surrounding area contains lowlying meadowlands, cornfields and small patches of coniferous and deciduous woodland.

\section{Criteria for inclusion $1(\mathrm{c})$}

International and National Importance The raised bogs are a breeding area for several uncommon or threatened bird species, and the site is one of the few breeding areas in Niedersachsen for the southern race of golden plover Pluvialis apricaria (25-26 pairs) Other breeding species include teal Anas crecca (40 pairs), curlew Numenius arquata (80 pairs), redshank Tringa totanus (40 pairs) and black-tailed godwit Limosa limosa (80 pairs). Some 150 black grouse Lyrurus tetrix also occur. Passage species include up to 500 crane Grus grus.

Changes in Ecological Character Since designation there has been a decrease in area from 17,850 ha mainly affecting the larger sector of the site. Peat cutting is still allowed in the reserves, and some areas have been degraded by soil improvement measures such as drainage.

Management Practices There is management of water levels in an attempt to restore the natural raised bogs in some areas.

\section{Scientific Research and Facilities No information}

Principal Reference Material The above information is taken from documents supplied by the Government of the Federal Republic of Germany for designation in 1978, and for the Cagliari Conference in November 1980.

Supplemented by:

- Carp, E. (1980). A Directory of Western Palearctic Wetlands. IUCN, Gland, Switzerland.

- Duffey, E. (1982). National Parks and Reserves in Western Europe. Macdonald and Co., London.

- Scott, D.A. (1980). A preliminary inventory of wetlands of international importance for waterfowl in west Europe and northwest Africa. IWRB Special Publication No. 2.

Additional references:

- Haarmann, K. (1978). Erster Bericht über den Zustand der Feuchtgebiete internationaler Bedeutung in der Bundesrepublik Deutschland. Biol. Abh. Nr. 36, 28 pages.

- Haarmann, K. and Pretscher, P. (1976). Die Feuchtgebiete inernationaler Bedeutung in der Bundesrepublik Deutschland. Vogelkdl. Bibliothek Band 4, Greven: Kilda-Verlag, 102 pages.

- Haarmann, K. (1984). Feuchtgebiete internationaler Bedeutung und Europareservate in der Bundesrepublik Deutschland. Zweiter Zustandbericht (Stand: Januar 1983). Ottendorf: Niederelbe-Verlag, 12 pages. (Fordsand Buch No. 3.) 


\section{Steinhuder Meer}

Location $52^{\circ} 28^{\circ} \mathrm{N}, 9^{\circ} 20^{\circ} \mathrm{E}$. Situated just west of the town of Neustadt am Rübenberge in the Federal State of Niedersachsen.

Area 5,730 ha

Degree of Protection The designated site is partially protected in Hagenburger Moor Nature Conservation Area (200ha) and Ostufer Steinhuder Meer Nature Conservation Area (280ha). Part of the site is a Landscape Protection Area. Further nature conservation areas are planned. Designated as a Ramsar site in November 1974 with ratification after February 1976.

Site Description The site comprises Steinhuder Meer (3,000ha), which is the largest inland lake in northern Germany, and includes remnants of moorland and raised bog. The lake lies in a glacial meltwater channel and is thought to be fed by springs in the lakebed despite there being no major inflows but the water level remains fairly constant. The east bank is the only part of the lake bordered by a broad belt of reedswamp and marsh vegetation, and has a greater area of original vegetation and raised bog than the west shore. These areas have been reduced by reclamation for grassland.

Criteria for inclusion 1 (a) and $1(b)$

International and National Importance The site is important in winter for large numbers of migrating and wintering birds including 3,500 teal Anas crecca (passage), mallard Anas platyrhynchos (10,000 maximum), pochard Aythya ferina (5,800 maximum), 500 smew Mergus albellus (1,100 maximum), goosander $M$. merganser (4,000 maximum), 750 shoveler Anas clypeata (passage) and great crested grebe Podiceps cristatus (500 maximum). Breeding birds include great crested grebe (150-250 pairs), bittern Botaurus stellaris (1-2 pairs), grey heron Ardea cinerea ( 90 pairs) and black-headed gull Larus ridibundus (600 pairs).

Changes in Ecological Character The site area has decreased by 45 ha since designation.

Management Practices No information

Scientific Research and Facilities No information

Principal Reference Material The above information is taken from documents supplied by the Government of the Federal Republic of Germany for designation in 1978, and for the Cagliari Conference in November 1980.

Supplemented by:

- Duffey, E. (1982). National Parks and Reserves in Western Europe. Macdonald and Co., London.

- Scott, D.A. (1980). A preliminary inventory of wetlands of international importance for waterfowl in west Europe and northwest Africa. IWRB Special Publication No. 2.

Additional references:

- Haarmann, K. (1978). Erster Bericht über den Zustand der Feuchtgebiete internationaler Bedeutung in der Bundesrepublik Deutschland. Biol. Abh. Nr. 36, 28 pages.

- Haarmann, K. and Pretscher, P. (1976). Die Feuchtgebiete inernationaler Bedeutung in der Bundesrepublik Deutschland. Vogelkdl. Bibliothek Band 4, Greven: Kilda-Verlag, 102 pages.

- Haarmann, K. (1984). Feuchtgebiete internationaler Bedeutung und Europareservate in der Bundesrepublik Deutschland. Zweiter Zustandbericht (Stand: Januar 1983). Ottendorf: Niederelbe-Verlag, 12 pages. (Fordsand Buch No. 3.) 


\section{Rhein zwischen Eltville und Bingen}

Location $50^{\circ} 02^{\prime} \mathrm{N}, 8^{\circ} 07^{\prime} \mathrm{E}$. Situated on the Rhine River near the city of Mainz between the towns of Bingen and Eltville in the Federal States of Hessen and Rheinland-Pfalz.

Area $475 \mathrm{ha}$

Degree of Protection The designated site is protected in three Nature Conservation Areas: Rudesheimer Aue (29ha); Fulder Aue-Ilmenaue (250ha) and Marianneaue (196ha). Designated as a Ramsar site in November 1974 with ratification after February 1976.

Site Description The site comprises three nature conservation areas which include four islands in the Rhine: Ilmen, Fulder, Rudesheimer and Mariannen. The navigable channel of the river has been deepened and the water channeled by artificial banks which created shallow still waters between the river margins and channel banks near the islands. Some of these areas are included in the designated area.

\section{Criteria for inclusion $1(a)$ and $1(b)$}

International and National Importance This is the only wetland of international importance in central Germany. The site is very important for migrating birds as the nearest wetlands are some $300 \mathrm{~km}$ north and $250 \mathrm{~km}$ southeast. A maximum of 10,000 waterfowl have been counted at the site in winter including pochard Aythya ferina (most numerous/maximum 7,500), tufted duck A. fuligula (2,500 maximum), smew Mergus albellus (550 maximum) and goosander $M$. merganser ( 800 maximum). Most species of European waterfowl have been seen here including the less common ducks such as garganey Anas querquedula and gadwall $A$. stepera. The shallow water areas are important for migrating waders particularly lapwing Vanellus vanellus, godwits Limosa spp., redshank Tringa totanus, greenshank $T$. nebularia, common sandpiper $T$. hypoleucos, green sandpiper $T$. ochropus and ruff Philomachus pugnax. Breeding birds are few in number but include nightingale Luscinia megarhynchos, Icterine warbler Hippolais icterina and golden oriole Oriolus oriolus.

Changes in Ecological Character There is considerable tourist pressure from wind-surfers, boats and anglers which disturb the waterfowl. There were demands for a new bridge across the Rhine at Geisenheim, which would have affected the island of Fulder Aue, but these have now been dropped.

Management Practices Management practices include protection of the remaining natural water meadow forest and of waterfowl resting sites, and the prevention of the establishment of cultivated poplars. The local association for Ornithology and Nature have proposed that winter closing time for the reserve be brought forward from 1 November to 1 October to lessen disturbance to resting birds.

\section{Scientific Research and Facilities No information}

Principal Reference Material The above information is taken from documents supplied by the Government of the Federal Republic of Germany for designation in 1978, and for the Cagliari Conference in November 1980.

Supplemented by:

- Duffey, E. (1982). National Parks and Reserves in Western Europe. Macdonald and Co., London.

- Scott, D.A. (1980). A preliminary inventory of wetlands of international importance for waterfowl in west Europe and northwest Africa. IWRB Special Publication No. 2.

Additional references:

- Haarmann, K. (1978). Erster Bericht über den Zustand der Feuchtgebiete internationaler Bedeutung in der Bundesrepublik Deutschland. Biol. Abh. Nr. 36, 28 pages. 
- Haarmann, K. and Pretscher, P. (1976). Die Feuchtgebiete inernationaler Bedeutung in der Bundesrepublik Deutschland. Vogelkdl. Bibliothek Band 4, Greven: Kilda-Verlag, 102 pages.

- Haarmann, K. (1984). Feuchtgebiete internationaler Bedeutung und Europareservate in der Bundesrepublik Deutschland. Zweiter Zustandbericht (Stand: Januar 1983). Ottendorf: Niederelbe-Verlag, 12 pages. (Fordsand Buch No. 3.)

\section{Bodensee}

Location $47^{\circ} 40^{\prime} \mathrm{N}, 9^{\circ} 09^{\prime} \mathrm{E}$. Situated west and northwest of Konstanz in the Federal State of Baden Württemberg.

\section{Area 1,080ha}

Degree of Protection Ownership is part state and part private. The designated site is totally protected as Wollmatinger Ried-Giehren Moos Dreifusswiesen Conservation Area (767ha) and Mindelsee Conservation Area (307ha). Designated as a Ramsar site in November 1974 with ratification after February 1976.

Site Description The site comprises: Wollmatinger reedbed with northeastern Ermatingen Basin; adjacent to Giehren marsh with the Bay of Hegne on the Gnadensee; and Mindelsee near Radolfze. These areas are on or adjacent to the part of the Bodensee (Lake Constance) known as Untersee. Bodensee was formed by a combination of earth movement (during uplifting of the Alps) and glacial action and was originally a typical subalpine waterbody, poor in nutrients. Due to industrial and domestic waste the waters have now become moderately nutrient-rich. The lake is partially bordered by reeds, marsh and meadows.

\section{Criteria for inclusion $1(\mathrm{a}), 1(\mathrm{~b})$ and $2(\mathrm{c})$}

International and National Importance Moulting, passage and wintering waterfowl include gadwall Anas strepera (2,000-2,500), red-crested pochard Netla rufina (1,500-2,000), pochard Aythya ferina $(20,000-40,000)$, tufted duck $A$. fuligula $(15,000-20,000)$, goldeneye Bucephala clangula (3,000), teal Anas crecca (2,000 maximum), 350 shoveler A. clypeata (350 maximum) and black-necked grebe Podiceps nigricollis (500 maximum). The site is particularly important as a moulting refuge for two species of pochard. Breeding waterfowl include 8 species of duck including red-crested pochard (40+ pairs). Wollmatinger Ried Nature Conservation Area contains a number of plants considered threatened in the Federal Republic of Germany, such as Siberian iris Iris sibirica, bird's-eye primrose Primula farinosa, marsh gladiolus Gladiolus palustris and sweet-smelling garlic Allium suaveolens (vunerable in Europe).

Changes in Ecological Character Problems include eutrophication and pressure from recreation requirements. In the lake, whitefish Coregonus spp. have been almost replaced by perch Perca sp.

Management Practices The meadows are mown to encourage Limicoline species, and the ponds have been dug to encourage nesting birds, insects and amphibians.

Scientific Research and Facilities Several institutes carry out research in and around the Bodensee, particularly limnological studies. Research is also carried out by several private organisations and at least three major Swiss institutes. Research in Mindelsee on ecology and ethology of reed warblers.

Principal Reference Material The above information is taken from documents supplied by the Government of the Federal Republic of Germany for designation in 1978, and for the Cagliari Conference in November 1980.

Supplemented by:

- Carp, E. (1980). A Directory of Western Palearctic Wetlands. IUCN, Gland, Switzerland. 
- Duffey, E. (1982). National Parks and Reserves in Western Europe. Macdonald and Co., London.

- Scott, D.A. (1980). A preliminary inventory of wetlands of international importance for waterfowl in west Europe and northwest Africa. IWRB Special Publication No. 2.

Additional references:

- Haarmann, K. (1978). Erster Bericht über den Zustand der Feuchtgebiete internationaler Bedeutung in der Bundesrepublik Deutschland. Biol. Abh. Nr. 36, 28 pages.

- Haarmann, K. and Pretscher, P. (1976). Die Feuchtgebiete inernationaler Bedeutung in der Bundesrepublik Deutschland. Vogelkdl. Bibliothek Band 4, Greven: Kilda-Verlag, 102 pages.

- Haarmann, K. (1984). Feuchtgebiete internationaler Bedeutung und Europareservate in der Bundesrepublik Deutschland. Zweiter Zustandbericht (Stand: Januar 1983). Ottendorf: Niederelbe-Verlag, 12 pages. (Fordsand Buch No. 3.)

\section{Donauauen und Donaumoos}

Location $48^{\circ} 27^{\prime} \mathrm{N}, 10^{\circ} 17^{\prime} \mathrm{E}$. Situated between the towns of Neu-Ulm and Lauingen on the Danube River in the Federal State of Bayern.

Area 8,000 ha

Degree of Protection Ownership is part state and part private. The area contains a number of Landscape Protection Areas and Nature Conservation Areas, and further Nature Conservation Areas are planned. Designated as a Ramsar site in November 1974 with ratification after February 1976.

Site Description The site comprises: the western part of the Danube peatbog from Riedheim in the west to Riedhausen in the east; the eastern part of the Danube peatbog from Riedhausen in the west to Unteren and Oberen Moosteile in the northeast, including some meadowland (combined area 2,000ha); and the Danube riverine forest in a band of varying width $(2-3 \mathrm{~km}$ ) on either side of the Danube from Lauingen to Neu Ulm $(4,000 \mathrm{ha})$. This woodland is flooded in March and June by alpine meltwater, and it therefore cannot be cultivated. It contains marshes and gravel pits. In the past 50 years the river has been increasingly regulated by many dams, and there are six reservoirs (Oberelchingen, Leipheim, Günzburg, Offingen, Peterswörth and Faimingen) created primarily for hydroelectric power. These also attract waterfowl.

\section{Criteria for inclusion $1(\mathrm{a})$ and $1(\mathrm{~b})$}

International and National Importance The reservoirs of Oberelchingen, Leipheim and Faimingen are of international importance and the reservoirs of Günzburg, Offingen and Peterswörth are of national importance for waterfowl. They attract numerous resting and overwintering birds including mallard Anas platyrhynchos (10,000 January average/15,000 maximum), pochard Aythya ferina (7,800 January average/10,000 maximum), little grebe Tachybaptus ruficollis (3,000 maximum), black-necked grebe Podiceps nigricollis (1,000 maximum), teal Anas crecca (1,400 January average/4,000 maximum) and coot Fulica atra (6,600 January average/11,000 maximum). The moorland areas are important for breeding and overwintering birds.

Changes in Ecological Character The area is in danger from gravel extraction, dumping of urban waste, reafforestation with conifers, industrial development, and disturbance from tourism and shooting.

Management Practices No information

Scientific Research and Facilities No information 
Principal Reference Material The above information is taken from documents supplied by the Government of the Federal Republic of Germany for designation in 1978, and for the Cagliari Conference in November 1980.

Supplemented by:

- Duffey, E. (1982). National Parks and Reserves in Western Europe. Macdonald and Co., London.

- Scott, D.A. (1980). A preliminary inventory of wetlands of international importance for waterfowl in west Europe and northwest Africa. IWRB Special Publication No. 2.

Additional references:

- Haarmann, K. (1978). Erster Bericht über den Zustand der Feuchtgebiete internationaler Bedeutung in der Bundesrepublik Deutschland. Biol. Abh. Nr. 36, 28 pages.

- Haarmann, K. and Pretscher, P. (1976). Die Feuchtgebiete inernationaler Bedeutung in der Bundesrepublik Deutschland. Vogelkdl. Bibliothek Band 4, Greven: Kilda-Verlag, 102 pages.

- Haarmann, K. (1984). Feuchtgebiete internationaler Bedeutung und Europareservate in der Bundesrepublik Deutschland. Zweiter Zustandbericht (Stand: Januar 1983). Ottendorf: Niederelbe-Verlag, 12 pages. (Fordsand Buch No. 3.)

\section{Lech Donau Winkel}

Location $48^{\circ} 43^{\prime} \mathrm{N}, 10^{\circ} 56^{\prime} \mathrm{E}$. Situated near the confluence of the River Lech and River Danube in the Federal State of Bayern.

Area 230ha

Degree of Protection The site contains Feldheim Reservoir, which is a proposed Nature Conservation Area. Designated as a Ramsar site in November 1974 with ratification after February 1976.

Site Description The site comprises two reservoirs built primarily to serve hydroelectric power stations: Feldheim Reservoir on the River Lech built in 1959, and Bertoldsheim Reservoir on the River Danube built in 1967. Both have fluctuating water levels although vegetation has developed on some of the Feldheim shoreline. The reservoirs are surrounded by meadow woodland.

Criteria for inciusion $1(a)$ and $1(b)$

International and National Importance The reservoirs are internationally important as resting and overwintering areas for northern species of waterfowl, and Feldheim is important as a breeding and moulting ground. Passage and wintering waterfowl include pochard Aythya ferina (7,600 maximum), tufted duck A. fuligula, little grebe Tachybaptus ruficollis (700 maximum), gadwall Anas strepera (280 maximum), teal $A$. crecca (2,300 maximum) and goosander Mergus merganser (175 maximum).

Changes in Ecological Character Bertoldsheim Reservoir is intensively used for water sports in summer, and although peak use does not coincide with peak waterfowl numbers, this is a disturbance in autumn and spring. There is some disturbance from sport fishermen in boats in winter.

Management Practices Nature Conservation Area status at Feldheim will include controls on fishing and watersports and probable banning of hunting. Some restrictions are planned on boats in Bertoldsheim.

Scientific Research and Facilities No information 
Principal Reference Material The above information is taken from documents supplied by the Government of the Federal Republic of Germany for designation in 1978, and for the Cagliari Conference in November 1980.

Supplemented by:

- Scott, D.A. (1980). A preliminary inventory of wetlands of international importance for waterfowl in west Europe and northwest Africa. IWRB Special Publication No. 2.

Additional references:

- Haarmann, K. (1978). Erster Bericht über den Zustand der Feuchtgebiete internationaler Bedeutung in der Bundesrepublik Deutschland. Biol. Abh. Nr. 36, 28 pages.

- Haarmann, K. and Pretscher, P. (1976). Die Feuchtgebiete inernationaler Bedeutung in der Bundesrepublik Deutschland. Vogelkdl. Bibliothek Band 4, Greven: Kilda-Verlag, 102 pages.

- Haarmann, K. (1984). Feuchtgebiete internationaler Bedeutung und Europareservate in der Bundesrepublik Deutschland. Zweiter Zustandbericht (Stand: Januar 1983). Ottendorf: Niederelbe-Verlag, 12 pages. (Fordsand Buch No. 3.)

\section{Ismaninger Speichersee mit Fischteichen}

Location $48^{\circ} 13^{\prime} \mathrm{N}, 11^{\circ} 41^{\prime} \mathrm{E}$. Situated about $5 \mathrm{~km}$ northeast of Munich in the Federal State of Bayern.

\section{Area 900ha}

Degree of Protection The area is owned by an hydro-electrical firm (Bayernwerk A.G.). The area is recognised by the Council of Europe as a Europa Reservat. Designated as a Ramsar site in November 1974 with ratification after February 1976.

Site Description The site comprises Ismaning Storage Reservoir, and over 30 fish ponds along the Mittlere Isar Canal. The reservoir (built in 1929) is $7 \mathrm{~km}$ long and divided into two basins. A gentle current prevents it from completely freezing over in winter. The south shore has a number of plant communities varying from reed to woodland. The fishponds, which contain carp Cyprinus carpio, serve as a biological purification system for partially treated sewage from Munich. The waters are rich in nutrients and variations in waterlevel expose mudflats which attract many waders.

\section{Criteria for inclusion $1(\mathrm{a}), 1(\mathrm{~b})$ and $2(\mathrm{c})$}

International and National Importance Passage and wintering waterfowi include tufted duck Aythya fuligula (13,000 maximum), coot Fulica atra (13,000 maximum), gadwall Anas strepera (3,660 maximum), red-crested pochard Netta rufina (1,690 maximum), black-necked grebe Podiceps nigricollis (480 maximum), mallard Anas platyrhynchos (8,200 maximum), shoveler A. clypeata (980 maximum) and goldeneye Bucephala clangula (570 maximum). Breeding waterfowl include cormorant Phalacrocorax carbo sinensis (8 pairs 1980), night heron Nycticorax nycticorax (6 pairs), grey heron Ardea cinerea (65 pairs), red-crested pochard ( 5 pairs), pochard (225 pairs) and tufted duck (600 pairs) and 9 species threatened in the Federal Republic of Germany.

Changes in Ecological Character There were outbreaks of avian botulism in 1973 and 1974. A road is planned through the area of the fishponds.

Management Practices There is an agreement between the Bavarian Ornithological Hunting Associations whereby hunting is restricted in two-thirds of the area. Fishing is only allowed from the dam in the east basin, the middle dam and the north dam of the west basin. Fishing from boats is prohibited. The Ornithological Association has built an aritifical island for waterfowl. 
Scientific Research and Facilities The Ornithological Association of Bavaria carries out midwinter waterfowl counts, faunal and ecological research.

Principal Reference Material The above information is taken from documents supplied by the Government of the Federal Republic of Germany for designation in 1978, and for the Cagliari Conference in November 1980.

Supplemented by:

- Carp, E. (1980). A Directory of Western Palearctic Wetlands. IUCN, Gland, Switzerland.

- Duffey, E. (1982). National Parks and Reserves of Western Europe. Macdonald and Co., London.

- Scott, D.A. (1980). A preliminary inventory of wetlands of international importance for waterfowl in west Europe and northwest Africa. IWRB Special Publication No. 2.

Additional references:

- Haarmann, K. (1978). Erster Bericht über den Zustand der Feuchtgebiete internationaler Bedeutung in der Bundesrepublik Deutschland. Biol. Abh. Nr. 36, 28 pages.

- Haarmann, K. and Pretscher, P. (1976). Die Feuchtgebiete inernationaler Bedeutung in der Bundesrepublik Deutschland. Vogelkdl. Bibliothek Band 4, Greven: Kilda-Verlag, 102 pages.

- Haarmann, K. (1984). Feuchtgebiete internationaler Bedeutung und Europareservate in der Bundesrepublik Deutschland. Zweiter Zustandbericht (Stand: Januar 1983). Ottendurf: Niederelbe-Verlag, 12 pages. (Fordsand Buch No. 3.)

\section{Ammersee}

Location $48^{\circ} 00^{\prime} \mathrm{N}, 11^{\circ} 07^{\prime} \mathrm{E}$. Situated west-southwest of Munich in the Federal State of Bayern.

Area $6,517 \mathrm{ha}$

Degree of Protection The lake surface and small areas in the south are under state ownership. The site includes Ammersee Südufer Nature Reserve (500ha) in the south. Protection of 530 ha in the north as a Nature Conservation Area was recorded in 1980 as almost complete. The whole area was established as a Landscape Protection Area in 1972. Designated as a Ramsar site in November 1974 with ratification after February 1976.

Site Description Lake Ammer lies in a glaciated landscape bordered to the west and east by moraine material. The designated site boundary follows the lake shore in the east and west but in the north and south includes areas of flat moorland with some scattered meadowland. Deposition from the Ammer River in the southern end of the lake (about 163,000 tonnes per year) has formed several peninsulas extending into the lake, with shallow bays largely fringed by reeds. The lake outlet is the River Amper in the north which eventually joins the River Isar.

Criteria for inclusion $1(\mathrm{a})$ and $1(\mathrm{~b})$

International and National Importance Passage and wintering waterfowl include tufted duck Aythya fuligula (17,000 maximum), coot Fulica atra (250 maximum), gadwall Anas strepera (250 maximum), mallard Anas platyrhynchos (4,600 maximum), pochard Anas ferina (2,500 maximum) and goldeneye Bucephala clangula (900 maximum). The flat moorlands north and south of the lake support many breeding species including black-headed gull Larus ridibundus (480 pairs), snipe Gallingo gallingo (7-9 pairs) and red-crested pochard Netta rufina (2-3 pairs).

Changes in Ecological Character There is considerable disturbance of waterfowl from tourism and boats. Particularly affected are birds breeding close to the lake edge. The vegetation of the lake margin and wet grassland is increasingly damaged by recreational activities. 
Management Practices The Nature Conservation Area is managed in cooperation with local naturalist associations.

Scientific Research and Facilities Past and current avifaunal studies.

Principal Reference Material The above information is taken from documents supplied by the Government of the Federal Repulbic of Germany for designation in 1978, and for the Cagliari Conference in November 1980.

Supplemented by:

- Scott, D.A. (1980). A preliminary inventory of wetlands of international importance for waterfowl in west Europe and northwest Africa. IWRB Special Publication No. 2.

Additional references:

- Haarmann, K. (1978). Erster Bericht über den Zustand der Feuchtgebiete internationaler Bedeutung in der Bundesrepublik Deutschland. Biol. Abh. Nr. 36, 28 pages.

- Haarmann, K. and Pretscher, P. (1976). Die Feuchtgebiete inernationaler Bedeutung in der Bundesrepublik Deutschland. Vogelkdl. Bibliothek Band 4, Greven: Kilda-Verlag, 102 pages.

- Haarmann, K. (1984). Feuchtgebiete internationaler Bedeutung und Europareservate in der Bundesrepublik Deutschland. Zweiter Zustandbericht (Stand: Januar 1983). Ottendorf: Niederelbe-Verlag, 12 pages. (Fordsand Buch No. 3.)

\section{Starnberger See}

Location $47^{\circ} 55^{\prime} \mathrm{N}, 11^{\circ} 18^{\prime} \mathrm{E}$. Situated southwest of Munich in the Federal State of Bayern.

Area 5,720 ha

Degree of Protection Starnerger Lake was established as a Landscape Protection Area in April 1967. There are no nature conservation areas within the designated site. Designated as a Ramsar site in November 1974 with ratification after February 1976.

Site Description The designated site boundary follows the lake shoreline, and includes the whole lake surface though excluding Rosen Island. The land to the west and east is of moraine material. The site contains some areas still in relatively undisturbed state including the Karpfenwinkel area on the west shore and an area near St Heinrich.

Criteria for inclusion $1(\mathrm{a})$ and $1(\mathrm{~b})$

International and National Importance The lake is important for overwintering waterfowl with a maximum of 24,390 recorded birds including tufted duck Aythya fuligula $(5,370$ maximum), coot Fulica atra (17,200 maximum), great crested grebe Podiceps cristatus $(1,400$ maximum) and goldeneye Bucephala clangula (650 maximum). Breeding species include black-headed gull Larus ridibundus (300-400 pairs). The lake does not freeze over completely in winter, and is therefore an important refuge for waterfowl from other areas during periods of severe frost.

Changes in Ecological Character The lake is near Munich, and is intensively used for recreation (particularly sailing). Consequently only a few small areas remain in an undisturbed and natural state. Breeding numbers of birds are small due to this disturbance and destruction of habitat. Recent changes in waste water disposal have resulted in a distinct improvement in the water quality of the lake.

Management Practices No information

Scientific Research and Facilities No information 
Principal Reference Material The above information is taken from documents supplied by the Government of the Federal Republic of Germany for designation in 1978, and for the Cagliari Conference in November 1980.

Supplemented by:

- Scott, D.A. (1980). A preliminary inventory of wetlands of international importance for waterfowl in west Europe and northwest Africa. IWRB Special Publication No. 2.

Additional references:

- Haarmann, K. (1978). Erster Bericht über den Zustand der Feuchtgebiete internationaler Bedeutung in der Bundesrepublik Deutschland. Biol. Abh. Nr. 36, 28 pages.

- Haarmann, K. and Pretscher, P. (1976). Die Feuchtgebiete inernationaler Bedeutung in der Bundesrepublik Deutschland. Vogelkdl. Bibliothek Band 4, Greven: Kilda-Verlag, 102 pages.

- Haarmann, K. (1984). Feuchtgebiete internationaler Bedeutung und Europareservate in der Bundesrepublik Deutschland. Zweiter Zustandbericht (Stand: Januar 1983). Ottendorf: Niederelbe-Verlag, 12 pages. (Fordsand Buch No. 3.)

\section{Chiemsee}

Location $47^{\circ} 53^{\prime} \mathrm{N}, 12^{\circ} 27^{\prime} \mathrm{E}$. Situated southeast of Munich in the Federal State of Bayern.

Area 8,660 ha

Degree of Protection The area was established as a Landscape Protection Area in 1967. Tiroler Ache was established as a Nature Conservation Area in 1954, and was extended to 730ha. Designated as a Ramsar site in November 1974 with ratification after February 1976.

Site Description Lake Chiem lies in a hilly landscape, and is surrounded to the east, west and north by moraine material. The site includes the entire lake surface and three islands, and a land area around the Ache river mouth in the southeast (Tiroler Ache). The Ache River falls some $5,290 \mathrm{~m}$ in $73 \mathrm{~km}$, and carries large quantities of gravel, silt and mud $(430,000$ metric tonnes annually) from the Alps. The deposition has formed a large area of shallow water, sandbars and mudflats extending into the southeast corner of the lake. The lake drains to the north by the River Alz. The surrounding land is mainly meadows, fields and some woodland. Parts of the lake have extensive reedbeds of Phragmites sp.

\section{Criteria for inclusion $1(\mathrm{a})$ and $1(\mathrm{~b})$}

International and National Importance During winter the site has many thousands of resting and over-wintering waterfowl which concentrate in Tiroler Ache including tufted duck $A y$ thya fuligula (16,600 maximum), coot Fulica atra (16,000 maximum), pochard Aythya ferina (4,000 maximum), goldeneye Bucephala clangula ( 900 maximum) and red-crested pochard Netta rufina ( 30 maximum). Breeding bird lists are not yet completed, but include great crested grebe Podiceps cristalus, black-necked grebe Podiceps nigricollis, gadwall Anas strepera, teal $A$. crecca, red-crested pochard, water rail Rallus aquaticus, snipe Gallingo gallingo and curlew Numenius arquata.

Changes in Ecological Character Few areas of the wetland have not been subject to activities by man. The whole area is extensively used for recreation, especially sailing with 5,000 licensed sailing boats. The lake suffers from pollution with waste water.

\section{Management Practices No information}

Scientific Research and Facilities The area was surveyed in 1979 to define those parts needing protection as nature conservation areas. 
Principal Reference Material The above information is taken from documents supplied by the Government of the Federal Republic of Germany for designation in 1978, and for the Cagliari Conference in November 1980.

Supplemented by:

- Duffey, E. (1982). National Parks and Reserves of Western Europe. Macdonald and Co., London.

- Scott, D.A. (1980). A preliminary inventory of wetlands of international importance for waterfowl in west Europe and northwest Africa. IWRB Special Publication No. 2.

Additional references:

- Haarmann, K. (1978). Erster Bericht über den Zustand der Feuchtgebiete internationaler Bedeutung in der Bundesrepublik Deutschland. Biol. Abh. Nr. 36, 28 pages.

- Haarmann, K. and Pretscher, P. (1976). Die Feuchtgebiete inernationaler Bedeutung in der Bundesrepublik Deutschland. Vogelkdl. Bibliothek Band 4, Greven: Kilda-Verlag, 102 pages.

- Haarmann, K. (1984). Feuchtgebiete internationaler Bedeutung und Europareservate in der Bundesrepublik Deutschland. Zweiter Zustandbericht (Stand: Januar 1983). Ottendorf: Niederelbe-Verlag, 12 pages. (Fordsand Buch No. 3.)

\section{Unterer Inn zwischen Haiming und Neuhaus}

Location $48^{\circ} 27^{\prime} \mathrm{N}, 13^{\circ} 25^{\prime} \mathrm{E}$. Situated on the Austrian border on the River Inn between the towns of Neuhaus and Haiming in the Federal State of Bayern.

Area 1,955ha

Degree of Protection Ownership is part state and part private. The designated site includes Egglfing and Ering reservoirs, which form a Nature Conservation Area (729ha) established in 1972. Ering is contiguous with the Austrian Hagenauer Bucht Nature Reserve. The whole area is a Europa Reservat. Designated as a Ramsar site in November 1974 with ratification after February 1976.

Site Description The site comprises four reservoirs on the River Inn: Egglfing, Ering, Scharding and Simbach. The larger reservoirs can be considered as sections of the river but with a slower current. Average water depth is $1-2 \mathrm{~m}$ with maximum of $5-7 \mathrm{~m}$. The River Inn carries a large load of suspended material including much organic detritus which, together with abundant plant nutrients, has resulted in the area having a very rich biological productivity.

\section{Criteria for inclusion $1(\mathrm{a})$ and $1(\mathrm{~b})$}

International and National Importance The wide range of habitats for waterfowl, and abundant foodsupply, have attracted many bird species to the site. Waterfowl numbers have further increased due to destruction of other wetlands in the Alpine region. $25 \%$ of the total waterfowl midwinter count in Bavaria and Austria occur in this area. Passage and wintering waterfowl include gadwall Anas strepera (1,900 maximum), mallard A. platyrhynchos $(10,500$ maximum), tufted duck Aythy'a fuligula (15,000-20,000), goldeneye Bucephala clangula (3,000-4,000), coot Fulica atra (8,000-15,000), ruff Philomachus pugnax (13,400 maximum), cormorant Phalacrocorax carbo sinensis (80-100), mute swan Cygnus olor (500 maximum), teal Anas crecca (4,200 maximum), red-crested pochard Netta rufina (120 maximum), lapwing Vanellus vanellus (8,000 maximum) and black-headed gull Larus ridibundus (30,000 maximum). Breeding species include great crested grebe Podiceps cristatus (100 pairs), little bittern Ixobrychus minutus (80 pairs), night heron Nycticorax nyticorax (80 pairs), purple heron Ardea purpurea (3 pairs), black-headed gull (1,670 pairs) and common tern Sterna hirunda (49 pairs). Beaver Caster fiber is present.

Changes in Ecological Character There is disturbance from fishing, hunting, recreation and forest clearance for agriculture. 
Management Practices No information

Scientific Research and Facilities Mainly avifaunal research. The ecological relationship of the four reservoirs has been studied since 1961 .

Principal Reference Material The above information is taken from documents supplied by the Government of the Federal Republic of Germany for designation in 1978, and for the Cagliari Conference in November 1980.

Supplemented by:

- Carp, E. (1980). A Directory of Western Palearctic Wetlands. IUCN, Gland, Switzerland.

- Scott, D.A. (1980). A preliminary inventory of wetlands of international importance for waterfowl in west Europe and northwest Africa. IWRB Special Publication No. 2.

Additional references:

- Haarmann, K. (1978). Erster Bericht über den Zustand der Feuchtgebiete internationaler Bedeutung in der Bundesrepublik Deutschland. Biol. Abh. Nr. 36, 28 pages.

- Haarmann, K. and Pretscher, P. (1976). Die Feuchtgebiete inernationaler Bedeutung in der Bundesrepublik Deutschland. Vogelkdl. Bibliothek Band 4, Greven: Kilda-Verlag, 102 pages.

- Haarmann, K. (1984). Feuchtgebiete internationaler Bedeutung und Europareservate in der Bundesrepublik Deutschland. Zweiter Zustandbericht (Stand: Januar 1983). Ottendorf: Niederelbe-Verlag, 12 pages. (Fordsand Buch No. 3.)

\section{Rieselfelder Münster}

Location $52^{\circ} 09^{\prime} \mathrm{N}, 7^{\circ} 39^{\prime} \mathrm{E}$. Situated $6 \mathrm{~km}$ north of the town of Münster in the Federal State of Nordrhein-Westfalen.

Area $233 \mathrm{ha}$

Degree of Protection The area is owned by the municipality of Münster and is administered by the Biological Station (Rieselfelder Münster, Wöstebach 11, 4400 Münster). It has been a Europareservat since 1978. Designated as a Ramsar site in 1983.

Site Description The site comprises about 140 ha water and 93 ha land. The water consists of shallow $(10-23 \mathrm{~cm})$ eutrophic ponds created by dredging, and the land is mainly agricultural with some woodland. It is a man-made environment originally used for sewage disposal. Dominant vegetation around the pools consists of celery-leaved crowfoot Ranunculus sceleratus, marsh yellow-cress Rorippa islandica, stinging nettle Urtica dioica, curled dock Rumex crispus, broad-leaved dock $R$. obtusifolius, redshank Polygonum persicaria, pale persicaria $P$. lapathifolium, tripartite bur marigold Bidens tripartita, Senecio sp., water plantain Alisma plantago-aquatica, hastate orache Atriplex hastata, reed Phragmites communis, reedgrass Phalaris arundinacea, great reedmace Typha latifolia, Gibbon's duckweed Lemna gibba and woody nightshade Solanum dulcamara.

Criteria for inclusion 2(a) and 2(c)

International and National Importance Rieselfelder Münster is the most important resting and moulting site for waders in the inner parts of the Federal Republic of Germany, and probably the principal summer resting and moulting site for teal Anas crecca and shoveler $A$. clypeata. Dominant species include lapwing Vanellus vanellus, snipe Gallingo gallingo, black-headed gull Larus ridibundus, mallard Anas platyrhynchos and reed bunting Emberiza schoenicus. 85 breeding species include 15 species listed in the Red Data Book (Federal Republic of Germany), including teal, shoveler, water rail Rallus aquaticus, snipe, redshank Tringa totanus, sparrow-hawk Accipiter nisus, hobby Falco subbuteo and turtle-dove Streptopelia turtur. 150 other bird species visit the site.

Changes in Ecological Character The site is endangered by possible industrial development in the immediate vicinity. 
Management Practices Present management practices include clearing overgrown areas, and regulation of visitors. Future management will include deepening of the ponds.

Scientific Research and Facilities The biological station at Rieselfelder has carried out ringing, moulting and ecological projects on ducks and waders for some years.

Principal Reference Material The above information is taken from documents supplied by the Government of the Federal Republic of Germany for designation in 1983.

Supplemented by:

- Carp, E. (1980). A Directory of Western Palearctic Wetlands. IUCN, Gland, Switzerland. Additional references:

- Haarmann, K. (1978). Erster Bericht über den Zustand der Feuchtgebiete internationaler Bedeutung in der Bundesrepublik Deutschland. Biol. Abh. Nr. 36, 28 pages.

- Haarmann, K. and Pretscher, P. (1976). Die Feuchtgebiete inernationaler Bedeutung in der Bundesrepublik Deutschland. Vogelkdl. Bibliothek Band 4, Greven: Kilda-Verlag, 102 pages.

- Haarmann, K. (1984). Feuchtgebiete internationaler Bedeutung und Europareservate in der Bundesrepublik Deutschland. Zweiter Zustandbericht (Stand: Januar 1983). Ottendorf: Niederelbe-Verlag, 12 pages. (Fordsand Buch No. 3.)

\section{Weserstaustufe Schlusselburg}

Location $52^{\circ} 23^{\prime}-52^{\circ} 30^{\prime} \mathrm{N}, 8^{\circ} 58^{\prime}-09^{\circ} 01^{\prime} \mathrm{E}$. Situated west of Hannover in the Federal State of Nordrhein-Westfalen.

Area 1,550ha (approx.)

Degree of Protection Ownership is divided between federal government, State of Nordrhein-Westfalen and private owners. The designated site contains three Nature Conservation Areas with the remaining area protected as Landscape Protection Areas. Designated as a Ramsar site in 1983.

Site Description The site comprises a section of the River Weser and a band of land on both banks between the town of Petershagen and the state border of Niedersachsen. Most of the land is used for agriculture comprising (95\% grassland and $5 \%$ woodland). The remainder is exploited for gravel extraction which has created eight lakes (3-5m depth). In periods of flood these lakes are in contact with the river water which is eutrophic and brackish. However, due to the influence of groundwater, the salinity of the lakes is usually less than that of the river.

Criteria for inclusion $1(\mathrm{~b})$

International and National Importance The site is important for passage and overwintering waterfowl, with 53 recorded species including pochard Aythya ferina $(2,500)$, goldeneye Bucephala clangula (1,500 maximum), goosander Mergus merganser ( 750 maximum) and golden plover Pluvialis apricaria (1,000 maximum). This wetland is the most important overwintering area in the northern Federal Republic of Germany for goldeneye. It has some 16 breeding species of waterfowl including white stork Ciconia ciconia (3-6 pairs).

Changes in Ecological Character There is increasing disturbance of waterfowl especially from water sports and angling. The area is threatened by further drainage and conversion of grassland to arable land.

\section{Management Practices No information}

Scientific Research and Facilities No information 
Principal Reference Material The above information is taken from documents supplied by the Government of the Federal Republic of Germany for designation in 1983.

Additional references:

- Haarmann, K. (1984). Drie neue Feuchtgebiete internationaler Bedeutung in der Bundesrepublik Deutschland. Ber. Dtsch. Sekt. Int. Rat. Vogelschutz 23.

\section{Unterer Niederrhein}

Location $51^{\circ} 36^{\prime}-51^{\circ} 50^{\prime} \mathrm{N}, 5^{\circ} 50^{\prime}-6^{\circ} 38^{\prime} \mathrm{E}$. Situated on the Netherlands border, $30 \mathrm{~km}$ northwest of Duisburg in the Federal State of Nordrhein-Westfalen.

Area 25,000 ha

Degree of Protection Ownership is part state and part private. The site is partially protected in five Nature Conservation Areas: Alter Rhein bei Bienen-Praest (340ha established in 1969), Xantener Altrhein (223ha/1969), Emmericher Wardt (313ha/1981), Reeser Wardt (24ha/1981) and Gänserastplatz ünterer Niederrhein (4,450ha/1980). Designated as a Ramsar site in 1983.

Site Description The site comprises part of the Lower Rhine floodplain on both sides of the river between the town of Wesel and the Netherlands border. It is mainly managed grassland used for grazing, but contains some small areas of woodland and arable land. There is gravel and sand extraction, which has created numerous artificial ponds and lakes which, together with the meadow dykes and old and present channels of the river, constitute a large area of open water. Water quality varies from mesotrophic/eutrophic in the gravel lakes to hyper-eutrophic and polluted in the river.

Criteria for inclusion 1(a), 1(b), 2(a) and 2(c).

International and National Importance The site is important for bean goose Anser fabalis, with $23 \%$ of the West European population overwintering here and the remainder of the population using the site as a resting area. Other resting or overwintering species include white-fronted goose Anser albifrons (20,000), lapwing Vanellus vanellus, coot Fulica atra, golden plover Pluvialis apricaria, pochard Aythya ferina, tufted duck A. fuligula and teal Anas crecca. Breeding species include lapwing, shovelor Anas clypeata and great crested grebe Podiceps cristatus. The area has 25 species considered threatened in the Federal Republic of Germany including teal, shoveler, water rail Rallus aquaticus, corncrake Crex crex, ruff Philomachus pugnax, redshank Tringa totanus, curlew Numenius arquata, snipe Gallingo gallingo and grey heron Ardea cinerea.

Changes in Ecological Character The site is threatened by further sand and gravel extraction, drainage, conversion of pasture to arable land, and expansion of recreational activities such as sailing, angling and camping.

Management Practices A number of measures are planned to improve the area for waterfowl including dredging of the old river channel in the Alter Rhein Nature Conservation Area.

Scientific Research and Facilities Some research has been carried out on the avifauna and conservation requirements of the wetlands.

Principal Reference Material The above information is taken from documents supplied by the Government of the Federal Republic of Germany for designation in 1983.

Supplemented by:

- Carp, E. (1980). A Directory of Western Palearctic Wetlands. IUCN, Gland, Switzerland. Additional references:

- Haarmann, K. (1984). Drie neue Feuchtgebiete internationaler Bedeutung in der Bundesrepublik Deutschland. Ber. Dtsch. Sekt. Int. Rat. Vogelschutz 23. (ICBP German Section report.) 


\section{GREECE}

Area 131,955 sq.km

\section{Population $9,740,417$ (1981 Census)}

Summary of Wetland Situation A number of the Greek wetlands are amongst the most important in the Mediterranean basin. They comprise rich ecosystems, with a wide variety of flora and fauna, and are important for nesting and migration, as well as for feeding and wintering of many water-bird species. With the accession of Greece to the Ramsar Convetion, 11 Greek wetlands have been designated as Wetlands of International Importance. However, the current situation regarding the conservation of these wetlands is not entirely satisfactory. This is attributed, to a certain degree, to the gaps and limitations of the existing legislation. However, under the recent Frame-law on the protection of the Environment (Law 1650/16 November 86), extensive and systematic protection of nature in general, and wetlands in particular, can be provided.

There has unfortunately been a considerable reduction in numbers of the waterfowl species in many wetlands in recent years. However, in others, as the lakes Kerkini, Vistonis, and parts of Amvrakikos and Mesolonghion Gulfs, bird populations seem to be in a relatively stable condition now, although there have been some problems over the past few years. Problems have largely occurred where natural vegetation and wildlife habitats have been affected by various human activities. These activities have included land reclamation, construction of river dams, illegal hunting and fishing, and agricultural pollution, in different degrees at each wetland. In some cases, wetlands have been threatened partly by urban and industrial pollution.

A series of assessment studies for the wetlands listed under the Convention have been initiated, which are gathering information on the status of the natural environment, and the threats and potential threats at each site. These assessments are also intended to indicate the main protective measures required within each area, and alreaay play an important role in the decision making process regarding the regulation of various activities in these sites. By using these studies and the instruments which are offered by the new legislation, and having the expression of relatively favourable disposition of Public Opinion and of the government services, it is likely that these wetlands will be more efficiently protected in the years to come.

Protected Areas Legislation The Presidential Decree 996/1971 enables the Greek Forest Service to establish National Parks and Aesthetic Forests, as well as Natural Monuments. Public Law $998 / 1979$ on forests and forest land protection, in addition to the above, includes in the protected areas "wetlands". Protection of flora and fauna is also provided by P.D. 61/1980 of the Greek Forest Service and Public Law 360/1976 Regional Planning and the Environment, Ministry of Coordination. Recently new legislation on the protection of the environment has also been passed (Law 1650/1986). Mikri Prespa lake was declared a National Park in 1974. For the rest of the listed wetlands in Greece planning protection is applied, and the Directorates of Physical Planning and of the Environment are reticent to grant permits for activities which could have negative affects on the wetland ecosystems (taking into account the protection measures proposed as a result of the wetlands assessment studies). The recent Frame-Law will be applied to all wetlands in Greece.

Protected Areas Administration The body responsible for the national parks and nature reserves is the Section of National Parks and Aesthetic Forests of the Greek Forest Service, Ministry of Agriculture. The coordinating body for all environmental activities is the Ministry of the Environment, Physical Planning, and Public Works, which has a Directorate of the Environment. 
Sites designated under the Convention

Accession on 21 August 1975 with 11 sites listed at accession

Amvrakikos gulf

Evros Delta

Group of lakes

- Lake Visthonis (Lake Bourou and Porto Lagos)

- Lake Mitrikou

- Lake Fanarion (Xirolimni)

- Lake Aroqhi (Karakatza)

- Lake Messi

- Lake Karakatzali (Ptelea-Elos-Limni)

Lake Kerkinitis

Lakes Volvis and Langada

National Park Mikra Prespa

Axios-Aliakmon-Loudias Delta

Lagoon of Gumburnou

Nestos Delta

Gulf of Mesolonghion

Lagoon of Kotichi

Government body responsible for administration of the Convention

Directorate of the Environment, Ministry of Environment, Physical Planning and Public Works, Patission 147, 11251 Athens.

\section{Amvrakikos Gulf}

Location $39^{\circ} 05^{\prime} \mathrm{N}, 20^{\circ} 50^{\prime} \mathrm{E}$. Situated on the Ionian coast, southwest of the town of Atra in the Prefectures (Nomos) of Prevezis and Artas, western Greece.

Area Approximately 26,000 ha

Degree of Protection Most of the coastal area is public property with some private or community owned areas. The wetland is administered by the Directorate of the Environment in collaboration with the local authorities and services. The area is currently unprotected except for Ramsar status, but there is an integrated Development Programme which is based on the effective environmental protection of the wetland. Designated as a Ramsar site at the time of ratification after 19 November 1974.

Site Description The gulf is a large, almost enclosed, shallow bay with brackish lagoons and extensive marshlands and reed swamps developed from silt deposited by the Lovros and Arakhthos rivers. It is connected to the Ionian Sea by a narrow channel near Prevesa. Extensive reedbeds of Phragmiles communis and Typha sp. fringe the lagoon and river deltas, and provide refuge and feeding grounds for breeding birds. The wetland has a high diversity of other plant communities including some remnant forests along the river courses. The lagoon is a very important fishing and spawning ground, and also supports an abundant herpetofauna with over 21 recorded species (University of Essen, 1979). Several small villages border the lagoon (including Smirtoula Kopraina and Preveza), and the road from Arta to Prevesa runs along the northern shore.

International and National Importance The site is one of only two sites in Greece where Dalmatian pelican Pelecanus crispus is known to breed.

Other breeding birds include white-eyed pochard Aythya nyroca, squacco heron Ardeola ralloides, little egret Egretta garzetta, black-crowned night heron Nycticorax nycticorax, black winged stilt Himantopus himantopus, glossy ibis Plegadis falcinellus, Kentish plover Charadrius alexandrinus, redshank Tringa tolanus and common tern Sterna hirundo. Stone curlew Burhinus oedicnemus and collared pratincole Glareola pratincola breed on the dry saltings. Large numbers of wintering birds including white spoonbill Platalea leucorodia 
avocet Recurvirostra avosetta, greylag goose Anser anser, wigeon Anas penelope, teal Anas crecca, pintail Anas acuta, northern shoveler Anas clypeata, common pochard Aythya ferina, coot Fulica atra and some cormorant Phalacrocorax pygmacus. Passage migrants include pelican Pelecanus onocrotalus and great egret Egretta alba. Other recorded species include purple heron Ardea cinerea, little bittern Ixobrychus minutus and white stork Ciconia ciconia.

Changes in Ecological Character There are several small settlements and associated access roads within the designated area. The deltic marshlands used to be more extensive ( $30 \mathrm{~km}$ by $10 \mathrm{~km}$ ), but much has been reclaimed for agriculture.

Management Practices An aquaculture (fisheries) development has been planned for a long section of the lagoon area. There is a Programme Agreement for the Amvrakikos area (signed on 27 March 1985), and the projects resulting from this Agreement have to be subject to an environmental impact study. Boundaries of three zones of protection covering the broader area, have been proposed by the Ministry of the Environment, and are under discussion before their final legal definition.

Scientific Research and Facilities The University of Essen (Federal Republic of Germany) carried out an ecological survey of the area in 1979. Project of Development and Environmental Protection: Ministry of the Environment, Physical Planning and Public Works, 1985-86.

Principal Reference Material The above information is taken from the Programme for determining the boundaries of the Ramsar Convention Wetlands - Ambrakikos Gulf - Ministry of the Environment, Physical Planning and Public Works - Athens, 1986.

Supplemented by:

- Duffey, E. (1982). National Parks and Reserves of Western Europe. Macdonald and Co., London.

- Joensen, A. H. and Madsen, J. (1985). "Waterfowl and Raptors Wintering in Wetlands of Western Greece, 1983-84" Natura Intlandica, Vol. 21, No. 11, pp 169-200.

- Scott, D.A. (1980). A preliminary inventory of wetlands of international importance for waterfowl in west Europe and northwest Africa. IWRB Special Publication No. 2.

- Sekliziotis, S. and Kainadas, E. (1980). National Report of Greece. Prepared for Technical Conference (Ramsar) held in Cagliari in November 1980. Ministry of Coordination, Athena.

- Sevastos, C.G. (1976). Greece. In Smart, M. (Ed.). International Conference on the Conservation of Wetlands and Waterfowl, Heiligenhafen, Federal Republic of Germany. Proceedings, 2-6 December 1974. IWRB, Slimbridge, England.

\section{Evros Delta}

Location $40^{\circ} 52^{\prime} \mathrm{N}, 26^{\circ} 00^{\prime} \mathrm{E}$. The Evros River forms the international boundary between Greece and Turkey. The delta is on the Aegean Sea to the west of Alexandroupolis in the Prefecture (Nomos) of Evrou in Thraki Province, northeast Greece.

Area Approximately 7,000 ha

Degree of Protection Public property. The wetland is administered by the Directorate of the Environment in collaboration with the local authorities and services. It is partially protected under the Decision passed by the National Council on 13 March 1980 and the Joint Ministerial Decision by the Ministers of Coordination and Agriculture on 3 May 1980 under which the conservation and management of the wetland is regulated. A number of shooting zones were established at the time of designation. A national park has been proposed which would include the wetland area. Designated as a Ramsar site at the time of ratification after 19 November 1974. 
Site Description The delta region contains a diversity of habitat types: offshore sand islands and dunes, halophytic marshlands interspersed with saltwater lagoons and managed artificial saltpans, the freshwater River Evros fringed with tamarix scrub, grassland or temporary freshwater marshes, and reedswamp fringing the scattered freshwater lagoons. Most of the inland delta has been reclaimed for agriculture and the canals are embanked by retaining dykes. The delta is a valuable supplementary feeding ground for 30 of the 36 birds of prey recorded in the hills to the north. The coastal lagoon is an important nursery area for mullet and prawn.

International and National Importance Despite considerable disturbance, the delta is an important breeding site for some bird species. Breeding birds include cormorant Phalacrocorax carbo, little cormorant Phalacrocorax pygmaeus, great egret Egretta alba, grey heron Ardea cinerea, purple heron Ardea purpurea, little bittern Ixobrychus minutus, Eurasian bittern Botaurus stellaris, ruddy shelduck Tadorna ferruginea, mallard Anas platyrhynchos, white-eyed pochard Aythya nyroca (fairly common breeder), oystercatcher Haematopus ostralegus, avocet Recurvirostra avosetta, black-winged stilt Himantopus himantopus, snowy plover Charadrius alexandrinus, lapwing Vanelus vanellus, redshank Tringa totanus and collared pratincole Glareola pratincola. Present but no longer breeding are squacco heron Ardeola ralloides, black-crowned night heron Nycticorax nycticorax, little egret $E$. garzetta and glossy ibis Plegadis falcinellus. Birds breeding successfully on the undisturbed sandy of shore islands are gull-billed tern Sterna nilotica, common tern $S$. hirundo, little tern $S$. albifrons and sandwich tern $S$. sandvicensis (first nesting record for Greece). Large numbers of some 240 resting or wintering species have been recorded including swan, geese, duck (Anatidae) and coot Fulica atra. Larus melanocephalus has also been recently observed to breed at the site.

Changes in Ecological Character The delta area has been disturbed by land reclamation schemes: the last remnant of gallery forest along the Greek side of the Evros River has been cleared for cultivation; almost all grassland areas (major feeding grounds for wintering geese) have been drained; the falling water level has opened up most of the important bird habitats to grazing cattle which are degrading the vegetation; and several new access roads will result in an increase of the already high hunting pressure (despite current legal restrictions). The breeding records for many species have consequently fallen, and some species have disappeared from the area such as greylag goose Anser anser, crane Grus grus, spoonbill Platalea leucorodia, and imperial eagle Aquilla heliaca. Formerly rich populations of cormorant have decreased to only a few non-breeding birds. Few of the waders in the lagoons and saltpans succeed in raising offspring (Hallmann, 1980). Recently, only a few individuals of white tailed eagle Haliaeetus albicilla have been observed, and only 30 glossy ibis Plegadis falcinellus were recorded during 1984.

Management Practices At the time of designation in 1974 the local authorities abolished the Evros Hunting Festival, shortened the open hunting season (now ending 31 January), established a number of no-shooting zones and limited the number of guns allowed in the area each day and the number of birds taken out by each hunter (10 duck, 3 geese and 35 coot). The coastal lagoons are fished commercially. Boundaries of three zones of protection, covering the broader area, have been proposed by the Ministry of the Environment and are being legally defined. Fishing, grazing and other activities are planned within the zone according to their potential impacts.

Scientific Research and Facilities WWF/IUCN Projects 1684 (birds of prey in Greece) and 1921 (national project for birds of prey) involved assessments of the wildfowl population of the delta. The site was visited and studied also, by a team in the context of the "Determination of boundaries of the Ramsar Convention wetlands" project (Ministry of the Environment, Physical Planning and Public Works). A biological station has been established by the Hellenic Society for the protection of Nature in the Delta area, and there are a few bird observation towers.

Principal Reference Material The above information is taken from:

- Sekliziotis, S. and Kainadas, E. (1980). National Report of Greece. Prepared for Technical Conference (Ramsar) held in Cagliari in November 1980. Ministry of Coordination, Athena. 
Supplemented by:

- Duffey, E. (1982). National Parks and Reserves of Western Europe. Macdonald and Co., London.

- Goutner, V. and Kattoulas, M.E. (in press). Breeding distribution of Lar i (Charadriiformes) in the Evros Delta, Greece.

- Hallman, B. (1980). Note on bird nesting and conservation in some Greek wetlands. IUCN/WWF Projects 1684 and 1921.

- Hallman, B. and Handrinos, G. (1984). Midwinter waterfowl census in Greece 1984. I.W.R.B. report.

- Hoffman, L., Bauer, W. and Muller, G. (1971). Proposals for Nature Conservation in northern Greece. IUCN Occasional Paper No. 1.

- Scott, D.A. (1980). A preliminary inventory of wetlands of international importance for waterfowl in west Europe and northwest Africa. IWRB Special Publication No. 2.

- Sevastos, C.G. (1976). Greece. In Smart, M. (Ed.). International Conference on the Conservation of Wetlands and Waterfowl, Heiligenhafen, Federal Republic of Germany. Proceedings, 2-6 December 1974. IWRB, Slimbridge, England.

\section{Group of lakes: Lake Visthonis (Lake Bourou and Porto Lagos, Lake Mitrikou, Lake Fanarion (Xirolimni), Lake Aroghi (Karakatza), Lake Messi and Lake Karakatzali (Ptelea-Elos-Limni).}

Location Visthonis Lake is centred at $41^{\circ} 03^{\prime} \mathrm{N}, 25^{\circ} 24^{\prime} \mathrm{E}$. The other lakes are centred at $41^{\circ} 00^{\prime} \mathrm{N}, 25^{\circ} 20^{\prime} \mathrm{E}$. The complex of coastal lakes and lagoons are situated on the northern Aegian coast between Porto Lago and Maronia in the Prefectures (Nomos) of Rodopis and Xanthis, Thraki Province, northeast Greece.

Area Visthonis Lake 5,000ha, Mitrikou Lake 400ha, Fanarion Lake 250ha, Aroghi lake 250ha, Messi Lake 400 ha and Karakatzali Lake 500ha.

Degree of Protection The lakes include both public and community property, and the wetland is administered by the Directorate of the Environement in collaboration with the local authorities and services. The area is currently not under a specific protection regime, except for Ramsar status, but there is an integrated study for the protection underway. Local authorities are responsible for fishing and hunting regulations, as well as forestry and housing development standards implementation. Designated as a Ramsar site at the time of ratification after 19 November 1974.

Site Description The site consists of a complex of freshwater and brackish lagoons and marshes, and includes the entire dune area and inshore coastal waters. Mitrikou Lake is a shallow freshwater lake fed by the Philiouris and Pospos Rivers. Vistonis is a shallow brackish system on which Porto Lagos is situated. It is fed by the Kosynthos, Komsatos and Travos Rivers, supports a prolific marshland vegetation, is fringed by extensive reedbeds of Phragmites communis, and is covered in summer by floating water chestnut Trapa natans, which attracts many waterfowl. To the south of there is an extensive area covered by halophytic and xerophytic vegetation. Cutlivated farmland surrounds the remainder of the wetlands. There are scattered settlements throughout the Vistonis-Porto Lagos lake complex, and the Xanthi-Porto Lagos road passes close to the western and southern shoreline of Lake Vistonis. The rest of the lakes are saline with Messi Lake having the highest salinity.

International and National Importance Vistonis Lake is one of the most imprtant resting and feeding grounds for waterfowl in Greece. It supports important colonies of glossy ibis Plegadis falcinellus, grey heron Ardea cinerea, black-crowned night heron Nycticorax nycticorax and little egret Egretta garzetta. In the late 1970s a new colony of grey heron, little egret and squacco heron Ardeola ralloides became established in a pine plantation near Porto Lagos. Many species of tern (Sterninae) and waders, such as grey-headed lapwing Vanellus cinereus occur in moderate numbers in nearby lagoons. Lake Mitrikou is the most important breeding site in Greece for whiskered tern Chlidonias hybrida. The lake complex is particularly important for wintering waterfowl and other bird species, including greylag 
goose Anser anser, white-fronted goose A. albifrons, shelduck Tadorna tadorna, ruddy shelduck $T$. ferruginea, wigeon, teal, mallard, pintail, northern shoveler, garganey (Anas penelope, A. crecca, A. platyrhynchos, A. acuta, A. clypeata, A. guerquedula), common pochard Aythya ferina, coot Fulica atra, cormorant Phalacrocorax carbo sinensis, pygmy cormorant and avocet. Dalmation pelican Pepecanus crispus and white pelican $P$. onocrotalus migrate through the area. Other breeding species include black tern $C$. niger, black-crowned night heron, squaccom heron, little egret, grey heron, purple heron Ardea purpurea, glossy ibis, white spoonbill Platalea leucorodia, little bittern Ixobrychus minutus, avocet Recurvirostra avosetta, Hoplopterus spinosus, and white-eyed pochard Aythya nyroca. Since 1984 in the lakes appears a large number of Phoenicopterus ruber.

Changes in Ecological Character Around the lakes there is a tendency for increasing agricultural and urban development, especially in the region east of the lake. There are also local pollution problems from chemicals sprayed on the surrounding agricultural land, which are entering the system via inflow channels, and also in some cases problems with decreased of the water level.

Management Practices Most of the lakes are exploited as fisheries. Dykes and canals have been constructed along the eastern edge of the Mitrikou Lake to maintain the integrity of the wetland. All activities have been taken into consideration in the Management Plan, and boundaries of three zones of protection, covering the broader area have been proposed by the Ministry of the Environment and are under discussion before their legal definition. Activities are planned within the zones according to their potential impacts (particulalry fishing, agriculture, grazing and construction).

Scientific Research and Facilities WWF/IUCN Projects 1684 (birds of prey in Greece) and 1921 (national project for birds of prey) included assessment studies of these areas. Studies for the ecological management and the pollution control of some of the lakes have been carried out by Greek Universities. The site was visited and studied also by a team in the context of "Determination of boundaries of the Ramsar Convention wetlands" project (Ministry of the Environment, Physical Planning and Public Works, 1986).

Principal Reference Material The above information is taken from the programme for determining the boundaries of the Ramsar Convention Wetlands. Ministry of the Environment, Physical Planning and Public Works - Athens, 1986.

Supplemented by:

- Duffey, E. (1982). National Parks and Reserves of Western Europe. Macdonald and Co., London.

- Hallman, B. (1980). Note on bird nesting and conservation in some Greek wetlands. IUCN/WWF Projects 1684 and 1921.

- Hoffman, L., Bauer, W. and Muller, G. (1971). Proposals for Nature Conservation in northern Greece. IUCN Occasional Paper No. 1.

- Scott, D.A. (1980). A preliminary inventory of wetlands of international importance for waterfowl in west Europe and northwest Africa. IWRB Special Publication No. 2.

- Sekliziotis, S. and Kainadas, E. (1980). National Report of Greece. Prepared for Technical Conference (Ramsar) held in Cagliari in November 1980. Ministry of Coordination, Athena.

- Sevastos, C.G. (1976). Greece. In Smart, M. (Ed.). International Conference on the Conservation of Wetlands and Waterfowl, Heiligenhafen, Federal Republic of Germany. Proceedings, 2-6 December 1974. IWRB, Slimbridge, England.

\section{Lake Kerkinitis}

Location $41^{\circ} 12^{\prime} \mathrm{N}, 23^{\circ} 06^{\prime} \mathrm{E}$. Situated in a military zone to the southeast of the intersection of the frontiers between Greece, Yugoslavia and Bulgaria in the Prefecture (Nomos) of Serron, northern mainland Greece.

Area Approximately $7,000 \mathrm{ha}-8,000 \mathrm{ha}$ (seasonal variation due to irrigation activities). 
Degree of Protection Public property. Existing legislation concerning prohibition of hunting in an area of 9,000 ha and management of felling and reclamation activities, is enforced by the local State Services (Prefecture). The definition of boundaries and a preliminary management plan are being legislated for by the responsible authority. Designated as a Ramsar sie at the time of ratification after 19 November 1974.

Site Description The site is an extensive shallow freshwater reservoir created in the 1950 s to supply the Serres plain with irrigation water from the Strymonas River. A small barrage and dam were constructed across the Strymon Valley resulting in the area between Mavrovouni in the south and Kerkini mountain in the north being gradually flooded by the river. An extensive littoral zone has since developed through the combined action of natural siltation and nutrient inflow, with a gradual rise and seasonal flutuation of the lake water level. The habitats formed are: (a) deep waters $(2 \mathrm{~m})$ covering an area of $6,500 \mathrm{ha}$, where water chestnut Trapa natans is growing, and most fish consuming birds such as pelicans, egrets and herons are feeding. During the summer, part of this area is transformed to mud islets and small water reservoirs; (b) Shallow waters, where a rich floating and submerged vegetation is growing, such as lilies Nymphaea, duckweed Lemna, water milfoil Myriophyllum and Potamogeton sp. (a very important breeding area for birds); (c) Shallow waters with Phragmites, Typha, Scirpus, Schocnoplectus, covering $1,000 \mathrm{ha}$ in the north (a very important breeding place for waterfowl); (d) Riverine forests along the river and estuary with Tamarix, Salix, Alnus, Populus, Platanus (tamarisk, willow, alder, poplar, plane) species (important bird breeding sites); (e) Sand and mud islets at the river banks (important as stands for birds); (f) Forests and bushes in the surrounding area, from Pinus, Fagus, Acer, Quercus, Pyrus species (important as breeding sites for birds of prey). There are several villages and towns near the lake.

International and National Importance The lake supports a relatively rich wildfowl species population in terms of both number and diversity. Winter observations (Hallmann, 1984) show that duck populations are still present in big numbers : Aythya ferina, Anas crecca, Anas platyrhynchos. Other species include Recurvirostra avosetta. Anser albifrons, Egretta alba, Pelecanus crispus, Phalacrocorax carbo, P. pygmaeus and Tachybaptus ruficollis, and species such as Pelecanus onocratalus, Platalea leucorodia, Ardeola ralloides, Egretta garzetta, etc., are reported to breed. Birds of prey, such as Haliaeetus albicilla. Circaetus gallicus, Hieraaetus fasciatus, Aquila pomarina, and Milvus migrans are breeding in nearby forests. Twenty five species on Annex I EEC Directive $79 / 409$ breed here. In total 227 bird species are found in the area, with 128 breeding. Two endemic sub-species of fish are found in the lake waters, Alburnus alburnus stumicae and Leuciscus cephalus macedonicus. Among the amphibians, most interesting is the presence of Triturus cristatus, T. vulgaris, and Hyla arborea. Reptiles such as Testudo hermanni, Lacerta viridis and Elaphe longissima are also reported. Mammals, such as Capreolus capreolus, Canis aureus, Canis Lupus, Felis catus and Lutra lutra, are found in the area.

Changes in Ecological Character The construction of a new dam in the same spot as the first one, was completed in 1982 and led to a rise in water levels (from $30.5 \mathrm{~m}$ to $38 \mathrm{~m}$ ) during the following spring. As a result, some of the habitats described (especially shallow waters with floating vegetation and Phragmites) have suffered alteration in extent. Bird populations have been affected, and some species have ceased breeding. However, the environmental impacts were not all negative. Parts of the riverine forests have been felled and the colonies of Egretta garzetla, Ardeola ralloides, Nycticorax nycticorax and Platalea leucorodia have moved to the bushes near the lake.

Management Practices Boundaries of three zones of protection covering the broader area have been proposed by the Ministry of the Environment, and are under discussion before their final legal definition. Activities are planned within the zones according to their potential impacts (in particular fishing, agriculture, grazing, felling and construction). 
Scientific Research and Facilities The Department of Ecology, University of Thessaloniki, is carrying out a project for the management of the habitats of Pelecanus crispus and other endangered bird species in wetlands of Northern Greece in collaboration with the Ministry of the Environment. The wetland was visited and studied by a scientific team in the context of the "Determination of boundaries of the Ramsar Convention Wetlands" project (Ministry of the Environment, Physical Planning and Public Works, 1986).

Principal Reference Material The above information is taken from the programme for determining the boundaries of the Ramsar Convention Wetlands - Lake Kerkini, Ministry of the Environment, Physical Planning and Public Works - Athens 1986. Supplementary and previous bibliographic references are available in the above edition.

Supplemented by:

- Duffey, E. (1982). National Parks and Reserves of Western Europe. Macdonald and Co., London.

- Hallman, B. (1980). Note on bird nesting and conservation in some Greek wetlands. IUCN/WWF Projects 1684 and 1921.

- Scott, D.A. (1980). A preliminary inventory of wetlands of international importance for waterfowl in west Europe and northwest Africa. IWRB Special Publication No. 2.

- Sekliziotis, S. and Kainadas, E. (1980). National Report of Greece. Prepared for Technical Conference (Ramsar) held in Cagliari in November 1980. Ministry of Coordination, Athena. Sevastos, C.G. (1976). Greece. In Smart, M. (Ed.). International Conference on the Conservation of Wetlands and Waterfowl, Heiligenhafen, Federal Republic of Germany. Proceedings, 2-6 December 1974. IWRB, Slimbridge, England.

\section{Lakes Volvi and Langada}

Location $40^{\circ} 40^{\prime} \mathrm{N}, 23^{\circ} 00^{\prime} \mathrm{E}$. Situated to the east of Thessaloniki in the prefecture (Nomos) of Thessalonikis, Makedhonia Province of northern Greece.

Area 13,000ha: Volvi Lake 8,000ha and Langada Lake 5,000ha.

Degree of Protection Mainly public property. The wetland is administered by the Directorate of the Environment in collaboration with local authorities and services. The area is currently unprotected except for Ramsar status. Local authorities are also responsible for fishing and hunting regulations, as well as forestry and housing development standards implementation. Designated as a Ramsar site at the time of ratification after 19 November 1974.

Site Description The site comprises two freshwater lakes which are connected across a narrow strip of land by an open channel. Lake Langada is located at the west side of Migdonia basin, and Lake Volvi at the central part of the east side. Lakgadi Lake is fed by the Bojdana River. The lakes are fringed with some areas of reedbeds Phragmites communis and patchy woodland of poplar Populus sp. or oak Quercus sp. and Paliurus sp. with shrubs. Most of the surrounding land is under arable cultivation. The strip of land between the lakes supports mature plane trees Platanus sp. which are used by nesting heron colonies. There are numerous villages in the vicinity of the lakes.

International and National Importance Approximately 204 bird species are found in some numbers in the area. The lakes are an important breeding ground for herons: black-crowned night heron Nycticorax nyctocorax, little egret Egretta garzetta, grey heron Ardea cinerea and stork Ciconia ciconia. Migrant visitors include white pelican Pelecanus onocrotalus, and Dalmatian pelican $P$. crispus, also feeding in the area. Occasional white-headed duck Oxyura leucocephala, great egret Egretta alba and white spoonbill Platalea leucorodia. Also large populations of coot Fulica atra winter at the lakes. 
Changes in Ecological Character There is a significant problem of water pollution due to fertilizers as, well as to the wastes from the town of Langada, which should be monitored and controlled. There would appear to be excessive hunting in the area because of neighbouring Thessaloniki, which seems to have negative impacts on the bird population. By determining specific areas for hunting (away from nests etc.) it is hoped that these impacts will be reduced.

Management Practices A preliminary management plan is being implemented. Boundaries of three zones of protection, covering the braoder area have been proposed by the Minitry of the Environment and are under discussion, before their final legal definition. Activities are planned within the zones according to their potential impacts, especially concerning fishing, agriculture, grazing and constructions.

Scientific Research and Facilities The site was visited and studied by a team in the context of the "Determination of boundaries of the Ramsar Convention Wetlands" project (Ministry of the Environment, Physical Planning and Public Works, 1986).

Principal Reference Material The above information is taken from the programme for determining the boundaries of the Ramsar Convention Wetlands - Lakes Volvi and Langada. Ministry of the Environment, Physical Planning and Public Works - Athens, 1986. Supplementary and previous bibliographic references are available in the above edition.

Supplemented by:

- Duffey, E. (1982). National Parks and Reserves of Western Europe. Macdonald and Co., London.

- Hoffman, L., Bauer, W. and Muller, G. (1971). Proposals for Nature Conservation in northern Greece. IUCN Occasional Paper No. 1.

- Scott, D.A. (1980). A preliminary inventory of wetlands of international importance for waterfowl in west Europe and northwest Africa. IWRB Special Publication No. 2.

- Sekliziotis, S. and Kainadas, E. (1980). National Report of Greece. Prepared for Technical Conference (Ramsar) held in Cagliari in November 1980. Ministry of Coordination, Athena.

- Sevastos, C.G. (1976). Greece. In Smart, M. (Ed.). International Conference on the Conservation of Wetlands and Waterfowl, Heiligenhafen, Federal Republic of Germany. Proceedings, 2-6 December 1974. IWRB, Slimbridge, England.

\section{National Park Mikra Prespa}

Location $40^{\circ} 45^{\prime} \mathrm{N}, 21^{\circ} 07^{\prime} \mathrm{E}$. Situated on the Greece/Albania frontier, west of the town of Florina in the Prefecture (Nomos) of Florinis, Makedhonia Province, northwest Greece.

\section{Area 5,200ha}

Degree of Protection Mainly public property. Three areas around the lake with reedbeds and dense vegetation were declared as reserves in 1971 to protect the pelican breeding colonies. The lake and a peripheral zone were declared a national park on 14 January 1974 by the Ministry of Agriculture under Presidental Decree 46/14/1/1974, and it is administered by the District Directorate of Forests, based at Florina. The wetland is administered in collaboration with local authorities and services. Designated as a Ramsar site at the time of ratification after 19 November 1974.

Site Description Lake Mikra Prespa is a shallow basin with a maximum depth of $7.70 \mathrm{~m}$, which, together with the neighbouring lakes of Ohrid, Megali, Prespa and Malik, is one of the deepest remains of the old Dassaritis Lake in the West Pelagonian massif of the Adriatic confluence. It lies between mountains at an altitude of $853 \mathrm{~m}$, and a sandy bar of alluvial deposits separates it from the Megali Prespa Lake. The lake is dimistic oligo-mesotrophic, but there is evidence that gradually it is becoming eutrophic. The flora of the park consists of 1249 wild plant species (Pavlidis, 1985). There are extensive areas of Phragmites australis, and many shallow lagoons of importance to breeding birds. Characteristic species of the aquatic 
ecosystem are: Nuphar lutea, Trapa natans, Nymphoides peltata, Nymphaea alba and Oenanthe aquatica. Salix cinerea. S. alba, S. fragilia and of the terrestrial ecosystem, Juniperus foetidissima. J. exelsa, Carpinus orientalis, Quercus sp., and Fagus sylvatica. There are also some endemic and rare species such as Centaurea prespana. 31 species of mammals have been reported in the area, among them Lutra lutra. Canis lupus, Ursus arctos, Lynx lynx and the introduced Myocaster coypus. The lake freezes over for a few days every year between December and February, and hence is of no importance for wintering wildfowl.

International and National Importance The lake is important for breeding water-birds, with large colonies using the marshlands. Particulalry important are the pelican colonies Pelicanus crispus and $P$. onocrotalus. As a result of the wide variety of biotopes and topography, the area is relatively species rich with over 200 species. Twenty two of the 74 bird species listed in Annex I of the EEC Directive on the conservation of wildbirds (79/409) breed in Prespa (Pyrovetsi et al, 1984): Phalacrocorax carbo sinensis, Neophron percnopterus, Nycticorax nycticorax, Gyps fulvus, Adeola ralloides, Circus aeruginosus, Egretta garzetla, Himantopus himantopus, Egretta alba, Glareola pranticola, Ardea purpurea, Tringa glareola, Plegadis falcinellus, Gelochelidon nilotica, Platalea leucorodia, Sterna sandvicensis, Aythya nycora, Sterna hirundo, Milvus migrans, Sterna albifrons, Haliaeetus albicilla and Chlidonias niger.

Changes in Ecological Character The introduced coypu are serously damaging the reedbeds and probably discouraging some birds from breeding in the area. There is a quarry which is still in operation. The local area is extensively farmed with some cattle grazing. The reedswamp is sometimes burnt illegally. Fishing continues. The park is a popular tourist attraction and has well developed road and trail systems. Changes have resulted in the eastern part of the wetland as a result of a programme which has included the improvement and extension of the irrigation network, and establishment of a fish breeding station.

Management Practices The national park is managed under the Lake Prespa management plan by a forest ranger and 3 forest service guards based at Laimos. Tourism is prohibited at bird nesting areas. The lake and the area around the lake are used, under certain conditions, for grazing and fishing by the local people. Hunting, fishing and other activities for visitors are prohibited or strictly controlled according to Park Regulations. Traditional agriculture is exercised around the lake to a certain degree.

Scientific Research and Facilities Several ornithological studies of the lake have been carried out, including some by the Ministry of Agriculture. A biological research station was established by the Hellenic Society for the Conservation of Nature between the villages of Mikrolimni and Kranies. There are bird observation towers at the lake.

Principal Reference Material The above information is taken from:

- Katsadorakis, G. (1986). Biotopes and vertebrates in Prespa Nationa IPark, Macedonia, Greece.

- Kousouris, T. and Diapoulis, A. (1983). Development and Protection of freshwater resources in Greece. Lake Mikri Prespa. I.O.K.A.E.

- Pavlidis, G. (1985). Geobotanical study of the National Park of lakes Prespa, NW Greece Part A (Ecology, Flora, Phytogeography, Vegetation). Thessaloniki, Greece.

- Pyrovetsi, M.D., Crivell, A.G., Gerakis, P.A., Karteris, M.A., Kastro, E.P., and Komninos, N. (1984). Integrated Environmental Study of Prespa National Park, Greece. Commission of the European Communities, DG XI (Contract E 83 1935/17-PM1/1983 D3 GR).

- Sekliziotis, S. and Kainadas, E. (1980). National Report of Greece. Prepared for Technical Conference (Ramsar) held in Cagliari in November 1980. Ministry of Coordination. Athena.

Supplemented by:

- Duffey, E. (1982). National Parks and Reserves of Western Europe. Macdonald and Co., London.

- Scott, D.A. (1980). A preliminary inventory of wetlands of international importance for waterfowl in west Europe and northwest Africa. IVRB Special Publication No. 2.

- Sevastos, C.G. (1976). Greece. In Smart, M. (Ed.). International Conference on the Conservation of Wetlands and Waterfowl, Heiligenhafen, Federal Republic of Germany. Proceedings, 2-6 December 1974. IWRB, Slimbridge, England. 
Additional information:

- Brosselin, M. and Molinier, A. (1968). Visite au lac de Mikra Prespa. Cyclostylé Bureau MAR, Paris.

- Broussalis, P. (1975). The Prespa National Park. Hellenic Society for the Protection of Nature, Athens.

- Crivelli, A. (1977). Mission en Grece du Nord. Rapport.

- Geroudet, P. (1975). Mikra Prespa, lac des pélicans. Nos oiseaux: 145-147.

- Hoffmann, L., Bauer. W. and Muller, G. (1971). Proposals for Nature Conservation in Northern Greece. IUCN Occasional Paper No. 1.

- Terrasse, J.F. and Brosselin, M. (1969). Avifaune d'un lac des Balkans: Mikra Prespa (Grece). L'Oiseau et la Revue Française D'Ornithologie 39:185-201.

- Thorpe, W.H., Cotton, P.T. and Holms, P.E. (1936). Notes on the birds of lakes Ochrid, Malik and Prespa. Ibis 13: 557-580.

\section{Axios - Aliakmon - Loudias Delta}

Location $40^{\circ} 34^{\prime} \mathrm{N}, 22^{\circ} 39^{\prime} \mathrm{E}$. Situated on the Thermaikos Gulf of the Aegean, southwest of Thessaloniki in the Prefecture (Nomos) of Imathios, Makedhonia Province, northern Greece.

\section{Area Approximately $2,000 \mathrm{ha}$}

Degree of Protection Public property. Local state authorities have now prohibited hunting in the area (1983), while fishing activities are regulated by national Laws. The definition of boundaries, and a preliminary management plan, are being legislated for by the responsible authority. Designated as a Ramsar site at the time of ratification after 19 November 1974.

Site Description The site comprises coastal saltwater lagoons and marshlands formed around the river mouths of the Axiou, Aliakmon and Loudias rivers. The whole length of the Axios river is embanked by retaining dykes. The vegetation comprises halophytic marshland along the shore succeeded inland by grassland and riverine forests. Characteristic species: Phragmites communis, Typha latifolia, Tamarix jampeana, Arthrocueum peren, Juncus aculus, Salix pedicellata, Salix alba, Populus alba, and Alnus glutinosa. There is apparently a high diversity of Cyanophycea and Chlorophycea. Dykes separate the wetland from reclaimed agricultural land, on which the principal crops are rice, wheat, cotton and maize. The grasslands are used for grazing. There are several villages and towns near the wetland.

International and National Importance Waterfowl numbers seem to be decreasing, but the site still supports significant breeding populations including black-crowned night heron Nycticorax nycticorax, squacco heron Ardeola ralliodes, little egret Egretta garzetta, mallard Anas platyrhynchos, shelduck Tadorna tadorna, collared pratincole Glareola pratincola and little tern Sterna albifrons. No longer breeding in the wetland are Mediterranean gull Larus melanocephala and slender-billed gull L. genei. In total 214 bird species are recorded in the area, of which 74 breed in the buffer zone. There are some 177 species seen on passage, and 61 wintering species. 56 bird species are included in ANNEX 1, of the EEC Directive 79/409. One endemic fish species, Gobio uranoscopus elimeins is found in the area, while 26 non-endemic species are recorded in Axios river and 30 in Aliakmon. Seven amphibians have been recorded, and 15 reptiles including Emys orbicularis and Testudo hermanni. Most outstanding of the 17 recorded species of mammals is Lutra lutra.

Changes in Ecological Character The delta area has been considerably modified by an extensive land reclamation scheme for agriculture. All three rivers, and especially Axios, are continually adding to the littoral zone as a result of excessive siltation. Fertilizers and wastes have altered the water qualities towards eutrophication, and are affecting the ecological character of the whole delta. Illegal hunting is also putting pressure on the bird population to some extent. 
Management Practices Local authorities are responsible for fishing and hunting regulations. Boundaries of three zones of protection covering the broader area have been proposed by the Ministry of the Environment, and are being legally defined. Fishing, grazing and farming activities are planned within the zones, according to their potential impacts.

Scientific Research and Facilities Several laboratories of the University of Thessaloniki, such as those of Ecology, Botany, Agriculutral Planning, and Torrent Water Management, are carrying out projects. The wetland was also visited and studied by a scientific team in the context of the "Determination of boundaries of the Ramsar Convention Wetlands" project (Ministry of the Environment, Physical Planning and Public Works, 1986).

Principal Reference Material The above information is taken from the programme for determining the boundaries of the Ramsar Convention wetlands - Axios - Aliakmon - Loudias Delta. Ministry of the Environment, Physical Planning and Public Works - Athens, 1986. Supplementary and previous bibliographic references are available in the above edition.

Supplemented by:

- Duffey, E. (1982). National Parks and Reserves of Western Europe. Macdonald and Co., London.

- Hoffman, L., Bauer, W. and Muller, G. (1971). Proposals for Nature Conservation in northern Greece. IUCN Occasional Paper No. 1.

- Scott, D.A. (1980). A preliminary inventory of wetlands of international importance for waterfowl in west Europe and northwest Africa. IWRB Special Publication No. 2.

- Sekliziotis, S. and Kainadas, E. (1980). National Report of Greece. Prepared for Technical Conference (Ramsar) held in Cagliari in November 1980. Ministry of Coordination, Athena.

- Sevastos, C.G. (1976). Greece. In Smart, M. (Ed.) International Conference on the Conservation of Wetlands and Waterfowl, Heiligenhafen, Federal Republic of Germany. Proceedings, 2-6 December 1974. IWRB, Slimbridge, England.

\section{Nestos Delta and Lagoon of Gumburnou}

Location Nestos Delta is centred on $40^{\circ} 57^{\prime} \mathrm{N}, 24^{\circ} 31^{\prime} \mathrm{E}$. Gumburmou Lagoon is centred on $40^{\circ} 53^{\prime} \mathrm{N}, 24^{\circ} 47^{\prime} \mathrm{E}$ to the west of Nestos river mouth. The town of Keramoti is on the coast between the two Ramsar sites. Situated in Kavalas Prefecture (Nomos), northeast Greece.

Area 1,800 ha (combined area)

Degree of Protection Public property and private property. The wetland is administered by the Directorate of the Environment in collaboration with local authorities and services. The area is unprotected except for Ramsar status. Local authorities are responsible for fishing and hunting regulations. Designated as separate Ramsar sites at the time of ratification after 19 November 1974.

Site Description The designated sites are: the area around the mouth of the Nestos river including reclaimed agricultural land and a few freshwater lagoons; and Gumburnou Lagoon at the western extreme of the delta, west of Keramoti. Most of the delta is covered by shrubland, grassland and agricultural crops, with a relict area of previously extensive groundwater forest (Kotzia Orman Wood) along the rivercourse near the mouth. Most of the Nestos river is embanked by retaining dykes to separate it from the cultivated reclaimed land. Gumburnou saltwater lagoon supports an abundant fish population.

International and National Importance Nestos Delta is an important breeding ground for spurwinged plover Hoplopterus spinosus (largest breeding population in Europe), purple heron Ardea purpurea, little egret Egretta garzetta, squacco heron Ardeola ralloides (occasional), avocet Recurvirostra avosetta and gull-billed tern Sterna nilotica. Mediterranean gull Larus melanocepha!a no longer breed in the delta area, but Gumburnou Lagoon still 
supports a population. Visitors to the delta area include little cormorant Phalacrocorax pygmaeus, Dalmatian pelican Pelecanus crispus, red-necked grebe Podiceps grisegena (occasionally breeding at Gumburnou), several species of rail (Rallidae) and gull (Laridae) and many duck (Anatidae) and coot Fulica atra.

Changes in Ecological Character Extensive reclamation schemes have converted much of Nestos Delta into cultivated agricultural land and Chryssoupolis Plain is being reclaimed.

Management Practices A preliminary management plan is being implemented.

Scientific Research and Facilities The site was visited and studied by a team in the context of the "Determination of boundaries of the Ramsar Convention Wetlands" project (Ministry of the Environment, Physical Planning and Public Works, 1986).

Principal Reference Material The above information is taken from the programme for determining the boundaries of the Ramsar Convention Wetlands - Nestos Delta. Ministry of the Environment, Physical Planning and Public Works - Athens, 1986. Supplementary and previous bibliographic references are available in the above edition.

Supplemented by:

- Duffey, E. (1982). National Parks and Reserves of Western Europe. Macdonald and Co., London.

- Hoffman, L., Bauer, W. and Muller, G. (1971). Proposals for Nature Conservation in northern Greece. IUCN Occasional Paper No. 1.

- Scott, D.A. (1980). A preliminary inventory of wetlands of international importance for waterfowl in west Europe and northwest Africa. IWRB Special Publication No. 2.

- Sekliziotis, S. and Kainadas, E. (1980). National Report of Gresce. Prepared for Technical Conference (Ramsar) held in Cagliari in November 1980. Ministry of Coordination, Athena.

- Sevastos, C.G. (1976). Greece. In Smart, M. (Ed.) International Conference on the Conservation of Wetlands and Waterfowl, Heiligenhafen, Federal Republic of Germany. Proceedings, 2-6 December 1974. IWRB, Slimbridge, England.

\section{Gulf of Mesolonghion}

Location $38^{\circ} 24^{\prime} \mathrm{N}, 21^{\circ} 25^{\prime} \mathrm{E}$. Situated in the extreme west of the south coast of mainland Greece on the Gulf of Patraikos on the Ionian Sea. In the Prefecture (Nomos) of Etoloakarnanias, Aitolia Province.

Area Approximately 10,000ha

Degree of Protection Mainly public property. The wetland is administered by the Directorate of the Environment in collaboration with the local authorities and services. The area is currently unprotected except for Ramsar status. Local authorities are responsible for fishing and hunting regulations. Designated as a Ramsar site at the time of ratification after 19 November 1974.

Site Description The site comprises brackish coastal lagoons, mudflats, saltmarshes, dunelands, sandbars and reclaimed polder, and it includes the deltas of the Acheloos and Evinos rivers. Freshwater inflow to the lagoon is from Lake Aitolikon and several streams. There are saltworks around Messolongion township. The local climate, topography and geomorphology of the gulf make it one of the most productive fishing grounds in Greece.

International and National Importance The Gulf of Mesolonghion is considered an important area for breeding and wintering of large bird populations. It is also an important area for rare and threatened waterfowl, and a principal migratory route recovery station. There are about 226 species of birds recorded here, approximately two-thirds of the number of species found in Greece. Out of these 135 species are seen regularly, and 95 species occur all year round. 
Characteristic species occuring in the area are Fulica atra. Himantopus himantopus, Sterna albifrons etc., as well as many raptor species breeding in the nearby hills and mountains and feeding in the area. Other species such as Anas penelope. Aythya ferina, Pelecanus crispus, Tadorna tadorna, Phalacrocorax carbo, Egretta garzetta, Egretta alba. Netta rufina, etc., occur in large numbers.

Changes in Ecological Character Large areas of the coastal lagoon system were reclaimed for agriculture but the crop production was not very successful. Other areas have been developed as commercial saltworks. Plans to extend the saltworks to cover about 2,900 ha of the lagoon started to be implemented in 1980, but the constructions stopped in the same year. Nevertheless, the modification of the landscape resulting from these activities has led to population decline of many species, and especially of geese, mallard, gadwall and teal which breed at the lagoon.

Management Practices The lagoons (Mesolonghion and Klisova) are intensively fished, and the saltworks are in operation. Boundaries of three zones of protection covering the broader area have been proposed by the Ministry of the Environment, and are under discussion before their final legal definition, and the impacts of these activities have been taken into consideration in the Management Plan. Local authorities are responsible for fishing and hunting regulations.

Scientific Research and Facilities The site was visited and studied by a team in the context of the "Determination of boundaries of the Ramsar Convention Wetlands" project (Ministry of the Environment, Physical Planning and Public Works, 1986).

Principal Reference Material The above information is taken from the programme for determining the boundaries of the Ramsar Convention Wetlands - Mesolonghion. Ministry of the Environment, Physical Planning and Public Works, Athens, 1986. Supplementary and previous bibliographic references are available in the above edition.

Supplemented by:

- Britton (April 1979). Environmental impact of proposed new salinas at Messolonghion.

Report.

- Scott, D.A. (1980). A preliminary inventory of wetlands of international importance for waterfowl in west Europe and northwest Africa. IWRB Special Publication No. 2.

- Sekliziotis, S. and Kainadas, E. (1980). National Report of Greece. Prepared for Technical Conference (Ramsar) held in Cagliari in November 1980. Ministry of Coordination, Athena.

- Sevastos, C.G. (1976). Greece. In Smart, M. (Ed.) International Conference on the Conservation of Wetlands and Waterfowl, Heiligenhafen, Federal Republic of Germany. Proceedings, 2-6 December 1974. IWRB, Slimbridge, England.

\section{Lagoon of Kotichi}

Location $38^{\circ} 00^{\prime} \mathrm{N}, 21^{\circ} 18^{\prime} \mathrm{E}$. Situated on the northwest coast of the Peloponnesus Peninsula on the Ionian Sea in the Prefecture (Nomos) of Ilias, Ilia Privince, southern Greece.

\section{Area Approximately 800 ha}

Degree of Protection Mainly public property. The wetland is administered by the Directorate of the Environment in collaboration with the local authorities and services. The area is currently unprotected except for Ramsar status. Local authorities are also responsible for fishing and hunting regulations, as well as forestry and housing development standards implementation. Designated as a Ramsar site at the time of ratification after 19 November 1974. 
Site Description The site comprises a small coastal freshwater lagoon and associated marshes isolated from the sea by dunes except for a narrow connecting channel. It is fed by several small streams which deposit a high content of suspended matter in the lagoon. This sedimantation process is steadily reducing the area of open water. The water is fringed with low vegetation which grades into grassland and finally agricultural land.

International and National Importance The lagoon is the largest existing wetland in Peloponnesus, and therefore very important (especially since the draining of the lakes Agoulinitsa and Mouria). It is also in an important geographic location, being on the western migratory route of birds in Greece. No recent figures of bird number are available, but there are excellent conditions for wintering of many ducks due to the mild winter. The predominant species in the area include mallard Anas platyrhynchos, wigeon $A$. penelope, pintail $A$. acuta, shoveler A. clypeata

little egret Egrella garzella and purple heron Ardea purpurea. Various birds of prey have also been observed as well as the rare great egret Egretta alba and Dalmation pelican Pelecanus crispus.

Changes in Ecological Character In 1980 a privately owned 50ha fishpond was being constructed on the northeastern part of the lagoon. No major reclamation schemes are planned. No important changes have been made in the lagoon during the last years.

Management Practices A preliminary management plan is being implemented. Main activities are fishing and agriculture, with grazing in the nearby areas. The impacts of each of these activities have been taken into consideration in the Management Plan. Boundaries of three zones of protection covering the broader area, have been proposed by the Ministry of the Environment, and are under discussion before their final legal definition.

Scientific Research and Facilities The site was visited and studied by a team in the context of the "Determination of boundaries of the Ramsar Convention Wetlands" project (Ministry of the Environment, Physical Planning and Public Works, 1986).

Principal Reference Material The above information is taken from the programme for determining the boundaries of Ramsar Convention Wetlands - Kotichi Lagoon. Ministry of the Environment, Physical Planning and Public Works - Athens, 1986. Supplementary and previous bibliographic references are available in the above edition.

Supplemented by:

- Scott, D.A. (1980). A preliminary inventory of wetlands of international importance for waterfowl in west Europe and northwest Africa. IWRB Special Publication No. 2.

- Sekliziotis, S. and Kainadas, E. (1980). National Report of Greece. Prepared for Technical Conference (Ramsar) held in Cagliari in November 1980. Ministry of Coordination, Athena.

- Sevastos, C.G. (1976). Greece. In Smart, M. (Ed.) International Conference on the Conservation of Wetlands and Waterfowl, Heiligenhafen, Federal Republic of Germany. Proceedings, 2-6 December 1974. IWRB, Slimbridge, England. 


\section{HUNGARY}

Area $93,030 \mathrm{sq} \cdot \mathrm{km}$

\section{Population $10,679,000(1984)$}

Summary of Wetland Situation The formerly vast area of 'puszta' or steppe in north-eastern Hungary has undergone dramatic changes, and much of its formerly characteristic flora and fauna has declined or disappeared. The famous Hortobàgy steppe (about $60,000 \mathrm{ha}$ ) has become interspersed with arable land and rice fields, although fishponds still account for about 700 ha. Nevertheless, considerable numbers of geese continue to frequent the steppe on migration and in winter, including white-fronted, greylag and lesser white-fronted geese.

The Biharagra fishpond complex, situated in an 8,000-10,000ha area of steppe and cultivation close to the Romanian border, provides wintering grounds for upwards of 15,000 white-fronted geese. Further south and west, the 100 ha natron lake of Kardoskut (surrounded by about 2,000 ha of fescue grass plains), declared a Nature Protection Area in 1965, remains fairly free from disturbance, and has become attractive to geese despite some scattered cultivation. Over 50,000 migrating and wintering white-fronted geese have been recorded, together with several hundreds, sometimes thousands of bean geese and several thousand lesser white-fronts. The nearby Pitvaros area, a complex of small, highly mineralized, eutrophic natron lakes in grassy plains (again with some cultivation), is also favoured by geese, their numbers building up when Kardoskut reaches saturation point.

In Central Hungary, another group of alkaline fishponds (of which the best known is the Feher To) is situated in the Tisza River valley. Feher To extends over about 850 ha and once attracted the country's third largest concentration of geese; although numbers have now declined as a result of over-hunting, oilfield exploitation and fisheries. Other natron lakes in the Pusztaszer area include Csaj To, Donger To, Saser and Labodar, each surrounded by characteristic alkaline steppe and marshes fed by rainwater. Breeding birds include avocet, and kentish plover, numerous duck, waders and herons may be present during migration periods. The area is also of considerable limnological interest. Lastly, in this region, the floodplains of the River Tisza further upstream, included in the Màrtély Landscape Conservation Area, are of great ornithological and botanical interest.

In the zone between the Tisza and Duna (Danube), the Szedlidi To and Kunfehér To are eutrophic soda lakes of great limnological interest. In western Hungary there is the Tata fishpond area, the importance of which is enhanced by the fact that one of the ponds and its associated channels are fed by warm springs (which prevent the water freezing). Lake Velence (Velencia To), lying between Budapest and Lake Balaton, is again of limnological interest as well as harbouring large flocks of bean goose in winter. Lake Balaton itself is the largest lake in Central Europe (around 55,000ha), with a typically 'Pannonian' character reflected in its flora and fauna. Its eutrophication is, however, increasing, and recreational activities have eliminated much of the shallow, sparsely vegetated marginal zone formerly used by roosting geese, forcing them to roost in deep open water. Little or $\mathrm{K}$ is Balaton, adjoining the main lake on the south-west, has hardly any open water, but its dense reedbeds provide cover for numerous nesting species, of which the night heron, squacco heron, little egret are among the more noteworthy. The wintering geese in the Balaton area may number as many as 40,000 (largely bean geese).

Protected Areas Legislation The Nature Conservation Act (1935) enabled the declaration of areas and natural assets as protected. The Nature Conservation Act (1961) established a national supreme body for the management of nature conservation, the National Authority for Environmental Protection. A Government Decree of 1972 provides for the establishment of national parks. The latest Nature Conservation Act was passed in 1982. Areas are protected as National Parks, Landscape Protection Areas, or Nature Conservation Areas, with the latter two repeated at a local level. It is worth noting that all caves in Hungary are apparently also protected. 
Protected Areas Administration At the national level nature conservation is supervised by the National Authority for Environment Protect and Nature Conservation (OKTH). This organisation has seven inspectorates which actually carry out management. The national parks are managed by their own Directorates, which are themselves part of the OKTH. Several other ministries and departments also have an interest in nature conservation, as do certain local administrations.

\title{
Sites designated under the Convention
}

Accession 11 April 1979 with 8 sites listed at accession

\author{
Szaporca Reserve \\ Velence-Dinnyés Reserve \\ Kardoskut Reserve \\ Kisbalaton or Little-Balaton Reserve \\ Màrtély Landscape Protection Area \\ Kiskunsàgi National Park \\ Pusztaszer Landscape Protection Area \\ Hortobàgy National Park
}

Government body responsible for administration of the Convention

National Authority for Environment Protection and Nature conservation (OKTH), PO Box 33, Budapest 1531

\section{Szaporca Reserve}

Location $45^{\circ} 50^{\prime} \mathrm{N}, 18^{\circ} 06^{\prime} \mathrm{E}$. Situated near Ilma-Puzzla village south of Pécs in Baranyo Province, southern Hungary near the Yugoslavia frontier.

\section{Area 250 ha}

Degree of Protection Owned by the state and agricultural cooperatives. Szaporca has been protected as a reserve since 1969 under the Register of Nature Conservation No. 89/TT/69. Designated as a Ramsar Site at the time of accession on 11 April 1979.

Site Description The site comprises a marshy oxbow lake derived but now separated from the Drava River. Most of the lake has now been invaded by reedbeds, and only a few brackish open water pools remain. The vegetation is dominated by Phragmites communis with some willow Salix sp. There is a rich and varied aquatic vegetation including water lily Nymphaea alba and water soldier Stratiotes aloides in the pools. The village of Ilma-Puszta lies in the central area enclosed on three sides by the isolated meander, with the river Drava flowing on the remaining side. The boundaries of the reserve are defined by the extent of flooding, and follow effectively the banks of the once-filled oxbow lake.

International and National Importance The site is an important nesting area for a number of waterfowl species including little egret Egretta garzetta, squacco heron Ardea ralloides, purple heron Ardea purpurea, white-eyed pochard Aythya nyroca, pochard A. ferinca, mallard Anas platyrhynchos and gadwall $A$. strepera.

Changes in Ecological Character None reported (1980)

Management Practices No information

Scientific Research and Facilities No information

Principal Reference Material The above information is taken from the document submitted at the time of accession in April 1979 and the National Report (1980) prepared for the Conference on the Conservation of Wetlands of International Importance especially as Waterfowl Habitat held in Cagliari, Italy in November 1980. 


\section{Velence - Dinnyés Reserve}

Location $47^{\circ} 10^{\prime} \mathrm{N}, 18^{\circ} 32^{\prime} \mathrm{E}$. Situated on the Lake of Velence, $45 \mathrm{~km}$ southwest of Budapest and $12 \mathrm{~km}$ east of Székesfehérvar in Fejer Province, west central Hungary.

Area 1,000 ha (part of a 24,000 ha lake and marshland complex).

Degree of Protection Owned by agricultural cooperatives and the state. The site is protected as Velence (established 1958) and Dinnyés (established 1966) Conservation Areas. Designated as a Ramsar Site at the time of accession on 11 April 1979.

Site Description The site comprises the disjunct Velence and Dinnyés conservation areas. Velence CA comprises a corner of the extensive Velence Lake fringed with extensive reedbeds of Phragmites communis with a rich and varied submerged vegetation in the eutrophic shallow waters. Dinnyes comprises the neighbouring moorland and periodically flooded pastures bordering the lake. Lake Velence was formed as a result of volcanic activity. A railway and main road between Budapest and Szekesfehervar run between the two conservation areas.

International and National Importance The site is the most significant area in Hungary for nesting and migrating waterfowl, including a major heronry of grey heron Ardea cinerea, purple heron A. purpurea, great egret Egretta alba and Eurasian bittern Botaurus stellaris. Other species include red-necked grebe Podiceps grisegena, white spoonbill Platalea leucorodia, greylag goose Anser anser, gadwall Anas strepera and black-headed gull Larus ridibundus. Large numbers of migrant geese visit the lake in winter including up to 20,000 bean goose Anser fabalis.

Changes in Ecological Character There is increasing pressure from development of recreation facilities on the lakeshore.

Management Practices The reedbeds are harvested annually, and there is a commercial fishery on the lake. Visitor access by permit only.

Scientific Research and Facilities Bird counts and observations have been carried out by the Ornithological Institute. There have been hydrobiological, botanical and zoological studies. There is a small research laboratory on the lakeshore.

Principal Reference Material The above information is taken from the document submitted at the time of accession in April 1979 and the National Report (1980) prepared for the Conference on the Conservation of Wetlands of International Importance especially as Waterfowl Habitat held in Cagliari, Italy in November 1980.

- Carp, E. (1980). A Directory of Western Palearctic Wetlands. IUCN, Gland, Switzerland.

Additional references:

- Donasky (1959). Das Leben des Szelider Sees. Budapest.

- Ruttkay, Tilesch and Veszprémi (1964). Nadgazdalkodas (reedculture). Budapest.

\section{Kardoskut Reserve}

Location $40^{\circ} 30^{\prime} \mathrm{N}, 20^{\circ} 28^{\prime} \mathrm{E}$. Situated to the west of the Tizza River, north of Szeged in Csongrad Province, southeast Hungary.

Area 500ha

Degree of Protection Cooperative ownership. Kardoskut has been protected as a reserve (conservation area) since 1965 under the Register of Nature Conservation No. 85/TT/66. Designated as a Ramsar Site at the time of accession on 11 April 1979. 
Site Description The site comprises the soda lake $(100 \mathrm{ha})$, associated marshlands and surrounding sodic meadow. One third of the shallow lake $(0.1-0.3 \mathrm{~m})$ is filled by reedbeds of Phragmites communis. The lake is extremely alkaline with a $\mathrm{pH}$ of 9 to 10 , and it frequently dries out during the dry summer months (July-September) leaving the white soda deposits from which its name Feher-to (white lake) is derived. It is fed by runoff from nearby high ground. Plant associations are typical of halophytic and heath vegetation growing in saline marshes and on sodic soils: Bolboschoenetum-Chenopodietosum botryoides, Bolboschoenetum-Phragmitetosum; Bolboschoenetum-Puccinellietonum; Agrosti-Caricetum distantis; Plantago maritima; Camphorosmetum annuae; Puccnellietum limosae; Salsola soda; Suaedetum maritimae-Crypsis; Acorelletum pannonici, Camphorosma-Fesuca pseudovina; and Astralago-Poetum angustifoliae typicum. The north side of the area is flanked by the Kardoskut-Hodmezovasarhely road and the east side by the Bekessomson road.

International and National Importance The highest concentration of geese in Hungary $(40,000-100,000)$ occur at the soda lake in late autumn, of which $90 \%$ are white-fronted goose Anser albifrons, $5 \%$ bean goose $A$. fabalis and $5 \%$ lesser white-fronted goose $A$. erythropus. Visiting migrants include crane Grus grus (5,000-10,000 October/November), mallard Anas platyrhynchos (up to 100,000), Eurasian curlew Numenius arquta, whimbrel $N$. phaeopus and numerous waders Limicola sp. Major breeding species are avocet Recurvirostra avoselta, Kentish plover Charadrius alexandrinus, black-tailed godwit Limosa limosa and lapwing Vanellus vanellus. The blind mole rat Spalax leucodon which is threatened in Hungary is reported to occur in the conservation area.

Changes in Ecological Character Grazing is allowed on the pastures surrounding the lake.

Management Practices Access to the site is restricted and visitors require permits.

Scientific Research and Facilities Bird counts and observations have been carried out by the Ornithological Institute.

Principal Reference Material The above information is taken from the document submitted at the time of accession in April 1979 and the National Report (1980) prepared for the Conference on the Conservation of Wetlands of International Importance especially as Waterfowl Habitat held in Cagliari, Italy in November 1980.

\section{Kisbalaton (Little Balaton) Reserve}

Location $46^{\circ} 40^{\prime} \mathrm{N}, 17^{\circ} 14^{\prime} \mathrm{E}$. Situated $5 \mathrm{~km}$ from the southwest corner of Balaton Lake, west of Balatonszentgyorgy in Somogy Province, west central Hungary.

Area 1,400 ha

Degree of Protection State ownership. The site has been protected as a strict nature reserve since 1951. Designated as a Ramsar Site at the time of accession on 11 April 1979.

Site Description The site comprises a marshy area centred around the Zala River Delta with some relict shallow open-water ponds and a raised island. The area was once part of the extensive Balaton Lake which become isolated from the river and filled in by alluvium deposition. The marshland is predominated by reedbeds of Phragmites communis with occasional stands of willow Salix spp., reedmace Typhia spp. and sedges (Cyperaceae), on $2-3 \mathrm{~m}$ of peaty soil. The small eutrophic ponds support a rich and varied aquatic vegetation including waterlily Nymphaea alba, yellow waterlily Nuphar lutea and water soldier Stratiotes aloides. The marsh complex is fed by the Zala River and several small canals (one of which defines the northern boundary of the site) and sometimes dries out during dry summers. 
International and National Importance The site is an important breeding ground for numerous bird species including cormorant Phalacrocorax carbo sinensis (only colony in Hungary), grey heron Ardea cinerea, purple heron $A$. purpurea, squacco heron Ardeola ralloides, black-crowned night heron Nycticorax nycticorax, great egret Egrelta alba, little egret E. garzetta, Eurasian wigeon Botaurus stellaris, white spoonbill Platalea leucorodia, greylag goose Anser anser, mallard Anas platyrhynchos, garganey Anas querquedula, northern shoveler Anas clypeata, gadwall Anas strepera, pintail Anas acuta, pochard Aythya ferina, white-eyed pochard Anas nyroca, lapwing Vanellus vanellus, Eurasian curlew Numenius arquata, black-tailed godwit Limosa limosa and common snipe Gallinago gallinago. It is less significant as a resting station, but principal migrants are goldeneye Bucephala clangula, tufted duck Aythya fuligula, geese Anser spp. and duck Anas spp.

Changes in Ecological Character The process of sedimentation is continuing to reduce the area of open water, and combined with the expansion of the reedbeds, could lead to eventual desiccation of the wetland.

Management Practices A regulated amount of reed cutting is allowed. Visitor access is by permit only, and is prohibited during the bird breeding season.

Scientific Research and Facilities Bird counts, observations and ringing programmes have been carried out by the Ornithological Institute. The Hungarian Academy of Sciences has been studying the hydrobiology and vegetation of the marshland. There is a field research station and several bird observation towers.

Principal Reference Material The above information is taken from the document submitted at the time of accession in April 1979 and the National Report (1980) prepared for the Conference on the Conservation of Wetlands of International Importance especially as Waterfowl Habitat held in Cagliari, Italy in November 1980.

- Carp, E. (1980). A Directory of Western Palearctic Wetlands. IUCN, Gland, Switzerland. Additional references:

- Darnay (1934). A Kisbalaton Osseszsugoradasa (the shrinking of Kisbalaton). Aquila 55-58: $169-187$.

- Keve, A. (1975). Adatok a Kis-Balaton Madarvilagahoz I (with German summary). Aquila 82: 49-79.

- Keve, A. (1976). Adatok a Kis-Balaton Madarvilagahoz II (with German summary). Aquila 83: 191-225.

\section{Martély Landscape Protection Area}

Location $46^{\circ} 25^{\prime} \mathrm{N}, 20^{\circ} 20^{\prime} \mathrm{E}$. Situated on the east bank of the Tisza River, adjacent to Martely village and north of Szeged in Csongrad Province, southern Hungary.

Area 2,300ha

Degree of Protection Owned by the state and agricultural cooperatives. The site has been protected as a 'District of Landscape Protection' since 1971. Designated as a Ramsar Site at the time of accession on 11 April 1979.

Site Description The site comprises two oxbow lakes isolated from the meandering Tisza River by dams constructed at the end of the 19th century, several flooded claypits (resulting from dam construction), the bank of the Tisza River, and associated floodplain marshlands and haymeadows. The river floods regularly in March and May/June, and occasionally in winter, and the flow in the site area is sufficiently fast to ensure that it rarely freezes over in winter. The isolated oxbow lakes are shallow $(1-4 \mathrm{~m})$ and eutrophic, with a rich aquatic vegetation of water chestnut Trapa natans, Myriophyllum vorticillatum, Najas marina, Polygonum amphibium, Ceratophyllum demersum, pondweed Potamogeton perfoliatus, Scirpus tabernaemontani and Dreissenia polymorpha (important foodsource for wintering diving ducks). The flooded claypits support a similiar aquatic flora, and are surrounded by woodland and scrub of 
willow Salix triandra, Cornus sanguinea, Galium aparine and the PolygonoChenopodion and Salicion incanae associations. The temporary flooded marshlands are covered by Polygonum lapathifolium, Angelica sylvestris, Leucojum aestivum, Aristolochia clematitis, Amorpha fruticosa, Sambucus ebulus, Iris pseudocorus and reedbeds of Phragmites communis with Tyhpa angustifolia. The drier haymeadows are characterised by Equisetum arvense, Melilotus officinalis, Chrysanthemum vulgare, wild carrot Dancus carota, D. vulgare, Lupinus lutea, L. albus, Trifolium camperstre, Falcaria vulgaris, chervil Anthriscus cerefolium, Asperula rivalis, Dipsacus laciniatus and Convulvulus arvensis. The designated marshland area is bordered by woodland of oak, poplar, willow and ash (Quercus sp., Populus sp., Salix sp., and Fraxinus sp.)

International and National Importance The site is an important breeding and wintering site for birds. Breeding birds include large numbers of wild duck such as mallard Anas platyrhynchos and garganey A. querquedula, squacco heron Ardeola ralloides, black stork Ciconia nigra, white spoonbill Platalea leucorodia and black-headed gull Larus ridibundus. Several thousands visitors on winter migration include mallard, teal Anas crecca, common pochard Aythya ferina, white-eyed pochard $A$. nyroca, coot Fulica atra and waders (Limicolae).

\section{Changes in Ecological Character None reported (1980)}

Management Practices No information

Scientific Research and Facilities No information

Principal Reference Material The above information is taken from the document submitted at the time of accession in April 1979 and the National Report (1980) prepared for the Conference on the Conservation of Wetlands of International Importance especially as Waterfowl Habitat held in Cagliari, Italy in November 1980.

\section{Kiskunsag National Park}

Location $46^{\circ} 37^{\prime}-47^{\circ} 12^{\prime} \mathrm{N}, 19^{\circ} 05^{\prime}-19^{\circ} 39^{\prime} \mathrm{E}$. Situated between the Danube and Tisza Rivers to the west of Kecskemet in Bacs-Kiskun Province, south central Hungary.

Area 4,000ha (within Kiskunsag National Park 30,527ha).

Degree of Protection $57 \%$ state, $42 \%$ co-operative and $1 \%$ private ownership. The designated site is within Kiskunsag National Park protected since 1974 under decree 1800/1974 of the Nature Conservancy Office. Park administration is at 6001 Kecskemét, Liszt Ferenc u 19. The Kiskunsag National Park was accepted as a Biosphere Reserve in May 1979. Designated as a Ramsar site at the time of accession on 11 April 1979.

Site Description The site comprises the Kiskunsag soda lakes complex of small basins (hollows) without outlet, reedbeds, marshy fields and fenwoods on the plain of the Danube. The surface of the plain was formed by fluvial accretion during the Pleistocene and Holocene periods, which continued until the regulation of the waterways at the end of the last century. The smooth surface is covered mainly with loose fine-grained deposits of loam and silt (rich in carbonates). Fluvial erosion is represented by former backwaters and dead channels of the Danube. The water level of the shallow natron lakes depends on rainfall, and most of the lakes dry up in dry summers. The water regulations have considerably modified the water balance, resulting in modification of the soil development and flora/fauna. Areas previously regularly flooded which were only locally sodic have now become saturated with native soda. Sodic soils of solonchak and solonchak-solonetz type with all types of salt microrelief occur. The meadows and sodic pastures are characteristic of dry and alkaline desert (salt puszta), with halophytic vegetation of Festuca pseudovina, Camphorosma annua, Matricaria chamomilla. Hordeum hystrix, Plantago tenuiflora, Salicola soda, P. schwarzebvergiana, Suaeda maritima 
and Puccinellia limosa. Endemic to the plain are Limonium gmelini subsp. hungaricum; Aster tripolium subsp. pannonicus. The fen meadows, marshy fields and wet (humid) grasslands bordering the lakes are characterised by Phragmites communis, Carex elata, Angelica silvestris, Sanguisorba officinalis, Lychnis flos-coculi, Succisia pratensis and Nymphaea alba. Birds nest in the open-water lakes (Kelemen-szék, Zab szék and Pipas-rét) or in lakes overgrown with reeds (Fehér-szék and Kis-rét).

International and National Importance Over 200 bird species occur at the site including 80 nesting species. Nesting birds include great bustard Otis tarda (in cultivated fields inside and outside the boundary), lapwing Vanellus vanellus (breeding in large numbers), black-tailed godwit Limosa limosa, redshank Tringa totanus, avocet Recurvirostra avosetta, collared pratincole Glareola pratincola, great egret Egretta alba, little egret E. garzetta, black-crowned night heron Nycticorax nycticorax, stone-curlew Burhinus oedicnemus, snowy plover Charadrius alexandrinus, black-winged stilt Himantopus himantopus, purple heron Ardea purpurea, white spoonbill Platalea leucordia, Eurasian bittern Botaurus stellaris, Baillon's crake Porzana pusilla and greylag goose Anser anser. Passage breeders include skylark Alauda arvensis and tawny pipit Anthus campestris. The site is also an important feeding and resting ground for flocks of white-fronted goose Anser albifrons, bean goose $A$. fabalis and golden plover Pluvialis apricaria.

Changes in Ecological Character Changes may result from drainage and flood control works. The area is crossed by a main road and a number of minor roads, power lines, buried gas pipes and canals. There is considerable organized tourism.

Management Practices The core zones in the park are completely undisturbed. Arable land, meadows and pastures are managed in accordance with nature conservation interests by 20 park staff. Visitor access is prohibited to the strictly protected conservation areas. There is a reintroduction programme (from the Wildfowl Trust) for the Oxyura leucocephala.

Scientific Research and Facilities Research in the national park is carried out by the Hungarian Academy of Sciences, Museum of Natural Science and several universities. Regular study and ringing of nesting and migratory birds is carried out by specialized staff of the Board of Directors. Accommodation is available for scientists, and there are some bird observation towers and a ringing station.

Principal Reference Material The above information is taken from the document submitted at the time of accession in April 1979 and the National Report (1980) prepared for the Conference on the Conservation of Wetlands of International Importance especially as Waterfowl Habitat held in Cagliari, Italy in November 1980.

Additional references:

Articles of scientific reviews, occasional and annual reports of research institutes and report of the SZAB on work carried out in the nature conservation area No. III of the Kiskunsag National Park.

- Pecsi, M. (1967). Danubian Lowland. (A Dunai Alföld). Budapest.

- Toth, K. National Park in Kiskunsag. (Nemzeti Park a Kiskunsagban).

- Tölgyesi, I. (1984). Nature conservation in Hungary: presentation of a National

Park. Parks 8(4): 1-3.

\section{Pusztaszer Landscape Protection Area}

Location $46^{\circ} 15^{\prime} \mathrm{N}, 20^{\circ} 10^{\prime} \mathrm{E}$. Situated to the north of Szeged on the west bank of the Tisza River in Csongrad Province, southern Hungary near the Romania frontier.

Area 5,000ha (part of the 22,000ha Pusztaszer Nature Conservation District). 
Degree of Protection State and cooperative ownership. The four wetland systems are protected as part of the extensive Pusztaszer Nature Conservation District established in 1976 under Nature Conservation Registration No. 122/TK/76. Sasker and Labodar Conservation Areas and the marshlands of the Pusztaszer-Budosszek Conservaton Area have strict protection. Designated as a Ramsar Site at the time of accession on 11 April 1979.

Site Description The designated site comprises four disjunct wetland systems: Szeged-Feherto artificial fishponds; Csaj Lake artificial fishponds and the meadows of Baks on the east bank of the Tisza river; Sasker and Labodar Conservation Areas; and the marshlands of Pusztaszer-Budosszek Conservation Area, separated from Csaz Lake system by a canal. The fish ponds are highly alkaline soda lakes surrounded by reedbeds of Phragmites communis with Thypa angustifolia (nesting area for herons) with characteristic sodic vegetation including Festuca pseudovina, Matricaria chamomilla, Plantago tenuiflora, $P$. schwarzebergiana, Suaeda maritima and Limonium gmelini ssp. hungaricum. In winter the levels of the ponds drop and the resultant shallows are valuable feeding grounds for visiting waders. The marshy flood-prone areas near the Tisza river, which of ten dry out, are characterised by Polygonum lapathifolium, Angelica sylvestris, Leucojum aestivum, Aristolochia clematitis, Amorpha fruticosa, Sambucus ebulus and Iris pseudocorus.

International and National Importance The fishponds attract large numbers of migrant waterfowl including 10,000-20,000 white-fronted goose Anser albifrons, numerous other Anatidae, and waders such as Eurasian curlew Numenius arquata and whimbrel A. phaeopus. The fringing reedbeds are used by colonies of breeding heron including grey heron Ardea cinerea, purple heron $A$. purpurea, squacco heron Ardeola ralloides, great egret Egretta alba, little egret $E$. garzetta, black-crowned night heron Nycticorax nycticorax and Eurasian bittern Botaurus stellaris. Other breeding species include red-necked grebe Podiceps grisegena, white stork Ciconia ciconia, white spoonbill Platalea leucorodia, mallard Anas platyrhynchos, garganey $A$. querquedula, northern shoveler $A$. clypeata, pochard Aythya ferina, white-eyed pochard A. nyroca, coot Fulica atra, lapwing Vanellus vanellus, snowy plover Charadrius alexandrinus, redshank Tringa totanus, black-tailed godwit Limosa limosa, black-winged stilt Himantopus himantopus, avocet Recurvirostra avosetta, stone-curlew Burhinus oedicnemus, black-headed gull Larus ridibundus, common tern Sterna hirundo and Mediterranean gull L. melanocephalus (only breeding ground in Hungary at Szeged-Feherto fishponds).

\section{Changes in Ecological Character None reported (1980)}

\section{Management Practices No information}

Scientific Research and Facilities The Ornithological Institute has carried out bird counts and observations in the district.

Principal Reference Material The above information is taken from the document submitted at the time of accession in April 1979 and the National Report (1980) prepared for the Conference on the Conservation of Wetlands of International Importance especially as Waterfowl Habitat held in Cagliari, Italy in November 1980.

\section{Hortobàgy National Park}

Location $46^{\circ} 00^{\prime}-47^{\circ} 26^{\prime} \mathrm{N}, 20^{\circ} 56^{\prime}-21^{\circ} 22^{\prime} \mathrm{E}$. Situated in the northeast of the Great Gromboalian Plain on the Tizza River in Szolnok Province, east central Hungary.

Area 15,000ha (including Hortobàgy fishpond and Zam, Pentezug and Angyalhaza steppes in Hortobàgy National Park 43,550ha; Tiszafured bird sanctuary which constitutes most of Tiszafured Conservation Area; and Juztus-Hagy as-Fekete meadowland in Egyek-Pusztakocsi Conservation Area). 
Degree of Protection 53\% state and $47 \%$ cooperative ownership. The designated site is partially in Hortobàgy National Park established on I January 1973 under Decree 1850/1972 of the Nature Conservancy Office 'to improve the characteristic values of nature in the puszta; preserve the peculiar landscape of the plains, the fauna and flora of Hortobàgy; and safeguard the undisturbed nesting and migration of Hortobàgy's specific avifauna'. Park management is at Debrecen, Böszörményu ut 138. The remaining areas are protected within Nature Conservation Areas. Hortobàgy National Park was accepted as a Biosphere Reserve in May 1979. Designated as a Ramsar Site at the time of accession on 11 April 1979.

Site Description The designated site comprises four disjunct wetlands on the extensive Hortobàgy Steppe, which is the largest secondary steppe (puszta) in Europe, formed in the ancient flood plain of the river Tisza. Its last natural form was typical wooded steppe at the end of the Bronze Age containing numerous lakes and marshes resulting from regular floods of the Tisza. This landscape has been transformed into a dry, treeless secondary steppe by human activities over the past centuries. Artificial fishponds and storage lakes have been established in the area from 1915 and extensive storage lakes have been recently formed along the Tisza river. The vegetation is characterised by halophytic and xerophilous species that have wide distribution in the Eurasian temperate zone, but there are also many Pontian and Pont-Mediterranean species. Prevalent species of the sodic soils of the alkaline steppes are Plantago maritima. P. tenuiflora, Suaeda maritima, Salsola soda, Matricaria chamomilla, Cerastium dubium, Hordeum hystrix, Puccinellia limosa, Festuca pseudovina, Trifolium angulatum, Limonium gmelini, Artemisia monogyna, Scorzonera cana, Ranunculus pedatus, Phaliurus pannicus, Camphorosma annua, inula britannica, Cirsium furiens, Calatella punctata, Armoracia macrocarpa and Achillea asplensifolia. The saltmarshes bordering the fishponds and occurring on the steppes are characterised by Eleocharis palustris, Lythrum virgatum, Bolboschoenus maritimus, Atriplex litoralis, Scirpus tabernaemontani, Typha angustifolia, Phragmites communis, Lycopus exaltatus, Stratiotes aloides, Sagittaria agittifolia, Hydrocharis morus-ranae, Nymphaea alba, Salvinia natans, Trapa natans, Marsilea quadrifolia and Ranunculus aquatilis. The flood zone of the Tisza (Tiszafured Sanctuary) supports patches of Populus alba. Populus nigra. Salix alba, Salix fragilia, Quercus rober, Salix triandra purpurea, Fraxinus sp. woodland. Endemics include Aster tripolium subsp. pannonica, Suaeda pannonica and Plantago schwarzenbergiana. Mean annual rainfall $400-500 \mathrm{~mm}$ with high temperatures in the growing season. There are only 1-10 windless days in the year and whirlwinds are frequent.

International and National Importance Hortobàgy National Park is an important area in Europe for migrating and wintering birds. Migrants include over 10,000 geese: white-fronted goose Anser albifrons, bean goose $A$. fabalis and $A$. orythropus (declining numbers), mallard (several 100,000 ), teal $A$. crecca and several hundred black stork Ciconia nigra and crane Grus grus. Some 300 recorded bird species occur at the site including 140 breeding. Breeding birds include collared pratincole Glareola pratincola, snowy plover Charadrius alexandrina, snipe Gallinago gallinago, redshank Tringa totanus, lapwing Vanellus vanellus, stone-curlew Burhinus oedicnemus, great bustard Otis tarda, Baillon's crake Porzana pusilla, little crake $P$. parva, great egret Egretta alba, little egret Egretta garzetta, grey heron Ardea cinerea, purple heron $A$. purpurea, squacco heron Ardeola ralloides, black-crowned night heron Nycticorax nycticorax, white stork Ciconia ciconia, black-winged stilt Himantopus himantopus, avocet Recurvirostra avosetta, white spoonbill Platalea leucordia, red-necked grebe Podiceps grisena, great-crested grebe $P$. cristatus, black-necked grebe $P$. nigricollis, greylag goose Anser anser, mallard Anas platyrhynchos, garganey A. querquedula, northern shoveler Anas clypeata, pochard Aythya ferina, white-eyed pochard $A$. nyroca, coot Fulica atra, white-winged black tern Chlidonias leucoptera, black tern $C$. nigra, whiskered tern $C$. hybrida, short-eared owl Asio flammeus, aquatic warbler Acrocephalus paludicola, lark Calandrella brachydactyla hungarica and bearded reedling Panurus biarmicus. Passage migrants include several uncommon prey species in Europe such as Imperial eagle Aquila heliaca, golden eagle $A$. chrysaetos, saker falcon Falco cherrug, peregrine falcon $F$. peregrinus, red-footed falcon $F$. vespertinus and short-toed eagle Circaetus gallicus. 20-25 white-tailed eagle Haliaeetus albicila overwinter here regularly. Mammals include otter Lutra lutra. 
Changes in Ecological Character The site contains 2,200ha farmland, 38,200ha alkali pastures (including $30,000 \mathrm{ha}$ free from irrigation and pesticide use), 2,500ha reedbeds and 1,000ha mowing meadows. There are some structures such as roads, canals and power lines. 1,000ha is used for tourism with severe overuse. The pastoral population (May-October) is small and decreasing. In past centuries this salt desert (unique in Europe) was used for semi-nomadic shepherding which contributed to form the present landscape of the puszta.

Management Practices The national park contains a number of core zones (varying from 15 to $200 \mathrm{ha}$ ) which represent the most important habitats. These areas appear to be little affected by human activity, although they have been subject to extensive grazing. The core zones are buffered from more intensive use. There are 37 national park staff with 18 assigned to protection and 19 to management and maintenance. Visitor access is prohibited to the strictly protected conservation areas. There is organised tourism in the park, but there are no accommodation facilities.

Scientific Research and Facilities Research work on the national park is carried out by the Hungarian Academy of Sciences, Museum of Natural Science and several universities. Since 1955 there have been studies of the synecology of the fauna, flora and soils, including using Margita Wood as an IBP model area. Current research is out on the ecology of pools, alkali low grounds, salt steppes, nesting bird communities, trace elements and man-made water bodies. Regular study of breeding and migratory birds is carried out by the Ornithological Institute and the specialised staff of the Board of Directors of the park. Extensive studies have been made of the animal species and communities in the park, sponsored by the Hungarian Academy of Sciences and the National Nature Conservaton Office.

Principal Reference Material The above information is taken from the document submitted at the time of accession in April 1979 and the National Report (1980) prepared for the Conference on the Conservation of Wetlands of International Importance especially as Waterfowl Habitat held in Cagliari, Italy in November 1980.

Additional references:

- Berenyi, D. (1964). Microclimatological Research in Hortbagy. Acta Univ. Debrecen, Series Geogr. IX/II.

- Kovacs, G. and Salamon, F. (1976). Hortobàgy, Budapest. Natura (further literature in preparation).

- Marosi, S. and Szilard, J. (1969). The Tisza Lowland. Budapest Acad.

- Szabolcs, I. (1954). Soils of Hortobàgy. Agricultural Publishing House, Budapest.

- Szabolcs, I. (1961). Effects of regulations of waterway's and irrigation on processes of soil formation from beyond the Tisza. Publishing House of the Hungarian Academy of Sciences, Budapest. Pp. 1-369.

- Szujko-Lacza, J. (1981). The vegetation of the Hortobàgy National Park. In Mahunka, S. (Ed.) The Fauna of the Hortobagy National Park. Vol. 1: 15-32. Publishing House of the Hungarian Academy of Sciences, Budapest.

- Udvardy, M. (1941). Avifauna of Hortobàgy. Tisia. 


\section{ICELAND}

Area $102,828 \mathrm{sq} \cdot \mathrm{km}$

Population $238,175,000(1983)$

Summary of Wetland Situation The volcanic island of Iceland has a wide variety of wetlands, including extensive bogs, marshes and inland waters, as well as the shallows, and intertidal areas of an extremely indented coastline. These provide excellent habitats for waterfowl migrating from the Canadian Arctic and Greenland to Western Europe and vice versa, as well as wintering grounds for several species (sea ducks in particular). Further evidence of their international importance is the fact that in several Icelandic wetlands the numbers of breeding, feeding, moulting or resting waterfowl must reach the level of $50-100,000$ individuals of a single species. Moreover, the freshwater lakes (which may be of glacial, volcanic or tectonic origin), are extremely diverse in their characteristics and hence offer the limnologist a wide field of study (which underlines their scientific importance).

Human interference with wetlands has so far been slight, but industrial and agricultural development and the accompanying road construction could affect several of them in the immediate future. At present only Thjorsarver is seriously threatened, in this case by flooding due to the construction of a dam for an hydro-electric power scheme. Thjorsarver, a wide river basin, is the nesting site for two-thirds of the world population of the pink-footed goose, which only breeds in Iceland and Greenland. Research into all aspects of the unique Thjorsarver ecosystem has been in progress since 1970, with a view to reducing, and if possible compensating for, the effects of the proposed inundation. Concern is also felt about the future of the Olfusforir wetland, which is situated in the richest agricultural area, not far from Reykjavik.

Little in the way of legal protection has been extended to wetland sites. However, the outstanding waterfowl nesting area of Lake Myvatn and its effluent river, the Laxa, have been protected by law since 1974, and Svarfadardalur, also in northern Iceland, has been made into a reserve. This means that any changes in the landscape require the approval of the Nature Conservation Council and that hunting is forbidden. These measures were followed up by Iceland's accession to the Conventiion.

Protected Areas Legislation The Nature Conservation Act no. 47 of 1971 contains provisions for the establishment and management of protected natural areas. Each area is designated by separate regulations except for Myvatn and Laxa, which is protected according to special act from 1974, and Thingvellir National Park which was established by legislation in 1928 . Several other acts have an important bearing on nature conservation including the Act on Bird Hunting and Bird Preservation (No. 33/1966), Forestry (No. 3/1955) and Soil Conservation (No. 17/1969). The aim of the Nature Conservation Act is to ensure that nature and natural sites and processes can continue undisturbed and unpolluted. Four types of area are defined, natural monuments, nature reserves, national parks and recreation areas. Designation of protected areas is commonly by management agreement, but protection can be made compulsory or land expropriated. Care of the countryside as a whole is exercised through consultation in the planning process.

Protected Areas Administration Nature Conservation matters come under the Ministry of Culture and Education. The provisions of the Nature Conservation Act are carried out by the Nature Conservation Council, which is the central organization for nature conservation. A special committee selected by Althingi, the legislative body, directs the matters of Thingvellir NP. No general guidelines exist for the management of the system of protected areas apart from the general provisions of the act. NCC is responsible for the planning of protected areas, and cooperates closely with local governments. It may also be directly or indirectly responsible for scientific research programmes connected with management problems. Many areas are traditionally used by farmers (though there may be some regulation of the intensity of use), and hunting and fishing may continue in some areas. 
Sites designated under the Convention

Accession on 2 December 1977 with 1 site listed at accession

Part of Myvatn-Laxa Region

Government body responsible for administration of the Convention

Ministry of Culture and Education, Hverfisgata 4, 101 Reykjavik.

\section{Part of Myvatn-Laxa Region}

Location $65^{\circ} 40^{\prime} \mathrm{N}, 17^{\circ} 00^{\prime} \mathrm{W}$. Situated in the northeast area of the highland interior of Iceland.

Area Approximately 20,000 ha (within Myvatn-Laxa Conservation Area 440,000ha).

Degree of Protection Owned by private individuals and local and national governments. Administered by the Nature Conservation Council (Hcerfisgata 26, 101 Reykjavik). The designated site is part of Myvatn-Laxa Conservation Area established on 2 May 1974 by a special act of parliament (No. 36/1974) issued on 9 March 1978. The whole area is protected by special law. Designated as a Ramsar site at the time of accession on 2 December 1977.

Site Description The designated site comprises the shallow eutrophic Myvatn Lake, its outflow river (Laxa) and numerous small lakes and ponds in the marshlands surrounding the lake. It is located in an active volcanic zone with frequent eruptions. The underlying geological formations are quite recent dating from the Ice Age and postglacial times. The uninhabited area is almost without soil or vegetation. Carpets of vegetation occur only in small oases associated with high ground-water levels. By springs and along streams garden angelica Angelica archangelica is common. The dominant plants in Lake Myvatn are the blue-green alga Anabaena flos-aquae, Fragilaria construens, Cladophora aegagropila, slender-leaved pondweed Potamogeton filiformis, spiked water milfoil Myriophyllum spicatum and three-leaved water crowfoot Ranunculus trichophyllus. Bogs and marshes occurring west and south of the lake are dominated by sedges Carex chordorrhiza, C. lyngbyei and C. rostrata. Birch Betula pubescens woodlands are conspicuous to the north and east. Common fauna are mink Mustela vison and long-tailed fieldmice Apodemus sylvaticus, but Arctic fox Alopex lagopus is now uncommon in the area and there is little fauna in the barren areas. Fish species include arctic charr Salvelinus alpinus (including local forms), three-spined stickleback Gasterosteus aculeatus, trout Salmo trutta and salmon $S$. salar. Lake Myvatn derives its name from the midges (Chironomids) and blackflies (Simuliids) swarming on the shores, which are an important foodsource for fish and birds. Important macroinvertebrates include Daphinia longispina, Eurycercus lamellatus, Chironomus islandicus, Tanytarsus gracilentus, Simulium vittatum, Lymnaea pereger, Pisidum spp, Tubifex tubifex and Hydra cf attenuata. Climate is fairly continental with short warm summers and cold winters. Much of the area is in the rain shadow of the Vatnajökull glacier, and it is the driest area in Iceland with annual precipitation under $400 \mathrm{~mm}$. Mean annual temperature $2.2^{\circ} \mathrm{C}$. Mean temperature $-4.2^{\circ} \mathrm{C}$ in February and $10.2^{\circ} \mathrm{C}$ in July.

International and National Importance Greater numbers of over 40 species of breeding birds occur at this site than elsewhere in Iceland, including 19 species of Anatidae, Barrow's goldeneye Bucephala islandica (only breeding site in Europe) and gadwall Anas strepera, and common scoter Melanilta nigra rarely breeding elsewhere in Iceland. Other waterfowl include tufted duck Aythya fuligula, scaup A. marila, wigeon Anas penelope, red-breasted merganser Mergus serrator, whooper swan Cygnus cygnus, red-necked phalarope Phalaropus lobatus, redshank Tringa totanus, snipe Gallinago gallinago, black-necked grebe Podiceps auritus and harlequin Histrionicus histrionicus.

Changes in Ecological Character Large scale (presumably natural) changes have been shown to occur in the area during the active phase of the volcanic cycle. The area is thought to be presently subject to such a phase. There is some human pressure on the duck breeding areas, dredging of diatomite in Lake Myvatn and a geothermal power station nearby at Krafla. 
Management Practices The Conservation Area has 5 seasonal rangers with 3 based at Myvatn and an allocation in December 1981 of $£ 28,000$. Normal farming practices are allowed in the area.

Scientific Research and Facilities The biology of Myvatn and Laxa has been studied extensively. Geological research has centered on Myvatn and the Krafla area. The NCC has a field station at Myvatn where extensive research is carried out ( $£ 20,000$ of the budget was assigned to the field station in December 1981).

Principal Reference Material Above information is taken from the National Report of Iceland (1980) prepared for the Conference on the Conservation of Wetlands of International Importance especially as waterfowl habitat held at Cagliari, Italy in November 1980 and the documents submitted at the time of accession on 2 December 1977.

Supplemented by:

- IUCN (1977). World Directory of National Parks and other Protected Areas. IUCN, Morges, Switzerland.

Additional references:

- Duffey, E. (1982). National Parks and Reserves of Western Europe. Macdonald and Co., London.

- Jonasson, P.M. (1979). Lake Myvatn. Oikos, Suppl. 32 


\section{INDIA}

\section{Area $3,287,593 \mathrm{sq} . \mathrm{km}$}

\section{Population $683,810,051(1981)$}

Summary of Wetland Situation As might be expected in a country the size of India there is a wide range of physiographic features. Rainfall also varies considerbly. In parts of the western coast annual rainfall can exceed $5,000 \mathrm{~mm}$, while other parts of the country may receive less than $200 \mathrm{~mm}$. Wetlands are therefore very varied, and in some areas numerous. Large amounts of water flow down from the Himalayan catchments, and in the Terai of the Himalayan foothills, some of the main wetlands are associated with the tributaries of the river Ganges. The wide variation in flow rate and volume of water can lead to large changes in the character of parts of the river bed, and consequently in the patterns and types of plants and animals along them. It is in rivers such as these that the endangered gharial Gavialis gangeticus is to be found. In addition, large areas of the Himalayan foothills used to be swamps and marshes. The pink-headed duck Rhodonessa caryophylacea occurred in forest ponds and swamps in this region, but it is now thought to be extinct in India.

In the peninsular, the flood plains of the Indo-Gangetic basin and the salt flats of the Little Rann of Kutch are both important wetland regions, and the Chilka Lake on the east coast is the largest brackish lake in India, with an area of $1165 \mathrm{sq} . \mathrm{km}$. India also has innumerable man-made lakes.

In Keoladeo (Bharatpur) National Park, the freshwater samp of Keoladeo Ghana forms an abundant food supply for large numbers of resident water birds, including painted stork Mycteria leucocephala, open-bill stork Anastomus oscitans, white spoonbill Platalea $l$. leucorodia, white ibis Eudocimus albus, three species of egret, Indian pond heron Ardeola grayii, heron Nycticorax sp., Indian darter Anhinga melanogaster, and the large and small cormorants. Over a million migratory ducks, geese and waders can winter here. A particularly noteworthy visitor is the Siberian crane Grus leucogeranus. Another important wetland area of India is the mangrove swamps of the Sundarbans, where the Ganges and Brahmaputra drain into the Bay of Bengal. Here the rivers divide into hundreds of streams and creeks, between which lie extensive tidal mudflats.

India contains important wintering grounds for the Caucasian and Siberian populations of a number of migratory birds, and an inventory of Indian wetlands, begun in the late 1960's by the Government of India, lists more than 400 sites. To update the available information, and to ascertain the present biological and ecological status of these wetlands, a working group was set up in 1983 to prepare a 'state of the ark' report.

Protected Areas Legislation Comprehensive central legislation in the form of the Wildlife (Protection) Act was enacted in 1972 to provide special legal protection to wildlife, and in particular to endangered fauna. The Act provides for the establishment of National Parks, Sanctuaries, Game Reserves and Closed Areas by state governments. It has been adopted by all States and Union Territories of the country apart from Jammu and Kashmir, and Nagaland. Jammu and Kashmir has similar legislation while Nagaland is likely to adopt the Act. National parks and sanctuaries have in general been established to protect and develop populations of species and their habitats.

Protected Areas Administration The Indian Board for Wildlife is the main advisory body to the Government, and is chaired by the Prime Minister. At State level, State Wildlife Advisory Boards have been established under the 1972 Act. At central government level, the Department of Environment, Forests and Wildlife is reponsible for environmental protection. It was established in September 1985. Previously, forestry and wildlife had been the responsibility of a Joint Secretary within the Forestry Division of the Department of Agriculture and Cooperation. In response to central government proposals, a number of states have set up their own State Departments of the Environment. Within the forest department of 
other states, there is usually a wildlife wing under a Chief Wildlife Warden who is likely to be Deputy (or Additional) Chief Conservator of Forests. Divisional Forest Officers are of ten reponsible for protected areas in their divisions, but important sanctuaries and national parks may be run by separate park and sanctuary superintendants.

\section{Sites designated under the Convention}

Accession 1 October 1981 with 2 sites listed at accession

Chilka Lake

Keoladeo National Park (Bharatpur)

Government body responsible for administration of the Convention

Government of India, Department of Environment, Forests and Wildlife, Technology Bhavan, New Mehravli Road, New Delhi 110016

\section{Chilka Lake}

Location $19^{\circ} 28^{\prime}-19^{\circ} 54^{\prime} \mathrm{N}, 85^{\circ} 06^{\prime}-85^{\circ} 35^{\prime} \mathrm{E}$. Situated on the east coast in the State of Orissa.

Area 116,500 ha

Degree of Protection State owned. Measures are being implemented to declare the area a 'Sanctuary' under the Wildlife (Protection) Act 1972. It already has 'Sanctuary' status under the Orissa Forest (Shooting) Rules 1972. Designated as a Ramsar site in October 1981.

Site Description Chilka is a shallow lake separated from the Bay of Bengal by a long sandy ridge not less than $200 \mathrm{~m}$ wide. The lake is about $71 \mathrm{~km}$ long and $3-32 \mathrm{~km}$ wide, with an area in the dry season (December-June) of $89,100 \mathrm{ha}$ and in the rainy season (July-October) 116,500 ha. The range in water depth is from $0.9-2.6 \mathrm{~m}$ in the dry season to $1.8-3.7 \mathrm{~m}$ in the rainy season. In the north, the Daya and Bhargavi rivers flow into the lake and, with some eight other rivers, annually discharge about 375,000 cusecs of freshwater carrying some 13 million metric tonnes of silt into the lake. The lake is connected to the Bay of Bengal via a channel through the sand ridge in the northeast. These factors tend to alternately dominate the lake environment resulting in extreme annual cyclic changes in salinity from 0.1 to 36.0 parts per thousand. The northern and central sectors become almost fresh during the monsoon but in November-December the salinity starts rising to an April-June peak. The southern sector shows comparatively less fluctuation in salinity with a range of 9.5 parts per thousand. The ranges of other parameters include: $\mathrm{pH} 6.8$ to 9.7 ; and water temperature $17.5^{\circ} \mathrm{C}$ to $32.5^{\circ} \mathrm{C}$. The lake vegetation varies with salinity. At high salinity it consists of species of the algae Entermorpha, Gracillaria, Spirogyra, Cladophora and Polysiphonia. At low salinity it consists of naiad Najas sp., stoneworts Chara sp., Nitella sp. and Hydrilla sp. Pondweeds Potomegeton spp. are present throughout the year. On the sandy ridge and some islands the vegetation is plantation forest. The fauna includes 158 species of fish and crustaceans, blackbuck Antilope cervicapra, spotted deer Axis axis, feral cattle, striped hyena Hyaena hyaena, golden jackal Canis aureus and dolphin.

Criteria for inclusion $1(a), 1(b), 1(c), 2(a), 2(b), 2(d)$ and 3

International and National Importance The site has a rich birdlife with over 150 recorded migratory and resident species. It has one of the largest concentrations of migratory waterfowl in India including large flocks of ducks (Anatinae), geese (Anserinae), flamingoes Phoenicopterus sp., pelican Pelecanus sp., plover Charadrius sp., gulls Larus sp. and terns Sterna sp.

Changes in Ecological Character The area is threatened by pollution from domestic and industrial waste. The large number $(400)$ of buffaloes on Nalban Island is disturbing the avifauna. 
Management Practices The lake supports a commercial fishery, involving some 12,250 fishermen. Nalban Island is the focal point for fishing activity. The emergent vegetation around the lake is cut for thatching.

Scientific Research and Facilities The Bombay Natural History Society has carried out some experimental bird ringing. The State Government of Orissa carries out research on salinity, temperature and turbidity of the lake and analyses fish catches.

Principal Reference Material The above information is taken from documents supplied by the Government of India for designation in 1981 and for the Groningen Meeting in May 1984.

Additional information contained in:

- Directorate of Fisheries (1970). The Chilka Lake. Directorate of Fisheries, Government of Orissa, Cuttack.

- Hussain, S.A., Mohapatra, K.K. and Ali, S. (1984). Avifaunal profile of Chilks Lake: a case for conservation. Technical Report No. 4. Bombay Natural History Society.

\section{Keoladeo National Park}

Location $27^{\circ} 07^{\prime}-27^{\circ} 12^{\prime} \mathrm{N}, 77^{\circ} 29^{\prime}-77^{\circ} 33^{\prime} \mathrm{E}$. Situated in eastern Rajasthan, the park is $2 \mathrm{~km}$ south-east of Bharatpur and $50 \mathrm{~km}$ west of Agra.

\section{Area $2,873 \mathrm{ha}$}

Degree of Protection State owned. The area was declared a National Park on 10 March 1982, and accepted as a World Heritage Site in December 1985. Previously the private duck shooting preserve of the Maharaja of Bharatpur since the 1850's, the area was designated as bird sanctuary on 13 March 1956 and a Ramsar site in October 1981. The last big shoot was held in 1964, but the Maharajah retained shooting rights until 1972.

Site Description The site comprises a freshwater swamp which is part of the Indogangetic Great Plains. For much of the year, however, the wetland area is only some 1,000 ha. The area is flooded in the monsoon (July-September) to an average depth of $1-2 \mathrm{~m}$. From October to January the water level gradually falls, and from February the land begins to dry out. By June only some water remains. The environment is partly man-made with dykes dividing the area into 10 units, each with a system of sluice gates to control water level. It is unlikely that the site would support such numbers of waterfowl as it does without the addition of water from Ajan Bund, a man-made impoundment. Soils are predominantly alluvial - some clay has formed as a result of the periodic inundations. The mean annual precipitation is $662 \mathrm{~mm}$, with rain falling on an average of 36 days per year. The aquatic vegetation is rich and provides a valuable foodsource for waterfowl. Species include water lilies Nymphea nouchatia. $N$. stellata and $N$. cristata, the true lotus Nilumbium sp., duckweeds Lemna sp. water fern Azolla sp. Vallesnernia sp., Hydrilla sp., Naga sp., Chara sp., Ipoma sp. sedges Cyperus sp. and lesser reedmace Typha angustata. There is also wild rice. Other vegetation is characteristic of a semi arid zone dominated by babul Acacia nilotica, ber Zizyphus mauritiana, khejri Prosopis cineraria. Salvadora oleoides, S. persica and Capparis aphylla. The fauna includes: rhesus macaque Macaca mulatta, langur Presbytis entellus, small carnivores such as Bengal fox Vulpes bengalensis, jackal Canis aureus, striped hyena Hyaena hyaena, common palm civet Paradoxurus hermaphroditus, small Indian civet Viverricula indica, Indian grey mongoose Herpestes edwardsi, fishing cat Felis viverrina, leopard cat $F$. bengalensis, jungle cat $F$. chaus and smooth-coated otter Lutra perspicillata. Ungulates include blackbuck Antilope cervicapra (60), chital Cervus axis (350), sambar C. unicolor, hog deer C. porcinus, nilgai Boselaphus tragocamelus (480) and wild boar Sus scrofa. The figures in brackets refer to the number of animals counted in the 1980 census. Other mammals include Indian porcupine Hystrix indica and Indian hare Lepus nigricollis.

Criteria for inclusion 1(a), 1(b), 1(c), 2(a), 2(d) and 3 
International and National Importance The site supports some 364 bird species and is considered to be one of the world's best and richest bird areas. It is the major wintering ground of the western population of the endangered Siberian crane Grus leucogeranus. A total of 41 , including eight young, were recorded in December 1984 - this is the highest number for many years (ICBP, 1985). Other species include gadwall Anas strepera, shoveler A. clypeata, common teal A. crecca, cotton teal Nettapus coromandelianus, tufted duck Aythya fuligula, comb duck Sarkidiornis melanotos, white spoonbill Platalea leucorodia, little cormorant Phalacrocorax niger, cormorant $P$. carbo, Indian shag $P$. fuscicollis, painted stork Ibis leucocepalus, Asian open-billed stork Anastomus oscitans, oriental ibis Threskiornis melanocephalus, ruff Philomachus pugnax (probably the most abundant wader), darter Anhinga melanogaster, spot-billed pelican Pelecanus philippensis, common sandpiper Tringa hypoleucos, wood sandpiper $T$. glareola, green sandpiper $T$. ochropus and Sarus crane Grus antigone. There are many birds of prey including the osprey Pandio haliaetus, peregrine Falco peregrinus, Pallas' fish eagle Haliaeelus leucoryphus, short-toed eagle Circaetus gallicus, tawny eagle Aquila rapax, imperial eagle $A$. heliaca, spotted eagle $A$. clanga and crested serpent eagle Spilornis cheela.

Changes in Ecological Character Leopard Panthera pardus have not been seen since their extermination from the area in 1964. Previous threats from fishing and cattle grazing have now been eliminated. The high level of pollutants in Arjan Bundh is believed to be responsitle for the increasing number of piscivorous birds seen in a dazed state and unable to fly. Notably fewer birds were recorded in 1984 than in previous years. Disturbance from visitors can be cause for concern. The ban on grazing (November 1982) has caused local resentment, and aquatic plant growth is no longer kept in check. Also livestock dung provided nutrients and supported insects.

Management Practices Water levels are regulated to benefit waterfowl. If the wetland is in danger of drying out completely there are arrangements to pump water from deep wells to ensure the survival of aquatic flora and fauna until the next monsoon. The boundaries are clearly delineated by a $32 \mathrm{~km}$ long, $2 \mathrm{~m}$ high stone wall, which totally encloses the park to prevent humans and domestic livestock from trespassing. Due to the dense human settlement surrounding the park, there is no possibility of creating a buffer zone. The road from Bharatpur town, which bisected the park, has been ciosed and relocated outside the boundaries. This has considerably reduced the level of disturbance by visitors from the town. Grazing and the collection of firewood and khus grass Vetiveria zizenoides were phased out in 1983. The absence of grazing, which is now believed to keep waterways open, is causing management problems as vegetation blocks up the channels.

Scientific Research and Facilities The Bombay Natural History Society has carried out bird ringing in the area for the past 20 years. Limnological studies are carried out by the Zoology Department of the University of Rajasthan, Jaipur. Monitoring of the population dynamics of birds has been undertaken by the park management. Under the Deputy Chief Wildlife Warden are a research officer, forester, three rangers, 20 wildlife guards, clerks and an accountant.

Principal Reference Material The above information is taken from documents supplied by the Government of India for designation in 1981 and for the Groningen Meeting in May 1984.

Additional information:

Abdulali, H. and Panday, J.D. (1978). Checklist of the birds of Delhi, Agra and Bharatpur. Unpublished report.

Ali, S. (1953). The Keoladeo Ghana of Bharatpur (Rajasthan). Journal of the Bombay Natural History Society 51: 531-536.

Ali, S. and Hussain, S.A. (1982). Studies on the movement and population structure of Indian avifauna. Annual Report II. Bombay Natural History Society, Bombay.

Breeden, S. and Breeden, B. (1982). The drought of 1979-1980 at the Keoladeo Ghana Sanctuary, Bharatpur, Rajasthan. Journal of the Bombay Natural History Society 79: 1-37.

Breeden, S. and Breeden, B. (1982-1983). A year at Bharatpur's Keoladeo National Park. Hornbill $1982(3,4)$ and $1983(1,2)$.

Grimwood, I.R. (1981). Impact of tourism on national parks in India. WWF-India. Unpublished report. Pp. 15-20.

ICBP (1985). World Birdwatch 7(1): 4. 
- Jackson, P. (1983). Crisis for birds and buffalos at Bharatpur. Unpublished report. 3pp.

- Saxena, V.S. (1975). A study of the flora and fauna of Bharatpur Bird Sanctuary. Department of Tourism, Jaipur, Rajasthan.

- Spillett, J.J. (1967). A report on wild life surveys in North India and southern Nepal: the large mammals of the Keoladeo Ghana Sancutary, Rajasthan. Journal of the Bombay Natural History Society 63: 602-607. 


\section{IRAN}

Area $1,648,184 \mathrm{sq} \cdot \mathrm{km}$

\section{Population $43,830,000(1984)$}

Summary of Wetland Situation Despite extensive rugged terrain and a climate of great extremes, Iran is one of the most important wintering areas for waterfowl from the east of the European part of the Soviet Union and from

western Siberia. The interior plateau, with its vast semi-arid and arid areas, including the salt deserts and pans in the Dasht-e-Kabir and Dasht-e-Lut, is surrounded on practically all sides by formidable mountain ranges. The Azarbaijan sector comprises high tablelands (with peaks rising to $4,500 \mathrm{~m}$ ) and lowland basins containing several lakes, of which the highly saline Oroomiyeh is the biggest.

Most of Iran has very low rainfall, the exceptions being the Caspian lowlands and Khuzestan in the south-west. In Khuzestan, rainfall during winter is abundant, and inundation of large areas of semi-arid country, and of the mudflats in the vicinity of the Gulf, can occur. The most important wintering areas for waterfowl border the Caspian, notably at Bancar-e-Anzali/Mordab and the bay of Gorgan, with the Miankaleh peninsula which encloses it. In Azarbaijan wintering flocks of geese (mainly greylag and white-fronted) occur in the valley of the River Aras (Araxes) on the USSR Border. To the south, Lake Rezaiyeh and the saltswamps along the border offer open water in winter for wintering ducks and coots, whilst the lake is an important breeding area for the greater flamingo and white pelican. Very high concentrations of waterfowl occur in Khuzestan, especially in the Shadegan marshes and their overspill after the winter rains, when large areas of semi-arid land and mudflats near the Gulf are inundated. Shadegan is little more than $100 \mathrm{~km}$ east of the Hawr Al Hammar in Iraq, where huge numbers of waterfowl spend the cold season, and considerable exchange of waterfowl between the two sites is likely.

To the east there are several more areas of importance for breeding and wintering waterfowl, the most interesting being the Neyriz basin with lakes Bakhtegan and Tashk, and the marshland complex of Dasht-i-Arjan and Lake Perishan, which was declared an International Reserve in 1971 on the occasion of the Ramsar Conference.

In eastern Iran the wetlands of Seistan in the Helmand Basin on the Afghan border, can be very important for waterfowl in years when the rains have been good. They comprise 'a mixture of fresh and brackish lakes and marshes, fed by overspill from four large rivers which rise in the Hindu Kush. Flood control in Afghanistan, and more particularly the construction of the Kajaki Dam on the Helmand River, have considerably affected the Seistan wetland, but the Hamun-i-puzak offered excellent conditions for waterfowl in 1976.

Protected Areas Legislation Prior to the revolution, the major enabling legislation was the Environment Protection and Enhancement Act of 1974 which was used to establish and protect national parks. This prohibited mining or the use of natural resources other than sport fishing. Following the revolution, the governing legislation is the Constitutional Act (No. 50) of the Islamic Republic of Iran, under which everyone is required to honour the conservation of nature and natural resources.

Protected Areas Administration Before the revolution a network of protected areas was proposed by the Game and Fish Department, an organization created in 1967 but succeeded by the Department of the Environment. Many areas were unfortunately imposed on the local population, and as a result the enforcement of the game laws and the wardening of the reserves had not been totally effective. The DOE was established in March 1972 with legal duties for environmental preservation. Some protected areas were controlled directly by local personnel of the DOE whilst others were controlled by local councils which include hunters and fishermen as well as department personnel. After the Islamic Revolution the department became responsible for environmental preservation according to a new philosophy, policy aim 
and strategy. This is centred on the continuous utilization of the environmental resources. The DOE is the only organisation undertaking long term studies and management projects, and is reponsible for the conservation and enhancement of wildlife resources and the prevention of pollution. As a part of this activity, the department promulgates regulations on habitat management.

\section{Sites designated under the Convention}

Signature subject to ratification on 25 August 1972. Ratification was deferred on 4 March 1975 as no sites were listed. Finally ratified on 23 June 1975. 18 sites listed at ratification.

Miankaleh Peninsula, Gorgan Bay and Lapoo-Zargmarz Ab-Bandans

Lake Parishan and Dasht-e-Arjan

Lake Oroomiyeh (ex-Rezaiyeh)

Neiriz Lakes and Kamjan Marshes

Anzali (ex-Pahlavi) Mordab Complex

Shadegan Marshes and tidal mud-flats of Khor-al Amaya and Khor Musa

Hamoun-e-Saberi

Lake Kobi

South end of Hamoun-e-Puzak

Shur Gol, Yadegarlu and Dorgeh Sangi Lakes

Bandar Kiashahr (ex-Farahnaz) Lagoon and Mouth of Sefid Rud

Amirkelayeh Lake

Lake Gori

Alagol, Ulmagol and A jigol Lakes

Khuran Straits (Bandar Abbas)

Deltas of Rud-e-Shur, Rud-e-Shirin and Rud-e-Minab

Deltas of Rud-e-Gaz and Rud-e-Hara

Gavkhouni Lake and Marshes of the lower Zaindeh Rud

Government body responsible for administration of the Convention

Department of the Environment, PO Box 1430, Tehran

\section{Miankaleh Peninsula, Gorgan Bay, Lapoo-Zaghmarz Ab-Bandans}

Location $36^{\circ} 50^{\prime} \mathrm{N}, 53^{\circ} 17^{\prime} \mathrm{E}$. Situated on the southeast shore of the Caspian Sea on the northern border of Iran in Mazandaran Province.

Area 40,000 ha (designated as 100,000 ha in 1975).

Degree of Protection Government owned. Miankaleh Peninsular and Gorgan Bay (about $4,000 \mathrm{ha}$ ) lie within Miankaleh Wildlife Refuge $(81,180 \mathrm{ha})$ which is part of Miankaleh Protected Region $(97,200 \mathrm{ha})$ established in 1970 . The wildlife refuge is administered by the Department of the Environment. 68,800 ha was approved as a Biosphere Reserve 1976. Lapoo-Zaghmarz $\mathrm{Ab}$-bandan marshes to the west are not included in any protected area. Designated as a Ramsar Site at the time of ratification after 23 June 1975.

Site Description The designated site is $18-25 \mathrm{~m}$ below sea level and comprises the open shallow saltwater (10-12\%) of Gorgan Bay, the dunes of Miankalieh Peninsula which virtually cut the bay off from the Caspian Sea (there is a $12 \mathrm{~km}$ wide channel in the east) and the mud flats and seasonal brackish marshes surrounding the bay, and small lakes at Lapoo-Zaghmarz Ab-Bandan (reservoir). The saltwater bay has a sand and mud bottom and is oligotrophic. The extensive marshes along the southern and eastern shore, which are flooded in autumn and winter, are eutrophic due to inflow from numerous freshwater streams, agricultural run-off and irrigation channels. The muddy-bottomed freshwater lakes and marshes are fed by irrigation, run-off and rainfall. Vegetation fringing the bay is predominantly glasswort Salicornia sp., sedges Carex spp. and rush Juncus sp. with some small reedbeds of Phragmites communis and Tamarix sp. There is a strip of vegetated sanddune along the Miankaleh peninsula, with some pomegranite Punica sp. scrub. Lapoo-Zagmarz Ab-bandans 
marshes are characterised by extensive Phragmites communis reedbeds, with stands of reedmace Typha sp., willow Salix sp., Ribes sp., Rubus sp., pomegranite and abundant submerged vegetation. Grasses of the genera Agropyron, Bromus, Dactylis, Cynodon and Festuca are predominant on the higher ground, with a shrub layer of hawthorn Crataegus $\mathrm{sp}$., pomegranite, buckthorn Rhamnus $\mathrm{sp}$. and Rubus $\mathrm{sp}$. Cultivation bordering the bay in the south is predominantly wheat and cotton. There are several small villages along the southern and eastern edge of the bay linked by road and rail. The area has variable annual rainfall $(200-1,000 \mathrm{~mm})$, and a temperature range of -6 to $34^{\circ}$.

International and National Importance This coastal area is of great value as a wintering station for over a quarter of a million birds, including Dalmation pelican Pelecanus crispus, greater flamingo Phoenicopterus ruber, greylag goose Anser anser, lesser white fronted goose A. erythropus, swans Cygnus spp., red-breasted merganser Mergus serrator and the rare Oxyura leucoscephala. The number of breeding birds is greatest in years of high summer rainfall, and includes heron (Ardeidae), pratincole Glareola pratincola (large colonies), Kentish plover Charadrius alexandrinus, little tern Sterna albifrons and a large colony of whiskered tern Chlidonias hybrida beside the Lapoo-Zagmarz ponds.

Changes in Ecological Character Considerable areas are open to livestock grazing; the unprotected Lapoo-Zaghmarz Ab-bandan have been subjected to heavy hunting pressure; a nuclear powerstation is planned $10 \mathrm{~km}$ to the west of the site; and nearby irrigation schemes may reduce the flow of fresh water into the bay system. There is a fish processing factory at the village of Ashuradeh.

Management Practices The Wildlife Refuge is managed as a nature reserve. A major programme for wildlife management was outlined in 1974 but there is no information on its implementation (1980). There is reed cutting and fishing by the local population in the protected area, and considerable areas are open to livestock grazing.

Scientific Research and Facilities SHILOT (Northern Fisheries Organisation) have carried out limnological and hydrobiological studies. The Environmental Research Centre of the Department of the Environment (formerly Game and Fisheries Department) have studied bird migration and made regular wildfowl censuses.

Principal Reference Material The above information is taken from:

- Mansoori, J. (1983). National Report on Iran's Wetlands of International Importance as Habitat for waterfowl for Groningen Conference, Netherlands in May 1984.

Supplemented by:

- Biosphere Reserve nomination submitted by Unesco-MAB Secretariat (1976).

- Carp, E. (1980). A Directory of Western Palearctic Wetlands. IUCN, Gland, Switzerland.

- IUCN (1977). World Directory of National Parks and other Protected Areas. IUCN, Morges, Switzerland.

\section{Lake Parishan and Dasht-e-Arjan}

Location $29^{\circ} 30^{\prime} \mathrm{N}, 52^{\circ} 00^{\prime} \mathrm{E}$. Situated on the southwest flank of the Zagros Mountains about $60 \mathrm{~km}$ west of Shirz and 15-25km southeast of Kazerun in the Province of Fars.

Area 6,600ha (Parishan Lake 4,200ha; Dasht-e-Arjan 2,400ha).

Degree of Protection Government owned, and administered by the Department of the Environment. Both wetlands lie within Arjan National Park and International Reserve (65,750ha) established in March 1972 and approved as a Biosphere Reserve in June 1976. Designated as a Ramsar Site at the time of ratification after 23 June 1975. 
Site Description The two wetlands are not physically connected, but were designated together as they are both in Arjan National Park. They are located in depressions in the Oligo-Miocene limestone formations of the Zagros Mountains. Lake Parishan is a large saline lake lying at $825 \mathrm{~m}$, with variable salinity and water level. In very wet years the bay areas are almost fresh. The lake is oligotrophic, and has a catchment area of some 29,000 ha. It is fed by numerous springs, some temporary watercourses and rainfall, but has no outflow channels. It is surrounded by eutrophic marshes with halophytic vegetation of the genera Salsola, Kochia, Camphorosma and Halocnemum and extensive reedbeds of Phragmites communis and Typha sp. where the salinity is low. Dasht-e-Arjan is a shallow freshwater lake and marshland lying at $1,950 \mathrm{~m}$ and surrounded by dry limestone mountains. It is eutrophic and fed by winter rainfall, snow melt, run-off, some small watercourses and the large springs at Chesmeh Salmon to the northwest. Because of the seasonality of the water supply and the outflow through swallow-holes in the southeast of this otherwise closed basin, lake area varies considerably from around $1,950 \mathrm{ha}$ in winter to only a few hundred hectares during summer. The lake edge and fringing marshlands are covered by reedbeds of Phragmites communis and Typha sp., rushes Juncus spp. and aquatic vegetation. The surrounding flat lands are usually covered by terrestrial grasses or remain as bare baked mud, but in wet years sedges Carex sp. predominate. Mean annual rainfall is $400-500 \mathrm{~mm}$, falling mainly in winter as snow and rain. Temperatures vary with altitude: Parishan Lake has a summer range of $22-40^{\circ} \mathrm{C}$ and winter range of $5-15^{\circ} \mathrm{C}$; Dasht-e-Arjan has a summer range of $15-35^{\circ} \mathrm{C}$ and a more extreme winter range of -10 to $15^{\circ} \mathrm{C}$.

International and National Importance The area is important as a resting station for large numbers of migrating wildfowl, including a large concentration of greater flamingo Phoenicopterus ruber, pintail Anas acuta, mallard A. platyrhynchos, teal $A$. crecca, ruddy shelduck Tadorna ferruginea, pochard Aythya ferina, coot Fulica atra, white headed duck Oxyura leucocephala, greylag goose Anser anser. crane Grus grus, pelicans Pelecanus sp. and grebes Podiceps spp. During wet years the area is an important breeding site for Dalmation pelican Pelecanus crispus, marbled teal Anas angustirostris, feruginous duck Aythya nyroca, coot Fulica atra, spoonbill Platalea leucorodia, glossy ibis Plegadis falcinellus, Baillon's crake Porzana pusilla, black-necked grebe Podiceps nigicollis, great crested grebe $P$. cristatus and little bittern Ixobrychus minutus, with a large mixed heronry and tern (Sternidae) colony on Perishan Lake.

Changes in Ecological Character The area to the south and west of Perishan Lake is cultivated for wheat, and there are several scattered settlements with gardens and orchards just outside the designated wetland areas (within the park). The area around the large village of Dasht-e-Arjan was grazed by cattle until recently. Hunting was prohibited in 1973 with national park status. Fishery ponds have been established in the west of Parishan Lake.

Management Practices The wetlands are managed as part of the national park which had a staff of 44 in 1976. There is some controlled grazing, reed cutting and fishing in the wetlands.

Scientific Research and Facilities The Department of the Environment have extensively studied the ecology of the area and carried out a programme of annual bird censuses from 1969. The Biological Research Centre for the Southern Region of Iran is located in Shiraz.

Principal Reference Material The above information is taken from:

- Mansoori, J. (1983). National Report on Iran's Wetlands of International Importance as habitat for watefowl for Gröningen Conference, Netherlands in May 1984.

Supplemented by:

- Biosphere Reserve nomination submitted to Unesco-MAB Secretariat (1976).

- Carp, E. (1980). A Directory of Western Palearctic Wetlands. IUCN, Gland, Switzerland.

- IUCN (1977). World Directory of National Parks and other Protected Areas. IUCN, Morges, Switzerland. 
Location $37^{\circ} 00-38^{\circ} 12^{\prime} \mathrm{N}, 44^{\circ} 40^{\prime}-45^{\circ} 50^{\prime} \mathrm{E}$. Situated about $70 \mathrm{~km}$ southwest of Tabriz, Azarbaijan Province in northwest Iran.

\section{Area 483,000ha (includes Oroomiyeh National Park 462,000ha).}

Degree of Protection Government owned. The lake area is administered by the Department of the Environment. The designated area includes Oroomiyeh Lake National Park established in August 1967 (as Rezaiyeh Lake) and approved as a Biosphere Reserve in June 1976. Designated as a Ramsar Site at the time of ratification after 23 June 1975.

Site Description The designated site comprises the shallow saline lake and islands (Oroomiyeh National Park) and the brackish marshlands on the northeast, northwest and south shores. The lake lies at $1,280 \mathrm{~m}$, and is the largest lake in Iran. It is fed by rainfall, run-off, streams, rivers, springs and seepage, with water level and salinity (8-28\%) fluctuating seasonally. It supports an abundant growth of algae Enteromorpha intestinalis, with a rich algal bloom and increase in brine shrimp Artemia salina numbers in summer. The brackish marshes support typical salt marsh plant communities of rushes Juncus spp., reedbeds Phragmites communis and occasional stands of Tamarix sp. where the freshwater rivers and streams enter the lake. The 56 islands in the lake (largest: Kabudan) are now uninhabitated but were formerly used for grazing livestock. Over 800 Armenian sheep Ovis ammon gmelini were recorded on Kabudan in 1976. Vegetation of the islands is characterised by steppe Artemisieta associations with remnant stands of pistachio trees Pistacia altantica. There are rolling wheatlands to the west and south, semi-arid steppe and hills to the north and east, and small settlements around the lake shore. Mean annual precipitation of $400-600 \mathrm{~mm}$ with hot summers and extremely cold winters $\left(-17^{\circ} \mathrm{C}\right)$.

International and National Importance

The site supports large breeding colonies of flamingo Phoenicopterus ruber, white pelican Pelecanus onocratalus, shelduck Tadorna tadorna, ruddy shelduck $T$. ferruginea, spoonbill Platalea leucorodia, herring gull Larus argentatus and slender-billed gull $L$. genei. It is an important feeding station for large numbers of migrant and wintering birds including shelduck, mallard Anas platyrhynchos, teal $A$. crecca, pintail A. acuta, coot Fulica atra, flamingo, herons (Ardeidae), sandpipers (Charadriidae) and plovers. Kabudan Island supports the highest concentration of chukar Alectoris chukar (partridge) of any Iranian reserve.

Changes in Ecological Character There are several small villages on the lake shore, and a tug and lighter service transports cattle between five small 'ports'. Recreational use of the lake is poorly developed but could threaten the integrity of the site if any expansion is not carefully planned and controlled. There is some threat of pollution from the nearby towns of Tabriz and Rezaiyeh.

Management Practices The wetland was managed as a nature reserve by 19 full time staff in 1976. The lake and 52 of the islands are included within the reserve, and constitute a sanctuary. Waterfowl nesting colonies are fully protected.

Scientific Research and Facilities Studies have been carried out on the pelican and flamingo populations. The Department of the Environment has carried out regular wildfowl counts.

Principal Reference Material The above information is taken from:

- Mansoori, J. (1983). National Report on Iran's Wetlands of International Importance as habitats for waterfowl. Prepared for Gröningen Conference, Netherlands in May 1984.

Supplemented by:

- Biosphere Reserve nomination submitted by Unesco-MAB Secretariat (1976).

- Carp, E. (1980). A Dircctory of Western Palearctic Wetlands. IUCN, Gland Switzerland. Additional references:

- Firouz, E. (1976). Environmental and Nature Conservation in Iran. Environmental Conservation $3(1): 33-42$. 
- Firouz, E. and Harrington, F.A. (1976). Iran: Concepts of biotic community conservation. A paper presented at the international meeting on ecological guidelines for the use of natural resources in the Middle East and South West Asia. IUCN Occasional Paper No. 15. IUCN, Morges, Switzerland.

- Savage, C.W.D. (1967). Lake Rezaiyeh: a specialised summer habitat for shelduck and flamingo. The Wild fowl Trust 15th Annual Report 1962-63: 108-113.

- Scott, D.A. (1975). Iran. In Kear, J. and Duplax-Hall, N. (Eds) Flamingoes. Pp. 18-32.

\section{Neiriz Lakes (Tashk and Bakhtegan) and Kamjan Marshes}

Location $29^{\circ} 40^{\prime} \mathrm{N}, 53^{\circ} 30^{\prime} \mathrm{E}$. Situated about $125 \mathrm{~km}$ east of Shiras in the Bakhtegan basin, Fars Province in southeast Iran.

Area 108,000ha (lakes: 98,000ha and Kamjan Marshes: 10,000ha).

Degree of Protection Mainly government owned, with some private rice paddies in the Kamjan marshes area. The wetland is adminstered by the Department of the Environment. The lakes lie within the extensive Bakhtegan Protected Region (327,820ha) established in 1968. The marshlands lie on the northwest boundary of the Protected Region. Designated as a Ramsar Site at time of ratification after 23 June 1975.

Site Description The lakes lie in Neiriz Basin in the Zagros Mountains at $1,550 \mathrm{~m}$, and the permanent Majan marshes lie in the Kor river valley upstream from where it enters the lakes. The two oligotrophic lakes are fed mainly by the Kor River and tributaries (which originate in the Zagros Mountains), supplemented by numerous springs such as Gomun Springs on the southeast shore of Bakhtegan Lake. The eutrophic marshlands around the edges of the lakes vary from brackish to freshwater, resulting in a range of salinity in the lake waters. During very wet winters the two lakes, normally separated by a narrow strip of land, merge as the area floods (although degree of flooding varies considerably with rainfall). In the summer of 1971 the whole complex dried out except for a small lake at Gomun, while in the winters of 1971/72 and $1972 / 73$ it was deeply flooded. Since the construction of the Dorvosan Dam on the Upper Kor River $95 \mathrm{~km}$ north of Shiraz, the degree of flooding has been greatly reduced with water being diverted for irrigation. The lake bottoms are covered by alluvial mud, sapropel, silt and some sand, deposited mainly by the river and floodwaters. They support a varied submerged vegetation, including numerous algae, stonewort Chara sp., pondweed Ruppia sp.. Althenia sp., and are fringed by Tamarix sp., seablite Suaeda sp., Cressa cretica, reedbeds Phragmiles communis, goosefoot (Chenopodiaceae) sedge Carex spp., and grasses. Most of the surrounding area consists of arid steppe hills and flats, with some cultivation along the Kor River valley. The lake islands support sparse steppe vegetation, with Artemisia and Astragalus species, and scattered almond Prunus amygdalus and Pistachio pistacia trees. There are several small settlements in the area.

International and National Importance The site is an important breeding area for waterfowl, including shelduck Tadorna tadorna and T. ferruginea, marbled teal Anas angustirostris, Baillon's crake Porzana pusilla, black-winged stilt Himantopus himantopus, avocet Recurvirostra avosetta, white-tailed plover Vanellis leucurvus, Kentish plover Charadrius alexandrinus and common tern Sterna hirundo. It is a resting station for large numbers of migrating and wintering birds including ducks (Anatidae), particularly pintail Anas actua and marbled teal, ruddy shelduck Tadorna ferruginea, geese Anser spp., common crane Grus grus and greater flamingo Pheonicopterus ruber.

Changes in Ecological Character A dam constructed on the Kor River to supply irrigation waters to local agriculture affects the hydrological regime of the lake, with increased seasonal variation in the water level. In dry years the permanent marshlands can dry out considerably, affecting the bird breeding populations. Some pollution enters the lakes via the river, and controls have been recommended (Carp, 1980). There is some light grazing pressure on the lake margins. Grazing and hunting continues in the marshlands and lower Kor River floodplain. 
Management Practices The wetland is protected as a nature reserve, and in 1975 was managed by 25 staff attached to Bakhtegan Protected Region.

Scientific Research and Facilities The Department of the Environment has conducted several studies and wildfowl counts in the area. The Biological Research Centre for the Southern Region of Iran is located in Sturaz. A limnological study of the lakes was carried out in the late 1950 s as part of the International Biological Programme.

Principal Reference Material The above information is taken from:

- Mansoori, J. (1983). National Report on Iran's Wetlands of International Importance as habitat for waterfowl. Prepared for Groningen Conference, Netherlands in May 1984.

- Carp, E. (1980). A Directory of Western Palearctic Wetlands. IUCN, Gland Switzerland.

- IUCN (1977). World Directory of National Parks and other Protected Areas. IUCN, Morges, Switzerland.

Additional references:

- Löfler, H. (1967). The hydrobiology of Lake Niriz, Iran. Proceedings of a Technical Meeting on Wetland Conservation. IUCN Publ. New Series No. 12. IUCN, Morges, Switzerland. Pp. 141-151.

\section{Anzali (ex-Pahlavi) Mordab Complex}

Location $37^{\circ} 23^{\prime}-37^{\prime} \mathrm{N}, 49^{\circ} 15^{\prime}-35^{\prime} \mathrm{E}$. Situated on the southwest shore of the Caspian Sea northeast of Rasht and adjacent to Bandar-e-Anzali township on the northern boundary in Gilan Province, northern Iran.

Area 15,000ha (including Anzali-Mordab 10,990ha, Siahkesheem Marsh 3,650ha and Selke Ab-bandans $360 \mathrm{ha})$.

Degree of Protection Mainly government owned, with some private ab-bandan (reservoirs). The wetland is administered by a council under the supervision of the Department of the Environment. Anzali-Mordab is not protected although Siahkesheem has been protected as a wildlife sanctuary since August 1967, and Selke since 1970. However in 1978-83 the areas could not be effectively protected. Designated as a Ramsar Site at the time of ratification after 23 June 1975.

Site Description The designated area comprises the Anzali-Mordab coastal lagoon, the associated Siahkesheem marshlands and the semi natural floodplain and marshes of the Selke Ab-bandans. Anzali-Mordab is a large shallow eutrophic freshwater lagoon fed by several rivers and streams (including tributaries of the Safi River) and rainfall run-off from the high ground around Rasht. It is separated from the Caspian Sea by an established dune system with only a narrow drainage channel flowing into the sea just east of Bandar-e-Anzali. Moderate seasonal fluctations in water level (autumn/winter) sometimes result in flooding of the Siahkesheem marshes and nearby pastures. The abundant floating and submerged vegetation includes species of duckweed Lemna, pondweeds Potamogeton, Elodea, milfoil Myriophyllum, hornwort Ceratophyllum and arrowhead Saggitaria. The lake is fringed by reedbeds of Phragmites communis and Typhas sp., with rushes Scirpus sp. and Cyperus sp., willow and alder (Salix sp., Alnus sp.) on drier ground. The adjacent Siahkesheem eutrophic freshwater marshlands are fed by numerous rivers (including the Hohambar, Chakoor, Siahdarveshan and Nargestan), irrigation channels and rainfall. It drains into the lagoon to the northwest, and is periodically flooded when rainfall is heavy. The marshland vegetation is similiar to that of the lagoon, with species of Ceratophyllum, Alnus and Scirpus absent but with species of water chestnut Trapa natans, sedges Carex and rushes Juncus. The Selke Ab-bandans (reservoirs) comprise a semi-natural floodplain and eutrophic marsh with dykes constructed along the northern edge for water storage. They have a flooded herbaceous vegetation, with algal growth during summer, some reedbeds Phragmites communis in the north and stands of rushes Juncas spp. and damp grassland in the south. The wetland is surrounded by cultivated land (rice), 
sanddunes, numerous small reservoirs and patches of forest to the south. Several small settlements border the area, and the town of Bandar-e-Anzali is on the northern shore of the lagoon. Mean annual rainfall is $1,000-2,000 \mathrm{~mm}$ and temperature range $-11^{\circ}$ to $30^{\circ} \mathrm{C}$.

International and National Importance The wetlands are an important feeding and resting station for breeding, migrant and wintering birds. Most breeding species nest by the lagoon or in the Siahkesheem marshes, and these include great crested grebe Podiceps cristatus, black-necked grebe $P$. nigricollis, purple swamp hen Porphyrio porphyrio, herons (Ardeidae), rail (Rallidae), pygmy cormorant Phalacrocorax pygmaeus and a large colony of whiskered tern Chlidonias hybrida. Apart from coot Fulica alra, few duck (Anatidae) breed in the wetland, but in winter it is a very important refuge for surface-feeding and diving ducks, swans Cygnus spp., herons and coot. Many herons, ducks and grebes pass through the wetlands on migration. Selke Ab-bandans are of particular importance as a feeding and roosting area for birds from the more disturbed Anzali-Mordab lagoon.

Changes in Ecological Character The lagoon area is heavily disturbed with commercial fishing, hunting of wildfowl, livestock grazing, reed cutting along the edges, and considerable boat traffic (centred round Bandar-e-Anzali). The gradual decline in the water level in the Caspain Sea will undoubtedly affect the wetland habitat in the long term. Reedbeds of Phragmiles communis are spreading into open water areas.

Management Practices Hunting of wildfowl is prohibited on the Selke Ab-bandans, which are also managed as water storage reservoirs. Reed cutting and grazing are allowed on the Siahkesheem marshes.

Scientific Research and Facilities Numerous limnological and hydroloigcal studies have been conducted by SHILOT (Northern Fisheries Organisation). The Department of the Environment have carried out wildfowl surveys.

Principal Reference Material The above information is taken from:

- Mansoori, J. (1983). National Report on Iran's Wetlands of International Importance as habitat for waterfowl. Prepared for Groningen Conference, Netherlands in May 1984.

Supplemented by:

- Carp, E. (1980). A Directory of Western Palearctic Wetlands. IUCN, Gland Switzerland.

- IUCN (1977). World Directory of National Parks and other Protected Areas. IUCN, Morges, Switzerland.

Additional reference:

- Ferguson, D.A. (1972). Waterfowl wintering, resting and breeding areas of the south west Caspian lowlands. Wild fowl 23: 5-24.

Shadegan Marshes and Tidal Mud-flats of Khor-Al Amaya and Khor Musa

Location $30^{\circ} 30^{\prime} \mathrm{N}, 48^{\circ} 45^{\circ} \mathrm{E}$. Situated about $45 \mathrm{~km}$ north and northeast of Abadan in Khuzestan Province at the southern frontier with Iraq on the Gulf.

Area $190,000 \mathrm{ha}(400,000 \mathrm{ha}$ at designation).

Degree of Protection Government owned except for about 1.000ha of private rice paddies. Administered by the Department of the Environment. The designated site lies in Shadegan Wildlife Refuge established in 1973. Hunting is prohibited. Designated as a Ramsar Site at the time of ratification after 23 June 1975.

Site Description The designated site is part of the largest lowland expanse in Iran $(3,800,000 \mathrm{ha})$, and comprises the alluvial delta plain of the Karun and five other rivers which drain the extensive $(11,500,000 \mathrm{ha})$ catchment area at the northwest end of the Zagros mountain range. The better drained inland areas in the north support fresh/brackish sedge marshes, giving way to saltmarsh vegetation with glasswort Salicomia in the central floodplain, and barren tidal mudflats, creeks, sandbars and a low muddy island in the coastal region. The 
wetland is bordered on the east, north and northwest by barren dried-out saline flats, with the more fertile rice paddies, date palm groves, and associated settlements in the northeast. The delta region is fed by overflow channels from the River Karun, seepage, irrigation canals, and to a lesser extent by local rainfall and run off. The water level is highest following spring floods but drains into the Gulf, and the sedge marshes in the north mostly dry out in summer. The road between Abadan on the eastern boundary and Bandar-e-Shahpur on the west passes through the northern sector of the wetland, and the Abadan-Ahwaz road runs along the north-northeast boundary. The climate is hot, with mean January temperature over $7^{\circ} \mathrm{C}$, and mean July temperate over $45^{\circ} \mathrm{C}$. Mean annual rainfall $146 \mathrm{~mm}$, with $92 \%$ falling between November and April.

International and National Importance The marshes are an important wintering and breeding area for a large number of waterfowl, with some 125 recorded species. During migration it is of particular importance to duck species, including a large proportion of the declining world population of marbled teal Anas angustirostris and also greylag goose Anser anser, herons (Ardeidae), sandpipers (Scolopacudae), gulls (Laridae), and large flocks of greater flamingo Phoenicopterus ruber. Breeding species include marbled teal, ferruginous duck Althya nyroca, purple heron Ardea purpurea, slender-billed gull Larus genei, terns (Sterninae) and possibly sacred ibis Threskiornis aeuthopicus. There is a large non-breeding population (several thousand) of Dalmation pelican Pelecanus crispus.

Changes in Ecological Character The wetland is situated in a currently sensitive military zone between Iran and Iraq. The irrigation scheme developed in the north on the Karun River has reduced the inflow of fresh water. Part of the designated site is cultivated in privately owned rice paddies. Some of the area has been degraded to sterile silt flats by natural salinity and soil deterioration, resulting from poorly managed irrigation schemes.

Management Practices The wetland is still used for traditional reed cutting, grazing and fishing.

Scientific Research and Facilities The Department of the Environment has conducted waterfowl surveys in the wetland.

Principal Reference Material The above information is taken from:

- Mansoori, J. (1983). National Report on Iran's Wetlands of International Importance as habitat for waterfowl. Prepared for Groningen Conference, Netherlands in May 1984.

Supplemented by:

- Carp, E. (1980). A Directory of Western Palearctic Wetlands. IUCN, Gland, Switzerland.

- IUCN (1977). World Directory of National Parks and other Protected Areas. IUCN, Morges, Switzerland.

Additional references:

- Firouz, E. (1971). The Wetlands and Waterfowl of Iran. Game and Fish Department of Iran, Tehran.

- Firouz, E. (1974). Environment Iran. The National Soiciety for the Conservation of Natural Resources and Human Environment, Tehran.

- Scott, D.A. and Carp, E. (1971). A survey in Kuzestan, Iran. Proc. Internat. Conf. on the Conservation of Wetlands and Waterfowl, Ramsar. Iran. Pp. 191-298. IWRB, Slimbridge, England.

\section{Hamount-E-Saberi}

Location $31^{\circ} 20^{\prime} \mathrm{N}, 61^{\circ} 20^{\prime} \mathrm{E}$. Situated on the eastern frontier with Afghanistan, $35 \mathrm{~km}$ northwest of Zabol in Seistan Province.

Area 50,000ha. Contiguous to South End of Hamoun-e-Puzak Ramsar site $(10,000 \mathrm{ha})$ on the eastern boundary. 
Degree of Protection Government owned, and administered by the Department of the Environment. 37,000 ha of the designated site lies in Hamoun Wildlife Refuge $(180,000 \mathrm{ha})$ which is in Hamoun Protected Region (329,000ha) established in 1967. Hunting is prohibited. Designated as a Ramsar site at the time of ratification after 23 June 1975.

Site Description The designated site is in the sparsely populated Hamoun river basin (Seistan lowlands), and comprises the southern portion of Saberi Lake (Hamun-e-Helmand) to the south, and the Hamoun-e-Saberi and Baring Dakegaz marshes extending southwards from Saberi Lake. The shallow (average depth $0.5 \mathrm{~m}$ ) fresh to brackish lake has a bottom of alluvial silt, and is fed mainly by the Harut and Helmand rivers, with low input from local run-off. Drainage is essentially closed, but if the water level is exceptionally high, any overspill flows into Helmand River effectively reversing the flow temporarily. The marshland is predominantly eutrophic, with extensive reedbeds of Phragmiles communis and Typha sp., sedges Carex spp. and Tamarix sp. In years of prolonged flooding (such as 1972), an abundant submerged vegetation develops on the floodplains. Halophytic vegetation fringes the wetland, and includes Halocnemum strobilaceum, sea lavender Limonium carnosum, glasswort Salsola spp. and the orache Atriplex verruciferum. The surrounding area is arid, with very few settlements and limited irrigated cultivation to the south and east. The climate is hot with mean January temperature of $15-20^{\circ} \mathrm{C}$ and mean July temperature $35-40^{\circ} \mathrm{C}$. Low mean annual rainfall of $100 \mathrm{~mm}$, falling mainly in winter.

International and National Importance The site supports a large number of breeding birds during wet years. Large concentrations of migrating and wintering birds include greylag goose Anser anser, mallard Anas platyrhynchos, teal Anas crecca, red-crested pochard Netta rufina, shoveler Anas clypeata, common pochard Aythya ferina, coot Fulica atra, white-headed duck Oxyura leucocephala, crane Grus grus, Dalmation pelican Pelecanus crispus and white pelican $P$. onocrotalus.

Changes in Ecological Character Irrigation schemes on the Helmand River (in Iran and Afghanistan) have reduced the water supply to the lake and marshes, and hence reduced the degree of flooding. The wetland now floods only in wet years, drying out completely in drought years.

Management Practices Sparsely populated region with little grazing and traditional reed-cutting.

Scientific Research and Facilities The Department of the Environment has carried out waterfowl counts and other studies in the wetland.

Principal Reference Material The above information is taken from:

- Mansoori, J. (1983). National Report on Iran's Wetlands of International Importance as habitat for waterfowl. Prepared for Groningen Conference, Netherlands in May 1984.

Supplemented by:

- Carp, E. (1980). A Directory of Western Palearctic Wetlands. IUCN, Gland, Switzerland.

- IUCN (1977). World Directory of National Parks and other Protected Areas. IUCN, Morges Switzerland.

Additional references:

- Firouz, E. (1971). The Wetlands and Waterfowl of Iran. Game and Fish Department of Iran, Tehran.

- Firouz, E. (1974). Environment Iran. The National Soiciety for the Conservation of Natural Resources and Human Environment, Tehran.

- Scott, D.A. and Carp, E. (1971). A survey in Kuzestan, Iran. Proc. Internat. Conf. on the Conservation of Wetlands and Waterfowl, Ramsar, Iran. Pp. 191-298. IWRB, Slimbridge, England. 


\section{Lake Kobi}

Location $36^{\circ} 57^{\prime} \mathrm{N}, 45^{\circ} 52^{\prime} \mathrm{E}$. Situated about $75 \mathrm{~km}$ southeast of Oroomiyeh Lake between the towns of Mahabad and Miandowab in Azarbaijan Province, northern Iran.

Area $1,200 \mathrm{ha}$

Degree of Protection Government owned, and administered by the Department of the Environment. The area is unprotected, however, and due to continuing political unrest in this region, the future of the lake as a conservation area is uncertain. Designated as a Ramsar Site at the time of ratification after 23 June 1975.

Site Description The designated site comprises freshwater Kobi Lake and associated but disjunct marshlands. The shallow (maximum depth $1.5 \mathrm{~m}$ ) muddy-bottomed lake lies at $1,240 \mathrm{~m}$, and is supplied from rainfall, run-off, several springs, seepages and temporary water courses fed by snow-melt. It has no outlet channels, and when full the lake overflows flooding the marshlands to the north. The lake is eutrophic and supports an abundant subrnerged vegetation. The sedge (Cyperaceae) marshlands are extensive with grasslands and reedbeds of Phragmites communis south of the lake and in the marshes to the northwest. The wetland is surrounded by rolling hilly steppe, with scattered settlements and cultivation to the north and south. The climate is cold, and the lake regularly freezes over in winter.

International and National Importance The site is of major importance as a feeding station during migration for a large number of dabbling and diving ducks Anas and Aythya species and coot Fulica atra. Waterfowl breeding in the area include night heron Nycticorax nycticorax, glossy ibis Plegadis falcinellus, ferruginous duck Aythya nyroca, white-headed duck Oxyura leucocephala, coot, avocet Recurvirostra avosetta, collared pratincole Glareola pratincola and common tern Sterna hirundo.

Changes in Ecological Character The site is in a politically sensitive zone, and its future as a conservation area is uncertain. There is some grazing and hunting of wildfowl but the wetland is thought to be generally undisturbed (Carp, 1980).

\section{Management Practices Some grazing and hunting}

\section{Scientific Research and Facilities Some wildfowl counts}

Principal Reference Material The above information is taken from:

- Mansoori, J. (1983). National Report on Iran's Wetlands of International Importance as habitat for waterfowl. Prepared for Gröningen Conference, Netherlands in May 1984.

Supplemented by:

- Carp, E. (1980). A Directory of Western Palearctic Wetlands. IUCN, Gland, Switzerland.

- IUCN (1977). World Directory of National Parks and other Protected Areas. IUCN, Morges, Switzerland.

\section{South End of Hamoun-E-Puzak}

Location $31^{\circ} 20^{\prime} \mathrm{N}, 61^{\circ} 45^{\prime} \mathrm{E}$. Situated $40 \mathrm{~km}$ northeast of Zabol in the vicinity of the villages of Takht-e-Shah, Manmoodi and Shangali, Seistant Province. On the eastern frontier with Afghanistan.

Area 10,000ha. Contiguous to Hamoun-e-Saberi Ramsar site $(50,000 \mathrm{ha})$.

Degree of Protection Government owned, and administered by the Department of the Environment. The site contains the 180,000 ha Wildlife Refuge of Hamount Protected Region (329,000ha), established in 1967. Designated as a Ramsar Site at the time of ratification after 23 June 1975. 
Site Description The designated site comprises only the southern tip of the extensive Hamoun-e-Puzak system, the major part of which is located in neighbouring Afghanistan. It comprises freshwater brackish lagoons and marshes, dependent for water supply on the Helmand, Kash and Khuspas rivers, and on the water level in the Afghan portion of Hamount-e-Puzak. Although it is the most permanent marshland area in the Iranian Seistan lowlands, it dries out during drought years. There is no overflow except in very wet years, when flooding usually occurs in late winter and spring. Vegetation includes extensive reedbeds of Phragmites communis and Typha sp. fringing the lagoons, sedges (Cyperaceae) and Tamarix sp. During prolonged periods of flooding an abundant submerged vegetation develops. The climate is hot, with mean January temperature $15-20^{\circ} \mathrm{C}$, and mean July temperature $35-40^{\circ} \mathrm{C}$. Low mean annual rainfall of $100 \mathrm{~mm}$ falling mainly in winter.

International and National Importance The wetland is an important nesting area for waterfowl in wet years, and is used as a resting station by many migrating species including feeding ducks and waders (Limicolae). Large numbers of Anas spp., herons (Ardeidae) and coot Fulica atra overwinter in the area.

Changes in Ecological Character Irrigation schemes along the Helmand River in Afghanistan threaten the marshlands in years of low rainfall, as they divert floodwaters away from the wetland. Some illegal hunting has been reported (1980). Traditional reed-cutring, fishing and some grazing continue.

\section{Management Practices No information}

Scientific Research and Facilities The Department of the Environment have carried out wildfowl counts and several special studies in the wetland.

Principal Reference Material The above information is taken from:

- Mansoori, J. (1983). National Report on Iran's Wetlands of International Importance as habitat for waterfowl. Prepared for Groningen Conference, Netherlands in May 1984.

Supplemented by:

- Carp, E. (1980). A Directory of Western Palearctic Wetlands. IUCN, Gland, Switzerland.

- IUCN (1977). World Directory of National Parks and other Protected Areas. IUCN, Morges, Switzerland.

Additional references:

- Firouz, E. et al. (1970). The Wildlife Parks and Protected Regions of Iran. Biol. Conservation 3(1): 37-45.

- Firouz, E. (1971). The Wetlands and Waterfowl of Iran. Game and Fish Department of Iran, Tehran.

\section{Shur Gol, Yadegarlu and Dorgeh Sangi Lakes}

Location $37^{\circ} 00^{\prime} \mathrm{N}, 45^{\circ} 26^{\circ}-35^{\prime} \mathrm{E}$. Situated northwest/west of Lake Kobe Ramsar Site in the plains south of Lake Oroomiyeh, and about $35 \mathrm{~km}$ northwest of Mahabad in Azarbaijan Province, northwest Iran.

Area 2,500ha (Shur Gol 2,000ha, Yadegarlu 350ha and Dorgeh Sangi $150 \mathrm{ha}$ ).

Degree of Protection Government owned, and administered by the Department of the Environment. The site is unprotected, and due to continuing political unrest in the region, its future as a conservation area is uncertain. Designated as a Ramsar Site at the time of ratification after 23 June 1975.

Site Description The designated site comprises the three lakes and their associated marshlands. The shallow silt-bottomed Shur Gol is surrounded by Hassanlu marshes. The water is brackish to saline, and is fed by rainfall, run-off from surrounding high grounds, springs, seepages and several small streams. The marsh usually floods during autumn and winter, and due to absence of outflow channel, dries out only in very dry years. The eutrophic 
marshlands support extensive stands of sedge Carex spp., with an abundant submerged vegetation during prolonged flooded periods. Yadegarlu is a much smaller shallow freshwater lake, supporting an abundant submerged vegetation, and surrounded by eutrophic marshlands of sedge (Cyperaceae) and grasses. It is fed by run-off, rainfall, springs, seepages and small streams, and its size fluctuates considerably, almost drying out completely by late summer. Dorgeh Sangi is the smallest of the three lakes and is also a shallow fresh water eutrophic lake fed by small springs, seepages, rainfall and run-off with size fluctuating considerably. After winter rains it can overspill to the west. The limited amount of vegetation includes some sedges and grasses, and sparse submerged vegetation. All three lakes freeze over to some degree during the cold winters. The disjunct wetland complex is surrounded by wheat cultivation on rolling hills and plains to the north, with more intensive agriculture around the villages in the south. There are several settlements interspersed among the lakes, and the main road north to Rezaujah passes through the wetland.

International and National Importance Breeding waterfowl include ruddy shelduck Tadorna ferruginea, marbled teal Anas angustirostris, coot Fulica atra, waders (Limicolae), terns (Sterninae), great crested grebe Podiceps cristatus and white stork Ciconia ciconia (at Yadergalu) and black-necked grebe $P$. rigricollis (at Dorgeh Sangi). Migrant visitors include greylag goose Anser anser. Anas and Aythya spp., and coot Fulica atra and occasional Bewick swan Cygnus columbianus bewickii visit Dorgeh Sangi and Yadegarlu when they are not completely frozen over. Small numbers of Anatidae including smew Mergus albellus winter in the area.

Changes in Ecological Character There is continuing threat from over-grazing and excessive hunting pressure on wildfowl. The local population is expanding, which could lead to degradation of the wetlands through urbanisation. The area is in a politically sensitive zone and its condition is uncertain.

Management Practices Traditional reed-cutting is still practised.

Scientific Research and Facilities The Department of the Environment has carried out waterfowl counts.

Principal Reference Material The above information is taken from:

- Mansoori, J. (1983). National Report on Iran's Wetlands of International Importance as habitat for waterfowl. Prepared for Groningen Conference, Netherlands in May 1984.

Supplemented by:

- Carp, E. (1980). A Directory of Western Palearctic Wetlands. IUCN, Gland, Switzerland.

- IUCN (1977). World Direciory of National Parks and other Protected Areas. IUCN, Morges, Switzerland.

Additional references:

- Firouz, E. (1971). The Wetlands and Waterfowl of Iran. Game and Fish Department of Iran, Tehran.

- Firouz, E. (1976). Environmental and nature conservation in Iran. Environmental Conservalion 3(1): 33-42.

- Firouz, E. and Harrington, F.A. (1976). Iran: concepts of biotic community conservation. A paper presented at the international meeting on ecological guidelines for the use of natural resources in the Middle East and South West Asia. IUCN Occasional Paper No. 15. IUCN, Morges, Switzerland.

Bandar Kiashahr (ex-Farahnaz) Lagoon and the mouth of Sefid Rud

Location $37^{\circ} 25^{\prime} \mathrm{N}, 49^{\circ} 19^{\prime} \mathrm{E}$. Situated $15 \mathrm{~km}$ north/northwest of Rasht town, east of Anzali Mordab Complex (Ramsar Site) on the Caspian Sea in Gilan Province, northern Iran.

Area 
Degree of Protection Government owned, and administered by the Department of the Environment. Unprotected except for Ramsar status. Designated as a Ramsar Site at the time of ratification after 23 June 1975.

Site Description The designated area comprises the lagoon, the mouth of the Sefid Rud and associated marshes, and grassy dunelands. The shallow freshwater coastal lagoon and swamp are fed by two streams from the Sefid Rud to the west, and they drain northward through a narrow channel into the Caspian Sea. The fresh water input is supplemented by seepages and rainfall, and (although fluctuations in water level tend to be slight) there can be some flooding in winter. The lagoon bottom is a mixture of sand and mud, and the waters are predominantly oligotrophic except towards the marshy western extreme. Reedbeds Phragmites communis and Typha sp. predominate in the west, with stands of rushes Juncus spp. in the eastern and southern marshy areas. Scrub and dune vegetation predominates on the higher ground in the north and northwest, with grasslands subject to periodic flooding along the Sefid Rud. There are several settlements to the south of the lagoon, surrounded by cultivated land with patches of woodland. The two streams from the Sefid Rud are used as a supply for local irrigation schemes.

International and National Importance The site is of major importance as a wintering area for waterfowl, including grebes Podiceps spp., Dalmation pelican Pelecanus crispus, greater flamingo Phoenicopterus ruber, herons (Ardeidae), greylag goose Anser anser, shelduck Tadorna tadorna, gulls (Laridae) and some waders (Limicolae). It is a breeding site for cormorant Phalacrocarox carbo and several species of heron (Ardidae). It is of less importance as a resting station with moderate numbers of passage species.

Changes in Ecological Character A fishery has been established on the lagoon. There is serious hunting and over-grazing pressure in the area and the level of disturbance is increasing with sport and recreational activities.

Management Practices Traditional reed-cutting, livestock grazing and commercial fisheries.

Scientific Research and Facilities The Department of the Environment has carried out waterfowl surveys.

Principal Reference Material The above information is taken from:

- Mansoori, J. (1983). National Report on Iran's Wetlands of International Importance as habitat for waterfowl. Prepared for Groningen Conference, Netherlands in May 1984.

Supplemented by:

- Carp, E. (1980). A Directory of Western Palearctic Wetlands. IUCN, Gland, Switzerland.

- IUCN (1977). World Directory of National Parks and other Protected Areas. IUCN, Morges, Switzerland.

Additional reference:

- Ferguson, D.A. (1972). Waterfowl wintering, resting and breeding areas of the Southwest Caspian lowlands. Wild fowl 23: 5-24.

\section{Amirkelayeh Lake}

Location $37^{\circ} 17^{\prime} \mathrm{N}, 50^{\circ} 12^{\prime} \mathrm{E}$. Situated on the shore of the Caspian Sea $15 \mathrm{~km}$ north of Langarva township and $60 \mathrm{~km}$ east of Rasht in the north of Gilan Province.

Area $1,200 \mathrm{ha}$ (reduced since 1980 from $1,230 \mathrm{ha}$ ).

Degree of Protection Government owned, and administered by a local Council under the supervision of the Department of the Environment. The designated site is in Amirkelayeh Wildlife Refuge (1,230ha) established in 1971. Designated as a Ramsar Site at the time of ratification after 23 July 1975. 
Site Description The designated site comprises a freshwater lake (3-4m depth) and associated marshes at $20 \mathrm{~m}$ below sea level. The eutrophic lake is fed by springs, run-off from nearby irrigated land, and rainfall. It can flood the marshes or at the highest flood levels overspill into the Caspian Sea to the north (although the fluctuation in water level is usually slight). The vegetation is predominantly reedbeds Phragmites communis with some reedmace Typha sp. and willow's Salix spp. The more open water supports an abundant submerged vegetation. There are several small settlements in the vicinity, with a small road linking those in the north to the Langarud road. The surrounding area comprises cultivated rice paddies with patches of woodlands of Salix caprea, S. micans and Pterocarya fraxinifolia, and there are remnants of former coastal forest cover.

International and National Importance The wetland is notable for breeding populations of heron (Ardeidae), duck (Anatidae) and rail (Rallidae), and large numbers of winter migrants such as coot Fulica atra, swans Cygnus spp. and herons (Ardeidas).

\section{Changes in Ecological Character None reported (1980)}

Management Practices The Wildlife Refuge is supervised by game guards from the Department of the Environment. For many years the wetland was maintained as a strict nature sanctuary with all exploitation and interference prohibited. Current management strategy is not known.

Scientific Research and Facilities The Department of the Environment has carried out some waterfowl surveys.

Principal Reference Material The above information is taken from:

- Mansoori, J. (1983). National Report on Iran's Wetlands of International Importance as habitat for waterfowl. Prepared for Groningen Conference, Netherlands in May 1984.

Supplemented by:

- Carp, E. (1980). A Directory of Western Palearctic Wetlands. IUCN, Gland, Switzerland.

Additional references:

- Ferguson, D.A. (1972). Waterfowl wintering, resting and breeding areas of the southwest Caspian Lowlands. Wild fowl 23: 5-24.

- Firouz, E. (1971). The Wetlands and Waterfowl of Iran. Game and Fish Department of Iran, Tehran.

- Harrison, J. (1972). South of the Caspian Sea. World of Birds (January).

\section{Lake Gori}

Location $3755^{\prime} \mathrm{N}, 46^{\circ} 42^{\prime} \mathrm{E}$. Situated $40 \mathrm{~km}$ east/southeast of Tabriz in Azarbaijan Province, northwest Iran.

Area 120 ha

Degree of Protection Government owned, and administered by the Department of the Environment, Tehran. Unprotected except for Ramsar status. Designated as a Ramsar Site at the time of ratification af ter 23 June 1975.

Site Description The site comprises a freshwater/brackish lake in a depression in the shale and rock substrate at $1,950 \mathrm{~m}$, surrounded by higher ground. It is fed by rainfall, run-off, springs, seepages and small streams, with inflow greatest during and after the spring thaw. The fluctuation in water level is slight, and any overflow feeds a small stream to the northeast. The lake always freezes over in winter, and is under deep snow by midwinter. It supports an abundant submerged vegetation, and is fringed by extensive reedbeds Phragmites communis, rushes Juncus spp., sedges Carex spp. and Scirpus sp. The surrounding area is semi-arid steppe, with a small settlement (Yvsef Abad) and associated wheat cultivation to the west, and damp grassland to the southwest. The main road between Tabriz and Tehran passes along the southern boundary of the designated site. 
International and National Importance Breeding birds include large colonies of grebes such as black-necked grebe Podiceps nigricollis, coot Fulica atra and a variety of ducks (Anatidae) including white-headed duck Oxyura leucocephala. Small numbers of various waterfowl species visit the area during their migration, except during winter when the lake is frozen over.

Changes in Ecological Character Recreational pressure from the urban population of Tabriz has increased, and could become excessive. Sport fishing, wildfowl hunting, grazing and reed-cutting persist.

\section{Management Practices No information}

Scientific Research and Facilities Some wildfowl counts have been carried out.

Principal Reference Material The above information is taken from:

- Mansoori, J. (1983). National Report on Iran's Wetlands of International Importance as habitat for waterfowl. Prepared for Gröningen Conference, Netherlands in May 1984.

- Carp, E. (1980). A Directory of Western Palearctic Wetlands. IUCN, Gland Switzerland.

- IUCN (1977). World Directory of National Parks and other Protected Areas. IUCN, Morges, Switzerland.

Additional reference:

- Gyllin, R. (1970). Bilder fran en persksk fagelsjo. Fauna och Flora 3: 113-117.

\section{Alagol, Ulmagol and Ajigol Lakes}

Location $37^{\circ} 23^{\prime} \mathrm{N}, 54^{\circ} 35^{\prime} \mathrm{E}$. Situated just south of the international frontier with USSR, a few km east of the Caspian Sea in Mazandaran Province, northern Iran.

Area 1,400ha (Alagol lake 1,000ha, Ulmagol lake $200 \mathrm{ha}$ and A jigol lake 200ha).

Degree of Protection Government owned, and administered by the Department of the Environment. Unprotected except for Ramsar status. Designated as a Ramsar Site at the time of ratification after 23 June 1975.

Site Description The designated site comprises the disjunct lake and marshland complex at sea level in the mud flats east of the Caspian Sea and south of the Atrak River. The mud and sand-based Alagol lake lies southwest of the other lakes. It is slightly saline and is fed by seepage, springs, rainfall and local run-off. The water level varies considerably due to the seasonal nature of the inflow, flooding in winter but drying out completely in particularly dry summers. The vegetation is sparse, with some fringing rushes Juncus spp., sedges Carex spp. and grasses (mainly in the north east), and small patches of reedbeds Phragmites communis. The closely associated Ulmagol and Ajigol are seasonal freshwater lakes fed by rainfall and run-off in autumn and winter, and drying out completely during periods of drought. They lie on a mud and clay substrate, but vary slightly in the vegetation they support. Ulmagol lake supports a sparse vegetation of Juncus spp, duckweed Lemna sp., Phragmites communis, Alhagi $\mathrm{sp}$. and algae. Ajigol lake supports some Tamarix sp., grasses and saltbush, with extensive reedbeds of Phragmites communis spreading over the lake at the eastern end and an abundant submerged vegetation. There are several small settlements in the general area of the lake complex.

International and National Importance The three lakes support a varied population of breeding wildfowl, including coot Fulica atra and Kentish plover Charadrius alexandrinus at Alagol Lake, little grebe Tachybaptus ruficollis and white-tailed plover Vanellus leucurvus at Ajigol lake and great crested grebe Podiceps cristalus at all three lakes. In winter there is a moderate influx of a wide variety of waterfowl on migration or overwintering, including greater flamingo Phoenicopterus ruber (at Alagol), geese and ducks (Anatidae) such as Anas spp, red-crested pochard Netta rufina, Aythya spp. and smew Mergus albellus, and large numbers of coot, grebes (Podicipitidae), great egret Egretta alba and swans Cy'gnus spp. 
Changes in Ecological Character The main disturbance is from hunters in winter, particularly at the smaller Ulmagol and Ajigol lakes where wildfowl hunting pressure can be considerable. Alagol lake being less accessible is relatively undisturbed.

Management Practices Reed-cutting, grazing and some fishing continue.

Scientific Research and Facilities Wildfowl counts were carried out each year between 1969 and 1974.

Principal Reference Material The above information is taken from:

- Mansoori, J. (1983). National Report on Iran's Wetlands of International Importance as habitat for waterfowl. Prepared for Groningen Conference, Netherlands in May 1984.

Supplemented by:

- Carp, E. (1980). A Directory of Western Palearctic Wetlands. IUCN, Gland, Switzerland.

- IUCN (1977). World Directory of National Parks and other Protected Areas. IUCN, Morges, Switzerland.

Additional reference:

- Firouz, E. (1971). The Wellands and Waterfowl of Iran. Game and Fish Department of Iran, Tehran.

\section{Khuran Straits (Bandar Abbas)}

Location $2640^{\prime}-27^{\circ} 03^{\prime} \mathrm{N}, 55^{\circ} 30^{\prime}-55^{\circ} 53$. Situated between the southern Iranian mainland and Qeshm Island. The wetland is approximately equi-distant between the towns of Bandar Abbas and Bandar-e-Lengen in Bandar Abbas Province on the Gulf Coast.

Area 100,000 ha

Degree of Protection Government owned, and administered by the Department of the Environment. The designated site includes 82,360 ha in Hara National Park which was enlarged and upgraded from the 65,750ha Hara Protected Region established in 1972, and 85,360ha in the fully protected Hara Biosphere Reserve approved in June 1976. The unprotected areas in the east are threatened with degradation through illegal logging of the mangroves. Designated as a Ramsar Site at the time of ratification after 23 June 1975.

Site Description The major feature of the reserve is the Mehran River delta, which forms extensive intertidal silt flats with marshy coastal shoreline and mangrove Avicennia sp. forests, numerous small islands and creeks and smaller estuaries. Red (Rhodophyceae) and brown (Phaeophyceae) algae predominate in the saline shallows. The intertidal and mangrove zones provide a suitable habitat for abundant crustaceae, which form an important foodsource for wildfo:wl. There are a few settlements scattered along the mainland shore. The climate is tropical to subtropical with summer temperature reaching $45^{\circ} \mathrm{C}$. Annual rainfall of 100-300 mm falling mainly between November and April.

International and National Importance The coastal wetland is an important breeding site for herons (Ardeidae), notably great egret Egrella alba, western reef heron $E$. gularis, Indian pond heron Ardeola grayii and goliath heron Ardea goliath, and also crab plover Dromas ardeola and stone-culew Burhinus oedienemus. Numerous species of plover (Charadriidae) pass through the area on migration. In winter the wetland is of special importance as a feeding station for heron, plover and sandpipers (Scolopacidae) including grey heron Ardea cinerea, redshank Tringa totanus, Terek sandpiper, $T$. cinereus, bar-tailed godwit Limosa lapponica and curlew Numenias arquata. Wintering flocks of Dalmation pelican Pelecanus crispus, spoonbill Platalea leucorodia and greater flamingo Phoenicopterus ruber have been recorded. The green turtle Chelonia mydas occurs in significant numbers offshore close to Qeshm Island.

Changes in Ecological Character The local population continues to cut mangroves and manufacture charcoal in some areas. There is some disturbance from continuing fishing and boat traffic in the straits. 
Scientific Research and Facilities Waterfowl counts have been carried out. There is a marine research station on Hormoz Island east of the reserve.

Principal Reference Material The above information is taken from:

- Mansoori, J. (1983) National Report on Iran's Wetlands of International Importance as Habitat for waterfowl for Groningen Conference, Netherlands in May 1984.

Supplemented by:

- Carp, E. (198\%). A Directory of Western Palearctic Wetlands. IUCN, Gland, Switzerland.

- Biosphere Reserve nomination submitted to Unesco-MAB Secretariat (1976).

- IUCN (1977). World Directory of National Parks and other Protected Areas. IUCN, Morges, Switzerland.

Additional references:

- Firouz, E. et al. (1970). The wildlife parks and protected regions of Iran. Biological Conservation $3(1): 37-45$.

- Firouz, E. (1971). Conservation and wildlife management in Iran. Game and Fish Department of Iran. Ziba Press, Tehran.

- Firouz, E. (1974). Environment Iran. The National Society for the Conservation of National Resources and Human Environment. Tehran.

- Firouz, E. (1967). Environmental and nature conservation in Iran. Environmental Conservation 3(1): 33-42.

- Firouz, E., Harrington, F.A. (1976). Iran: concepts of biotic community conservation. A paper presented at the international meeting on ecological guidelines for the use of natural resources in the Middle East and South West Asia. IUCN Occasional Paper No. 15. IUCN, Morges, Switzerland.

- Harrington, F.A. (1976). Surveys of the southern Iranian coastline with recommendations for additional marine reserves in promotion of the establishment of marine parks and reserves in the Norlhern Indian Ocean, Red Sea and Persian Gulf. IUCN Publ. New Series No. 35. IUCN, Morges, Switzerland. Pp. 50-75.

\section{Deltas of Rud-e-Shur, Rud-e-Shirin and Rud-e-Minab}

Location $27^{\circ} 00^{\prime} \mathrm{N}, 56^{\circ} 22^{\prime}-57^{\circ} 00^{\prime} \mathrm{E}$. $55 \mathrm{~km}$ stretch of coast on the Strait of Homuz (the Gulf) $25 \mathrm{~km}$ east of Bandar Abbas in Bandar Abbas Province, southern Iran.

Area 20,000ha. Just east of Khouran Straits Ramsar site (100,000ha).

Degree of Protection Government owned, and administered by the Department of the Environment. Unprotected except for Ramsar status. Designated as a Ramsar Site at the time of ratification after 23 June 1975 .

Site Description The designated site comprises tidal mudflats, mangrove Avicennia sp., swamp and saltmarsh formed around the mouths of the three rivers. Rud-e-Shirin and Rud-e-Minab are freshwater rivers, while Rud-e-Shar is more brackish. All tend to flood in winter and spring. The inshore zone is shallow with numerous sandbars and spits formed from alluvium, silt and mud deposited by the rivers. The mudflats are barren of vegetation except for stands of mangrove in the creeks and rivermouths, and characteristic saltmarsh plant associations. The arid plains stretching northwards inland from the coast are sparsely vegetated, while the steppelands to the south support some Acacia spp. and data palm Phoenix dactylifera. There are a few small settlements near the wetland.

International and National Importance The coastal wetland is an important wintering area for cormorant Phalacrocorax carbo, various herons (Archdeidae), greater flamingo Phoenicopterus ruber, waders such as oystercatcher Haematopus ostralegus, bar-tailed godwit Limosa lapponica and curlew Numenius arquata, and gulls (Laridae). The breeding population has yet to be investigated in detail and could be comparable with the nearby Khouran Straits Ramsar Site. 
Changes in Ecological Character Fishing and cutting of brushwood for fuel continue in the area.

Management Practices Traditional fishing practices and firewood collection continue.

Scientific Research and Facilities The wetland is poorly studied as yet although some wildfowl counts have been carried out. There is a marine research station established on Hormoz island just of the western end of the designated area.

Principal Reference Material The above information is taken from:

- Mansoori, J. (1983). National Report on Iran's Wetlands of International Importance as habitat for waterfowl. Prepared for Gröningen Conference, Netherlands in May 1984.

Supplemented by:

Carp, E. (1980). A Directory of Western Palearctic Wetlands. IUCN, Gland, Switzerland.

- IUCN (1977). World Directory of National Parks and other Protected Areas. IUCN, Morges, Switzerland.

\section{Deltas of Rud-e-Gaz and Rud-e-Hara}

Location $25^{\circ} 55^{\prime}-26^{\circ} 32^{\prime} \mathrm{N}, 57^{\circ} 10^{\prime} \mathrm{E}$. Situated on the east side of the straits of Hormoz (Gulf of Oman) $120 \mathrm{~km}$ southeast along the coast from Bandar Abbas in Bandar Abbas Province, southern Iran.

Area 15,000 ha

Degree of Protection Government owned, and administered by the Department of the Environment. Unprotected except for Ramsar status. Designated as a Ramsar Site at the time of ratification after 23 June 1975.

Site Description The designated site comprises tidal mudflats, creeks, saltmarsh, mangroves, sandbanks and low muddy offshore islands formed at the mouths of the two main rivers and several intermittant streams. The river waters vary from fresh to brackish and have a sluggish flow, which has resulted in deposition of alluvium, silt, mud and sand in the shallow inshore zone. The saltmarshes and sand dunes support typical vegetation, and there are stands of mangrove Avicennia sp. and agao in the shallows. The mudflats are barren, with no covering of seaweed. The low lying hinterland to the east of the wetland is very arid and only sparsely vegetated. The whole area is remote and sparsely populated.

International and National Importance This coastal wetland is an important wintering site for cormorant Phalacrocorax carbo, several species of heron (Ardeidae), spoonbill Platalea leucorodia, Dalmation pelican Pelecanus crispus, waders such as oystercatcher Haematopus ostralegus, redshank Tringa totanus, bar-tailed godwit Limosa lapponica and curlew Numenius arquata and gulls (Laridae). The area's breeding population has yet to be investigated in detail but it could be comparable with the nearby Khouran Straits Ramsar Site.

Changes in Ecological Character Fishing and cutting of brushwood for fuel continue in the area.

Management Practices Traditional fishing and firewood collection continue.

Scientific Research and Facilities The wetland is poorly studied as yet, although some wildfowl counts have been carried out. There is a marine research station established on Hormoz Island just off the western end of the designated area.

Principal Reference Material The above information is taken from:

- Mansoori, J. (1983). National Report on Iran's Wetlands of International Importance as habitat for waterfowl. Prepared for Gröningen Conference, Netherlands in May 1984. 
Supplemented by:

- Carp, E. (1980). A Directory of Western Palearctic Wetlands. IUCN, Gland, Switzerland.

- IUCN (1977). World Directory of National Parks and other Protected Areas. IUCN, Morges, Switzerland.

\section{Gavkhouni Lake and marshes of the lower Zaindeh Rud}

Location Gavkhouni Lake: $32^{\circ} 08^{\prime}-20^{\prime} \mathrm{N}, 52^{\circ} 45^{\prime}-52^{\prime} \mathrm{E}$. Lower Zaindeh Rud: $32^{\circ} 30^{\prime} \mathrm{N}$, $51^{\circ} 55^{\prime}-52^{\circ} 18^{\prime} \mathrm{E}$. Situated equi-distant (about $120 \mathrm{~km}$ ) between Sfahan city and Yazd in Isfahan Province, Central Iran.

Area 43,000ha (Gavkhouni Lake 12,000ha, permanent marsh 1,000ha and temporary marsh $30,000 \mathrm{ha})$.

Degree of Protection Government owned, and administered by the Department of the Environment. Unprotected except for Ramsar status. Designated as a Ramsar Site at the time of ratification after 23 June 1975.

Site Description The designated site comprises the disjunct enclosed basin of the shallow saltwater Gavkhouni Lake, and associated marshlands upstream on the Zaindeh Rud. Zaindeh Rud is the main water supply to the lake, supplemented by rainfall and run-off from the surrounding high ground. The water level fluctuates considerably, with floods occurring in winter and spring. The temporary flooded marshlands can extend over $50 \mathrm{~km}$ upriver in a wet year. The lake is oligotrophic, with a limited vegetation of Phragmites communis and Tamarix $\mathrm{sp}$. around the river delta area, surrounded by a low cover of halophytic vegetation. There are expanses of bare saltflats and mud-flats. The marshes upstream on the lower Zaindeh Rud are a complex of freshwater marsh and floodplain, predominantly fed by the main river supplemented by irrigation channels, numerous small streams, rainfall and run-off. The area usually floods in early winter and dries out in spring. The substrate is rich alluvial soil, silt and mud, and much of the land is now used for agriculture (wheat and rice cultivation) with only a small amount of marshland remaining. The flooded areas sometimes freeze over in winter.

International and National Importance The lake and river marshlands are of great importance to wintering and migrating birds, particularly Anas and Tadorna spp., crane Grus grus and coot Fulica atra. As they usually dry out in summer they are of minor importance for breeding birds.

Changes in Ecological Character Parts of the floodplain are used for agriculture, livestock grazing and wildfowl hunting. Gavkhouni saltlake is relatively inaccessible, especially during winter floods, and is still mainly undisturbed although brushwood collection for fuel, grazing and some hunting occurs in about 1,000 ha at the mouth of the Zaindeh. The Zaindeh Rud flows from Isfahan, and pollution from the city may be carried into the wetland and lake.

\section{Management Practices No information}

Scientific Research and Facilities The Department of the Environment has carried out some waterfowl surveys.

Principal Reference Material The above information is taken from:

- Mansoori, J. (December 1983). National Report on Iran's Wetlands of International Importance as habitat for waterfowl. Prepared for Groningen Conference, Netherlands in May 1984. 


\section{Supplemented by:}

- Carp, E. (1980). A Directory of Western Palearctic Wetlands. IUCN, Gland, Switzerland.

- IUCN (1977). World Directory of National Parks and other Protected Areas. IUCN, Morges, Switzerland.

Additional reference:

- Firouz, E. (1971). The Wetlands and Waterfowl of Iran. Game and Fish Department of Iran, Tehran. 


\section{Population $3,368,217$ (1979 census)}

Summary of Wetland Situation Ireland with its mild winters provides an ideal wintering area for huge numbers of waterfowl. Many suitable habitats exist all round the coast, extending to over $70 \mathrm{~km}$ inland up the Shannon estuary on the west coast. However, because the country's economy is largely based on agriculture, efforts to improve marginal farming areas have resulted in the disappearance of a number of good inland wetlands. This applies particularly to the former 'turlough' area in Counties Galway and Mayo. Another threat is the increase in the amount of peat extracted from the bogs since the energy crisis began in 1973/74.

Virtually the only winter quarters of two distinctive populations of wild geese are in Ireland. The Greenland race of the white-fronted goose Anser albifrons flavirostris winters mainly on the Wexford Slobs in the south-east and along the Little Brosna River (in the centre of the country, west-southwest of Dublin); the Greenland population or pale-breasted race of Brent goose Branta bernicla hrota has its winter quarters in various sites from the Rogerstown and Malahide estuaries and North Bull Island to the north of Dublin, south and west round the coast to Tacumshin Lake, Castlemaine Harbour, Tralee Bay and Cummeen Strand in Sligo Bay. Both whooper swan Cygnus cygnus and Bewick's swan C. columbianus bewickii winter on the River Shannon and Rahasane turlough; the whooper only, on Lough Oughter, Birra Lough and Lough Swilly; Bewick's only, on the Wexford Slobs. Finally, large numbers of waders winter in Dundalk Bay, North Bull Island, Wexford Harbour and Slobs, Cork Harbour and Ballymacoda estuary $12 \mathrm{~km}$ to the east of it, and the Shannon Estuary. The numbers of ducks of surface-feeding species nesting in Ireland have decreased in recent years, whilst both resident and wintering diving ducks are increasing.

Protected Areas Legislation The Department of Fisheries and Forestry has responsibility under the Wildlife Act 1976 for the conservation of Wildlife and Wildlife habitats. They have the power to establish nature reserves on State land; establish nature reserves on privately owned land which is being managed in the appropriate way by the owner; designate refuges for fauna on certain land where it is considered that a particular species should be specially protected. Thirty five nature reserves have been established to date (1986/7). The Office of Public Works has been responsible for the establishment and management of National Parks since 1969. The main conservation act is the Wildlife Act 1982.

Protected Areas Administration The Department of Fisheries has primary resposibility for conservation of wildlife (fauna and flora). However, the Department of Local Government and local authorities also have certain functions in this field while National Parks are the responsibility of the Office of Public Works. The Forest and Wildlife Service, which is part of the Department of Fisheries, is the largest single landowner in the State, holding some 350,000 ha. The functions of the Department of Local Government and the local authorities are governed, mainly, by the provision of the Local Government (Planning and Development) Acts, 1963 and 1976. The main instrument for the implementation of the provisions of the Acts is the development plan which each planning authority (there are 87 in all) is required to prepare and keep updated and which sets out the objectives and requirements of the authority for the physical planning and development of the area.

Sites designated under the Convention

Ratification 15 November 1984, with one site listed at ratification and another four added on 31 July 1986. 
Wexford Wildlife Reserve

The Raven Nature Reserve

Pettigo Plateau Nature Reserve

Slieve Bloom Mountains Nature Reserve

The Owenduff Catchment

Government body resposible for adminstration of the Convention

No information

\section{Wexford Wildfowl Reserve}

Location $52^{\circ} 30^{\prime} \mathrm{N}, 6^{\circ} 20^{\prime} \mathrm{W}$. Situated on the north side of Wexford Harbour on North Slob, Co. Wexford.

Area 110ha

Degree of Protection Jointly owned by the Ministry for Fisheries and Forestry (75\%) and the Irish Wildbird Conservancy $(25 \%)$, which is a voluntary non-governmental organisation, with the help of a financial contribution from WWF. Established as a statutory Nature Reserve under Section 15 of the Wildlife Act, 1976, by the Minister for Fisheries and Forestry on 3 June 1981. Designated as a Ramsar site at the time of ratification on 15 November 1984.

Site Description Wexford Harbour is a mud-filled arm of the sea into which the River Slaney flows. The 'sloblands' to the north and south of the harbour are areas of alluvial mud now reclaimed, drained and under cultivation or grazing. Extensive areas of wheatfield and pasture are separated by drainage ditches, which empty into larger drainage channels. The water level can be controlled to provide irrigation in summer. Within the slobs, plant communities, other than controlled pasture-swards and arable crops, are restricted to the ditches and their margins. Elsewhere there are areas of sand-dune and saltmarsh bordering the harbour-edge, particularly in the vicinity of Raven and Rosslare Points, the Rosslare dune communities being unusual in that they contain patches of dune scrub of which introduced sea buckthorn Hippophae rhamnoides is a notable ingredient. The main plant communities in the sloblands are:- On drained land re-seeded grassland dominated by rye grasses Lolium perenne and L. multiflorum, cat's tail Phleum pratense and white clover Trifolium repens, plus fields of wheat and barley; in the small undrained area of the North Slob, old pastures of mixed common and creeping brent Agrostis tenuis and stoloniflera, scented vernal grass Anthoxanthum odoratum and Yorkshire fog Holcus lanatus. Communities of aquatic and emergent plants in the drainage channels and the small areas of sea-wrack and saltmarsh in the harbour itself, the more impotant being:- Phragmition communis, Scirpetium maritimae, Scirpeto-Phragmitetum (reeds and club-rush), tassel pondweed Ruppio maritimae, pondweeds Ptoamogetalia, glasswort Salicornietum europaeae and eel-grass Zosterion.

Criteria for Inclusion 1(a), 3(a), 3(b), 3(c) and 4(a)

International and National Importance The North Slob is the World's most important wintering ground for the Greenland white-fronted goose Anser albifrons flavirostris, with more than half $(5,000-7,000)$ of the world population seen there during the winter months. The Greenland white-fronted goose is listed in Annex 1 of the EEC Directive 79/409, on the conservation of wildbirds, as a subspecies whose habitat requires special protection measures. Other species occurring on the reserve include: Bewick's swan Cygnus columbianus bewickii, greylag goose Anser anser, pink-footed goose A. brachyrhynchus, Brent goose Branta bernicla, barnacle goose $B$. leucopsis, Canada goose $B$. canadensis, wader species and a large variety of duck such as mallard, teal, pintail, gadwall, shoveler, and wigeon (Anas platyrhynchos, A. crecca, A. acula, A. strepera. A. clypeata, A. penelope), goldeneye Bucephala clangula, black-tailed godwit Limosa limosa, scaup Aythya marila and tufted duck Anthya fuligula. 
Changes in Ecological Character Traditional agricultural activities continue on the reserve. Use of fertilizers and pesticides, or change in farming priorites would adversly affect the feeding grounds.

Management Practices The reserve is managed by the Department of Fisheries and Forestry. Mangement practices include the growing of special crops, primarily in the interest of the Greenland white-fronted goose. Hunting is not permited. The northern side of the harbour is mostly arable farmland with some cattle pasture. A system of ditches and drainage channels operates to keep the ground surface dry throughout the year and, conversely, is sometimes used in summer for irrigation purposes. Control over the use of agricultural chemicals in the area would be desirable.

Scientific Research and Facilities There have been important and continuing studies of the ecological preferences of Anser albifrons flavirostris and of how changing farming practices have affected their behaviour and distribution. The reserve has an interpretation centre and observation tower for general public use.

Principal Reference Material The above information is taken from documents supplied by the Government of Ireland at the time of designation in November 1984.

Supplemented by:

- Carp. E. (Ed.) (1980). A Directory of Western Palearctic Wetlands. IUCN, Gland, Switzerland.

Additional references:

- Poore, D. and Gryn-Ambroes, P. (1980). Nature conservation in northern and western Europe. For UNEP and IUCN, with the financial support of WWF. IUCN, Gland, Switzerland.

- Duffey, E. (1982). National Parks and Reserves of Western Europe. Macdonald and Co., London.

\section{The Raven Nature Reserve}

Location $52^{\circ} 20^{\prime} \mathrm{N}, 6^{\circ} 19^{\prime} \mathrm{W}$. In County Wexford, south-east Ireland, on the northern side of the estuary of the River Slaney.

Area 589 ha

Degree of Protection The site was established as a statutory Nature Reserve under Section 15 of the Wildlife Act 1976, and is owned and managed by the Ministry of Tourism, Fisheries and Forestry. It was designated a Ramsar site on 31 July 1986.

Site Description The site comprises a sand dune system which extends southwards into the estuary of the River Slaney as a highly unstable spit; the intertidal zone and inshore waters make a total water area of $604 \mathrm{ha}$. It is bordered to the west by the North Wexford Slob wetland ecosystem (also a Ramsar site).

International and National Importance The spit is the world's most important winter night roost for the Greenland white-fronted goose Anser albifrons flavirostris, and a flock of 6000-8000 use the site, feeding by day on the Wexford Slobs. Two other species which are listed in Annex 1 of the EEC Directive $79 / 409$ as species whose habitat requires special conservation measures nest on the spit, the common tern Sterna hirundo and little tern S. albifrons.

\section{Changes in Ecological Character No information}

Management Practices No information 
Scientific Research and Facilities No information

Principal Reference Material The above taken from documents submitted by the Government of Ireland for designation.

\section{Pettigo Plateau Nature Reserve}

Location $54^{\circ} 36^{\prime} \mathrm{N}, 7^{\circ} 55^{\prime} \mathrm{W}$. In County Donegal, north-west Ireland, just west of Lough Derg.

Area 900ha

Degree of Protection The site was established is a statutory Nature Reserve under section 15 of the Wildlife Act 1976 and owned and managed by the Ministry of Tourism, Fisheries and Forestry. It was designated a Ramsar site on 31 July 1986.

Site Description The site is an excellent example of highland blanket bog at approximately $200 \mathrm{~m}$ above sea level, and includes low hills and broad basins. There are numerous pools and lakes, including Dunragh Lough, Dunrach Middle Lough, Lough Barderg and part of Lough Golagh, within the reserve. The vegetation is dominated by purple moor grass Molinia caerulea, with a notable absence of Schoenus nigricans, except in flushes. Other species present include cross-leaved heath Erica tetralix, deer sedge Scirpus cespitosus, Calluna spp., sundews Drosera l. spp., white-beaked sedge Rhynchospora alba, bog asphodel Narthecium ossifragum and lichens. Dryer rocky sites are characterised by an abundance of ling Calluna vulgaris with woodland elements like hard fern Blechnum spicant.

International and National Importance The site is a traditional feeding and roosting site for the Greenland white-fronted goose Anser albifrons flavirostris. It is also a relatively undisturbed example of highland blanket bog.

Changes in Ecological Character No information

Management Practices No information

Scientific Research and Facilities No information

Principal Reference Material The above taken from documents supplied by the Government of Ireland for designation.

\section{Slieve Bloom Mountains Nature Reserve}

Location $53^{\circ} 02^{\prime} \mathrm{N}, 7^{\circ} 38^{\prime} \mathrm{W}$. In the centre of southern Ireland, in Counties Offaly and Laois.

Area 2,230ha

Degree of Protection The site was established as a statutory Nature Reserve under section 15 of the Wildlife Act 1976, and is owned and managed by the Ministry of Tourism, Fisheries and Forestry. It was designated a Ramsar site on 31 July 1986.

Site Description The reserve covers part of a mountain blanket bog at an altitiude of about $400 \mathrm{~m}$ which has a total area of $2230 \mathrm{ha}$. The vegetation consists of hummocks of Calluna and Cladonia spp. and Sphagnum capillifolium with Hyphnum jutlandicum, cotton grasses Eriophorum spp., bilberry Vaccinium myrtillus, deer sedge Scirpus cespitosus, bog asphodel Narthecium ossifragum and lesser twayblade Listera cordata. The main variations in this type of vegetation are to be found in flushed sites and stream sides, where patches of Molinia and/or Juncus spp. occur, or small stands of Salix spp. 
International and National Importance The site is an excellent example of a mountain blanket bog, one of a range of bog types occurring in Ireland. Of particulr interest is the presence of bog rosemary Andromeda polifolia and cranberry Vaccinium oxycoccos, and their occurrence along with crowberry Empetrum nigrum is particularly noteworthy.

\section{Changes in Ecological Character No information}

Management Practices No information

Scientific Research and Facilities No information

Principal Reference Material The above taken from documents submitted by the Government of Ireland for designation.

\section{The Owenduff Catchment}

Location $54^{\circ} 03^{\prime} \mathrm{N}, 9^{\circ} 40^{\prime} \mathrm{W}$.: In County Mayo, western Ireland.

\section{Area $1,382 \mathrm{ha}$}

Degree of Protection Designated a Ramsar site on 31 July 1986. At the time of designation, Owenduff was in the process of being given statutory protection as a Nature Reserve under Section 15 of the Wildlife Act 1976. It is owned and managed by the Ministry of Tourism, Fisheries and Forestry.

Site Description The site is part of an extensive area of lowland blanket bog which grades into mountain blanket bog and wet heath. It includes most of the headwaters of two small streams, and there are a few small pools. The lowland bog vegetation includes purple moor grass Molinia caerulea, blackbog rush Schoenus nigricans and deer sedge Scirpus cespitosus, with white-beaked sedge Rhynchospora alba in wetter places. This group of characteristic species is completed by cross-leaved heath Erica tetralix, ling Calluna vulgaris, bog asphodel Narthecium ossifragum, carnation sedge Carex panicea, bog cotton Eriophorum angustifolium, tormentil Potentilla erecta, spike rush Eleocharis multicanlis, sundew Drosera spp. and the grass Nardus stricta. Mosses include Leucobryum glaucum, Sphagnum rubellum and Campylopus atrovirens. Lichens present include Cladonia impexa and C. uncialis. Pool complexes and wet areas with Sphagnum hummocks are also present.

International and National Importance The site is one of the best developed and least disturbed examples of Atlantic blanket bog in Europe. It supports a small flock of the Greenland white-fronted goose Anser albifrons flavirostris in winter, and in summer breeding birds include golden plover Pluvialis apricaria.

\section{Changes in Ecological Character No information}

Management Practices No information

\section{Scientific Research and Facilities No information}

Principal Reference Material The above taken from documents submitted by the Government of Ireland for designation. 


\section{ITALY}

Area 301,190 sq. $\mathrm{km}$

\section{Population $56,929,101(1983)$}

Summary of Wetland Situation In Roman times approximately one tenth of Italy (almost 3 million hectares) consisted of wetlands. Only 764,000 ha remained by 1865 , and just over a century later, in 1972, after a massive drive to eliminate malaria and to provide agircultural land, the figure had been further reduced to only 190,000ha. A Special Committee of the Senate dealing with ecological problems in 1972, recommended that the remaining wetlands should be preserved and protected as useful and necessary for maintianing an ecological balance in the country as a whole.

Some large wetland complexes still exist, particularly along the north-west shores of the Adriatic (Lagune di Marana e Grado, Laguna di Venezia, Delta del Po and the Valli in the Porvinces of Ferrara and Ravenna); all of them still retain most interesting flora and fauna, and remnants of their formerly characteristic landscapes. Surveys to assess their importance as a habitat for breeding, migrating and wintering waterfowl are continuing, but there is little doubt that these wetlands harbour waterfowl which reach internationally important numbers, especially in severe winters in Central and South East Europe.

Only a few wetland reserves exist along the Tyrrhenian coast (Bolgheri, Orbetello, Saline Tanquinia and Circeo National Park). The wetlands of Sardinia, are important to migrating and wintering waterfowl, including greater flamingos. In some of the 'stagni' the scarce purple gallinule still breeds. It is likely that some of the wetlands in Sicily are important staging posts for migratory waders, and these should be further investigated.

A number of wetlands of the mountainous regions in Northern and Central Italy, and others situated in Puglia, Sicilia and even on the small island of Pantelleria, rate as internationally important because of their limnological interest.

Protected Areas Legislation There are no general laws on nature conservation, though the Constitution stipulates that the Republic shall "protect the landscape". The national parks were created by specific legislation and were established both for protection of flora, fauna and landscape, and for tourism (except for Gran Paradiso which excluded tourism). Not until 1968, nine years after establishment of the first nature reserve, was an act passed which conferred full legal status on the term 'nature reserve'. The absence of general or enabling legislation has been exacerbated to some extent by the problems of regionalisation. A presidential decree $(616 / 1977)$ completed transfer to the regions of administrative responsibility for agriculture, forestry, hunting, fishing (inland), protection of nature, nature reserves and nature parks. More recently some of the responsibility for National Parks has also been devolved. One issue of past legislation which may have more effect on present day attitudes is that all four major national parks were established by decree during the facist periods, and were imposed on local communities without adequate compensation.

Protected Areas Administration Prior to 1977, primary responsibility for nature conservation and protected areas rested with the Ministry of Agriculture and Forests (though the Ministry of Cultural and Environmental Heritage also had an interest), and in particular with the State Forest Administration. Presumably much of their powers have now been devolved to the regions. Although the legal situation varies from park to park, in at least one (Stelvio) regionalisation has caused some problems because the park lies within more than one region. If there is human activity in the reserves it is generally strictly controlled, this in contrast to national parks where diverse human activities have continued, including agriculture and forestry. 


\section{Sites designated under the Convention}

Signed subject to ratification on 10 January 1975; ratified on 14 December 1976. 19 sites were listed at ratification, with one site added on 10 March 1978, four on 28 March 1979, one on 14 May 1979, one on 2 August 1979, one on 19 September 1980, one on 21 July 1981, six on 4 September 1981, two on 3 May 1982 and four on 5 December 1984:

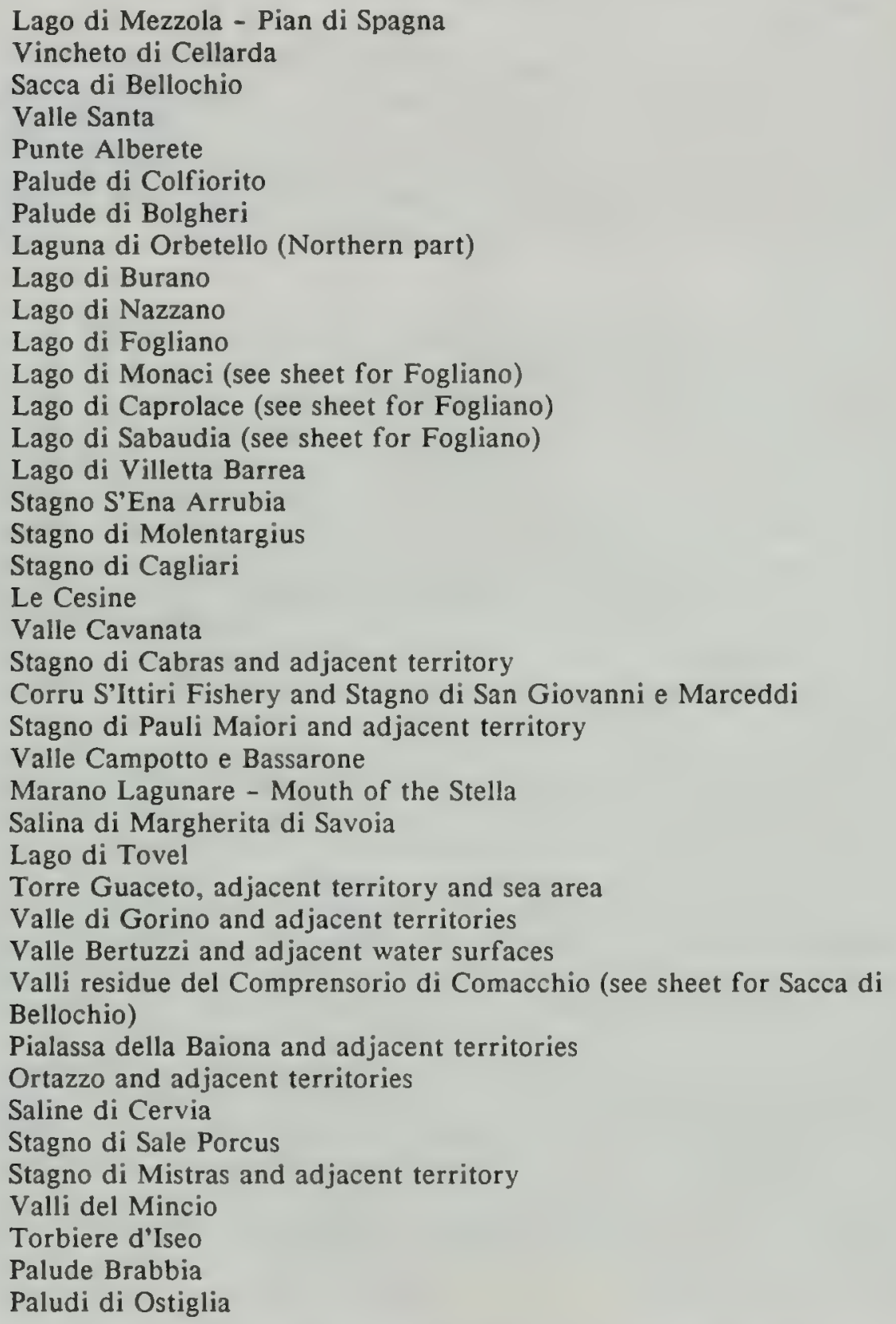

Government body responsible for administration of the Convention Ministry of Agriculture and Forests, Direzione Generale per l'Economia Montana e le Foreste, Divisione 2, Via Carducci 5, 00100 Rome

\section{Lago di Mezzola - Pain di Spagna}

Location $46^{\circ} 13^{\prime} \mathrm{N}, 9^{\circ} 26^{\prime} \mathrm{E}$. The lake is near Novate Mezzola town and straddles the border between Como and Sondrio Provinces in the Lombardi region of northern Italy. 
Area 1,740ha. Extended from 1,086ha in 1980 by the inclusion of Spagna Plain.

Degree of Protection Mezzola Lake (1,086ha) was designated as a Ramsar site at the time of ratification after 14 December 1976. Spagna plain was included in June 1980 by Ministerial Decree No. 275.

Site Description The site comprises a freshwater lake in the foothills of the Alps connected by a channel to Lake Como, and the broad floodplains around the confluence of the Adda and Mera rivers which flow into the lake.

International and National Importance The wetland is an important breeding and wintering area for mute swan Cygnus olor. Numerous waterfowl, including some threatened species, use the lake as a resting station during migration. They include red-crested pochard Netta rufina, European pochard Aythya ferina, tufted duck A. fuligula, mallard Anas platyrhynchos, green-winged teal $A$. crecca, common coot Fulica atra and great crested grebe Podiceps cristatus. European otter Lutra lutra is thought to still be present in the area.

\section{Changes in Ecological Character None reported (1980)}

\section{Management Practices No information}

Scientific Research and Facilities The Universities of Milano and Pavia have conducted research on birds and mammals of the lake area.

Principal Reference Material The above information is taken from the decree document (11 June 1980) for the designation Gazzetta Ufficiale della Republica Italiana No. 275 (7 October 1980).

\section{Vincheto di Cellarda}

Location $46^{\circ} 01^{\prime} \mathrm{N}, 11^{\circ} 58^{\prime} \mathrm{E}$. Situated between the villages of Cellarda to the south and Nemeggio to the northwest in Feltre commune, Belluno Province of Venezia, northeast Italy.

Area 99ha

Degree of Protection Designated as a Ramsar site at the time of ratification after 14 December 1976.

Site Description The site lies in a valley bottom in the foothills of the Alps on the west bank of the River Piare, and includes a portion of the channels and mudbanks of this sluggishly flowing braided stretch of the river. The area contains a mixture of willow woodland and meadows, which provide ideal nesting sites and refuges for a varied waterfowl population.

International and National Importance No information

Changes in Ecological Character A network of tracks runs throughout the site, and there is a fishery in the northwest.

Management Practices No information

Scientific Research and Facilities No information

Principal Reference Material The above information is taken from the decree document for the designation Gazzetta Ufficiale della Republica Italiana No. 70 (11 March 1978). 
Location $44^{\circ} 35^{\prime}-38^{\prime} \mathrm{N}, 12^{\circ} 10^{\prime}-16^{\prime} \mathrm{E}$. Situated about $14 \mathrm{~km}$ due north of Ravenna in Ferrara Province, Emilia Romagna.

\section{Area Contiguous Ramsar sites: Comacchio dam 13,500ha; Sacca di Bellochio 223 ha.}

Degree of Protection Azienda Valli Comacchio and Orsi-Mangelli Preserve are privately owned, and the wetland complex contains several private bird sanctuaries and hunting reserves in which hunting is controlled. The remaining area (Ente Delta Padona) is state owned. The complex also includes a Landscape Reserve and Hydrological Reserve, in which the water regime is regulated. 1,000 ha of bird refuges with adequate protection have been established. Sacca di Bellochio was designated as a Ramsar site after August 1979. The residual plains of Comacchio were designated as a Ramsar site two years later in September 1981.

Site Description The designated sites comprise the residual Valli di Comacchio and the adjacent Vene Bellochio which extend from the Reno River estuary on the Adriatic to Agosta dam on the western boundary and from Comacchio township in the north to the banks of the Reno River in the south. The Valli di Comacchio are the remnants of a large coastal and inland complex of lagoons and marshes which were extensively drained since the 1850 s for agricultural purposes. The valli, Fossa di Porto, Campo and Lido di Magnavacca, constitute a lagoon (maximum depth $2.5 \mathrm{~m}$ ) fed by inflow from the sea and freshwater rivers, particularly the Reno. They are partially separated from one another by sand and shell banks and small islands which indicate historial shorelines. Sacca di Bellochio is part of the Vene Bellochio which are a complex of saltmarshes and parallel basins bordering the Adriatic. The submerged vegetation comprises mainly Chara spp., Lamprothamnium papulosum (Vene Bellochio and Valle Lido di Magnavacca) and tassel pondweed Ruppia spiralis (Valle Fossa di Porto). Halophytic vegetation includes pure stands of shrubby glasswort Salicornia fruticosa, and associations in which dominant species include $S$. herbacea or sea blit Sueda maritima and saltwort Salsola soda or couchgrass Agropyron elongatum and golden samphire Inula Crithmoides. Occasional freshwater bodies support reedbeds of Phragmites communis and glasswort Salicornia. Orsi-Mangelli hunting preserve is the only uncontimated area at the northern end of the marsh, and is partially covered by woods of stone pine Pinus pinea.

International and National Importance The wetland complex supports a rich avifauna including breeding and winter migrant populations. Breeding birds include black-winged stilt Himantopus himantopus, avocet Recurcirostra avosetta, purple heron Ardea purpurea, mallard Anas platyrhynchos, garganay A. querquedula, northern shoveler A. clypeata, pochard Aythya ferina, white-eyed pochard $A$. nyroca, shelduck Tadorna Ladorna, redshank Tringa totanus, collared pratincole Glareola pratincola, little tern Sterna albifrons, Caspian tern S. caspia, sandwich tern S. sandvicensis, common tern S. hirundo, gull-billed tern Gelochelidon nilotica, Mediterranean gull Larus melanocephalus, slender-billed gull L. genei, herring gull L. argentatus and bearded tit Panurus biarmicus. Hundreds of thousands of passage and wintering wildfowl visit the wetland complex, including pochard (over 20,000), coot Fulica atra (about 40,000), bean goose Anser fabalis, white-fronted goose A. albifrons, Eurasian wigeon Anas penelope, gadwall A. strepera, teal A. crecca, mallard, northern shoveler, white-eyed pochard and tufted duck Anas fuligula. The otter Lutra lutra is thought to still be present in Orsi-Mangelli preserve.

Changes in Ecological Character Traditional fishing practices are being replaced by fish farming projects, with associated excessive clearing of Salicornia vegetation to enlarge the fish ponds. The northern area of the marshes is completely degraded, and the wetlands are slightly contaminated by cropspray and water pollutants carried in by the River Reno. Since the mid $1950 \mathrm{~s}$, some $25,000 \mathrm{ha}$ of Valli di Comacchio have been drained for cultivation. The reclamation programme has been suspended but there is still some degree of threat from agriculture in Orsi Mangella, as well as in the rest of the Comacchio Valley.

Management Practices The inflow to the Valli from the sea and the Reno River is fully controlled. Orsi-Mangelli hunting preserve is well managed, with shooting maintained at a moderate level. 
Scientific Research and Facilities Hydrobiological research projects by the Universities of Bologna and Ferrara. Studies have been undertaken concerning the establishment of a regional park.

Principal Reference Material The above information is taken from:

- Carp, E. (1980). A Directory of Western Palearctic Wetlands. IUCN, Gland, Switzerland. Supplemented by:

- Scott, D.A. (1980). A preliminary inventory of wetlands of international importance for waterfowl in west Europe and northwest Africa. IWRB Special Publication No. 2.

Additional references:

- Ferrari, G., Pirola, A. and Piccoli, F. (1972). Saggio Cartografico della Vegetatione delle Valli di Comacchio. Ann. Univ. Ferrara. N.S.I, 1(2): 35-64.

- Montalenti, G. (ed.) (1967). Relazione sulla protezione delle lagune e degli stagni costieri della penisola e delle grandi isole. Ricerca Scientifica No. 38, C.N.R., Roma. 47pp.

- Pondesan, M. and Bucci, V. (1972). Gli antichi cordoni litoranei del settore sud-occidentale delle Valli di Comacchio. Atti Acc. Sci. Ferrara 48: 1-18.

- Toschi, A. and Spagnesi, M. (1971). Ricerche di Biologia della Selvaggina. Ricirca Scientifica No. 52, Caccia, Bologna. 99pp.

\section{Valle Santa}

Location $44^{\circ} 34^{\prime} \mathrm{N}, 11^{\circ} 50^{\prime} \mathrm{E}$. Situated east of Portomaggiore $27 \mathrm{~km}$ southeast of Ferrara, $27 \mathrm{~km}$ from the Adriatic and $36 \mathrm{~km}$ northwest of Ravenna, Ferrara Province, Emilia Romagna.

Area 261ha. Separated from Valle Campotto e Bassarone Ramsar site (1,363ha) by the Sussulano Canal.

Degree of Protection Privately owned by the Societa Bonifiche Renane. Valle Santa is a partially protected bird and fish sanctuary with shooting prohibited. Under control of several bodies and the University of Parma. Commercial and sport fishing allowed. Designated as a Ramsar site at the time of ratification after 14 December 1976.

Site Description The site comprises a shallow reservoir (maximum depth $2 \mathrm{~m}$ ) which, with Valle Campotto, supplies Ravenna and its industries and acts as an overflow basin for Reno River floodwaters. It is one of the last remnants of the formerly extensive swamps of the southeast River Po floodplains, which were mostly drained for reclamation during the 19th century. The low level pollution has made it a highly productive eutrophic lake supporting extensive reedbeds of Phragmites communis, interspersed with channels and stretches of open water (maintained by man) with floating white water lily Nymphaea alba and typical submerged plant associations. The rich aquatic fauna includes pike Esox lucious, tench Tinca tinca (fished commercially and for sport), and the pond terrapin Emys orbicularis.

International and National Importance Great numbers of waterfowl including grebes (Podicipedidae), herons (Ardeidae), ducks (Anatidae), rails and coots (Rallidae), plovers (Charadriidae) and sandpipers (Scolopacidae) congregate in the reservoir in winter. Breeding species include black-crowned night-heron Nycticorax nycticorax, purple heron Ardea purpurea, squacco heron $A$. ralloides, bittern Botaurus stellaris, little egret Egretta garzelta, glossy ibis Plegadis falcinellus, several hundred pairs of great crested grebe Podiceps cristatus, mallard Anas platyrhynchos, gadwall $A$. strepera, garganey $A$. querquedula, coot Fulica atra, a large colony of whiskered tern Chlidonias hybrida and black tern $C$. nigra.

Changes in Ecological Character Low level pollution has resulted in a small degree of eutrophication making the waters extremely productive for phyto- and zooplankton and fish. The otter Lutra lutra is probably locally extinct.

Management Practices Management is subject to some hydrological constraints, as Valle Sante is a supply reservoir. The water level is kept generally low to attract birds, although the area is sometimes flooded by the River Reno. Some reed cutting and clearing of channels. 
Scientific Research and Facilities Two companies (Tecneco and Italeco) have carried out ornithological and hydrological studies on behalf of the regional government.

Principal Reference Material The above information is taken from:

- Carp, E. (1980). A Directory of Western Palearctic Wetlands. IUCN, Gland, Switzerland. Additional reference:

- Toschi, A. (1968). Interesse faunistico e paesistico delle Valli dolci e salmastre delli Emilia orientale. Studi Romagnoli XIX, 12pp.

\section{Punte Alberete}

Location $44^{\circ} 32^{\prime} \mathrm{N}, 12^{\circ} 09^{\prime} \mathrm{E}$. Situated about $10 \mathrm{~km}$ north of Ravenna on the northwest coast of the Adriatic, Ravenna Province, Emilia Romagna.

\section{Area 480ha}

Degree of Protection Most of the area is owned by the Municipality of Ravenna. The site includes Punte Alberete Bird Sanctuary (222ha) and Valle della Canna created in 1969 which is managed as a nature reserve by WWF and other organisations. Designated as a Ramsar site in August 1981.

Site Description The site comprises only a part of the extensive inland wetland complex which occupies the floodplains of the River Po system north of Ravenna. Much of the site is covered by swampy woodland associations dominated by white poplar Populus alba and willows Salix spp. Ash Fraxinus oxycarpa and English elm Ulmus procera grow on the relict sand dunes which mark the former shoreline. The lower lying areas are flooded, mainly by the waters of the River Lamone, and support extensive reedbeds of Phragmites communis with stands of reedmace Typha latifolia and $T$. angustifolia, and plant associations with sedges Carex spp. and fen-sedge Cladium mariscus. The more open water (maximum depth $2 \mathrm{~m}$ ) has a covering of floating aquatic plants such as white water lily Nymphaea alba and pondweeds Potamogeton spp., with a rich submerged flora including stonewort Chara sp., bladderwort Utricularia vulgaris and frogbit Hydrocharis morsus-ranae. The marshland vegetation includes greater water parsnip Sium latifolium, Jersey orchid Orchis laxiflora and field gladiolus Gladiolus italicus (segetum). The area has a rich aquatic fauna including the amphibians: newts Triturus vulgaris meridionalis and $T$. cristatus carnifex, frogs Rana dalmatina and $R$. latastei and pond terrapin Emys orbicularis.

International and National Importance The site is a unique example of swampy woodland on the eastern edge of the River Po floodplains and is an important site for breeding and overwintering (up to 15,000) wildfowl. Breeding birds include great crested grebe Podiceps cristatus, whiskered tern Chlidonias hybrida, Eurasian bittern Botaurus stellaris, gadwall Anas strepera, white-eyed pochard Aythya nyroca, marsh harrier Circus aeruginosus and a large heronry of night heron Nycticorax nycticorax (4-500 pairs), squacco heron Ardeola ralloides (10-20 pairs), purple heron Ardea purpurea, little egret Egretta garzelta (7-800 pairs) and occasional glossy ibis Plegadis falcinellus (1-5 pairs). The winter population includes gadwall, mallard Anas platyrhynchos, northern shoveler A. clypeata, garganey A. querquedula, pochard Aythya ferina $(5,000)$, coot Fulica atra $(8,000)$, penduline tit Remiz pendulinus, bearded tit Panurus biarmicus, occasional white-eyed pochard A. nyroco, and also two pairs of breeding pigmy cormorant Haliëtor pygmeus. Several locally rare invertebrates occur in the wetland, such as the beetle Carabus clathratus antonelli and the endemic Iphydrus carrarei.

Changes in Ecological Character Hunting pressure is often severe in the neighbouring unprotected Valle Mandriole, which is an important feeding ground for the waterfowl breeding populations at Punte Alberete. 
Management Practices The bird sanctuary is managed by WWF and other organisations. Water level in the lagoon is controlled; and canals and small pools are kept open. Other management practices include reed-cutting and fishing, and food is put out for the birds in winter.

Scientific Research and Facilities Investigations by the Laboratorio di Zoologia in Bologna, Instituto Botanico di Bologna and a team from two companies (Tecneco and Italeco) in connection with the regional park project. An observation tower, open to the public, has been constructed in the bird sanctuary.

Principal Reference Material The above information is taken from:

- Carp, E. (1980). A Directory of Western Palearctic Wetlands. IUCN, Gland, Switzerland. Additional reference:

- Stinchi, E., Toschi, A. and Corbetta, F. (1968). Le Punte Alberete e la Valle del Lamone. Ricerca Scientifica No. 48. C.N.R., Roma.

\section{Palude di Colfiorito}

Location $43^{\circ} 01^{\prime} \mathrm{N}, 12^{\circ} 53^{\prime} \mathrm{E}$. Situated to the southeast of Forcatura township in Foligno Commune, Perugia Province, Umbria.

Area 157ha

Degree of Protection Designated as a Ramsar site at the time of ratification after 14 December 1976.

Site Description The site comprises marshland and a network of drainage ditches on the limestone plateau (Carsica) between the Eastern Alps and the Illyria Mountains, and is flanked along the southeast and northeast boundary by roads. It provides a valuable refuge for many relict plant species confined to isolated pockets along the Appenine chain of mountains.

International and National Importance No information

Changes in Ecological Character None reported (1977)

Management Practices No information

Scientific Research and Facilities The marshland has been the site of numerous university research projects.

Principal Reference Material The above information is taken from the decree document for the designation Gazzelta Ufficiale della Republica Italiana (17 December 1977).

\section{Palude di Bolgheri}

Location $43^{\circ} 14^{\prime} \mathrm{N}, 10^{\circ} 30^{\prime} \mathrm{E}$. Situated near Renaione on the west coast in Castagneto Carducci Commune, Livoeno Province, Tuscany.

Area $562 \mathrm{ha}$

Degree of Protection Privately owned by the Marquese della Rocchetta. The ponds lie within the Bolgheri Wildlife Refuge (22,000ha) which was established by the owner in 1962 with termination of hunting rights. Management was taken over by WWF Italy in 1970. Designated as a Ramsar site at the time of ratification after 14 December 1976. 
Site Description The site is a coastal wetland comprising a freshwater swampland separated from the sea by the Bolgheri sand dunes (tombolo). The marshland is a grid system of pools and ditches recently extended to favour the waterfowl. The site is bounded to the north by a ditch which drains into the sea, to the west by the Tyrrhenian Sea, and to the east by a parallel road and railway. The Bolgheri sand dunes support a mixed vegetation of woodland and maquis-type associations.

International and National Importance The wetland is the most southerly nesting area in Italy for lapwing Vanellus sp. Other breeding birds include black-winged stilt Himantopus himantopus, night heron Nycticorax sp. and purple heron Ardea purpurea. Many migrant species of wader and other wildfowl have been recorded, including osprey Pandion haliaetus, lesser spotted eagle Aquila pomarina, black stork Ciconia nigra, crane Grus grus, western bluethroat Luscinia svecica and Blyth's reed warbler Acrocephalus dumetorum. The European otter Lutra lutra occurs in the reserve.

Changes in Ecological Character The marshland has been extended to improve its value to waterfowl by a series of ditches along which water is pumped.

Management Practices Managed as a nature reserve by WWF Italy.

Scientific Research and Facilities There is an observation tower in the marshlands for ornithological studies.

Principal Reference Material The above information is taken from the decree document ofr the designation Gazzella Ufficiale della Republica Italiana No. 210 (2 August 1977).

Supplemented by:

- Duffey, E. (1982). National Parks and Reserves of Western Europe. Macdonald and Co., London.

\section{Laguna di Orbetello}

Location $42^{\circ} 27^{\prime} \mathrm{N}, 11^{\circ} 13^{\prime} \mathrm{E}$. Coastal lagoon situated at the base of the Argentario peninsula, about $35 \mathrm{~km}$ south of Grosseto town in Grosseto Province, southwest Tuscany.

Area $887 \mathrm{ha}$

Degree of Protection Part state and part local government ownership. The site is included in the landscape reserve with some protection of the lake area. The area contains 1,000ha of Salicornia covered dunes which are protected and managed as a WWF reserve. Designated as a Ramsar site at the time of ratification after 14 December 1976. In 1982 a very important brackish part of this lagoon bordering the Ramsar site was declared a State Nature Reserve of 800 ha.

Site Description The designated site comprises the northern portion of Orbetello lagoon $(4,200 \mathrm{ha})$, and the surrounding coastal wetland. It is a typical brackish lagoon with salinity varying from $15 \%$ to $30 \%$ (average $20 \%$ ). Separated from the sea by two narrow sand dunes (tombolo). Typical brackish-water vegetation of Salicornia fruticosa and some well developed fringing reedbeds of Phragmites communis. The shallow parts of the lagoon (average depth $1 \mathrm{~m}$ ) have a submerged vegetation of aquatic genera such as Chaetomorpha, Valonia, Cistoseira, Cymodocea and Zostera, with an abundance of associated small invertebrates such as sandhoppers (Amphipoda) and mosquitoes (Culicidae), which are an important foodsource for visiting birds and commercial fish stocks. Fish species include eel Anguilla anguilla, mullet Mugil spp., bass Dicentrarchus labrax and toothcarp Aphanius fasciatus. 
International and National Importance The lagoon is an important feeding station for migrating and wintering waterfowl including wigeon Anas penelope, teal $A$. crecca, pintail A. acuta, pochard Aythya spp., shelduck Tadorna tadorna, red-breasted merganser Mergus serrator, plovers (Charadriidae), great crested grebe Podiceps cristatus, black-necked grebe $P$. nigricollis, cormorant Phalacrocorax carbo sinensis, little egret Egrelta garzelta and flocks of gulls (Laridae). Breeding birds include mallard Anas platyrhynchos, black-winged stilt Himantopus himantopus (50 pairs), snowy plover Charadrius alexandrinus, stone curlew Burhinus oedicnemus, Montagu's harrier Circus pygargus, great spotted cuckoo Clamator glandarius and common bee-eater Merops apiaster.

Changes in Ecological Character Visitor pressure is increasing, especially on the coastal dunes. The expansion of Orbetello port, and the organic pollution from the town entering the lake, are increasingly degrading the environment.

Management Practices The areas of Salicornia covered dunes in the WWF reserve are actively managed. Commercial fishing including eel, mullet, bass and tooth carp.

Scientific Research and Facilities Stazione Romana per la Osservazione e la Protezione degli Occelli has been studying the avifauna since 1965.

Principal Reference Material The above information is taken from:

- Carp, E. (1980). A Directory of Western Palearctic Wellands. IUCN, Gland, Switzerland. Supplemented by:

- Scott, D.A. (1980). A preliminary inventory of wetlands of international importance for waterfowl in west Europe and northwest Africa. IWRB Special Publication No. 2.

Additional reference:

- Pratesi, F. el al. (1972). In Pedrotti, F. (ed.). Una Vita per la Natura. Associazione Italiana per il WWF, Roma. Pp. 331-350.

\section{Lago di Burano}

Location $42^{\circ} 22^{\prime}-24^{\prime} \mathrm{N}, 11^{\circ} 23^{\prime}-25^{\prime} \mathrm{E}$. Situated south of the Argentaria peninsula on the western Tyrrhenian sea coast. $10 \mathrm{~km}$ east-southeast of Orbetello Ramsar site, in the Grosseto Province of Tuscany.

Area 410 ha

Degree of Protection Privately owned and rented by WWF. The reserve was established in 1962 , and is part of as $496 \mathrm{ha}$ landscape reserve. Hunting is prohibited. Designated as a Ramsar site at the time of ratification after 14 December 1976.

Site Description The site comprises a saline lake about $3 \mathrm{~km}$ long, isolated from the sea by a double line of sanddunes (tombolo) except for one connecting channel. Several plant associations typical of lagoons and marshlands occur. Dominant species include tassel pondweed Ruppia spiralis, reeds Phragmites communis, sea club rush Scirpus maritimus and fen sedge Cladium mariscus. The Tombolo di Capalbio supports a Mediterranean maquis vegetation which includes Monterey cypress Cupressus macrocarpa, juniper Juniperus phoenicea, olive Olea europea var. oleaster, myrtle Myrtus communis, mastic tree Pistacia lentiscus and holm oak Quercus ilex. There are scattered patches of herbaceous vegetation with spring sedge Carex caryophyllea, clover Trifolium cherleri, Romulea columnae and Crassula tillaea.

International and National Importance The lake is a wintering site for waterfowl, particularly cormorant Phalacrocorax carbo sinensis, grey heron Ardea cinerea, wigeon Anas penelope, teal $A$. crecca, pintail $A$. acuta, pochard Aythya ferina and coot Fulica atra and breeding site for marsh harrier Circus aeruginosus and mallard Anas platyrhynchos. 
Changes in Ecological Character Disturbances include traffic on the road along the sanddunes, pollution and excavation of sandpits nearby, and intensive tourist use with some accidental fires during dry summers. Before the reserve was established about 6,000 birds were killed annually by hunters, but hunting is now prohibited.

Management Practices Managed as a sanctuary by WWF Italy. Commerical fishing is still allowed, but hunting is prohibited.

Scientific Research and Facilities WWF has supervised research on the lake biota.

Principal Reference Material The above information is taken from:

- Carp, E. (1980). A Directory of Western Palearctic Wetlands. IUCN, Gland, Switzerland.

Additional references:

- Orsomando, E. (1971). Censimento dei biotopi de relevante interese vegetazionale meritevole di conservazione in Italia. Soc. Bot. Ital. publication. Camerino.

- Pratesi, F. (1970). Palude, lagune e stagni costieri in Italia: nuove prospettive ed indirizzi per la loro conservazione. Italia Nosira No. 6, Roma. 62pp.

\section{Lago di Nazzano}

Location $42^{\circ} 13^{\prime} \mathrm{N}, 12^{\circ} 36^{\prime} \mathrm{E}$. Situated in the hills northeast of Rome in Roma Province, Latium.

\section{Area 265ha}

Degree of Protection Designated as a Ramsar site at the time of ratification after 14 December 1976.

Site Description The site is an artificial reservoir formed by damming the River Tevere where it meanders through the flat plain just south of Torrita, and includes the surrounding marshes. The lake level is regulated by man. The whole region, being close to Rome, is highly developed. The north-south motorway to Rome is on the western boundary of the site, a main railway on the eastern boundary, and a major road cuts across the site from east to west.

International and National Importance A wintering area for dabbling ducks (1000 birds maximum), including teal Anas crecca, pintail A. acuta, pochard Aythya ferina and coot Fulica atra.

Changes in Ecological Character The whole reserve is artifically maintained by the dam system. It is a popular tourist attraction for the nearby urban populations, and there is easy road access. The lake shores are dissected by numerous pathways.

Management Practices The hydrological regime is regulated.

Scientific Research and Facilities No information

Principal Reference Material The above information is taken from the decree document for the designation Gazzetta Ufficiale della Republica Italiana No. 45 (15 February 1978).

\section{Lago di Fogliano, Monaci, Caprolace e Sabaudia (Laghi Pontini)}

Location $41^{\circ} 17^{\circ}-24^{\prime} \mathrm{N}, 12^{\circ} 54^{\prime}-13^{\circ} 02^{\prime} \mathrm{E}$. The lakes are within Circeo National Park on the west coast of Italy in Latina Province, Latium.

Area Fogliano Lake 395ha; Monaci Lake 94ha; Caprolace Lake 229ha; Sabuadia Lake 1,475ha. Within Circeo National Park 8,400ha. 
Degree of Protection State owned. The lakes were included in Circeo National Park in 1975. Circeo was established in 1967 and is administered by the Ministry of Agriculture and Forestry. The park also contains the Foret Domaniale du Circeo (near Sabaudia Lake) which was approved as a Biosphere Reserve in January 1977. The designated sites have partial protection from hunting and commerical fishing allowed. The four lakes were designated as four separate Ramsar sites at the time of ratification after 14 December 1976.

Site Description The four sites are brackish coastal lakes isolated from the sea, except for occasional narrow outflow channels, by an extensive sand dune system. The salinity of the lakes varies from $1 \%$ (Monaci) to $3.9 \%$ (Caprolace) depending on the presence or absence of direct connections with the sea, another lake or freshwater inflow. Aquatic plants include Potamogeton spp. and Chaetomorpha, with marsh plant communities along the lake shores and Mediterranean marquis vegetation on the dunes including Phoenician juniper Juniperus phoenicea, prickly juniper J. oxycedrus and Thymelaea hirsula. The lakes provide a favourable environment for fish such as eel, sand smelt, sole, bass (Anguilla anguilla, Atherina presbyter, Solea sp., Dicentrarchus labrax), silver bream (Diplodus sargus, Sparus auratus) and mullets (Mugil cephalus, M. chelo, M. capito). The coastal area has a mean annual rainfall of $850-937 \mathrm{~mm}$ falling on 82-105 days. Mean annual temperature is $15.5^{\circ} \mathrm{C}$ with mean annual minimum of $11^{\circ} \mathrm{C}$. The Palace of the Roman Emperor Dominican, built in the first century AD on the shores of Sabuadia Lake, is being excavated.

International and National Importance The lakes are important overwintering and resting stations for migratory waterfowl, with over 220 recorded species including cormorant Phalacrocorax carbo sinensis (January maximum 600), garganay Anas querquedula (up to 15,000), wigeon Anas penelope (up to 3,000), northern shoveler A. clypeata (up to 470), teal $A$. crecca (up to 3,000 ), pochard Aythya ferina (up to 2,600), coot Fulica atra (up to 21,000 ), spoonbill Platalea leucorodia (up to 20 on passage) and glossy ibis Plegadis falcinellus (up to 30 on passage).

Changes in Ecological Character The whole coastal area has been considerably modified by human interference, and about 8,000 people live within the park boundary centred on the recently constructed new town of Sabandian on the northeast shore of Sabaudia Lake in the designated area. A system of asphalt roads have been constructed in the coastal zone and along the length of dunes which separate the lakes from the sea. The increase in visitors from Rome and nearby urban areas, using the improved access roads, is leading to degredation of this delicate ecosystem. The lakes are threatened by increasing levels of pollution discharged by local industrial centres. The construction of the new town and tourist accommodation required filling in of some wetland areas. Shooting pressure on the wildfowl is heavy in sume areas.

Management Practices There are commercial fisheries. Some sites have partial protection from hunting.

Scientific Research and Facilities The Laboratorio Centrale di I'drobiologia based in Rome have made some studies of the lakes. The Roman site at Sabaudia is being excavated.

Principal Reference Material The above information is taken from:

Allavena, S. (1978). Circeo National Park: reclaiming a rich heritage. Parks 3(3).

Carp, E. (1980). A Directory of Western Palearctic Wetlands. IUCN, Gland, Switzerland.

- Duffey, E. (1982). National Parks and Reserves of Western Europe. Macdonald and Co., London.

- Scott, D.A. (1980). A preliminary inventory of wetlands of international importance for waterfowl in west Europe and northwest Africa. IVRB Special Publication No. 2.

Additional reference:

- Montalenti, D. (ed.) (1967). Relazione sulla protezione delle lagune e degli stagni costieri della Peniscola e della grande isole. Quaderni de la Ricerca Scientifica No. 38 C.N.R., Roma. 47pp. 
Location $41^{\circ} 47^{\prime} \mathrm{N}, 13^{\circ} 58^{\prime} \mathrm{E}$. Situated between Viletta Barrea and Barrea villages, $35 \mathrm{~km}$ south of Siena in the central Apennines. L'Aquila Province, Abruzzi.

Area 303 ha (contained within Abruzzo National Park 40,000ha).

Degree of Protection The lake is owned by the local municipality, and is administered by Abruzzo National Park Agency. The designated site is within Abruzzo National Park established in 1922 and protected by law in 1923. The site therefore has full protection. Abruzzo received the European Diploma Award for the Conservation of Nature from the Council of Europe in 1972. The lake was designated as a Ramsar site at the time of ratification after December 1976.

Site Description The freshwater lake lies at about $800 \mathrm{~m}$ in the northeast of Abruzzo National Park.

International and National Importance It is a wintering area for teal Anas crecca, mallard $A$. platyrhynchos and wigeon $A$. penelope. Several endemic amphibian species and subspecies occur in the site, yellow bellied toad Bombina variegata pachypus and the toad Bufo bufo spenosa.

Changes in Ecological Character There is heavy visitor pressure in this easily accessible area of Abruzzo.

Management Practices The lake is managed as part of the national park which has some 50 permanent and 50 temporary staff.

Scientific Research and Facilities There is an active research programme in the national park.

Principal Reference Material The above information is taken from:

- Council of Europe (1972). Diploma European pour la Sauvegarde de la Nature (leaflet).

\section{Stagno S'Ena Arrubia}

Location $39^{\circ} 49^{\prime} \mathrm{N}, 8^{\circ} 34^{\prime} \mathrm{E}$. Situated north of Arborea township on the Gulf of Oristano, Oristano Province in western Sardinia.

Area $300 \mathrm{ha}$

Degree of Protection Owned by the Land Reclamation Syndicate of Ardorea (Consorzio di Bonifica di Arborea). The site lies within Oasi Permanente di Protezione Faunistica e di Catura ( 351 ha), in which hunting is prohibited. Commercial fishing is allowed. Designated as a Ramsar site at the time of ratification after 14 December 1976.

Site Description The freshwater lagoon is the last remnant of Sassu Pond (originally 3,270ha) which included over 200 small ponds and marshes, all reclaimed for agriculture between 1934 and 1937. The lagoon once contained brackish water, but the natural channel connecting the site to the sea has been converted to an outflow canal with sluice control and is fed by three canals which derive their water from irrigation channels and run-off from surrounding farmland. The submerged aquatic vegetation is characterised by curled pondweed Potamogeton crispus, fennel-leaved pondweed $P$. pectinata, horn-wort Ceratophyllus demersum and water milfoil Myriophyllum verticillatum with extensive reedbeds of Phragmites communis, reedmace Typha latifolia and sea club rush Scirpus maritimus fringing the shallow edges and on the small islands in the southwest of the lagoon. The temporary flooded areas support a typical halophytic vegetation of searush Juncus maritimus, cordgrass Spartina sp. (probably S. versicolor) and glasswort Salicornia fruticosa. There is a small area of pine woodland on the sand dunes which separate the lagoon from the sea. It has a typical 
Mediterranean maquis type shrub layer with narrow-leaved cistus Cistus monspeliensis, mastic tree Pistacia lentiscus, Asparagus albus and the broom Calicotome spinosa. The lagoon waters support an abundant fish population including carp, eel Anguilla anguilla and mullet Mugil sp. Gambusia affinis were introduced during the anti-malaria campaign, and have become established in the canals.

International and National Importance The lagoon is an important breeding location for purple swamphen Porphyrio porphyrio, with 40-45 pairs recorded each year from 1966 to 1976. Other breeding species include great crested grebe Podiceps cristata (3-5 pairs), little grebe Tachybaptus ruficollis, purple heron Ardea purpurea (10 pairs), little bittern Ixobrychus minutus, mallard Anas platyrhynchos, common pochard Aythya ferina (2-3 pairs 1979), white-eyed pochard $A$. nyroca (irregular), red-chested pochard Netta rufina (5 pairs), coot Fulica alra, grey moorhen Gallinula chloropus, water rail Rallus aquaticus and marsh harrier Circus aeruginosus (1 pair 1980). Numerous migratory birds stop over or winter in the wetland, including little grebe (480 September), cormorant Phalacrocorax carbo sinensis (60 January), grey heron Ardea cinerea (65 January), teal Anas crecca (maximum 1,600 January), tufted duck Aythya fuligula (1,300 January), white-eyed pochard (210 September) and coot (8,000 February).

Changes in Ecological Character The area surrounding the lagoon has been extensively reclaimed for agriculture, and the outflow channel into the sea is now controlled by a sliuce. Water entering the lagoon from the surrounding farmland carries a high level of artifical fertilisers and pesticides, resulting in eutrophication of the waters and consequent change in vegetation. Partially decomposed organic debris is collecting on the bottom. The continuing eutrophic conditions could soon have a detrimental effect on the wetland ecology, and the fish mortality rate is already high - especially in summer due to de-oxygenation of the water. There is some poaching within the protected area.

Management Practices The water level of the lagoon is controlled by a pumping station, and the lagoon is utilised for fish production. Hunting is prohibited.

Scientific Research and Facilities Study of local vegetation by the University of Sassari; geomorphological research by the University of Cagliari; and mid-winter counts of waterfowl from 1974-77 in cooperation with IWRB. A comprehensive biological and hydrological research programme to improve planning and conservation of Sardinia's coastal wetlands has been launched by the Regione Autonome della Sardegna.

Principal Reference Material The above information is taken from:

- Schenk, H. (1980). Wetlands of International Importance in Sardinia. Annex to the Italian National Report prepared for the Conference on the Conservation of Wetlands of International Importance especially as Waterfowl Habitat held in Cagliari, Italy.

Additional references:

- Di Gregoria, F. (1977). Studio geomorfologico del Golfo di Oristano. Boll. Soc. Sard. Sci. Nat. 16: 113-122.

- Hudson, R. (1975). Threatened birds of Europe. London.

- Morani, V. (1957). La bonifica di Arborea di Sardegna e i suoi problemi agronomici. Gallizi, Sassari.

- Schenk, H. (1976). Analisi della situazione faunistica in Sardogna. Uccelli e mammiferi. SOS Fauna, Animali in pericolo in Italia p. 465-556.

- Valsecchi, F. (1972). La vegetazione della stagno di S'Ena Arrubia nel Golfo di Oristano.

- Walter, H. (1964). Vogel an sardischen Salinen. Bonn. Zool. Beitr. 15:

- 198-210.

\section{Stagno di Molentargius}

Location $39^{\circ} 14^{\prime} \mathrm{N}, 9^{\circ} 0^{\prime} \mathrm{E}$. Situated on the northern shore of Cagliari Gulf between Cagliari township to the west and Quartu S. Elena to the east in Cagliari Province, southern Sardinia. 
Area 1,401 ha; including Molentargius pond (454ha), Quartu pond (218ha), Bellarosa pond (118ha) and Is Arenas fossilised dunes (about 600ha).

Degree of Protection 500ha privately owned and the remaing area state owned. The designated site is a landscape reserve in which hunting is prohibited. Designated as a Ramsar site at the time of ratification after 14 December 1976.

Site Description The site comprises a lagoon complex of the man-made saltpans Molentargius and Quartu ponds; Bellarosa pond, which is a freshwater basin separated from the saline evaporation ponds by a large earth bank; and the fossilised dunes of Is Arenas which lie between Molentargius and Quartu ponds. The saltpans are fed with seawater through an artificial canal into Molentargius pond which acts as the primary evaporation basin. The gradient of salinity increases from 3.5 parts per thousand in the peripheral basins to 10 parts per thousand in the shallows (Bassofondo) from where the water flows through a connecting canal into the second evaporation basins of Quartu pond where the salt concentration increases to 20 parts per thousand prior to entering the final crystallisation pans. The saline density is lowest during winter, due to high rainfall and minimum evaporation, and highest in July. The salt is extracted in September. The vegetation of the less saline peripheral basins is characterised by tassel pondweed Ruppia spiralis, glasswort Salicornia fruticosa and sea purslane Halimione portulacoides, with a rich aquatic fauna of molluscs, crustacea and insects. Fish species include smelt Atherina mochon and Ciprinidon calaritanus, which are abundant in the shallow medium-salininty waters. Vegetation cover becomes more sparse with increasing salinity, with sea wormwood Artemisia maritima, Dunalia sp. and blue green algae (Cyanophycae) in basins of medium to high salinity, and halophytic communities of fleabane Inula crithmoides, Arthrocnemum sp., hairgrass Aira capillaris, sea plantain Plantago maritima, squirrel-tail grass Hordeum marinum and Halocnemum strobilaceum along the edge of Quartu pond. Bellarosa pond originally stored freshwater from three temporary streams and regularly dried up in summer. Since the early 1960s, sewage inflow to the pond has gradually transformed it from a temporary pond with halophytic vegetation to a permanent freshwater system with rapidly expanding reedbeds of Phragmites isiaca. Typha angustifolia and $T$. latifolia. Floating vegetation is characterised by water milfoil Myriophyllum spicatum. Zostera sp. and (especially in spring and summer) an extensive coverage of the alga Enteromorpha intestinalis. In temporary flooded areas there are dense zones of Juncas subulatus, surrounded by glasswort $S$. fruticosa, sea purslane $H$. portulacoides, Cressa cretica and sea aster Aster tripoloium, with bushes of shrubby orache Atriplex halimus along the raised banks. The fossilised dunes are covered by crops such as cereals, vines and almond orchards, and act as an effective buffer zone against the sewage inflow.

International and National Importance Breeding waterfowl include purple swamphen Porphyrio porphyrio (45 pairs 1980), black-winged stilt Himantopus himantopus (50 pairs 1980), avocet Recurvirostra avoselta (200 pairs 1976), little tern Sterna albifrons (about 100 pairs 1971: continual deline), little grebe Tachybaptus ruficollis, mallard Anas platyrhynchos, garganay $A$. querquedula (1-2 pairs 1965-80), pochard Aythya ferina (40 pairs 1980), water rail Rallus aquaticus, grey moorhen Gallinula chloropus, coot Fulica atra, little ringed plover Charadrius dubius (single pairs irregularly), snowy plover C. alexandrinus (20-30 pairs) and herring gull Larus argentatus michahellis (single paris irregularly). Greater flamingo Phoenicopterus ruber nested in the area in 1975 and 1980 . Migratory waterfowl include cormorant Phalacrocorax carbo sinensis (maximum 620 in 1979), greater flamingo (1,437 January average 1974-78; 3,200 November), northern shoveler Anas clypeata (1,538 January average 1974-78; 2,500 January maximum 1980), coot (10,000 December), snowy plover (800 in September), spotted redshank Tringa erythropus ( 840 in October), little stint Calidris minuta (400 in November), Audoiun's gull Larus audouinii (70 July/August), grey heron Ardea cinerea (200 in November), little egret Egretta garzetta (330 November), great egret $A$. alba (3 in November/December), shelduck Tadorna tadorna (120 January), Eurasian wigeon Anas penelope (1,100 November; maximum 2,500 January), mallard (2,200 November), common pochard (2,600 January), little ringed plover ( 320 September), black-tailed godwit Limosa limosa (650 March), redshank Tringa totanus (1,000 November), marsh sandpiper $T$. slagnatilis (5-10 April), slender-billed gull Larus genei (70 April), little 
gull L. minutus (330 February), black tern Chlidonias nigra (660 September). The site is one of the few Italian overwintering areas for black-winged stilt (30-60), wood sandpiper Tringa glareola (10-15), ruff Philomachus pugnax, bluethroat Luscinia svecica cyanecula and barn swallow Hirundo rustica.

Changes in Ecological Character The great increase in nutrient levels (particularly phosphates) in Bellarosa Minore basin as a result of sewage inflow since the 1960 s initially increased the diversity of vegetation types, and resulted in an increase of breeding bird species from 8 in 1962 to 22 in 1976. Eutrophication is still increasing, and some areas are now totally covered by reedbeds with partially decomposed organic debris collecting on the basin floor. Sulphide-reducing bacteria associated with the eutrophic conditions release hydrogen sulphide, which can poison shallow waters. These chemical and environmental changes could soon have a detrimental effect on the ecology of the pond. Uncontrolled visitor access and unleashed dogs disturb the bird breeding colonies, and powerlines crossing the saltpans are a hazard to birds in flight.

Management Practices Plans have been proposed by the 'Commune di Cagliari' to build a sewage treatment plant in the area of Is Arenas dunes. It is hoped that this will improve the eutrophic conditions in Bellarosa Minore. Salt is extracted commercially from the state saltpans, and the water level of the ponds is regulated. The regional government of Sardinia has been promoting a conservation and utilisation plan for the entire wetland area.

Scientific Research and Facilities Geomorphological, vegetation and ornithological studies have been carried out. A hydro-biological research programme was carried out by Calgiari University in 1980. Annual mid-winter bird census is conducted in cooperation with IWRB.

Principal Reference Material The above information is taken from:

- Schenk, H. (1980). Wetlands of International Importance in Sardinia. Annex to the Italian National Report prepared for the Conference on the Conservation of Wetlands of International Importance especially as Waterfowl Habitat held in Cagliari, Italy.

Additional references:

- Hudson, R. (1975). Threalened birds of Europe. London.

- Massoli-Novelli, R. (1976). Lo Stagno di Molentargius. Cagliari.

- Mistretta, P., Mossa, L., Schenk, H., Lo Monaco, M. and Puddu, P. (1976). Il sistema del Molentargius. Critica Tecrica 5(3): 1-24.

- Palmerini, V. and Zidda, P. (1977). Ricerca geosedimentologica su alcuni sondaggi effettuati negli Stagni di Molentargius e Quartu (Cagliari). Redn. Sem. Fac. Sci. Universita di Cagliari 62: 314 .

- Schenk, H. (1970). Uber vorkommen, salztoleranz, vergesellschanftung und

- mauser des schwarzhalstauchers Podiceps nigricollis auf Sardinien. Vogelwelt 91: 230-235.

- Schenk, H. (1976). Analisi della situazione faunistica in Sardogna. Uccelli e mammiferi. SOS Fauna, Animali in pericolo in Italia p. 465-556.

- Soprintendenza ai Monumenti e Gallerie di Cagliari (1975). Piano Territoriale Paesistico del Molentargius. Cagliari.

- Walter, H. (1964). Vogel an sardischen Salinen. Bonn. Zool. Beitr. 15: 198-210.

\section{Stagno di Cagliari}

Location $39^{\circ} 11^{\prime}-13^{\prime} \mathrm{N}, 9^{\circ} 12^{\prime}-17^{\prime} \mathrm{E}$. Situated on the northern shore of Cagliari Gulf to the west of Cagliari township in Cagliari Province, southern Sardinia.

Area 3,466ha. Santa Gilla pond and Macchiareddu saltpan were added to the Ramsar site in 1979 , increasing the area from 3,105 ha. 258 ha were removed from the site after 1980 to allow construction of the industrial port of Cagliari, but 360 ha were subsequently added at the other end of the designated water surface. 
Degree of Protection State owned. The Ramsar site lies within Oasi Permanente Faunistica ( $5,000 \mathrm{ha})$, in which hunting is prohibited. Commerical and sport fishing have been banned since 1976. Designated as a Ramsar site at the time of ratification after 14 December 1976.

Site Description The site comprises Calgiari pond and the contiguous saltpans on the west bank. The site is bounded to the east by the Cagliari-Elmas railway, and separated from the saline Cagliari Bluff by sand dunes. The site is part of a flooded delta fed by freshwater inflow from the Cixerra and Mannu rivers, which has been modified extensively by land reclamation schemes. The man-made saltpans now cover nearly 2,000 ha of the Cagliari pond area, and are divided into a series of connected evaporation basins in which the salinity increases along a gradient of 3.5 - 20 parts per thousand. The salt is extracted in September following the dry summer. The open lagoon supports an abundance of molluscs such as cockles, carpet shell, Mediterranean mussel (Cerasloderma sp., Venerupis decussatus, Mytilus galloprovincialis); crustacea such as Mediterranean crab Carcinus mediterraneus; and fish such as eel, smelt, bass, sole, gilthead (Anguilla anguilla. Alherina mochon, Dicentrarchus labrax, Solea solea, Sparus auratus) and mullets (Mugil auratus, M. cephalus). The northern shore of the pond near the freshwater inflow is dominated by large reedbeds of Phragmites communis, Typha sp. and Juncus spp. The central and southern areas of the lagoon, and the low salinity saltpans, are characterised by typical brackish and saltwater associations of glasswort Salicornia sp., seablite Sueda sp., orache Atriplex sp., and the very localised Halocnemum strobilaceum.

International and National Importance The wetland is important for breeding and migrating birds. Breeding birds include purple swamphen Porphyrio porphyrio (30-50 pairs), black-winged stilt Himantopus himantopus (40-70 pairs), avocet Recurvirostra avosetta (250 pairs in 1980), snowy plover Charadrius alexandrinus, gull-billed tern Gelochelidon nilotica (90 pairs in 1980), little tern $S$. albifrons (200 pairs), little egret Egretta garzetta (10-15 pairs in 1979: first recording record for Sardinia), little bittern Ixobrychus minutus, shelduck Tadorna tadorna (2 pairs in 1979), mallard Anas platyrhynchos, marsh harrier Circus aeruginosus (1-2 pairs), water rail Rallus aquaticus, grey moorhen Gallinula chloropus, coot Fulica atra, little ringed plover Charadrius dubius (maximum 10 pairs), redshank Tringa totanus (3-5 pairs), collared pratincole Glareola pratincola (single pairs breeding irregularly), herring gull Larus argentatus (about 50 pairs), black-headed gull L. ridibundus (20 pairs in 1980), common tern Sterna hirundo (50-60 pairs in 1980). In 1979 about 50 pairs of greater flamingo Phoenicopterus ruber nested in the wetland, and in 1980 breeding purple gallinule Porphyrula martinica and over 700 pairs of slender-billed gull Larus genei were recorded: all on the Red List of threatened birds in Europe (Hudson, 1975). Migratory waterfowl include cormorant Phalacrocax carbo sinensis (maximum 620 in 1979) with the winter population continually increasing from 1976 due to lack of competition from fishermen, greater flamingo Phoenicopterus ruber, avocet Recurvirostra avosetta (800 in November), little stint Calidris minuta (1,000 in February), black-necked grebe Podiceps nigricollis (140 in November), great egret Egretta alba (3-5 in October to January), wigeon Anas penelope (2,400 in January), pintail Anas acuta (2,350 in January), pochard Aythya ferina (3,700 in February), coot Fulica atra (7,100 in January), marsh sandpiper Tringa stagnatilis (25 in April), curlew sandpiper Calidris ferruginea (500 in August), Audouin's gull Larus audouinii (regularly up to 35 in July/August) and slender-billed gull L. genei (up to 50 in October/March).

Changes in Ecological Character Industrial pollution (mainly from a petro-chemical plant built on the northwest shore of the pond in the 1960s) and urban pollution have resulted in a marked decline of the fish population. All fishing is now prohibited. An industrial port is now being built on the Cagliari Pond, and the ecological consequences for the Ramsar site will be very negative. Bird breeding colonies in the salt pans are being disturbed by poachers and illegal egg collecting.

Management Practices The RAS implemented a programme for about 2,000 ha of the pond to reduce pollution. A network of stations have been established to monitor the physical, chemical and biological parameters within the pond system. Wetland management measures have been planned for 360 ha in the southwest of S. Gilla saltpan, with emphasis on the wildfowl population. 
Scientific Research and Facilities Cagliari University has been studying the local flora, hydrobiology of the pond, and effects of pollution since 1965. There is a long-term research programme (started in 1976) on the bird breeding communities in the saltpans, particularly the ecology of the slender-billed gull, by the Centro Italiano Studi Ornithology. Regular waterfowl censuses in January as part of a mid-winter population monitoring scheme coordinated by IWRB, and monthly counts are made of the flamingo population in cooperation with Tour du Valat/Carmague.

Principal Reference Material The above information is taken from:

- Schenk, H. (1980). Wetlands of International Importance in Sardinia. Annex to the Italian National Report prepared for the Conference on the Conservation of Wetlands of International Importance especially as Waterfowl Habitat, held in Cagliari, Italy.

Additional references:

- Cottiglia, M., Manca, G. and Mascia, L. (1968). Fenomeni di inquinamento nelle acque della Sardegna. Influenza di una industrila petrolchimica sul biotopo salmastro di S. Gilla e conseguenti ripercussioni sulla ittiofauna. Acqua Industriale pp 3-19.

- Cottiglia, M., Axia, C. and Tagliasacchi, M.L. (1973). L'inquinamento nello Stagno di Cagliari. La Programmazione in Sardegna 48: 3-55. Cagliari.

- Hudson, R. (1975). Threatened birds of Europe. London.

- Italia Nostra (1973). Santa Gilla - una laguna condannata a morte. Cagliari.

- Mistretta, P., Mossa, L. and Schenk, H. (1975). Lo Stagno di Cagliari come zona umida d'importanza internazionale in base alla Convenzione di Ramsar (Iran) 1971. Relazione p. 1-13 e allegati. Regione Autonoma della Sardegna. Assessorato Difesa Ambiante.

- Schenk, H. (1976). Analisi della situazione faunistica in Sardogna. Uccelli e mammiferi. SOS Fauna, Animali in pericolo in Italia p. 465-556.

- Walter, H. (1964). Vogel an sardischen Salinen. Bonn. Zool. Beitr. 15: 198-210.

\section{Le Cesine}

Location $40^{\circ} 20^{\prime} \mathrm{N}, 18^{\circ} 23^{\prime} \mathrm{E}$. Situated on the east coast of the 'heel' of southern Italy, north of Cape Otranto (the eastern extreme of Italy) in Vernole commune, Lecce Province, Puggia.

Area 620ha

Degree of Protection The site is managed as a nature reserve by the WWF Italy with shooting prohibited. Designated as a Ramsar site in December 1977.

Site Description The site comprises a coastal brackish wetland centred around the swamp of Pantano Grande, which is fed by the freshwater Collettore canal entering the reserve near Idrovoro monument in the north. Habitats include marshland, patches of woodland, isolated brackish pools and sand dunes fringing the Adriatic shoreline. The designated area is bounded to the east by the Adriatic sea, and to the west and south by the Allacciante canal. Several tracks and pathways provide access to most parts of the site.

International and National Importance The site is an important resting station for migrants and overwintering birds, with over 10,000 birds visiting the wetland each year. Species include glossy ibis Plegadis falcinellus (100 on passage), black-winged stilt Himantopus himantopus (150), little egret Egretta garzetta (300), spoonbill Platalea leucorodia (30), crane Grus grus (100), teal Anas crecca (up to 3,000) and gull-billed tern Gelochelidon nilotica (40-50 on passage).

Changes in Ecological Character None reported (1980)

Management Practices No information

Scientific Research and Facilities No information 
Principal Reference Material The above information is taken from the decree document for the designation Gazzetta Ufficiale della Repubblica Italiana No. 215 (8 August 1977).

Supplemented by:

- Scott, D.A. (1980). A preliminary inventory of wetlands of international importance for waterfowl in west Europe and northwest Africa. IWRB Special Publication No. 2.

\section{Valle Cavanata}

Location $45^{\circ} 45^{\circ} \mathrm{N}, 13^{\circ} 29^{\prime} \mathrm{E}$. Situated on the northern shore of the Gulf of Trieste on the Adriatic. In Grado Commune, Gorizia Province, Friuli-Venezia Giulia, northeast Italy.

\section{Area 243 ha}

Degree of Protection Designated as a Ramsar site in March 1978.

Site Description The site comprises the brackish Cavanata pool; an artifical fishery separated from the pool by a sand embankment; the terminal portion of Averto Canal; and surrounding marsh areas. The site is separated from the Gulf of Trieste by a series of sandbanks, and is surrounded by reclaimed agricultural land irrigated by a network of channels. The pool supports a rich aquatic fauna with amphibians, reptiles such as the pond terrapin Emys orbicularis, fish, crustacea and molluscs.

International and National Importance The site is an important breeding area and rest station for migrating waterfowl, particularly greylag goose Anser anser and breeding little tern Sterna albifrons.

\section{Changes in Ecological Character None reported (1978)}

Management Practices The fishery is managed for commercial purposes.

\section{Scientific Research and Facilities No information}

Principal Reference Material The above information is taken from the decree document for the designation Gazzetla Ufficiale della Republica Italiana No. 50 (20 February 1978).

\section{Stagno di Cabras and adjacent territory}

Location $39^{\circ} 53^{\prime} \mathrm{N}, 8^{\circ} 28^{\prime} \mathrm{E}$. Situated in the southeast of Sinis Peninsula in Riola Sardo Cabras Commune, Oristano Privince, west Sardinia. Just south of Sale Porcus Ramsar site.

Area 3,575ha

Degree of Protection Privately owned. The Regione Autonoma della Sardegna was negotiating purchase of some of the area in 1980. Hunting is prohibited in about 30 ha on the northern edge of Mari e Pauli pond, which is protected as an Oasi Permanente di Protezione Faunistica e di Cattura. A regional nature park or a series of nature reserves have been proposed for Sinis peninsula, which would include Cabras pond. Designated as a Ramsar site in March 1979.

Site Description Cabras pond is the largest shallow freshwater lake in Sardinia, and together with Mistras pond and Sale Porcus (Ramsar sites) is a remnant of an ancient channel which once separated Sinis peninsula from the mainland. Mare Foghe river is the main freshwater feeder, with smaller inflows along the eastern edge draining the nearby agricultural land. The pond is joined to Oristano Gulf by a natural connecting channel, but the inflow of seawater is minimal, especially since a large canal was constructed nearby leading to the gulf. The aquatic vegetation is characterised by water milfoil Myriophyllum verticillatum, 
horn-wort Ceratophyllum sp., pondweed Potamogeton spp. and Enteromorpha sp., with tassel pondweed Ruppia spiralis in the more brackish areas such as along the eastern edge of the pond. Extensive beds of pennywort Hydrocotyle ranunculoides grow along the main pond. Some mixed stands of Phragmites communis and sea club rush Scirpus maritimus. In Mari e Pauli pond there is a typical vegetation succession from $P$. communis to reedmace Typha sp. The series of depressions along the eastern edge of Cabras pond collect rainwater from October to April but usually dry out completely during the summer. Mineral salts accumulate as a result of these alternating wet and dry periods and a typical halophytic plant community has developed with glasswort Salicornia fruticosa, sea purslane Halimione portulacoides, saltwort Salsola soda, sea lavender Limonium vulgare and sea club rush, with extensive areas of submerged tassel pondweed and pondweed Potamogeton pectinatus when filled with water. The pond is very rich in fish, with an annual production before 1970 of $225 \mathrm{~kg} / \mathrm{ha}$ (primarily mullet Mugil sp., eel Anguilla anguilla, smelt Atherina mochon and Cyprinidae).

International and National Importance Due to limited human impact in the area, the breeding bird population of the wetland is an important example of undisturbed freshwater and brackish water communities of the central Mediterranean region. The site should therefure be regarded as of particular importance for the maintanence of genetic and ecological diversity in this region. Breeding birds include purple heron Ardea purpurea (15 pairs), little bittern Ixobrychus minutus, Eurasian bittern Botanus stellaris, black-winged stilt Himantopus himantopus (10-30 pairs 1970-80), purple swamphen Porphyrio porphyrio (over 50 pairs 1976-80), moorhen Gallinula chloropus, great crested grebe Podiceps cristatus (4-12 pairs 1965-76), little grebeTachybaptus ruficollis, white-headed duck Oxyura leucocephala (maximum 5 pairs; no recent breeding records), mallard Anas platyrhynchos, garganay $A$. querquedula, common pochard Aythya ferina (5 pairs), red-crested pochard Netta rufina (10-15 pairs 1976-80), water rail Rallus aquaticus, little ringed plover Charadrius dubius, snow plover C. alexandrinus, stone curlew Burhinus oedicnemus, coot Fulica atra, collared pratincole Glareola pratincola, black-headed gull Larus ridibundus (45 pairs 1980), little tern Sterna albifrons, marsh harrier Circus aeruginosus (5-6 pairs) and Montagu's harrier C. pygargus (1-2 pairs 1980). The ancient dune system to the west supports an important population of Barbary partridge Alectoris barbara and large colonies of bee-eater Merops apiaster. Nearby seacliffs have small breeding colonies of cormorant Phalacrocorax carbosinensis, shag $P$. aristotelis desmarestii, herring gull Larus argentalus michahellis, common kestrel Falco tinnunculus, lesser kestrel $F$. naumanni and peregrine falcon $F$. peregrinus brookei. Large numbers of migratory birds visit the wetland including greater flamingo Phoenicopterus ruber (maximum 2,500 October 1980), great crested grebe (200 February), black-necked grebe Podiceps nigricollis (25 February), glossy ibis Plegadis falcinellus (34 September), Eurasian wigeon Anas penelope (i,650 February), teal $A$. crecca (1,500 January), pintail duck $A$. acula (1,700 January), red-crested pochard (about 100 April and August), common pochard (4,500 December), coot (2,100 January), avocet Recurvirostra avosetta (200 September) and cormorant (200 February).

Changes in Ecological Character The construction of the canal from the pond to the north of Oristano Gulf has almost precluded inflow of seawater into the freshwater pond. Run-off from surrounding agricultural land entering the wetland system contains high levels of fertilisers and pesticides, which is resulting in eutrophication of the waters especially in the small Mari e Pauli and Su Sali ponds on the eastern edge. Some of the temporary ponds have been reclaimed for agriculture. Poaching and legal hunting in the area has had a significant impact on wintering wildfowl populations.

Management Practices Fisheries and hunting are allowed in the wetland. The bird population is monitored, and an ornithological station is being established near Mari e Pauli pond.

Scientific Research and Facilities Botanical research has been carried out by the University of Bologna; monthly counts of the flamingo population; annual monitoring of the breeding populations of purple swamp hen and red-crested pochard; and several studies concerning the proposed regional nature park or series of nature reserves. 
Principal Reference Material The above information is taken from:

- Schenk, H. (November 1980). Wetlands of International Importance in Sardinia. Annex the Italian National Report prepared for the Conference on the Conservation of Wetlands of International Importance especially as Waterfowl Habitat, held in Cagliari, Italy.

Additional references:

- Hudson, R. (1975). Threatened birds of Europe. London.

- Schenk, H. (1976). Analisi della situazione faunistica in Sardogna. Uccelli e mammiferi. SOS Fauna, Animali in pericolo in Italia p. 465-556.

- Walter, H. (1964). Vogel an sardischen Salinen. Bonn. Zool. Beitr. 15: 198-210.

\section{Corru S'Ittiri Fishery and Stagno di San Giovanni e Marceddi}

Location $39^{\circ} 44^{\prime} \mathrm{N}, 8^{\circ} 30^{\prime} \mathrm{E}$. Situated in the southern part of Oristano Gulf near Torralba, in Oristano and Cagliari Provinces on the west coast of Sardinia.

Area 2,610ha (Corru de S'Ittiri Fishery 250ha; San Giovanni and Marceddi Ponds 1,200ha).

Degree of Protection Public property. The site is a designated fish reservoir with commercial fishing and hunting allowed. Designated as a Ramsar site in March 1979.

Site Description The designated site comprises a system of lagoons separated from the southern part of Oristano Gulf by a system of sand dunes, except for a wide communicating channel. The three main ponds in the system have different hydrological characteristics. Corru S'Ittiri (which merges with Marceddi) is the most northerly, with only one marine inflow entering at the north from Pauli Pirastu storage pond (which contains water already used for agricultural irrigation). Marceddi pond is brackish. San Giovanni is a freshwater pond separated from Marceddi by an embankment broken by small channels. It is fed by two freshwater rivers, the Flumini Mannu and Riu Mogoro, which once formed a large river delta with numerous small fresh and brackish ponds, (now all reclaimed for agriculture). The vegetation demonstrates a typical succession determined by water salinity, with vast reedbeds of Phragmiles communis, reedmace Typha sp., Scirpus sp., Juncus spp. and Tamarix sp. around the freshwater S. Giovanni pond, and halophytic associations of glasswort Salicornia sp., seablite Suaeda sp. and Cressa cretica around Marceddi and Corru S'Ittiri. The ponds are very productive for fish (San Giovanni $390 \mathrm{~kg} /$ ha per annum, Marceddi $140 \mathrm{~kg} / \mathrm{ha}$ and Corru S'Ittiri $416 \mathrm{~kg} / \mathrm{ha}$ ). The main species are eel, smelt, bass, gilthead (Anguilla anguilla, Atherina mochon. Decentrachus labrax, Sparus aurata), mullet, goby Gobius sp. and Lithognathus mormyrus.

International and National Importance Breeding birds include purple heron Ardea purpurea (10 pairs), little bittern Ixobrychus minutus, Eurasian bittern Botanus stellaris, purple swamphen Porphyrio porphyrio (about 30 pairs in San Giovanni and Pauli Pirastu 1978-80), moorhen Gallinula chloropus, great crested grebe Podiceps cristatus (5-10 pairs), little grebe Tachybaptus ruficollis, mallard Anas platyrhynchos, garganay A. querquedula (2-3 pairs), red-crested pochard Nella rufina (2-3 pairs), water rail Rallus aquaticus, little ringed plover Charadrius dubius (occasional), snowy plover C. alexandrinus (20-30 pairs), coot Fulica atra, collared pratincole Glareola pratincola (irregular breeder at Corru Mannu), little tern Sterna albifrons (maximum 50 pairs especially at Corru Mannu; decreasing) and marsh harrier Circus aeruginosus (1 pair). A maximum of 10,600 migratory coot have been recorded at this site in December, but the numbers are decreasing. Other migrants include greater flamingo Phoenicopterus ruber (300 in April), black-necked grebe Podiceps nigricollis (50 January), Eurasian wigeon Anas penelope (1,650 February), teal $A$. crecca (1,500 January), pintail duck $A$. acuta (900 January), common pochard Aythya ferina (1,300 January), tufted duck $A$. fuligula (500 December) and cormorant Phalacrocorax carbo sinensis (maximum 150 December/January).

Changes in Ecological Character Mining and other industrial effluent, agricultural runoff and urban pollutants flow into the wetland system, with adverse effects including eutrophication (especially at Corru S'Ittiri). The bird population is subject to hunting pressures, with hunting being legal in the area. 
Management Practices commercial basis.

Scientific Research and Facilities Cagliari University has conducted research on fish production and pollution. Irregular mid-winter waterfowl counts are made. The Autonomous Region of Sardinia has launched a comprehensive programme on the biology and hydrology of the site.

Principal Reference Material The above information is taken from:

- Schenk, H. (1980). Wetlands of International Importance in Sardinia. Annex the Italian National Report prepared for the Conference on the Conservation of Wetlands of International Importance especially as Waterfowl Habitat held in Cagliari, Italy.

Additional references:

- Cottiglia, M. (1970). Pesca marritima e lagunare in Sardegna. La Programmazione in Sardegna 27: 29-32.

- Cottiglia, M. (1972). La Pesci negli stagni salmastri in Sardegna. La Programmazione in Sardegna 39/40: 48-52.

- De Angelis, C. (1953). Osservazione su alcuni stagni della Sardegna. Boll. Pesca. Piscicoltura e Idrodiologia 28.

\section{Stagno di Pauli Maiori and adjacent territory}

Location $39^{\circ} 52^{\prime} \mathrm{N}, 8^{\circ} 37^{\prime} \mathrm{E}$. Situated east of Santa Giusta Pond, in Oristano Province near the west coast of Sardinia.

Area $287 \mathrm{ha}$ including $60 \mathrm{ha}$ of open water.

Degree of Protection Public property. Hunting and fishing allowed. Designated as a Ramsar site in March 1979.

Site Description This irregularly shaped site comprises the small freshwater Pauli Maiori Pond and extensive surrounding reedbeds. The only natural inflow is runoff from the Campidano di Oristano irrigation scheme, and a communicating canal with Santa Giusta pond supplies a very low inflow of brackish water. A railway line cuts across the wetland just west of the pond. The submerged aquatic vegetation of the open water consists of dense beds of pondweed Potamogeton sp., hornwort Ceratophyullus sp. and water milfoil Myriophyllum sp. The extensive reedbeds are dominated by Phragmites communis, with local stands of reedmace Typha angustifolia. The feeder rivers and some smaller shallow bays are partially covered by pennywort Hydrocotyle ranuncoloides.

International and National Importance The wetland is most important for breeding waterfowl, with the highest concentration of purple swamphen Porphyrio porphyrio in Sardinia (about 70 pairs). Other breeding waterfowl include purple heron Ardea purpurea (30-35 pairs), little bittern Ixobrychus minutus, bittern Botaurus stellaris (status uncertain), moorhen Gallinula chloropus, little grebe Tachybaptus ruficollis, white-headed duck Oxyura leucocephala (status unknown), mallard Anas platyrhynchos, water rail Rallus aquaticus, coot Fulica atra, marsh harrier Circus aeruginosus (2-4 pairs 1976-80) and Montagu's harrier C. pygargus (2 pairs since 1976: first nesting record for Sardinia). The wetland is also a stopover and wintering station for various waterfowl.

Changes in Ecological Character The inflow of agricultural and urban pollutants has caused a problem of eutrophication in the wetland.

Management Practices The pond supports extensive fisheries, and hunting is permitted.

Scientific Research and Facilities The Autonomous Region of Sardinia has launched a comprehensive research programme on the biology and hydrology of the site. 
Principal Reference Material The above information is taken from:

- Schenk, H. (November 1980). Wetlands of International Importance in Sardinia. Annex the Italian National Report prepared for the Conference on the Conservation of Wetlands of International Importance especially as Waterfowl Habitat held in Cagliari, Italy. Additional reference:

- Montalenti, G. (1967). Relazione sulla protezione delle lagune e degli stagni costieri della peniscola e delle grandi isole. La Ricerca scientifica 38, Roma.

- Gruppo Lavaca, A. (1972/75). Studio del Parco del Limbara sul sistema Regionale di Parchi. Prima e seconda fase. Centro Regionale di Programmazione. Cagliari.

\section{Valle Campotto e Bassarone}

Location $44^{\circ} 35^{\prime} \mathrm{N}, 11^{\circ} 49^{\prime} \mathrm{E}$. Situated about $38 \mathrm{~km}$ northwest of Ravenna in Ferrara Province, Emilia Romagna.

Area 1,363ha. Separated from Valle Sante Ramsar site (261 ha) by the Sussulario canal.

Degree of Protection Privately owned by the Societa Bonifiche Renane. The site is partially protected as a private hunting reserve in which shooting is controlled. Commerical and sport fishing allowed. Designated as a Ramsar site in March 1979.

Site Description The site comprises a shallow freshwater reservoir which, with Valle Sante, supplies Ravenna and its industries with water and acts as an overflow basin for Reno River floodwaters. It is one of the last remnants of the formerly extensive swamps of the southeast Po floodplains, which were mostly drained for reclamation during the 19th century. The low level pollution has made it a highly productive eutrophic lake supporting extensive reedbeds of Phragmites communis, interspersed with channels and stretches of open water (maintained by man) with floating white water lily Nymphaea alba and typical submerged plant associations. The rich aquatic fauna includes pike Esox lucious, tench Tinca tinca (fished commercially and for sport) and the pond terrapin Emys orbicularis.

International and National Importance Great numbers of waterfowl including grebes (Podicipedidae), herons (Ardeidae), ducks (Anatidae), rails and coots (Rallidae), plovers (Charadriidae) and sandpipers (Scolopacidae) congregate in these reservoirs in winter. Breeding species include black-crowned night-heron Nycticorax nycticorax, purple heron Ardea purpurea, squacco heron $A$. ralloides, bittern Botaurus stellaris, little egret Egretla garzetla, glossy ibis Plegadis falcinellus, several hundred pairs of great crested grebe Podiceps cristatus, mallard Anas platyrhynchos, gadwall A. strepera, garganey A. querquedula, coot Fulica atra, a large colony of whiskered tern Chlidonias hybrida (reputedly the only one in Italy), and black tern C. nigra.

Changes in Ecological Character Low level pollution has resulted in a small degree of eutrophication making the waters extremely productive for phyto-and zoo plankton and fish. The otter Lutra lutra is probably locally extinct.

Management Practices Management is subject to some hydrological constraints, as Valli Campotto e Bassarone is a supply reservoir. The water level is kept generally low to attract birds, although the area is sometimes flooded by the River Reno. Some reed cutting and clearing of channels.

Scientific Research and Facilities Two companies (Tecneco and Italeco) have carried out ornithological and hydrological studies on behalf of the regional government.

Principal Reference Material The above information is taken from:

- Carp, E. (1980). A Directory of Western Palearctic Wetlands. IUCN, Gland, Switzerland. Additional reference:

- Toschi, A. (1968). Interesse faunistico e paesistico delle Valli dolci e salmastre delli Emilia orientale. Studi Romagnoli XIX, 12pp. 


\section{Marano Lagunare - Mouth of the Stella}

Location $45^{\circ} 45^{\prime} \mathrm{N}, 13^{\circ} 08^{\prime} \mathrm{E}$. Northern shore of the Adriatic (Gulf of Trieste) in Udine Province of Friuli-Venezia Giulia, northwest Italy.

Area 1,400 ha

Degree of Protection The wetland is under state and private ownership including some wildfowl refuges created from previous private hunting reserves. The area is legally unprotected, but all planned alterations to the wetland must by approved by the authorities responsible for landscape conservation. Commerical fishing and shooting are allowed in the bay, and there are some private hunting reserves. Designated as a Ramsar site in May 1979.

Site Description The site is part of a larger wetland complex within the extensive Marano Lagoon on the Adriatic coast which includes Grado Lagoon, Valli di Zignago, Cortelazzo pool and Tagliamento River estuary. The site lies between two headlands, and is separated from the open sea by a line of dunes. The water is brackish to saline, and is a highly productive source of fish. The vegetation is dominated by associations of glasswort Salicornita and tassel pondweed Ruppieta maritimae.

International and National Importance Large numbers of waterfowl breed or overwinter on the wetland including little tern Sterna albifrons (250 pairs), purple heron Ardea purpurea (50 pairs) and black-winged stilt Himantopus himantopus (30 pairs). Wintering wildfowl include goldeneye Bucephala clangula (January average 2,000/maximum 5,100), red breasted merganser Mergus serrator (January average 700/maximum 1,600), coot Fulica atra (January average 14,000/maximum 20,000), teal Anas crecca $(2,200)$ and pintail $A$. acuta $(830)$.

Changes in Ecological Character The most serious threats in the area are drainage, in-filling, tourist developments such as the construction of marinas for pleasure boats, and increasing pollution.

\section{Management Practices No information}

\section{Scientific Research and Facilities No information}

Principal Reference Material The above information is taken from:

- Carp, E. (1980). A Directory of Western Palearctic Wetlands. IUCN, Gland, Switzerland. Additional references:

- Fornaciari, G. (1968). Aspetti floristici e fitosociologici della laguna di Grado e del suo litorale. Alt. Acc. Sc., Lelt. Arti. Udine Serie VII (6).

- Montalenti, G. (1967). Relazione sulla protezione delle lagune e degli stagni costieri della Penisola e delle grandi isole. Ricerca Scientifica No. 38, Consiglio nazionale delle Ricerche, Roma.

\section{Salina di Margherita di Savoia}

Location $41^{\circ} 24^{\prime} \mathrm{N}, 16^{\circ} 05^{\prime} \mathrm{E}$. Situated immediately northwest of the town of Barletta on the Adriatic coast in Foggia Province, Puglia.

\section{Area 3,871 ha}

Degree of Protection State owned saltlands. The area is now protected as a state nature reserve with access only allowed for those accompanied by a guide. Shooting prohibited. The reserve is administered by the Ministry of Agriculture and Forests (General Direction of Mountain Economy and Forests). Designated as a Ramsar site in August 1979. 
Site Description The reserve comprises a complex of saltwater basins linked by a network of channels to a series of canals opening into the Gulf of Manfredonia. The hydrology of the saltpans is varied, with brackish to saltwater depending on the depth and rates of evaporation. They support a rich flora of rushes (Juncaceae), sedges (Cyperaceae), goosefoot (Chenopodiaceae) and aquatic algae.

International and National Importance The saltpans are important for breeding, wintering and migrating waterfowl. Breeding species include black-winged stilt Himantopus himantopus, avocet Recurvirostra avoselta, pratincole Glareola pratincola, gull-billed tern Gelochelidon nilotica and little tern Sterna albifrons. Many thousands of birds winter or pass through the area on migration, including avocet, glossy ibis Plegadis falcinellus, black-winged stilt, crane Grus grus, spoonbill Plalalea leucorodia, white-fronted goose Anser albifrons, wigeon Anas penelope (up to 19,000), pintail A. acuta $(2,100)$, gadwall $A$. strepera, shoveler A. clypeata (1,700), teal A. crecca (500), shelduck Tadorna tadorna $(2,200)$, pochard Aythya ferina (210), coot Fulica atra (10,000), little stint Calidris minuta, curlew Numenius tenvirostris, common cormorant Phalacrocorax carbo, slender-billed gull Larus genei and gull-billed tern Gelochelidion nilotica.

Changes in Ecological Character Although hunting is prohibited, there is still some poaching. A road runs along the dunes between the saltpans and the sea, making access to the site difficult to control.

Management Practices The area is managed as a nature reserve by the Ministry of Agriculture and Forests, and the channels and basins are maintained.

Scientific Research and Facilities There are observation huts for ornithological studies.

Principal Reference Material The above information is taken from:

- Duffey, E. (1982). National Parks and Reserves of Western Europe. Macdonald and Co., London.

- Scott, D.A. (1980). A preliminary inventory of wetlands of international importance for waterfowl in West Europe and northwest Africa. IWRB Special Publication No. 2.

\section{Lago di Tovel}

Location $46^{\circ} 15^{\prime} \mathrm{N}, 11^{\circ} 00^{\prime} \mathrm{E}$. Situated northwest of Trento immediately southwest of Tuenno village in the dolomitic mountains of northern Italy in Trento Province, Trentino Alto Adige.

Area 37ha (within Adamello-Brenta Natural Park 436ha).

Degree of Protection The area is protected as a nature reserve being park of Adamello-Brenta Natural Park. Designated as a Ramsar site in September 1980.

Site Description The lake is an alpine freshwater lake fed by numerous streams originating in the surrounding mountains and surrounded by coniferous and mixed woodland. The lake supports an alga (Rhodophyta) which turns the water red at certain times of the year.

International and National Importance No information

Changes in Ecological Character There is unrestricted public access within the park, and visitor pressure is high at the lake which is easily accessible from Tuenno.

Management Practices The park is managed as a nature reserve.

Scientific Research and Facilities No information 
Principal Reference Material The above information is taken from:

- Duffey, E. (1982). National Parks and Reserves of Western Europe. Macdonald and Co., London.

Torre Guaceto, adjacent territory and sea area

Location $40^{\circ} 43^{\prime} \mathrm{N}, 17^{\circ} 48^{\prime} \mathrm{E}$. Situated on the Adriatic coast immediately north of Brindisi Port on the heel of Italy in Brindisi Province, Puglia.

Area 940ha

Degree of Protection Puglia regional government is responsible for the conservation and management of the area. Designated as a Ramsar site by the Ministry of Agriculture and Forestry by Decree No. 0212 on 18 May 1981, and added to the Ramsar list in July 1981.

Site Description The site comprises the coastal marshlands around the Guaceto headland (Torre Guaceta), littoral dunes, and the small offshore islands. The vegetation comprises three main associations: glasswort Salicornetum fruticosa; halophytic Suedeto-Salsoletum-Sodae; and reedbeds dominated by Phragmites communis. There are bronze-age archaeological remains, and evidence of a neolithic village have been found nearby.

International and National Importance Birds recorded in the wetland include dotterel Eudromia morinellus.

Changes in Ecological Character None reported (1981)

Management Practices No information

Scientific Research and Facilities No information

Principal Reference Material The above information is taken from:

- Ministry of Agriculture and Forestry Decree No. 0212 (May 1981).

\section{Valle di Gorino and adjacent territories}

Location $44^{\circ} 49^{\prime} \mathrm{N}, 12^{\circ} 21^{\prime} \mathrm{E}$. Situated west of Gorino on the Adriatic coast of northern Italy in Ferrara Province, Emilia Romagna.

Area 1,330ha

Degree of Protection Part of the area has recently been declared, in part, a State Nature Reserve administered by the Ministry of Agriculture and Forest, the remaining part is protected by the Province of Ferrara. Designated as a Ramsar site in September 1981.

Site Description The site comprises the coastal lagoons west of the Po di Goro river mouth and is part of the large estuarine complex around Porto Tolle where three major rivers (Po di Goro, Po di Tolle and Po Grande) enter the sea. The lagoon area is enclosed on three sides by sandbars, islets and sediments from the river deposited as a result of onshore coastal currents, but is open to the sea on the fourth side.

International and National Importance No information

Changes in Ecological Character None reported (1981)

Management Practices No information 
Scientific Research and Facilities No information

Principal Reference Material No information

\section{Valle Bertuzzi and adjacent water surfaces}

Location $44^{\circ} 47^{\prime} \mathrm{N}, 12^{\circ} 13^{\prime} \mathrm{E}$. Situated on the Adriatic coast in the vicinity of Comachio, $35 \mathrm{~km}$ north of Ravenna in Ferrara Province, Emilia Romagna.

\section{Area 3,100 ha}

Degree of Protection Privately owned by the Societa Berufiche Terreni Ferraresi. The designated site includes a partially protected Landscape Reserve (1,900ha). It has been proposed that the area be included in a Regional Park on the coast, but no information is available on implementation. Commercial fishing is controlled and some of the area is a shooting preserve. Designated as a Ramsar site in September 1981.

Site Description The wetland comprises a brackish lagoon on the Adriatic isolated form the sea by sandspits. The inner Valle Contone and outer Valle Bertuzzi (divided by sand islands) are the remnants of the vast 'valli' which once extended from Ferrara to the sea. They represent the only large natural body of water between the Valli di Comacchio to the south and the Po di Goro to the north (Porto Tolle). The wetland is a complex of habitat types: shrubby glasswort Salicornia fruticosa on the ancient dunes which mark the old shoreline; communities of halophytes such as couch grass Agropyron sp., golden samphire Inula crithmoides and sea aster Aster tripolium on the small islands in the lagoon; typical Mediterranean species including thickets of holm oak Quercus llex and Phillyrea sp. on the higher dunes; and reedbeds of Phragmites communis in the shallow, less saline waters of the inner Valle Contone which merge with the regularly inundated coastal mudflats offshore.

International and National Importance Breeding waterfowl include purple heron Ardea purpurea (100 pairs), little tern Sterna albifrons (200 pairs), common tern S. hirundo (70-80 pairs), little egret Egretta garzetta (50 pairs), black-winged stilt Himantopus himantopus (10 pairs), herring gull Larus argentatus (300 pairs), mallard Anas platyrhynchos, coot Fulica atra, and in some years pratincole Glareola pratincola. Wintering and migrating birds include tufted duck Aythya fuligula (January average 3,600/maximum 6,200), coot (January average 11,000/maximum 24,000), mallard, teal Anas crecca, wigeon $A$. penelope, great crested grebe Podiceps cristatus, little grebe Tachybaptus ruficollis, grey heron Ardea cinerea, plovers and sandpipers (Charadriiformes).

Changes in Ecological Character Freshwater from the heavily polluted Volano River cannot be used for abstraction purposes. Yields of traditional fisheries have been decreasing because the lagoon water of ten becomes severely deoxygenated during summer droughts, due to the isolation from the sea and polluted waters from the Volano. The pollution may also have adverse effects on birds which use the fish as a food source. Areas of the wetland have been drained in the past, but drainage programmes have now stopped almost completely.

Management Practices The water level in the lagoon is controlled. In the 1970s, shooting in the area was prohibited for at least two years, but there was no resultant increase in the numbers of wintering waterfowl.

Scientific Research and Facilities Vegetation study by Corbetta (1968). A feasibility study for the Regional Park project undertaken by two companies (Tecneco and Italeco) was sponsored jointly by the government and the Regione Emilia-Romagna.

Principal Reference Material The above information is taken from:

- Carp, E. (1980). A Directory of Western Palearctic Wetlands. IUCN, Gland, Switzerland. Additional references: 
- Corbetta, F. (1968). La vegetazione della 'valli' del litorale ferrarese e ravennate. Not. Filosoc. 5: 67-98.

- Toschi, A. and Spagnesi, M. (1971). Ricerche di Biologia della Selvaggina. Quaderni de la Ricerca Scientifica No. 52, Caccia, Bologna.

\section{Pialassa della Baiona and adjacent territories}

Location $43^{\circ} 30^{\prime} \mathrm{N}, 12^{\circ} 15^{\prime} \mathrm{E}$. Situated on the Adriatic coast southeast of Ravenna in Ravenna Province, Emilia Romagna.

Area 1,630 ha

Degree of Protection Designated as a Ramsar site in September 1981.

Site Description The site is a brackish-water coastal wetland drained by a dendritic netivork of canals. Bounded to the east and west by pine plantations.

International and National Importance The wetland complex supports a rich avifauna including breeding and winter migrant populations. Breeding birds include black-winged stilt Himantopus himantopus, avocet Recurvirostra avosetta and little tern Sterna albifrons. It is also an important feeding area for little egret Egretta garzetta.

Changes in Ecological Character There is heavy hunting pressure.

Management Practices No information

Scientific Research and Facilities No information

Principal Reference Material No information

Ortazzo and adjacent territories

Location $44^{\circ} 21^{\prime} \mathrm{N}, 12^{\circ} 19^{\circ} \mathrm{E}$. Situated on the Adriatic coast in Ravenna Province, Emilia Romagna.

Area 440 ha

Degree of Protection State owned. Hunting is prohibited. Designated as a Ramsar site in September 1981.

Site Description The site encloses the confluence of the rivers Bevano and Ghiaia, and includes the river mouths, estuarine lagoons, coastal dunes and some arable grassland. A pine wood has been planted behind the dunes.

International and National Importance This coastal area is an important wintering ground for teal Anas crecca (8,000 January) and mallard A. platyrhynchos (5,000 January).

Changes in Ecological Character None reported (1981)

Management Practices No information

Scientific Research and Facilities No information

Principal Reference Material The above information is taken from:

- Scott, D.A. (1980). A preliminary inventory of wetlands of international importance for waterfowl in West Europe and northwest Africa. IIVRB Special Publication No. 2. 


\section{Salina di Cervia}

Location $44^{\circ} 15^{\prime} \mathrm{N}, 12^{\circ} 19^{\prime} \mathrm{E}$. Situated immediately inland from Cervia on the east coast of Italy in Ravenna Province, Emilia Romagna.

Area 785 ha (part of a state nature reserve $1,100 \mathrm{ha}$ ).

Degree of Protection State owned. The saltpans are protected as a state nature reserve. Designated as a Ramsar site in September 1981.

Site Description The site comprises a grid complex of artifically maintained saltpans, derived from coastal lagoons but now isloated from the sea. It is bounded on all sides by Girondario and Cirondarie canals. A road bisects the site.

International and National Importance Important for breeding and migratory waterfowl. Breeding species include black-winged stilt Himantopus himantopus (50 pairs), avocet Recurvirostra avosetta (15 pairs) and little tern Sterna albifrons (60-70 pairs). Migratory species include little egret Egrelta garzetta (up to 500), little stint Calidris minuta $(2,000)$, curlew sandpiper $C$. ferruginea $(3,000)$, ruff Philomachus pugnax $(12,000)$ and black-tailed godwit Limosa limosa $(5,000)$.

Changes in Ecological Character None reported (1980)

Management Practices No information

Scientific Research and Facilities No information

Principal Reference Material The above information is taken from:

- Scott, D.A. (1980). A preliminary inventory of wetlands of international importance for waterfowl in West Europe and northwest Africa. IWRB Special Publication No. 2.

\section{Stagno di Sale Porcus}

Location $40^{\circ} 01^{\prime} \mathrm{N}, 8^{\circ} 25^{\prime} \mathrm{E}$. Situated north of Cabras Pond (Ramsar site) in the north of Sinis Peninsula, Oristano Province in western Sardinia.

Area 330ha: $325 \mathrm{ha}$ is open water in winter. (Initially proposed as $450 \mathrm{ha}$.)

Degree of Protection Owned by the Autonomous Region of Sardina, and protected as an 'Oasi Permanante di Protezione Faunistica e di Cattura'. Hunting is prohibited. Managed by the Commune of San Vero Milis and the Italian League for the Protection of Birds (LIPU). Designated as a Ramsar site in May 1982.

Site Description Sale Porcus pond is the largest temporary water body in Sardinia, and is part of a large complex of temporary salt lakes (similiar to the North African 'sebkha') along the western edge of the permanent Cabras Pond. The cycle of wet and dry conditions has led to the accumulation of mineral salts such as sodium chloride (salt) in the soil, which forms a white covering on the dried up pond during summer. The vegetation is halophytic with seablite Suaeda sp. and glasswort Salicornia sp., with only a narrow belt of reed Phragmites communis interspersed with Tamarix sp. along the eastern edge. The three small islets in the north are important resting and breeding sites for waterfowl when the pond is filled.

International and National Importance The site is one of the most important areas in the Mediterranean for migrating flamingo Phoenicopterus ruber between September and April (depending on water level), with 5,000 in mid-January $1977 / 78$ and maximum of 8,500 in November. Other wintering species include avocet Recurvirostra avosetta (700 November), snowy plover Charadrius alexandrinus (900 November), little stint Calidris minuta (1,000 November), shelduck Tadorna tadorna (80 March), northern shoveler Anas clypeala (820 
January), tufted duck Aythya fuligula (780 January), coot Fulica atra (1,500 February), spotted redshank Tringa erythropus (400 November), redshank $T$. totanus (450 November) and crane Grus grus (5-10 October to February; maximum 16 November 1980). Breeding species include shelduck (1-2 pairs), avocet and black-winged stilt Himantopus himantopus (5-10 pairs) on the islets; snowy plover (10-15 pairs), moorhen Gallinula chloropus, purple swamphen Porphyrio porphyrio (unconfirmed), water rail Rallus Aquaticus, mallard Anas platyrhynchos, coot (depending on water level) and little tern Sterna albifrons (5 pairs irregularly).

Changes in Ecological Character Increasing eutrophication from surrounding agricultural areas.

Management Practices A nature trail with observation hides has been established along the eastern shore of the pond. Educational and research activities in the wetland are promoted by the Executive Committee of the Sanctuary. A feasibility study was carried out in 1980 on a habitat management project to encourage flamingo to breed at the site.

Scientific Research and Facilities The Autonomous Region of Sardinia has launched a comprehensive research programme on the biology and hydrology of the site. There are monthly counts of flamingo, and midwinter counts of waterfowl.

Principal Reference Material The above information is taken from:

- Schenk, H. (1980). Wetlands of International Importance in Sardinia. Annex to the Italian National Report prepared for the Conference on the Conservation of Wetlands of International Importance especially as Waterfowl Habitat held in Cagliari, Italy. Additional reference:

- Gruppo Lacava, A. (1972/75). Studio del Parco del Limbara nel Sistema Regionale di Parchi. Prima e seconda fase. Centro Regionale di Programmazione. Cagliari.

\section{Stagno di Mistras and adjacent territory}

Location $39^{\circ} 54^{\prime} \mathrm{N}, 8^{\circ} 27^{\prime} \mathrm{E}$. Situated just south of Cabras Pond on the northern shore of Oristano Gulf in Cabras Commune, Orisano Province, Sardinia.

Area 680 ha (originally proposed as $450 \mathrm{ha}$ ).

Degree of Protection Private ownership. Protected as an 'Oasi Permanenti di Protezione Faunistica e di Cattura' in which hunting is prohibited. Designated as a Ramsar site in May 1982.

Site Description The site comprises the shallow (1-1.7m) Mistras lagoon, which opens into Oristano Gulf via a wide channel containing Mistras fishery (just outside the boundary), and includes the surrounding wetland and coastal dunes. The lagoon waters are brackish but variable, with salinity reaching 49 parts per thousand during dry summers, compared with normal levels of below the average for seawater. There are no inflow rivers or canals, and freshwater input comes almost exclusively from rainfall and runoff. The shallow eastern part of the lagoon, with numerous sandbanks and islets, can dry up in summer as a result of high evaporation rate and low rainfall. The bottom fauna is rich in bivalve molluscs. Fish include bass Dicentrarchus labrax, gilthead Sparus aurata, bream Pagellus mormyrus and mullet Mugil cephalus. The lagoon vegetation is characteristically halophytic, with aquatic communities of tassel pondweed Ruppia maritima and Enteromorpha intestinalis, and glasswort Salicornia fruticosa, S. europaea (= S. herbacea), saltwort Salsola soda and shrubby glasswort Arthrocnemum glaucum are found fringing the lagoon and on the islets.

International and National Importance Breeding birds include collared pratincole Glareola pratincola (maximum 30 pairs), black-winged stilt Himantopus himantopus (10-15 pairs), little ringed plover Charadrius dubius (about 10 pairs), snowy plover $C$. alexandrinus (50-60 pairs), mallard Anas platyrhynchos, black-headed gull Larus ridibundus (15-20 pairs), herring 
gull L. argentatus (about 30 pairs), common tern Sterna hirundo (10-20 pairs 1978-80) and little tern S. albifrons (80-100 pairs 1979-80). The lagoon is an important resting station for migrating greater flamingo Phoenicopterus ruber, with 1,400 recorded in January 1978-79 and a minimum of 2,000 during August. Other winter migrants include snowy plover (350 November/December), grey heron Ardea cinerea (60 December) and cormorant Phalacrocorax carbo sinensis. Numerous waders and gulls on passage particularly during spring migration.

Changes in Ecological Character There are some unauthorised settlements at Sa Siccu. Grazing sheep threaten ground nesting areas as they can trample the nests. Access to the wetland is uncontrolled and there is poaching. There are plans to construct a fishery within the lagoon, although productivity has decreased from $140 \mathrm{~kg} / \mathrm{ha}$ per annum to $25 \mathrm{~kg} /$ ha over the past decade. Excavation of a broad channel has transformed part of the lagoon system and adjacent areas, but has also created new habitats used by breeding colonies of little tern, kentish plover and praticole.

Management Practices It is proposed to construct commercial intensive and semi-intensive fish rearing facilities over 8.2 ha of the central part of the lagoon. However, before giving their approval, the Autonomous Region of Sardinia is insisting on an environmental/impact assessment study (with particular reference to the waterfowl population).

Scientific Research and Facilities Hydrological, botanical and geomorphological research has been carried out. Counts of flamingoes are carried out monthly.

Principal Reference Material The above information is taken from:

- Schenk, H. (1980). Wetlands of International Importance in Sardinia. Annex to the Italian National Report prepared for the Conference on the Conservation of Wetlands of International Importance especially as Waterfowl Habitat held in Cagliari, Italy.

Additional references:

- Corbetta, F. and Lorenzoni, G.G. (1976). La vegetazione degli stagni del Golfo di Oristano (Saredegna). Suppl. Ric. Biol. Selv. 7: 217-219.

- de Angelis, C. (1953). Observazione su alcuni stagni della Sardegna. Boll. Pesca, Piscicultura e Idrobiol 28(2): 5-43.

- Schenk, H. (1979). Zone umide Italiane come habitat degli Uccelli acquatici. Quad. Agricol. Amb. Suppl. aln 3 di Agricoltura Ambiente. Settembre 1979: 20-28.

\section{Valli del Mincio}

Location $45^{\circ} 03^{\circ} \mathrm{N}, 10^{\circ} 46^{\circ} \mathrm{E}$. Located in the province of Mantova, in the Lombardia region.

Area $1,082 \mathrm{ha}$

Degree of Protection Designated as a Ramsar site on 5 December 1984.

Site Description No information

International and National Importance The site is an important area for migratory waterfowl.

Changes in Ecological Character No information

Management Practices No information

Scientific Research and Facilities No information

Principal Reference Material The above information is taken from the documents supplied by the Government of Italy for designation in December 1984. 


\section{Torbiere d'Iseo}

Location $45^{\circ} 38^{\prime} \mathrm{N}, 10^{\circ} 02^{\prime} \mathrm{E}$. Located in the province of Brescia, in the Lombardia region

Area 325 ha

Degree of Protection Designated as a Ramsar site on 5 December 1984. The northern part of the Ramsar site was listed as an Important Bird Area (IBA) by the EEC in February 1979.

Site Description The site consists of lowland, inland, open waters and basin mires.

International and National Importance The site is an important area for migratory waterfowl. Breeding species listed for the IBA site include: grey heron Ardea cinerea (2 pairs), purple heron $A$. purpurea (5 pairs), black-crowned night heron Nycticorax nycticorax ( 5 pairs), ferruginous duck Aythya nyroca (3-4 pairs) and marsh harrier Circus aeruginosus (1 pair). Also listed for the area: little bittern Ixobrychus minutus, garganey Anas querquedula, spotted crake Porzana porzana and little crake $P$. parva.

Changes in Ecological Character No information

Management Practices No information

Scientific Research and Facilities No information

Principal Reference Material The above information is taken from the documents supplied by the Government of Italy for designation in December 1984, supplemented by information supplied by ICBP.

Additional reference:

- Brichetti, P., (1975). L'avifauna nidificante della Torbiera d'Iseo. Natura Bresciana No. 12. Brescia.

- Crescini, A. (Sept. 1969). Lama (Torbiera) d'Iseo. In Gruppo di Lavoro per la conservazione della natura della Societa' Botanica Italiana (1971). Censimento dei biotopi di relevante interesse vegetazionale meritevoli di conservazione in Italia. Savini-Mercuri, Camerino.

\section{Palude Brabbia}

Location $45^{\circ} 44^{\prime} \mathrm{N}, 8^{\circ} 40^{\prime} \mathrm{E}$. Located in the province of Varese, in the Lombardia region.

Area 459 ha

Degree of Protection Designated as a Ramsar site on 5 December 1984.

Site Description No information

International and National Importance The site is an important area for migratory waterfowl.

Changes in Ecological Character No information

Management Practices No information

Scientific Research and Facilities No information

Principal Reference Material The above information is taken from the documents supplied by the Government of Italy for designation in December 1984. 


\section{Paludi di Ostiglia}

Location $45^{\circ} 04^{\prime} \mathrm{N}, 11^{\circ} 06^{\prime} \mathrm{E}$. Located in the province of Mantova, in the Lombardia region.

Area $123 \mathrm{ha}$

Degree of Protection Designated as a Ramsar site on 5 December 1984.

Site Description The site consists of inland, open waters, with running water.

International and National Importance The site is an important area for migratory waterfowl. Breeding species listed for the IBA site just south of the Ramsar site including the Ostiglia révara include: purple heron $A$. purpurea, black-crowned night heron Nycticorax nycticorax, little egret Egretta garzetta, black kite Milvus migrans, Montagu's harrier Circus pygargus, stone curlew Burhinus oedicnemus, common tern Sterna hirundo, little tern S. albifrons and common kingfisher Alcedo atthis. Little bittern Ixobrychus minutus is also listed for the area.

Changes in Ecological Character No information

Management Practices No information

Scientific Research and Facilities No information

Principal Reference Material The above information is taken from the documents supplied by the Government of Italy for designation in December 1984, supplemented by information supplied by ICBP. 


\section{JAPAN}

\section{Area $369,698 \mathrm{sq} . \mathrm{km}$}

\section{Population $120,020,000(1984)$}

Summary of Wetland Situation Some $70 \%$ of Japan is mountainous, and the wetland habitats are thus restricted to the flood plains of water courses, coastal marshes, and estuaries of the major rivers. Wetlands tend to be small in size and consequently the water-bird populations tend to be small on individual wetlands. Japan, has however, important heron and egret breeding colonies, and is a major wintering area for cranes. There are three major problerns faced by Japanese wetlands. Large-scale land reclamation and drainage activities for extra industrial and agricultural land peaked in the 1960s and severely affected the Tokyo Bay and Seto Inland Sea coastal areas. Since 1975 there have been no further large scale reclamation projects. Water pollution in wetlands surrounded by residential and agricultural lands occurs. This pollution is largely effluent, both domestic and industrial. Commercial fishing causes disturbance and reduces food resources. There have been reports of egrets causing damage to fish stocks and wigeon Anas penelope damaging seaweed cultures. The hunting season at present lasts until 15 February (31 January in Hokkaido).

Since 1970 Winter Waterfowl counts have been held in mid-January, and about 3260 localities are censused throughout Japan. These counts are organised by the Environmental Agency, which relies on voluntary help. A wader count has been held annually in May and September since 1973, organised by the Wild Bird Society of Japan. An annual Japanese Crane Count has been held every December since 1952. The 1986 counts showed the presence of some 28,000 swans, 10,000 geese, 1,576,000 duck, and between 50,000 and 100,000 waders on passage. The largest number of duck included over 200,000 Anas platyrhynchos and Anas poecilorhyncha. There are indications that the numbers of ducks, cranes, and geese are increasing. A ringing programme has also been carried out, and in 1986100,000 birds were ringed including waders, ducks, swans and hooded cranes Grus monachus.

Protected Areas Legislation The National Park Commission was established in 1930 in the Ministry of the Interior, resulting in the enactment of the National Park Law (No. 36) in 1931, and the designation of the first National Park in 1934. After 1945, it was realised that it would be necessary to safeguard for recreational purposes those areas marginally below international standards. Since 1950, these have been designated as Quasi-National Parks through the National Park Law.

There are a number of laws relevant to current wetland protection. The Natural Park Law (No. 161 of 1957) aims at the protection of the places of scenic beauty and also, through the utilisation of them, to the health, recreation and culture of the people. Based on this law, many natural parks, which include national parks, quasi-national parks and prefectural natural parks, have been established throughout the country. The Nature Conservation Law of 1972 aims at setting forth the basic concept of the natural environment and other basic matters relating to the conservation of natural environment. Based on this law, nature conservation areas have been established at both prefectural and national level. The aims of the Wildife Protection and Hunting Law (1918 as amended in 1978) include the protection and propagation of wildlife, and control of harmful species. Wildlife Protection Areas have been established under this law to protect birds and mammals from hunting, as well as to conserve their habitat. Habitats are only conserved in Special Protection Areas which are established inside the boundaries of Wildlife Protection Areas. The water quality of wetlands is controlled by the Water Pollution Control Law (1970). Some endemic species are protected as natural assets under the Cultural Asset Conservation Law (1950). Wetland migratory species conservation is taken into account in the Migratory Birds Treaties with the United States of America (1974), Australia (1981) and China (1981), which deal with the protection of migratory and endangered birds. 
Protected Areas Administration National Parks are administered by the Environmental Agency (under the powers of the Director General), with advice from the Council of Nature Conservation, and delegated to the Governor of the Prefecture as provided for by Cabinet Order. Quasi-National Parks are administered by Prefectual Governments in accordance with the provisions of the National Parks Law. A particular feature of parks management is the designation of Special Protection Areas (SPA) in the Quasi-National Parks. Nature Conservation Areas and Wildlife Protection Areas are established and managed either by the Environmental Agency or prefectural governments.

\section{Sites designated under the Convention}

Accession 17 June 1980, with 1 site listed at accession and another added 13 September 1985.

Kushiro-shitsugen (Hokkaido Island)

Izu-numa and Uchi-numa

Government body responsible for administration of the Convention

Environment Agency, 1-2-2 Kasumigaseki, Chiyoda-Ku, Tokyo

\section{Kushiro-Shitsugen}

Location $43^{\circ} 09^{\prime} S, 144^{\circ} 26^{\prime} \mathrm{E}$. North of Kushiro city on Hokkaido.

Area $5,012 \mathrm{ha}$

Degree of Protection Ownership is mainly state (4,878ha) and some private (134ha). Designated as a Special Protection Area in 1935 by the Director General of the Environment Agency under the law concerning wildlife protection and hunting, and also protected as a National Monument under the Law for the Protection of Cultural Properties. Land reclamation, tree and bamboo felling and building of structures are strictly controlled and hunting and fishing are prohibited. Administered by the Environmental Agency. Designated as a Ramsar site at the time of accession on 17 June 1980.

Site Description This is a lowland site at $10-80 \mathrm{~m}$ altitude, comprising a marshy floodplain surrounded by high ground on three sides, including a hilly area, a flat tableland and a terrace area, but open to the south. The wetland has developed along the Kushiro River, which cuts through the centre of the plain, and the Akan River which flows along the western edge. The waters of these rivers combine within the site and flow south to the river mouth at Kushiro. The whole area is underlain by peat soils of predominantly low quality. Mean annual temperature of $5.5^{\circ} \mathrm{C}$ and mean annual rainfall $1,112 \mathrm{~mm}$. The weather in spring through summer is cold and humid due to the influence of sea fogs, but autumn and winter tends to be fine and dry, maintained by continental or mobile high pressure conditions. There is snow in winter, with a maximim of $123 \mathrm{~cm}$ falling at one time. The wetland vegetation is dominated by reedbeds of Phragmites communis with extensive areas of sedges Carex augustinowiczii, C. caespitosa and $C$. schnidtii. Other common species include Calamagrostis langsdorffii, Alnus japonica and Sanguisorba tenuifolia var. alba. The site contains 26 recorded mammal species including red fox Vulpes vulpes, racoon-dog Nyctereutes procyonoides, weasel Mustela nivalis and Siberian chipmunk Tamias sibiricus; 150 bird species; 10 species of amphibian and reptile including Salamandrella keyserlingii, Hyla arboreajaponica and skink Eumeces latiscutatus; 31 fish species including carp Cyprinus carpio. Carassius carass and Hucho perryi; 46 dragonfly species (Odonata); and 84 butterfly species (Lepidoptera).

International and National Importance This site is one of the most valuable remaining wetlands in Japan due to its undisturbed condition. Birds include the endemic Japanese crane Grus japonensis, dusky thrush Turdus naumanni and Eurasian siskin Carduelis spinus. The wetland supports a rich migrant avifauna. Summer visitors include little grebe Tachybaptus ruficollis, red-necked grebe Podiceps grisegena, spotbill duck Anas poecilorhyncha, water rail Rallus aquaticus, Japanese snipe Gallinago hardwickii, 
stonechat Saxicola torquata, robin Erithacus sp., black-browed reed warbler Acrocephalus bistrigiceps and reed bunting Emberiza schoeniclus. Winter visitors include whooper swan Cygnus cygnus, northern shoveler Anas clypeata, tufted duck Aythya fuligula, greater scaup $A$. marila and goldeneye Bucephala clangula.

Changes in Ecological Character The wetland is in a largely undisturbed state with no notable artificial developments.

Management Practices Under the management plan, trained managers are stationed at the site throughout the year based at the specially constructed management office and observation tower. Officials in charge of wildlife protection undergo an annual training session at the Training Institute for Environmental Pollution Control (Environmental Agency).

Scientific Research and Facilities The wetland was surveyed in 1978 as part of a national wildlife survey. An annual winter survey of the living conditions of ducks (Anatidae) is conducted with the help of volunteers (one of 4,171 locations throughout Japan). The Japanese crane habitat was surveyed in 1985 by the Environment Agency in order to promote their effective conservation. In addition, two surveys were conducted by the Agency in 1983 and 1985 in order to assess how best to conserve the site.

Principal Reference Material Above information is taken from Japan's National Report prepared for the Conference on Conservation of Wetlands of International Importance held in Cagliari, Italy in November 1980.

Supplemented by:

- Japanese National Section ICBP (1984). National Report on Wetlands and Waterfowl Conservation in Japan. Unpublished manuscript presented at the 10th Asian Continental Section Conference of ICBP.

- ICBP (1984). Wellands in East Asia - A preliminary review and inventory. ICBP Study Report No.6. ICBP, Cambridge, England.

\section{Izu-numa and Uchi-numa}

Location $38^{\circ} 43^{\prime} \mathrm{N}, 141^{\circ} 06^{\prime} \mathrm{E}$. In the north of Miyagi prefecture in the northern part of Hokkaido Island.

Area 559ha

Degree of Protection In November 1966, an area of 520 ha of this wetland was designated as a Prefectural Wildlife Protection Area under the Wildlife Protection and Hunting Law, 1917. In September 1967, 520ha of this wetland was designated as a Natural Monument "Birds and Their Habitat of Izu-numa and Uchi-numa" under the Cultural Properties Preservation Law, 1950. In August 1973 559ha was designated as "Izu-numa and Uchi-numa Prefectural Nature Conservation Area". Subsequently, in November 1982, this area was taken into a newly designated National Wildlife Protection Area which covers 1,450 ha, including a 920 ha Special Protection Area. Designated as a Ramsar site on 13 September 1985.

Site Description The site contains two lakes. Izu-numa lake is $7 \mathrm{~m}$ above sea level, just over a metre deep, and extends $4.5 \mathrm{~km}$ west-east and $2 \mathrm{~km}$ north-south, covering about $400 \mathrm{ha}$. Uchi-numa lake is situated south-west of Izu-numa, extending $1.5 \mathrm{~km}$ west-east and $1.2 \mathrm{~km}$ north-south, and covers about 150ha. The two lakes are connected by a channel half a kilometre long. The wetland area of these two lakes was formed through the alluvial banking process of the Sako River. Frequent land reclamation works carried out on the wetland since the late 19th century contributed to shaping it into the present landscape. In the central area of the lakes submerged plants such as Hydrilla verticillata occur, and floating water plants such as East Indian lotus Nelumbo nucifera and water chestnut Trapa natans var. quadrispinosa are abundant. Along the lakeshore Manchurian wild rice Zizania latifolia or reed Phragmites japonica communities are dominant. 
International and National Importance The site is an important breeding area for reedbed birds, and in winter is visited by thousands of migrant birds. The avifauna comprises about 200 species. In summer the reed and wild rice beds on the lakeshore form the breeding habitat for eastern great reed-warbler Acrocephalus arundinaceus orientalis, von Schrenk's reed-warbler $A$. bistrigiceps, Japanese fan-tail warbler Cisticola juncidis brunniceps, Chinese little grebe Tachybaptus ruficollis poggei, coot Fulica atra atra, Japanese ruddy crake Porzana fusca erythrothorax, Indian moorhen Gallinula chloropus indica, spot-bill duck Anas poecilorhyncha zonorhyncha, etc. In winter, the lakes provide a habitat for many Anatidae including eastern bean-goose Anser fabalis serrirostris, whistling swan Cygnus columbianus and whooper swan C. cygnus. In the National Survey of Anatidae conducted in January 19854,100 geese and 5,100 swans ( $45 \%$ and $20 \%$ respectively of total migrants to Japan) were counted in this wetland. In spring and autumn the wetland plays an important role as a migration stopover for many species, especially common sandpiper Tringa hypoleucos, common snipe Gallinago gallinago gallinago, eastern solitary snipe $G$. solitaria japonica and eastern golden plover Pluvialis dominica fulva.

Changes in Ecological Character No information

Management Practices No information

Scientific Research and Facilities The area was surveyed in 1985 as part of the National Survey of Anatidae.

Principal Reference Material The above information was taken from the document submitted at the time of designation in September 1985.

Supplemented by:

- Anon. Izunuma Marsh. A wildlife preserve, Miyagi, Japan. Yasuhito Goto, Miyagi, Japan. (English version of guide book.)

- ICBP (1984). Wetlands in East Asia - A preliminary review and inventory. ICBP Study Report No.6. ICBP, Cambridge, England.

- Japanese National Section ICBP (1984). National Report on Wetlands and Waterfowl Conservation in Japan. Unpublished manuscript presented at the 10th Asian Continental Section Conference of ICBP. 


\section{JORDAN}

Area 97,739 sq.km

Population $3,500,000(1982)$

Summary of Wetland Situation Among the few wetlands of this semi-arid to very arid country, the A'zraq Oasis in the Eastern Desert is probably the only one which is of international importance. It is an outstanding example of the ecosystems characteristic of areas in semi-arid regions where surface water is available. As such, it is of the greatest importance as a migration stage for huge numbers of migratory birds, while concentrations of wintering waterfowl can exceed 100,000 individuals. Declared by Royal Proclamation as a reserve in 1965, the A'zraq Oasis has subsequently been under consideration for elevation to National Park status. In the meantime, in January 1977, with the ratification of the Ramsar Convention by the Jordanian Government, the greater part of the area, over 7,000ha out of an estimated total of 10,000 ha, has been designated for inclusion on the Convention List of Wetlands of International Importance.

Protected Areas Legislation Reserves are at present established by Royal Proclamation. Further legislation is under study.

Protected Areas Administration The Royal Society for the Conservation of Nature carries out wildlife functions on behalf of the government, the responsible department being the Ministry of Agriculture.

Sites designated under the Convention

Accession on 10 January 1977 with 1 site listed at accession

A'zraq Oasis

Government body responsible for administration of the Convention

Ministry of Municipalities and the Environment, PO Box 1799, Amman

\section{A'zraq Oasis}

Location $31^{\circ} 49^{\circ} \mathrm{N}, 36^{\circ} 48^{\circ} \mathrm{E}$. North central Jordan in Zarga District. The oasis lies just north of the main road between Zarqua and An Nabk in Saudi Arabia.

Area $7,372 \mathrm{ha}$ (expanded by $10 \mathrm{ha}$ in 1982 to include an area of mudflats)

Degree of Protection The reserve is state owned. The wetland is administered locally by the Royal Society for the Conservation of Nature (P.O.Box 6354, Amman). It is part of A'zraq Wetland Reserve (10,000ha), established under Royal Proclamation of 1965, in which hunting is prohibited. Designated as a Ramsar site at the time of accession on 10 January 1977.

Site Description The designated site comprises the marshy areas, mudflats and waterpools of A'zraq oasis, and lies in a depression at $500-600 \mathrm{~m}$ altitude. The whole area is limestone bedrock overlain by grey desert soil (with or without flint particles), with solonchak soils in the depressions. Several major vegetation communities can be identified, whose composition is influenced by soil moisture content and salinity: Nitraris retusa and Tamarix macrocarpa on the saline silty dunes (an important stablilising species); the Typha angustata - Scirpus littoralis - Cyperus laevigatus association dominant on wet low-salinity soils; Tamarix jordanis and $N$. retusa on islands in the marsh; the dominant succulent halophytes Halopeplis amlexicaulis and Halocnemum strobilaceum fringing the barren salt flats; and mixed scrub woodland on the area immediately surrounding the wetland. The unique fresh and saltwater communities support numerous hydrophytic plants, largely unrestricted within Jordan to 
A'zraq, which include Catabrosa aquatica, Eleocharis palustris, Epilobium hirsutum, Juncus acutus, J. arabicus, J. bufonius, J. fontanesii, J. gerardi, J. maritimus, Lemna gibba, Scirpus maritimus and Zannichellia palustris pedicellata. Four fish species have been recorded in the seasonal lagoon covering the depression each winter: Aphanius dispar and the introduced Tilapia zillii, T. aurea and Clarius lazera. The marsh frog Rana ridibunda and black water snake Tropidonotus tessalate are abundant. Mean minimum temperature of $4.5^{\circ} \mathrm{C}$ with few frosts. Mean annual rainfall $50-75 \mathrm{~mm}$.

International and National Importance The wetland is of major importance to raptors and waterfowl on the Palaearctic-Ethiopian migration routes, and is also a breeding side for some 70 bird species. Migrants include Egyptian vulture Neophron percnopterus, osprey Pandion haliaetus, honey buzzard Pernis apivorus, sparrowhawk Accipiter nisus, short-toed eagle Circaetus gallicus, spotted eagle Aquila clanga, grey crane Grus grus, stints Calidris minuta, C. teminckii and C. alba, redshank Tringa totanus, sandpipers Tringa spp., roller Coracias garrulus, swallows Hirundo spp., warblers Sylvia spp., buntings Emberiza spp. and redstarts Phoenicurus ochrurus and $P$. phoenicurus (IWRB, 1980). Some breeding birds are restricted in Jordan to A'zraq, including mallard Anas platyrhynchos, purple heron Ardea purpurea, squacca heron $A$. ralloides, lesser bittern Ixobrychus minutus, Kentish plover Charadrius alexandrinus, spur-winged plover Vanellus spinosus, pratincole Clareola pratincola, blue-cheeked bee-eater Merops superciliosus persicus, great reedwarbler Acrocephalus arundinaceus, moustached warbler A. melanopogon, sedge warbler A. scirpaceus, waterhen Callinula chloropus, Ballion's crake Porzana pusilla and water rail Rallus aquaticus.

Changes in Ecological Character Wildboar Sus scrofa libyca were cummon in the marsh prior to a major fire in 1957 , but are now probably locally extinct. For several years water was pumped from the Ain Soda Spring to the townships of A'zraq North and Amman, which lowered the water level in the marshes seriously. The incomplete boundary fence (since completed and maintained) was cut in several places allowing access for cars and grazing animals. Illegal hunting, fishing and fires, and general misuse of the area by visitors, was a serious problem with lack of effective management staff. However, since $1981 / 2$ most of these activities have been stopped or controlled, and conditions are improving. The populations of the nearby villages of A'zraq Druse and Schischan are declining as people move out of the area.

Management Practices WWF Project 1608 (1980) prepared a management plan for the reserve, and in $1981 / 2$ a game warden was appointed. The boundary fence was completed with funding help from WWF, and grazing animals are now excluded. The reserve has also been supplied with 2 vehicles, a motorcycle, and an excavator to develop new wells, and a radio network is planned. The wetland has been investigated for springs to supplement supply to the marshes, and eight new wells have been developed. The scheme pumping water from the marshes to the townships has been successfully stopped by the RSCN. The Roman Wall spring has been excavated, and there are plans to develop the Oasis pools for tourism.

Scientific Research and Facilities Research has been carried out by the Universities of Jordan and Yarmouk, and the oasis vegetation has been studied in detail by Nelson (1973). An International Biological Research Station was established at the site in 1968 but was closed in 1969.

Principal Reference Material Above information is taken from the Jordan National Report produced for the Conference on the Conservation of Wetlands of International Importance especially as Waterfowl Habitat at Cagliari in Italy in November 1980.

Supplemented by:

- Madany, M.H. (1978). An ecological framework for a nature preserve system in Jordan.

BSc Thesis. University of Illinois, USA.

- WWF/IUCN Project 1267 - Jordan, A'zraq Wetland Refuge.

Additional references:

- Clarke, J.E. (1977). Review of 1966 Proposed A'zraq National Park Management Plan.

RSCN, Amman. 
- Conder, P.J. (1980). Proposed management plan for the A'zraq wetland reserve. Prepared by WWF/IUCN for the Royal Society for the Conservation of Nature, Amman, Jordan. WWF Project 1608.

- Nelson, B. (1973). A'zraq: Desert Oasis. Allen Lane, London.

- RSCN (1980). Document held by the IWRB containing an extensive checklist of bird species recorded from the wetland. 


\section{MAURITANIA}

Area $1,118,604$ sq. km

Population $1,834,500(1984)$

Summary of Wetland Situation The two principal areas of importance within Mauritania are the Banc d'Arguin area, and the wetlands of the Senegal River Valley. The Banc d'Arguin is a National Park covering some 15,000 sq. $\mathrm{km}$ of shallow seas, islands, mudflats and adjacent desert landmass, and is clearly of major importance for wintering water birds with up to two million birds each winter. There are also a number of major breeding colonies on the islands.

Various sites in the Senegal Delta are of importance, with a series of floodplains, temporary freshwater marshes, shallow brackish lakes, channels and mangroves all deriving water from the annual flood of the river. The adjacent Aftout-es-Sahel, a series of depressions running parallel to the coast north of the delta with an irregular water supply, is similarly important. Further upstream there are a number of other interesting sites in the Senegal flood plain, such as the lakes of Aleg and Mal, both of which dry out periodically.

Protected Areas Legislation No information, apart from the decree of 1976 establish the Parc national Banc d-Arguin.

Protected Areas Administration Basically the responsibility of the Directorate of Nature Protection (i.e. of Water and Forests) within the Ministry of Rural Development. The Parc national Banc d'Arguin is directly controlled by the government. The park is managed by an Administrative Council in which the government is actively involved.

Sites designated under the Convention

Accession 22 October 1982 with 1 site listed at accession

Banc d'Arguin

Government body responsible for administration of the Convention

Secretariat General du Governement, Gouvernement de la République Islamique de Mauritanie, Nouakchott

\section{Banc D'Arguin}

Location $19^{\circ} 21^{\prime}-21^{\circ} 51^{\prime} \mathrm{N}, 16^{\circ}-16^{\circ} 45^{\prime} \mathrm{W}$. On the West Africa coast, midway between Nouakchott and Nouadhibou.

Area $1,173,000$ ha

Degree of Protection The designated site comprises Banc D'Argiun National Park established on 24 June 1976 by Decree No. 76147/PR, with total protection by law but no permanent surveillance on the ground. Park administration is at Nouadhibou, but only a caretaker at Iwik (research station) and a guide are present in the park for any significant period. Designated as a Ramsar site in 1982.

Site Description The site is a vast area (between sea level and $15 \mathrm{~m}$ ) of coastal seas and mudflats between sea level and $15 \mathrm{~m}$, with 14 permanent islands including mainly areas of sand, sandhills and cliffs. It is a unique example of where the Sahara Desert meets the Atlantic Ocean. Extrapolations from the weather stations at Nouakchott and Nouadhibou are difficult due to the great difference in latitude, but the area is of great meteorological interest with contrasts between the coastal climate, the 'desert cold' and hot continental climates with strong winds $(8 \mathrm{~m} / \mathrm{sec})$ reported. Rainfall is irregular and very low, with an average of $34 \mathrm{~mm}$ per 
year. Temperatures are fairly similar all year, with a mean monthly minimum in December of $8^{\circ} \mathrm{C}$ and maximum in September of $34^{\circ} \mathrm{C}$. The sandy seashores and islands have a halophyte vegetation such as Salsola baryosma, Salicornia senegalensis, Suaeda fruticosa and Arthrocnemum sp., Zostera noltii. Cymmodocea nodosa and Halodule wrightii on mudflats; and various seaweeds. The land area is dominated by an African-type of Saharen vegetation, although there is a Mediterranean influence. Tree species include Acacia tortilis raddiana, Balanites aegyptiaca, Maerus crassifolia and Capparis decidua. Herbaceous species include Panicum turgidum, Cassia italica, Pergularia tomentosa and Heliotropium bacciferum. The dunes are dominated by Stipagrostis pungens, Cornulaca monacantha, Euphorbia balsamifera and Calligonum comosum. Two small stands of mangrove Avicennia africana exist near the northern tip of Tidra and near Cap Timiris. These are probably relicts from the period when some of the coastal "oueds" carried fresh water. They are the most northerly stands of mangrove on the eastern shore of the Atlantic. The southern fringe of the site is dominated by Euphorbia balsamifera. There is a two-way gradient of littoral between the marine and continental flora and north-south, with many species at extreme limits of their distribution. Recorded mammals include Dorcas gazelle Gazella dorcas, jackal Canis aureus, fennec fox Fennecus zerda, sand fox Vulpes rueppelli, sand cat Felis margarita, wild cat $F$. silvestris, Saharan striped weasel Poecilogale albinucha, ratel Mellivora capensis, striped hyena Hyaena hyaena and several species of dolphin such as Atlantic humpback Sousa teuszi, common Delphinus delphis, rough-toothed Steno bredanensis, bottle-nosed Tursiops truncatus, Risso's Grampus griseus and killer whale Orcinus orca. Other recorded species include fin or common rorqual Balaenoptera physalus and common porpoise Phocoena phocoena.

International and National Importance The site is reported to be the most important area on the western side of the Atlantic for waders and as a crossroad for migrant waterfowl between Europe and Northern Asia and most of Africa. Migrants include over 2 million waders recorded in winter, hundreds of thousands of black tern Chlidonias nigra and tens of thousands of flamingo Phoencopterus ruber, ringed plover Charadrius hiaticula, grey plover Pluvialis squatarola, knot Calidris canutus, whimbrel Numenius phaeopus, curlew sandpiper C. ferruginea, dunlin C. alpina, little stint Calidris minuta, turnstone Arenaria interpres, redshank Tringa totanus and bar-tailed godwit Limosa lapponica. Breeding birds include white pelican Pelecanus onocrotalus, endemic subspecies of heron Ardea cinerea and white spoonbill Platalea leucorodia, African spoonbill Platalea leucorodia balsaci, reed cormorant Phalacrocorax africanus, cormorant Phalacrocorax carbo lucidus, western reef heron Egretla gularis, gullbilled tern Gelochelidon nilotica, caspian tern Hydroprogne caspian, royal tern Sterna maxima, common tern Sterna hirundo, brindled tern Sterna anaethetus and slender-billed gull Larus genei. There is a small population of the endangered monk seal Monachus monachus in the 'annex' of Cap Blanc near Nouadhibou. Four species of threatened turtle frequent the area, all of which are endangered or vulnerable: Chelonia mydas, Caretta caretla, Eretmochelys imbricate and Dermochelys coriacea. The site is a very important fish reproduction area.

Changes in Ecological Character A population of the Imraguen tribe (450) live and fish in the area, although they must go outside the boundary for freshwater. Use of the area by nomads is decreasing due to the area becoming more desertified. Illegal hunting of gazelle (by motorcycle) and marine turtles (particularly for tourist demand), and overgrazing by several hundred camels and goats have been reported. Black rats have invaded the area. Pollution particularly from non-biodegradable waste, is found along the shoreline. Fishing nets could have a negative impact on monk seal, but this has not been studied. The status of the monk seal population in the area is critical after collapse of their breeding caves in 1982. Much of the area has been little or never disturbed by man. The Baie du Lévrier and the harbour of Nouadhibou have become a very important base for a fleet of fishing boats, including factory ships from many nations, especially Japan, USSR, Portugal and Spain, but also from Poland, Romania, Norway, Sweden, Egypt, Morocco, Cuba and France. Overfishing by the international fishing fleets in the waters just of $f$ the Banc d'Arguin might cause a decline in the breeding colonies of the fish-eating bird species such as cormorants and pelicans.

Management Practices A preliminary management plan was published in January 1984 by WWF and IUCN with the collaboration of the Royal Institute of Natural Sciences. 


\section{Mauritania}

Scientific Research and Facilities Research includes ornithology, oceanography, inventories of species, study of the phyto-plankton biomass and studies on the reproductive biology of the white pelican Pelecanus onocrotalus. A station in the park (IWIK) is equipped for six persons with three Zodiacs, one motor launch and three radio stations for both broadcasting and receiving. An international meeting was held in Paris in April 1982 to discuss future research and management of the park.

Principal Reference Material The above information is taken from the documents submitted at the time of designation in 1982.

- Verschuren, J. (1984). Replublique Islamique de Mauritanie Parc National du Banc d'Arguin Plan Directeur Preliminaire. Published by WWF/IUCN in collaboration with the Institut Royal des Sciences Naturelles de Belgique Bruxelles, Belgique 1984.

Supplemented by:

- Englemoer, M., Piersma, T., Altenburg, W. and Mes, R. (1984). The Banc d'Arguin (Mauritania). In Evan, P.R., Goss-Custard, J.D and Hale, W.G. (eds). Coastal waders and wild fowl in winter. Cambridge University Press, Cambridge. Pp. 293-310.

- Gee, J.P. (1984). Birds of Mauritania. Malimbus 6:31-66.

- IUCN/WWF Project 1333. Mauritania, Banc d'Arguin National Park.

- NOME (1982). Wintering waders on the Banc d'Arguin. Waddense Working Group.

- Scott, D.A. (1980). A priliminary inventory of wetlands of international importance for waterfowl in West Europe amd Northwest Africa. IWRB Special Publication No. 2. 


\section{MEXICO}

Area $1,972,355$ sq. $\mathrm{km}$

Population $78,996,000$

Summary of Wetland Situation Mexico has about $6,760 \mathrm{~km}$ of coastline on the Pacific and some $2,900 \mathrm{~km}$ on the Gulf of Mexico. The coastal plains vary greatly in width, and are crossed by numerous rivers which are subject to seasonal flooding, particularly the delta regions, where lagoons are important for waterfowl. Inland the country has two great mountain systems running parallel to the coasts rising to over $3,000 \mathrm{~m}$, between which is an immense dry plateau where there were once numerous lakes, most of which have now dried out. These cordillera join in the region of the Valle de Mexico, forming the Sierra Madre del Sur, which is connected by a lower ridge to the Sierra de Chiapas in the east. To the north and north-east of these sierras are the plains of Tabasco, a vast delta region with extensive lakes and marshes, and the lowlands of Campeche, Yucatan and Quintana Roo on the Yucatan Peninsula. This peninsula is a calcareous plain with subterranean drainage which comes to the surface near the coast, giving rise to a series of wetlands. The lagoons on the north of the peninsula are some of the most important areas for migratory waterfowl in Mexico. The central plateau has a temperate climate with summer wet season but the lowlands are tropical, with high humidities and rainfall in the Gulf of Mexico and a much drier climate on the Pacific coast. Hurricanes along the Gulf of Mexico Coast have had a destructive effect on wetlands on several occasions, and the Yucatan Peninsula wetlands have still not recovered from the effects of hurricanes in the 1930 s and 1940 s when large areas of mangroves were destroyed. The country incorporates parts of two biogeographic realms, the Nearctic and Neotropical, and thus possesses a great diversity of flora and fauna as well as being on a land route for many birds migrating between the north and south American continents.

The Pacific coast is particularly important for wintering brown pelican Pelecanus occidentalis and brent goose Branta bernicla and herons Ardeidae. The Bahia de Santa Maria is the principal area for wintering brent geese, and this site, with the Ensenada del Pabellon and Boca de la Barra, are important breeding areas for many birds, including 3,000 brown pelican. These sites also held about 113,000 waders in January 1972. Further south, the Marismas Nacionales which cover 200,000 ha are extremely important for breeding and wintering birds of a wide range of species, but are being threatened by encroachment by the local population and tourism, and have suffered from low water levels since dry seasons from 1978 and 1982. Some areas in the southern part of the Pacific Coast have declined considerably in importance for Anatidae since the 1940's. One of the few protected areas on this coast (established in 1937), is the Lagunas de Chacahua National Park, $150 \mathrm{~km}$ south-west of Oaxaca, Oaxaca state, which includes 3,525ha of wetlands important for breeding, passage or wintering waders and wintering Anatidae. In the south-western lowlands, largely in Jalisco, are a group of inland lakes of both freshwater and saline nature which are important for wintering ducks and breeding herons, and particularly important for wintering American avocet Recurvirostra americana.

The Gulf of Mexico coast is particularly important for breeding Ciconiiformes, with over 20,000 pairs at one site; for wintering Anatidae and coot Fulica spp., and for other species on passage. This area is particularly under threat from agricultural expansion and drainage, urbanisation and oil development (large oil fields were recently discovered in this area). Mangroves are also being exploited for timber. Several areas in Yucatan have some form of protection: The Faunal Refuge of Ria de Celestum $(59,130 \mathrm{ha})$ was established in 1979 and holds large numbers of wintering birds, including up to 100,000 Anatidae and up to 100,000 American coot Fulica americana. It also has large numbers of breeding birds, and is an important feeding area for greater flamingo Phoenicopterus ruber from Rio Lagartos, the latter being the only Yucatan breeding area for this flamingo, and a Faunal Refuge of $48,000 \mathrm{ha}$, also established in 1979. Off the north-east tip of Yucatan, the Isla Contoy Ecological Reserve was 
established in 1971 and is important for breeding brown pelican (up to 600 pairs), and also has large breeding colonies of seabirds. In Quintana Roo two large shallow bays, Bahia de La Ascension and Bahia del Espiritu Santo, are extremely important for breeding, passage and wintering Ardeidae but unimportant for wintering Anatidae.

The north-east part of Mexico and the Gulf Coast north of Baja California is generally important for breeding and wintering Ardeidae and wintering waders. The sandhill crane Grus canadensis winters at a few sites. It is also important for some endangered species of salamander: Ambystoma dumieri dumieri, A. lermaensis and A. mexicanum, each only known from one site.

Protected Areas Legislation Protected areas are established by Presidential Decree under sections of the Ley Organica de la Administracion Publica Federal, the Ley Federal de Caza, the Ley Forestal and the regulatory decree of the Forestry Law. Declarations are published in the Diario Official. The protected areas system includes Faunal Reserves, Refuges, Sanctuaries, Biological Reserves and National Parks. The first national park was established in 1917 and in 1986 there were fifteen areas designated as Faunal Reserves. Hunting legislation relevant to the present day dates from 1952 but the system of hunting control is inefficient and no longer applicable in the present situation. A number of parks and reserves have been declared protected but do not fulfil the criteria with which they are defined.

Protected Areas Administration The Direccion General de Parques, Reservas y Areas Ecologicas Protegidas (Secretaria de Desarrolo Urbano y Ecologia) is reponsible for protected areas. The Direccion General de Flora y Fauna Silvestres (Secretaria de Desarrolo Urban y Ecologia) conducts research, including studies relating to the conservation of greater flamingo and osprey Pandion haliaetus. The Direccion de Flora y Fauna Acuaticas (Direccion de Flora y Fauna Silvestres), a recently created body, is responsible for an inventory of aquatic flora and fauna. The Comision del Lago de Texcoco (Secretaria de Agricultura y Recursos Hidraulicos) is concerned with the investigation and conservation of Lago de Texcoco. There are many private organisations dedicated to conservation of wetlands, including the Instituto de Ecologica, which is dedicated to ecological research and the creation of reserves, Ducks Unlimited Mexico (DUMAC) which concentrates on migratory waterfowl, and a number of Mexican universities.

\section{Sites designated under the Convention}

Accession 28 July 1986 with one site listed at succession

Rio Lagartos, Yucatan

Government body responsible for administration of the Convention Secretaria de Desarrollo Urbano y Ecologia.

\section{Rio Lagartos, Yucatan}

Location $21^{\circ} 30^{\prime} \mathrm{N}, 87^{\circ} 34^{\prime}-88^{\circ} 18^{\prime} \mathrm{W}$. On the coast of the Gulf of Mexico, $50 \mathrm{~km}$ north of Tizimin, Yucatan.

Area 47,480 ha

Degree of Protection The site is a Faunal Refuge, established in 1979 to protect flamingo nesting habitat. Land tenure is divided between the state, local government and private owners. It was designated a Ramsar site on 4 July 1986. 
Site Description The site includes about $75 \mathrm{~km}$ of low-lying coastline, including several small estuaries and a string of lagoons separated from the sea by a sand barrier. The lagoons are all flooded at high tide, and there is some inflow of fresh water from seepage and local rainfall. Salinities vary from 33 to 107 parts per thousand. About 30,000 ha are permanently flooded but the rest dries out during the dry season. There are fringing mangrove swamps with Avicennia germinans, Laguncularia racemosa and Rhizophora mangle. Parts of the sand dunes are vegetated, and there is some halophytic vegetation.

Criteria for Inclusion $1 \mathrm{c}, 2 \mathrm{a}$ and $3 \mathrm{a}$

International and National Importance The refuge is the only regular breeding site for the Yucatan population of the greater flamingo Phoenicopterus ruber, and supports large numbers of other waterfowl. Greater flamingo numbers increased from an estimated 8000 birds in 1975 to 26,000 in 1981 , and are probably still increasing. The breeding population at Rio Lagartos numbered at least 4,250 pairs in 1982, and was thought to be 5000 in 1984 . Other breeding birds include 150 pairs of olivaceous cormorant Phalacrocorax olivaceous and large numbers of laughing gull Larus atricilla, royal tern Thalasseus maximus and elegant tern $T$. elegans. The area is also an important feeding area for brown pelican Pelecanus occidentalis, American wood ibis Mycteria americana, white ibis Eudocimus albus, roseate spoonbill Ajaia ajaja, boat-billed heron Cochlearius cochlearius, snowy egret Egretta thula and many passage or wintering waders and Laridae. Relatively few Anatidae winter in the area, the only species present in significant numbers being red-billed whistling duck Dendrocygna autumnalis, American wigeon Anas americana, pintail $A$. acuta, blue-winged teal $A$. discors and lesser scaup Aythya affinis. Other fauna include the endangered Morelet's crocodile Crocodylus moreletii, olive ridley turtle Lepidochelys olivacea and leatherback turtle Dermochelys coriacea.

Changes in Ecological Character Disturbance from tourists, particularly in powerboats, has caused problems in the flamingo colony, and further development of facilities for tourist recreation in the area is likely to increase the problem in the future. In addition, flamingo feeding and nesting habitat is being destroyed for salt extraction, and fishing is carried out.

Management Practices Experiments are now being carried out with the construction of artificial nest sites for the flamingos. These would not be subject to flooding.

Scientific Research and Facilities Basic floral and faunal surveys have been conducted in the refuge and the flamingo population has been studied for some years (including work on the effect of the recent provision of artificial nest sites).

Principal Reference Material Documents supplied by the Government of Mexico at the time of designation.

- Scott, D.A. and Carbonell, M. (Compilers) (1986). A Directory of Neotropical Wetlands. IUCN Cambridge and IWRB Slimbridge.

Supplemented by:

- Hernandez, G.M.A. and Vargas N.A. (1976). Censo de patos cazados en las costas de Yucatan. Bosque y Fauna 13.

- Mondragon S.J. (1979). Los flamencos de Yucatan. Bosque y Fauna 2.

- Saunders, G.B. and Saunders, D.C. (1981). Waterfowl and their wintering grounds in Mexico, 1937-64. FWS, U.S. Department of the Interior, Res. Publ. 138. 
Summary of Wetland Situation Situated on the Mediterranean coast of Morocco, the estuary of the Moulouya river is of international significance as habitat for waterfowl. This is enhanced by the fact that the Spanish Islas Chafarinas, just off the Cabo di Aqua $10 \mathrm{~km}$ north-west of the rivermouth, are the breeding place of perhaps two-thirds of the world population of the rare Audouin's gull Larus audouinii.

The wetlands along the Atlantic coast are of extraordinary importance as feeding and roosting sites for great numbers of waterfowl moving between their breeding grounds in Northern Europe and wintering areas in tropical West Africa. The Merja Zerga towards the northern end of the coast, and the Lagune de Khnifiss close to the southern end, are reckoned to be the most valuable of these sites. The Lagune is one of the places where the nesting of the Greater Flamingo Phoenicopterus ruber has been recorded.

Several of the mountain lakes in the Atlas region are of limnological interest. Some of them in the Moyen Atlas offer suitable habitat for waterfowl, and have important populations of the rare, declining, and now possibly threatened, crested coot Fulica cristata.

Finally, near to where the River Dra meets the southern border with Algeria, the highly variable Iriki wetland in some years provides suitable conditions for the greater flamingo.

Protected Areas Legislation National Parks are established under a Royal Decree of 11 September 1934 on the creation of national parks, and Ministerial Order of 26 September 1934 which lays out the procedures to be followed. Each park is actually created by Ministerial Order or Decree, in which the regulations governing the area are laid down individually for each area. Basically any act liable to lead to modification of the environment is forbidden without authorisation from the Administration of Water and Forests.

Protected Areas Administration The responsible authority is the Division of hunting, fishing and the protection of nature, within the Ministry of Agriculture and Agrarian Reform (and in particular within the Administration of water and forests and soil conservation). The National Parks Consultative Committee is formed of representatives from various administrations and services.

Sites designated under the Convention

Signed without reservation as to ratification on 20 June 1980 with four sites listed at signature

\section{Merja Zerga}

Douiya Sidi-Bou-Rhaba

Lac d' Affennourir

La Baie du Khnifiss ou Puerto Cansado

Government body responsible for administration of the Convention

Direction des Eaux et des Forêts de la Conservation des Sols, Ministère de l'Agriculture et de la Réforme Agraire, Rabat.

\section{Merja Zerga}

Location $34^{\circ} 50^{\circ} \mathrm{N}, 6^{\circ} 20^{\prime} \mathrm{W}$. Situated adjacent to Moulay Bousselham in the Province of Kenitra. 
Area 3,500ha (Biological Reserve is 7,425ha).

Degree of Protection There is a proposal to establish the area as a national park. Merja Zerga Biological Reserve was established in 1978. Designated as a Ramsar site in 1980. The Eaux et Forêts has authority over all wildlife and fish in the reserve.

Site Description The site comprises a vast tidal lagoon whose size ranges from 1,500 ha to $3,200 \mathrm{ha}$. It is separated from the sea by sand dunes except for a connecting stream. There are large areas of mudflats at lowtide. Apart from the avifauna there is little noteworthy fauna apart from a selection of reptiles including turtles, lizzards and snakes.

Criteria for Inclusion 1(a), 1(b), 2(a), 3(c) and 4(a).

International and National Importance Merja Zerga is recognised as the premier wetland site in Morocco, and is the most important wintering area in Morocco for several tens of thousands of waterfowl. Counts of ducks and waders include: gadwell Anas strepera (8000), wigeon $A$. penelope $(21,000)$, teal $A$. crecca $(20,000)$, shoveler $A$. clypeata $(16,000)$, avocet Recurvirostra avoselta (2000), ringed plover Charadrius hiaticula (5000), kentish plover C. alexandrinus (3000), grey plover Pluvialis squatarola $(8-10,000)$ and black-tailed godwit Limosa limosa (10,000). Slender-billed curlew Numenius tenuirostris have also been recorded here, and the area is known to be an important staging site for spoonbill. Also listed: little stint Calidris minuta, shelduck Tadorna tadorna, pintail Anas acuta, pochard, mallard A. platyrynchos, greylag goose Anser anser (150), coot Fulica atra $(12,000)$, crested coot (40), lapwing Vanellus vanellus (40-50,000), dunlin Calidris alpina (100-150,000), spotted redshank Tringa erythropus (500), redshank T. totanus (5-6000), greater flamingo Phoencopterus ruber (183), blue-throat nightjar, warblers, and African marsh owl, as well as mute swans and darter.

Changes in Ecological Character SOCHATOUR has hunting rights north of Oued Drater for waterfowl except geese and shelducks, and waders (snipe, redshanks, spotted redshanks, curlews, grey and golden plovers and lapwings). There are problems with local people capturing and/or killing flightless birds and killing non targeted species such as flamingo and terns. Fishing is permitted in the outlet of Merja Zerga and the ocean. It is a popular resort for Moroccan tourists. There are two campsites along the south side of the Merja Zerga outlet and the lake is used for numerous water sports. The 204 ha of marsh vegetation of the west side of Merja Zerga is cut. Incidental cutting occurs around the northern end of Merja Zerga and possibly along the east side. Shooting is described as excessive by Carp (1980), but was reported to have stopped with the shooting butts and huts dismantled. Morgan (1982) recommended that the development of tourism needed to be carefully controlled and noted that grazing pressure, thought by some to be detrimental to the site, was not excessive.

\section{Management Practices No information}

\section{Scientific Research and Facilities No information}

\section{Principal Reference Material}

Carp, E. (1980). A Directory of Western Palearctic Wetlands. IUCN, Gland, Switzerland.

- Fender, W. and Bousselham, M. (1985) Merja Zerga Biological Reserve in service trainging site report. Nov. 19-22, 1985. Maroc. Peace Corps Volunteers unpublished report.

- Gryn-Ambroes, P. (1980). Preliminary annotated lists of existing and potential Mediterranean protected areas. UNEP/IUCN Report. UNEP/IG 20.

- Kersten, M. and Smit, C.J. (1984). The Atlantic coast of Morocco. In Evans, P.R., Goss-Custard, J.D., and Hale, W.G. (eds). Coastal waders and wildfowl in winter. Cambridge University Press, Cambridge. Pp. 276-291.

- Morgan, N.C. (1982). An ecological survey of standing waters in Northwest Africa: III. Site description for Marocco. Biol. Cons. 24:161-182.

- Poorter, E.P.R. and Wigbels, V.L. (1984). Verslag van de Lepelaarstudiereis Naar Frankrijk, Spanje en Marokko in Februari en Maart 1984. (Report on Spoonbills in France, Spain and Morocco in February and March 1984.) Nederlandse Stichting voor internationale vogelbescherming, Zeist. Lelystad. 
- Scott, D.A. (1980). A preliminary inventory of wetlands of international importance for waterfowl in West Europe and Northwest Africa. IWRB Special Publication No. 2.

- Scott, D.A. and Prater, A.J. (1982). Slender-billed curlew Numenius tenuirostris. Unpublished manuscript.

\section{Douiya Sidi-Bou-Rhaba}

Location $34^{\circ} 15^{\prime} \mathrm{N}, 6^{\circ} 40^{\circ} \mathrm{W}$. Situated near (north) Rabat at Mehdia in the Province of Kenitra.

Area $\quad 150-250$ ha

Degree of Protection Protection of the area is being considered. Designated as a Ramsar site in 1980.

Site Description The site comprises a coastal non-tidal brackish marsh separated from the ocean by an area of sanddunes. It is surrounded by dense thickets of Juniperus woodland.

Criteria for inclusion 1(a), 1(c), 1(d), 2(a), 3(c) and 4(a).

International and National Importance Particularly important during periods of passage for large numbers of duks and waders. The site is also a wintering and nesting site for waterfowl. The uncommon crested coot Fulica cristata nests here.

Changes in Ecological Character The lake was reported to be under considerable recreational pressure. However, measures have been taken by the Administration des Eaux et Forêt to improve the situation. Grazing of cattle is prevented on the marshland surrounding the lakes. This has caused some problems recently as in several places the extensive marhsland vegetation consisting of Juncus sp., has been overgrown by a tall stand of mixed Phragmites and Typha communities

\section{Management Practices No information}

Scientific Research and Facilities Situated close to the main university of Rabat, the site is frequently visited by school groups and students during courses. Eaux et Forêts constructed a museum in 1976, which is to be used as a visitors centre.

\section{Principal Reference Material}

- Gryn-Ambroes, P. (1980). Preliminary annotated lists of existing and potential Mediterranean protected areas. UNEP/IUCN Report. UNEP/IG 20.

- Morgan, N.C. (1982). An ecological survey of standing waters in Northwest Africa: III. Site description for Marocco. Biol. Cons. 24:161-182.

\section{Lac d'Affennourir}

Location $36^{\circ} 99^{\prime} \mathrm{N}, 08^{\circ} 42^{\prime} \mathrm{W}$. Situated in the region of Azrou in the Province of MeKnès.

Area 380 ha

Degree of Protection Designated as a Ramsar site in 1980.

Site Description The site comprises a mountain lake.

International and National Importance The site is a wintering area and crossroads for migrants and a nesting site for waterfowl.

Changes in Ecological Character No information 
Management Practices No information

Scientific Research and Facilities No information

Principal Reference Material No information

\section{La Baie du Khnifiss ou Puerto Cansado}

Location $28^{\circ} 00^{\prime} \mathrm{N}, 12^{\circ} 25^{\prime} \mathrm{W}$. Situated north of La'youn in the Province of Tarfaya.

Area $6,000-7,000 \mathrm{ha}$

Degree of Protection Designated as a Ramsar site in 1980.

Site Description The site comprises a large coastal brackish lagoon (20km long and $3 \mathrm{~km}$ wide) with several marshy areas. It is open to the sea via a gulley through the littoral zone. There are vast areas of mudflats and Rupia spp. which are uncovered at low tide.

Criteria for Inclusion 1(a), 1(b), 1(c), 1(d), 1(e), 2(a), 4(a) and 4(b).

International and National Importance Recognised as being the second most important wetland site in Morocco. The numbers of waders counted here has varied markedly, with $95,000-115,000$ in $1964,25,700$ in 1972,5080 in 1973 and 23,000 in 1974, with the most numerous species being dunlin Caldris alpina (max. 10,000), knot C. canutus (max. 4000), grey plover Pluvialis squatarola (max. 3000), bar-tailed godwit Limosa lapponica (max. 2000) and redshank Tringa totanus (max. 1000). The largest number of slender-billed curlew Numenius tenuirostris reported outside the USSR this century were recorded here, with $500-800$ birds in January 1964, however, none have been recorded at this locality since.

Changes in Ecological Character Carp (1980) suggests that road building and military activity would be detrimental to the area from increased disturbance. Oil exploitation could also affect the area. The extent to which this has advanced, and the result of such exploitation, should be evaluated.

Management Practices No information

Scientific Research and Facilities No information

Principal Reference Material

- Carp, E. (1980). A Directory of Western Palearctic Werlands. IUCN, Gland, Switzerland.

- Gryn-Ambroes, P. (1980). Preliminary annotated lists of existing and potential Mediterranean protected areas. UNEP/IUCN Report. UNEP/IG 20.

- Kersten, M. and Smit, C.J. (1984). The Atlantic coast of Morocco. In Evans, P.R., Goss-Custard, J.D., and Hale, W.G. (Eds). Coastal waders and wildfowl in winter. Cambridge University Press, Cambridge. Pp. 276-291.

- Scott, D.A. (1980). A preliminary inventory of wetlands of international importance for waterfowl in West Europe and Northwest Africa. IWRB Special Publication No. 2.

- Scott, D.A. and Prater, A.J. (1982). Slender-billed curlew Numenius tenuirostris. Unpublished manuscript. 


\section{NETHERLANDS}

Area 36,174 sq. $\mathrm{km}$

Population $14,394,589(1984)$

Summary of Wetland Situation The flat, open country of the Netherlands, dominated by the deltas of the rivers Rhine, Maas, Schelde, IJssel and their numerous distributaries, has a great number of wetlands of international importance.

The Wadden Sea, which extends from the north of the country along the coasts of the Federal Republic of Germany and Denmark, is undoubtedly the most important single wetland in Western Europe, and of vital importance to huge numbers of waterfowl both breeding in the area and passing through during migration seasons. Its shallow and relatively warm water provides an excellent nursery-ground for many species of fish and crustacea.

In the delta area, many inlets of the sea along the coast and between the islands of the Zuid-Holland and Zeeland provinces have been closed off by dykes to prevent a repetition of the catastrophic floods of 1953. As a result, the salt water character of the wetlands in this region has been giving way to a freshwater environment. These areas, which have always been of great importance to waterfowl (especially wintering geese), seem to maintain their former significance.

In various inland parts of the country, a number of major freshwater lake complexes are of great importance to breeding and wintering waterfowl. Several of them are of limnological interest, and many also serve recreational purposes during the summer months. The characteristic deep waterholes along riverbanks (in Dutch: wielen), formed by dyke-falls, are of particular scientific interest by reason of their limnological and hydrobiological qualities. Some of the recently drained polders of the IJsselmeer provide additional suitable habitats for waterfowl.

Protected Areas Legislation The principal act is the Nature Conservation Act of 15 November 1967 which protects all designated sites from activities which are harmful to their natural or scientific interest (although some activities are allowed with a permit). Proposals for designation of a protected natural area are made by ministerial announcement after which interested parties make their views known. Decisions are taken by the Minister in consultation with the Nature Conservation Council and the Government Physical Planning Commission. The law enables the Minister to devise a management plan for each protected area. Other acts that affect the management of these sites are the Physical Planning Act of 1962 and the Land Consolidation Act of 1954.

In the Netherlands Antilles there is no general legislation on parks or reserves with the exception of the act on establishing underwater parks.

Protected Areas Administration Responsibility for wetlands is vested in the Ministry of Agriculture and Fisheries in The Hague, through its Department for Nature Conservation, Environmental Protection and Fauna Management. The Minister is advised by the Nature Conservancy Council (set up under the 1967 Act). He is assisted by the National Forest Service of the Ministry, and by the Research Institute for Nature Management (RIN), a scientific research institute. The Ministry has a nature conservation officer based in each province. With assistance from the State, private associations also play a major role in purchasing, creating and managing protected natural areas. The most important of these groups is the 'Vereniging tot Behoud van Natuurmonumenten' which, for example, manages and owns Het Naardermeer. It is policy that all state nature reserves should have management plans. These are prepared by local managers and then submitted to the Research Institute for Nature Management and National Forest Service. The approved plan is deposited with the Ministry. 
In the Netherlands Antilles there is no government organisation administering parks and reserves, which is done instead by the Netherlands Antilles National Parks Foundation (Stichting Nationale Parken Naderlandse Antillen - STINAPA).

\title{
Sites designated under the Convention
}

Accession 23 May 1980 with 12 sites listed at accession (6 in the Netherlands Antilles) and another added May 1984

\author{
De Groote Peel \\ De Weerribben \\ Het Naardermeer \\ De Boschplaat \\ De Griend Island \\ Part of De Biesbosch \\ Dutch section of the Wadden Sea

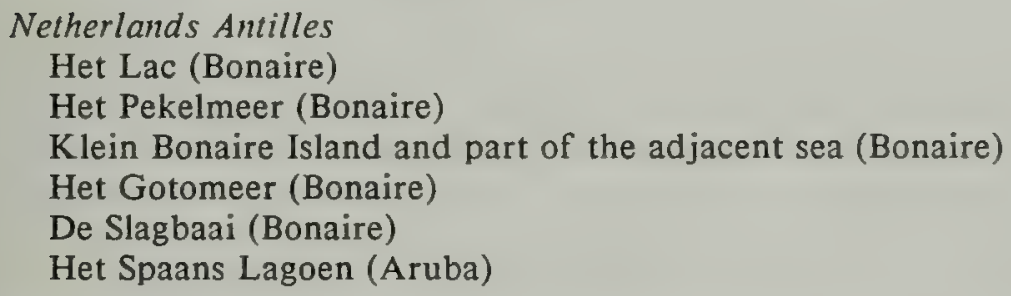

Government body responsible for administration of the Convention

Ministry of Agriculture and Fisheries, Directorate for Nature Conservation, Environment Protection and Fauna Management, Postbus 20401, 2500 EK The Hague

\section{De Groote Peel}

Location $51^{\circ} 20^{\prime} \mathrm{N}, 5^{\circ} 45^{\prime} \mathrm{E}$. Situated near Eindhoven in Noord Brabant Province, south-east Netherlands.

\section{Area 900 ha}

Degree of Protection The site is part of De Groote Peel Nature Reserve (1,400ha) which was established in 1953 and is managed by the National Forestry Service. In 1985 De Groote Peel was declared a National Park in formation. Designated as a Ramsar site at the time of accession on 23 May 1980.

Site Description De Groote Peel and the nearby Mariapeel Nature Reserve are all that remain of some 30,000 ha of peat moor, now extensively reclaimed for agriculture. The site contains a range of habitats including open water pools, wet marshlands, peat moorlands, heaths and birch Betula sp. woodland in the drier areas. Numerous artificial channels dissect the southern sector. The area is still relatively undisturbed, and supports an abundant species-rich fauna, especially insects, including dragonflies (Odonata) and butterflies (Lepidoptera) characteristic of peat moors and heathlands.

International and National Importance De Groote Peel is important as a breeding ground and as a feeding area for wintering and migrant birds. Breeding species include teal Anas crecca, northern shoveler $A$. clypeata, tufted duck Aythya fuligula, pochard $A$. ferina, black tern Chlidonias niger, common tern Sterna hirundo, black-headed gull Larus ridibundus, Eurasian bittern Botaurus stellaris, curlew Numenius arquata, black-tailed godwit Limosa limosa, redshank Tringa totanus, lapwing Vanellus vanellus and oystercatcher Haematopus ostralegus. Partridge Perdix perdix and pheasant Phasianus colchicus breed in the heathlands. 
The wetland is one of the few areas in the Netherlands used by hundreds of crane Grus grus on autumn migration. It is also an important winter refuge for up to 3,000 bean goose Anser fabalis and a stopover for hundreds of white-fronted goose $A$. albifrons and thousands of mallard Anas platyrhynchos, teal and shoveler.

Changes in Ecological Character In most parts, the peat has been cut. The area around the reserve has been extensively drained and reclaimed for agriculture, and mostly for arable farming which requires the water table to be maintained at a low level. Wetlands have to therefore be artificially maintained to keep their original marshy condition. The main threat to the site is acidification of the water by nitrous oxides. Also, high ammonia input from the surrounding intensive stock farms, causes eutrophication of bog areas. There is a constant problem of invasion of heathlands by grasses and tree seedlings, and a large colony of black-headed gulls is competing for habitats used by waterfowl. The ruff Philomachus pugnax has disappeared.

Management Practices The heathlands are managed to maintain heathland plant communities, and to prevent invasion by grass and tree species. In 1984 a shepherded flock of sheep was introduced for this purpose. The reserve management plan is designed to promote optimum environmental conditions for waterfowl, and includes dredging canals, maintaining the water table at a sufficient level for marsh conditions and regeneration of Sphagnum mosses, controlled burning of heathlands and some reed-cutting.

Scientific Research and Facilities In 1985 two research projects were undertaken, one concerning the hydrology of the reserve in relation to its surroundings, and one concerning the possibilities of regeneration of the ombrotrophic peat-forming processes. In 1986 another project was initiated to study the effects of the high concentrations of ammonia on peat-forming processes an on the oligotrophic vegetation types which characterise the area.

Principal Reference Material The above information is principally taken from the document submitted at the time of designation in May 1980, supplemented by recent additions from the Ministry.

Supplemented by:

- Duffey, E. (1982). National Parks and Reserves of Western Europe. Macdonald and Co., London.

- Scott, D.A. (1980). A preliminary inventory of wetlands of international importance especially for waterfowl in west Europe and northwest Africa. IWRB Special Publication No. 2.

Additional reference:

- Beintema-Hietbrink, R.J. (1985). Handboek van natuurgebieden en wandelterreinen in Nederland. Vereniging tot Behoud van Natuurmonumenten in Nederland, s'-Graveland.

\section{De Weerribben}

Location $52^{\circ} 37^{\prime} \mathrm{N}, 5^{\circ} 59^{\prime} \mathrm{E}$. Situated $10 \mathrm{~km}$ west of Meppel and Steenwijk in the north-west of Overijssel Province.

Area 3,400 ha (increased from 2,500 ha originally designated).

Degree of Protection State owned. The designated site includes 2,150ha within the Weerribben National Nature Reserve established in 1957. The area has recently been declared a National Park in formation. Designated as a Ramsar site at the time of accession on 23 May 1980.

Site Description De Weerribben and Wieden National Park $(4,004$ ha) comprise a substantial part of the once extensive lowlands of water and peat. The wetland habitat includes all stages of peat formation, areas of poor soil, reed marshes and quaking bogs, and has been greatly affected by centuries of peat cutting. Most of the fenlands and open-water broads are the result of over-intensive peat cutting which has exposed the lower peats and soil to wind 
erosion. The diversity of vegetation types is of great botanical interest and includes: various stages of the aquatic Hydrochrito-Stratiotetum succession in the open water ponds; floating mat vegetation in former peatholes (quaking bogs) comprising numerous species such as sphagnum moss, bog bean Menyanthes trifoliata, slender cotton grass Eriophorum gracile, downy-fruited sedge Carex lasiocarpa, two-stemmed sedge C. diandra, fen orchid Liparis loeselii, early marsh orchid Dactylorchis incarnata, water forget-me-not Myosotis scorpioides, Parnassus grass Parnassia palustris and bladderwort Utricularis intermedia; reedmarsh dominated by Phragmites communis; Cirsio-Molinetum (thistle moor grass) community dominating the natural meadows; shrubby marshes and woodland (climax community) of bog myrtle Myrica gale, birch Betula pubescens, buckthorn Frangula alnus and common alder Alnus glutinosa. The dark sedge Carex buxbaumii (threatened throughout Europe) occurs in the transition zone between the quaking bog and drier unmanured pastures. The fauna is diverse in wetland species, including the highly localised large copper butterfly Lycena dispar. The wetland is surrounded by reclaimed polder, with several small settlements on the boundary and the viliage of Kalenberg within the reserve. Several roads pass through the wetland linking Ossenzijl, Kalenberg and Wetering.

International and National Importance The site is important for breeding birds and migrants. Breeding birds include grey heron Ardea cinerea, purple heron A. purpurea, Eurasian bittern Botaurus stellaris, great-crested grebe Podiceps cristatus, curlew Numenius arquata, snipe Gallinago gallinago, shoveler Anas clypeata, black-headed gull Larus ridibundus, black tern Sterna nigra, marsh harrier Circus aeruginosus, hen harrier C. cyaneus, long-eared owl Asio otis and Savi's warbler Locustella luscinioides.

Changes in Ecological Character Eutrophication is resulting from the intake of water from the canals between Ossenzijl and Blokzijl (largely derived from the Ijsselmeer, and originating from the River Rhine). From these canals eutrophic water penetrates into the waterzone beneath the floating mats of vegetation. Another problem concerns the reduction of upwelling water originating from Pleistocene rocks near Paaslo, which was caused by the creation of the Noordoostpolder in the Ijsselmeer in the 1940s where the water table is maintained at a low level, and by cultivation of the neighbouring Wetering polder. These problems will increase because the water table of the surrounding polders will have to be lowered still further as the peat underlying them dries out, oxidises and shrinks.

Management Practices Traditional agricultural practices have been retained at a regulated level as part of the management plan. They include reed-cutting, woodland coppicing, hay-making, some grazing, the dredging of ditches and waterways, and localised, strictly controlled, hunting. Recreational activities are controlled.

Scientific Research and Facilities The University of Amsterdam, the Agricultural University of Wageningen, and the RIN have carried out hydrobiological and hydrological investigations.

Principal Reference Material The above information is principally taken from the document submitted at the time of designation in May 1980, supplemented by information recently supplied by the Ministry.

Supplemented by:

- Carp, E. (1980). A Directory of Western Palearctic Wetlands. IUCN, Gland, Switzerland.

- National Report on the Netherlands (1984). Meeting of the Contracting Parties, Groningen.

- Scott, D.A. (1980). A preliminary inventory of wetlands of international importance especially for waterfowl in west Europe and northwest Africa. IWRB Special Publication No. 2.

Additional references:

- Beintema-Hietbrink, R.J. (1985). Handboek van natuurgebieden en wandelterreinen in Nederland. Vereniging tot Behoud van Natuurmonumenten in Nederland, s'-Graveland.

- Gerritsen, G. (1984). Noord-West Overijssel. In: Vogels in Overijssel. Waanders, Zwolle.

- Leentvaar, P. (1945). Hydrobiologische waarnemingen in het plassengebied van N.W. Overijssel I. Biol. Jaarboek Dodonea 33.

- Luther, H. and Rzoska, J. (1971). Project AQUA IBP Handbook No. 21.

- Schroevers, P. (1965). Hydrobiologische waarnemingen N.W. Overijssel II. Biol. Jaarboek Dodonea 33. 
- Westhoff, V., Bakker, B.A., van Leeuwen, C.G. and Van der Voo, C.G. (1971). Wilde Planten Deel II and list of references Deel III. Vereniging tot Behoud van Natuurmonumenten in Nederland, Amsterdam.

- Wirdum, G. van (1982). The ecohydrological approach to nature protection. Annual Report 1981, Research Institute for Nature Management, Arnhem.

\section{Het Naardermeer}

Location $52^{\circ} 17^{\prime} \mathrm{N}, 5^{\circ} 07^{\prime} \mathrm{E}$. Situated between Amsterdam and Hilversum in Noord Holland Province.

\section{Area $752 \mathrm{ha}$}

Degree of Protection Privately owned by the Vereniging tot Behoud van Natuurmonumenten. Designated as a Ramsar site at the time of accession on 23 May 1980.

Site Description The wetland comprises a typical lowland mire system. The open water pools are colonised by pondweeds Potamogeton, waterlilies Nuphar and Hydrocharitaceae, and by small concentrations of the genera Chara. Reedbeds and grassy marshlands support Phragmiles communis, Typha angustifolia. Scirpus lacustris, Carex paniculata and C. elongata. There is meadowland on poor soil, and swamp woodland of Alnus sp. and birch Betula pubescens. The site is surrounded by agricultural polders on three sides and to the east by the densely populated districts of Naarden and Bussum in the Hilversum conurbation.

International and National Importance The wetland is an important breeding ground for waterfowl, including grey heron Ardea cinerea, purple heron A. purpurea (50-75 pairs), Eurasian bittern Botaurus stellaris, spoonbill Platalea leucorodia (125 pairs), red-crested pochard Netla rufina, gadwall Anas strepera, black tern Chlidonias niger and cormorant Phalacrocorax carbo sinensis (5,000 pairs: the largest colony in Europe). Other breeding birds include bearded tit Panurus biarmicus, and several species of warbler including Savi's Locustella luscinoides. Large numbers of dabbling and diving duck (Anatidae) pass through on autumn and spring migration, and may overwinter in a mild winter.

Changes in Ecological Character Until 1984 polluted surface water was being discharged into the pools from surrounding farmland, in an attempt to compensate for the reduction in oligotrophic seepage entering the wetland. This had caused increased eutrophication, and caused expansion of reedbeds and rushes. Instead, a water purification plant was employed. Power cables in the area are a potential hazard to birds. There are no other significant disturbances. The black-crowned night heron Nycticorax nycticorax and the white-eyed pochard Aythya nyroca have both disappeared.

Management Practices Management practices include some reed-cutting to maintain the diversity of mire plant communities. Access to some parts is strictly limited. Visitors have to make an appointment, and must be accompanied by a reserve guide.

Scientific Research and Facilities The vegetational succession has been studied for over 50 years. Ornithological research has included regular monitoring of breeding species and in particular studies of the biology and population dynamics of spoonbill.

Principal Reference Material The above information is taken from the document submitted at the time of designation in May 1980 and from material provided by the Vereniging tot Behoud van Natuurmonumenten in Nederland.

- Carp, E. (1980). A Directory of Western Palearctic Wetlands. IUCN, Gland, Switzerland. Supplemented by:

- Scott, D.A. (1980). A preliminary inventory of wetlands of international importance especially for waterfowl in west Europe and northwest Africa. IWRB Special Publication No. 2. 
Additional references:

- Beintema-Hietbrink, R.J. (1985). Handboek van natuurgebieden en wandelterreinen in Nederland. Vereniging tot Behoud van Natuurmonumenten in Nederland, s'-Graveland.

- Vereniging tot Behoud van Natuurmonumenten (1974). Het Naardermeer Nature Reserve Handbook. Amsterdam.

\section{De Boschplaat}

Location $53^{\circ} 27^{\prime} \mathrm{N}, 5^{\circ} 30^{\prime} \mathrm{E}$. Situated on the eastern part of Terschelling Island in the Wadden Sea, Friesland.

Area 4,400ha.

Degree of Protection State owned. The beach and outer dune ridge are managed by the Ministry of Public Works and the remaining area by the Friesian branch of the Netherlands National Forestry Service. Protected as a Nature Reserve since 1924. The site is contiguous with two other reserves on Terschelling Island: Noordvaarder and Koegelwieck, amounting to a total protected area on the island of $9,400 \mathrm{ha}$. De Boschplaat received the European Diploma for Nature Conservation in 1970. Designated as a Ramsar site at the time of accession on 23 May 1980.

Site Description De Boschplaat developed from sandflats which were built up into dunes not always covered by the flood tide, and which then became linked with Terschelling Island when the Koggesdiep channel silted up. The construction of an artificial dune ridge in 1931-36 enabled vegetation to become established on the dunes which were then protected from the high North Sea tides. The vegetation ranges from pioneer species such as glasswort Salicornia curopaea on the saltmarsh to mud rush Juncus gerardii, creeping fescue Festuca rubra, thrift Armeria maritima and distant sedge Carex distans on the highest levels of the sandflats. Where the influence of salt diminishes and periods of flooding are shorter, Salicornia is replaced by Puccinella maritima, Atriplex maritima and Obione pedunculata. Behind the dunes lies a thick scrub of sea buckthorn Hippophae rhamnoides and crowberry Empetrum nigrum. In the southern slacks a natural 'woodland' (the first of its kind in the Wadden area) has developed naturally, with silver birch Betula alba, aspen Populus tremula, grey willow Salix cinerea and some Viburnum opulus and Sambucus nigra. The dunes and their hinterland support a fascinating diversity of plant communities, depending on salinity, soil chemistry, stage of dune development and geomorphology. Mammals are scarce and many common species are absent.

International and National Importance The site's position between the North Sea and Wadden Sea, the rich food resources of the mudflats, and isolation from many predators make it important for breeding birds as well as migrants. It has almost 50 breeding bird species including hen harrier Circus cyaneus, Montagu's harrier $C$. pygargus, marsh harrier C. aeruginosus, kestrel Falco tinnunculus, short-eared owl Asio flammeus, eider Somateria mollissima, shelduck Tadorna tadorna, curlew Numenius arquata, redshank Tringa lotanus, black-tailed godwit Limosa limosa, lapwing Vanellus vanellus, oystercatcher Haematopus ostralegus, wheatear Oenanthe oenanthe, grasshopper warbler Locustella naevia, reed bunting Emberiza schoeniclus, avocet Recurvirostra avoselta, spoonbill Platalea leucorodia, herring gull Larus argentatus, lesser black-back gull L. fuscus, common gull L. canus, common tern Sterna hirundo, arctic tern $S$. paradisea, little tern S. albifrons, Kentish plover Charadrius alexandrinus, ringed plover $C$. hiaticula, and occasionally sandwich tern $S$. sandvicensis. In autumn some 30,000 migratory birds have been counted along the coast, including large numbers of teal Anas crecca, wigeon A. penelope, shelduck, dunlin Calidris alpina, knot Calidris canutus, bar-tailed godwit Limosa lapponica, curlew and oystercatcher. Less numerous species include greylag goose Anser anser, brent goose Branta bernicla, eider, grey plover Pluvialis squatarola, greater black-backed gull Larus marinus, herring gull, common gull and turnstone Arenaria interpres. Migrants also include small numbers of birds of prey such as osprey Pandion haliaetus, white-tailed eagle Haliaeetus albicilla, peregrine Falco peregrinus and merlin $F$. columbarius. 
Changes in Ecological Character Terschelling Island has a permanent population of over 4,300 , and farmers are allowed to graze cattle on 300 ha of dune meadow within the reserve. The large breeding population of herring gull threatens the success of other less abundant breeding species.

Management Practices Open to the public all year. The Forest Service controls access paths to minimise erosion of the dunes by walkers; bird breeding grounds are patrolled; access is restricted from mid-April to mid-July; and motor traffic within the reserve is prohibited. There is a forestry officer in charge of the area, with 1-2 wardens increased to four during the bird breeding season. Measures are being taken to restrict the number of breeding pairs of herring gull.

Scientific Research and Facilities There is continuous monitoring of of the dune vegetation development and bird breeding colonies. There is a Biological Research Station (Schellingerland) on Terschelling run by the Research Institute for Nature Management.

Principal Reference Material The above information is taken from the Council of Europe (1970), European Diploma for Nature Conservation: Boschplaat Leaflet, and the document submitted at the time of designation in May 1980.

Supplemented by:

- Duffey, E. (1982). National Parks and Reserves of Western Europe. Macdonald and Co., London.

- National Report on the Netherlands (1984). Meeting of the Contracting Parties, Groningen. Additional reference:

- Beintema-Hietbrink, R.J. (1985). Handboek van natuurgebieden en wandelterreinen in Nederland. Vereniging tot Behoud van Natuurmonumenten in Nederland, s'-Graveland.

- Verwey, J. et al. (1966). A plea for the Waddensee. Committee for Nature and Landscape Preservation, Den Haag.

\section{De Griend}

Location $53^{\circ} 15^{\prime} \mathrm{N}, 5^{\circ} 15^{\prime} \mathrm{E}$. An island in the west-central part of the Wadden Sea, south-west Friesland, and the fringe of islands north of Den Helder.

Area $23 \mathrm{ha}$

Degree of Protection State owned. Griend Island is protected as a Nature Reserve. This island and several other areas of the Wadden Sea were recently declared a State Nature Monument under Article 21 of the Nature Conservation Act. Designated as a Ramsar site at the time of accession on 23 May 1980.

Site Description Griend is a small uninhabited island which is the highest part of the 'Griender Waard', a sandy mudflat on which saltmarsh vegetation has become established. It is in a favourable undisturbed location for breeding birds, especially as it is inaccessible to land predators such as rats, weasels and polecats. The island is surrounded by tidal marshes.

International and National Importance The island is an important breeding ground for sandwich tern Sterna sandvicensis, Arctic tern S. paradisaea, little tern $S$. albifrons, common tern S. hirundo, oystercatcher Haematopus ostralegus, redshank Tringa totanus, shelduck Tadorna tadorna and several other species of duck (Anatidae). It is important as a high tide roost and as a stopover for migrants. Numbers are comparable with those of larger Wadden islands. Species include dunlin Calidris alpina, knot $C$. canutus, turnstone Arenaria interpres, shelduck, eider Somateria mollissima, curlew Numenius arquata, brent goose Branta bernicla, great black-backed gull Larus marinus, common gull L. canus and black-headed gull $L$. ridibundus. The island and surrounding marshes are probably the most important area in the Wadden Sea for bar-tailed godwit Limosa lapponica and grey plover Pluvialis squatarola. 
Changes in Ecological Character The island is largely undisturbed but there is increasing industrial activity in the surrounding area of the Wadden Sea, including gas and oil exploration, pollution with waste discharged from the mainland, military exercises, and tourist recreation. There is some tidal erosion of this unstable mud island.

Management Practices The breeding colonies are patrolled by reserve wardens. Access is prohibited during the breeding season under a management programme to optimise environmental conditions for waterfowl populations. A coastal protection project has been undertaken in an attempt to minimise tidal erosion of the island.

Scientific Research and Facilities The Wadden Working Group and the Institute for Marine Research on Texel Island have carried out research projects for the governmental Wadden Sea Committee.

Principal Reference Material The above information is taken from the document submitted at the time of designation in May 1980, and from:

- Carp, E. (1980). A Directory of Western Palearctic Wetlands. IUCN, Gland, Switzerland. Supplemented by:

- National Report on the Netherlands (1984). Meeting of the Contracting Parties, Groningen.

- Scott, D.A. (1980). A preliminary inventory of wetlands of international importance especially for waterfowl in west Europe and northwest Africa. IWRB Special Publication No. 2.

Additional references:

- Beintema-Hietbrink, R.J. (1985). Handboek van natuurgebieden en wandelterreinen in Nederland. Vereniging tot Behoud van Natuurmonumenten in Nederland, s'-Graveland.

- Verwey, J. et al (1966). A plea for the Waddensee. Committee for Nature and Landscape Preservation, Den Haag.

\section{Part of De Biesbosch}

Location $51^{\circ} 56^{\circ} \mathrm{N}, 4^{\circ} 48^{\prime} \mathrm{E}$. Situated between the Amer and Nieuwe Merwede branches of the Rhine Delta where these flow into the Hollands Diep; south-east of Rotterdam in Noord-Brabant Province, south-west Netherlands.

Area 1,700ha.

Degree of Protection Owned mainly by the Ministry of Agriculture and Fisheries. The designated area includes 1,500 ha protected as Brabantse Biesbosch State Nature Reserve. All land outside the dykes is classified as 'natural area' in the land use plans of the neighbouring municipalities. De Biesbosch has been declared a National Park in formation. Designated as a Ramsar site at the time of accession on 23 May 1980.The area is contiguous with Dordtsche Biesbosch and Sliedrechtse Nature Reserves on the opposite bank of the Nieuwe River.

Site Description The designated site is bounded by two tributaries of the Rhine and Maas rivers as they flow into the delta, and comprises a network of large and small creeks enclosing a mosaic of reclaimed polders, water reservoirs, marshland and swampy woodland. The man-made reservoirs (for drinking water) and some agricultural polders are excluded from the designated site. Biesbosch was originally a freshwater tidal area, but in November 1970 the Haringvliet Dam was completed with the result that the average tidal range was reduced from $2 \mathrm{~m}$ to $20 \mathrm{~cm}$, resulting in some areas which used to be regularly uncovered being permanently underwater while others remained dry. This has had a drastic effect on the structure and composition of the subsoil and plant and animal communities, and the area is gradually becoming a marshland with some closed creeks drying out to form peat. The vegetation succesions include reed Phragmites communis, bulrush Scirpus triducter, marsh marigold Caltha palustris var. araneosa and willow Salix sp., and communities with species of thistle Cirsium and nettle Urtica dioica invading the drier areas. 
International and National Importance Biesbosch is an area of great scientific interest, particularly for ornithology. The new, drier, conditions attract a great variety of breeding birds with numbers still increasing, including marsh harrier Circus aeruginosus, gadwall Anas strepera, garganey $A$. querquedula and shoveler $A$. clypeata; new species nesting since 1970 include great-crested grebe Podiceps cristatus, tufted duck Aythya fuligula, kingfisher Alcedo atthis and nightingale Luscinia mergarhynchos. Bittern Botaurus stellaris, grey heron Ardea cinerea and Savi's warbler Locostella luscinoides also breed here. The area used to be the most northerly breeding site in Europe for colonies of night heron Nycticorax nycticorax but now only a few isolated pairs remain. The changing conditions are unlikely to affect the importance of the area as a stopover for migrating geese including greylag Anser anser. Other migrants include mallard Anas platyrhynchos, teal $A$. crecca, pintail $A$. acuta and pochard Ayhtya ferina. Cormorant Phalacrocorax carbo and spoonbill Platalea leucorodia use the wetlands as a post-breeding feeding ground. Osprey Pandion haliaetus winters at this site.

Changes in Ecological Character The construction of Haringuliet Dam has dramatically changed the nature of the wetland, including increasing the number and variety of breeding birds, particularly those favouring stagnant water and rough vegetation. However, the disappearance of mud has reduced the number of waders, and the reduction in reedbeds has reduced the numbers of birds dependent on these. On the other hand, the increased acreage of stagnant water and rough bank vegetation has resulted in a growing number of birds common to these habitats. The most serious threats to the wetland are pollution of river sediment and of the water in the Maas River, installation of power lines, reservoir construction, and increasing recreational activities.

Management Practices Some sectors of the reserve are closed to the public and managed as a strict reserve. Some waterways are closed to motorboats. Reed-cutting continues in some places. Fishing and the controlled catching of ducks with the help of decoys is still allowed in places. A large scale recreational development was being built in 1984 just outside the reserve boundary in an attempt to reduce recreational pressure in the sensitive parts of the wetland, and a similar project, also outside the reserve, was being planned in 1986.

Scientific Research and Facilities There are studies of vegetation succession, and zoological and hydrobiological studies, particularly on birds and insects.

Principal Reference Material The above information is taken from the document submitted at the time of designation in 1980, and from:

- Carp, E. (1980). A Directory of Western Palearctic Wetlands. IUCN, Gland, Switzerland. Supplemented by:

- Duffey, E. (1982). National Parks and Reserves of Western Europe. Macdonald and Co., London.

- National Report on the Netherlands (1984). Meeting of the Contracting Parties, Groningen. Additional references:

- Anon (1970). Over de hartslag van het National Park de Biesbosch. Grontmij, de Bilt.

- Zonneveld, I.S. (1970). De Biesboch is dood, leve de Biesbosch. Natuur en Landschap 24(4).

\section{Het Lac}

Location $12^{\circ} 06^{\prime} \mathrm{N}, 68^{\circ} 14^{\prime} \mathrm{W}$. Situated on the coast of Bonaire Island to the east of Curaçao in the Lesser Antilles (in the Caribbean off the coast of Venezuela).

Area $700 \mathrm{ha}$ (within the Underwater Park of $6,000 \mathrm{ha}$ which includes the complete coastline of Bonaire and Klein Bonaire).

Degree of Protection Owned by the Government of Bonaire. Protected within the Underwater Park (6,000ha) established in May 1979. Designated as a Ramsar site at the time of accession by the Netherlands on 23 May 1980. 
Site Description Het Lac is a shallow $(0-3 \mathrm{~m})$ sandy/muddy-bottomed lagoon, partly separated from the open sea by a bar of coral debris cemented together by red coralline algae (Lithothamnion) and other organisms. The lagoon is fringed by mangrove swamps and beds of sea grass Thalassia testudium. The mangroves provide shelter, and produce large amounts of organic debris which is washed into the lagoon making the waters highly productive for fish and invertebrates (a rich food source for birds). The sea grass is browsed by invertebrates such as queen conch Strombus gigas, sea urchins and giant seastar Oreaster reticulatus, which are also a food source.

International and National Importance The lagoon is an important feeding ground for birds including waders, terns (Sternidae), frigate bird Fregata sp., pelicans Pelecanus spp. and herons (Ardeidae). Numerous species breed in the shelter of the mangroves.

Changes in Ecological Character The site is undisturbed.

Management Practices None reported (1980)

Scientific Research and Facilities The Caribbean Marine Biological Institute based in Curaçao is studying the coastal coral reefs.

Principal Reference Material The above information is taken from:

- Kristensen, I. (1980). Description of the Netherlands Antilles Wetlands to be conserved. Caribbean Marine Biological Institute, Curaçao.

\section{Het Pekelmeer}

Location $12^{\circ} 02^{\prime} \mathrm{N}, 68^{\circ} 15^{\prime} \mathrm{W}$. Situated on the southern coast of Bonaire Island, east of Curaçao in the Lesser Antilles (in the Caribbean of the coast of Venezuela).

Area $400 \mathrm{ha}$ (including the Flamingo Sanctuary $56 \mathrm{ha}$ ).

Degree of Protection Owned by the International Antillean Salt Company (AISCO). The designated site includes the Flamingo Sanctuary supervised by the Flamingo Sanctuary Commission, AISCO, Bonaire. Designated as a Ramsar site at the time of accession by the Netherlands on 23 May 1980.

Site Description Pekelmeer is a shallow strip of seawater located between a solid ridge of beachrock (recrystallised coral debris) and the AISCO solar saltworks. A channel has been dug at the eastern tip of the lagoon linking it with the open sea. The Flamingo Sanctuary along the north bank of the lagoon is separated from Pekelmeer by a dyke. A pump maintains the water level in the sanctuary. Vegetation is sparse, with a coating of algae on the muddy bottom: the major foodsource for the flamingo.

International and National Importance The sanctuary is one of the few breeding sites in the Caribbean for the red flamingo Phoenicopterus ruber ruber, with an average of 1,000 pairs recorded during the breeding season. Terns (Sternidae) and pelicans Pelecanus spp. fish in the lagoon.

Changes in Ecological Character There is a problem of disturbance during the flamingo breeding season mainly by visiting photographers and ornithologists, light aircraft overflying the area and some poachers.

Management Practices Access to the bay in the sanctuary by visitors and scientists is prohibited during the flamingo breeding season.

Scientific Research and Facilities The population and behavioural ecology of the flamingo colony has been studied since 1959. 
Principal Reference Material The above information is taken from:

- Kristensen, I. (March 1980). Description of the Netherlands Antilles Wetlands to be conserved. Caribbean Marine Biological Institute, Curaçao.

Additional references:

- de Boer, B.A. (1979). Flamingos on Bonaire and in Venezuela. STINAPA Documentation Series No. 3.

- Rooth, J. (1965). The flamingo on Bonaire. Utrecht.

\section{Klein Bonaire Island and part of the adjacent sea}

Location $12^{\circ} 10^{\prime} \mathrm{N}, 68^{\circ} 19^{\prime} \mathrm{W}$. Situated $2 \mathrm{~km}$ off the west coast of Bonaire in the Lesser Antilles (in the Caribbean of $f$ the coast of Venezuela).

Area 600 ha

Degree of Protection The island is privately owned. The surrounding sea and coastal reefs are owned by the Island Government of Bonaire, and the reefs are protected within Bonaire Underwater Park established in 1979 under the administration of the Underwater Park Board of STINAPA (Stichting Nationale Parken Nederlandse Antillen), Curaçao. Designated as a Ramsar site at the time of accession by the Netherlands on 23 May 1980.

Site Description Klein Bonaire is a small uninhabited coral island. It is flat and barren, with little topsoil supporting only sparse vegetation of shrubs and cacti. There are salinas along the southern shore, and the water is brackish for most of the year. The coral reefs surrounding the island support an extremely rich reef fauna.

International and National Importance The offshore coral reefs are of great scientific interest, supporting an abundant and species-rich reef fauna.

Changes in Ecological Character The coral reefs are damaged by illegal spear-fishing, collection of coral, boats anchoring offshore, and local oil spills.

\section{Management Practices None reported (1980)}

Scientific Research and Facilities None reported (1980)

Principal Reference Material The above information is taken from:

- Kristensen, I. (March 1980). Description of the Netherlands Antilles Wetlands to be conserved. Caribbean Marine Biological Institute, Curaçao.

Supplemented by:

- IUCN (1982). IUCN Directory of Neotropical Protected Areas. Tycooly Int. Pub. Ltd., Dublin.

- Material collected for the Directory of Coral Reefs of International Importance. IUCN Cambridge, England.

\section{Het Gotomeer}

Location $12^{\circ} 14^{\prime} \mathrm{N}, 68^{\circ} 22^{\prime} \mathrm{W}$. Situated on the north-west coast of Bonaire Island in the Lesser Antilles (in the Caribbean off the coast of Venezuela).

Area $150 \mathrm{ha}$ (within Washington-Slagbaai National Park of 5,900ha). 
Degree of Protection Owned by the Island Government of Bonaire. The lake is protected within Washington-Slagbaai National Park established in May 1969 (extended September 1977). The park is administered by the Netherland Antillean National Parks Foundation (STINAPA). Designated as a Ramsar site at the time of accession by the Netherlands on 23 May 1980.

Site Description Gotomeer is a shallow coastal lagoon isolated from the sea by a bank of beachrock (recrystallised coral debris). The water in parts of the lake is supersaline for much of the year, becoming brackish after periods of heavy rain. The evaporation is partly compensated for by a constant seepage of seawater through the beachrock barrier. Brine shrimp Artemia salina and brine fly Aphydra sp. are abundant in the supersaline areas, and constitute a valuable foodsource for birds.

International and National Importance The lake is an important feeding ground for many species of wader, red flamingo Phoenicopterus ruber ruber, herons (Ardeidae) and stilts (Recurvirostridae).

Changes in Ecological Character The BOPEC oil terminal is situated just southwest of the lake.

\section{Management Practices None reported (1980)}

\section{Scientific Research and Facilities None reported (1980)}

Principal Reference Material The above information is taken from:

- Kristensen, I. (1980). Description of the Netherlands Antilles Wetlands to be conserved. Caribbean Marine Biological Institute, Curaçao.

Supplemented by:

- IUCN (1982). Directory of Neotropical Protected Areas. Tycooly Int. Pub. Ltd., Dublin. Additional reference:

- Anon (1979). Field Guide to Washington National Park. STINAPA Documentation Series No. 9.

\section{De Slagbaai}

Location $12^{\circ} 16^{\prime} \mathrm{N}, 68^{\circ} 25^{\prime} \mathrm{W}$. Situated on the northwest coast of Bonaire Island in the Lesser Antilles (in the Caribbean off the coast of Venezuela).

Area $90 \mathrm{ha}$ (within Washington-Slagbaai National Park 5,900ha).

Degree of Protection Owned by STINAPA. The lake is protected within Washington-Slagbaai National Park established in May 1969 (extended in September 1977). The park is administered by the Netherland Antillean National Parks Foundation (STINAPA). Designated as a Ramsar site at the time of accession by the Netherlands on 23 May 1980.

Site Description Slagbaai is a shallow, landlocked lake, isolated from the sea by a bank of beachrock (recrystallised coral debris). The water in parts of the lake is supersaline for much of the year, becoming brackish after periods of heavy rain. The evaporation is partly compensated by a constant seepage of seawater through the beachrock barrier. Brine shrimp Artemia salina and brine fly Aphydra sp. are abundant in the supersaline areas and constitute a valuable foodsource for birds.

International and National Importance The lagoon is an important feeding ground for many species of wader, red flamingo Phoenicopterus ruber ruber, herons (Ardeidae) and stilts (Recurvirostridae).

Changes in Ecological Character None reported (1980) 


\section{Management Practices None reported (1980)}

Scientific Research and Facilities None reported (1980)

Principal Reference Material The above information is taken from:

- Kristensen, I. (March 1980). Description of the Netherlands Antilles Wetlands to be conserved. Caribbean Marine Biological Institute, Curaçao.

Supplemented by:

- IUCN (1982). IUCN Directory of Neotropical Protected Areas. Tycooly Int. Pub. Ltd., Dublin.

Additional reference:

- Anon (1979). Field Guide to Washington National Park. STINAPA Documentation Series No. 9.

\section{Het Spaans Lagoen}

Location $12^{\circ} 30^{\circ} \mathrm{N}, 70^{\circ} 00^{\circ} \mathrm{W}$. Situated on the south coast of Aruba Island in the Lesser Antilles (in the Caribbean off the coast of Venezuela).

Area 70 ha

Degree of Protection Owned by the Island Government of Aruba. The lagoon is protected as a Conservation Area under the administration of the Netherland Antillean National Parks Foundation (STINAPA). Designated as a Ramsar site at the time of accession by the Netherlands on 23 May 1980.

Site Description Het Spaans is a narrow coastal inlet $2 \mathrm{~km}$ long and $200-500 \mathrm{~m}$ wide, fringed by mangrove swamps and mudflats. The mangroves provide a stopover site for numerous bird species, and the lagoon is an important nursery area for fish and shrimps which are a food source for the birds.

International and National Importance The lagoon is an important resting and feeding ground for numerous bird species.

\section{Changes in Ecological Character None reported (1980)}

Management Practices None reported (1980)

Scientific Research and Facilities None reported (1980)

Principal Reference Material The above information is taken from:

- Kristensen, I. (1980). Description of the Netherlands Antilles Wetlands to be conserved. Caribbean Marine Biological Institute, Curaçao.

\section{Dutch section of the Wadden Sea}

Location $53^{\circ} 15^{\prime} \mathrm{N}, 5^{\circ} 15^{\prime} \mathrm{E}$. The marine zone situated between the mainland of the Provinces of Groningen, Friesland and Noord Holland, and the fringe of islands bordering it to the west and north from Den Helder to Borkum-Emden. The Dutch Wadden Sea is the westernmost sector of the vast complex of shallows stretching along the coast of the Federal Republic of Germany and thence north to Esbjerg on the west coast of Denmark. The Boschplaat and Griend Island are part of the Wadden Sea area.

Area 250,000 ha 
Degree of Protection Mostly state-owned (Ministry of Finance; Domeinen) but some small areas, totalling about 4,5000 ha are privately owned. The Eendracht-polder salt marshes on Texel are on a long-term lease to the Vereniging tot Behoud van Natuurmonumenten. Several areas are protected as state-owned, wardened, nature reserves: the mudflats of the Dollard (with a $14 \mathrm{~km}$ coastline), the De Band polder including some of its periphery (320ha), Bildtpolden $(3,200 \mathrm{ha})$, saltmarshes behind the Eendracht polder on Texel $(6,700 \mathrm{ha})$, Eyerlandse Gat seal reserve $(20,000 \mathrm{ha})$, Noordsvaarder $(650 \mathrm{ha})$, Boschplaat $(4,400 \mathrm{ha}$, awarded the Council of Europe's Diploma), another seal reserve south-east of Schiermonnikoog, Kobbeduinen $(2,400 \mathrm{ha})$ and Griend (23ha). The implementation of the Nature Conservation Act on 18 May 1981 resulted in the designation 150,000 ha as a national area of natural beauty. Designated as a Ramsar site on 2 May 1984.

Site Description The Dutch Wadden Sea stretches for about $200 \mathrm{~km}$ between the mainland and a string of offshore islands, from the province of North-Holland in the west, north along the Enclosure Dam and then eastwards along the coast of Friesland and Groningen to the mouth of the river Eems. Its width varies from about $30 \mathrm{~km}$ at Texel to $6-7 \mathrm{~km}$ at Ameland. Sea inlets vary in width from $3-6 \mathrm{~km}$, with depths in places of $30-50 \mathrm{~m}$. The area is an extensive, open and relatively flat region comprising open water, sandbanks, mud flats, marsh and reclaimed land. Large areas of sandbanks and mud flats on the lee side of the chain of islands become exposed at low tide, and they are dissected by a fine network of small channels. Some areas are dyked to prevent flooding, but outside the dykes the salt marshes in particular have interesting plant communities including some rare species, and there is a marked zoning of halophitic plants, related to tidal movements.

Texel, the largest of the Wadden Sea islands, has two nature reserves, De Geul en Westerduinen (1681ha) and De Muy en De Slufter (700ha). De Slufter consists of a coastal plain with mudflats and a shallow lagoon connected to the North Sea by several creeks. De Geul, at the southern end of the island, contains open dunes, wet valleys and areas of scrub and mudflats with many interesting species. Terschelling, the second largest island in the Dutch Wadden Sea, has three nature reserves: Koegelwieck (250ha), Noordvaarder (650ha) and Boschplaat (4400ha). The plant life ranges from pioneer species such as glasswort on the saltmarsh to mud rush, creeping fescue, thrift and distant sedge at the highest levels of the sandflats. Behind the dunes is a thick scrub of sea buckthorn and crowberry. In some areas there are beautiful dune valleys with orchids, dyer's greenweed, marsh gentian and impressive areas of dune heath. The flora of the reserve also includes some interesting immigrant species from the north, notably the bearberry and the chickweed wintergreen, both normally montane plants. The Noordvaarder and Koegelwieck reserves are both extensive dune valleys of sand with a low lime content, on which a rich flora has developed. The coastal strip of the mainland along the Dutch area of the Wadden Sea is an area of low population density, concentrated in the harbour towns of Den Helder (60,000 residents), Harlingen (15,000 residents) and Delfzijl (25,000 residents).

International and National Importance The Wadden Sea is ecologically the most important tidal area of Western Europe, and a vital stopover on the Western Palearctic migration route for waterfowl. From July to September the bird population in the area is greatest. On the sandbanks and saltmarshes of Texel, breeding birds include shelduck Tadorna tadorna, eider Somateria mollissima, oystercatcher Haematopus ostralegus, avocet Recurvirostra avosetta, Kentish plover Charadrius alexandrinus, terns Sterna spp., marsh harrier Circus aeruginosus and several more common species. The birdlife on Terschelling Island is extraordinarily rich. Among the less common birds breeding on the island are the Kentish plover, avocet, black-tailed godwit Limosa limosa, hen harrier Circus cyaneus, Montagu's harrier C. pygargus, spoonbill Platalea leucorodia and several species of duck including eider and pintail Anas acuta and occasionally sandwich tern Sterna sandvichensis. The reserves are also important stopovers for several species of wading birds. The Wadden Sea is an extremely important nursery and spawning ground for North Sea fish, and the only part of the Netherlands with a harbour seal colony of any size. 
Changes in Ecological Character The area is affected by mass recreation and other tourist activities; gas and oil exploitation; industrialisation at Dollarthafen; military manoeuvres; pollution by waste water; and by canal construction. It is also confronted with pollution from heavy metals, pesticides and polychorinated biphenyls absorbed by organisms of the area, resulting in the death of birds and to a decline in the reproduction of seals.

Management Practices Most reserves in the area are closed to the public, but some can be visited on guided tours. The nature reserves and the bird breeding colonies are wardened, and measures are taken to restrict the number of breeding pairs of herring gull Larus argentatus.

Scientific Research and Facilities Investigation into the hydrological, hydro-biological, floral, faunal and ecological aspects of the area have been carried out for many years and are continuing. A multidisciplinary group of scientists, the Wadden Working Group, and the Institute for Sea Research (NIOZ) on Texel in particular, have been involved in the studies undertaken for the governmental Wadden Sea Committee.

Principal Reference Material The above information is taken from the document submitted at the time of designation in May 1984

Supplemented by:

- Braakhekke, W.G. and Drijver, C.A. (1984). Wetlands importance, threats and protection. The Dutch Society for the Protection of Birds, Zeist, Netherlands.

- Bruning, H.A. (1981). Analysis of the present state of the recreational activities in the area of the Dutch Wadden Sea. Contribution to the 3rd Danish-Dutch-German symposium on environmental problems of the Wadden Sea on Norderney, October, 27th-30th, 1981.

- Carp, E. (1980). A Directory of Western Palearctic Wetlands. IUCN, Gland, Switzerland.

- Duffey, E. (1982). National Parks and Reserves of Western Europe. Macdonald and Co., London.

Additional References:

- Anon. (1974). Rapport van de Waddenzeecommissie. Staatsuitgeverij, Den Haag.

- IUCN/WWF (1983). Serious threats in the Dutch Wadden Area. Vadehaus Waddenzee Wattenmeer. Watt International Nr. 2.

- Verwey, J. et al. (1966). A plea for the Waddon Sea. Contact Committee for Nature and Landscape Preservation, Den Haag.

- Waddenzee Provinces Steering Committee (1981). The Waddenzee - on course for the future. Summary of part 4 of The Interprovincial Structure Plan for the Waddenzee region. The Structure Plan. Published jointly by the provinces of North Holland, Friesland and Groningen. 
Area $268,675 \mathrm{sq} . \mathrm{km}$

Population $3,291,300(1985)$

Summary of Wetland Situation New Zealand has a widespread, diverse range of wetland habitats, being a geologically complex archipelago which has experienced recent glacial and volcanic activity. It is in middle latitudes, and has a humid, temperate climate. Wetland communities which are particularly distinctive of the country include flax swamps of Phormium sp.; braided rivers which form good waterfowl habitat; high country with cushion bogs and tarns; salt rush and reed estuaries with Leptocarpus and Juncus spp.; and kahikatea swamp forest with Dacrycarpus dacrydoides. There is a considerable history of modification and use of wetlands. Activities such as kauri-gum digging, flax milling, land drainage, gold mining, flood control, land clearance and agricultural development have collectively contributed to their depletion. It is estimated that only $10 \%$ of the pre-European wetlands remain, and this represents less than $2 \%$ of the total land area of New Zealand. A major effort is now underway to stem the loss of wetland environments, including: ratification of a Government policy in 1986; an inventory: Wetlands of Ecological and Representative Importance (WERI) has been compiled; the provision of government financial subsidies to drain wetlands is to be phased out; and a new Department of Conservation with a mandate to conserve natural heritage will bring together several agencies with an interest in the ecology of wetlands and responsibility for their protection and management.

Protected Areas Legislation The National Parks Act (1980) contains provision for the establishment of National Parks and Special Areas within them. Scientific and Scenic Reserves are covered under the Reserves Act (1977), Wildlife Sanctuaries and Refuges under the Wildlife Act (1953) and Forest Reserves under the Forest Act (1949). Separate legislation covers the establishment of Marine Reserves (Marine Reserves Act 1971).

Protected Areas Administration National Parks and Scenic, Nature and Scientific Reserves are all administered by the Department of Lands and Survey (being the responsibility of the Director of National Parks and Reserves). The Wildlife Sanctuaries, Management Reserves and Refuges are administered by the Wildlife Service in the Department of Internal Affairs. The Maritime Parks each have their own Park Board.

Sites designated under the Convention

Signature without reservation as to ratification 13 August 1976, with two sites listed at signature.

Waituna Lagoon Scientific Reserve

Farewell Spit Nature Reserve

Government body responsible for administration of the Convention

Department of Internal Affairs, Wildlife Service, Private Bag, Wellington

\section{Waituna Lagoon Scientific Reserve}

Location $46^{\circ} 34^{\prime} \mathrm{S}, 168^{\circ} 36^{\prime} \mathrm{E}$. Located about $10.5 \mathrm{~km}$ southeast of the city of Invercargill on the southern coast of the South Island.

Area 3,556ha 
Degree of Protection Government owned. The area is is a Scientific Reserve subject to the Reserves Act 1977 and administered by the Department of Lands and Survey under the control of the Commissioner of Crown Lands, Invercargill who has established an advisory committee. Designated a Ramsar site on 13 August 1976.

Site Description The site comprises a lagoon and surrounding peat bogs on the coastal margin of a glacio-fluvial plain of quartz rich gravels. Longshore drift of sediment has created a spit barrier behind which the lagoon has formed. By impeding drainage the spit has allowed the development of thick deposits of peat which extend for some miles inland. The reserve contains over 150 species of native plants, including montane and subalpine species which are otherwise confined to mountainous areas above $900 \mathrm{~m}$ in the North Island. Other vegetation includes the peat moss communities; some stunted coastal rimu Dacrydium cupressinum forest on better drained parts of the peat; several types of lagoon edge vegetation (salt marsh and allied communities are extremely well developed in southeastern New Zealand); and coastal species along the shore. The lagoon is a trout fishery of some importance (brown trout Salmo trutta) and there was commercial eel fishing of short-finned eel Anguilla australis schmidtii and long-finned eel $A$. dieffenbachii.

International and National Importance The site is an important summer refuge and feeding area for many trans-equatorial migrants, and the only significant habitat in the far south for sooty crake Porzana tabuensis. It has 69 recorded bird species including 55 of waterfowl. Breeding birds include great cormorant Phalacrocorax carbo, little pied cormorant $P$. melanoleucos brevirostris, white-faced heron Ardea novaehollandiae, Australian bittern Botaurus stellaris poiciloptilus, black swan Cygnus atratus, Australian grey duck Anas superciliosa, New Zealand shoveler A. rhynchotis variegata, purpie swamp hen Porphyrio porphyrio melanotrus, Baillon's crake Porzana pusilla, oystercatcher Haematopus ostralegus, variable oystercatcher $H$. unicolor, banded dotteral Charadrius bicinctus, black-winged stilt Himantopus himantopus, southern black-backed gull Larus dominicanus, caspian tern Hydroprogne caspia, white-fronted tern Sterna striata and fern bird Bowdleria punctata punctata. The lagoon is the principal black swan habitat in the southern region, and probably one of the most important remaining grey duck localities in the far south. It is also an important moulting refuge for New Zealand shoveler and Baillon's crake. Visiting birds include white spoonbill Platalea leucorodia, paradise duck Tadorna variegata, grey teal Anas gibberifrons, American golden plover Pluvialis dominica, New Zealand dotterel Charadrius pluvialis obscura, far eastern curlew Numenius madagascariensis, asiatic whimbrel $N$. phacopus variegatus, bar-tailed godwit Limosa lapponica, turnstone Arenaria interpres, knot Calidris canutus, sharp-tailed sandpiper $C$. acuminata and pectoral sandpiper $C$. melanotos. The reserve is also important for its unique moorlike vegetation characterised by herbs and shrubs adapted to cold peaty conditions more and usually found in montane or subalpine conditions, and not at sea level These include Donatia novae-zelandiae cushion bog with grass lily Oreostylidium subulatum and comb sedge Carpha alpina.

Changes in Ecological Character The swamp areas are largely unaffected by artifical drainage. However, fire has periodically damaged some swamp vegetation temporarily, and some bird species have been adversely affected, particularly fern bird, although some, such as banded dotterel and whimbrel, take advantage of the bare burnt ground for breeding or roosting. Due to periodic blocking of the sea outlet, the lagoon is subject to considerable fluctuations in water level. When blocked during high rainfall periods the water floods back into marginal vegetation. If this occurs during July-November it can stimulate the breeding activity of black swan to a marked degree. However it can also be very detrimental for other species such as waders; as the mudflats are not exposed, or the small islands favoured as nesting sites for tern, oystercatcher and stilts are submerged. When tidal conditions prevail, some drying out of the marginal vegetation occurs. Blocking of the inlet also causes drainage problems on some farms close to the lagoon, and a number of farmers are requesting drainage schemes that could adversely affect the reserve. There is some pollution from adjacent farmlands via creeks draining into the lagoon. The reserve lies near (and possibly over) extensive lignite coal fields, which are being investigated for possible exploitation. 
Management Practices These include the preservation of flora and wildlife, and fishing and shooting are controlled. Periodic opening of the tidal inlet through the shingle bar is carried out to facilitate lagoon drainage. Entry to the reserve is not restricted and there is limited hut accommodation but the relative isolation and difficulty of access ensure minimum disturbance. A management plan has been almost completed.

Scientific Research and Facilities There are annual bird checks by the Ornithological Society. A survey of the vegetation was carried out in 1967. There is a bird ringing station.

Principal Reference Material The above information is taken from documents provided by the New Zealand Government for designation in 1976 and for the Cagliari Conference in November 1980.

Additional references:

- Kelly, G.C. (1967). Proposal for a wetland reserve adjacent to Waituna Lagoon. Toetoes

Bay Southland Dept. Lands and Survey, Private Bag, New Zealand.

- Sutton, R.R. (1967). Whimbrels at Lake Waituna, Southland. Notornis 14(1): 34.

- Sutton, R.R. (1967). Sanderlings at Lake Waituna, Southland. Notornis 14(2): 83.

\section{Farewell Spit Nature Reserve}

Location $40^{\circ} 30^{\prime}-40^{\circ} 36^{\prime} \mathrm{S}, 172^{\circ} 46^{\prime}-173^{\circ} 05^{\prime} \mathrm{E}$. Located $38 \mathrm{~km}$ from the town of Takaka in Nelson district at the north-west extremity of the South Island.

Area $11,388 \mathrm{ha}$

Degree of Protection Government owned. The area is a Nature Reserve subject to the Reserves Act 1977, and is administered by the Department of Lands and Survey under control of the Commissioner of Crown Lands, Nelson. Day-to-day management is by the Abel Tasman National Park Board. It has been a protected area since 1938 when almost all the land ( 1,961 ha) above high-tide level was set aside as a Flora and Fauna Reserve, and all the area uncovered at low tide $(9,360 \mathrm{ha})$ was set aside as a Sanctuary for the Preservation of Wildlife. Designated a Ramsar site on 13 August 1976.

Site Description Farewell Spit is a classic recurved spit, composed predominantly of uniform quartz sand derived from rivers draining westwards and transported northward by the westland current. The subaerial part of the spit averages about $1 \mathrm{~km}$ in width, and extends for about $22 \mathrm{~km}$ eastwards into Golden Bay. It is reported to be extending eastwards by $15 \mathrm{~m}$ annually. At low tide, sandflats and salt marsh extend for about $6 \mathrm{~km}$ to the south of the spit. Along the northern coast there is a succession of fairly stable barchans up to $27 \mathrm{~m}$ height (a dune formation rare in New Zealand). The interdune areas contain a series of damp hollows and small lakes, some of which have fresh water and may be semi-permanent. The dry land areas are almost totally transformed from original light coastal bush, scrub and native grasses, to a predominantly exotic cover dominated by marram grass Ammophila arenaria and lupin Lupinus arboreus, but with some native manuka Leptospermum scoparium, kanuka L. ericoides, flax Phormium tenax, bracken Pteridium aquilinum var esculentum, sedges Carex $\mathrm{Sp}$. and herbs. Isolated regeneration forest species include the native kaitomako Pennantia corynbosa, rimu Dacrydium cupressinum and some small akeake Dodomaea viscosa. The dune hollows and small lakes contain milfoil Myriophyllum sp., Glossostigma elatinoides, Limosolla tenuifolia, Lilaeopsis orbiculatus, sand gunnera Gunnera arenaria, sedges Carex sp. and rushes Juncus spp. The saltmarsh follows a classical development, with eelgrass Zostera sp. at the lower limit, then distinct zones of glasswort Salicornia sp., sea rush Juncus maritimus var australiensis and jointed rush Leptocarpus simplex and finally a zone of flax near the dunes.

International and National Importance The spit is of national and international importance for many of the 18 migratory species of bird which breed in arctic and sub-arctic regions but spend the northern winter feeding throughout coastal New Zealand, parts of Australia and the South Pacific. These number up to 46,000 , with $99 \%$ comprising red knot Calidris canutus, bar-tailed godwit Limosa lapponica and turnstone Arenaria interpres. New Zealand is the 
major overwintering area for bar-tailed godwit and red knot. The site also supported in 1967 a total of 5,500 birds of eight species breeding inland in New Zealand and returning to the coast for late summer, autumn or winter, dominated by oystercatcher Haematopus ostralegus, banded dotterel Charadrius bicintus and black-billed gull Larus bulleri. Up to 10,000 black swan Cygnus atratus are also present, with up to $15 \%$ of the New Zealand population using the area as a moulting refuge. Twenty-nine other resident and breeding species include variable oystercatcher Haematopus unicolor and caspian tern Sterna caspia. About 10 other species are observed in small numbers but not breeding. 95 bird species were recorded on the spit in March 1974.

Changes in Ecological Character In 1975 all cattle and sheep were removed from the spit, and since then, despite the presence of some deer, the natural vegetation has begun to regenerate, including golden pingao Desmoschoenus spiralis which, in the absence of introduced marram grass, would be one of the chief sand-binders. There is evidence to suggest that this species is now competing successfully with marram grass. There are still problems with invasion of other introduced species such as gorse Ulex europeus, blackberry Rubus fruticosus and cordgrass Spartina sp. There is some damage and disturbance from off-road vehicles such as dune buggies and trail bikes.

Management Practices Measures are being taken to eradicate introduced plant species. Access is by permit only. A management plan has been recently completed for the reserve.

Scientific Research and Facilities Waterfowl research including periodic bird censuses. Colour infra-red analysis of Farewell Spit vegetation has been investigated during 1985.

Principal Reference Material The above information is taken from documents supplied by the Government of New Zealand for designation in 1976 and for the Cagliari Conference in November 1980.

Additional references:

- Barlett, R.M. (1985). Farewell Spit Vegetation - Colour Red Analysis. Department of Lands and Survey, unpublished.

- Kelly, G.C. (1972). Farewell Spit science and allied reserves report. Dept. Lands Survey, Botany Division, Private Bag, New Zealand.

- Simpson, M.J.A. (1973). Farewell Spit: Valuable sanctuary and interesting botanical study. Forest and Bird 190: 19-21. 
Summary of Wetland Situation With its long, rugged coastline, fiords, multitude of large and small islands, watercourses, lakes and vast mires, Norway offers excellent breeding, moulting and roosting areas for a great variety fo migrating waterfowl. The coastal waters and some of the lakes in the southern part of the country also provide important wintering grounds for many of the more northerly breeding species. Norway is of great scientific interest geologically, and many of the lakes, fiords and other water bodies are of international importance for limnological research.

The principal Conservation Authority in Norway is the Directorate for Nature Management under the Ministry of the Environment. A special working group for Scandinavian co-operation in the field of international nature conservation has drawn up a list of 40 wetland sites in Norway and seven more in Svalbard, which are deemed to be of outstanding importance. Since the early 1970s the Ministry of the Environment has initiated systematic surveys of wetlands, mires and breeding sites of importance to seabirds. Based on these surveys, plans for the establishment of nature reserves have been published county by county. 79 wetland areas (305 sq. km.), 120 mires (197 sq.km.) and 196 seabird colonies (204 sq.km.) are protected as nature reserves (1985).

Protected Areas Legislation A wide range of long-term planning and protective measures intended to preserve the quality of life for the future, are laid down in legislation. The Planning and Building Act (1985) specifies that nature conservation interests must be taken into account in the planning process. The Nature Conservation Act of 1970, which is administered by the Ministry of the Environment, constitutes the legal base for the establishment of National Parks, Nature Reserves, and Protected Landscapes. Decisions to designate protected areas under the Nature Conservation Act are made by the government. Strict regulations are given for National Parks and Nature Reserves, including a ban on hunting and public access in most wetlands reserves. In addition the Wildlife Act (1981) provides for the protection of habitats of importance to wildlife.

Protected Areas Administration The County Governors (on the Mainland) and Governor of Svalbard (on Svalbard) are the local management authorities for the protected areas. Physical management takes place in a few nature reserves, but in most areas the policy remains to let nature evolve without intervention (most of the ecosystems being relatively undisturbed by man). Research tends to be directly related to management problems or conservation objectives.

\section{Sites designated under the Convention}

Signature without reservation as to ratification 9 July 1974, with one site listed at signature and another 13 added 24 July 1985.

Akersvika Nature Reserve (Banks of Lake Mjosa)

Ora Nature Reserve

Kuref jorden Nature Reserve

Nordre Oyeren Nature Reserve

Ilene and Presterodkilen Wetland system

Jaeren Wetland system

Orlandet Wetland system

Tautra and Svaet Nature Reserve

Stabbursneset Nature Reserve

Forlandsoyane Bird Sanctuary

Dunoyane Bird Sanctuary 
Kongsf jorden Bird Sanctuary

Isoyane Bird Sanctuary

Gasoyane Bird Sanctuary

Government bodies responsible for administration of the Convention

Ministry of Environment, P.O. Box 8013 - Dep. N-0030, Oslo 1.

Directorate for Nature Management, Turgasletta 2, N-7000 Trandhiem.

\section{Akersvika Nature Reserve}

Location $60^{\circ} 50^{\prime} \mathrm{N}, 11^{\circ} 08^{\prime} \mathrm{E}$. Situated on Lake Mjosa near the town of Hamar in Hedmark County.

Area 415 ha (300ha lake surface)

Degree of Protection The man-made area of the reserve is privately owned by 32 individuals and a local municipality. The area was established as a Nature Reserve in July 1974. Designated as a Ramsar site in July 1974 as a site of 300 ha, and extended as a Ramsar site in July 1985.

Site Description The site comprises a shallow bay on the eastern side of the freshwater Mjosa Lake, and includes the lower part of one of the two rivers entering the bay. It is surrounded by urban, industrial and agricultural land. The vegetation is strongly influenced by the regulation of water-levels in Lake Mjosa. The vegetation in the reserve is wet grassland, and alder Alnus sp. and willow Salix sp. scrub. Willow also occurs along the shore with broad zones of bladder sedge Carex vesicaria, Carex juncella and the grass Calamagrostis purpurca and several species of Salix. Near the shore the vegetation is dominated by the moss Fontinalis hypnoides.

International and National Importance The site is of special importance to migrating ducks and waders, being an important part of the eastern flyway for waterfowl in Norway. About 190 species have been observed here, of which $60-70$ are wetland species.

Changes in Ecological Character In early 1984 the reserve was extended from 300 ha to 415 ha. During the last 10 years there has been some expansion of alder and willow species into former grassland, due to a reduction in grazing. The National Report (1980) reported a proposal to locate a waste recycling plant near the reserve, but the decision on this is unknown. There are also threats from potential road building projects. Due to changes in the control of pollution, the water quality in Lake Mjosa has improved since the mid-1970s, but the situation is still not satisfactory.

Management Practices A management plan is being prepared, based on the results of a botanical study initiated in 1980, and ornithological studies. An observation tower was raised in May 1985, and public infermation improved.

Scientific Research and Facilities Surveys on wildlife have been undertaken and a botanical study was initiated in 1980, and finished in 1983. A detailed vegetation map was produced.

Principal Reference Material The above information is taken from documents supplied by the Government of Norway for designation in 1974 and from the Norwegian National Report to the Cagliari Conference in November 1980 and to the Groningen Meeting in May 1984.

\section{Ora Nature Reserve}

Location $59^{\circ} 10^{\prime} \mathrm{N}, 11^{\circ} 00^{\prime} \mathrm{E}$. Situated at the outlet of River Glomma at Fredrikstad, Ostfold County. 
Degree of Protection Most of the area is owned by the Fredrikstad municipality. Ora was established as a nature reserve in September 1979, under local administration of the Ostfold County Governor. Strict regulations prevent human activity, including building, hunting, and drainage, as well as visiting in two key resting areas in spring and autumn, and in a few breeding localities for gulls, etc. Designated as a Ramsar site in July 1985.

Site Description The reserve comprises a large estuary, formed by the outlet of River Glomma. There are lots of small, granitic islands, of ten with large areas of fluvial sediments. Except a few deep channels, most of the sea area comprises shallow water. Reed areas cover extensive parts of the estuary.

International and National Importance Very important resting and wintering area for ducks, swans and waders. More than 500 whooper swans Cygnus cygnus and 500 mute swans $C$. olor have been observed in one day. In autumn, large numbers of mallard Anas platyrhychos and teals $A$. crecca forage in the shallow areas, whereas goldeneyes Bucephala clangula occurs in large numbers in late winter. The most numerous wader species are the dunlin Calidris alpina and the ruff Philomachus pugnax. More than 220 bird species have been registered in the area, of which 67 species are waterfowl. Many threatened species are regularly observed in the Ora Estuary. Breeding species include black-tailed godwit Limosa limosa and dunlin Calidris alpina, and Caspian tern Hydroprogne tschegrava was found breeding a few years ago.

Changes in Ecological Character Due to building of a large stone pile along the river course in 1974, salinity of the water within the estuary increased gradually for some years. The increased salinity led to great ecological changes, and in particular a few dominant bottom plants nearly disappeared. To protect the estuary, it was decided to remove the stone pile, and to secure supply of fresh water by building a channel from the river into the estuary. It is not yet clear whether these measures have served to improve the flora and fauna situation. The estuary is also subjected to pollution from the River Glomma, and the situation is under continual supervision by the Norwegian State Pollution Control Authority.

Management Practices No management measures have so far been taken in the area.

Scientific Research and Facilities Extensive zoological, botanical geophysical research has been carried out in the reserve. No facilities are available. In 1986, a research project was carried out on the ecological status of the area, in order to show the effects of the channel from the river into the estuary.

Principal Reference Material The above information is taken from documents supplied by the Government of Norway for designation in July 1985.

Additional references include the publications of the Zoological Museum, Oslo, and the local ornithological society, and:

- Krohn, O. (Ed.) (1981). Ora Naturreservat. Ostlandske Naturvernforenings Smaskrifter 11: $1-60$.

\section{Kurefjorden Nature Reserve}

Location $59^{\circ} 30^{\prime} \mathrm{N}, 11^{\circ} 00^{\prime} \mathrm{E}$. Situated on the eastern coast of the Oslo Fjord in Ostfold County.

Area $400 \mathrm{ha}$ (30ha land area)

Degree of Protection Privately owned, with 25 individual owners. Kurefjorden was established as a nature reserve in December 1978. Strict regulations prevent human activity, including building, hunting, drainage etc. Visits are forbidden in two key bird resting areas in spring and autumn. Designated as a Ramsar site in July 1985. 
Site Description The reserve covers a shallow marine bay on the Oslo Fjord coast, mainly surrounded by agricultural land. Land vegetation is dominated by wet grassland, whereas mudflats are covered by Salicornia europaea. Zostera marina and Ruppia spp. cover extensive parts of the shallow bottom areas.

International and National Importance Kuref jorden is one of the most important resting areas for migrating waterfowl at the Oslo Fiord. The most numerous species are mallard Anas platyrhynchos, teal A. crecca, goldeneye Bucephala clangula, dunlin Calidris alpina and ruff Philomachus pugnax. More than 2000 ducks and 1000 waders are observed in autumn, and more than 200 bird species have been registered. More than 60 species of waterbirds are annually observed, among them several threatened species.

Changes in Ecological Character None recorded within the reserve, but extensive drainage projects have recently been completed in the surrounding area, for agricultural purposes.

\section{Management Practices None}

Scientific Research and Facilities Extensive zoological and botanical studies have been carried out in the reserve.

Principal Reference Material The above information is taken from documents supplied by the Government of Norway for designation in July 1985.

Additional references include unpublished and published records in Department of Zoology, University of Oslo, and the local ornithological society, and:

- Lagbu, O. and Rosnes, A. (1982). Kurefjorden 1973-1978. O1 nitologiske undersokelser og utviklingen i omradet. Ost fold-Natur 10: 1-84.

\section{Nordre Oyeren Nature Reserve}

Location $59^{\circ} 53^{\prime} \mathrm{N}, 11^{\circ} 09^{\circ} \mathrm{E}$. Situated in the northern part of Lake Oyern in Akershus County, $20 \mathrm{~km}$ east of Oslo.

\section{Area 6,260 ha $(5,510$ lake surface $)$}

Degree of Protection Mostly privately owned. The area was established as a Nature Reserve in December 1975, under local administration of the Oslo and Akershus County Governor. Strict regulations prevent human activity, but maintenance of agriculture, and outdoor recreation such as boat traffic, fishing and regulated hunting for ducks are possible.

Site Description The reserve comprises the largest inland delta in Scandinavia, formed by the outlets of the Rivers Glomma, Leira and Nitelva. The delta consists of flat accumulated islands and land tongues, with varying degree of vegetation. In front of the delta the lake is shallow, more than 50 sq. $\mathrm{km}$ has a depth of less than $5 \mathrm{~m}$. The vegetation in Nordre Oyern is a mixture of the deciduous forest, salix-scrub, grassland, cultivated ground and helophyte vegetation. Recently formed islands lack vegetation.

International and National Importance Nordre Oyeren is one of the most important resting area for swans, ducks and waders in southern Norway. As many as 100 species of waterfowl have been recorded in the reserve. In early winter more than 1000 whooper swans Cygnus cygnus may be seen in the delta, and in spring and autumn shallow areas function as feeding grounds for huge numbers of mallard Anas platyrhynchos, teal $A$. crecca, wigeon $A$. penelope, goldeneye Buchephala clangula and goosander Mergus merganser. The most characteristic waders are ruff Philomachus pugnax, lapwing Vanellus vanellus and dunlin Calidris alpina. Nordre Oyeren is one of only a few few breeding sites for black-tailed godwit Limosa limosa in this part of Norway.

\section{Changes in Ecological Character None recorded}


Management Practices A plan for management of the area has been worked out. The administration practices controlled burning and exclusion of scrubs for maintaining the variation of different biotopes. However, structural changes in agricultural practice have made practical management of the area more difficult. Burning of scrub and mowing are practised as experiments. To protect the bird populations, regulations and reductions in the hunting for ducks has been established.

Scientific Research and Facilities Zoological, botanical and limnological studies are carried out in the Reserve. No facilities are available.

Principal Reference Material The above information is taken from documents supplied by the Government of Norway for designation in July 1985.

Additional references:

- Publication of the Norges Landbrukshoyskole and the Zoologisk Museum, Oslo.

- Nordre Oyeren Fuglestasjon 1979: "Nordre Oyeren - rapport 1976" pg. 139

- Nordre Oyeren Fuglestasjon 1984: "Nordre Oyeren - rapport 1977-1983" pg. 105.

- Annual reports from Avlopssambandet Nordre Oyeren (ANO) Reports from Norwegian Institute for Water Research (NIVA).

Ilene and Presterodkilen Wetland System

Location $59^{\circ} 15^{\prime} \mathrm{N}, 10^{\circ} 20^{\prime} \mathrm{E}$. Situated on the western coast of the Oslo Fiord, at Tonsberg in Vestfold County.

Area $177 \mathrm{ha}(45 \mathrm{ha}$ land area)

Degree of Protection Most of the areas are in private ownership, with 15 individual owners. Established as nature reserves in 1969 (Presterod-kilen) and 1981 (Ilene), under local administration of the County Govenor. Strict regulations prevent human activity, including building, hunting, drainage etc. Designated as a Ramsar site in July 1985.

Site Description Shallow marine bays with mud flats, at Tonsberg. Ilene has a mosaic landscape with reed areas, meadows, pastures and spruce forests. Presterodkilen is surrounded by belts of reeds, and is more urbanized than Ilene.

International and National Importance More than 55 species of waterfowl have been recorded in the area. Ilene/Presterodkilen is one of the most important resting areas for migrating waterbirds at the Oslo Fiord coast, especially for waders and dabbling ducks. Teal, mallard, mute swan, dunlin, ruff and lapwing (Anas crecca, A. platyrhynchos, Cygnus olor, Calidris alpina, Philomachus pugnax and Vanellus vanellus) are the most numerous species. Several threatened species are regularly found in the area, and dunlins breed annually.

Changes in Ecological Character Large areas in the surroundings of Ilene were drained for agricultural purposes before the reserve was established.

Management Practices None at present. An information centre and observation tower will be established at Ilene.

Scientific Research and Facilities Extensive ornithological studies including ringing of waders and passerines take place in the reserve.

Principal Reference Material The above information is taken from documents supplied by the Government of Norway for designation in July 1985.

Additional references include published and unpublised records made by the local ornithological society. 


\section{Jaeren Wetland System}

Location $58^{\circ} 50^{\prime} \mathrm{N}, 5^{\circ} 34 \mathrm{E}$. Comprising several separate lakes, shallow sea areas and sea shores, west and south of the City of Stavanger, in the Jaeren area, Rogaland County, south-west Norway.

Area Approximately $400 \mathrm{ha}$ (excluding sea area) are at the moment under legal protection.

Degree of Protection Mostly privately owned. One important area of the wetland system, Grudevatnet, was established as a nature reserve in July 1974, whereas Kolnes, Revtangen and Skeie received landscape protection and bird life protection in September 1977. These areas are under strict regulations preventing human activities such as building, hunting, drainage etc. Planning is in progress to put other important parts of the wetland system under legal protection, (e.g. Hafrsfjord, Orrevatnet, Ergavatnet og Soylandsvatnet). The Jaeren wetland system was designated as a Ramsar site in July 1985.

Site Description The Jaeren area has a gently undulating landscape, mainly build-up by moraine soil. Jaeren is one of the main agricultural districts in Norway, with the northern parts having a more urban character. The lakes are eutropic, mainly due to influence of pollution from agricultural areas, resulting in rich aquatic vegetation. Reed Phragmites communis and Sedge Scirpus spp. are wide-spread in most lakes, and Salix shrub is also common. The coastline comprises both sand dune shores and shores, consisting of pebbles and boulders.

International and National Importance Jaeren is the most important resting and wintering area for waterfowl in south-west Norway. More than 10,000 individuals are regularly seen in the area in winter. Several threatened species breed and rest in the area, and more than 250 species have been recorded. Large numbers of ducks use the area in autumn and winter, with mallard Anas platyrhynchos being the most common species. Thousands of arctic waders rest in the area, especially during autumn migration.

Changes in Ecological Character Pollution has intensified growth of aquatic vegetation, which may change the habitat considerably within a few years. Pollution has also resulted in more or less yearly blooms of blue-green algae, some of which are toxic. The potential effects on bird life are not yet known.

Management Practices A plan for management of the Grudevatn nature reserve has been worked out, but no practical measures have so far been taken.

Scientific Research and Facilities Extensive ornithological studies have been made in the area, including regular winter counts of waterfowl. Stavanger Museum runs a bird ringing station at Revtangen.

Principal Reference Material The above information is taken from documents supplied by the Government of Norway for designation in July 1985.

Additional references include published and unpublished recordings made by the Department of Zoology, Stavanger Museum and the local ornithological society, and:

- Byrkjedal, I. and Eldoy, S. (1980). Bestanden av ender, svaner og sothons pa Jaeren gjennom vinterhalvaret i tiarsperioden $1965 / 66$ - 1974/75. Fauna norv. Ser. C. Cinclus 3: 36-48.

- Byrkjedal, I. and Eldoy, S. (1981). Forekomsten av gjess pa Jaeren - vinterbestand i perioden 1963/64 - 1979/80 og variasjoner gjennom aret. Stav. Mus. Arb. 1980: 31-39.

- Eldoy, S. (1980). Grundevatnet Nature Reserve. Stav. Mus. Arb. 1979: 79-102.

- Eldoy, S. (1981). Jaerstrendene landskapsvernomrade. Stav. Mus. Arb. 1980: 53-76.

- Lye, K.A. (Ed.) (1978) Naturmil joet Jaerboka 2: 263-274. Stavanger. 


\section{Orlandet Wetland System}

Location $63^{\circ} 42^{\prime} \mathrm{N}, 9^{\circ} 35^{\prime} \mathrm{E}$. Four wetland areas at the Trondelag coast, Sor-Trondelag County, Central Norway. The four areas are Grandefjaera nature reserve, Krakvagsvaet, Innstrandf jaera and Hovsf jaera Bird Sanctuaries.

Area 2,920ha (87ha land area).

Degree of Protection Most of the area is in private ownership, with some 97 different owners. The areas were placed under protection in December 1983, and are under the local administration of the Sor-Trondelag County Governor. Strict regulations prevent human activity such as building, hunting, and drainage. Designated as a Ramsar site in July 1985.

Site Description Orlandet wetland system comprises four areas, mainly consisting of large tidal mud flats and shallow marine water. Belts of seaweed form the outer edge of the tidal zone. Large areas with meadows and marsh land used to make up the inner part of the shore, but most of these areas have recently been drained for agricultural purposes.

International and National Importance Orlandet wetland system is the most important resting and wintering area for wetland birds in Central Norway. Large numbers of ducks and waders have been observed in autumn and winter, with common eider Sommateria mollissima, velvet scoter Melanitla fusca, purple sandpiper Calidris maritima and dunlin C. alpina the most numerous species. More than 70 different species of wetland birds have been recorded, and several threatened species are regularly observed in the areas.

\section{Changes in Ecological Character None recorded}

Management Practices No information

Scientific Research and Facilities Ornithological studies have been conducted by Department of Zoology, DKNVS Trondheim Museum, and by the local ornithological society. No facilities are available.

Principal Reference Material The above information is taken from documents supplied by the Government of Norway for designation in July 1985.

Additional references:

- Bevanger, K. and Frengen, O. (1979). Ornitologiske verneverdier i Orland kommunes vatmarksomrader, Sor-Trondelag. K. norske Vidensk. Selsk. Mus. Rapport Zool. 1: 1-93.

\section{Tautra and Svaet Nature Reserve}

Location $63^{\circ} 35^{\prime} \mathrm{N}, 10^{\circ} 37^{\prime} \mathrm{E}$. Situated in the Trondheim Fiord, at the southern point of the Frosta peninsula, Nord-Trondelag County, Central Norway.

Area 2,054 ha (174ha land area).

Degree of Protection Most of the area is in private ownership, with 20 owners. Established as a nature reserve in 1984, under local administration of the County Governor. Strict regulations prevent human activity, including building, hunting, and drainage, in two smaller reserve areas, whereas there is less regulation of activity within the two larger bird sanctuaries. In the nature reserves public access is prohibited part of the year. Designated a Ramsar site in July 1985.

Site Description Large, flat island surrounded by shallow marine water. The northern part is dominated by cultural landscape, with farms, houses, roads etc. Most of the southern part is agricultural land, with a small, eutrophic pound. The southern point is dominated by spruce wood and juniper shrub. 
International and National Importance Tautra is of considerable importance as a breeding and resting area for waterfowl. Common eider Somateria mollissima and velvet scoter Melanitta fusca are the predominant duck species, and oystercatcher Haematopas ostralegus, dunlin Calidris alpina little stint C. minuta and ringed plover Charadrius hiaticula are the most numerous wader species.

Changes in Ecological Character The island is now connected to the mainland by a stone pile. This has made it possible for the mink Mustela vison, pine marten Martes martes and the fox Vulpes vulpes to reach the island, and as a consequence nest predation has increased considerably.

Management Practices No measures have been taken so far, except a few trials to reduce numbers of predators on the island.

Scientific Research and Facilities Extensive ornithological research has been carried out in the reserve.

Principal Reference Material The above information is taken from documents supplied by the Government of Norway for designation in July 1985.

Additional references:

- Suul, J. and Frengen, O. (1976). Notat om fuglefaunaen pa Tautra, Frosta kommune, Nord-Trondelag. DKNVS museet i Trondheim.

\section{Stabbursneset Nature Reserve}

Location $70^{\circ} 10^{\prime} \mathrm{N}, 24^{\circ} 40^{\prime} \mathrm{E}$. Situated on the west coast of the inner part of Porsanger Fiord, Finnmark County, northern Norway.

Area $1,620 \mathrm{ha}(22 \mathrm{ha}$ land area)

Degree of Protection Parts of the area are in private ownership, with five individual owners. Stabbursnes Nature Reserve was established in December 1979. Strict regulations prevent human activity, such as building, hunting, and drainage. Visitors are not permitted in parts of the reserve in the spring. Designated as a Ramsar site in July 1985.

Site Description Stabbursneset is part of an estuary situated at the outlet of Stabburselva. Most of the area consists of shallow marine water, with sand banks exposed at low tide. The land area is covered by salt marshes, with wet mires in the inner part.

International and National Importance Stabbursneset is very important as a resting area during migration, and as a moulting area for waterfowl, and is also botanically important because of its shore meadows containing arctic plant associations and species. More than 30,000 knots Calidris canutus have been observed in the area in May. Other numerous species are dunlin $C$. alpina and bar-tailed godwit Limosa lapponica. Little stint $C$. minutus has been found breeding. Common eider Somateria mollissima is the predominant species moulting in the area, with more than 5000 individuals recorded in July. In addition, large numbers of velvet scoter Melanitta fusca have been recorded. The area is a regular resting site for lesser white-fronted goose Anser erythropus in the spring (30-50 individuals).

\section{Changes in Ecological Character None recorded}

Management Practices No measures have been taken.

Scientific Research and Facilities The area is not well studied yet, and only irregular observation activity has been conducted. No facilities are available.

Principal Reference Material The above information is taken from documents supplied by the Government of Norway for designation in July 1985. 


\section{Forlandsoyane Bird Sanctuary}

Location $78^{\circ} 20^{\prime} \mathrm{N}, 11^{\circ} 36^{\prime} \mathrm{E}$. Situated on the west side of Spitsbergen.

Area About 60 ha

Degree of Protection The area is owned by the Norwegian state, and was established as a bird sanctuary in June 1973 under local administration of the Governor of Svalbard. Strict regulation prevent human activity, including building, hunting, and drainage. Designated as a Ramsar site in July 1985.

Site Description The reserve is situated on three islands and a few small skerries. One island is completely bare, the two others are grassy islands with small ponds.

International and National Importance Breeding site for three geese species, barnacle goose Branta leucopsis (500-600 pairs), brent goose $B$. bernicla (5-10 pairs) and pink-footed goose $A$. brachyrhynchos (20-30 pairs), and a large colony of common eider Somateria mollissima (500-1000 pairs).

Changes in Ecological Character No changes have occurred in the biotope. The common eider population has decreased considerably since the turn of the century when $10-11,000$ pairs bred. This is due mostly to egg and down collection.

Management Practices No management measures have so far been taken.

Scientific Research and Facilities Some zoological research has been carried out in the sanctuary. No facilities are available.

Principal Reference Material The above information is taken from documents supplied by the Government of Norway for designation in July 1985.

Additional references include the publications of the Norwegian Polar Research Institute.

\section{Dunoyane Bird Sanctuary (Spitsbergen)}

Location $77^{\circ} 04^{\prime} \mathrm{N}, 15^{\circ} 00^{\prime} \mathrm{E}$. Situated at the southern point of Spitsbergen.

Area 120ha

Degree of Protection The area is owned by the Norwegian state, and was established as a bird sanctuary in June 1973 under local administration of the Governor of Svalbard. Strict regulations prevent human activity, including building, hunting, and drainage. Designated as a Ramsar site in July 1985.

Site Description Three islands and a number of small islets. The islands have rich, grassy vegetation and several freshwater ponds, whereas the islets are barren and rocky.

International and National Importance Dunoyane is one of the most important breeding and moulting areas for barnacle goose Branta leucopsis and common eider Somateria mollissima (about 500 pairs) on Spitsbergen.

\section{Changes in Ecological Character None recorded}

Management Practices No management measures have been taken.

Scientific Research and Facilities Some zoological research has been carried out in the sanctuary. No facilities are available. 
Principal Reference Material The above information is taken from documents supplied by the Government of Norway for designation in July 1985.

Additional references include the publications of the Norwegian Polar Research Institute.

\section{Kongsfjorden Bird Sanctuary (Spitsbergen)}

Location $78^{\circ} 55^{\prime} \mathrm{N}, 12^{\circ} 10^{\prime} \mathrm{E}$. Situated on the north-western part of Spitsbergen, at Ny-Alesund.

Area About 140 ha

Degree of Protection The area is owned by the Norwegian state, and was established as a bird sanctuary in June 1973 under local administration of the Governor of Svalbard. Strict regulation prevent human activity, including building, hunting, and drainage. Designated as a Ramsar site in July 1985.

Site Description Consists of about 10 islands of various size. Most of the islands have rich, grassy vegetation, except two islands which until recently were covered by ice. Small freshwater ponds are found on some islands.

International and National Importance The area has a very dense breeding population of common eider Somateria mollissima (3000-4000 pairs), and large numbers rest in the area before the breeding season.

Changes in Ecological Character Human activity and increased tourism have resulted in reduced breeding populations of the common eider.

Management Practices No management measures have been taken.

Scientific Research and Facilities Extensive zoological research has been carried out in the sanctuary. Modern research facilities are available in $\mathrm{Ny}$-Alesund.

Principal Reference Material The above information is taken from documents supplied by the Government of Norway for designation in July 1985.

Additional references include publications of the Norwegian Polar Research Institute.

\section{Isoyane Bird Sanctuary (Spitsbergen)}

Location $77^{\circ} 08^{\prime} \mathrm{N}, 14^{\circ} 48^{\prime} \mathrm{E}$. Situated in the south-western part of Spitsbergen.

Area $30 \mathrm{ha}$

Degree of Protection The area is owned by the Norwegian state, and was established as a nature reserve in June 1973 under local administration of the Governor of Svalbard. Strict regulation prevent human activity, including building, hunting, and drainage. Designated as a Ramsar site in July 1985.

Site Description The site consists of two islands, of which the northern one has rich, grassy vegetation and small freshwater ponds. The southern island has less developed vegetation.

International and National Importance Among the more important breeding localities for the barnacle goose Branta leucopsis on Spitsbergen.

Changes in Ecological Character None recorded

Management Practices No management measures have been taken. 
Scientific Research and Facilities Extensive zoological research has been carried out in the sanctuary. No facilities are available.

Principal Reference Material The above information is taken from documents supplied by the Government of Norway for designation in July 1985.

Additional references include the publications of the Norwegian Polar Research Institute.

\section{Gasoyane Bird Sanctuary (Spitsbergen)}

Location $78^{\circ} 20^{\prime} \mathrm{N}, 11^{\circ} 36^{\prime} \mathrm{E}$. Situated on the west side of Spitsbergen, on three islands in the Billef jord area.

\section{Area About 100ha}

Degree of Protection The area is owned by the Norwegian state, and was established as a bird sanctuary in June 1973 under local administration of the Governor of Svalbard. Strict regulations prevent human activity, including building, hunting, and drainage. Designated as a Ramsar site in July 1985.

Site Description Three small islands, partly vegetated and with a few freshwater ponds. Parts of the shoreline have cliffs, giving possibility for nesting by seabirds (e.g. puffin Fraterula arctica).

International and National Importance The sanctuary has a large breeding population of barnacle goose Branta leucopsis, common eider Somateria mollissima and arctic tern Sterna paradisnea.

Changes in Ecological Character No changes have occurred in the biotope. Due to the short distance to Longyearbyen, egg and down collection has been a serious disturbance to the common eider population.

Management Practices No management measures have so far been taken.

Scientific Research and Facilities Some zoological research has been carried out in the sanctuary. No facilities are available.

Principal Reference Material The above information is taken from documents supplied by the Government of Norway for designation in July 1985.

Additional references include the publications of the Norwegian Polar Research Institute. 


\section{PAKISTAN}

\section{Area 803,941 sq. $\mathrm{km}$}

\section{Population $84,250,000(1981)$}

Summary of Wetland Situation Most of the natural lakes in this predominantly semi-arid and arid country have disappeared over the last fifty years, as a result of irrigation projects and drainage aimed at providing more arable land for food production. However, several new lakes have been created upstream of dams constructed in recent years on the River Indus (water for human consumption as well as for irrigation). Some have become very important wintering areas for waterfowl, and these and other wetlands, particularly in the great valleys of Sind and Punbjab, are feeding grounds for huge concentrations of Anatidae and also for coots. Elsewhere, the mudflats and mangrove vegetation along the coast of the Arabian Sea provide particularly favourable habitat for herons, ibises and pelicans, as well as great numbers of waders.

The Government is well aware of the rich natural resources represented and indicated by these birds, and has developed an active conservation policy. The Forest Department and the Sind Wildlife Management Board have been particularly active in the creation of protected areas, and many of the state-owned lakes have become Game Sanctuaries. Such natural lakes as survive are of ten in private ownership, but they are generally used for hunting on only a few days a year. They are generally well managed, and are kept free from disturbance for the rest of the year.

Several wetlands in the Punjab are of importance to threatened species. Thus the white-headed duck Oxyura leucocephala winters in some numbers on Lake Khabbaki, Lake Nemal Game Sanctuary and the Kharrar Lake Wildlife Sanctuary. The bar-headed goose Anser indicus seems to have its main wintering area in Pakistan at Taunsa Barrage Wildlife Sanctuary and at Chastima Lake Wildlife Sanctuary. Other areas with notable concentrations of a wide variety of waterfowl in winter are Lalsohanra National Park in the Punjab; and Ghuaspur Jheels, Lakes Drigh (W.S.), Langh (W.S.), Kalri, Hadero Lake (W.S.) and Haleji Lake (W.S.) in Sind.

The mouth of the River Indus is another area of special interest, with its extensive mudflats and mangroves (mainly Avicennia of ficinalis and Ceriops candoleana). Bird species frequenting it include spot-billed pelican Pelecanus philippensis, western reef heron Egretta garzetta gularis, grey heron Ardea cinerea and many species of Limicolae. The construction of dams and large scale irrigation projects further upstream has reduced the flow of water, and many former rice growing areas near the rivermouth, around Keti Bandar for example, have been replaced by dry pastures.

The black finless porpoise Neophocaena phocaenoides inhabits the tidal zone of the Indus, and the shallows along the coast. Five species of marine turtle, all of which are threatened, occur in territorial waters; the green turtle Chelonia mydas, olive ridley Lepidochelys olivacea, loggerhead Caretta caretta, leatherback Dermochelys coriacea and hawksbill Eretmochelys imbricata.

Molluscs of economic importance include Plocuna sp., found in shallow waters of creeks and along the coast, and the oysters Ostrea gryphoides, $O$. cuculata and $O$. discoides, which are common in the creek system of Korangi. Commercial fishing has increased greatly, and the stock of shrimps is showing signs of depletion. Research is being carried out to measure the effects of fishing on stocks, and to help in developing conservation measures.

Protected Areas Legislation Draft legislation prepared by the Wildlife Enquiry Committee, set up in 1968, has been adopted, with minor modifications, at provincial level through the provision of various acts and an ordinance, namely: Sind Wildlife Protection Ordinance, 1972, Punjab Wildlife (Protection, Preservation, Conservation and Management) Act 1974, Baluchistan Wildlife Protection Act, 1974, North-West Frontier Province Wildlife (Protection, 
Preservation, Conservation and Management) Act, 1975. Separate laws were passed for the Northern Areas, Azad State of Jammu and Kashmire and Federal Capital Territory of Islamabad. These are the Northern Areas Wildlife Preservation Act, 1975, Azad Jammu and Kashmir Wildlife Act, 1975 and the Islamabad Wildlife (Protection, Preservation, Conservation and Management) Ordinance, 1979 (Rau, 1984). This is the first time in the history of Pakistan's wildlife legislation that an attempt has been made to conserve habitat (although limited to protected areas) and species other than game species. All of these statutes provide for the creation and management of national parks, wildlife sanctuaries (synonymous with wildlife reserves in the Northern Areas Act), game reserves (synonymous with controlled hunting areas in the Northern Areas Act) and, in the case of the Punjab, NWFP and Islamabad legislation, private game reserves.

Protected Areas Administration Following the recommendations of the Wildlife Enquiry Committee (Government of Pakistan, 1971), a National Council for Conservation of Wildlife was established on 7 July 1974 within the Federal Ministry of Agriculture, Food and Cooperatives, to co-ordinate central and provincial government efforts in the formulation and implementation of wildlife policies. The Inspector General of Forests is assisted by a Conservator of Wildlife, who acts as an adviser on wildlife, but the actual management of wildlife is handled by the provincial forest (wildlife) departments. Sind, Punjab and Azad State of Jammu and Kashmir have separate wildlife departments but in North-West Frontier Province, Baluchistan and Northern Areas wildlife is administered by branches of the respective forest departments. In general, forest staff look after wildlife in reserved or protected forests while wildlife staff are concerned with protecting wildlife in other protected areas and elsewhere. Within the Capital Territory of Islamabad, the Directorate of Horticulture is responsible for the administration of protected areas. In addition, legal provision has been made for the creation of a wildlife management board, to approve wildlife policies and monitor development activities, in Punjab, Sind, North West Frontier Province and Islamabad. North West Frontier Province and Sind have effectively operating wildlife management boards, which are considered to be the most progressive wildlife organizations in Pakistan. Boards exist in Baluchistan, Azad State of Jammu and Kashmir and Northern Areas but only in an advisory capacity. Provision has been made for the appointment of honorary officers to help implement wildlife legislation in all areas except Baluchistan and Islamabad.

\section{Sites designated under the Convention}

Signature subject to ratification 17 November 1975. Finally Ratified on 23 July 1976 with 9 sites listed at ratification.

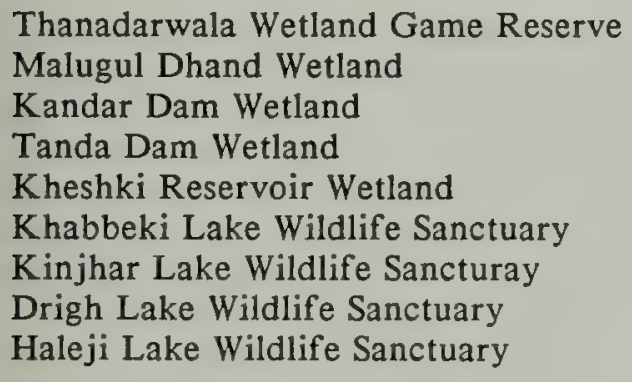

Government body responsible for administration of the Convention

National Council for Conservation of Wildlife in Pakistan, Ministry of Food, Agriculture and cooperatives, Government of Pakistan, Bungalow No 485, St. No 84, G-6, Islamabad, Pakistan.

\section{Thanadarwala Wetland Game Reserve}

Location $32^{\circ} 35^{\prime} \mathrm{N}, 71^{\circ} 05^{\prime} \mathrm{E}$. Situated in Lakki Tehsil of Bannu Province. 
Degree of Protection State owned. Administered by the National Council for Conservation of Wildlife in Pakistan based in Islamabad. Legal protection under provincial law. Designated as a Ramsar site on 23 July 1976.

Site Description The wetland is a seepage lagoon supplied from the River Kurram. The surrounding areas are saline in character. The vegetation is comprised of Tamarix dioica, Thypha angustata, Phagmites karka, Saccharum spp., Desmostachya bipinuata and Imperata cylindrica.

Criteria for Inclusion None reported (1980).

International and National Importance The wetland provides an excellent habitat for the migratory waterfowl.

Changes in Ecological Character No information

Management Practices No information

Scientific Research and Facilities No information

Principal Reference Material The above information is taken from the Pakistan National Report prepared for the Conference on the Conservation of Wetlands of International Importance especially as Waterfowl Habitat held in Cagliari, Italy in November 1980.

\section{Malugul Dhand Wetland}

Location $33^{\circ} 00^{\prime} \mathrm{N}, 70^{\circ} 36^{\prime} \mathrm{E}$. Situated between the villages of Mughal Mangi Wala (west), Chikarry Wanda (east) and Kala Magiwala (south).

Area 405 ha

Degree of Protection State owned. Administered by the National Council for Conservation of Wildlife in Pakistan based in Islamabad. Legal protection under provincial law. Designated as a Ramsar site at the time of ratification on 23 July 1976.

Site Description The wetland comprises a waterlogged area with slightly brackish water, bounded to the north by the Kurram River. Vegetation comprises Juncus sp., Typha angustala, Phragmites karka, Demostachya bipinnata and Imperata cylinderica. The surrounding area is mainly canal-irrigated, with some tropical thorn forest of Prosopis spp., Tamarix articulata and Saccharum spp.

International and National Importance No information

Changes in Ecological Character None reported (1980).

Management Practices No information

Scientific Research and Facilities No information

Principal Reference Material The above information is taken from the Pakistan National Report prepared for the Conference on the Conservation of Wetlands of International Importance especially as Waterfowl Habitat held in Cagliari, Italy in November 1980. 


\section{Kandar Dam Wetland}

Location $33^{\circ} 36^{\prime} \mathrm{N}, 71^{\circ} 29^{\prime} \mathrm{E}$. Situated in the district of Kohat in North West Frontier (Banu) Province.

Area 251 ha

Degree of Protection State owned. Administered by the National Council for Conservation of Wildlife in Pakistan based in Islamabad. Legal protection under provincial legislation. Designated as a Ramsar site at the time of ratification on 23 July 1976.

Site Description No information

International and National Importance No information

Changes in Ecological Character None reported (1980).

Management Practices No information

\section{Scientific Research and Facilities No information}

Principal Reference Material The above information is taken from the Pakistan National Report prepared for the Conference on the Conservation of Wetlands of International Importance especially as Waterfowl Habitat held in Cagliari, Italy in November 1980.

\section{Tanda Dam Wetland}

Location $33^{\circ} 35^{\prime} \mathrm{N}, 71^{\circ} 29^{\prime} \mathrm{E}$. In the Province of NWFP (Banu) between the village of Barh in the west and Kohat city in the east.

Area - 405 ha

Degree of Protection State owned. Administered by the National Council for Conservation of Wildlife in Pakistan based in Islamabad. Legal protection under provincial legislation. Designated as a Ramsar site at the time of ratification on 23 July 1976.

Site Description Freshwater reservoir bounded by hills in the north, and by the cultivated areas of Shahpur in the south and Bai in the west. Vegetation in and surrounding the reservoir is scanty, with no reed beds. Resting areas for ducks are provided by some mudbanks. The paucity of submerged aquatic vegetation has resulted in low fish productivity, despite the Fisheries Department stocking programme. Terrestrial vegetation is typical sub-tropical broad leaf forest dominated by Acacia modesta, with Dodonaea viscosa, Monotheca buxifolia and Gymnosporia roylaena. Important grass species are Desmostaya bipinnata, Cymbopigon jwarancusa, C. shoenanthus, Aristida depressa, Saccharum spontaneum and Pannisetum orientale. Agricultural crops around the lake provide food for ducks.

International and National Importance Important wildfowl species are mallard Anas platyrhynochos, tufted duck Aythya fuligula, great crested grebe Podiceps cristatus, black-necked grebe $P$. nigricollis, grey heron $A$. anerea, egret Egretta alba and herring gull Larus argentatus.

Changes in Ecological Character None reported (1980).

Management Practices No information

Scientific Research and Facilities No information 
Principal Reference Material The above information is taken from the Pakistan National Report prepared for the Conference on the Conservation of Wetlands of International Importance especially as Waterfowl Habitat held in Cagliari, Italy in November 1980.

\section{Kheshki Reservoir Wetland}

Location $34^{\circ} 00^{\prime} \mathrm{N}, 72^{\circ} 02^{\prime} \mathrm{E}$. Situated between Kheshki village (east) and Samad Garhi (west) in the district of Peshawar, North West Frontier (Banu) Province.

Area 263ha

Degree of Protection State owned. Administered by the National Council for Conservation of Wildlife in Pakistan based in Islamabad. Legal protection under provincial legislation. Designated as a Ramsar site at the time of ratification on 23 July 1976.

Site Description A small reservoir fringed with reedbeds and surrounded by forest providing shelter for waterfowl. There is a PAF Boating Club resthouse on the bank.

International and National Importance Waterfowl species include grey heron $A$. anerea, green-winged teal Anas crecca, coot Fulica atra, lapwing Vanellus vanellus, green sandpiper Tringa ochropus and common snipe Gallinago gallinago.

Changes in Ecological Character Waste from a papermill and sugar refinery nearby is discharged into the lake which has adversely affected water quality.

Management Practices No information

Scientific Research and Facilities A hydrological study was carried out from May 1975 to May 1976 by PCSIR.

Principal Reference Material The above information is taken from the Pakistan National Report prepared for the Conference on the Conservation of Wetlands of International Importance especially as Waterfowl Habitat held in Cagliari, Italy in November 1980.

\section{Khabbeki Lake Wildlife Sanctuary}

Location $34^{\circ} 00^{\prime} \mathrm{N}, 72^{\circ} 00^{\prime} \mathrm{E}$. In the Province of Punjab.

Area $283 \mathrm{ha}$

Degree of Protection State owned. Administered by the National Council for Conservation of Wildlife in Pakistan based in Islamabad. Legal protection under provincial legislation. Designated as a Ramsar site at the time of ratification on 23 July 1976.

Site Description The water level of the lake is very low. There are no reedbeds.

International and National Importance Waterfowl species include mallard Anas platyrhynchos, grey heron A. Ardea cinerea, egret Egretta alba, Eurasian wigeon Anas penelope, green-winged teal Anas crecca, tufted duck Aythya fuligula, common pochard Aythya ferina, white-headed duck Oxyura leucocephala, little grebe Tachybaptus ruficollis, black-necked grebe $P$. nigricollis, coot Fulica atra, greater flamingo Phoenicopterus ruber, lapwing Vanellus vanellus and snowy plover Charadrius alexandrinus.

Changes in Ecological Character None reported (1980).

Management Practices No information 
Principal Reference Material The above information is taken from the Pakistan National Report prepared for the Conference on the Conservation of Wetlands of International Importance especially as Waterfowl Habitat held in Cagliari, Italy in November 1980.

\section{Kinjhar (Kalri) Lake Wildlife Sanctuary}

Location $24^{\circ} 56^{\prime} \mathrm{N}, 68^{\circ} 03^{\prime} \mathrm{E}$. Situated in the district of Tatta in Sind Province, $104 \mathrm{~km}$ east of Karachi. The town of Thatta is $19 \mathrm{~km}$ to the south on the Hyderabad road.

Area 13,468 ha (comprising the lake surface area). The buffer zone of 1 mile radius was increased to 3 miles in July 1975. An enlargement to enclose the 3 seepage lagoons as far as the Hyderbad road has been recommended.

Degree of Protection Owned by the Provincial Government of Sind. First protected as a game sanctuary in 1971 under section 15/1 of the West Pakistan Wildlife Ordinance of 1959. Declared a wildlife sanctuary in March 1977 under section 14 of the Sind Wildlife Protection Ordinance of 1972, which affords complete protection to flora and fauna. As a source of freshwater for Karachi the Karachi Development Authority has prohibited swimming. Fishing is still allowed under license. The area is closed to hunting, shooting or trapping, and is defined as an undisturbed breeding ground. The protection status applies to all natural resources of the area. Designated as a Ramsar site at the time of ratification on 23 July 1976.

Site Description Large irregular shaped freshwater lake in stony desert landscape underlain by alternating layers of fossil-bearing limestone and sandstone. It is the major source of freshwater for Karachi, and was created in the 1930s from the two lakes Kinjhar and Kalri by the construction of a dam at Chilia Bangla and an 8 mile long embankment (bund) along the east side. The low-lying flat western shore is predominantly sandstone, while higher land of ten comprises limestone capped peninsulas. The lake is $38.9 \mathrm{~km}$ by $10.36 \mathrm{~km}$ at the widest point, with a maximum depth of $8 \mathrm{~m}$. It is flanked to the northwest by the road from Buradabad to Hyderabad, and to the southeast by the national highway from Thatta to Hyderabad running alongside the Indus River. The lake is fed in the northeast by the K.B. feeder, and on the north and west by many streams (during the rainy season). The only outlet is through the dam and the branch canal in the southeast. The shallow waters in the west and north sustain a rich aquatic/semi-aquatic vegetation of Hydrilla verticillata, Juncus articulatus, Phragmites karka, Polygonum barbatum, Potamogeton pectinatus, $P$. perfoliatus, Tamarix dioeca and Typha angustata, which supports a large waterfowl population using the lake as a winter refuge. On the east side of the bund a new canal, carrying water for irrigation, was being constructed in 1976/77. Beyond this canal, between Hillaya and the north end of the bund, are 3 seepage lagoons seperated by stands of Acacia trees. The central of the 3 lagoons is fringed by Tamarix dioeca, and is popular with dabbling ducks. Regional mean annual rainfall is $175 \mathrm{~mm}$ falling mainly during the monsoon season. Summers are hot with temperatures up to $49^{\circ} \mathrm{C}$ in the shade, and winters cold with mean January temperature of $1.7^{\circ} \mathrm{C}$. The prevailing wind direction is from WSW from May-September and NE in December and January.

International and National Importance The lake provides a winter refuge for a major population of tufted duck Aythya fuligula. Other recorded species include mallard Anas platyrhynochos, spotbill duck $A$. poecilorhyncha (nationally threatened), gadwall $A$. strepera, Eurasian wigeon $A$. penelope, pintail $A$. actua, green-winged teal $A$. crecca, northern shoveler A. clypeata, common pochard Aythya ferina, ferruginous duck $A$. nyroca, shelduck Tadorna tadorna, ruddy shelduck $T$. ferruginea, cotton pygmy goose Nettapus coromandelianus, red-crested pochard Netla rufina, coot Fulica atra, purple swamphen Porphyrio porphyrio, moorhen Gallinula chloropus, pheasant-tailed jacana Hydrophasianus chirurgus, great crested grebe Podiceps cristatus, little grebe Tachybaptus ruficollis, great cormorant Phalacrocorax carbo, pygmy cormorant P.niger, purple heron Ardea purpurea, grey heron A.Ardea cinerea, egret Egretta alba, little egret E. garzetta, Indian pond heron Ardeolia grayii, red-wattled lapwing Vanellus indicus, 
white-tailed lapwing $V$. leucurus, snowy plover Charadrius alexandrinus, greenshank Tringa nebularia, green sandpiper $T$. orchropus, Eurasian curlew Numenius arquata, black-winged stilt Himantopus himantopus, river tern Sterna aurentia, herring gull Larus argentatus, black-headed gull L. ridibundus, great black-headed gull L. ichthyaetus, Indian shag Phalacrocorax fuscicollis, black-crowned night-heron Nycticorax nycticorax, white spoon-bill Platalea leucorodia, wood sandpiper Tringa glareola, marsh sandpiper T. stagnatilis, whiskered tern Chlidonias hybrida and marsh harrier Circus aeruginosus.

Changes in Ecological Character The commercial fishing disturbs the resting and feeding waterfowl.

Management Practices The sanctuary was managed according to a management plan prepared in 1976/77 for the major wetlands of Sind Province. Fencing is required along the southern limits of the central lagoon near the village, to prevent encroachment for grazing, etc. Management efforts should be concentrated on the seepage lagoons rather than the main lake where fishing is a major disturbance. This would involve the maintanence of water supply to the lagoons; raising the level of the small islands to improve roost facilities for the birds, and active management of the vegetation. A nature education centre is proposed for the visitor complex being constructed by the Pakistan Tourist Development Corporation at Hillaya. In 1977 there were no wardens based at Kinshar.

Scientific Research and Facilities Annual waterfowl census from 1971 to 1978 carried out in collaboration with Sind Wildife Management Board. A booklet on the ducks, geese and swans of Pakistan has been produced. A survey of main waterfowl foods and their distribution should be conducted and used to enhance management.

Principal Reference Material The above information is taken from the Pakistan National Report prepared for the Conference on the Conservation of Wetlands of International Importance especially as Waterfowl Habitat held in Cagliari, Italy in November 1980.

Supplemented by:

- WWF Project Reports 1360 and 1656.

- Conder, P.J. (1977). Lake Kinjhar Wildlife Sanctuary management plan.

\section{Drigh Lake Wildlife Sanctuary}

Location $27^{\circ} 35^{\prime} \mathrm{N}, 67^{\circ} 51^{\prime} \mathrm{E}$. Situated $32 \mathrm{~km}$ northwest of Larkana, in the district of Larkana in Sind Province. Access from Larkana is by road via Qambar.

\section{Area $182 \mathrm{ha}$}

Degree of Protection Owned by the Provincial Government of Sind. Established as a Wildlife Sanctuary for 5 years in 1972 under section 14 of the Sind Wildlife Protection Ordinance 1972 which affords complete protection to flora and fauna. The area is closed to hunting, shooting or trapping and is defined as an undisturbed breeding ground. The protection status applies to all natural resources of the area. Designated as a Ramsar site at the time of ratification on 23 July 1976.

Site Description Situated on the silt soils of the Indus River floodplains. The lake is an ancient arm of the Indus, but the river now flows some $32-48 \mathrm{~km}$ away. Fertile soils containing about $20 \%$ sand and $80 \%$ clay and silt. In 1977 the soils were heavily impregnated with salts following heavy flooding. The land surrounding the lake is generally flat with limestone and sandstone hills of the Kalat range some $80 \mathrm{~km}$ to the west. The plains area is divided into small fields used mainly for rice cultivation, with irrigation canals from the Indus River, and is a good feeding ground for lake birds. The lake is fed by monsoon rains, but water also enters via a small canal to the north. There is no outlet channel. During the dry summer months parts of the lake dry up. The eastern boundary of the sanctuary is defined by an earth bunker constructed to help retain the water. The main road from Larkana to Quamper defines the northern boundary. The lake vegetation contains aquatic and marshland species 
including Cyperus alternifolius, Hydrilla verticillata, Najas minor, Scirpus littoralis, Ipomoea aquatica, Juncus articulatus, J. maritimus, Nymphaea lotus, Potamogeton pectinatus, Tamarix dioica (predominant) and Typha angustata. The higher ground is partially covered with Sacchrum grass. Regional mean rainfall is $175 \mathrm{~mm}$ falling mainly during the monsoon season. Summers are hot with maximum temperature $49^{\circ} \mathrm{C}$ in the shade. Winters are cold with January mean of $1.7^{\circ} \mathrm{C}$.

International and National Importance Important overwintering site for numerous waterfowl species including gadwall $A$. strepera, pintail $A$. actua, garganey $A$. querquedula, wigeon $A$. penelope, green-winged teal $A$. crecca (several thousands), northern shoveler $A$. clypeata, mallard $A$. platyrhynchos, tufted duck Aythya fuligula, common pochard A. ferina, ferruginous duck $A$. nyroca, little grebe Tachybaptus ruficollis, great cormorant Phalacrocorax carbo, pygmy cormorant P.niger, purple heron Ardea purpurea, grey heron $A$. cinerea, little egret $E$. garzetta, grey white egret $E$. alba, black-crowned night-heron Nycticorax nycticorax, common snipe Gallinago gallinago, pond heron Ardeola grayii, darter Anhinga anhinga and painted snipe Rostratula benghalensis. Roosts can number up to 18,000 . The following birds of prey have also been recorded: osprey Pandion haliaetus, marsh harrier Circus aeruginosus, pallid harrier $C$. macrourus, shikra Accipiter badius, great spotted eagle Aquila clanga, tawny eagle A. rapax, imperial eagle $A$. heliaca and bonelli's eagle Hieraaetus fasciatus.

Changes in Ecological Character Outbreaks of Kuthari, the Tamarisk defoliating caterpillar, occur from time to time. Regular bird shoots are held. Some grazing, woodfuel collection and poaching.

Management Practices The sanctuary was managed according to a management plan prepared in 1976/77. Recommendations for improved management include the construction of an embankment (bund) with sluices, around the sanctuary to control water levels and minimise the threat of flooding and the consequential problems of salinity.

Scientific Research and Facilities Annual waterfowl census from 1971 to 1978 carried out in collaboration with Sind Wildife Management Board. A booklet on the ducks, geese and swans of Fakistan has been produced. A proposed research programme includes preparing inventories of plant life and a bird ringing programme. Tower hides should be constructed and boats purchased for use by visitors and scientists.

Principal Reference Material The above information is taken from the Pakistan National Report prepared for the Conference on the Conservation of Wetlands of International Importance especially as Waterfowl Habitat held in Cagliari, Italy in November 1980.

Supplemented by:

- WWF Project Reports and Management Plan 1360 and 1656.

- Conder, P.J. (1977). Lake Drigh Wildlife Sanctuaries management plan.

\section{Haleji Lake Wildlife Sanctuary}

Location $24^{\circ} 47^{\circ} \mathrm{N}, 67^{\circ} 46^{\prime} \mathrm{E}$. $80 \mathrm{~km}$ from Karachi and $16 \mathrm{~km}$ from the town of Tatta in the district of Tatta in Sind Province.

Area 1,704ha, surrounded by a buffer zone of 3 miles radius (extended from 1 mile in 1975).

Degree of Protection Owned by the Provincial Government of Sind but managed by the Sind Wildlife Management Board by agreement with the Karachi Development Authority which affords complete protection to flora and fauna. It was established as a Wildlife Sanctuary in March 1977. The area is closed to hunting, shooting or trapping and is defined as an undisturbed breeding ground. The protection status applies to all natural resources of the area although fishing is allowed under locally issued licenses. Designated as a Ramsar site at time of ratification on 23 July 1976. 
Site Description Perennial freshwater lake set in a stony desert of limestone and sandstone bedrock, an important water source for Karachi during April when the lake Kinjhar canal is cleaned. To the west the land is $12 \mathrm{~m}$ higher with a cap of limestone which dips gently to the west. To the north-east the land is more fertile, but elsewhere waterlogging and salinity preclude agriculture. It is fed by lake Kinjhar through the Jambranch canal, and is drained by a link canal at the south-west corner. The maximum depth of water in winter is $17 \mathrm{ft}$. The lake is surrounded by embankments (bunds) constructed in 1938/39 which carries a Kacha road lined with Acacia arabica, Ficus sp. and Casuarina sp. These in turn are encircled by a series of seepage lagoons fed during the monsoon by overflow from the lake via the by-pass regulator. The seepage lagoons are an integral part of the waterfowl habitat. Beyond these is a zone of stoney desert sparsely covered with Euphorbia cauduciflora vegetation. Chateji Dhaud, which only floods during heavy monsoons, lies near the village of Kalri, between lake Haleji and Hadero. The lake has abundant aquatic vegetation with common species including Phragmites karka, Typha angustata, Juncus articulatus, Ipomoea aquatica, Cyperus alterniflora. Scirpus tuberosus, S. littoralis, Polygonum barbatum and patches of Nymphaea lotus. Submerged species include Potamogeton pectinatus, P. perfoliatus, P. lucens and Hydrilla verticillata. Dominant land vegetation around the lake comprises Calotropis, Acacia arabica, Alhaji, Zizyphus, Parkinsonia, Prosopis spicigera, Salvadora, Salix, Euphorbia, Saggitoria and Salsola genera which provide nesting cover for forest birds, notably large numbers of small warblers which breed in the north and winter here. They are chiefley representatives of the following genera - Acrocephalus, Celtia, Hippolais, Phylloscopus and Sylvia. It is also a suitable habitat for many insects on which the birds feed. The site harbours a large concentration of wildfowl which are undisturbed from October through February. Regional mean annual rainfall is $175 \mathrm{~mm}$ falling mainly during the monsoon season. Summers are hot with temperatures up to $49^{\circ} \mathrm{C}$ in the shade and winters cold with mean January temperature of $1.7^{\circ} \mathrm{C}$.

International and National Importance The large waterfowl population includes mallard Anas platyrhynochos, spotbill duck $A$. poecilorhyncha (nationally threatened), gadwall $A$. strepera, Eurasian wigeon $A$. penelope (several thousand), pintail $A$. actua, green-winged teal $A$. crecca (up to 6,000), garganay $A$. querquedula, northern shoveler $A$. clypeata, tufted duck Aythya fuligula, common pochard $A$. ferina, ferruginous duck $A$. nyroca, red-crested pochard Netta rufina, shelduck Tadorna tadorna, cotton pygmy goose Nettapus coromandelianus, vast numbers of coot Fulica atra (up to 70,000), purple swamphen Porphyrio porphyrio, moorhen Gallinula chloropus, white-breasted waterhen Amauromis phoenicurus, pheasant-tailed jacana Hydrophasianus chirurgus, great crested grebe Podiceps cristatus, little grebe Tachybaptus ruficollis, European white pelican Pelecanus onocrotalus, dalmatian pelican $P$. crispus, great cormorant Phalacrocorax carbo, pygmy cormorant $P$. niger, 12 species of heron such as purple heron Ardea purpurea, grey heron Ardea cinerea and Indian pond heron Ardeolia grayii. Also listed: egret Egretta alba, little egret E. garzetta, little bittern Ixobrychus minuts, black bittern Dupetor flaricollis, glossy ibis Plegadis falcinellus, great flamingo Phoenicopterus ruber, red-wattled lapwing Vanellus indicus, white-tailed lapwing $V$. leucurus, Kentish plover Charadrius alexandrinus, little stint $C$. teminckii, spotted redshank Tringa erythropus, redshank $T$. totanus, greenshank $T$. nebularia, green sandpiper $T$. orchropus, Eurasian curlew Numenius arquata, black-winged stilt Himantopus himantopus, river tern Sterna aurentia, white-winged black tern Chlidonias leucopterus, herring gull Larus argentatus and black-headed gull $L$. ridibundus. The lake also supports crocodile Crocodilus palustris. Black cobra Naia tripudians occurs in the area.

Lake Haleji is attractive to birds of prey. The commonest species are marsh harrier Circus aeruginosus and osprey Pandion haliaetus. Other species are great spotted eagle Aquila clanga, imperial eagle $A$. heliaca, tawny eagle $A$. rapax, black kite Milvus migrans, white-rumped vulture Gyps bengalensis, griffon vulture G. fulvus, black-shouldered kite Elanus caeruleus, brahminy kite Haliastur indicus, pallas fish eagle Haliaeetus leucoryphus, which has a regular nest site near the lake, white tailed eagle $H$. albicilla, egyptian vulture Neophron percnopterus, black vulture Aegypius monachus, short-toed eagle Circaetus gallicus, pallid harrier Circus macrourus, shikra Accipiter badius, white-eyed buzzard Butastur teesa, long-legged buzzard Buteo rufinus, kestrel Falco tinnunculus, red-headed merlin $F$. chicquera and peregrine falcon $F$. peregrinus 
Changes in Ecological Character There are several small villages and nomadic settlements within the buffer zone. It is preposed to build another reservoir nearby. The extensive beds of Phragmites are mown annually by boat. Uncut patches are used as roosts by herons. Chateji Dhaud is occasionally illegally shot for waterfowl, and is disturbed by fishing and other activities by the nearby nomadic camp people. There is some illegal fishing, shooting and encroachment, in and around the main Haleji lake. The lake has been dredged in the past.

Management Practices The sanctuary was managed according to a management plan prepared in $1976 / 77$ for the major wetlands of Sind Province. The administrative plan for management recommends the appointment of a sanctuary warden, 2 or 3 deputy wardens and 7 assistants to cover both lake Haleji and lake Hadero, with a system of active patrols to discourage illegal access. Spoil from any further dredging should be used to create roosting islands in the lake for wintering birds. A restaurant and observation tower have been planned and 5 partially built hides already exist. An interpretive nature centre should be added with exhibition space, lecture hall and administrative facilities for the wardens. Visiting permits are not required. The proposed reservior should be integrated with the Haleji management plan. The Karachi Development Authority has a camp beside the lake where the water engineer is based along with a police post, rest house and houses used by KDA staff. There is a small tea house and building used by the game wardens beside the entry gate as well as 2 huts near the tail regulator. 2 pumping stations extract water from the lake and water is discharged, through the by-pass regulator, from the tail regulator into the seepage lagoons.

Scientific Research and Facilities Annual waterfowl census from 1971 to 1978 carried out in collaboration with Sind Wildife Management Board. A booklet on the ducks, geese and swans of Pakistan has been produced. The Limnological Department of Karachi University has studied the lake, and several papers have been published in the Pakistan Journal of Ecology. Recommended studies include the preparation of an inventory of food plants used by water fowl to be used to recommend management procedures; monthly census" of birds should be made; a research biologist should be assigned to the reserve.

Principal Reference Material The above information is taken from the Pakistan National Report prepared for the Conference on the Conservation of Wetlands of International Importance especially as Waterfowl Habitat held in Cagliari, Italy in November 1980.

Supplemented by:

- WWF Project Reports 1360 and 1656.

- Conder, P.J. (1977). Lake Haleji Wildlife Sanctuary management plan. 


\section{POLAND}

\section{Area 312,677 sq. $\mathrm{km}$}

\section{Population $37,187,000(1985)$}

Summary of Wetland Situation Poland is especially rich in lakes, the majority of which provide excellent habitat for breeding and migrating waterfowl. There are about 9300 lakes which cover an area greater than one hectare, with a total area of about $3,200 \mathrm{sq} . \mathrm{km}$. ( $1 \%$ of the territory). The majority are postglacial lakes, which are polymictic and eutrophic or mesotrophic in character, with a relatively well-formed reed belt and banks frequently forested. Most of the freshwater sites freeze over in winter for about four months, so wintering ducks and geese are comparatively few in total. The Polish Baltic coast is on one of the more important bird migration routes. In spring and autumn, haffs, bays and coastal lakes act as refuges for many waterfowl.

The most important wetland complex in the country is the Mazurian Lakes in the north-east. This complex includes over 4,000 lakes (with a total surface area of about 115,000ha), the largest being Sniardwy (10,660ha) and Mamry (10,400ha). The Mazurian lakes are of various types, ranging from shallow with dense vegetation to deep with rather poor plant cover, and are often surrounded by forest. They are of great interest both limnologically and for waterfowl. Typical breeding species include bittern Botaurus stellaris, grey heron Ardea cinerea, black stork Ciconia nigra, mute swan Cygnus olor, greylag goose Anser anser, several of the Anas ducks, and raptors including white-tailed eagle Haliacelus albicilla and osprey Pandion haliaetus. Lake Luknajno (Nature Reserve) is notable for having the densest breeding population of mute swans in Europe (about 1,000 pairs). Lake Druzno, situated in the extreme north-west of the Mazurian complex, near Elblag, is an ornithological reserve.

Between the Mazurian Lakes and the town of Bialystok is a considerable area of marshland along the Biebrza river and Augustowski canal. Of the original 50,000ha, about 3,500 ha have already been protected. Characteristic breeding birds of this area include bittern, grey heron and black stork, as well as black grouse Tetrao tetrix, ruff Philomachus pugnax, curlew Numenius arquata and penduline tit Remiz pendulinus.

Although in general the wetlands away from the north-east tend to be smaller, Lake Miedwie in the north-west, the Liwia Luza and Lubiatowskie lakes close to the Baltic coast, and Lebsko and Gardno lakes further to the east and only separated from the sea by a narrow strip of land, are all of value to breeding waterfowl, and support large concentrations during migration. The two last-named are of particular importance as breeding places of crane Grus grus, greylag goose and mute swan, and have been included in a National Park. Another important nesting area, particularly for Anatidae and Limicolae, is the Ptasi Raj Reserve situated around the Wisla (Vistula) river mouth and including two densely overgrown lakes.

Further south, the Zegrze reservoir, near the confluence of the Bug and Narew rivers, is of importance to migrating waterfowl, as are the marshes to the west of Warsaw and north-west of Lodz along the Warta river, and also the 6521 ha fishpond complex of the Barycz river near Milicz. This complex, created in the 14 th century, has, or had, a good breeding population of greylag geese, several species of Anas, and some bittern and black stork although in winter and during the migration hundreds more geese, mainly greylag and white-fronted, and several thousand duck arrive. A large part of the complex is a nature reserve.

In the south-east are Imielty Lug Lake and marshes, surrounded by uninhabited peat bogs and vast forests. But the most important wetlands in southern Poland are situated to the west of Krakow, the fishponds of Zator, the reservoir of Goczalkowice further upstream, and the fishponds of Lezczak. They are particularly important to waterfowl migrating through the Moldawska Gate, the main pass between the Sudety and the Carpathian ranges. 
Two further sites, lakes Dobskie and Warmoly, also sustain large numbers of waterfowl. The conservation of waterfowl habitat has also increased with the creation of two sites which include a substantial amount of good waterfowl habitat, the Suwalk Landscape Park with a protected zone of $8,470 \mathrm{ha}$, and the Wigry Landscape Park $(10,940 \mathrm{ha})$ with a protected area of $2,770 \mathrm{ha}$, both in the extreme north-east of the country.

Protected Areas Legislation The Legal basis for conservation and protected areas legislation remains the Law on Nature Protection of 7 April 1949 (Dz.U. nr. 25, poz. 180) which was broadened on 20 January 1980 by passage of the Law on the Protection and Management of the Environment.

National parks and nature reserves are proposed by the State Council for Nature Conservation at Voirodship and national level and are created by Resolution of the Council of Ministers (in the case of national parks) or by the Minister of Forestry (in the case of nature reserves). Landscape parks and Areas of Landscape Protection are created by Voivodship authorities. Protected areas are further covered by numerous laws and resolutions dealing with the protection of water resources, fisheries, agriculture, forests, tourism and special planning. The Council of Ministers Order of 29 December 1977 requires prior authorization from the Minister of Forestry before developments are carried out in any protected areas, while Section 2, Article 20 of the 1980 Law prohibits any negative developments in wetland systems which threaten colonial breeding birds or any protected species. Habitats of protected species are further protected by the Declaration of the Ministry of Forestry of 30 December 1983.

Protected Areas Administration This was previously under the Ministry of Forests and Timber Industries but since November 1985 responsibility for nature conservation rests with the Ministry of Environment and Natural Resources, which deals with environmental protection, water management, geology and nature conservation. There is a Chief Conservator for Nature who is in charge of a Department of Nature Protection and Soil Conservation, which is staffed by professionals who maintain a central register of protected areas. Spatial management remains the responsibility of the Ministry of Construction and Communal Economy. Although the Ministry for Conservation of the Environment is responsible for the management of natural resources, the national park system is controlled by the Ministry of Agriculture, Forestry and the Food Economy through its Department of Forests and National Parks. The State Council of Nature Conservation is the chief consultative body, passing judgement on proposed national parks, nature reserves and landscape parks. At the regional level the Voivodship Conservation of Nature is the responsible authority, and the regional office of the conservator of nature is the professional body concerned. They are advised by the Regional Committee to Nature Protection. The State forest administration bodies supervise directly the regulations governing protection of nature (alongside the voirodship authorities).

\title{
Sites designated under the Convention
}

Accession 22 November 1977 with 1 site listed at accession and 4 sites added on 3 January 1984

\author{
Luknajno Lake Nature Reserve \\ Slonsk Reserve \\ Swidwie Lake \\ Karas Lake \\ Siedem Wysp (Seven Islands) Reserve
}

Government body responsible for administration of the Convention

Ministry for Conservation of the Environment and Natural Resources, Wawelska 52/54, 00-922 Warsaw

\section{Luknajno Lake Nature Reserve}

Location $53^{\circ} 49^{\prime} \mathrm{N}, 21^{\circ} 38^{\prime} \mathrm{E}$. Located in the east Baltic lowland, $2.5 \mathrm{~km}$ east of the town of Mikolajki in north-east Poland. 


\section{Area 710 ha}

Degree of Protection State owned. Managed by the State Forest District Board at Bialystok (Nadlesnictwo Maskulinskie, Superintendent Forestry Maskulinskie, 12-220 Ruciane-Nida, Poland). Established as a Reserve in 1947 to protect the habitat of mute swan Cygnus olor and other waterfowl. The protected area includes the entire lake and a $300 \mathrm{~m}$ wide strip of surrounding shore. Accepted as a Biosphere Reserve in June 1976. Designated as a Ramsar site at the time of accession on 22 November 1977.

Site Description The reserve comprises 585 ha of open water, 101 ha bank swamp area, 15 ha forest and 9 ha meadows and grassland. Lukajno Lake is $115 \mathrm{~m}$ in altitude and of glacial origin, with a flat-bottom and maximum length north-south of $3,300 \mathrm{~m}$ and east-west of $2,900 \mathrm{~m}$. Average depth is $0.6 \mathrm{~m}$ and maximum depth about $3 \mathrm{~m}$. The lake is fed by numerous drainage channels from the surrounding marshy areas, and water flows out if it through a channel to Sniardwy Lake. The major aquatic plant communities are: Charetum acuteolatae (occupying nearly two-thirds of the lake bottom); C. contrariae ( $25 \%$ of the lake bottom); and C. asperae and $C$. tomentosae, which are the main foodsource for swan Cygnus olor. 166 species of vascular plants have been recorded in the reserve including starwort Callitriche verna, mezerion Daphne mezereum, willow Salix nigiricans, small bur-reed Sparganium minimum, marsh stitchwort Stellaria palustris and marsh arrow-grass Triglochin palustris. The lake is a natural spawning ground for many fish species. The mean annual air temperature is $6.5^{\circ} \mathrm{C}$ and mean annual precipitation $550-600 \mathrm{~mm}$.

International and National Importance The reserve contains the largest wild colony of mute swan Cygnus olor, with up to 2,000 birds including about 20 breeding pairs, which migrate each winter. There are about 168 species of birds in the reserve or its immediate surroundings, of which 122 breed or probably breed, and 36 are wintering or migrant species. Breeding birds include black-necked grebe Podiceps nigricollis (180 pairs), coot Fulica atra (80 pairs breeding and about 5000 birds during migration), red-crested pochard Netla rufina (3-5 pairs), Eurasian bittern Botaurus stellaris (about 15 pairs), black-headed gull Larus ridibundus (200 pairs), Bewick swan Cygnus columbianus bewickii, crane Grus grus (4-5 pairs), bearded tit Panurus biarmicus (1-2 pairs), black kite Milvus migrans (1 pair), marsh harrier Circus aeruginosus (about 10 pairs), hen harrier C. cyaneus (1 pair), white-tailed eagle Haliaetus albicilla (2 pairs), golden eagle Aquila chrysaetos, lesser-spotted eagle $A$. pomarina (1 pair) and osprey Pandion haliaetus (2 pairs).

Changes in Ecological Character The lake is considered to be largely unmodified by man, although much of the surrounding watershed is used for agriculture. There is no tourist accommodation within the reserve.

Management Practices The $300 \mathrm{~m}$ strip of land within the reserve surrounding the lake constitutes a buffer zone. Supervision of protection and management of the reserve is carried out by the district nature conservator in the district office at Suwalki. The reserve is guarded by a warden for nature conservation, and by forest personnel. Access is carefully controlled to prevent disturbance of birds. Hunting is prohibited, and fishing is allowed only after the mute swan migration in autumn.

Scientific Research and Facilities Major topics needing further research include: influence of agriculture in the catchment on eutrophication; pesticide residue impacts and methods of protecting the lake against pollution; population dynamics of waterfowl including mute swan and their impact on aquatic vegetation. Scientific supervision of the reserve is carried out by the Field Station of the Zoology and Ecology Institute of the Warsaw University.

Principal Reference Material The above information is taken from the Biosphere Reserve nomination submitted to Unesco (1976).

Additional references:

A bibliography of 35 entries is on file with MAB Secretariat, Unesco, Paris. 


\section{Slonsk Reserve}

Location $52^{\circ} 33^{\prime} \mathrm{N}, 14^{\circ} 41^{\prime}-14^{\circ} 46^{\prime} \mathrm{E}$. Situated in Gorzow province near the confluence of the Warta and Odra rivers on the German Democratic Republic frontier in western Poland. The nearest towns are Kostrzyn on the northwest boundary, Czarnow to the south, and Slonsk to the south-east.

\section{Area 4,166.22ha (including a Strict Nature Reserve of $1,128.16 \mathrm{ha}$ ).}

Degree of Protection State owned. The area is protected as a nature reserve established under the order of the Minister of Forestry and Timber Industries of 21 July 1977 (Monitor Polski $1977 \mathrm{Nr} 19$ pos. 107). The reserve contains a Strict Nature Reserve. Designated as a Ramsar site on 3 January 1984.

Site Description The site is in the ancient Torun-Eberswalde Valley, and comprises the Warta river, the winding Postomia river, marshlands and numerous old drainage canals, shallow lakes, meadows and pastures in the Warta river floodplain, and a disused artificial reservoir. The water level of the river varies considerably, with annual range of up to $4 \mathrm{~m}$. The area is flooded for about 8 months of the year. Characteristic plant species include great yellow-cress Rorippa amphibia, water dropwort Oenanthe aquatica, water speedwell Veronica anagalis, Polygonum persicaria, bistort P. amphibius, plantain Plantago pauciflora, golden dock Rumex maritimus, great water dock $R$. hydrolapathum, reed canary-grass Phalaris arundinacea, goosefoot Chenopodium vulvaria, marsh cudweed Gnaphalium uliginosum, crack willow Salix fragilis, white willow $S$. alba, eared sallow $S$. aurita and dispersed stands of alder Alnus glutinosa.

International and National Importance Slonsk Reserve is one of the more important inland sites for waterfowl, as a breeding and moulting ground, resting station for migrants, and a wintering site. There are at least 40 species recorded breeding, including greylag goose Anser anser (about 100 pairs), mute swan Cygnus olor (25 pairs), mallard Anas platyrhynchos (1,900 pairs), garganey $A$. querquedula (150 pairs), gadwall $A$. strepera (120 pairs), northern shoveler $A$. clypeata (150 pairs), pochard Aythya ferina (150 pairs), tufted duck $A$. fuligula (100 pairs), coot Fulica atra (10,000 pairs), black-headed gull Larus ridibundus (6,000 pairs) and cormorant Phalacrocorax carbo (64 pairs). White-tailed eagle Haliaeetus albicilla has bred successfully in the area. Visiting migrants recorded during November include 35,000-40,000 geese (mainly bean goose Anser fabilis), 30,000-70,000 duck (Anatidae) and 800 swans Cygnus spp.

Changes in Ecological Character Since establishment of the reserve the area has been relatively undisturbed. There are traces of abandoned drainage and road building works.

Management Practices Grass-mowing and cattle grazing are allowed in the reserve after 15 June (end of the breeding season), except in the strictly protected area.

Scientific Research and Facilities Scientific supervision of the reserve is provided by the Scientific Station of the Polish Hunting Association in Czempin.

Principal Reference Material The above information is taken from:

- Ministry of Forestry and Timber Industries (1983). Selected Wetlands of International Importance in Poland. Document submitted at the time of Designation in January 1984. Warsaw.

\section{Swidwie Lake}

Location $53^{\circ} 34^{\prime} \mathrm{N}, 14^{\circ} 22^{\prime} \mathrm{E}$. Situated north of Szczecin town and west of Wegornik, in Szczecin Province on the frontier with the German Democratic Republic in northern Poland. 
Degree of Protection State owned. The lake area is protected as a Nature Reserve (382.03ha) established on 14 January 1963 by order of the Ministry of Forestry and Timber Industries (Monitor polski 1963, Nr 14 pos. 82). Designated as a Ramsar site on 3 January $1,984$.

Site Description Swidwie is a eutrophic lake with the area of open water gradually reducing through hydroseral succession. At present about $75 \%$ of the lake area is overgrown by reedbeds of Phragmites communis and bulrush Scirpus lacustris, and stands of reed $P$. communis and reedmace Typha latifolia divide the lake surface into several small areas of open water varying from one to $50 \mathrm{ha}$. These shallow $(0.7-1.5 \mathrm{~m})$ relict waterbodies are rapidly silting up with organic debris, and are covered by water plants, predominantly water soldier Stratiotes aloides. The wetland is fed by four ditches draining from the surrounding meadows and fields. Gunica River is the only outflow. The reserve is surrounded by some $2,800 \mathrm{ha}$ of meadows and fields, and $25,000 \mathrm{ha}$ of the ancient virgin forest of Wkra. The villages of Bolkow, Wegornik and Zawisie lie close to the perimeter and connecting roads pass around the area. The wetland itself is inaccessible as treacherous mats of vegetation overlie deep water.

International and National Importance Swidwie Lake is an important wildfowl resting and feeding station located at the intersection of two major spring and autumn migration routes. Thousands of birds pass through the area including greylag goose Anser anser (several thousand), bean goose $A$. fabilis, white-fronted goose A. albifrons (major spring migrant), pochard Aythea ferina, greater scaup A. marila, garganey Anas querquedula, mallard A. platyrhynchos (spring migrant), spotted crake Porzana porzana, little crake $P$. parvus and water rail Rallus aquaticus. In July to October up to 3,000 warblers a day pass through the reserve, particularly reed warbler Acrocephalus scirpaceus, sedge warbler $A$. schoenobaenus and marsh warbler $A$. palustris. Immature and moulting species recorded include crane Grus grus (60-80 non-breeding birds: March to October), greylag (20-30 moulting birds: April to September) and mute swan Cygnus olor (30-80 immature birds in spring). Birds breeding include white-tailed eagle Haliaeetus albicilla ( 1 pair), osprey Pandion haliaetus ( 1 pair), Montague's harrier Circus pygargus (1 pair), hen harrier C. cygancus (3 pairs), black stork Ciconia nigra ( 1 pair), goldeneye Bucephala clangula ( 4 pairs), mute swan (10 pairs), bluethroat Luscinia svecica (5 pairs) and bearded tit Panurus biarmicus ( 9 pairs).

Changes in Ecological Character A sluice gate built on the Gunica River has raised the water level in the reserve by about $0.3 \mathrm{~m}$. The main threat to the reserve is spraying of insecticides and fungicides onto adjoining fields and meadows.

Management Practices All economic activities are prohibited in the reserve.

Scientific Research and Facilities Scientific supervision of the reserve is provided by the "Swidie" Ornithological Station.

Principal Reference Material The above information is taken from:

- Ministry of Forestry and Woodworking Industries (1983). Selected Wetlands of International Importance in Poland. Document submitted at the time of Designation in January 1984. Warsaw. Ministry of Environment Protection and Natural Resources.

\section{Karas Lake}

Location $53^{\circ} 33^{\prime} \mathrm{N}, 19^{\circ} 38^{\prime} \mathrm{E}$. Situated west of Ostroda in Olsztyn Province, northern Poland.

Area $815.88 \mathrm{ha}$

Degree of Protection State owned. The lake is protected as a Nature Reserve established on 12 April 1958 under the order of the Minister of Forestry and Timber Industries (Monitor Polski 1958 No. 42 pos. 243). Designated a Ramsar site on 3 January 1984. 
Site Description The nature reserve comprises 377.49 ha lake area surrounded by 246.83 ha forest, 182.4 ha peatbogs and marshlands, and 3.21 ha drainage ditches. The lake basin is at an advanced stage of hydroseral succession, with shallow areas of open water (on average $0.6 \mathrm{~m}$ deep, maximum $2.8 \mathrm{~m}$ ) which are rapidly filling in with sediment and are extensively colonised by submerged vegetation of charales Chara fragilis, $C$. aspera and $C$. intermedia, and vascular plants such as the pondweeds Potamogeton lucens, $P$. perfoliatus and $P$. gramineus, bladderwort Utricularia vulgaris and Najas marina. The area bordering the water, which is exposed when water level drops, and the islands on the interlake shallows, are covered by rushes Juncus spp. and reedbeds of Phragmites communis, Scirpus lacustris, Typha latifolia and $T$. angustifolia. To the west of the lake, extensive peatbogs have formed with sedges Carex gracilis and C. rostrata predominant. On the higher ground near the edge of the original lake basin is scrub and woodland of willows Salix cineria, $S$. rosmarinifolia, $S$. pentandra; birches Betula pubescens, B. verrucosa; alder Alnus glutinosa and buckthorn Frangula alnus. Marsh species include sundews Drosera rotundifolia and $D$. anglica (vulnerable within Poland), marsh helleborine Epipactis palustris and lesser butterfly orchid Platanthera bifolia.

International and National Importance The reserve was established to protect the important Polish breeding site of greylag goose Anser anser, with 20 breeding pairs and up to 100 non-breeding birds. After moulting, some 500 birds gather in the reserve prior to migration. Other waterfowl breeding in the wetland include mute swan Cygnus olor (some pairs and about 100 non-breeding birds), gadwall Anas strepera, wigeon $A$. penelope, northern shoveler A. clypeata, red-crested pochard Netta rufina, common goldeneye Bucephala clangula, common merganser Mergus merganser, red-necked grebe Podiceps grisegena and black-headed gull Larus ridibundus (1,000 pairs). The reserve is a moulting refuge for the males of various species such as greylag goose and mallard, and is a resting station for spring and autumn migrants. European otter Lutra lutra has been recorded in the reserve.

Changes in Ecological Character The lake is exploited as a commercial fishery.

\section{Management Practices None reported (1983)}

\section{Scientific Research and Facilities None reported (1983)}

Principal Reference Material The above information is taken from:

- Ministry of Forestry and Timber Industries (1983). Selected Wetlands of International Importance in Poland. Document submitted at the time of Designation in January 1984. Warsaw.

\section{Siedem Wysp (Seven Islands) Reserve}

Location $54^{\circ} 20^{\prime} \mathrm{N}, 21^{\circ} 36^{\prime} \mathrm{E}$. Situated in northwest Poland at the intersection of the Polish Provinces of Suwalkie and Olsztyn, and the frontier with the Soviet Union.

Area $1,016.83 \mathrm{ha}$

Degree of Protection State owned. The wetland is protected as a Nature Reserve established on 30 May 1956 under the order of the Ministry of Forestry and Timber Industries (Monitor Polski 1956, Nr 54 pos. 591). Designated as a Ramsar site on 3 January 1984.

Site Description The reserve comprises Oswin Lake (339.21 ha); associated marshlands (474.96ha); meadows (67.55ha); and woodland (134.24ha). Oswin Lake is a shallow (1-3m) freshwater lake colonised by aquatic plants such as pondweed Potamogeton spp., and extensively overgrown by reedbeds Phragmites communis. Genera predominant in the woodland areas are alder, oak, ash, lime and elm (Alnus, Quercus, Fraxinus, Tilia and Ulmus). Mammals in the reserve include wild boar Sus scrofa, roe deer Capreolus capreolus, elk Alces alces, fox Vulpes vulpes, hare Lepus sp., beaver Castor fiber and muskrat Ondatra zibethicus. 
International and National Importance The lake is very important during migration times, particularly during the autumn migration when it is a resting place for flocks numbering dozens of crane Grus grus, many thousands of ducks and geese (Anatidae), gulls and coots. Over 180 bird species have been recorded in the reserve including 99 breeding or probably breeding. Breeding birds include great crested grebe Podiceps cristatus (up to 90 pairs), bittern Botaurus stellaris (6-7 pairs), black stork Ciconia nigra, mute swan Cygnus olor (up to 20 pairs breed, with 30 to 200 non-breeding summer visitors), greylag goose Anser anser (one breeding pair but up to 10 birds in summer), white-tailed eagle Haliaeetus albicilla ( 1 pair), crane (6-7 pairs, black-headed gull Larus ridibundus 3000-5000 pairs, peregrine falcon Falco peregrinus, river warbler Locustella fluviatilis (15-20 pairs), bluethroat Luscina svecica (ca 20 pairs) and bearded tit Panurus biarmicus (8 pairs).

Changes in Ecological Character The area is inaccessible and still undisturbed.

Management Practices None reported (1983)

Scientific Research and Facilities None reported (1983)

Principal Reference Material The above information is taken from:

- Ministry of Forestry and Woodworking Industries (1983). Selected Wetlands of International Importance in Poland. Document submitted at the time of Designation in January 1984. Warsaw. 
PORTUGAL

Area $\cdot 91,971$ sq. km

Population $9,930,000(1983)$

Summary of Wetland Situation Several Portuguese wetlands are of special importance as feeding areas for large numbers of wintering and migrating waders and gulls, in particular the Ria d'Aveiro, the Tejo Estuary, the Sado Estuary, and the mudflats and marshes near Faro.

The Ria d'Aveiro comprises a 6,000ha lagoon and a network of channels, much of them covered by rushes and eel grass. The lagoon is full of fish, but excessive algal growth prevents large scale fishing. The algae are harvested for fertilizer. In the northern part of the lagoon, which is connected with the sea by a narrow inlet, saltpans provide favourable habitat for the waders and gulls, and there is a heronry in the Pinus pinaster stand around Sao Jacinto, on the sandbar separating the lagoon from the sea. This colony has lost its importance as a breeding place for other species of waterfowl, mainly because of disturbance. Hunting pressure in winter is severe, but there are plans for establishing a 1,500ha Nature Reserve at Pateira de Fermentelos, comprising a marsh with reedbeds.

The Tejo (Tagus) estuary upstream of Lisbon is a vast intertidal zone of mudflats uncovered at low tide, bordered by about $2,800 \mathrm{ha}$ of saltmarsh and ricefields. Inland to the east the polder-landscape has been somewhat modified by industrial installations, but the estuary is still frequented in winter and at migration time by over 50,000 waders, including avocet Recurvirostra avoselta, sandpipers Calidris spp., curlew Numenius arquata, and godwits Limosa spp., as well as by several thousand duck, mainly mallard Anas platyrhynchos, wigeon $A$. penelope, teal $A$. crecca, shoveler $A$. clypeata and pochard Aythya ferina. The greater flamingo Phoenicopterus ruber also occurs occasionally. Some 22,850 ha of the saltmarsh, mudflats at Pancas and islands of the inner estuary, including Mouchao do Lombo do Tejo, Mouchao da Povoa, Mouchao do Alhandra and Mouchao des Garcas, are included in a 'Reserva Natural', but only the Pancas flats and saltmarsh, and the lagoon on Mouchao do Lombo, are strict reserves.

Nearly $100 \mathrm{~km}$ up the Tejo from Lisbon the Paul do Boquilobo Nature Reserve near Golega was established. It includes a freshwater marsh, with a lake and surrounding willow and poplar stands, with abundant submerged and emergent vegetation, the sedges being grazed by horses and cattle in summer. The reserve has the most important mixed heronry in Portugal, with little egret Egretta garzetta, cattle egret Bulbulcus ibis, squacco heron Ardea ralloides and night heron Nycticorax nycticorax, with a total of about 2,000 nests. In winter the area is visited by up to 2,500 duck, mainly mallard (1,000), pintail Anas crecca (500) and shoveler (400 to 500), but also teal, wigeon, gadwall $A$. strepera and tufted duck Aythya fuligula.

The Ria Sado estuary also comprises vast mudflats and saltmarshes, with several small reservoirs (for irrigation purposes) and extensive rice-fields. Up to 20,000 waders winter in this varied habitat, including avocet, redshank Tring a totanus and curlew. Further south in teh Algarve is another major site for wintering waders and gulls, in the vicinity of Faro and the coastal strip eastwards to Tavira. The area consists of a mixture of sandy islands, coastal marshes and mudflats. The Ludo marsh in particular is excellent waterfowl habitat, and the site of a nature reserve (very necessary in the light of the hunting pressure and tourist development in the Algarve region).

A few other areas are of interest. The Ilha Berlengo some $12 \mathrm{~km}$ offshore from Peniche, has nesting colonies of seabirds, mainly of herring gull Larus argentatus, but also small numbers of Cory's shearwater Calonectis diomedia and razorbill Alca torda. The coast South of Lisbon between Sesimbra and Setubal, declared a 'Parque Natural' in 1977, is composed of calcareous cliffs of palaeontological interest, the cliff tops covered by a rich maquis-type flora, and the offshore rocks providing nesting ledges for guillemots Uria aalge. Further south again, the cliffs of Cabo de Sao Vicente are still inhabited by peregrine falcon Falco peregrinus and 
chough Pyrrhocorax pyrrhocorax, and provide an excellent look-out post for studying migration. Separated from the Portuguese mainland by some $1,200 \mathrm{~km}$ of Atlantic Ocean, the Ilhas Selvagens, situated between Madeira and the Canary Islands, have important breeding colonies of seabirds which include Cory's shearwater, frigate petrel Pelagodroma marina, Madeiran petrel Oceanodroma castro, little shearwater Puffinus assimilis and Bulwer's petrel Bulweria bulwerii, and a rich flora with several endemic species. The seabird colonies, which were decimated in 1975 and 1976 by fishermen taking not only young but also adults from the nest, are reported to be recovering since the islands were wardened and became a protected area in 1977.

Protected Areas Legislation There are three types of conservation area defined in Portugal: National Park, Nature Park and Nature Reserve. There is only one National Park, Peneda-Gerês, and the primary objectives of this area are conservation and education. By definition only park facilities are allowed within the boundaries of the park. Nature Parks are areas planned to meet the requirements of recreation, nature conservation and landscape protection, but do not have the size or recreational value of a national park. There would appear to be some emphasis on Portugal's conservation effort being combined with traditional rural land use.

Protected Areas Administration The Secretaria de Estado Ambiente e Recursos Naturais within the Ministério do Plano da Administraçao do Territorio, and especially the Servicio Nacional de Parques, Reservas e Conservaçao da Natureza, are making great efforts to extend and improve the network of reserves in Portugal. They are being assisted by organizations such as the Centro de Estudos de Migraçies a Protecçâo de Aves (CEMPA).

\section{Sites designated under the Convention}

Signature subject to ratification 15 July 1976, finally ratified on 24 November 1980 with 2 sites listed at ratification.

Natural Reserve of the Tagus Estuary

Natural Reserve of Formosa Sound

Government body responsible for administration of the Convention

Secretaria de Estado do Ambientee Pecursos Naturais, Ministério do Plano da Administraçao do Territorio, Rua do Século 51, 1200 Lisboa

\section{Natural Reserve of the Tagus Estuary}

Location $38^{\circ} 45^{\circ}-55^{\prime} \mathrm{N}, 8^{\circ} 54^{\prime}-9^{\circ} 00^{\prime} \mathrm{E}$. Situated in the Tagus River estuary about $17 \mathrm{~km}$ northeast of Lisbon on the southwest coast of Portugal.

\section{Area 14,563 ha}

Degree of Protection Most of the reserve is privately owned, with some public corporation and private land. The designated site is protected within the Natural Reserve established by Order in Council No. 565/76 on 19 July 1976. (Partially altered on 17 November 1977). The following are prohibited or restricted in the reserve: construction activities, erection of telephone or power cables, introduction of exotic plants and animals, aircraft overflying below $300 \mathrm{~m}$, hunting outside defined areas, camping, and navigation of motorboats outside defined channels. An area in the east has been set aside as a Strict Nature Reserve in which all hunting, fishing and access for domestic animals, the public or vehicles is prohibited. The Natural Reserve is administered by the Central Department of the National Parks Service.. Designated as a Ramsar site at the time of ratification on 24 November 1980.

Site Description The site is a complex of saltmarshes, mudflats, shallow lagoons, dunelands and reclaimed polders around the tidal estuary of the Tagus River and its tributary, the Sorraia. The marshlands and consolidated dunes (7,000ha) support a diverse Lusitanian flora. The water channels are predominantly covered by water hyacinth Eichornia crassipes, an 
introduced pest species. The estuary is bordered by a hinterland of dry grassland, cornfields and woodland of stone pine Pinus pinea and cork oak Quercus suber. Several reptile and amphibian species occur, including the European pond terrapin Emys orbicularis, and stripe-necked terrapin Mauremys caspica. The reserve is surrounded by agricultural land, and the urban developments of Alcochete, Sacavém, Vila Franca de Xira and Benavente.

International and National Importance The marshlands are an important feeding ground for large numbers of migrating waterfowl, including an estimated $75 \%$ of the western European population of avocet Recurvirostra avosetta. Other species include grey plover, ringed plover, dunlin, redshank, curlew, godwits, mallard, shoveler, teal, greylag goose, spoonbill, ruff and greater flamingo (Pluvialis squatarola, Charadrius hiaticula, Calidris alpina, Tringa totanus, Numenius arquata, Limosa spp., Anas platyrhynchos, A. clypeata, A. crecca, Anser anser, Platalea leucorodia, Philomachus pugnax and Phoenicopterus ruber). Nesting species include purple heron Ardea purpurea, grey heron A. cinerea, avocet, stone curlew Burhinus oedicnemus, Kentish plover Calidris alexandrinus, black-winged stilt Himantopus himantopus, red-crested pochard Netta rufina, white stork Ciconia ciconia and collared pratincole Glareola pratincola. Non-aquatic birds breeding in the drier areas include black kite Milvus migrans, black-shouldered kite Elanus caeruleus, short-toed eagle Circaetus gallicus, Montagu's harrier Circus pygargus, red-legged partridge Alectoris rufa, little bustard otis tetrix, red-necked night jar Caprimulgus ruficollis, European bee-eater Merops apiaster, spotless starling Sturnus unicolor and azure-winged magpie Cyanopica cyanus.

Changes in Ecological Character The rapid expansion of floating water-hyacinth is choking the water channels, and by superceding the natural aquatic vegetation reducing the fish population. There is a serious threat of pollution as the reserve is surrounded by military, naval, oil refining and other industrial installations.

Management Practices The reserve is managed by staff from the Central Department of the National Service for Parks, Reserves and Nature Conservation, and has received grants from WWF. Access to, and activities within, the reserve are strictly controlled.

Scientific Research and Facilities A study of the Tagus estuary has been undertaken by the National Commission for the Environment within the framework of the UNESCO Man and Biosphere Programme. The National Service of Parks coordinates studies of the reserve's flora and fauna.

Principal Reference Material The above information is taken from:

- Carp, E. (1980). A Directory of Western Palearctic Wetlands. IUCN, Gland, Switzerland..

Supplemented by:

- Duffey, E. (1982). National Parks and Reserves of Western Europe. Macdonald and Co., London.

- Natureza e Paisagem. Bulletin published by National Service for Parks, Reserves and Nature Conservation.

Scott, D.A. (1980). A preliminary inventory of wetlands of international

importance especially for waterfowl in west Europe and northwest Africa.

- IWRB Special Publication No. 2.

\section{Natural Reserve of Formosa Sound}

Location $36^{\circ} 57^{\prime}-37^{\circ} 10^{\prime} \mathrm{N}, 7^{\circ} 32^{\circ}-8^{\circ} 01^{\prime} \mathrm{W}$. Situated on the south coast near the town of Faro.

Area $16,000 \mathrm{ha}$

Degree of Protection Part state and part private ownership. The site includes Ludo Game Reserve (744ha) west of Faro. Designated as a Ramsar site at the time of ratification on 24 November 1980. 
Site Description The site is a complex of freshwater and brackish marshes, lagoons, mudflats, beaches, dunes and saltpans, and extends from some $15 \mathrm{~km}$ west of Faro to about $60 \mathrm{~km}$ east of the town. There are extensive beds of Phragmites sp. and Typha sp., and the site contains a wide range of habitats which is reflected in the abundance of bivalve molluscs, crustaceans and fish. Exploitation of these resources provide a living for some 5,000 people.

International and National Importance The site is an important passage and wintering area for waterfowl, with up to 20,000 waders in winter (January average 15,000). Species include ringed plover, Kentish plover, bar-tailed godwit, knot, little stint, dunlin and wigeon (Charadrius hiaticula, C. alexandrinus, Limosa lapponica, Calidris canutus, C. minuta, C. alpina and Anas penelope). Breeding species include purple gallinule Porphyrio porphyrio, little egret Egretta garzetta, grey heron Ardea cinerea, white stork Ciconia ciconia, black-winged stilt Himantopus himantopus, little tern Sterna albifrons, pratincole Glareola pratincola, Kentish plover, avocet and redshank Tringa totanus, Other species occurring at the site include greater flamingo Phoenicopterus ruber and white spoonbill Platalea leucorodia.

Changes in Ecological Character Some offshore sandbars are crowded with holiday homes, and there is some pollution by sewage. The western part of the reserve lies in the flightpath of Faro Airport. There is also considerable hunting pressure.

Management Practices Since the establishment of Formosa Natural Reserve, any new buildings or change in agricultural or industrial practices must have authorisation from the administrating committee. No form of exploitation except fishing is allowed in Ludo Game Reserve.

Scientific Research and Facilities Research includes studies of the flora, molluscs and fish culture and ornithology.

Principal Reference Material The above information is taken from the documents supplied by the Government of Portugal for designation in 1980.

Supplemented by:

- Carp, E. (1980). A Directory of Western Palearctic Wetlands. IUCN, Gland, Switzerland.

- Duffey, E. (1982). National Parks and Reserves of Western Europe. Macdonald and Co., London.

Additional reference:

- Rufino, R., Miranda, P., Pina, J.P. and Araujo, A. (1983). Wader populations in the Ria Formosa. $X X I X I W R B$ Meeting, Huelva - Espana 


\section{SENEGAL}

Area 197,160 sq.km

Population $6,274,000(1984)$

Summary of Wetland Situation The country is generally flat, apart from the volcanic peaks of Cape Verde and the Fouta Djallon. The major wetland areas are rivers and their deltas, the levels of which vary enormously through the year; the major sites for waterfowl depend on this alternation of wet and dry, fresh and salt cycles. The most important areas are:

The Senegal Delta (partly in Mauritania). This area is of international importance, being one of the three great wetlands in West Africa for Palaearctic migrants. It is the first available stopping point after a $200 \mathrm{~km}$ crossing of the Sahara. Development projects carried out since 1963 have canalized the river, preventing large areas from being flooded, while recent droughts have aggravated this process and greatly decreased the value of the Senegalese side of the delta for waterfowl. Major wetland areas, such as Djoudj, the floodplains of rivers Lampsar and Djeuss, Langue de Barbarie National Park, the Gueumbeul Reserve, Trois Marigots, the Ndiaël depression and the Richard-Toll Lake, still exist.

The Gambia river and its tributaries. In particular it supplies the Niokolo-Koba National Park in the south-east. By the end of the rainy season, the sudanese savannas and marshes are almost entirely under water, but in May, at the end of the dry season, they resemble a semi-desert. It is an important area for birds, with over 320 recorded species. The area is threatened by the Gambia and Niokola-Koba damming projects.

The Saloum delta is situated on the central coast, consists of a mosaic of sandy islands and lagoons, with a wide variety of mangrove swamps, some of the most northerly in Africa. The islands have herbaceous populations of helophiles of varying importance. The surrounding area comprises open forest with sandy soil. The avifauna is mainly seabirds, though flamingos do breed here. The greatest threat to the area, particularly the mangroves, is the extension of the rice culture.

The Casamance river and its regime of watercourses in the extreme south has little in common with northern Senegal. The area is densely populated, with rich well-watered soils and areas of tropical rainforest and mangroves. Birds are well represented, with over 200 species including a number of Palaearctic migrants and species of the Ethiopian biogeographic zone.

The Senegal government is attempting to alleviate the consequences of drought and construction of dams etc. by reflooding areas. It is considering the possibility of creating another reserve in the Palmarin in the Saloum delta areas, having recently established the Gueumbeul Reserve in the Senegal delta. In addition, sections of all four wetlands are designated National Parks.

Protected Areas Legislation The Forest Code and the Code of hunting and the Protection of Nature are in force, and are currently being improved. Each protected area also has its own set of rules and regulations. Presidential Decree 69-858 of 22 July 1969 made the National Parks Office responsible for all parks, under the Prime Minister. The Direction des Parcs nationaux was set up a by Parks Directorate of April 1973.

Protected Areas Administration The National Parks Directorate comes under the direct responsibility of the Ministry of Nature Protection. There is also a National Committee to deal with poaching, and a Council of Hunting. National Parks are seen as having three main roles, conservation, scientific research, and controlled tourism, the aim being to conserve complete ecological units in as many of Senegal's ecosystems as is possible. The Reserve Ornithologique de Kalissaye was established specifically to protect the breeding colonies of sea birds and breeding sites of marine turtles. 


\section{Sites designated under the Convention}

Accession 11 July 1977, with 2 sites listed at accession, another added 3 on 3 April 1984 and another added in September 1986.

Parc national des Oiseaux du Djoudj

Bassin de la Réserve spéciale de faune du Ndiaël

Le Delta du Saloum

Réserve spéciale de faune de Gueumbeul

Government body responsible for administration of the Convention

Ministère de la Protection de la Nature, Building Administratif, Point E, BP 5135, Dakar Fan.

\section{Parc national des Oiseaux du Djoudj}

Location $16^{\circ} 30^{\circ} \mathrm{N}, 16^{\circ} 10^{\circ} \mathrm{W}$. Situated $15 \mathrm{~km}$ north of Ross-Bethio and about $60 \mathrm{~km}$ northeast of Saint-Louis on the Senegal River delta, Fleuve Region, in the extreme north of Senegal.

Area 16,000 ha

Degree of Protection State owned. Administered by Conservateur, Parc national des Oiseaux de Djoudj (Saint Louis BP 80, Senegal). Total protection as a national park, with access permitted only for 'educational tourism' and scientific research. Established on 14 April 1971 by Decree No. 71-411. Enlarged from 13,000ha in 1975 by Decree No. 75-1222. Accepted as a World Heritage site in 1981. Designated as a Ramsar site in 1977.

Site Description The site comprises a vast basin in the delta of the Senegal river, with impermeable halomorphic soils forming saline flats between the main channel to the north, and Djoudj and the Gorom channels to the south. The delta has been subject to flooding and the development of dyke systems (most recently in 1963), which have allowed longer retention of waters in the Djoudj basin than normal. This has been beneficial to the waterfowl. Salinity varies with water level from nearly fresh during winter inundations to brackish as the water level falls. Climate is Sahelian with alternate wet and dry seasons. Minimum annual precipitation $300 \mathrm{~mm}$, and mean annnual temperature $27^{\circ} \mathrm{C}$. During the dry season the site is the only naturally verdant area in the region. The vegetation reflects the relatively low rainfall on unfavourable halomorphic soils, and is Sahelien type with savanna dominated by spiny bushes, acacias such as $A$. nilotica, $A$. raddiana and $A$. seyal, tamarisk Tamaris senegalensis and Balanites aegyptiaca. During the rains, dense populations of Typha and waterlily species appear in the flooded zones. Halophyllic plants such as Salicornia cover much of the area. Mammals include warthog Phacochoerus aethiopicus and West African manatee Trichecus senegalensis. Several species of crocodile and gazelle have been successfully reintroduced into the area.

International and National Importance The Senegal delta, along with the Inner Niger Delta (Mali) and Lake Chad, is one of the three major West African sanctuaries for Palaearctic migrants (being one of the first places with permanent freshwater south of a $200 \mathrm{~km}$ stretch of the Sahara) with an estimated 3 million passage migrants in September to April. The avifauna is the main reason for establishment of the park, with some 300 recorded species. Common migrants are ducks and waders including garganey Anas querquedula, shoveler $A$. clypeata, pintail A. acuta, ruff Philomachus pugnax and black-tailed godwit L. limosa. Regular nesting species include cormorants Phalacrocorax spp., white pelican Pelecanus onocrotalus, white-faced tree duck Dendrocy'gna viduata, fulvus tree duck $D$. bicolor, spur-winged goose Plectropterus gambensis, purple heron Ardea purpurea, night heron Nycticorax nycticorax, egrets Egretta spp., spoonbill Platalea leucorodia, anhinga A. anhinga and Arabian bustard Otis arabs. 
Changes in Ecological Character The park includes only part of the delta. A serious concern for water management in the region is the planned barrages at Diama and Manantali. It seems generally thought that absence of water is more of a problem than excess, and that up-stream damming and proper water control could possibly help rather than harm the waterfowl populations in the sanctuary. There is intense cultivation upstream of the park with agricultural products draining into the Goram. Another potential problem is the construction of a road between Senegal and Mauritania.

Management Practices Administration zones are coordinated by park wardens stationed in 5 watch posts. The park is closed for three months of the year for management purposes. There are plans for construction of a dyke around the park, and a dam system so that water levels will not be affected by the alternating flow of the River Senegal after the barrages have been built.

Scientific Research and Facilities Research includes rodent studies, identification of new species, origin of the birds, lines of migration and population dynamics (ringing studies). ORSTOM has sponsored research in the area since 1955. An eco-museum and observation hut were financed by ANCGE. Studies of waders were carried out in 1983-1984 by Station Biologique de la Tour du Valat, France.

Principal Reference Material The above information is taken from:

- Dupuy, A.R. (1971). Les oiseaux et les mammifères de la cuvette du Djoudj (delta du fleuve Sénégal). Bull. IF AN 33 A(1): 237-248.

- Dupuy, A.R. (1971). Contribution à l'étude de l'avifaune du delta du Sénégal. Bull. IFAN 33 A(3): 737-753.

Dupuy, A.R. (1971). Mission au nouveau parc national des oiseaux du Djoudj. Notes Africaines 132.

Dupuy, A.R. (1972). Le parc national des oiseaux du Djoudj. Bull. IF AN 34 A(3): 775-81.

- Dupuy, A.R. and Suiro, P. (1983). Les Oiseaux du Djoudj. Parcs Nationaux du Senegal.

- Roux, F., Jarry, G., Mahéo, R. and Tamisier, A. (1976). Importance, structure et origine des populations d'Anatides hivernant dans le delta du Sénégal. L'Oiseau R.F.C. 46: 299-336 and 47: 1-24.

- Secretariat d'Etat charge de la nature (1974). Le parc national des oixeaux du Djoudj, Dakar.

- Thorsell, J. (1985). World Heritage Report - 1984. Parks 10(1):8-9. World Heritage Nomination submitted to UNESCO. Documentation submitted to the Ramsar Convention Secretariat.

\section{Bassin de la Réserve spéciale de faune du Ndiaël}

Location $16^{\circ} 10^{\prime} \mathrm{N}, 16^{\circ} 05^{\prime} \mathrm{W}$. Situated on the Senegal River delta about $12 \mathrm{~km}$ southeast of Djoudj National Park, and $40 \mathrm{~km}$ northeast of Saint-Louis in the extreme north of Senegal.

Area 10,000 ha (basin)

Degree of Protection State owned. The Special Fauna Reserve $(46,550 \mathrm{ha})$ was created by Decree No. 65/053 on 2 February 1965 to protect the rich avifauna of the Senegal delta. Designated as a Ramsar site in 1980.

Site Description The site comprises a basin with impermeable halomorphic soils dominated by a graminaceous perennial vegetation, with an abundance of annuals such as Paspalum, Panicum and Eragrostis spp.

International and National Importance When the area was regularly inundated in good seasons, it was particularly important for Palaearctic migrants, due to the shallow muddy water and inaccessibility for man. Avifauna is essentially similar to Djoudj National Park. 
Changes in Ecological Character The construction of the Saint-Louis to Rosso road and the reservoirs of Guier Lake and Lampsar-Djeuss (for irrigation supply) involved damming of the Niet Yone, Ngalam and Bombol rivers (all of which replenished the site). The Ndiaël has therefore dried up, to some extent, although it still receives a small amount of water each year when the SAED (Société d'Aménagement et d'Exploitation du Delta) drain the rice plantations in the upper delta. There is a possibility that the construction of the Diama dam on the River Senegal will enable water supplies to be restored to Ndaiël.

Management Practices The Minister for Rural Development and Hydrology has given formal instructions to the agricultural organisations to release water to inundate the Ndiael during development.

\section{Scientific Research and Facilities No information}

Principal Reference Material The above information is taken from the documents supplied by the Government of Senegal at the time of designation in 1980 and the National Report for the Conference on Wetlands of International Importance especially as waterfowl habitat held at Cagliari, Italy in November 1980.

\section{Le DeIta du Saloum}

Location $13^{\circ} 35^{\prime}-13^{\circ} 55^{\prime} \mathrm{N}, 16^{\circ} 27^{\prime}-16^{\circ} 48^{\prime} \mathrm{W}$. Located $150 \mathrm{~km}$ from Dakar, on the main road between Dakar and Banjul, and $80 \mathrm{~km}$ from Kaolack.

Area 73,000ha. The Biosphere Reserve is 180,000 ha, with a core zone of 73,000 ha (the National Park). Four-fifths of the national park is marine, whereas the biosphere reserve comprises a 72,000 ha marine sector, 23,000 ha of flooded areas, and 85,000 ha of terrestrial islands.

Degree of Protection The core area (the National Park) and part of the buffer zone are government-owned. The remainder belongs to the local community. Established as a National Park by Decree no. 76-577, 28 May 1976. An international park with the Gambia is being planned. The national park and its surroundings were accepted as a Biosphere Reserve in 1980, and the national park was listed as a Ramsar site in 1984.

Site Description In the Delta of the seasonal Sine and Saloum rivers, the area includes many sand islands and lagoons, the Sangomar point and coastal waters, and the forests of Fathala. Most of the terrestrial area of the park is covered by mangroves made up principally of four species: Rhizophora racemosa, $R$. mangle, $R$. harrisonii and Avicennia nitida; sand dunes are present, and there is open forest on sandy soils. There are islands of herbaceous populations of halophiles - Sesuvium portulacastrum, Philoxerus vermicularis, and Paspalum vaginatum. The distributaries of the delta at the coast are almost exclusively saline. The fauna is however sudano-sahelien and very varied, with many small mammals in the dry forest of Fathala. There are also bay colobus Colobus badius temmincki present. Large mammals have probably never been abundant here. It is an important nesting and wintering site for waterfowl. The climate comes between the sudanese and the sudano-sahelien types characterised by a rainy season in July-October (maximum in August). The mean annual temperature is $28^{\circ} \mathrm{C}$ and mean annual precipitation $800 \mathrm{~mm}$.

International and National Importance Many seabirds nest on the deserted islands, including about 1000 pairs each of lesser flamingo Phoenicopterus minor and greater flamingo $P$. ruber, 4000 grey pelicans Pelecanus rufescens, and there are ten pairs of goliath heron Ardea goliath. Many wintering waders use the area. On the coast species of particular note include the manatee Trichechus senegalensis and hump-backed dolphin Sousa teuszii. Reptiles are well represented predominately by marine turtles, including olive ridley Lepidochelys olivacea, green Chelonia mydas, and loggerhead Caretta caretta. Crocodile Crocodylus niloticus are also present. It is an important fish spawning ground. 
Changes in Ecological Character The mangroves could be damaged by extension of rice culture and exploitation of forest in the Fathala area. Protection does not extend to the salt flats, or to the whole of the Fathala forest. There are, however, proposals to include the whole of the latter within the park. Fire in the forest zone, excessive fishing, destruction of bird colonies, projects on reintroducing species such as antelope Hippotragus sp., and conflicts with industrial and agricultural development, could all be extremely detremental to the area.

Management Practices The core area of national park is surrounded by a buffer zone (which gives a total of just over $73,000 \mathrm{ha}$ ). The classified forest zone, where exploitation is forbidden, comprises the forests of the islands of Saloum, Behtanti, Sangako, and Fathala (around $70,000 \mathrm{ha}$ ). Part of the groundnut lands and Point Sangomar and its fishing cooperative (around $90,000 \mathrm{ha}$ ) are included in the buffer zone. A special faunal reserve has been establihed at Palmarin. Several administrative sectors are co-ordinated by a Park Conservator. There is an environmental education programme. The inhabitants of the biosphere reserve participate in its running and management through a rural council in liaison with national park and forest service authorities. Radios have been provided by an IUCN/WWF Project to help safeguard the fish spawning grounds.

Scientific Research and Facilities There have been studies of birds and mammals, vegetation and water pollution, but little published. There is a meteorological station.

\section{Principal Reference Material}

Documentation submitted to the Ramsar Convention Secretariat.

IUCN/WWF Project 3113. Proposed Delta du Saloum International Park.

Larivière, J. and Dupuy, A. (1978). Sénégal: Ses parcs, Ses animaux. Editions Fernand Nathan, Paris.

\section{Réserve Spéciale de faune de Gueumbeul}

Location $15^{\circ} 75^{\circ} \mathrm{N}, 16^{\circ} 28^{\prime} \mathrm{W}$. Near the coast of northern Senegal in the district of Rao, Dagana region, about $12 \mathrm{~km}$ south of Saint-Louis. The road from Gandiole to Rao forms the southern boundary.

Area 750 ha

Degree of Protection The site was made a Special Faunal Reserve under decree No.83-550 of 30 May 1983; it is classified as forest estate and managed by the National Parks Service. Designated a Ramsar site on 29 September 1986.

Site Description The site comprises a lagoon about $2.5 \mathrm{~km}$ long by nearly $1 \mathrm{~km}$ wide, and the land for about $500 \mathrm{~m}$ around it, which forms a shallow depression. The lagoon varies in depth and salinity; in winter it is fed by rainwater and saltwater inflow from creeks of the Senegal river and the Djeuss marsh. Many of the soils are halomorphic. Along its shoes are sandy ridges with sparse thorny vegetation, dominated by acacias. There is a relict area of mangrove which is one of the most northerly in Africa.

International and National Importance The site is an important wintering area for thousands of birds, particularly waders, the most important being avocet Recurvirostra avosetta, black-tailed godwit Limosa limosa, ruff Philomachus pugnax, greater flamingo Phoenicopterus ruber, grey plover Pluvialis squatarola, European spoonbill Platalea leucorodia, ringed plover Charadrius hiaticula, little ringed plover $C$. dubius, black-winged stilt Himantopus himantopus, curlew Numenius phaeopus, redshank Tringa totanus and little tern Sterna albifrons. Other well-represented species are African spoonbill Platalea alba, Kittlitz's sand plover Charadrius pecuarius, lesser flamingo Phoenicopterus minor, slender-billed gull Larus genei, grey pelican Pelecanus rufescens and Senegal wattled plover Vanellus senegallus. Some species, including little terns, breed here. 
Changes in Ecological Character The possible development for hydrological and agricultural purposes in the lower Senegal River valley may affect water quality and levels in the lagoon, and this is being investigated. The ministry responsible for water protection has considered the possibility of reintroducing animals which disappeared from this area long ago, including giraffe, gazelle and osrich.

Management Practices Hunting, fishing and agriculture are prohibited, as are any other activities which might interfere with the environment, except when authorised by the National Parks Directorate and for scientific purposes or for disease prevention in human or animal populations. Overflying the reserve at an altitude of less than $300 \mathrm{~m}$ is forbidden, to avoid disturbing bird flocks. Its boundaries are delimited by signs and fencing.

Scientific Research and Facilities The ringing of young little terns has been started. It is hoped that this site will add another link to the chain of reserves for migrant bird populations, and form another site for their study.

Principal Reference Material Material supplied by the Ministry of Nature Protection and National Parks of Senegal at the time of designation. 


\section{Area $1,221,038$ sq.km}

\section{Population $26,750,000(1984)$}

Summary of Wetland Situation South Africa is a largely semi-arid country, with a mean annual rainfall of only $475 \mathrm{~mm}$ (with much of this falling on the eastern and southern coastal belts, and some of the inland mountain areas of the north). Most of the country consists of a high inland plateau with only a narrow coastal strip, and therefore there are few lowland wetland regions of any significance. Consequently, although there are twenty species of ducks and geese this is an indication of the variety of wetland types rather than the overall amount of wetland.

Wetlands also tend to be strongly seasonal in most cases, and therefore wetlands of no apparent importance may become very significant at certain times. A direct result of the highly seasonal rainfall has been the creation of numerous artificial impoundments, many of which have become major habitats for waterfowl.

Concentrations of anatids are not large by Holarctic standards, the largest only consisting of some 5,000 birds, but even these are rather unusual. The more common situation is small concentrations moving round restlessly.

Protected Areas Legislation Legislation pertaining to the establishment of conservation areas in the Republic of South Africa includes the National Parks Act of 1926 (for Kruger National Park and other national parks), the Financial Relations Consolidation and Amendment Act of 1945 (for provincial game and nature reserves) the National States Consolidation Act of 1971 (for game and nature reserves in national states), the Forest Act of 1968 and the Mountain Catchment Areas Act of 1970 (for nature reserves and wilderness areas administered by the Directorate of Forestry). The provisions of these Acts relate to the acquisition of land and the establishment and administration of various management categories of conservation area, the provision of facilities and control and prosecution of those not complying with specific regulations, etc. The numerous revisions and amendments to these acts and to provincial ordinances are reviewed by Fuggle and Rabie (1983).

Protected Areas Administration Conservation areas in South Africa are administered by the National Parks Board, the Natal Parks Board, the Directorate of Forestry and the Nature Conservation Divisions of provincial administrations, National States and the Governments of Transkei, Bophuthatswana, Venda and Ciskei. In the Cape Province, some reserves are administered by Divisional Councils. Management objectives vary widely from area to area, but all fall within those of IUCN Management Categories I to V. The terminology used for these areas includes National Park, Nature Reserve, Game Reserve, Mountain Reserve, Public Resort, Nature Reserve, Game Park, State Forest, Mountain Catchment Area, Wilderness Area, etc. Due to the continuum of differing management objectives relating to these areas, it is not possible to place individual areas into rigidly defined IUCN categories - the categories indicated should be regarded as the 'best fit' presently available. The Sub-Antarctic islands of Prince Edward and Marion are administered by the Department of Transport. Visits to the islands are only undertaken by members of the research stations teams on the islands and by other visiting scientists and logistic personnel.

\section{Sites designated under the Convention}

Signature without reservation as to ratification 12 March 1975, with 2 sites listed at signature, and four more sites added in October 1986.

De Hoop Vlei (Province of the Cape of Good Hope)

Barberspan (Province of Transvaal)

De Mond State Forest (Heuningnes Estuary) 
Blesbokspruit

Turtle Beaches/Canal Reefs of Tongaland

St Lucia System

Government body responsible for administration of the Convention

Department of Environment Affairs, Environmental Conservation Branch, Private Bag X447, Pretoria 0001

\section{De Hoop Vlei}

Location $34^{\circ} 24^{\prime}-34^{\circ} 30^{\prime} \mathrm{S}, 20^{\circ} 18^{\prime}-20^{\circ} 26^{\prime} \mathrm{E}$. 56km from Bredasdorp in the Cape Province.

Area $750 \mathrm{ha}$ (within a nature reserve of $5,168 \mathrm{ha}$ ).

Degree of Protection An area originally established to breed game for the restocking of farms was established as De Hoop Nature Reserve in 1956, and is administered and managed by the Department of Nature and Environmental Conservation. A part of this, which includes most of the eastern shore of the vlei, some of the western bank and parts of the vlei itself, is known as De Hoop Wildproefplaas and probably coincides with the Ramsar site at the time of designation on 12 March 1975. The Ramsar site was expanded on 2 December 1986 to include "all of the vlei between the causeway at Apolsfontein in the north and Die Mond in the south".

Site Description The vlei is a coastal lake, formed when the mouth of the Sout river was blocked by coastal dunes, and it still contains some estuarine organisms. The river is more like a rivulet and only flows in the winter months, (the wet season), when the area receives $40-50 \mathrm{~mm}$ of rainfall, mostly between March and October. The lake is $16 \mathrm{~km}$ long by $0.5 \mathrm{~km}$ wide on average with a surface area of $750 \mathrm{ha}$ when full. Its depth varies considerably from a maximum during periods of flooding (in 1906 and 1957) to drying out completely, which has happened at least once this century. Its salinity can also vary from salt to fresh eutrophic conditions, and changes may be very rapid, from 50 to 3 parts per thousand of salt in two months. During years of flooding, vast areas to the south-west of the vlei are inundated and flooded conditions may persist for several years. The northern end of the vlei lies in a gorge with high limestone sides which extend as a low cliff along the eastern side of the southern part of the vlei. The southern portion of the western bank is a gradually shelving shore of sand.

Marginal vegetation is scarce due to the changing water levels, but a few areas of reedbeds of Phragmites australis are present, mostly around freshwater springs. There are extensive underwater beds of Potamogeton pectinatus and some areas of Chara stachymorpha and Ruppia spp. On the exposed bed of the vlei Salicornia species are dominant. The vegetation of the surrounding area is coastal macchia and white milkwood Sideroxylon inerme trees are common along the lake shore. Birds are the most prominent constituent of the fauna, and 228 species have been recorded from the whole of the De Hoop Nature Reserve, at least 75 of which are dependent on wetlands.

An abundance of zooplankton has been recorded in the lake with the small whelk Tomichia ventricosa in the benthos. There is one indigenous fish the Cape kurper Sandelia capensis, but tilapia Oreochromis mossambicus has been introduced and now occurs in large numbers. The Cape clawed frog Xenopus laevis is common, but water turtles Pelomedusa subrufa, which were present in large numbers until the 1960 s, have become a rarity. A variety of large mammals are present in the Nature Reserve as a whole.

International and National Importance The De Hoop Vlei area is well known as the only breeding site in South Africa of the greater flamingo Phoenicopterus ruber, in 1960 and 1963, during the recession of the 1957 floods. The nesting colonies were to the west and south-west of the vlei, outside the nature reserve, but associated with floodwaters from the lake. Greater flamingo do however use the vlei as feeding habitat, and up to 1,473 individuals have been recorded. A number of other bird species which only breed at a few sites in South Africa use the vlei as feeding habitat and it is critical habitat for a number of other bird species 
(maximum numbers in brackets): white pelican Pelecanus onocrotalus (60), black stork Ciconia nigra (14), lesser flamingo Phoeniconaias minor (1,715), caspian tern Sterna caspia (11) and occasional little bittern Ixobrychus minutus and chestnut-banded sand plover Charadrius pallidus. It is also of great value to a number of other wetland dependent birds, including yellow-billed duck Anas undulata $(4,626)$, Cape shoveler $A$. smithii $(3,004$, over $6 \%$ of the world population), both of which also breed on the vlei, red-knobbed coot Fulica cristata (24,400 and more than 10,000 regularly present) and Egyptian goose Alopochen aegyptiacus $(2,166)$. The number of birds visiting and breeding varies considerably with water levels and salinity, but the most numerous species at all times is red-knobbed coot.

Changes in Ecological Character The development of the Overberg Missile Testing Range is not likely to result in any significant disturbance to the avifauna of the vlei, and the impact of missile testing will be monitored and kept within the strict requirements that have been laid down. The upper part of the lake's catchment is not protected, and the possibility of increased eutrophication from polluted runoff containing fertilisers or pesticides needs investigation. Veld fires, which originate on adjacent farmland, are a further problem which is compounded by unsatisfactory boundary alignments.

Management Practices Until recently, only a part of the lake was included in the De Hoop Nature Reserve, but protection has recently been extended to include the whole lake. Dykes built along its edge are to be removed. Facilities for conservation education were established in the area in 1982. A hiking trail of about $70 \mathrm{~km}$ encircles the Nature Reserve and private vehicles can be driven in certain parts of this reserve, although access to other areas is restricted.

Scientific Research and Facilities A major research programme was begun in 1984 to monitor the effect of the Overberg Missile Testing Range on the flora and fauna, and also on the effects of possible pollution. Monthly counts of waterfowl have been made since May 1979. For the De Hoop Nature Reserve as a whole, a complete fauna list of vertebrates is available, a floristic list is being compiled, and studies and classification of the vegetation have been completed or are in progress. No special research facilities are available, although there is accommodation for visiting scientists in the Nature Reserve.

Principal Reference Material The above information is taken from documents submitted by the Government of South Africa at the time of designation in 1975, and at the time of extension in 1986.

Supplemented by:

- Greyling, T. and Huntley B.J. (Eds) (1984). Directory of southern African conservation areas. South African National Scientific Programmes Report No. 98. Council for Scientific and Industrial Research, Pretoria, South Africa.

- Reader's Digest (1983). Illustrated guide to the Game Parks and Reserves of Southern Africa. Reader's Digest Association of South Africa, Cape Town.

- Uys, C.J. and Macleod, J.G.R. (1967). The birds of the De Hoopvlei Region Bredasdorp, and the effect of the 1957 inundation over a 10-year period (1957-1966) on the distribution of species, bird numbers and breeding. Ostrich 38(4):233-254.

\section{Barberspan}

Location $26^{\circ} 35^{\prime}, 25^{\circ} 35^{\prime} \mathrm{E}$. Situated $15 \mathrm{~km}$ north-east of Delareyville in the Transvaal Province.

Area $3,118 \mathrm{ha}$

Degree of Protection The designated site includes a provincial Nature Reserve 3,118ha. The protected area includes land up to $1.6 \mathrm{~km}$ from high water mark. The southeast of the pan is set aside for anglers. Designated as a Ramsar site in 1975. 
Site Description Barberspan is a shallow depression (maximum depth $9.6 \mathrm{~m}$ ) in the fossil course of the Harts River, and was formed by the prevailing northerly winds and herds of springbok and other animals trampling the bottom of the waterhole. Water supply is supplemented by the Hart River along the fossil course. Overflow reaches the Vaal River via Schweizer-Reneke. Barberspan is a highly alkaline perennial lake subject to considerable fluctuations in water level due to its large area and shallowness. Annual average temperature range: minimum $-9^{\circ} \mathrm{C}$, maximum $-27^{\circ} \mathrm{C}$. Annual rainfall $557 \mathrm{~mm}$, falling mainly in summer (October to April). The grassland landscape is characterised by absence of any marked physiographic features, and can be described as a great undulating plain. Marginal vegetation is normally unable to keep up with the advance and retreat of the water level. Aquatic surface vegetation is primarily rafts of Potamogeton pectinatus. The marginal vegetation is comprised of rushes (Juncaceae) and sedges (Cyperaceae). Karroid encroachment is notable on one shore. The lake has rich zooplankton and phytoplankton, but poor benthic levels due to a bare limestone substrate. Fauna occurring at the site include: mammals - blesbok Damaliscus dorcas phillipsi, red hartebeest Alcelaphus buselaphus, Burchell's zebra Equus burchelli, and black wildebeest Connochaetes gnou; reptiles - striped long-tail lizard Nucras taeniolata ornata, Cape thick-toed gecko Pachydactylus capensis capensis, aurora housesnake Lamprophis aurora, leopard tortoise Geochelone pardalis babcocki, serrated tortoise Psammobates oculifer, and ring-necked spitting cobra Hemachatus haemachatus.

International and National Importance Barberspan is very important as a stopover site for waterfowl, with over 320 recorded species including Palaearctic species, red knot Calidris canutus and black-tailed godwit Limosa limosa. Species present include all indigenous waterfowl species except the tropical dwarf goose Nottapus auritus. Barberspan is the only locality in the Republic of South Africa where pintail Anas acuta has been recorded. Some waterfowl species breed in the wetland. The species found here which are regarded as endangered in South Africa include: South African hedgehog Erinaceus frontalis, striped weasel Poecilogale albinucha, Peregrine falcon Falco peregrinus, fish eagle Haliaeetus vocifer, openbilled stork Anastomus lamelligerus, goliath heron Ardea goliath, pink-backed pelican Pelecanus rufescens, white pelican Pelecanus onocrotalus, Caspian tern Hydroprogne caspia, and yellow-billed stork Mycteria ibis.

\section{Changes in Ecological Character No information}

Management Practices There is an observation hide for visitors, and a bird-watcher's trail is being developed on the shore of the pan. There is one nature conserver and 16 labourers.

Scientific Research and Facilities Migration patterns are monitored by staff of the research station.

Principal Reference Material The above information is taken from the documents supplied at the time of designation in 1975.

Supplemented by:

- Greyling, T. and Huntly B.J. (Eds) (1984). Directory of southern African conservation areas. South African National Scientific Programmes Report No. 98. Council for Scientific and Industrial Research, Pretoria, South Africa.

- Hutchinson, G.E., et al. (1932). A contribution to the hydrobiology of pans and other inland waters of South Africa. Arch Hydrobiology, 24, 1-136.

- Reader's Digest (1983). Illustrated guide to the Game Parks and Reserves of Southern Africa. Reader's Digest Association of South Africa, Cape Town.

\section{De Mond State Forest (Heuningnes Estuary)}

Location $34^{\circ} 41^{\prime}-34^{\circ} 45^{\prime} \mathrm{S}, 20^{\circ} 05^{\prime}-20^{\circ} 10^{\prime} \mathrm{E}$. On the edge of the Indian Ocean, $25 \mathrm{~km}$ from Bredasdorp, Cape Province. 
Degree of Protection De Mond Nature Reserve was created on 27 March 1975 under section 7 of the Forest Act 1968 from an area of the larger De Mond State Forest, to preserve the fauna and the coastal macchia vegetation. The Nature Reserve includes the Heuningnes Estuary and some of the dunes to either side, and forms the Ramsar site designated on 2 December 1986.

Site Description The site includes the southernmost estuary in Africa, formed where the Heuningnes river reaches the sea through a double ridge of sand dunes. It is situated on the flat coastal plain of Bredasdorp where many of the river channels are ill-defined, and long periods of heavy precipitation can cause extensive flooding. At other times river flow can be insufficient to keep the mouths open. This area has a Mediterranean type climate with a rainfall of about $500 \mathrm{~mm}$, mostly falling in winter (May to September). In January the daily temperature range is $15^{\circ} \mathrm{C}-28^{\circ} \mathrm{C}$ and in July $6^{\circ} \mathrm{C}-17^{\circ} \mathrm{C}$.

In its natural state, water in the lower estuary tended to dam up behind the dune barrier which was periodically breached during flood discharge from the Heuningnes river, and an elongated lagoon about $2.5 \mathrm{~km}$ long used to form between the dune ridges. However, extensive flooding also occurred in the hinterland, which was becoming used for farming, and in 1937 the Department of Agriculture and Forestry began to take steps to keep the river mouth open. The sand dunes on either side of the estuary, and the dune spit to the north, are now artificially stabilised by planting exotic marram grass Arenaria ammophila which disappears as indigenous species take over. This prevents sand migrating across the mouth and blocking the channel.

Dune areas and pebble slacks behind the beach are important for nesting terns. The landward face of the inner dune has become colonised by coastal macchia scrub, and there are some wooded areas. The mouth of the estuary comprises an extensive bay with sand and mudflats, and three areas of tidal salt marsh on sandy substrate dominated by Limonium spp., Salicornia spp. and Sarcocornia spp. However, through the construction of road protection levées, tidal activity has been reduced and these areas are becoming invaded by terrestrial species such as Tetragonia decumbens and Chrysanthemodes monilifera. Further upstream there are salt marshes on muddy substrate with species such as Sarcocornia perennis, S. decumbens, Chenolea diffusa, Suaeda maritima, Limonium scabrum and Juncus kraussi. There is a tidal influence $12 \mathrm{~km}$ upstream but a causeway $1.3 \mathrm{~km}$ from the sea obstructs the tidal flow considerably in the upper reaches. Patches of reedbeds Phragmites australis occur at place along the river banks. Flood plain vegetation above the marshes is heavily grazed. Owing to the turbidity of the water in the estuary aquatic plants are scarce, but a species of Ruppia does occur and there are a number of marine fish which are an important food source for terns and the seahorse Hippocampus sp. occurs here.

National and International Importance This area is one of the few confirmed breeding sites of the Damara tern Sterna balaenarum in South Africa. This species breeds mainly in Angola and to a lesser extent in South Africa, in which there are only two breeding sites protected by nature reserves. An estimated $15 \%$ of the national population of the species can be found in this wetland including 5-7 breeding pairs. Several pairs of Caspian tern S. caspia also breed regularly, and there is a large colony of kelp gull Larus dominicanus (about 300 pairs). Other breeding birds include black oystercatcher Haematopus moquini, blue crane Tetrapteryx paradisea, Kittlitz's sand plover Charadrius pecuarius and Egyptian goose Plectropterus gambensis. A small number of waders also use the lower estuary, with about 600 birds recorded in January 1981 of about 10 migrant species and three resident ones. As the most southerly estuary in Africa, the site is scientifically important for species distribution extremities, including the southernmost records of tropical species like the ginger prawn Penaeus japonicus, giant mud crab Scylla serrata and a gastropod Nerita albicilla.

Changes in Ecological Character The practise of artificial dune stabilisation has reduced the potential Damara tern nesting habitat, but this is being curtailed. There is increasing pollution from agricultural activities upstream as pesticides and fertilisers are widely used on the farmland further inland. Recreational use and coastal development pressures are increasing, and the use of two, three and four wheeled vehicles is an increasing problem in the dunes, and a severe threat to the nesting of Damara terns. 
Management Practices The mouth of the estuary is kept open by dune stabilisation and also by brushwood abutments either side of the river channel. This prevents the ecosystem stagnating, prevents flooding of farmland further inland during periods of high rainfall, and also benefits the Damara terns which feed on the marine fish of the estuary. However, dune stabilisation measures are now limited to maintenance work to allow the maximum area of bare ground for Damara tern nesting habitat. No areas are planted within $300 \mathrm{~m}$ of tern nesting sites, which are mostly in the dunes immediately behind the beach. The breeding bird colonies are monitored.

Public access for recreation and fishing is controlled by a permit system, but this does not extend below the high tide mark. No camping or power boating is allowed within the nature reserve. A burning system on a 8-15 year rotation may be introduced to encourage a diverse indigenous flora. The possibility of closing the estuary mouth in the event of an oilspill is envisaged. Stricter control of vehicles in the dunes is planned. The land upstream of the State Forest has been declared a private nature reserve, and a local landowners' association, the Heuningnes Riparian Owners Association, has been formed which is sympathetic to the aims of conservation.

Scientific Research and Facilities Many aspects of the estuary's ecology have been studied, including the requirements of the Damara tern, and censuses of waterbirds have been undertaken. A detailed report (Bickerton, 1984) has been produced in the Estuaries and Coastal Research Unit (ECRU) series on this estuary.

Principal Reference Material The above information taken from documents supplied by the Government of South Africa at the time of designation Supplemented by:

- Bickerton, I.B. (1984). Estuaries of the Cape. Part II: Synopses of Available Information on Individual Systems. Report No.25 Heuningnes Estuary. National Research Institute for Oceanology Council for Scientific and Industrial Research: Stellenbosch.

\section{Blesbokspruit}

Location $26^{\circ} 12^{\prime}-26^{\circ} 23^{\circ} \mathrm{S}, 28^{\circ} 30^{\prime} \mathrm{E}$. In Springs district, about $3 \mathrm{~km}$ east of the town of Springs, province of Transvaal.

\section{Area 1,858 ha}

Degree of Protection In the early 1970s an area of about 500ha of marshland at the southern end of the vlei was donated by Marievale Consolidated Mines to the Transvaal Division of Nature Conservation to be managed as a Bird Sanctuary (Provincial Nature Reserve). A further 385 ha was donated in 1976. An agreement entered into in the mid-1980s between the Anglo-American Corporation and the Transvaal Provincial Administration made an area of the farm Grootvaly, at the northern end, to be managed as a reserve. The Ramsar site was designated on 2 December 1986.

Site Description The Blesbokspruit is a typical highveld vlei at an altitude of $1600 \mathrm{~m}$ dominated by common reed Phragmites communis and greater reedmace Typha latifolia, with some Juncus and Cyperus species. To the north of Springs the spruit flows through a wide grassy valley which is probably the historical condition of the whole valley. Between Springs and Marievale Bird Sanctuary, water levels in the spruit are artificially maintained by embankments and by mining, industrial and municipal effluents. Pollution from these also produce highly eutrophic water conditions favoured by the vast reedbeds which provide habitat for a variety of birds. The permanently waterlogged parts are fringed by a band of Paspalum dilatatum, and the drier areas also have grasses but no trees. An important food plant for geese Alisma plantago also occurs, and there are patches of Potamogeton sp. in places. 
Criteria for inclusion The Blesbokspruit supports significant numbers of waterfowl, including up to 4,000 yellow-billed duck Anas undulata, 1,000 red-billed duck Anas erythrorhyncha and 1,000 spur-winged goose Plectropterus gambensis in the dry season, when water levels are maintained artificially at a high level. The high-productivity water provides food for greater flamingo Phoenicopterus ruber, lesser flamingo Phoeniconaias minor and goliath heron Ardea goliath, which are all South African Red Data Book Species. Other notable birds include avocet Recurvirostra avosetta, purple heron Ardea purpurea, spoonbill Platalea alba, glossy ibis Plegadis falcinellus and yellow-billed stork Mycteria ibis. African marsh harrier Circus ranivorus, which has been displaced from much of the veld, maintains a strong population here. There are at least three heron roosts with a total of over 3,500 birds.

Changes in Ecological Character The natural condition of much of the vlei has been modified, although this has increased the site's suitability for a number of species. There is siltation from gold mining spoil, and pollution from industrial and domestic sources. Possible threats include excessive abstraction of water, and the channelling of additional water into the vlei via canals, both of which could alter water levels. Urban encroachment and low overflying by aircraft could also become problems.

Management Practices Water levels are largely controlled, mainly by the Ergo causeway sluice at Daggafontein. Some of the area is fenced and patrolled by game guards. Fire breaks are maintained by controlled burns and cutting. Herbicides are used on some of the vlei vegetation and for fence protection. Game are introduced, but alien animals and plants, including cats and dogs, are eradicated. Vlei water is used for irrigation. Hunting was once very popular along the spruit but is now prohibited over most of the land although there is still an annual duck shoot at Daggafontein which is, however, strictly controlled by the landowners. Some quarry pits are scheduled for rehabilitation. Urbanisation in the surrounding area is increasing and it has been recommended that the whole area should be fenced to control access. The popularity of Marievale Bird Sanctuary at the southern end attests to the vlei's potential for recreation and education. Here, there are bird-watching hides and picnic facilities. Similar developments are planned at Grootvaly at the northern end, and interpretive centres are proposed for both areas. The vlei is part of the proposed Blesbok hiking trail.

Scientific Research and Facilities Research has included a study of the capability of reedbeds to remove heavy metals and suspended solids over a distance of $20 \mathrm{~km}$. The site is within one hour's drive of South Africa's two largest universities. Scientists from these have produced a number of reports, particularly on waterbirds and the effects of mining activities on their habitat.

Principal Reference Material The above taken from documents supplied by the Government of South Africa at the time of designation.

\section{Turtle Beaches/Coral Reefs of Tongaland}

Location $25^{\circ} 51^{\prime}-28^{\circ} 08^{\prime} \mathrm{S}, 32^{\circ} 33^{\prime}-51^{\prime} \mathrm{E}$. On the coast of Natal province, stretching from just south of Cape Vidal northwards to the border with Mozambique.

\section{Area $39,500 \mathrm{ha}$, being the area of St Lucia Marine Reserve}

Degree of Protection State owned. The site consists of two contiguous areas, the St Lucia Marine Reserve and the proposed Maputaland Marine Reserve. Although it would appear that while both sites will eventually be included in the list, only the area of the St Lucia Marine Reserve has been given by the authorities. The St Lucia Marine Reserve lies between low water and $5 \mathrm{~km}$ of fshore, along $79 \mathrm{~km}$ of the Maputaland coastline. However, in contradiction to material provided when the site was designated as a Ramsar site, it would appear from the reserve management plan that it extends $5.6 \mathrm{~km}$ out to sea (which increases the gazetted size of the reserve to $44,240 \mathrm{ha}$ ). The Reserve was proclaimed in the Government Notice R312 of 23 February 1979 under the Sea Fisheries Act No. 58 of 1973, which defines the areas, and lays down regulations for the control of the capture or disturbance of almost all marine life 
(excluding seals and sea birds). The other site runs from the northern boundary of the current reserve, some $51 \mathrm{~km}$ north to the border with Mozambique and is also some $5 \mathrm{~km}$ wide. The current status of this site is unclear from the information supplied. Designated a Ramsar site in October 1986.

Site Description The site comprises an extensive area of coastal waters, lying along the coast of Maputaland. This area is the only really subtropical part of the South African coastline. Conditions favour the growth of corals, reef fish and a variety of Indo-Pacific fauna and flora, but true reef formation does not occur to a marked degree this far south. Although virtually indistinguishable from true reefs, the coral communities consist of an encrustment of sandstone reefs. These are composed of a sandy calcarenite which represents lithified cores of former coastal sand dunes. They are abundantly colonized by corals and other groups of benthic and pelagic biota normally associated with true coral reefs, and are in particular found of $f$ Sodwana, Jesser Point, and at a further four localities, between Jesse Point and Leven Point, north of Lake St Lucia, and lie $1-2 \mathrm{~km}$ offshore. The most extensive community is on Leadman shoals, north of Leven Point. The area is an important transition zone between true reef areas and areas where luxuriant reef communities occur on non-limestone substrates. In total sixteen coral species are listed for the St Lucia Marine Reserve. It is estimated that some 1,200 fish species are to be found of $f$ the Maputaland coast, five marine turtles (Eretmochelys imbricata, Chelonia mydas, Lepidochely's olivacea, Caretha caretta and Dermochely's cariacea) and the sea snake Pelamis platurus are also recorded. Some 41 marine mammals are thought to occur in these waters, including possibly dugong Dugong dugon. 49 species of bird have been identified. The littoral waters of Maputaland are generally clear with visibility up to $50 \mathrm{~m}$. Prevailing winds are mainly north-easterly and south-westerly, and the dominant current throughout the year is the Agulhas Current which flows southwards from Mozambique. The mean sea water temperature for Maputaland is $26.5^{\circ} \mathrm{C}$, and temperatures rarely fall below $20^{\circ} \mathrm{C}$.

National and International Importance Although only the sea below the low tide mark is listed, adjacent shorelines are protected and it is this coastline system as a whole, with its associated coral reefs, intertidal zone and turtle breeeding areas, which is in a natural undisturbed state, and which is of particular importance. Several of the species which use the area are threatened, including some of the cetaceans, dugong, and all five turtle species.

Changes in Ecological Character The number of visits to adjacent protected areas on the coast is increasing, particularly at Sodwana Bay, where there were some 36,000 visitors in 1982-83. Pressures from boating, fishing, diving and other water sports are increasing. The area is generally away from industrial development, although pollution from oils spills might be a possibility.

Management Practices The Natal Parks Board manages the marine reserve, whose boundaries are marked by beacons at each end. Within this reserve is a sanctuary area, indicated by notices. Access for vehicles to the beach is controlled by permit, which ensures that only suitable vehicles use the area, and gives staff an opportunity to give information. The management plan for St Lucia Marine Reserve includes a proposed system of zoning, but these and many other proposals refer to the coastal strip rather than to the designated wetland.

Scientific Research and Facilities Research policy is to conduct such research as is necessary for the effective management of the reserve. Ongoing work includes turtle monitoring programmes, survey of marine benthic algae, and marine molluscs, and monitoring of shark movements. Research is carried out by a variety of organisations, including the National Parks Board.

Principal Reference Material This information is compiled from documents provided when the site was listed,

supplemented by the St Lucia Marine Reserve Management Plan, and material collected during compilation of the IUCN Directory of Coral Reefs of International Importance.

Additional References:

- Bruton, M.N. and Cooper, K.H. (Eds) (1980). Studies on the Ecolog yof Maputaland.

Rhodes University Press, Grahamstown. 
- Crass, R.S. (1976). A historical review the of St Lucia system and its management problems. St Lucia Scientific Advisory Council Workshop Meeting, Charles Creek, February (1976). Natal Parks Board, Pietermaritzburg.

- Taylor, R.H. (Ed) (1982). St Lucia research review. NPB publication.

Unfortunately, some of the information available for compilation of this account proved contradictory. As the sites were listed some months after this review was begun it did not prove possible to check all of the above facts with the responsible authorities. The editors apologise for any errors of fact or omission.

\section{St Lucia system}

Location $27^{\circ} 37^{\prime}-28^{\circ} 30^{\prime} \mathrm{S}, 32^{\circ} 22^{\prime}-34^{\prime} \mathrm{E}$. On the Natal coast, between the Umfolozi Swamps just south of the Mfolozi River in the south, to the Mkuze River in the north.

\section{Area 155,000 ha}

Degree of Protection Mainly state owned. The site includes the St Lucia Game Reserve (36,826ha), False Bay Nature Reserve (2,247ha), St Lucia Park (12,545ha), and all or part of several state forests. The St Lucia Game Reserve has existed in some form or another for about 90 years. Designated a Ramsar site in October 1986, and contiguous for some $25 \mathrm{~km}$ with the Tongaland Coast Ramsar site.

Site Description The site extends from the southern boundary of the Umfolozi Swamps, and includes the whole of the St Lucia lagoon system (including False Bay) and the swamps along the lower Mkuze River. Also included is the whole area between the St Lucia lake and the coast, and the coastal habitats south to the Umfolozi Swamps. The site therefore largely comprises falt to undulating sandy country around a lagoon-estuary complex, lying behind a system of coastal dunes with steep seaward slopes. Lake St Lucia covers some $30,000 \mathrm{ha}$, and is separated from the sea by a strip of land between $2 \mathrm{~km}$ and $11 \mathrm{~km}$ in width. Recent wind-blown sands and alluvial sediments cover much of the area, while pans and vleis have high peat and clay content. Vegetation types consist primarily of coastal grassland dominated by Themeda trianda, Aristida junciformis, and hygrophilous species such as Sporobolus subtilis and Acroceras macrum. There is dune forest with Mimusops caffra, Diospyrus natalensis and Ziziphus mucronata, and the area includes the highest forested dune within South Africa. Marshland is dominated by Phragmites communis and Cyperus papyrus, groundwater forest by Barringtonia racemosa, Ficus hippopotami and Syzygium cordatum, and the woodland by Terminalia sericea, Acacia spp., and Trichilia emetica. Sections of the lake shore are lined by mangroves. Pans, reed and sedge swamp are dominated by Eleocharis dregeana and Fuirena spp. Mean annual temperature range minimum: $12-20^{\circ} \mathrm{C}$, maximum: $20-30^{\circ} \mathrm{C}$. Annual rainfall $2,000 \mathrm{~mm}$ falling mainly in summer (October-April).

National and International Importance The St Lucia system is the largest estuarine system on the African continent, and the wetland forms a critical habitat for a large number of species and several communities. It contains, for example, the largest hippopotomus Hippopotomus amphibius, crocodile Crocodylus niloticus, white-backed pelican Pelecanus onocrotalus and pink-backed pelican Pelicanus rufescens populations in South Africa, as well as extensive Cyperus papyrus swamps, and Barringtonia racemosa swamp forest. The wetland has extremely high productivity, and is regarded as an outstanding area for wildlife. Over 350 species of bird have been recorded within the area, including at least 20 species of ducks and geese, two flamingo Phoenicopterus ruber and $P$. minor, and some 15 herons and egrets.

Changes in Ecological Character Development within the catchment area has had some effect on water quality and quantity. This and the resulting increased salinity has affected animal and bird populations to some extent. Other disturbances include poaching, and part of the Sodwana state forest is used for missile testing (ivhich has led to problems with fires). On the shore, there has been some disturbance by off-road vehicles, but this is not thought to be a problem at this stage. 
Management Practices Attempts to counter the problems from changed use of water in the hinterland have resulted in various actions being taken over the years to maintain the St Lucia system, including the digging and dredging of channels, and diversion of river waters. Continued remedial action is still necessary to maintain the site in its present condition. There is a management plan covering this area, which discusses both management policy and needs within St Lucia.

Scientific Research and Facilities Extensive research has been caried out in this area over many years, and it would not be possible to describe this in detail. There are limited laboratory facilities within the area. Taylor (1982) provides a review of research activities within the St Lucia area.

Principal Reference Material This information is compiled from documents provided when the site was listed, supplemented by the St Lucia Marine Reserve Management Plan, and:

- Greyling, T. and Huntley, B.J. (1984). Directory of southern African conservation areas. South African National Scientific Programmes REport No. 98. CSIR, Pretoria. Additional References:

- Bruton, M.N. and Cooper, K.H. (Eds) (1980). Studies of the Ecology of Maputaland. Rhodes University Press, Grahamstown.

- Taylor, R.H. (Ed) (1982). St Lucia research review. NPB publication.

- Taylor, W.M. (1984). Recreational utilization of the greater St Lucia area. NPB report. 


\section{SPAIN}

Area 504,745 sq. $\mathrm{km}$

\section{Population $38,220,000(1983)$}

Summary of Wetland Situation There are few natural water bodies in the interior, apart from the big rivers, and since the flow is very dependent on rainfall many of the smaller tributaries and streams dry out in summer. However, during the last three decades a large number of reservoirs have been built for irrigation purposes on most of the big rivers.

In the north, along the Galicia and Asturias coasts, the fiordlike 'rias bajas' are of importance to wintering and migrating waterfowl, and the inshore waters are frequented by large concentrations of sea ducks in winter. Inland, the Pantano del Ebro holds similar concentrations of diving ducks, mainly during migration seasons but also in winter, and more occasionally some greylag and bean geese. However, the main wintering area of bean goose is in the central Duero basin, close to the Portuguese border where the Laguna de Villafafila and Embalse del Esla are the best-known sites.

On the east coast the lagoons just south of Rosas could well be of international importance, being the kind of wetland which has become scarce along the Spanish Mediterranean coast and therefore more vital as a staging post for migratory waterfowl. The Ebro delta, is of course precisely in that category, but two-thirds of the delta are now under cultivation and there are still threats of further urbanization and establishment of marinas and suchlike developments for the tourist industry, not to mention off-shore oil-rigs. To the west of the delta, the Laguna de Gallocanta has recently become a major wintering area for ducks, coots and cranes, with more than 100,000 observed in December 1978, including some 3,000 common crane.

The great lagoon known as La Albufera de Valencia, once a very important breeding and wintering place for waterfowl, has suffered severely from urban and industrial pollution as well as from an inflow of agricultural pesticides and herbicides; although purification systems have now been made compulsory, Pola y Torrevieja and nearby Pantano de Elche on the coast of Alicante Province are important for migrating and wintering ducks and waders, the Santa Pola saltpans having also on two occasions in recent years provided a nesting site for greater flamingo, a species which visits similar pans at Cabo de Gata to the south-east and others to the south-west of Almeria. Flamingo also breed regularly in the Laguna de Fuente de Piedra; the only place where it does so in the north-west Mediterranean apart from the Camargue. This lagoon is the biggest of a number of scattered lakes of a rather variable character. Some of these lakes are of great value for two scarce and declining species, the white-headed duck and crested coot.

The most important wetland in Spain and indeed south-west Europe comprises the still largely intact ecosystems of the Marismas del Guadalquivir. The Parque Nacional de Donana covers $35,000 \mathrm{ha}$ of the marismas and of the tongue of land separating the marshes from the sea (protecting some of the most interesting habitats of the area). Unfortunately, interference with the hydrology, agricultural development, and the use of pesticides in surrounding areas, still threaten the park. A more intractable problem is the end-of-summer outbreaks of botulism which have caused severe losses among waterfowl in recent years.

In central Spain, the Tablas de Daimiel, the marshy floodplain where the Gigüela and other tributaries join to from the Guadiana, is an important breeding area for ducks, especially red-crested pochard, good numbers of duck also being found in winter. An area of $1,875 \mathrm{ha}$ is protected in the Parque Nacional de las Tablas de Daimiel, but drainage projects in the area surrounding the park are still a threat. The great reservoirs constructed along the Guadiana and Tajo rivers have become important wintering areas for grebes and cormorants as well as for ducks, and some of them serve as roosts for wintering cranes. 
Turning finally to the Spanish islands, the major wetland of Mallorca, the Albufera de Alcudia, has been severely affected by urbanization projects in the vicinity, but is still visited by ducks in winter. Purple herons and several other species of waterfowl breed in the reedbeds at the southern end of this site, and the small saltpan complex nearby (like those in the south of Mallorca) may have importance for migrating waders. Across the western arm of the Mediterranean the Islas Chafarinas, just off the Moroccan coast, harbour the biggest known breeding colony of the scarce Audouin's Gull Larus audouinii.

Protected Areas Legislation The Constitution (1978) embodies principles of conservation including rational use of resources, and protection and restoration of the environment. Prior to the establishment of ICONA in 1971 (see below) there were apparently no laws specifically related to nature conservation, but since then acts have been passed which completely revise the legislation on Hunting Reserves, as well as the Natural Spaces Protection Act (15 May 1975). This Act (under regulations introduced in 1977) provides for protection of Reserves of Scientific Interest, National Parks, Natural Sites of National Interest and Natural Parks. National Hunting Reserves are covered under the Hunting Reserves legislation; hunting is authorised in these areas, but control has been very strict and the legislation is aimed at improvement in the numbers of particular species through habitat protection and management. National Refuges (under the Hunting Act) provide for strict protection to the whole fauna existing in protected areas, and should provide a basis for environmental policy guidelines and provide a better legal basis for ICONA and its policies.

Protected Areas Administration The Body responsible for nature conservation and protection of natural resources is the National Institute for the Conservation of Nature (ICONA) set up in 1971 within the Ministry of Agriculture. There was no management planning in national parks prior to the $1975 \mathrm{Act}$, and activities were limited to maintenance and supervision. The task of administering and managing natural areas lies with the Conservation Managers in charge of each National and Natural Park. With increased regionalisation of Spain, the balance of activites within the national organisation is changing to increasing participation of the Regional Administrations.

Sites designated under the Convention

Accession 4 May 1982, with two sites listed at accession and one site added 8 August 1983.

Donana National Park

Las Tablas de Daimiel National Park

Lagune de Fuentapiedra National Hunting Reserve

Government body responsible for administration of the Convention

ICONA, Gran Via de San Francisco 35, Madrid 5

\section{Donana National Park}

Location $36^{\circ} 45^{\prime}-37^{\circ} 15^{\prime} \mathrm{N}, 05^{\circ} 55^{\prime}-06^{\circ} 55^{\prime} \mathrm{W}$. Situated southwest of Seville in the triangular area between the Atlantic coast (Cadiz Gulf) and the Guadalquivir River which forms the boundary between Huelva and Seville Provinces and Cadiz to the east. The town of Sanlucar de Barrameda lies at the mouth of the river. Southwest coast of Spain.

\section{Area 49,225 ha (included in Donana National Park 50,720ha).}

Degree of Protection More than $60 \%$ of the national park is local and state owned, and the surrounding areas are private or owned by local communes. The designated site is included in Donana National Park, which was first protected in 1969 and established as a national park on 28 December 1978 by Ley $91 / 1978$. The park includes a 6,000 ha Biological Reserve controlled by the Consejo Superior de Investigaciones Cientificas (Ministry of Education). The whole area is administered by the ICONA. Designated as a Ramsar Site at the time of accession on 4 May 1982. 
Site Description The site comprises a variety of biologically diverse habitats: sparsely vegetated sandy beaches and marine tidal zone on the Atlantic seaboard; dunes and coastal slacks with poor cover of marram grass Ammophila arenaria on the seaward side; stabilised dune heath supporting stone pine Pinus pinea, prickly juniper Juniperus oxycedrus and Phoenicean juniper $J$. phoenecia woodlands and clumps of shrubby Halimium halimifolium; mixed thickets of pine and cork oak Quercus suber and $H$. halimifolium fringing the scattered freshwater lagoons; and grasslands separated from the marshland by sedges (Cyperaceae), Scirpus sp. and saltwort Salicornia sp. with glasswort Arthrocnemum glaucum and shrubby glasswort Limoniastrum monopetalum. The Marisma area is fed by the Madre de las Marismas, which flows parallel with the Coto Donana dune ridge. Ancient branches of the Guadalquivir River form canal-like depressions in the marshlands, and there are several shallow lakes that retain water even when the rest of the marismas dry out in late summer. These deltaic marshlands are flooded during spring and when water levels are at their highest, only the small elevated islands (vetas) remain dry. The shallow lakes of Marismas de Hinojos, Gallega, Las Nuevas, El Sapillo, Lucio Real, and Sanlucar are important wintering areas for birds. Mammals in the park include fox Vulpes vulpes, badger Meles meles, small-spotted genet Genetta genetta, wildcat Felis sylvestris, wild boar Sus scrofa, fallow deer Dama dama and red deer Cervus elaphus. Raptors such as imperial eagle Aquila heliaca adalberti, short-toed eagle Circaetus gallicus, booted eagle Hieraetus pennatus, buzzard Buteo buteo, black kite Milvus migrans, red kite $M$. milvus, kestrel Falco tinnunculus, and hobby Falco subbuteo predominate in the stablilized sands.

International and National Importance Donana is probably the only large almost intact wetland ecosystem in southwest Europe. Large numbers of waders and Anatidae make use of the flat islands (vetas) during the winter floods. The most numerous species are gadwall Anas strepera, wigeon $A$. penelope (up to 60,000 ), teal $A$. crecca (up to 32,000 ), pintail $A$. acuta, northern shoveler $A$. clypeata (up to 22,000), pochard Aythya ferina, greylag Anser anser (20-30,000) and coot Fulica atra $(10,000+)$. Breeding Anatidae include mallard Anas platyrhychos, marbled teal $A$. angustirostris, red-crested pochard Netta rufina and pochard. White-headed duck Oxyura leucocephala probably no longer breeds here. Other species include purple gallinule Porphyrio porphyrio and crested coot Fulica cristata (declining). Important colonies of black-crowned night-heron, squacco heron, cattle egret, little egret, grey heron, purple heron, spoonbill and white stork (Nycticorax nycticorax, Ardeola ralloides, Bubulcus ibis, Egretta garzetta, Ardea cinerea, Ardea purpurea, Platalea leucocordia and Ciconia ciconia) nest in the Quercus-Halamium scrub. Greater flamingo Phoenicopterus ruber are present in the park throughout the year, but only nest occasionally. About 10 pairs of the endangered Spanish race of imperial eagle Aquila heliaca adalberti nest in the park. Threatened mammals include European otter Lutra lutra and Spanish lynx Felis pardina.

Changes in Ecological Character For centuries the delta area remained undisturbed and protected as a royal hunting reserve, however the area is now threatened by: intensive rice cultivation in reclaimed delta areas just outside the park, which disturbs the local water regime; pollution by insecticides and fertilizers; and with improved access from major towns such as Huelva, increasing recreational pressure on the coastal area. Plans have been proposed to build a motorway between Huelva and the port of Cadiz, which would cut through the park. There have been several outbreaks of botulism in the park contracted from stagnant pools (in 1973 some 30,000 birds died). The original cause seemed to be, as it is also presumed for the 1986 disaster, the use of pesticides in the rice fields north of the park.

Management Practices Wells have been dug to provide sufficient freshwater to attract birds away from shallow pools where the risk of contracting botulism is greatest. The park management plan includes the creation of several new ponds with observation towers or hides to cater for increasing numbers of visitors, and a carefully planned network of access roads in a limited area of the park.

Scientific Research and Facilities Palacio de Donana was converted into a biological research station in 1972. Ornithological field studies have been carried out in the wetland since the 1950s. Since 1978 there has been a research programme including studies of vertebrates, zoology, botany, plant ecology, geography, ethology, entomology, pesticides and infectious and contagious diseases. 
Principal Reference Material The above information is taken from:

- Carp, E. (1980). A Directory of Western Palearctic Wetlands. IUCN, Gland, Switzerland. Supplemented by:

- Duffey, E. (1982). National Parks and Reserves of Western Europe. Macdonald and Co., London.

Additional references:

- Fernandez, J.A. (1975). Guia del Parque Nacional de Donana. ICONA Madrid.

- ICONA (1982). Donana. Prospeccion e inventario de ecosistemas. Monografias 18. Ministerio de Agricultura, Madrid.

\section{Las Tablas de Daimiel National Park}

Location $39^{\circ} 04^{\prime}-39^{\circ} 35^{\prime} \mathrm{N}, 03^{\circ} 20^{\prime}-03^{\circ} 55^{\prime} \mathrm{W}$. Situated about $30 \mathrm{~km}$ northeast of Cuidad Real and $10 \mathrm{~km}$ north of Daimiel in Ciudad Real Province, south of Madrid in central Spain.

Area 1,812 ha (included in the National Park $(2,232 \mathrm{ha})$ which is protected by a $968 \mathrm{ha}$ buffer zone).

Degree of Protection Mainly state owned with some private ponds and lakes. The designated site is fully protected within Tablas de Daimiel National Park administered by ICONA in Cuidad Real. The area was established as a National Hunting Reserve in 1966 with National Park status in 1973. The shallow reservoir in the west of the park (Embalse de Gasset) acts as a wildfowl refuge in which hunting is prohibited. Designated as a Ramsar Site at the time of accession on 4 May 1982.

Site Description The 'Tablas' (areas of shallow water) de Daimiel are extensive areas of marshland formed in the basin around the point where two rivers unite to form the Guadiana River which flows to the Embalse de Vicario east of Ciudad Real. The Gigüela River carries brackish water drained from the high Cabrejas moorland into the wetland. The freshwater Guadiana rises some $15 \mathrm{~km}$ south of the park. The waters from both rivers mingle to produce a distinctive hydrosere mire in which fresh and brackish water plants include freshwater reedbeds of Phragmites communis with Typha sp. and Cladium sp. fringing the water courses, and cut-sedge dominated by Carex sp. common in the brackish areas (Daimiel is said to have the most extensive areas of cut-sedge in Europe). A large expanse of chara Chara hispida (the food supply for waterfowl, mainly Anatidae and coot Fulica atra) extends over almost all of the submerged surface. There are numerous small islands (up to $30 \mathrm{ha}$ ) in the marshes. In the west of the park is a shallow reservoir - Embalse de Gasset - which is a major breeding area for waterfowl. The park is fringed by stands of Tamarix gallica (the only tree species on the Tablas). The water level of the wetland fluctuates considerably. The wetland area is surrounded by intensively cultivated areas with vines and cereals, much reclaimed from the Tablas by drainage. The mammal population comprises mainly smaller European species such as polecat, otter, watervole, stoat, rabbit and hare, but wild boar Sus scrofa has been increasing in number. The most conspicuous raptor is the marsh harrier Circus aeruginosus.

International and National Importance Tablas de Daimiel are renowned for large breeding population of ducks (Anatidae) including over 1,000 pairs of red-crested pochard Netla rufina (possibly the largest population in Europe), mallard Anas platyrhynchos, gadwall $A$. strepera, garganey $A$. querquedula, shoveler $A$. clypeata, marbled pochard $A$. angustirostris and pochard Aythya ferina. Other breeding species are black-necked grebe Podiceps nigricollis, small colonies of black-crowned night-heron Nycticorax nycticorax, little egret Egretta garzetta, purple heron Ardea purpurea and bittern Botaurus stellaris. Non-breeding marsh birds include black-winged stilt Himantopus himantopus, avocet Recurvirostris avosetta, redshank Tringa totanus, ruff Philomachus pugnax, Kentish plover Charadrius alexandrinus, bearded tit Panurus biarmicus and Savi's warbler Locustella luscinioides. Large numbers of surface-feeding ducks such as mallard use the wetland as a moulting refuge, and large numbers of waterfowl overwinter here. European otter Lutra lutra occurs in the wetland. 
Changes in Ecological Character The park was established to save the wetland from extensive land reclamation, but this is still a potential threat with intensive surrounding agricultural developments. Drainage of areas outside the park seriously affects the integrity of the park by affecting the regional hydrological regime. There is potential threat of pollution from small industrial factories on higher ground bordering the wetland basin.

Management Practices The management plan focuses mainly on restoration of the water level, at present very low (some metres under the surface) due to a combination of natural drought during the last decade and water extraction by local people (for irrigation). Recently, a comprehensive study of potential water regeneration has been made, and on the basis of this a project for the permanent supply of water to the park has been outlined.

Scientific Research and Facilities ICONA have undertaken some hydrological studies and bird surveys. There is a recuperation centre for the anatids.

Principal Reference Material The above information is taken from:

- Carp, E. (1980). A Directory of Western Palearctic Wetlands. IUCN, Gland, Switzerland. Supplemented by:

- Duffey, E. (1982). National Parks and Reserves of Western Europe. Macdonald and Co., London.

Additional references:

- Coronado, R., del Portillo, F. and Saez-Royuela, R. (1973). Guia de las Anatidas en Espana. ICONA, Madrid.

- Coronado, R., Leon Jimenez, F. and Morillo Fernandez, C. (1974). Guia del Parque Nacional de las Tablas de Daimiel. ICONA, Madrid.

\section{Lagune de Fuentapiedra National Hunting Reserve}

Location $37^{\circ} 07^{\prime} \mathrm{N}, 04^{\circ} 46^{\prime} \mathrm{N}$. Situated about $17 \mathrm{~km}$ northwest of Antequera in Malaga Province, southern Spain.

Area About 1,750ha (maximum area of the lake 3,000ha).

Degree of Protection The lake is state owned. It is at present protected as a Reserve of Scientific Interest. Designated as a Ramsar Site on 8 August 1983.

Site Description Fuentapiedra is a shallow salt lake (average depth less than a metre) situated about $500 \mathrm{~m}$ above sea level. It is fed by run-off from the surrounding hills, and during the dry summer months dries out almost completely. It is fringed by halophytic vegetation.

International and National Importance The lake harbours the only regular breeding colony of greater flamingo Phoenicopterus ruber in Spain. Other breeding waterfowl include black-winged stilt Himantopus himantopus, avocet Recurvirostria avosetta and gull-billed tern Sterna nilotica. In winter up to 50,000 coot Fulica atra and ducks (Anatidae), including up to 15,000 pochard Aythya ferina, may be present in the wetland.

Changes in Ecological Character The wetland is relatively undisturbed. There is a potential threat from increased use of pesticides on the surrounding agricultural land, which could contaminate the water and affect birds feeding outside the reserve.

Management Practices A pump has been installed near the deepest part of the lake to retain sufficient water in at least a small area for the unfledged juvenile flamingo during the summer drought. Hunting is prohibited in the reserve.

Scientific Research and Facilities The flamingo colony has been studied in some detail by research teams from the University of Malaga. A study of the hydrological system of the whole area has been carried out. 
Spain

Principal Reference Material The above information is taken from:

- Carp, E. (1980). A Directory of Western Palearctic Wetlands. IUCN, Gland, Switzerland.

Several articles on Fuentapiedra have been published in the journal Ardeola. 


\section{SURINAME}

Area 163,800 sq. $\mathrm{km}$

Population 352,041 (July 1980)

Summary of Wetland Situation Geologically the country can be divided into four regions: young coastal plain, old coastal plain, savanna belt and interior.

The young coastal plain is approximately $8 \mathrm{~km}$ wide in the east and broadens to $50 \mathrm{~km}$ wide in the west. The coastal zone is comprised of vast tidal mudflats, some narrow sandy beaches and mangrove swamps. Inland, the coastal fringe is bordered by shallow saline and brackish lagoons and swamps, with some mangrove forests. Further inland the marshes become fresh, and there are patches of swamp forest dominated by Erythrina glauca and mixed dryland forests on sandy ridges. The five major wetland areas of this zone totalling $325,000 \mathrm{ha}$, are all of international importance as wintering and staging areas for migratory shorebirds and breeding areas for various Ardeidae and Anatidae.

The old coastal plain is approximately $20 \mathrm{~km}$ wide. There are various types of grassy swamp, swamp forest and dryland forest similar to those of the young coastal plain, but in addition there are large areas of ombrogenous peat swamp. The extensive tracts of wetland habitat in this zone remain very poorly known.

The savanna belt is a dissected plain consisting of coarse sands and loams, and is characterized by white sand savannas. The zone is covered with xeryophytic and mesophytic dryland and swamp forests, and dry to very wet grass and shrub savannas. Wetland habitat occurs only in small scattered patches.

In the interior the almost uninhabited lowlands are covered with primeval humid tropical forest, interrupted only by small patches of savanna, exposed rocky outcrops, and patches of marsh forest along the rivers and creeks. At higher elevations, sub-montane forests are found on deep soils, and xerophytic forests and shrubbery on shallow soils. Apart form the riverine and creek systems, the only significant wetlands in this zone are the huge recently constructed Brokopondo Lake and the Sipaliwini Savanna.

Protected Areas Legislation The first game sanctuary was established by Resolution in 1953 based on the Police Penal Law of 1942. However, the principles of nature conservation were first formulated and embodied into law in the Nature Protection Law of 1954 (GB No. 26), and provide the legal basis for establishment of nature reserves by Resolution. The Forest Law of 1947 also allows for the establishment of forest reserves. Long-term lease areas (leased under the Lands' Law) can also be managed as protected areas; for example, Brownsberg Nature Park.

Protected Areas Administration The Forest Service of the Ministry of Natural Resources and Energy has a Nature Conservation Department which is responsible for managing the parks and reserves. The Department is assisted by the Foundation for Nature Preservation in Suriname (STINASU), a semi-governmental organization. Nature reserves are established on public lands, which are of scientific, aesthetic or cultural value. These may not necessarily be sites of exceptional interest, but will include areas which are regarded as representative samples of ecosystems or landscapes. In 1980, the total expenditure of the Department of Nature Conservation was US $\$ 310,000$, of which a great part was used for the management of the nature reserves.

Sites designated under the Convention

Accession 18 March 1985, with one site listed at accession.

Coppename Rivermouth Nature Reserve 
Government body responsible for administration of the Convention

Nature Conservation Department of the Forest Service, PO Box 436, Paramaribo, Suriname; assisted by STINASU, PO Box 436, Paramaribo, Suriname.

\section{Coppename Rivermouth Nature Reserve}

Location $5^{\circ} 50^{\prime} \mathrm{N}, 55^{\circ} 50^{\prime} \mathrm{W}$. Between the mouths of the Coppename River and Suriname River, Saramacca District, central coast.

Area 12,000 ha.

Degree of Protection Federally owned. Protected since 1953, but established as a reserve since 22 April 1966 and as a Ramsar site at the time of accession on 18 March 1985.

Site Description Wide tidal mud flats, lagoons and brackish herbaceous swamps, in the estuary of the Coppename and Suriname Rivers and along the Atlantic coast. Sand beaches, coastal mudgrass vegetation with Spartina brasiliensis, various types of young and old stages of mangrove forest with Avicennia germinans and Laguncularia racemosa, salt water ponds and shallow lagoons with Sesuvium portulacastrum, Batis maritima, and Sporobolus virginicus. Coastal beach vegetation with Hibiscus tiliaceus, Thespesia populnea and Avicennia germinans, and littoral ridge wood with Crataeva tapia and Cereus hexagonus. In the estuary the species change because of the freshwater influence. The short grass and fern swamps include two species of sedge Eleocharis mutata and Cyperus articulatus, and in the estuarine mangroves the Avicennia and Laguncularia species are joined by Rhizophora mangle, and the palm Euterpe oleracea.

Criteria for Inclusion 1,2 and 3.

International and National Importance A very important area for breeding, passage and wintering waterfowl. Breeding birds include up to 250 pairs of black-crowned night heron Nycticorax nycticorax, 1500 pairs of yellow-crowned night heron Nyctanassa violacea, 500 pairs of boat-billed heron Cochlearius cochlearius, 4000 pairs of little blue heron Egretta caerulea, 3000 pairs of tricoloured heron E. tricolor, great white egret E. alba and 1000 pairs of snowy egret $E$. thula. Up to 4000 pairs of scarlet ibis Eudocimus ruber have bred in recent years, with the exceptional total of 6200 pairs in 1984 . Non-breeding visitors include up to 200 greater flamingo Phoenicopterus ruber, 1500 laughing gull Larus atricilla and 10,000 black skimmer Rynchops nigra. The coastal mudflats are particularly important for passage and wintering Nearctic shorebirds. Peak estimates have included 2500 grey plover Pluvialis squatarola, 2500 semipalmated plovers Charadrius semipalmalus, 1500 whimbrel Numenius phaeopus, 10,000 greater yellowlegs Tringa melanoleuca, 50,000 lesser yellowlegs $T$. flavipes, 10,000 willets Catoptrophorus semipalmatus over 5000 turnstones Arenaria interpres, 50,000 short-billed dowitcher Limnodromus griseus and 750,000 semipalmated sandpiper Calidris pusilla. Also listed: roseate spoonbill Platalea ajaja and the magnificent frigatebird Fregeta magnificans. The black spider monkey Ateles paniscus is also present, and the Caribbean manatee Trichechus manatus has been reported.

Changes in Ecological Character There is some illegal hunting and contamination with pesticides. Urbanisation and the expansion of agricultural activites are the principal threats.

Management Practices One game warden and two guards.

Scientific Research and Facilities Ornothological research, no facilities.

\section{Principal Reference Material}

- IUCN (1982). IUCN Directory of Neotropical Protected Areas. Tycooly, Dublin.

- Scott. D.A. and Carbonell, M., (1986). Directory of Neotropical Wetlands. IUCN, Gland, Switzerland and Cambridge, U.K., and IWRB,

Slimbridge, U.K. 
- Schulz, J.P., Mittermeier, R.A. and Reichart, H.A. (1977). Wildlife in Suriname. Oryx XIV(2): 133-144.

- Spaans, A.L. and de Jong, B.H.J. (1982). Present status of some colonial waterbird species in Surinam, South America. J. of Field Ornithology 53(3):269-272.

- Teunissen, P.A., (Ed.) (1972). Natuurreservaat Coppenamemonding. Natuurgids Serie A,1. STINASU. 


\section{SWEDEN}

Area $449,791 \mathrm{sq} . \mathrm{km}$

Population $8,358,139(1986)$

Summary of Wetland Situation The wetlands of Sweden cover approximately $20 \%$ of the national territory and are very varied in type, including, for example, coastal marshes, rivers, lakes, fens, mires and peatbogs. The pressure on many of these sites is increasing, particularly along the coasts, but also inland where much swampy forest is being drained to increase timber production or to eliminate excess water in neighbouring agricultural areas. The excavation of mires to extract peat for agricultural or horticultural purposes continues incessantly, and peat could again become important as fuel in the not too distant future. Potential for exploitation for HEP may also pose a threat to certain wetland areas.

With regard to future economic and ecological needs, the Swedish Government in 1977 ordered a survey of all shallow waters, mires, moist grasslands and groundwater forest. This survey was carried out by the Swedish Environmental Protection Board (EPB) under the authority of the Ministry of Agriculture. Stage II comprises studies of various aspects of land use, conservation, recreation, water-management and scientific research, and is expected to last until 1988. The final report would serve as a basis for long-term management of the wetland nature resource.

Protected Areas Legislation The Nature Conservancy Act of 1964, as amended in 1973 and 1975, permits the setting aside of National Parks, Nature Reserves, Nature Conservation Areas and Wildlife Sanctuaries. The Royal Proclamation issued in 1964 lays down ways in which the Act must be implemented and administered. A further proclamation of 1965 deals with Wildlife Sanctuaries which have now also come under the Act. National Parks are established by the government only on crown lands. Reserves, Conservation Areas and Sanctuaries are designated by the County Administration (24 counties). The regulations for parks and reserves normally govern land use, industrial or rural activities, fishing and hunting (especially in parks) and access. In Conservation Areas the regulations are less restrictive. In Wildlife Sanctuaries hunting and access may be restrictied or prohibited during certain parts of the year. Several other legislative measures are of direct relevance to nature conservation in Sweden: the Beech Forest Law (1974), the Hunting Act (1938), the Fishing Act (1950), the Hunting Statute (1938) and the Deciduous Forest Law (1983).

Protected Areas Administration Formally, responsibility for the management of parks lies with the national Environmental Protection Board which is an independent agency within the Ministry of Agriculture. The board has three main functions: provision of advice to bodies with executive responsibility for protected areas; financial control of purchase, compensation, facilities etc.; and fostering ecological research. The Swedish Forest Service provides day-to-day management in consultation with the Board. The responsibility for the management of protected areas rests with the appropriate County Administration, and is normally delegated to the Regional Forestry Board (under the National Board of Forestry). The Forest Service manages state-owned areas.

Sites designated under the Convention

Signature without reservation as to ratification 5 December 1974, with 20 sites listed at signature

Falsterbo-Bay of Foteviken

Klingavälsän-Krankesjön

Helga River

- Hammarsjön and Egeside sjö

- Araslövssjön

Ottenby

Södviken 


\section{Getterön}

Store Mosse and Kävsjön

Isles off Gotland

- Grötlingboholme and Rone Ytterholme

- Laus Holmar

- Skenholmen

Hornborgasjön

Takern

Kvismaren

Hjälstaviken

Annsjön

Gammelstadsviken

Persöf järden

Tärnasjön

Tjalmejaure-Laisdalen

Laidaure

Sjaunja-Kaitum

Taavavuoma

Government body responsible for administration of the Convention

National Environmental Protection Board, PO Box 1302, 171-25 Solna

\section{Falsterbo-Bay of Foteviken}

Location $55^{\circ} 25^{\prime} \mathrm{N}, 12^{\circ} 55^{\prime} \mathrm{E}$ Located in the extreme south-west of Sweden, $30 \mathrm{~km}$ south of Malmo and less than $25 \mathrm{~km}$ from the nearest point on the Danish coast.

Area 7,150 ha

Degree of Protection Ownership is part private and part local authority. Parts of the designated site are protected as Nature Reserves: Maklappen, Skannors Ljung, Flommen and Hammars Nas, and Eskilstorp's Islets (total 2,045ha). Designated as a Ramsar site on 15 December 1974.

Site Description The site comprises shallow coastal waters, sandbanks, lagoons, sand and shingle beaches, grazed and ungrazed coastal meadows (influenced by salt spray and partly of marshland type), heatherclad moors and damp heaths, and some cultivated land. Soils are mainly sand, moraine clay and coastal meadow peat. The coastline is being continually changed by the processes of erosion and accumulation. The vegetation is influenced by geology, water and past/present landuse. The sandy beaches, dunes and sandbanks are clad with lymegrasses Elymus arenarius, marram grass Ammophila arenaria and Rosa rugosa. The coastal meadows contain sedges, arrow-grass, glasswort, seablite, aster, meadow grass, plantain, rush and sea milkwort (Scirpus sp., Triglochin spp., Salilcornia spp., Suaeda sp., Aster sp., Puccinellia sp., Plantago sp. Juncus sp. (including J. maritima) and Glaux maritima. Where the pasture recedes there is an abundant growth of tufted vetch Vicia cracca, trefoil Lotus spp. and aster. The heaths are mainly heather Calluna vulgaris, cross-leaved heath Erica tetralix and sweet gale Myrica gale.

International and National Importance This site is an important breeding, resting and wintering area for waterfowl, and there is a spectacular gathering of many millions of birds in autumn. The concentrations of passage migrants, mainly birds of prey and waders, is without equal in northern Europe. The area is an important resting and wintering locality for ducks and waders. Mute swan Cygnus olor, goosander Mergus merganser and red-breasted merganser $M$. serrator occur in internationally important numbers in winter. Regular breeding species include mallard Anas platyrhynchos, eider Somateria mollissima, red breasted merganser Mergus serrator, shelduck Tadorna tadorna, moorhen Gallinula chloropus, coot Fulica aira, lapwing Vanellus vanellus, oystercatcher Haematopus ostralegus, redshank Tringa totanus, ringed plover Charadius hiaticula, herring gull Larus argentatus, 
common gull $L$. canus and Arctic tern Sterna paradisaea. Other breeding birds include whinchat Saxicola rubetra, reed bunting Emberiza schoeniclus, yellow wagtail Motacilla flava and meadow pipit Anthus pratensis. There are permanent populations (unusual for Nordic countries) of avocet Recurvirostra avosetta, Kentish plover Charadrius alexandrinus, dunlin Calidris alpina, sandwich tern Sterna sandvicensis and little tern S. albifrons. The sandy island of Maklappon is an important breeding area for grey seal Halichoerus grypus and common seal Phoca vitulina. Other important fauna include natterjack toad Bufo calamita and green toad Bufo viridis.

Changes in Ecological Character There has been a decline in the numbers of livestock grazing in the meadows. The area is very popular for recreation, with three golf courses and considerable swimming, boating and fishing.

Management Practices Access is restricted in some parts of the reserves.

Scientific Research and Facilities A considerable amount of bird ringing and bird observation takes place at Falsterbo Bird Station, as part of the National Environmental Monitoring Programme.

Principal Reference Material The above information is taken from documents supplied by the Swedish Government for designation in 1974 and for the Cagligari Conference in November 1980.

Supplemented by:

- Carp, E. (1980). A Directory of Western Palearctic Wetlands. IUCN, Gland, Switzerland. Additional reference:

- Ulfstrand, S. et al. (1974). Visible bird migration at Falsterbo Station. Misc. Report of Falsterbo Bird Station. $189 \mathrm{pp}$.

\section{Klingavälsän - Krankesjön}

Location $55^{\circ} 37^{\prime} \mathrm{N}, 13^{\circ} 38^{\prime} \mathrm{E}$ About $40 \mathrm{~km}$ east of Malmö in Malmohus Ian in the extreme south of Sweden.

Area 3,975 ha

Degree of Protection Ownership is part private and part local authority. The site includes two nature reserves totalling 2,181 ha. Vomb meadowland has been protected by law since 1923, and the whole valley of the River Klingavälsän has been protected by law since 1968 . Designated as a Ramsar site on 5 December 1974.

Site Description The site includes the areas around the river Klingavälsän and lake Krankesjön which consist of shallow nutrient-rich lakes, meandering streams, marshes, forests of alder Alnus sp. and willow Salix sp. thicket. Large areas are still used for grazing or hay cutting. Soil is mainly sand and shallow layers of peat. The meadows along the River Klingavälsän flood annually and consist of hummocky pasture of tufted hair-grass Deschampsia cespitosa, tall herbs and Carex sedges. In some places stands of alder and old peat layers overgrown with birch Betula spp. and willows dominate. South of Krankesjön is Silvakra marsh, formed when the lake level was lowered in 1892. The marsh and lake shores are overgrown with reeds Phragmites australis, great reedmace Typha latifolia and tall Carex sedges. Occasionally great fen sedge Cladium mariscus occurs around the lake. Lake Sövdesjön is mainly surrounded by grazing meadows and small areas of reed.

International and National Importance The open lands along the river Klingavalsän have few counterparts in Sweden. The meadows support a variety of breeding birds, are important during migration, and, provide wintering areas for some species,. The overgrown sections are of major importance to the large population of red deer Cervus elaphus. Birds breeding on the open meadowlands include lapwing Vanellus vanellus, curlew Numenius arquata, redshank Tringa totanus, snipe Gallinago gallinago, meadow pipit Anthus pratensis, yellow 
wagtail Motacilla flava, black-tailed godwit Limosa limosa, dunlin Calidris alpina and shelduck Tadorna tadorna. Krankesjön has long been one of Sweden's most well known bird lakes, with a rich population of breeding mallard Anas platyrhynchos, garganey $A$. querquedula, teal A. crecca, shoveler A. clypeata, pochard Aythya ferina, tufted duck $A$. fuligula, great-crested grebe Podiceps cristatus, little grebe Tachybaptus ruficollis and black-necked grebe $P$. nigricollis. Species in the reedbeds include bittern Botaurus stellaris, sedge warbler Acrocephalus schoenobaenus, great reed warbler A. arundinaceus and peduline tit Remiz pendulinus. Birds visiting on migration include white-fronted goose, ruff, wood sandpiper, greenshank, spotted redshank (Anser albifrons, Philomachus pugnax, Tringa glarenla, $T$. nebularia, $T$. erythropus), and very occasionally white stork Ciconia ciconia. The area is a very important wintering site for bean goose Anser fabalis, and a winter locality for birds of prey such as white-tailed eagle, golden eagle, buzzard, rough-legged buzzard, red kite and hen harrier (Haliaeetus albicilla, Aquilla chrysaetos, Buteo buteo, B. lagopus, Milvus milvus and Circus cyaneus.

Changes in Ecological Character The Vomb meadowlands were formerly used as irrigation meadows, and had a very diverse fauna and flora. However, since a drainage project in 1938-43, the meadows have become much drier with greatly impoverished fauna and flora. During the last few years a significant reduction in the waterfowl populations has occured in Krankesjön due to a widespread disappearance in aquatic (submerged) plants.

Management Practices Flush irrigation has been resumed experimentally at Vomb meadows over a limited area. Access is restricted in the nature reserves. Some areas around Krankesjön are used for military training, and the Sövdesjön and Vombsjön lakes are used for fishing, bathing and other recreation. A management plan is being prepared for the area.

Scientific Research and Facilities A field station on Krankesjön is the base for ecological research on the area.

Principal Reference Material The above information is taken from documents supplied by the Swedish Government for designation in 1974, for the Cagliari Conference in November 1980 and for the Groningen meeting in May 1984.

Supplemented by;

- Carp, E. (1980). A Directory of Western Palearctic Wetlands. IUCN, Gland, Switzerland.

Additional references:

- Bengtsson, S. (1972) Vombs ängar-vegetation, fägelliv, markanvändning samt synpunkter pa restaurering och skötsel (mimeo.).

- Larsson, T. (1972). Fagelinventering. Vombs och Karups ängar, Klingavälsans NR. Env. Prot. Board. (mimeo).

\section{Helga River}

Location $56^{\circ} 00^{\prime} \mathrm{N}, 14^{\circ} 12^{\prime} \mathrm{E}$. A section of the River Helga to the immediate north and south of Kristianstad, the chief town of Kristianstad Ian in the south of Sweden.

Area 4,600 ha

Degree of Protection Ownership is part state and part private. The designated site includes a nature reserve at Haslov meadows (166ha), adjacent to lake Hammarsjön. Designated as a Ramsar site on 5 December 1974.

Site Description The site comprises the lower River Helga and is in two sectors: 1,150ha including Lake Araslövssjön; and 3,450ha including most of Lake Hammarsjön and the former lakes Svarto sjo and Egeside. The River Helga is one of Scania's largest watercourses, and flows through a flat, arable valley. Most of the lakes along its course have been drained. Habitats include reedbeds, scrubland and large areas of damp hummocky pasture. Some areas are cut for hay. 
International and National Importance The region, especially Haslov meadows at lake Hammarsjön, is one of Scania's most important breeding localities for birds. Breeding species include black-tailed godwit Limosa limosa (about 65 pairs: 1976), ruff Philomachus pugnax (50 pairs), dunlin Calidris alpina (15 pairs), black tern Chlidonias niger (100 pairs: 1978), black-headed gull Larus ridibundus (2,000-3,000 pairs), spotted crake Porzana porzana, corncrake Crex crex and 15-20 marsh harrier Circus aeruginosus. Regular annual visitors include grasshopper warbler Locustella naevia (about 100), river warbler L. fluviatilis, Savi's warbler $L$. luscinioides and common rose finch Carpodacus erythrinus. The site is also an important resting station for migrant waders, ducks and geese. During autumn and spring migrations thousands of ducks visit the lakes, and during March-April and October-November some 5,000-6,000 bean goose Anser fabilis graze at the Arasövssjön, Hammarsjön and Yngsjön lakes. For some years, 2,000 Canada goose Branta canadensis have been overwintering at the lakes.

Changes in Ecological Character Some areas are in danger of becoming overgrown.

Management Practices Access is restricted to parts of the nature reserve. Reed cutting is practised.

\section{Scientific Research and Facilities No information}

Principal Reference Material The above information is taken from documents supplied by the Swedish Government for designation in 1974 and for the Cagliari Conference in November 1980.

Supplemented by:

- Carp, E. (1980). A Directory of Western Palearctic Wetlands. IUCN, Gland, Switzerland.

Additional references:

- Bengtsson, S. (1963). Hammarsjöns hachfagelfauna. (Breeding bird fauna of the Hammarsjön.) Skanes Natur.

- Bjork, S. (1971). Araslövsjön och Hammarsjön. Forslag til restaureringsatgärden (Restoration plan). Limn. Inst. Lunds University (mimeo)

- Lennerstedt, J. (1968). Hammarsjön-Araslövsjön. Meddel. fran Sk. O.F.

\section{Ottenby}

Location $56^{\circ} 12^{\prime} \mathrm{N}, 16^{\circ} 24^{\prime} \mathrm{E}$. Located at the southern tip of the island of Oland which is off the eastern coast of southern Sweden.

Area 1,600 ha

Degree of Protection The area is owned by the state. All the land in the designated site and the sea area around the islands is included in a Nature Reserve of $995 \mathrm{ha}$. Designated as a Ramsar site on 5 December 1974.

Site Description The site comprises the tongue of land south of 'Charles X's Wall' which was built in the 17th century to enclose the deer of Ottenby. The central area is covered by a large deciduous wood of birch Betula sp., aspen Populus tremuloides and oak Quercus sp. In the east and south are the flat open sheep grazing pastures (Schaferiangarna), and west of the wood shrubby cinquefoil Potentilla fruticosa and juniper Juniperus communis are common. The coastal landforms include sand and pebble beaches, sandbanks and small bays. There are extensive shallows and long sections of beaches covered in banks of seaweed which are an important feeding site for resting waders. Fallow deer Dama dama live on the pasture and in the woods.

International and National Importance The site is famous for migrating birds, with birds passing through all year round to and from breeding areas. Many have only a short stopover, but species using the area for a longer stopover include small waders such as dunlin Calidris alpina, brent goose Branta bernicla and barnacle goose B. leucopsis. Breeding species include 
avocet Recurvirostra avosetta, which breed on the beaches and adjoining meadows, and breed in very few other parts of Sweden. Ottenby Wood is an important shelter for migrating passerine birds Breeding birds in and around the wood include golden oriole Oriolus oriolus, barred warbler Sylvia nisoria, red-breasted flycatcher Ficedula parva, common rose finch Carpodacus erythrinus and a dense population of icterine warbler Hippolais icterina.

Changes in Ecological Character Lack of grazing animals poses a threat to the open character of the pastures.

Management Practices There is some restriction on access in the nature reserve. Ottenby is one of Sweden's most visited conservation areas, but visitors must keep to the nature paths. A Management Plan is currently being prepared.

Scientific Research and Facilities Further out on Oland's southern tongue is Lange Jan lighthouse and Ottenby bird station, where ornithological studies, mainly bird ringing and observation of bird migration, have been carried out since the 1940s. These studies are now part of the National Environmental Monitoring Programme. In 1741 the famous Swedish naturalist Linnaeus came here to record plants and birds.

Principal Reference Material The above information is taken from documents supplied by the Swedish Government for designation in 1974, for the Cagliari Conference in November 1980 and for the Groningen Meeting in May 1984.

Supplemented by:

- Carp, E. (1980). A Directory of Western Palearctic Wetlands. IUCN, Gland, Switzerland.

- Duffey, E. (1982). National Parks and Reserves of Western Europe. Macdonald and Co., London.

Additional references:

- Edelstam, C. (ed.) (1972). The visible migration of birds at Ottenby, Sweden. Var Fagelvärld suppl. 7.

- Larsson, A. (1974). Ottenby naturreservat, vegetation och markanvändning. Medd. Ekol. Bot. Lunds Universitet 2:6.

- Several other reports in Var Fagelvärld.

\section{Södviken}

Location $57^{\circ} 02^{\prime} \mathrm{N}, 16^{\circ} 55^{\prime} \mathrm{E}$. A bay situated on the north-east coast of Öland Island which is off the eastern coast of southern Sweden.

Area 790 ha

Degree of Protection Privately owned. The central and north-west part of the area are set aside as a Bird Sanctuary. Designated as a Ramsar site on 5 December 1974.

Site Description Sodviken is situated between the towns of Föra and Persnäs. The site is of great ecological interest and consists of shallow coastal waters with islands, and includes the surrounding low-lying land. The habitats include sandy banks, low grassy holms, marshland, open coastal meadows and scrublands. The irregular coastal section is about $15 \mathrm{~km}$ long.

International and National Importance Södviken is an important breeding site, especially for waders, with 11 species regularly breeding including black-tailed godwit Limosa limosa, dunlin Calidris alpina schinzii and a large colony of avocet Recurvirostra avosetta. Other breeding birds include scaup Aythya marila, little tern Stern albifrons and little gull Larus minutus. There is also a major breeding ground on Öland for eider. The barred warbler Sylvia nisoria is found in more scrubby parts of the coastal meadows. The area is much used by migrating waders, especially those from the Arctic.

Changes in Ecological Character None reported (to December 1986) 
Management Practices Hunting is prohibited in the Bird Sanctuary and visitors restricted for part of the year.

\section{Scientific Research and Facilities No information}

Principal Reference Material The above information is taken from documents supplied by the Swedish Government for designation in 1974, for the Cagliari Conference in November 1980 and for the Groningen Meeting in May 1984.

Supplemented by:

- Carp, E. (1980) A Directory of Western Palearctic Wetlands. IUCN, Gland, Switzerland.

\section{Getterön}

Location $57^{\circ} 08^{\prime} \mathrm{N}, 12^{\circ} 14^{\prime} \mathrm{E}$. Located about $62 \mathrm{~km}$ south of Göteborg and just north of Varberg in Halland Ian on the Kattegat shore of the west coast.

Area 340 ha

Degree of Protection Ownership is divided between State, Local Authority and private. The whole area is a nature reserve established in 1970. Designated as a Ramsar site on 5 December 1974.

Site Description Before the 1930s Getterön was an island, but through the dumping of dredged material to form an embankment, and the construction of a road, it is now connected to the mainland. The main part of the nature reserve comprises Farehammarsviken Bay, an area which has become partly enclosed and desalinated following the embankment construction. The bay has a freshwater inflow, and consists of brackish water basins containing reed Phragmites australis, glaucous bulrush Scirpus tabernae montani and other higher plants. The surrounding coastal meadows are of various degrees of wetness, and are grazed by cattle. The cattle also graze on the wide belts of Scirpus spp.

International and National Importance In the past few decades the area has become one of the most important bird localities on the west coast of Sweden. It has a very rich fauna of breeding waterfowl including avocet Recurvirostra avosetta (2 pairs 1978), black-tailed godwit Limosa limosa (7 pairs), redshank Tringa totanus (22 pairs), dunlin Calidris alpina schinzii (11 pairs), ruff Philomachus pugnax (9 pairs), teal, gadwall, shoveler, wigeon, eider, shelduck and spotted crake (Anas crecca, A. strepera, A. clypeata, A. penelope. Somateria mollissima, Tadorna tadorna and Porzana porzana). Several pairs of yellow wagtail Motacilla flava also breed here. Getterön is also one of the most important resting places for waterfowl on the west coast of Sweden. Large numbers of brent goose Branta bernicla winter here. The area is used regularly as a hunting ground by many birds of prey including peregrine falcon Falco peregrinus, osprey Pandion haliaetus, marsh harrier Circus aeruginous and short-eared owl Asio flammeus.

Changes in Ecological Character From time to time the site is threatened by the possible expansion of an adjacent airport. In the long term, the current revegetation with macrophytes will have adverse effects.

Management Practices There is restricted admission to the reserve. Restoration measures have started on an experimental scale, and further activities are under consideration.

Scientific Research and Facilities Facilities for bird watchers include an observation tower, and a new bird station from which the bay and surrounding meadows can be surveyed without causing disturbance to the birds.

Principal Reference Material The above information is taken from documents supplied by the Government of Sweden for designation in 1974, for the Cagliari Conference in November 1980 and for the Groningen Meeting in May 1984. 
Supplemented by:

- Carp, E. (1980). A Directory of Western Palearctic Wetlands. IUCN, Gland, Switzerland.

- Duffey, E. (1982). National Parks and Reserves of Western Europe. Macdonald and Co., London.

Additional references:

- Pehrsson, O. et al. (1973). Getteröns fagelreservat. Report to the Environmental Protection Board No. PM 423 (mimeo).

- Pehrsson, O. et al. (1980). Getteröns fagelreservat. Investigations and proposals for management. PM 1264 (mimeo in Swedish).

\section{Store Mosse and Kävsjön}

Location $57^{\circ} 18^{\prime} \mathrm{N}, 13^{\circ} 57^{\prime} \mathrm{E}$. Located about $70 \mathrm{~km}$ south of Jonköping in southern Sweden.

\section{Area 7,450 ha}

Degree of Protection State owned. The area has been protected as a nature reserve since 1971 and is now a national park established in 1982, and as such is protected from all forms of exploitation. Designated as a Ramsar site on 5 December 1974.

Site Description The site comprises a mosaic of raised bog, fen and open water. The fens are partly natural but also formed by artificial lowering of the lakes in the 1840s and 1870s. Now only Kävsjön and Kälvasjön remain as permanent lakes. Lakes Haradssjön and Horssjön only have open water at high-water periods. There are a number of smaller pools. The site contains typical mire vegetation interspersed with patches of Scots pine Pinus sylvestris and treeless areas of dwarf scrubs. The flora includes a number of Orchidaceae such as marsh helleborine Epipactis palustris, fragrant orchid Gymnadenia conopsea and meadow orchid Dactylorhiza incarnata. Conditions are very favourable for breeding and migratory birds especially waterfowl.

International and National Importance The site is important for its diverse bird community, having a remarkable mix of northern and southern bird species, and is Sweden's most extensive mire complex outside of Norrland. The mire area is a breeding ground for possibly Sweden's largest population of crane Grus grus (tens of pairs). Other species include red-throated diver, black throated diver, Slavonian grebe, red-necked grebe, teal, pintail, wigeon, shoveler, garganey, pochard, coot, water rail, spotted crake, wood sandpiper, redshank, golden plover, dunlin, ruff and short-eared owl (Gavia stellata. G. arctica, Podiceps auritus, $P$. grisegena, Anas crecca, A. acuta, A. penelope, A. clypeata, A. querquedula, Aythya ferina, Fulica atra, Rallus aquaticus, Porzana porzana, Tringa glareola, Tringa totanus, Pluvialis apricaria, Calidris alpina, Philomachus pugnax and Asio flammeus). The most common resident duck species are mallard Anas platyrhynchos, teal, tufted duck Aythya fuligula and goldeneye Bucephala clangula. Especially remarkable is the regular annual breeding of jack snipe Lymnocryptes minimus and whooper swan Cygnus cygnus, both of which occur mainly in northernmost Sweden. During spring and autumn Kavsjön is a resting site for passage migratory waterfowl, including large numbers of whooper swan and bean goose Anser fabalis.

Changes in Ecological Character There has been invasion by scrub in areas where hay is no longer cut, or where cattle no longer graze. This has decreased the value of these areas for bird life. As the old ditches are filled, the water level of the surrounding land rises.

Management Practices A management plan for the area is currently being prepared. There is restricted access to parts of the park during the bird breeding season. Restoration measures, including rotary cultivation of some areas, have been undertaken.

Scientific Research and Facilities Hydrological, botanical, limnological and ornithological investigations have been undertaken as part of a project to restore some swamp and peatland which has been invaded by scrub. 
Principal Reference Material The above information is taken from the documents supplied by the Swedish Government for designation in 1974, for the Cagliari Conference in November 1980 and for the Groningen Meeting in May 1984.

Supplemented by:

- Carp, E. (1980). A Directory of Western Palearctic Wetlands. IUCN, Gland, Switzerland.

- IUCN (1977). World Directory of National Parks and other Protected Areas. IUCN, Gland, Switzerland.

Additional references:

- Committee Reports on restoration, including results of botanical, ornithological, limnological and hydrological investigations. (Arbetsgruppen för Kävsjön restaurening). Jonköping, 1974.

- Nilsson, L. et al., (1976). Kävsjöns fagelfauna 1972-1975. Fauna och Flora 71: 242-253 (English summary).

- Nilsson, L. et al., (1982). Kävsjön som fagelsjö - hackande och rastande vattenfaglor 1972-1980, samt om restaureringen av strandöngsbiotoper. Vai Fagelvărld 41: 297-314 (English summary).

\section{Isles off Götland}

Location Grötlingboholme-Rone Ytterholme $57^{\circ} 07^{\prime} \mathrm{N}, 18^{\circ} 30^{\prime} \mathrm{E}$; Laus Holmar $57^{\circ} 17^{\prime} \mathrm{N}$, $18^{\circ} 45^{\prime} \mathrm{E}$; and Skenholmen $57^{\circ} 48^{\circ} \mathrm{N} 19^{\circ} 03^{\prime} \mathrm{E}$. In the Baltic Sea off the east coast of Götland.

Area Total 2,290ha. Grötlingboholme-Rone Ytterholme 1050ha; Laus Holmar 540ha; Skenholmen 700 ha.

Degree of Protection Ownership is part state and part private. In the part known as Grötlingboholme-Rone Ytterholme there are two nature reserves totalling 340 ha. Laus Holmar is a bird sanctuary. Designtated as a Ramsar site on 5 December 1974.

Site Description The site is in three sections which surround a number of low-lying limestone islands which have long been used for sheep, cattle and horse grazing, and have a short grassy sward and gravelly soils with hardly any trees or bushes. Large parts of Grötlingboholme comprise beach gravel in marked ridges, especially at the southern end. On Rone Ytterholme there are long series of ridges on the beaches. Both islands are treeless. Close to Rone Ytterholme there are large shallow water areas with projecting banks. A few kilometres north of Grötlingboholme-Rone Ytterholme is the section known as Laus Holmar which consists of three islands: Storholmen, Skarpholmen and Gräsholmen. On the shores of these islands is a system of ridges, some of which consist of spurs formed by a rise in land level. Skarpholmen and Gräsholmen are ungrazed and to a certain extent have a well developed plant vegetation. Storholmen is grazed by cattle, and the grass here is much shorter. There are some small wetlands on the islands. The most northerly of the three sections is Skenholmen, a flat, grassy, almost completely treeless island, which is used for sheep grazing and military target practice.

International and National Importance The main reason for the inclusion of these islands is their importance to flocks of migrating barnacle goose Branta leucopsis which breed in areas on the Arctic Ocean. Tens of thousands graze here during a spring stopover of almost two months (generally in April and May). In autumn their stopover (from the end of September) is much shorter. This area is probably the most important locality in the Baltic for barnacle geese. The islands are also important for migrating brent goose B. bernicla and greylag goose Anser anser. Grötlingboholme-Rone Ytterholme is considered to be the Baltic's most important moulting ground for greylag geese. This area also supports breeding colonies of black-headed gull Larus ridibundus and sandwich tern Sterna sandvicensis. There are also many species of ducks and waders including dunlin Calidris alpina schinzii. Laus Holmer has 35 breeding species including greylag goose, eider Somateria mollissima, dunlin, little tern Sterna albitrons, avocet Recurvirostra avoselta and turnstone Arenaria interpres. Periodically there are also large colonies of gulls. Skenholmen is an important breeding ground for eider, greylag, black-tailed 
godwit Limosa limosa, little gull Larus minutus, ruff Philomachus pugnax, dunlin, caspian tern Sterna caspia, little tern S. albifrons and black-headed gull. In winter the island is an important resting place for ducks, swans and birds of prey. During the last few years a colony of barnacle geese has started to breed here with about 620 pairs in 1986.

Changes in Ecological Character There is possibly overgrazing by sheep.

Management Practices Skenholmen is used for target practice by the military except during the goose migration period, however this use would appear to be favourable to nature conservation since military regulations forbid public access. The use of the islands for grazing is also reasonably compatible with the presence of the geese. The two nature reserves at Grötlingboholme-Rone Ytterholme and Laus Holmer have restricted access.

Scientific Research and Facilities No information

Principal Reference Material The above information is taken from the documents supplied by the Swedish Government for designation in 1974, for the Cagliari Conference in November 1980 and for the Groningen Meeting in May 1984.

Supplemented by:

- Carp, E. (1980). A Directory of Western Palearctic Wetlands. IUCN, Gland, Switzerland.

\section{Hornborgasjön}

Location $58^{\circ} 19^{\prime} \mathrm{N}, 13^{\circ} 33^{\prime} \mathrm{E}$. Situated between lakes Vanern and Vättern in Skaraborg Ian.

Area 6,350 ha

Degree of Protection Private and state ownership. The designated site includes two nature reserves. Designated as a Ramsar site on 5 December 1974.

Site Description Hornborgasjön is a shallow lake, originally $3 \mathrm{~m}$ deep, but in which the water level has been lowered five times since 1802. After the last two lowerings in 1904-1911 and 1932-33 the lake was almost completely overgrown by emergent vegetation. B; 1933 it had been completely canalised, with inflow being led directly to the outlet, and the lake used to dry up every summer until 1954 when a $1,200 \mathrm{ha}$ area in the north was enclosed by dykes. In 1965 the lake had become overgrown with reed Phragmites australis, slender tufted sedge Carex acuta and willow Salix sp., which led to some experimental clearing of reeds being carried out, and an enquiry to investigate the best method of preserving the area for waterfowl was instigated. In 1973 the final report was forwarded to the Government by the Environment Protection Board which proposed that the emergent vegetation be cleared over an area of $1,100 \mathrm{ha}$ and the water level raised. This was approved by the Swedish Parliament in 1977.

International and National Importance During the 1970s, breeding waterfowl included all of Sweden's five species of grebe, mute swan (20 pairs), greylag goose, crane, mallard, shoveler, teal, garganey, gadwall, pochard, tufted duck, coot (1,000 pairs), water rail, moorhen, spotted crake, lapwing, redshank, green sandpiper, wood sandpiper, ruff and black-headed gull (8,000 pairs) (Cygnus olor, Anser anser, Grus grus, Anas platyrhynchos, A. clypeata, A. crecca, A. querquedula, A. strepera, Aythya ferina, A. fuligula, Fulica atra, Rallus aquaticus, Gallinula chloropus, Porzana porzana, Vanellus vanellus, Tringa totanus, T. ochropus, T. glareola, Philomachus pugnax and Larus ridibundus). Other breeding species include grasshopper warbler Locustella naevia (60 pairs), thousands of sedge warbler Acrocephalus schenobaenus and reed warbler $A$. scirpaceus, and a few pairs of common rose finch Carpodacus erythrinus. The Hornborgasjön supports the second largest population of marsh harrier Circus aeruginosus in Sweden (20 pairs), and the only known remnant of the southern Swedish population of hen harrier Circus cyaneus. In the summer a number of osprey Pandion haliaetus are seen fishing here. The lake is of great importance as a stopover for migrants including mute swan, bean goose, ruff and wigeon. The area is particularly important for crane Grus grus with 4,000-6,000 individuals resting there April-May, some staying on to breed. 
Changes in Ecological Character The area has been extensively modified by man over the past 200 years. It used to be famous as a resting and nesting site for waterfowl, and it is hoped that after restoration is completed it will once again become one of Sweden's finest waterfowl lakes. The experimental clearing has already had beneficial effects, with little gull, black tern, dunlin and ruff starting to breed here. The restoration is expected to increase the number of ducks in particular.

Management Practices Original plans were to raise the water level by a metre. However, in 1986 the Government commissioned the Board of Management to present a detailed restoration alternative which included a $0.8 \mathrm{~m}$ raising of the water level, but with no or few embankments along the shores. It is believed this will create better habitats for wetland birds compared to the original plans. Lake restoration will include clearing vegetation over an area of 1,100ha, and should be completed by 1987. Public access has to be restricted during April-May when cranes are present. Some potatoes are grown as food for cranes.

Scientific Research and Facilities Avifaunal studies have been carried out for a long period. More recently there has been extensive research into lake restoration methods, especially on developing methods for reed eradication. A field station has been established and an information centre was opened in 1986. When lake restoration is complete, the Hornborgasjön will provide valuable case study material for restoration of degraded wetlands.

Principal Reference Material The above information is taken from documents supplied by the Swedish Government for designation in 1974, for the Cagliari Conference in November 1980 and for the Groningen Meeting in May 1984.

Supplemented by:

- Carp, E. (1980). A Directory of Western Palearctic.Wetlands. IUCN, Gland, Switzerland.

- Gelin, C. (1978). The restoration of freshwater ecosystems in Sweden. In: Holdgate, M.W. and Woodman, M.J. (Eds). The Breakdown and Restoration of Ecosystems. NATO Conference Series, I Ecology.

Additional references:

- Bjork, S. (1972). Swedish lake restoration program gets results. Ambio 1:153-165.

- Environment Protection Board (1973). Hornborgasjön utredningen. 3 vols. (summary, limnological and ornithological aspects). Committee Report PM 280.

- Several papers in Var Fagelvarld with English summaries.

Täkern

Location $58^{\circ} 21^{\prime} \mathrm{N}, 14^{\circ} 49^{\prime} \mathrm{E}$. Located about $40 \mathrm{~km}$ west of Linkoping in Ostergötland Ian.

Area 5,600ha

Degree of Protection Private ownership. Most of the designated site is included in a nature reserve of 5,420ha. Designated as a Ramsar site in December 1974.

Site Description Lake Täkern lies east of Lake Vättern in a region dominated by Cambrio-Silurian bedrock and cultivated clay plains. The lake is very eutrophic and shallow, with an average depth of $0.8 \mathrm{~m}$. In the last century the water level was permanently lowered, allowing vast reedbeds of Phragmites sp. to develop. These now cover about one-third of the lake's area. The shallows contain water milfoil Myriophyllum spp., stoneworts, Chara spp., pondweeds Potomageton sp. and Ranunculus spp. which are a foodsource for waterfowl.

International and National Importance The lake has a large number of the birds common to central Swedish lakes, and also a number of unusual species. There are large numbers of birds dependent on reeds. The populations of marsh harrier Circus aeruginosus (40 pairs), bittern Botaurus stellarius, bearded tit Panurus biarmicus and great reed warbler Acrocephalus arundinaceus are probably the largest in Sweden. All five species of grebe breeding in Sweden occur here, including over 100 pairs of red-necked grebe Podiceps grisegena. A colony of black tern Chlidonias niger established in 1970 has become one of Sweden's largest, with about 
30 pairs in 1979. Other breeding waterfowl include 10 species of duck. Lake Täkern also supports Sweden's largest population of black-headed gull Larus ridibundus. The breeding area for waders is limited at present due to lack of spring flooding and the low amount of pasturage, however birds currently breeding here include dunlin Calidris alpina, ruff Philomachus pugnax, redshank Tringa totanus and oystercatcher Haematopus ostralegus. Migrant visitors include most of Sweden's wader species and large numbers of duck and geese including mallard Anas platyrhynchos, teal A. crecca, wigeon A. penelope, goosander Mergus merganser and all European species of geese (especially bean goose Anser fabalis) with about 40,000 pairs maximum in November. The area is also an important summering and moulting ground for ducks, greylag goose Anser anser and 2,000-3,000 mute swan Cygnus olor.

Changes in Ecological Character Certain bird species have declined in number.

Management Practices Some improvements in water level regulation have been achieved. Practices also include experimental removal of vegetation along the shores by means of amphibious vehicles. Most of the reserve has restricted access.

Scientific Research and Facilities Some limnolo-botanical studies have been made, and a bird ringing station has been in operation for some years and formed the base for ornithological work.

Principal Reference Material The above information is taken from documents supplied by the Swedish Government for designation in 1974, for the Cagliari Conference in November 1980 and for the Groningen Meeting in May 1984.

Supplemented by:

Carp, E. (1980). A Directory of Western Palearctic Wetlands. IUCN, Gland, Switzerland.

Duffey, E. (1982). National Parks and Reserves of Western Europe. Macdonald and Co., London.

\section{Kvismaren}

Location $59^{\circ} 10^{\prime} \mathrm{N}, 15^{\circ} 23^{\prime} \mathrm{E}$. About $140 \mathrm{~km}$ west of Stockholm, south of the town of Orebro.

Area 800 ha

Degree of Protection Privately owned. The site includes a nature reserve (558ha). Designated as a Ramsar site on 5 December 1974.

Site Description Kvismaren valley is a mainly fertile and rather flat agricultural landscape. Formerly there were large areas of sedge and horsetail meadows surrounding two lakes, however following a comprehensive lowering of the water level during the $1880 \mathrm{~s}$ the lakes dried out completely. They have now been replaced by extensive stretches of reeds Phragmites sp. interspersed with willow Salix sp. thickets and surrounded by marshy meadows, low-lying pasture, and arable land with many dense woods along the shores. The hydrology of the area is subject to strict control by canals and embankments to protect the surrounding arable land. However, a small area known as Bird Lake has been dyked so that the water level can be raised.

International and National Importance The area is a resting site for most of the wader and duck species passing through central Sweden. Species include a large number of bean goose Anser fabalis (100-200). Between 2 and 4 golden eagle Aquila chrysaetos winter in the valley. Annual summer visitors include quail Coturnix coturnix, corncrake Crex crex, little crake Porzana parva, little gull Larus minutus, black tern Chlidonias niger, golden oriole Oriolus oriolus, river warbler Locustella fluviatilis, short-eared owl Asio flammeus, long eared owl A. otus and hen harrier Circus cyaneus. Characteristic breeding birds at this site are marsh harrier Circus aeruginosus (5-7 pairs), bittern Botaurus stellaris (2-4 individuals), spotted crake Porzana porzana, gadwall Anas strepera (10-15 pairs), greylag goose Anser anser 
(a few pairs), little grebe Tachybaptus ruficollis (1-2 pairs), black-tailed godwit Limosa limosa (1-3 pairs), great red warbler Acrocephalus arundinaceus (3 pairs), grasshopper warbler Locustella naevia (about 100 pairs), marsh warbler Acrocephalus palustris, common rosefinch, Carpodacus erythrinus and thrush nightingale Luscinia luscinia.

Changes in Ecological Character Potential threats are increased drainage and cultivation, and decreasing grazing. Hen harrier, black-tailed godwit, short-eared owl and long-eared owl used to breed regularly in 1950 s-early 1960 s but are now rarely seen in the region.

Management Practices Various restoration measures carried out since 1980 have included the burning of reed and scrub, rotary cultivation, and raising of the water level in an area of 85 ha. Large-scale restoration measures will continue.

Scientific Research and Facilities Kvismaren bird station has been carrying out extensive research in the area since 1960 . Work has concentrated on biocide problems, population studies, and, since the 1970s, on the development of various methods to control the vegetation.

Principal Reference Material The above information is taken from the documents supplied by the Swedish Government for designation in 1974, for the Cagliari Conference in November 1980 and for the Groningen Meeting in May 1984.

Supplemented by:

- Carp, E. (1980). A Directory of Western Palearctic Wetlands. IUCN, Gland, Switzerland.

- Sondell, J. et al. (1985). Kvismaren-och Fagelarna. Foreningen Kvismaren Fagelstation, Orebro. (In Swedish).

\section{Hjälstaviken}

Location $59^{\circ} 40^{\circ} \mathrm{N}, 17^{\circ} 23^{\prime} \mathrm{E}$. Located $20 \mathrm{~km}$ south of the town of Uppsala and $17 \mathrm{~km}$ east of the town of Enkobing in Uppsala Ian.

\section{Area 790 ha}

Degree of Protection Ownership is part private and part state. The area was established as a nature reserve in 1948. Designated as a Ramsar site on 5 December 1974.

Site Description Lake Hjälstaviken is a shallow almost completely enclosed bay of Lake Malaren, surrounded by tussocky meadows that merge into drier pasture and fields. The site includes two patches of deciduous trees overlooking the bay, and to the east a conifer covered hill with exposed rocks. The average lake depth is $1 \mathrm{~m}$, and it is characterised by clear water and a very flocculant sediment. Only 30 ha of the lake area is open water, with the remainder invaded by reed Phragmites communis, rushes Scirpus spp. and reedmace Typha spp. The reed belts are $200-400 \mathrm{~m}$ wide. The submerged and floating vegetation has declined in recent years.

International and National Importance About 100 bird species breed in the area including 30 associated with the wetland. Species include bittern Botaurus stellaris, marsh harrier Circus aeruginosus, hobby Falco subbuteo, teal Anas crecca, gadwall $A$. strepera, garganey $A$. querquedula, shoveler $A$. clypeata, pochard Aythya ferina, tufted duck $A$. fuligula, water rail Rallus aquaticus, grasshopper warbler Locustella naevia and spotted crake Porzana porzana. There are regular sightings of Slavonian grebe Podiceps auritus, little crake Porzana parva, common rosefinch Carpodacus erythrinus and osprey Pandion haliaetus. Lake Hjälstaviken is a resting place for ducks, geese and waders during spring and autumn migration, including great snipe Gallinago media, jacksnipe Limnocryptes minimus, black-tailed godwit Limosa limosa, crane Grus grus, bean goose Anser fabalis, Canada goose Branta canadensis and goosander Mergus merganser. In winter the lake and surrounding area are important for a number of birds of prey, notably golden eagle Aquila chrysactos, rough-legged buzzard Buteo lagopus and goshawk Accipiter gentilis. This lake has served as a base from which mute swan Cygnus olor has colonised Sweden. 
Changes in Ecological Character The encroachment by marginal vegetation, and loss of submerged and floating macrophytes, has adversely affected the value of the area for birdlife, and the number of ducks using the site has declined in recent years. A further potential problem is the heavy use of fertilisers in the surrounding farmland. This is one of Sweden's most popular bird reserves and has large numbers of visitors.

Management Practices The surrounding pastures are grazed. Public access is restricted to nature trails. A management plan has recently been prepared for this area. Minor restoration and management measures have been carried out in the lake and in some of the surrounding meadows.

Scientific Research and Facilities Research includes studies in ornithology, hydrology, vegetation and the potential effects of fertiliser contamination from surrounding fields.

Principal Reference Material The above information is taken from documents supplied by the Swedish Government for designation in 1974, for the Cagliari Conference in November 1980 and for the Groningen Meeting in May 1984.

Supplemented by:

- Carp, E. (1980). A Directory of Western Palearctic Wetlands. IUCN, Gland, Switzerland.

\section{Annsjön}

Location $63^{\circ} 16^{\prime} \mathrm{N}, 12^{\circ} 33^{\circ} \mathrm{E}$. Located about $80 \mathrm{~km}$ due west of the lake Storsjön in Jamtland Ian.

Area 11,300ha (including the lower River Handolan)

Degree of Protection Privately owned. Designated as a Ramsar site on 5 December 1974.

Site Description Annsjön is a very shallow oligotrophic lake in the upper part of the Indal River drainage system and is surrounded by extensive mire. At the western end, the confluence of two rivers has formed the Handol Delta. There are also deltas iri the northwest (Hara) and southeast (Jarpan). About half the lakeshore is marshy ground, with one sandy section about $2 \mathrm{~km}$ long in the east forming a high narrow ridge. Some sections of the lakeshore are eroded peat in steps $3-4 \mathrm{~m}$ high. The lower course of the River Handolan has many canyon features including torrent areas and magnificent waterfalls. The proximity of the lake to the wilderness-like forested areas in the south and east contribute to its varied animal life.

International and National Importance The mire delta areas and shallow open waters are important for migrating and breeding birds. Breeding species include at least 10 species of duck including wigeon Anas penelope, common scoter Melanitta nigra, velvet scoter $M$. fusca, long-tailed duck Clangula hyemalis and pintail Anas acuta, red-throated diver Gavia stellata and bean goose Anser fabalis (occasionally), and 14 species of wader including broad-billed sandpiper Limicola falcinellus, red-necked phalarope Phalaropus lobatus, Temminck's stint Calidris temminckii and curlew Numenius arquata. A total of 90 bird species breed regularly in the area. Annsjön is very important as a resting station for wetland birds that breed further north. The mires are good examples of oceanically-influenced types and have a diverse flora. The lake has 35 species of vascular plants making it notably richer than lakes further downstream.

Changes in Ecological Character Lesser white-fronted goose Anser erythropus used to breed at the lake occasionally, but do so no longer.

Management Practices The lake is used for fishing and recreation, but access is restricted in some areas. 
Principal Reference Material The above information is taken from documents supplied by the Swedish Government for designation in 1974 and for the Cagliari Conference in November 1980.

Supplemented by:

- Carp, E. (1980). A Directory of Western Palearctic Wetlands. IUCN, Gland, Switzerland. Additional reference:

- Persson, C. (1943). Faglar vid Annsjön.

\section{Gammelstadsviken}

Location $65^{\circ} 38^{\prime} \mathrm{N}, 22^{\circ} 00^{\prime} \mathrm{E}$. Situated immediately northwest of the town of Lulea in Norbotten Ian at the head of the Gulf of Bothnia.

Area $440 \mathrm{ha}$

Degree of Protection Privately owned. The area was established as a nature reserve in 1969. Designated as a Ramsar site on 5 December 1974.

Site Description Lake Gammelstadsviken was formed when a $41 \mathrm{~km}$ long coastal bay was isolated from the sea by land elevation. It is a shallow lake with large areas less than $1 \mathrm{~m}$ in depth and a maximum depth of $4 \mathrm{~m}$. The floor consists of fine grained marine sediment, clay and fine sand, covered by an increasing depth of lake mud. The inflows are small in volume and consequently the water exchange is low. Along large stretches of the shores is a quagmire-like zone consisting of reed Phragmites communis, greater reedmace Typha latifolia, water horsetail Equisetum fluviatile and bogbean Menyanthes trifoliata. The floating vegetation is dominated by least waterlily Nuphar pumila, small waterlily Nymphaea candida and common duckweed Lemma minor.

International and National Importance As a eutrophic lake with a very northerly position it has become an outpost for many southern plant and animal species. It supports 190 bird species including an unusually large number of ducks. Breeding species include Slavonian grebe, Canada goose, teal, wigeon, shoveler, pochard, goldeneye, little gull, red-necked phalarope, redshank, ruff, snipe, red-necked grebe and marsh harrier (breeds here regularly) (Podiceps auritus, Branta canadensis, Anas crecca, A. penelope, A. clypeata, Aythya ferina. Bucephala clangula, Larus minutus, Phalaropus lobatus, Tringa totanus, Philomachus pugnax, Gallinago gallinago, Podiceps grisegena and Circus aeruginosus), and probably wood sandpiper $T$. glareola. Occasional hen harrier $C$. cyaneus, osprey Pandion haliaetus and little grebe Tachybaptus ruficollis. Visitors in spring and autumn migrations include crane Grus grus, smew Mergus albellus, spotted redshank Tringa erythropus, bar-tailed godwit Limosa lapponica, black-tailed godwit L. limosa, curlew sandpiper Calidris ferruginea and broad-billed sandpiper Limicola falcinellus.

Changes in Ecological Character A road was recently built across the northern section of the lake, but so far it has not been possible to estimate the effect on the area. The lake is close to the town of Lulea, and some urbanisation is taking place close to the shoreline.

Management Practices Some areas of the nature reserve have restricted access.

Scientific Research and Facilities No information

Principal Reference Material The above information is taken from documents supplied by the Swedish Government for designation in 1974, for the Cagliari Conference in November 1980 and for the Groningen Meeting in May 1984. 
Supplemented by:

- Carp, E. (1980). A Directory of Western Palearctic Wetlands. IUCN, Gland, Switzerland.

- Duffey, E. (1982). National Parks and Reserves of Western Europe. Macdonald and Co., London.

\section{Persöfjärden}

Location $65^{\circ} 47^{\prime} \mathrm{N}, 22^{\circ} 09^{\prime} \mathrm{E}$. Located about $30 \mathrm{~km}$ north of the town of Lulea in Norrbotten Ian, at the Head of the Gulf of Bothnia.

Area 3,350 ha

Degree of Protection The site is privately owned and has no statutory conservation protection. Preparations for the area to be protected as a nature reserve have started. Designated as a Ramsar site on 5 December 1974.

Site Description Lake Persöf järden was formed when part of a coastal bay was isolated from the sea by a rise in land level. It is about $15 \mathrm{~km}$ long, and is shallow with flat shores. In 1937 the lake level was lowered by about $1.3 \mathrm{~m}$, which encouraged the spread of extensive belts of rushes and reeds into the lake (which almost divide the lake into two at one point). The spread of floating vegetation is also extensive. Some areas in the south-west have been invaded by willows Salix sp. Before 1937 Persöfjärden was noted for its diverse fish and bird populations, but after the change in water level the fish largely disappeared though the number of bird species increased. Many sections of the shore still regularly flood and provide good conditions for wetland bird species. The bird fauna is not well known, mainly due to its large size, though it is probably similar to that of Lake Gammelstadsviken, another Ramsar site.

International and National Importance The site is probably of most importance as a resting area for ducks, geese and waders. Flocks of bean goose Anser fabalis are regular feeders at the lake. It is also an important locality for birds of prey during the migration period. Breeding species include red-necked phalarope Phalaropus lobatus, the lake being one of only two or three inland lakes in Norrbotten where this species breeds. Other probable breeding species include marsh harrier Circus aeruginosus, little gull Larus minutus and Slavonian grebe Podiceps auritus. 187 bird species have been recorded.

Changes in Ecological Character There are some indications that a decrease in the breeding bird population has occurred in the last few years. In recent years a decrease in the $\mathrm{pH}$ of the lake water has been recorded. The regular flooding, which still occurs, causes problems for local farmers, and has prompted requests for further drainage of the area. This could possibly threaten nature conservation in certain sections of the area.

Management Practices Raising the water level is being considered, and is already gradually taking place because the lake outlets have been allowed to become blocked by vegetation.

Scientific Research and Facilities No information

Principal Reference Material The above information is taken from documents supplied by the Swedish Government for designation in 1974 and for the Cagliari Conference in November 1980.

Supplemented by:

- Carp, E. (1980). A Directory of Western Palearctic Wetlands. IUCN, Gland, Switzerland.

\section{Tärnasjön}

Location $66^{\circ} 00^{\prime} \mathrm{N}, 15^{\circ} 19^{\circ} \mathrm{E}$. Located about $40 \mathrm{~km}$ south-west of the town of Ammarnäs in Vasterbotten Ian. 
Area 11,800ha

Degree of Protection State owned. The whole area is a nature reserve. Designated as a Ramsar site on 5 December 1974.

Site Description Tärnasjön is a long narrow lake occupying a stretch of the upper Ume river system. It is situated completely within the sub-alpine region, and lies in a flat marshy basin characterized by parallel moraine ridges. In the southern part of the lake these ridges form a distinctive landscape with a very indented marshy shoreline and numerous small islands. Vegetation is mainly heathlike woods of birch Betula spp. with dwarf scrub often reaching down to the shore. Some tall Carex species occur. The area floods in spring. In the south towards Ankadalen are extensive mire areas and a mosaic of mires, small lakes and moraine ridges covered with birchwoods. Most of the lakeshore is composed of moraine deposits with a rich flora. The river Tärna enters the lake in the north, forming a delta which has been modified by human activities. Northwest of the delta are botanically important mires, and further north at Lake Laivajaure are the southernmost and probably the best developed 'Palsa' mires in Sweden.

International and National Importance The site is an important breeding area for 10 duck species and 10 wader species particularly in the delta to the north, the archipelago in the southern end of Tärnasjön, and the surrounding mires north of Lake Guttajaure and towards and in Ankadalen Valley. Breeding duck include wigeon Anas penelope, teal $A$. crecca, scaup Aythya marila, common scoter Melanitta nigra and velvet scoter $M$. fusca. Breeding waders include whimbrel Numenius phaeopus, ruff Philomachus pugnax, red-necked phalarope Phalaropus lobatus and great snipe Gallinago media. A number of birds of prey also breed. Other important fauna include European beaver Castor fiber which has been introduced to the area. The site is botanically important for its extensive mire complexes, and is one of the few areas in the region not yet affected by water regulation for hydro-electric schemes.

Changes in Ecological Character None reported (up to December 1983)

Management Practices Fishing is allowed on the lake.

\section{Scientific Research and Facilities No information}

Principal Reference Material The above information is taken from documents supplied by the Swedish Government for designation in 1974 and for the Cagliari Conference in November 1980.

Supplemented by:

- Carp, E. (1980). A Directory of Western Palearctic Wetlands. IUCN, Gland, Switzerland.

\section{Tjalmejaure-Laisdalen}

Location $66^{\circ} 15^{\circ} \mathrm{N}, 16^{\circ} 11^{\prime} \mathrm{E}$. Near Peljekajse National Park (to the north) and the Norwegian border (to the west) in the south-west of Norrbotten Ian.

Area 13,400 ha

Degree of Protection State owned. The designated site includes a nature reserve of 500 ha in the Yraf Delta. Bird Sanctuary regulations apply to a large part of the area. Designated as a Ramsar site on 5 December 1974.

Site Description The site comprises two mountain valleys which converge above Lake Yraf, and includes a delta formed in the lake by the combined rivers. The southern of the two valleys contains a series of lakes with wide flat shores: Bosjujaure - Tjalmejaure and Gavajaure. The northern, Laisdalen valley is much narrower. Either side of the river is a 
marshy strip bordered by birch Betula sp. woods (partly 'meadow' birch forest) with a sparse element of pine Pinus sp. Fauna includes wolverine Gulo gulo, brown bear Ursus arctos, lynx Lynx lynx, pine marten Martes martes and a diverse bird community.

International and National Importance The lake system in the southern valley is an important breeding and resting ground for waterfowl. Breeding birds include some 10 species of duck, broad-billed sandpiper Limicola falcinellis, purple sandpiper Calidris maritima, great snipe Gallinago media, snowy owl Nyctea scandiaca and red-throated pipit Anthus cervinus. Laisdalen is one of the richest of all Swedish mountain valleys in animal species, and has long been known as an extremely productive region for willow grouse Lagopus lagopus and ducks. The woodland in the valley is important for waxwing Bombycilla garrulus, Siberian jay Perisoreus infaustus and capercaillie Tetrao urogallis (unusually abundant). Also numerous are various birds of prey including golden eagle Aquila chrysaetus, rough-legged buzard Buteo lagopus, osprey Pandion haliaetus and merlin Falco columbarius. The valley is also unusual because the ranges of a number of species extend further into the mountains than has been observed elsewhere in Sweden. In spring it is visited by large numbers of migrating birds and is the last stopover before their breeding grounds.

Changes in Ecological Character In recent years, lesser white-fronted goose Anser erythropus has disappeared from the southern valley, where several pairs used to breed regularly.

\section{Management Practices No information}

Scientific Research and Facilities No information

Principal Reference Material The above information is taken from documents supplied by the Swedish Government for designation in 1974, for the Cagliari Conference in November 1980. Supplemented by:

- Carp, E. (1980). A Directory of Western Palearctic Wetlands. IUCN, Gland, Switzerland.

\section{Laidaure}

Location $67^{\circ} 07^{\prime} \mathrm{N}, 17^{\circ} 45^{\prime} \mathrm{E}$. About $86 \mathrm{~km}$ north-west of the town of Jokkmokk and on the south-eastern border of Sarek National Park, Norrbotten Ian.

Area $4,150 \mathrm{ha}$

Degree of Protection Ownership is divided between the State, the Swedish Society for the Conservation of Nature and private owners. Part of the designated site ( $300 \mathrm{ha})$ in the region of the River Rapa delta is included in Sarek National Park. Designated as a Ramsar site on 5 December 1974.

Site Description The site lies between the mountainous region of Sarek National Park and a zone of coniferous forests. It comprises Lake Laidaure, into which the delta of the River Rapa is rapidly expanding at the eastern end. It has a diverse bird community and other fauna include brown bear Ursus arctos and moose Alces alces.

International and National Importance The delta is the most important bird locality in the Sarek region and is especially important as a breeding ground for duck including wigeon, pintail, teal, tufted duck, scaup and goldeneye (Anas penelope, A. acuta, A. crecca, Aythya fuligula, A. marila and Bucephala clangula). Numerous waders also breed in the delta and along the shores of Lake Laidaure, including common sandpiper Tringa hypoleucos, wood sandpiper $T$. glareola and red-necked phalarope Phalaropus lobatus. The area, particularly the delta, is an important resting and moulting ground for various species of duck and large numbers of whooper swan Cygnus cygnus, mainly following the break-up of the ice in spring. Numerous species of passerines are also found on the delta. 
Changes in Ecological Character There is increasing tourist pressure in the area, mainly from canoeing. Proposals for water regulation for hydroelectrical purposes have so far been turned down.

\section{Management Practices No information}

\section{Scientific Research and Facilities No information}

Principal Reference Material The above information is taken from documents supplied by the Swedish Government for designation in 1974 and for the Cagliari Conference in November 1980.

Supplementeđ by:

Carp, E. (1980). A Directory of Western Palearctic Wetlands. IUCN, Gland, Switzerland.

Thornback, J. and Jenkins, M. (1982). IUCN Mammal Red Data Book Part I.

IUCN, Gland, Switzerland.

\section{Sjaunja-Kaitum}

Location $67^{\circ} 17^{\prime} \mathrm{N}, 19^{\circ} 49^{\prime} \mathrm{E}$. Located about $50 \mathrm{~km}$ south-west of Kiruna in West Norrbotten Ian.

Area 176,000 ha

Degree of Protection State owned. Most of the area is included within the boundary of a nature reserve. Designated as a Ramsar site in December 1974.

Site Description The site comprises virgin wilderness with a wide range of habitats including open water, mire moraine ridges and mountain slopes. The mountain region has been included in the designation to cover the whole catchment area. Sjaunja district contains the most extensive mire in Europe outside the Soviet Union. It is characterised by a mixture of open marshes, shallow lakes and birch Betula sp. woods. In drier parts are virgin spruce Picea sp. and Pine pinus sp. forests. The area contains at least 25 mammal species including brown bear Ursus arctos, lynx Lynx lynx, wolverine Gulo gulo and European otter Lutra lutra (all occurring regularly).

International and National Importance The area is important for its mires, and the Sjaunja region supports a greater number of vertebrate species than any other mountain region in Sweden, including over 150 bird species with 100 known to breed in the wetland (about 50 of which are dependent on wetland habitat). Permanently resident species include white-tailed eagle Haliaeetus albicilla, golden eagle Aquila chrysaetos and numerous species of waterfowl including whooper swan Cygnus cygnus. Other breeding birds include jack snipe Lymnocryptes minimus, spotted redshank Tringa erythropus, broad-billed sandpiper Limicola falcinellus, red-necked phalarope Phalaropus lobatus, short-eared owl Asio flammeus, red-throated pipit Anthus cervinus, rustic bunting Emberiza rustica and little bunting E. pusilla. Gyr falcon Falco rusticolus appears sporadically.

Changes in Ecological Character There is some disturbance in spring from the use of snowmobiles.

Management Practices Some hunting is allowed in the bird sanctuary.

Scientific Research and Facilities Research is largely confined to studies of the bird fauna.

Principal Reference Material The above information is taken from documents supplied by the Swedish Government for designation in 1974 and for the Cagliari Conference in November 1980. 
Supplemented by:

- Carp, E. (1980). A Directory of Western Palearctic Wetlands. IUCN, Gland, Switzerland. Additional references:

- Curry-Lindahl, K. (1971). Sjaunja och Kaitum.

- Reports of the Environment Protection Board and Botanical Survey and Draft Wildlife Management Plan.

\section{Taavavuoma}

Location $68^{\circ} 30^{\prime} \mathrm{N}, 20^{\circ} 45^{\prime} \mathrm{E}$. In Norbotten Ian, $85 \mathrm{~km}$ north-north-east of the town of Kiruna, about $30 \mathrm{~km}$ east of the border with Norway and $40 \mathrm{~km}$ south of the border with Finland.

Area 8,900 ha

Degree of Protection State owned. Designated as a Ramsar site on 5 December 1974.

Site Description The site consists of a mosaic of mires, watercourses, lakes and pools, lying in a depression in one of the northernmost plateau regions of Lapland (altitude $900-1,000 \mathrm{~m}$ ). It forms part of the catchment area for the River Lainio, which is one of the two main tributaries of the River Torne. The presence of permafrost has influenced the vegetation, creating unusually extensive formations of 'Palsas' mire which can reach a height of $6-7 \mathrm{~m}$. Its arctic and sub-arctic peatlands and lakes are of considerable botanical and zoological interest.

International and National Importance Particularly rich concentrations of birds occur along the River Taavaätno and on the lakes in the south, making this area one of the most ornithologically rich regions in Lapland. Breeding species of waterfowl include whooper swan, pintail, teal, long-tailed duck, smew, red-necked phalarope, wood sandpiper, spotted redshank, ringed plover, golden plover, dunlin, ruff and long-tailed skua (Cygnus cygnus, Anas acuta, A. crecca, Clangula hyemalis, Mergus albellus, Phalaropus lobatus, Tringa glareola, T. erythropus, Charadrius hiaticula, Pluvialis apricaria, Calidris alpina, Philomachus pugnax and Stercorarius longicaudus). Species of breeding passerines include red-throated pipit Anthus cervinus, Lapland bunting Calcarius lapponicus and arctic redpoll Acanthis hornemanni. Other birds include lesser white-fronted goose Anser erythropus, bean goose $A$. fabalis, broad-billed sandpiper Limicola falcinellus, golden eagle Aquila chrysaetos, Gyr falcon Falco rusticolus and hen harrier Circus cyaneus.

Changes in Ecological Character None reported up to December 1983.

Management Practices No information

Scientific Research and Facilities No information

Principal Reference Material The above information is taken from documents supplied by the Swedish Government for designation in 1974 and for the Cagliari Conference in November 1980.

Supplemented by:

Carp, E. (1980). A Directory of Western Palearctic Wetlands. IUCN, Gland, Switzerland. Additional references:

- Arvidsson. B. (1979). Taavavouma. Forum, Stockholm. (In Swedish).

- Report on the avifauna (Fältbiologerna, Göteborg 1973, mimeo.). 
Population $6,423,100(1983)$

Summary of Wetland Situation Several important waterbodies are situated on the Swiss borders. The River Rhine having formed the frontier with Liechtenstein over a length of about $25 \mathrm{~km}$ and with Austria over a length of about $30 \mathrm{~km}$, passes through the Bodensee (the northern shore of which is the territory of the Federal Republic of Germany) then forms the German frontier for the final $75 \mathrm{~km}$ of its course in Switzerland. The border with Italy twice transects the Lago di Lugano and also the northern end of the Lago Maggiore. Also, some $60 \mathrm{~km}$ of the southern shore of Lake Geneva is French territory.

Lake Constance, Lake Geneva and Lake Neuchâtel are of special international importance as wintering or moulting places for very large numbers of waterfowl, as supported by data for 25 winters. For example, in January 1983 about 140,000 waterfowl (excluding gulls) were present on Lake Geneva alone, the most numerous being great crested grebe Podiceps cristatus (11,000), black-necked grebe $P$. nigricollis (4,700), tufted duck Aythya fuligula 59,000), pochard A. ferina (19,000), goldeneye Bucephala clangula $(3,000)$, goosander Mergus merganser $(1,650)$ and coot Fulica atra $(31,000)$. These lakes and many other low-lying waterbodies are also of great limnological interest, as are several lakes in the Swiss mountains, most of which are oligotrophic and not remarkable for their waterfowl.

Numbers of diving duck wintering in Switzerland have increased since the spectacular increase of the zebra mussel Dreissena polymorpha in the Swiss lakes. The concentration areas for wintering and migrating waterfowl include shallow reservoirs in the Canton Aargau (Stausee Klingnau) and in Canton Bern (Stausee Niederried). Eutrophication of the large lakes is quite heavy and pressures of urban development and recreation activities, including boating, are increasing.

Protected Areas Legislation There is no general provision in Swiss Federal legislation covering protection of areas for nature conservation, and areas are protected by ordinanance on a case-by-case basis. The Federal Law of 1 July 1966 on Protection of Nature and Countryside forbids in a general way interference with riverine vegetation and authorisation is given to canton authorities to ensure the best protection possible or, if necessary, adequate restoration of vegetation. The new federal law of 1986 on hunting and the protection of mammals and wild birds gives authority to the federal council to delimit faunal reserves including ones for migratory birds of international and national importance. The Swiss Forest Law (1902) requires that the area of forest within the country should not diminish, but has no control over silvicultural methods. Most other protection is assured either by planning controls or by the acquisition of land by cantons, private groups or individuals for creation of reserves.

Protected Areas Administration Responsibility for nature conservation and the National Park is vested in the Department of the Interior, advised by the Federal commission for the Protection of Nature and Landscapes. The Federal Inspectorate of Forests and Landscape Conservation administers the programme and provides the Secretariat for the Commission. This pattern is repeated to some extent at a lower level in the cantons. The degree of management varies from reserve to reserve, and there is no standard approach to regulations applied in reserves. The policy in the national park is to allow the area to evolve naturally.

\section{Sites designated under the Convention}

Signature subject to ratification 21 February 1974. Finally ratified on 16 January 1976, with one site listed at ratification and one site added on 18 February 1982

Fanel Bay and le Chablais (Berne, Neuchâtel and Vaud)

Bolle di Magadino (Ticino) 
Government body responsible for administration of the Convention

Office fédéral des forêts et de la protection du paysage, Département fédéral de l'intérieur, Case postale 1987, Lapenstrasse 20, 3001 Berne

\section{Fanel Bay and le Chablais}

Location $46^{\circ} 59^{\prime} \mathrm{N}, 7^{\circ} 03^{\prime} \mathrm{E}$. The two contiguous reserves are at the north-east end of Lake Neuchâtel in north-west Switzerland, separated from one another by the canal de la Broye.

Area $1,155 \mathrm{ha}$

Degree of Protection The site is situated in the cantons of Berne (530ha), Neuchâtel (4!0ha), and Vaud (410ha) and administered by the commission responsible for monitoring and management of the cantons' reserves. The combined wetland site is included in the Inventory of Landscapes and Natural Sites of National Importance. Designated as a Ramsar site at the time of ratification on 16 January 1976.

Site Description The Ramsar site comprises 630 ha lake surface, 125 ha reedbed and marshland, 325 ha woodland and 75 ha meadows. Fanel reserve is bounded to the north by the canal de la Thielle. Le Chablais reserve extends southwards from the canal de la Broye to Cudrefin village. Lake Neuchâtel is eutrophic and maintained at a constant level. Two islands in Fanel reserve, one $120 \mathrm{~m}$ long in Berne canton and one $40 \mathrm{~m}$ long in Neuchâtel, are important nesting sites for birds and were modified to compensate for the erosion caused by changes in water level. The extensive reedbeds are fringed by deciduous woodland. The extensive marsh vegetation comprising bogrush Schoenus sp., moorgrass Molina sp., marsh helleborine Epipactis palustris and marsh gentian Gentiana pneumonanthe supports an interesting and varied insect population.

International and National Importance The site is an important breeding area for many wetland species including over 2,000 pairs of black-headed gull Larus ridibundus, 200-300 pairs of great-crested grebe Podiceps cristatus, 200 pairs of common tern Sterna hirundo and 10-20 pairs of grey heron Ardea cinerea. Garganey A. querquedula, gadwall $A$. strepera, shoveler $A$. clypeata, teal $A$. crecca, red-crested pochard Netta rufina, spotted crake Porzana porzana, little crake $P$. parva, common snipe Gallinago gallinago, herring gull Larus argentalus, Mediterranean gull $L$. melanocephalus and common gull $L$. canus all breed in small numbers and are Red-List species of Switzerland. Lapwing Vanellus vanellus, spotted redshank Tringa erythropus and ruff Philomachus pugnax also occur. The wetland is a moulting refuge for 2,000-3,000 mallard Anas platyrhynchos and 300 goosander Mergus merganser and an important resting place for many migrating waders. The site is of international importance for wintering waterfowl including up to 6,000 great-crested grebe, 2,000 mallard, 5,000 pochard Aythya ferina, 20,000 tufted duck $A$. fuligula, 100 goosander and 8,500 coot Fulica atra.

\section{Changes in Ecological Character No information}

Management Practices The canton ordinance prohibits hunting, fishing, boats and watersports on the lake area within the reserves. Under the ordinance there is also restricted access to marshland and reedbed areas, visitors must not leave the access paths during the breeding season or disturb the wildlife at any time, and dogs must be kept on leads at all times. The state councils of Fribourg and Vaud cantons approved a Management Plan in 1983 for the southern shore of Lake Neuchâtel and the shoreline of Lake Morat. This is expected to be beneficial to the already protected Fanel and Chablais bays on the northern shore of Neuchâtel.

Scientific Research and Facilities No information 
Principal Reference Material Above information was taken from the document deposited at the time of ratification (1976), and the National Report prepared for the Conference on the Conservation of Wetlands of International Importance especially as Waterfowl Habitat held in Cagliari, Italy in November 1980.

Supplemented by:

- Duffey, E. (1982). National Parks and Reserves of W'estern Europe. Macdonald and Co., London.

\section{Bolle di Magadino}

Location $46^{\circ} 10^{\prime} \mathrm{N}, 8^{\circ} 52^{\prime} \mathrm{E}$. Situated on Lake Maggiore within the communes of Gordola, Locarno, Magadino and Tenero-Contra in the republic and canton of Tessin.

\section{Area 661 ha}

Degree of Protection Established as a protected area by Canton Ordinance in 1974. The Canton de Tessin created a foundation in 1975, linked to the Confederation of the Swiss League for the Protection of Nature (LSPN) and WWF Switzerland, which is responsible for the financing and implementation of patrolling, conservation, management and maintenance of the protected area. The foundation has employed two full-time wardens for patrol and maintenance. The site is included in the Inventory of Landscapes and Natural Sites of National Importance. Designated as a Ramsar site on 18 February 1982.

Site Description The site comprises a delta area and part of the shore of Lake Maggiore, including an area of almost undisturbed virgin water edge vegetation, reedbed and forest, and a wide variety of marsh and aquatic plant associations. Some of the area is pasture with controlled grazing allowed.

International and National Importance The area is one of the few intact river deltas in Switzerland, and the only one south of the Alps. The area is particularly important for migratory birds.

Changes in Ecological Character Agricultural chemicals are used on the surrounding lands.

Management Practices The Canton Ordinance defines three management zones. Zone A comprises the lake edge and immediate delta area with absolute protection status and all access prohibited except along a few official paths. Zone $\mathrm{B}$ comprising the pastureland and other agricultural land behind Zone $\mathrm{A}$ is a utility area with controlled traditional grazing permitted. Zone $\mathrm{C}$ comprises the areas bordering Zones $\mathrm{A}$ and $\mathrm{B}$, with less restriction on access and camping and boating controlled by permits from the Department of the Environment. Agricultural practices in the site are controlled by the agricultural section of the Department of Public Economy in consultation with the Department of the Environment, and quantities of herbicide, pesticide and fertiliser used are fixed each year. A consultant commission was set up by the government to represent the organisations concerned with the site and to co-operate with the Department of the Environment on implementation of the protection ordinance. The Canton Ordinance prohibits construction of buildings or fences (unless to enclose pasture lands), excavation or dumping, introduction of plants and animals not native to the area, irresponsible fires, and release of pollutants into the environment. Under the ordinance dogs must be kept on the lead at all times.

Scientific Research and Facilities Permanent quadrats for investigation of vegetation changes were established during the 1970s. Bird observations and counts have continued for a number of years, and a ringing station was established in 1981. Since 1984 studies of the hydrology have begun, and a study on coleoptera was initiated in 1986. 
Principal Reference Material Above information is from the document deposited at the time of designation.

Additional references:

- Antonietti, Aldo (Redaz.), (1964): Le Bolle di Magadino. Società ticinese per la conservazione delle bellezze naturali e artistiche. Quaderni Ticinesi N. 7, Locarno, 43 p. + Appendice $24 \mathrm{p}$.

- Antonietti, Aldo (1964): Le Bolle di Magadino. Bollettino della Società Ticinese di Scienze Naturali 57, 11-30.

- Antonietti, Aldo (1977): Das Naturschutzgebiet der Bolle di Magadino. Schweiz. Zeitschrift für Forstwesen 128, 365-375.

- Buffi, Roberto (Redaz.), (1983): Le Bolle di Magadino. Fondazione Bolle di Magadino e Dipartimento cantonale dell'ambiente. Bellinzona, $59 \mathrm{p}$.

- Consiglio di Stato della Repubblica e Cantone del Ticino: Ordinanze per la protezione delle Bolle di Magadino (del 30 marzo 1979).

- Laboratorio Studi Ambientali (Dipartimento cantonale dell'ambiente), (1985): Studio idrobiologico delle Bolle di Magadine. Campagna 1984. Bellinzona, $1985,71+22$ p (dattiloscr.).

- Laboratorio Studi Ambientali (Dipartimento cantonale dell'ambiente), (1986): Studio idrobiologico delle Bolle di Magadine. Campagna 1985. Bellinzona, $1986,62+13$ p (dattiloscr.).

- Meyer, Martin (1981): Bolle di Magadino. Anlage und Aufnahme von Dauerquadraten. Herrliberg, Februar 1981, 67 S. (maschinengeschrieben).

- Meyer, Martin (1982): Bolle di Magadino. Rilievo dei quadrati permanenti 1982. Herrliberg, dicembre 1982, 33 p. (dattiloscr.).

- Meyer, Martin (1985): Bolle di Magadino. Rilievo dei quadrati permanenti 1985. Klosters-Dorf, dicembre 1985, 38 p. (dattiloscr.).

- Schifferli, Alfred and D'alessandri, Pietri (1986): Brutvorkommen der Wasservögel im Tessin und im Misox GR. Ornith. Beob. 1983, 159-167.

- Selldorf, Paolo (1980): Elaborazione di nuovi criteri per uno sfruttamento migliore, adattato alle condizioni particolari di un'azienda agricola del Piano di Magadino. Lavora di diploma del Politecnico federale di Zurigo, luglio 1980, 104 p. (dattiloscr.). 


\section{TUNISIA}

Area 164,148 sq.km

\section{Population $6,966,173$ (census 1984)}

Summary of Wetland Situation The Wetlands of Tunisia are of outstanding importance for huge numbers of migrating and wintering waterfowl. Numbers present in winter can increase considerably when severe cold spells affect the northern parts of the Mediterranean. Two scarce and declining species which are regularly observed on certain Tunisian wetlands (notable the Lac de Tunis and Sebkhet el Djem) are the marbled teal and the white-headed duck.

The Garaet Ichkeul to the south-west of Bizerte is comparable in importance to the Camargue in France and the Marismas del Guadalquivir in Spain. The group of wetlands in the vicinity of Tunis (Lac de Tunis, Sebkhet Ariana, Sebkhet es Sedjoumi) is also extremely rich in waterfowl. The salt lakes in several parts of the country provide favourable habitat for large numbers of flamingos Phoenicopterus ruber and, in some years, (depending on the amount of winter rainfall), they find conditions suitable for nesting in one or more of four sites, namely: Sebkhet Sidi el Hani, Chott el Fedjadj, Sebkhet el Hamma and Chot Djerid. However some of the lakes can completely dry out if the rains are poor, leaving sites which were previously thought secondary with major populations of waterbirds. Mention should also be made of the reservoirs which can support reasonable numbers of waterbirds at certain times of the year.

The Kneïs Islands, off the coast half-way between Sfax and Gabès, and the coast itself are in the only area of the Western Mediterranean which is markedly tidal and as such are of great importance as a feeding, roosting and breeding place for waders, gulls and terns.

Protected Areas Legislation There is provision for setting up National Parks under Forestry Code Law 66-60, Articles 58-60. Objectives in establishment of national parks are to protect and manage the physical and biological features, and to develop both education and the appreciation of nature with increased tourism.

Protected Areas Administration Protected areas are the responsibility of the Forestry Administration of the Ministry of Agriculture.

Sites designated under the Convention

Accession 24 November 1980, with 1 site listed at accession

Ichkeul Wetland

Government body responsible for administration of the Convention

Ministére de l'Agriculture, Direction des Forêts, 30 rue Alain Savory, Tunis

\section{Ichkeul Wetland}

Location $37^{\circ} 10^{\prime} \mathrm{N}, 9^{\circ} 40^{\prime} \mathrm{E}$. Situated on the Mateur plain, $25 \mathrm{~km}$ southwest of Bizerta and $15 \mathrm{~km}$ north of Mateur in Bizerta District.

Area 12,600 ha (comprising lake 8,900 ha in summer to 11,500 ha in winter, Djebel 1,363 ha and marshes 770ha).

Degree of Protection Classified as a National Park on 12 December 1980 by Decree 80-1608 and gazetted in the J.O.R.T. No 77. Hunting, fishing and grazing are prohibited or strictly controlled. The lake and Djebel are state property, and the marsh is privately owned. The site 
is administered by the Ministry of Agriculture (Direction des Forêts, 30 rue Alain Savary, Tunis). Approved as a Biosphere Reserve in January 1977. Inscribed as a World Heritage Site in September 1980. Designated as a Ramsar site in June 1980.

Site Description The wetland site is part of Ichkeul National Park which includes Lake Ichkeul, the largest area of fresh water in the country, marshland; and Djebel Ichkeul, an isolated massif between the marshes and lake which was an island in Roman times. The lake's level and salinity varies on an annual cycle. From October to May it is fed by six oueds but in summer the level falls and salinity increases due to high evaporation rates and inflow of water from the sea for four months via Bizerte Lake and Tindja Oued, (which makes the north-east of the lake particularly saline). The lake and marsh are underlain by Quaternary alluvium, but Djebel Ichkeul is composed of Triassic and Jurassic dolomitic limestone which has been metamorphosed to form marble, and contains many fossils. Altitude ranges from $-1.5 \mathrm{~m}$ at the lake bed to $511 \mathrm{~m}$ at the top of the Djebel. The mean monthly temperature is a minimum of $11.3^{\circ} \mathrm{C}$ in January and a maximum of $25.2^{\circ} \mathrm{C}$ in July. The annual temperature range is $0^{\circ} \mathrm{C}-48^{\circ} \mathrm{C}$. Average annual rainfall is $625 \mathrm{~mm}$ over 113 days, with only $4 \%$ falling in summer. About 300 million cubic metres of rainwater pour into the lake each year. Up to a third of the lake's area, particularly in the west, is covered with fennel-leaved pondweed Potamogeton pectinatus. The marsh vegetation is dominated by Scirpus maritimus, S. lacustris, Juncus sublatus and Zannichellia palustria. The zoning of aquatic vegetation is complex and varies from year to year, related to lake levels and salinity. Reeds Phragmites communis fringe the lake and glasswort Salicornia arabica and seablite Suaeda sp. cover the most saline areas. Higher well drained ridges are dominated by Hordeum maritimum with Lolium multiflorum and Dancus carota, or Nerium oleander and Zizyphus lotus. Ranunculus ophioglossum, recorded from only a few sites in Tunisia, also grows in the marshes. Stable populations have been reported of crested porcupine Hystrix cristata, mongoose Herpestes ichneumon, wild cat Felis sylvestris lybica and small-spotted genet Genetta genetta. Otter Lutra lutra is occasionally found on the shores of the lake and the Ichkeul water buffalo Bubalis bubalis was being reintroduced into the marshes, there being none in Tunisia at present. Main fish species are the eel Anguilla anguilla; mullets Mugil cephalus, 3M. ramada; bass Dicentrarchus labrax; barbel Barbus barbus; sole Solea solea and Twaite shad Alosa fallax. There are currently only small populations of tooth-carp Aphanius fasciatus and pipefish Sygnathus sp. Marsh frog Rana ridibunda is abundant in the lake and Clemys leprosa occurs in the marsh.

International and National Importance Ichkeul is the most important site in North Africa for wintering waterfowl, with 300,000-400,000 birds passing through. Almost the whole European population of greylag goose Anser anser (about 20,000) winter here, as do vast numbers of coot Fulica atra $(70,000$, with a maximum of 188,000). There are lesser numbers of wigeon Anas penelope $(30,000-50,000$, with a maximum of 110,000$)$, teal $A$. crecca $(11,000)$, shoveler A. clypeata (5000) and pochard Aythya ferina $(50,000-75,000$, with a maximum of 120,000). The lake may also be the most important area west of the Caspian Saea for white-headed duck Oxyura leucocephala of which over 600 (or $4 \%$ of the known world population) are resident. Many waders and herons pass through on spring and autumn migration, including great white egret Egretta alba, glossy ibis Plegadis falcinellus, black stork Ciconia nigra, greater flamingo Phoenicopterus ruber and black-winged stilt Himantopus himantopus. Nesting birds are few and prefer the Djebel, including booted eagle Hieraaetus pennatus, Bonelli's eagle $H$. fasciatus, peregrine falcon Falco peregrinus, Egyptian vulture Neophron percnopterus and the rare Moussier's redstart Phoenicurus moussieri. Ichkeul is also a breeding ground for black-crowned night heron Nycticorax nycticorax. Over 185 bird species have been recorded.

Changes in Ecological Character This region of Tunisia is one of the most important for water supply in the country. Locally, around the lake, there is pressure for land and the water to irrigate it. Dams have been built on the Djoumine and Rhezla rivers, reducing the lake's supply of fresh water and upsetting water and salinity levels. This has altered the vegetation composition; the area of Potamogeton on which many bird species feed was greatly reduced in 1986 due to high salinities; Scirpus maritimus is being replaced in many places by $A m m i$ visnaga and Scolimus maculatus. The construction of a sluice on the Oued Tindja to control seawater inflow and contain fresh water will not be an entirely satisfactory solution as it will increase summer evaporation and hence salinity in some areas, reducing the Potomageton area 
and affecting many bird species' numbers. The tenders received for the sluice in 1986 were too expensive and this might delay its construction until 1988-89. A drainage canal on the Djoumine marsh has still not been filled in, and there are plans to build a large dam on the Sedjuane river. The lake has been silting up since Roman times, partly due to over-clearance of vegetation from hillsides. Overgrazing by domestic cattle on the marshes has probably led to death by malnutrition of the reintroduced water buffalo. Some illegal ploughing of 5 ha of the marshes was recently stopped, and resettlement of some of the local population is planned. Marble quarries on the Djebel are still expanding.

Management Practices There is a buffer zone of an additional 6,000ha. There has been much research into how best to manage the lake now that dams have been built on several streams which formerly supplied fresh water. The University of London (UCL) has been contracted to investigate this and produced computer models of the water and salinity balances (Warren et al. 1970). The most urgent management objectives are the building of a sluice on the Oued Tindja and infilling of a drainage canal on the Djoumine marsh (Hollis, 1986). Other plans include possibilities of reducing the area of freshwater lake to cut down evaporation. These are related to the main objectives of controlling sediment infill of the lake and maintenance of Potamogeton and other vegetation types which are important food sources for birds. The EEC was funding a four-year management study by UCL, the International Wildfowl Research Bureau (IWRB) and French scientists from 1981-85.

Scientific Research and Facilities Studies of the biological environment of Lake Ichkeul have been made by the University of Tunis and Salambo Oceanographic Institute. Palaeontological excavations in 1947, 1948 and 1949 made it possible to study the Villafranchian (Calabrian) stratum of the lake and bring to the surface mammal fossils that are rare in North Africa. A phytoecological map of the region has been produced. Observation and censusing of waterfowl is being carried out with the collaboration of IWRB and the Tour du Valat Biological Station (France).

Principal Reference Material The above information is taken from documents submitted by the Tunisian government at the time of designation.

Supplemented by:

- Baccar, H. (1982). The role of Ichkeul national Park in conserving genetic resources. Invited paper, coastal and marine workshop, 18-20 October 1982. Produced for IUCN's Commission on National Parks and Protected Areas in cooperation with the United Nations Environment Programme.

- Carp, E. (1980). A Directory of Western Palearctic Wetlands. IUCN, Gland, Switzerland.

- Hollis, G.E. and Wood, B.J. (1982). Garaet el Ichkeul. Progress of studies to Spring 1982. EEC Contact Group on Birds, Sienna, Italy. Unpublished report.

- Hollis, E., Wood, B. and Warren, A. (1980). Rare wetlands in a National Park. Geographical Magazine 32:331-334.

- Hollis, G.E. (1986). The modelling and management of the internationally important wetland at Garaet El Ichkeul, Tunisia. Ecology and Conservation Unit, University College of London. (Lists many unpublished reports).Skinner, J. (1985). Lake in the desert. Birds 10(7): 29-33.

- Smart, M. (1974). The wetlands of North Africa and their importance to waterfowl. Bureau International de Recherche sur la Sauvagine (BIRS).

- The Conservation Course, University College of London (1977). A management plan for the proposed parc national de l'Ichkeul, Tunisia. Report Series 10. (Contains a list of birds of Ichkeul and an extensive bibliography.)

- Warren, A., Hollis, G.E., Wood, J.B., Hooper, M.D. and Fisher, R.C. (1979). Ichkeul, the problems of a wet park in a dry country. Parks 4(3): 6-10.

- Zaouali, J. (1976). Contribution à l'étude écologique du Lac Ichkeul. Institut National Scientifique et Technique d'Océanographie et de Pêche, Tunisie (INSTOP). 


\section{USSR}

Area $22,272,000$ sq. km

\section{Population $276,300,000(1985)$}

Summary of Wetland Situation The wetlands of the European part of the USSR and indeed most of those in the vast Asian sector, particularly to the west of the Mid-Siberian Plateau, provide the main breeding grounds for the majority of migrant waterfowl wintering in south-western Europe and the Mediterranean basin, south-west Asia and much of Africa. The eastern Siberian wetlands are similarly the principal station for the migrants which winter in the rest of southern Asia and, also in the case of the waders, in Australasia.

The sites were selected as characteristic of particular vegetational or climatic zones or regions. The Gulf of Kandalaksha site is characteristic of taiga, for example, Matsalu Bay of the mixed forest country, the Black Sea bays and Sivash Bay, Sea of Azov, of the steppes, the Volga delta and eastern Caspian bays of desert country, and the Kirov bays (south-west Caspian coast), of the Caucasian region. Designated sites tend to be either broad expanses of shallow water, such as the various sea bays, or integrated wetland systems, such as those of the Volga delta or north of the Danube river mouth. They comprise both salt and fresh water sites with varying diversity of flora and fauna (especially of waterfowl), high biological productivity, and a protected status which enables them to sustain populations of waterfowl at different stages in their annual life cycle. Thus the most northerly site, Kandalaksha, serves mainly as a breeding-ground; Matsalu bay on the Baltic both for breeding and as a stopover on migration; the Black Sea sites and Volga delta for nesting, moulting, as migratory staging-posts and to a limited extent for wintering; and the southernmost sites of the eastern and south-western Caspian mainly as wintering grounds, notably of two species included in the USSR Red Data Book: the greater flamingo Phoenicopterus ruber and the red-breasted goose Branta ruficollis.

Protected Areas Legislation The first Decree on 'Protection of Nature Monuments, Gardens and Parks' signed by Lenin was promulgated in 1921. The recent legislative status of State Nature Reserves (Zapovedniks) is based on three Acts of the Supreme Soviet of the USSR, 'Principles of Land Legislation of the U.S.S.R. and Union Republics' (adopted 13 December 1968), 'Principles of Water Legislation of the USSR and Union Republics' (adopted 10 December 1970) and 'On Conservarion and Use of Animal life of the USSR' (adopted 25 June 1980). In line with these Acts, the existing State regulations 'The Standard Status of the State Zapovedniks, Nature Monuments, etc.' confirmed 27 April 1981 by the GOSPLAN of the USSR and GKNT together with the relevant regulations of the Republics, have been revised. State Zapovedniks (or Nature Reserves) are defined as 'scientific institutions aimed at the protection and study of natural complexes and established on the part of the land excluded from economic utilization'.

Protected Areas Administration State Zapovedniks are under the direct (for the most important) or indirect supervision of the Department of Nature Conservation, Zapovedniks and Game Management of the USSR of the Gosagroprom of the USSR. The majority of zapovedniks are managed by Departments or Committees of Nature Conservation of the Republics, but some fall within the system supervised by the USSR Academy of Sciences. Their main objectives are: (1) protection of wildlife and its habitats, including maintenance of entire ecosystems; (2) scientific research, for which each Zapovednik has a scientific staff of about 20 to 50 specialists, additional research being undertaken by the Academy of Sciences, Universities and other institutions; and (3) recreational activities which are strictly limited, although in some cases include controlled scientific tourism. There are projects for establishing six National or Natural Parks in Latvia, Estonia, on Lake Baikal, in the Caucasus and elsewhere, mainly aimed at ecologically orientated recreation and environmental education through organised tourism, bird-watching, etc. 
Sites designated under the Convention

Signature subject to ratification 13 February 1974. Finally ratified on 11 October 1976, with 12 sites listed at ratification.

\author{
Kandalaksha Bay, White Sea (Russian SSR) \\ Matsalu Bay, Baltic Sea (Estonian SSR) \\ Volga Delta (Russian SSR) \\ Kirov Bays, Caspian Sea (Azerbaijan SSR) \\ Krasnovodsk and North-Cheleken Bays, Caspian Sea (Turkmenian SSR) \\ Sivash Bay, Sea of Azov (Ukrainian SSR) \\ Karkinitski Bay, Black Sea (Ukrainian SSR) \\ Intertidal Areas of the Dounai, and Yagorlits and Tendrov Bays (Ukrainian SSR) \\ Kourgal'dzhin and Tengiz Lakes (Kazakhstan SSR) \\ Lakes of the lower Turgay and Irgiz (Kazakhstan SSR.) \\ Issyk-kul Lake (Kirghiz SSR) \\ Lake Khanka (Maritime Basin of the Russian SSR)
}

\title{
Government body responsible for administration of the Convention
}

Department of Nature Conservation, Nature Reserves and Game Management, Gosagroprom of the USSR, Orlikov per. 1/11, Moscow, 107139.

\section{Kandalaksha Bay}

Location $66^{\circ} 45^{\prime}-67^{\circ} 08^{\prime} \mathrm{N}, 32^{\circ} 31^{\prime}-34^{\circ} 05^{\prime} \mathrm{E}$. The north-west end of Kandalaksha Bay on the White Sea including the offshore islands. $2 \mathrm{~km}$ south of Kandalaksha in the district of Murmansk, Russian SSR.

Area $208,000 \mathrm{ha}$, comprising 191,100 flooded and 16,900 dry land.

Degree of Protection The site is state owned and administered by the Main Department of Game Management and Zapovedniks by the RSFSR Council of Ministers. The designated wetland area contains three zones: an island archipelago and adjoining mainland coasts which are part of Kandalaksha Zapovednik $(30,900 \mathrm{ha})$ established in 1932 as a strict nature reserve with complete protection and all activities including tourism prohibited; the zakaznik $(21,000 \mathrm{ha})$ in which all hunting is prohibited and exploitation of natural resources is controlled to conserve the wetland as a wildfowl habitat; and an exploitation zone $(113,000 \mathrm{ha})$ in which all economic activity is controlled. Designated as a Ramsar site at the time of ratification on 11 October 1976.

Site Description The site is an $180 \mathrm{~km}$ stretch at the head of Kandalaksha Bay, up to $50-60 \mathrm{~km}$ wide. The terrain is a glacial landscape with outcrops of crystalline rocks of the Basaltic Shield and podsolic soils. The coastal vegetation is predominantly taiga consisting of coniferous forest of Scots pine Pinus sylvestris, spruce Picea abies and birch Betula sp. There are over 860 islands in the bay composed of sedimentary rock, chains of glacial erratics or rocky outcrops. The shore is mainly pebble and sand, and rarely exceeds $100 \mathrm{~m}$ in width. It is rich in invertebrates (a food source for birds) including molluscs (mussels and winkles Littorina sp.), barnacles Balanus spp. and lugworm Arenicola maritima. Eel grass Zostera spp. grows on the sandy alluvial soil and algae such as Fucus spp. on the intertidal rocks. The mean monthly temperature is $-10^{\circ} \mathrm{C}$ in January and $13-14^{\circ} \mathrm{C}$ in July. Mean annual rainfall is $400-500 \mathrm{~mm}$.

International and National Importance This site is particularly important as a nesting site with 16-17,000 breeding pairs including eider Somateria mollissima (2,000-9,500 pairs), red-breasted merganser Mergus serrator, herring gull Larus argentatus, common gull $L$. canus, Arctic tern Sterna paradisaea, oystercatcher Haematopus ostralegus and white-tailed eagle Haliaeetus albicilla (10 pairs). It is a moulting site for eider, white-winged scoter Melanitta fusca and black scoter $M$. niger. 
Management Practices controlled.

Scientific Research and Facilities Studies concern biology of eider, seabird colonies and other components of the ecosystem. There are equipped laboratories in Kandalaksha Zapovednik and Belomorskaya Biological Station belonging to Moscow State University.

Principal Reference Material The above information was taken from the USSR National Report prepared for the Conference on the Conservation of Wetlands of International Importance especially as Waterfowl Habitat held in Cagliari, Italy in November 1980. Supplemented by:

- Biank, V. (1978). Kandalaksha Bay. Okhota i okhotn. Khozyaistvo No.12, pp. 24-25.

- Carp, E. (1980). A Directory of Western Palearctic Wetlands. IUCN, Gland, Switzerland.

- Karpovitch, V. and Kester, B. (1970). Resources of eider on the Murman and White Sea. Proc. Internat. Regional Meeting Conserv. Wildfowl Resources. Leningrad, USSR. Pp.58-59.

- Proceedings of the Kandalaksha State Nature Reserve Vol 1-9 (1960-1977).

\section{Matsalu Bay}

Location $58^{\circ} 40^{\prime}-58^{\circ} 54^{\prime} \mathrm{N}, 23^{\circ} 20^{\prime}-23^{\circ} 24^{\prime} \mathrm{E}$. Situated on the eastern Baltic shore in the north-west of the Estonian SSR, $25 \mathrm{~km}$ south of the Kazari River mouth and $90 \mathrm{~km}$ south-west of Tallinn.

Area $48,634 \mathrm{ha}$, including $26,272 \mathrm{ha}$ water.

Degree of Protection The site is state owned and administered by the Ministry of Forestry and Nature conservation of the Estonian SSR. The Ramsar site comprises Matsalu Zapovednik (36,697ha) established in 1957 with full protection; and a protected zone of $8,937 \mathrm{ha}$ managed by the Matsula Zapovednik administration where hunting is prohibited, fishing is controlled and use of natural resources is managed in accordance with wetland and waterfowl conservation. Designated as a Ramsar site on 11 October 1976.

Site Description The wetland comprises the shallow Matsula Bay enclosed on the seaward side by an archipelago of large rocky islands (including Saare Maa and Hiiu Maa); small shingly islands and spits in the western saline part of the bay; and the delta and floodlands of the River Kazari in the east. On the shores of the straits of Matsulu (only slightly above sea level) watermeadows $(4,000 \mathrm{ha})$ of sedges (Cyperaceae), marsh cinquefoil Potentila palustris and red rattle Sedicularis palustris, and floodplain marshes with reedbeds of Phagmites communis, Typha latifolia, T. angustifolia and bulrush Scirpus lacustris predominate. Rocky marine coastline in the west supports only patchy short herbaceous vegetation. The freshwater fen areas comprise flowering rush Butomus umbrellatus, cornmint Mentha arvensis, loosestrifes Lythrym salicaria and Naumbergia thyrsiflora, spearwort Ranunculus lingua and many Orchidaceae. The freshwater floating aquatic vegetation is dominated by white waterlily Nymphaea alba and yellow waterlily Nuphar lutea, frogbits (Hydrocharitaceae) and butterworts (Lentibulariaceae). Coastal marine vegetation includes eelgrass Zostera marina. Other vegetation types include coastal pastures, inland hay meadows and woodlands. 44 mammal species, 255 bird species and 30 fish species have been recorded in the reserve area. There is a rich invertebrate fauna which is a major food source for the waterfowl population.

International and National Importance This site is important for breeding, migrating and moulting wildfowl. 40,000-45,000 birds nest in the area including mute swan Cygnus olor (30-40 pairs), greylag goose Anser anser (250-300 pairs), eider Somateria mollissima (1,400 pairs), tufted duck Aythya fuligula (over 400 pairs), common merganser Mergus merganser (100-120 pairs), white-winged scoter Melanitta fusca (100-125), coot Fulica atra (1,000-1,500 pairs), black-headed gull Larus ridibundus (12,500 pairs), common gull L. canus (2,500 pairs), Caspian tern Sterna caspia (100-200 pairs), great crested grebe Podiceps cristatus, red-necked 
grebe $P$. grisegena, gadwall Anas strepera, goldeneye Bucephala clangula, marsh harrier Circus aeruginosus, lanceolate warbler Locustella lanceolata, reed warbler Acrocephalus scirpaceus and white-tailed eagle Haliaetus albicilla. About 950,000 birds stopover at the wetland during their spring migration including numerous whooper swan Cygnus cygnus, Bewick swan C. columbianus bewickii, barnacle goose Branta leucopsis (about 80,000) and ruff Philomachus pugnax (75,000-100,000). The site is a moulting refuge in summer for mallard Anas platyrhynchos $(17,000)$ and common pochard Aythya ferina. Other birds include pintail Anas acuta, scaup Aythya sp., red-breasted merganser Mergus serrator, Arctic tern Sterna arctica and bittern Ixobrychus sp.

Changes in Ecological Character This unique Baltic area of combined woodland and meadows has been formed by prolonged human activity.

Management Practices The authorities have implemented measures to conserve the natural wetland complex and reduce interference.

Scientific Research and Facilities The area has been extensively studied by ornithologists, botanists, hydrologists and ichthyologists from the Estonian Academy of Sciences. About 100,000 birds are ringed annually with the help of amateur volunteers. The reserve contains equipped laboratories and a museum with natural history study collections. Boats are available for scientific work. The majority of the annual 5,000 visitors to the reserve are scientists and ornithologists.

Principal Reference Material The above information was taken from the USSR National Report prepared for the Conference on the Conservation of Wetlands of International Importance especially as Waterfowl Habitat held in Cagliari, Italy in November 1980. Supplemented by:

Anon (1968). Bird life in Matsaly Bay. Valgus, Tallinn. 58pp.

Carp, E. (1980). A Directory of Western Palearctic Wetlands. IUCN, Gland, Switzerland.

- Kumari, E.V. (1970). Changes in the bird fauna of Matsalu Bay during the last 100 years. Ornis Fennica 47(2): 45-51.

- Kumari, E.V., Mihelson, H.A. and Ivanauskas, T.L. (1970). Wildfowl in Soviet Baltic Region. Proc. Internat. Regional Meeting Conserv. Wildfowl Resources. Leningrad, USSR.

- Loodusevaatlusi (Nature observtions - Proceeding of the Matsalu Reserve) 1978-1981. Valgus, Tallinn.

\section{Volga Delta}

Location $45^{\circ} 24^{\prime}-46^{\circ} 24^{\prime} \mathrm{N}, 47^{\circ} 46^{\prime}-49^{\circ} 20^{\prime} \mathrm{E}$. Situated in the northern part of the Caspian Sea in Astrakhan District of Russian SSR. Near Kazakhstan SSR in the east.

Area 650,000 ha

Degree of Protection The site is state owned and administered by the Gosagroprom of the USSR (Astrakhan Zapovednik) and by the Main Department of Game Management and Zapovedniks by the RSFSR Council of Ministers. It contains Astrakhan Zapovednik $(62,400 \mathrm{ha})$ established in 1919 with total protection; a zakaznik $(155,300 \mathrm{ha})$ in which hunting is controlled; a General Protection Zone in which exploitation of natural resources is strictly controlled in accordance with wetland conservation; and a buffer zone $(31,000 \mathrm{ha})$ in which hunting is prohibited, fishing is controlled and boat or vehicle movement is restricted and under ranger supervision. Designated as a Ramsar site on 11 October 1976.

Site Description The wetland is a typical river delta on the northern coastal region of the Caspian sea, and comprises flat alluvial islands separated by a complex network of shallow distributary channels emptying into the fore-delta. The humid climate and high salinity of the delta water create exceptionally favourable conditions for aquatic vegetation and wildfowl. The vegetation types are a mosaic determined by waterflow, spring and autumn floods, topography and plant succession sequences. The natural zones include dense patches 
of Vallisneria spiralis, reedswamps of Phragmites communis and Typha angustifolia; willow Salix triandra forest areas along the lower reaches of the delta; salt meadows (declining in waters deeper than 1.5-2m); and bur reed Sparganium spp. predominant beyond the furthest alluvial islands of the submerged delta region. Other aquatic species along the branches of the river include water lettuce Salvinia natans, Najas marina and $N$. minor, white waterlily Nymphaea alba, pondweeds Potamogeton perfoliatus and $P$. pectinatus, liquorice plant Glycyrrhiza glabra and water chestnut Trapa natans. The large fish population includes pike, carp, catfish, perch and zander (Esox lucius, Cyprinus carpoi, Silvris glanis, Perca fluviatilis and Stizostedion lucioperca). Mean temperature in January $-6^{\circ} \mathrm{C}$ and in July $24^{\circ} \mathrm{C}$. 100 days per year have temperatures below $0^{\circ} \mathrm{C}$. Mean annual precipitation is $200 \mathrm{~mm}$. The area is characterised by prolonged periods of flooding.

International and National Importance The delta is important for breeding, migrating and moulting waterfowl due to a high carrying capacity (feeding/nesting resources) and its location on the migration route from European USSR, western Siberia and Kazakhstan. About 230,000 pairs breed on the islands and delta lowlands, including 180,000 pairs of Anatidae such as mute swan Cygnus olor (4,500 pairs), greylag goose Anser anser (14,000 pairs), coot Fulica atra (150,000 pairs) and red-crested pochard Netta rufina (5,000 pairs); and waders such as common cormorant Phalacrocorax carbo (30,000 pairs), the threatened Dalmatian pelican Pelecanus crispus (160 pairs), grey heron Ardea cinerea (2,000-2,800 pairs), purple heron $A$. purpurea (2,500 pairs), great white egret Egretta alba (4,500 pairs), little egret E. garzetta (3,500 pairs), squacco heron Ardeola ralloides (4,000 pairs), night heron Nycticorax nycticorax (4,000-4,200 pairs), spoonbill Platalea leucorodia (1,000-1,200 pairs) and glossy ibis Plegadis falcinellus (4,000-4,500 pairs). About 150 pairs of white-tailed eagles Haliaeetus albicilla are breeding here. During spring and autumn migration an estimated 5-7 million birds stopover at the delta taking advantage of the abundant food resources. These include whooper swan Cygnus cygnus, mallard Anas platyrhynchos, tufted duck Aythya fuligula, white-eyed pochard $A$. nyroca, gadwall Anas strepera, teal $A$. crecca and pintail $A$. acuta. The shallow fore-delta (up to $1 \mathrm{~m}$ deep) is a moulting site for 300,000-350,000 ducks including gadwall, teal, mallard, pintail and garganay $A$. querquedula. During warm winters up to 46,500 swans and 49,000 ducks stay here. Mammals in Astrakhan Zapovednik include wolf Canis lupus, fox Vulpes vulpes and wild pig Sus scrofa. The wetland also contains the endemic lotus Nelumbo nucifera, which is protected.

Changes in Ecological Character The water regime of the delta is influenced by large hydrotechnical installations in the Volga River and by land reclamation schemes, and there is some drainage from spring burning of reed vegetation. Some uncontrolled hunting.

Management Practices Navigation is restricted to the sea channel in the western part of the delta. Fishing is restricted to defined channels.

Scientific Research and Facilities Regular studies have been carried out since 1930 by research staff of the Astrakhan Zapovednik and since 1960 by the Caspian Ornithological Station. Research includes local zoogeography and fisheries science.

Principal Reference Material The above information was taken from the USSR National Report prepared for the Conference on the Conservation of Wetlands of International Importance especially as Waterfowl Habitat held in Cagliari, Italy in November 1980. Supplemented by:

- Anon (1977). Waterfowl resources of the Caspian Sea coast and adjacent areas (protection, use and study). Astrakhan. $151 \mathrm{pp}$.

- Carp, E. (1980). A Directory of Western Palearctic Wetlands. IUCN, Gland, Switzerland.

- Krivonosov, G. (1970). The Volga Delta as a Wildfowl Hunt. Proc. Internat. Regional Meeting Conserv. Wild fowl Resources. Leningrad, USSR. Pp. 70-72.

- Krivonosov, G. (1978). Project MAR and Volga Delta. Okhota $i$ okhotn. Khozyaistvo. No.11, pp. 16-18.

- Proceedings of the Astrakahn State Reserve. Vol.1-13 (1939-1970). 


\section{Kirov Bays}

Location $38^{\circ} 53^{\prime}-39^{\circ} 18^{\prime} \mathrm{N}, 48^{\circ} 40^{\circ}-49^{\circ} 15^{\prime} \mathrm{E}$. Situated on the south-west Caspian coast about $133 \mathrm{~km}$ south-south-west of Baku in Lenkoran, Masally and Neftechala Districts, Azerbaijan SSR.

Area $132,500 \mathrm{ha}$, including $55,700 \mathrm{ha}$ water.

Degree of Protection The site is state owned and administered by the Gosagroprom of the USSR (Kyzyl-Agach Zapovednik) and by the Ministry of Forestry of Azerbaijan SSR. It contains Kyzyl-Agach Zapovednik (88,400ha) established in 1929 with full protection; and Malyi Kyzyl-Agach Zakaznik (10,700ha) in which hunting is prohibited, commercial fishing is controlled and exploitation of natural resources is strictly controlled in accordance with wetland conservation. The remaining area has general protection status. Designated as a Ramsar site on 11 October 1976.

Site Description This coastal area is made up of bays, spits, alluvial deposits, a system of floodlands and lagoons, and marine terraces (evidence of a recent fall in sea level). The local hydrological regime is dependant on the water level of the Caspian Sea, the flow of water into the bay, and water consumption by local agriculture and rainfall. Water salinity is variable and highly seasonal due to the variable inflow of freshwater. The narrow Sara Peninsula divides the larger bay from the shallow small bay (average depth $1 \mathrm{~m}$ ) except for an impermanent channel, and the small bay is linked to the Caspian Sea by two impermanent channels. Soils are mainly saline or Sierozem. The waterbodies are shallow, eutrophic, and rich in surface macrophytes and submerged aquatic vegetation. Main vegetation types are reedbeds of Phragmites communis along the shore; floating macrophytes such as pondweeds Potamogeton pectinatus, $P$. crispus, Ceratophyllum sp., Myriophyllum sp., water chestnut Trapa natans, water lettuce Salvinia natans and Lemna sp.; and submerged vegetation of eelgrass Zostera sp. in the deeper water $(2.5 \mathrm{~m})$. The terrestrial vegetation in the zapovednik ranges from semi-desert of wormwood Artemisia fragrans and glasswort Salsola dendroides to thickets of thorny scrub with Rubus spp. Mammals include the Asiatic jackal Canis aureus, jungle cat Felis chaus and wild pig Sus scrofa. Mean temperature in January is $1-2^{\circ} \mathrm{C}$ and July $25^{\circ} \mathrm{C}$. Mean annual precipitation is $200-300 \mathrm{~mm}$.

International and National Importance The coastal fringes and shallow bays are wintering grounds for some 300,000-400,000 waterfowl including swans Cygnus spp. (5,000); Anatidae: geese $(38,000)$ and ducks $(550,000)$; storks Ciconiidae $(20,000-24,000)$; coot Fulica atra and two species listed in the USSR Red Data Book: greater flamingo Phoenicopterus ruber and red-breasted goose Branta ruficollis. Nesting species of 20,000-24,000 pairs include squacco heron Ardeola ralloides (8,000-9,600 pairs), night heron Nycticorax nycticorax $(6,000-7,000$ pairs), little egret Egretta garzetta (1,000-4,800 pairs), cattle egret Bubulcus ibis, glossy ibis Plegadis falcinellus (900 pairs), pygmy cormorant Phalacrocorax pygmaeus $(1,400-2,000$ pairs), purple swamphen Porphyrio porphyrio (up to 500 pairs) and greater flamingo (up to 100 pairs).

Changes in Ecological Character The general level of the Caspian Sea is falling due to the use of river water for irrigation, and to fluctuations in local water levels due to irregular discharge or withdrawal of water by fish breeding enterprises. Some poaching occurs.

Management Practices Commercial fishing in the smalle bay is controlled. There are fish breeding and spawning installations. Measures are being taken by Azerbaijan SSR to improve the condition of the wetland.

Scientific Research and Facilities Research has been carried out on a regular basis since the 1950 s by staff of the zapovednik.

Principal Reference Material The above information was taken from the USSR National Report prepared for the Conference on the Conservation of Wetlands of International Importance especially as Waterfowl Habitat held in Cagliari, Italy in November 1980. 
Supplemented by:

- Anon (1968; 1972). Waterfowl Resources of the USSR; their reproduction and use. Moscow.

- Anon (1977). Waterfowl resources of the Caspian Sea coast and adjacent areas (protection, use and study). Astrakhan.

- Carp, E. (1980). A Directory of Western Palearctic Wetlands. IUCN, Gland, Switzerland.

- Proceedings of the Kyzyl-Agach State Reserve. Vol.1 (1979), Baku, 253pp.

\section{Krasnovodsk and North-Cheleken Bays}

Location $39^{\circ} 37^{\prime}-40^{\circ} 01^{\prime} \mathrm{N}, 53^{\circ} 00^{\prime}-20^{\prime} \mathrm{E}$. Situated south-east of Krasnovodsk, the main port at the southern end of the east coast of the Caspian Sea in the Turkmenian SSR.

Area 188,700 ha, including 157,800 ha water.

Degree of Protection The site is state owned and administered by the Gosagroprom of the USSR. The designated site is surrounded by the Krasnovodsk Zapovednik 192,300ha established in 1968 in which all hunting, economic exploitation and tourism is prohibited. This total protection status also applies to the wetland site. Designated as a Ramsar site on 11 October 1976.

Site Description The site comprises extensive shallow saltwater bays (average depth $2-2.5 \mathrm{~m}$ ) bordered by a vast desert zone of aeolian sand dunes and plains extending to the east. The saline to brackish waters of the two bays are separated from the Caspian Sea by the low, sandy Krasnovodsk and North Cheleken Islands, and a chain of smaller islands. Most of the coastal area lies below sea level. Soils vary from saline to heavy clay or sandy loam. The local hydrological regime is determined by the level of the Caspian Sea and the strength of prevailing winds. The productive bay waters support a rich submerged and aquatic vegetation of Charophyta, Potamogeton, Ruppia and Zostera species, and a rich zoobenthos of molluscs, crustacea and marine worms which provides a foodsource for waterfowl. The shoreline vegetation types are a mosaic dependent on salt tolerance and capacity to withstand the strong drying winds and soil erosion. It is characteristically composed of an arid scrub vegetation of desert ephemerals, interspersed along the shoreline with reedbeds of Typha spp. and Phragmites communis with halophytes such as saltwort Salsola incanescens on more saline soils. The watermeadow and floating aquatic vegetation includes meadowgrass Poa bulbosa, water chestnut Trapa natans, Alhagi pseudoalhagi, milkvetch Astragalus sp., Tamarix sp. and the monotypic genera Halocnemum strobilaceum and Halostachys caspica. Mammals in the area include wolf Canis lupus (V), crested porcupine Hystrix cristata, hare Lepus talai, jackal Canis aureus, fox Vulpes vulpes, honey badger Mellivora indica, wild pig Sus scrofa and goitred gazelle Gazella subgutturosa. Mean temperature in January is $4^{\circ} \mathrm{C}$ and July $28^{\circ} \mathrm{C}$ with $240-260$ frost-free days. Mean annual precipitation is $100-200 \mathrm{~mm}$.

International and National Importance This wetland is the most important site in the eastern Caspian region for waterfowl during spring and autumn migrations and for overwintering. Up to one million ducks (Anatidae) pass through the area on migration. Between a half million and two million birds overwinter including coot Fulica atra $(220,000)$, common pochard Aythya ferina, tufted duck $A$. fuligula $(10,000)$, red-crested pochard Netta rufina, mallard Anas platyrhynchos, pintail $A$. acuta, teal $A$. crecca, marbled teal A. angustirostris, goldeneye Bucephala clangula, white-headed duck Oxyura leucocephala, whooper swan Cygnus cygnus, mute swan C. olor, greylag goose Anser anser, grey heron Ardea cinerea and the largest wintering population in the USSR of greater flamingo Phoenicopterus ruber (up to 18,000). White-tailed eagle Haliaeetus albicilla is also recorded from this area.

Changes in Ecological Character During recent years the Caspian sea level has risen, which has caused changes in the aquatics of the wetland.

Management Practices In the late 1970s/early 1980s a series of measures were implemented as part of the Turkmenian policy of improved conservation in the Caspian Sea area to improve the habitat conditions for birds. 
Scientific Research and Facilities Studies of the complex shallow water ecosystems and adjacent desert regions; research on wintering waterfowl including greater flamingo, ducks and coot; and an annual bird census conducted in cooperation with the Caspian Ornithological Station. Equipped laboratories and transport are available in the zapovednik.

Principal Reference Material The above information was taken from the USSR National Report prepared for the Conference on the Conservation of Wetlands of International Importance especially as Waterfowl Habitat held in Cagliari, Italy in November 1980. Supplemented by:

- Anon (1977). Waterfowl resources of the Caspian Sea coast and adjacent areas (protection, use and study). Astrakhan.

- Skokova, N.N., Vinokurov, A.A. (1982). Recent status and conservation perspectives for overwintering waterfowl in south-eastern coast of the Caspian Sea. Reports Mosc. ob-va ispyt. prirody. zool. and botan., 1980, Moscow. Pp.13-16.

\section{Sivash Bay}

Location $46^{\circ} 09^{\prime}-46^{\circ} 12^{\prime} \mathrm{N}, 34^{\circ} 21^{\prime}-34^{\circ} 50^{\prime} \mathrm{E}$. Situated between Genishesk and the north-east coast of the Crimea Peninsula on the Sea of Azov, Kherson District, Ukranian SSR.

\section{Area 45,700 ha including 22,400 ha water}

Degree of Protection The site is state owned and administered by the Gosagroprom of the Ukranian SSR. The Ramsar site comprises the Azavo-Sivashskiy Zakoznik, with strictly controlled hunting. Designated as a Ramsar site on 11 October 1976.

Site Description The bay is largely isolated from the Sea of Azov by the Arabatskaya Strelka. The shallow saltwater bay (up to $3 \mathrm{~m}$ depth) has an indented shoreline and contains several spits and islands, some originally part of the mainland. The water level fluctuates according to the prevailing wind which exposes the shallows. These shallows become subject to intense evaporation in summer, followed by wind erosion. The generally flat and windswept coastal area is covered with a halophytic sward. The site includes two alluvial islands on which desert/halophytic steppe scrub and halophilous meadow vegetation predominate. The high salinity of the water confines the aquatic flora and fauna to salt tolerant species. Their high productivity under the eutrophic conditions forms a valuable foodsource for birds.

International and National Importance This wetland is of great importance to nesting, moulting and migrating birds. Numerous ducks (Anatidae) and waders (Charadriiformes) migrate through the area including shelduck Tadorna tadorna $(2-10,000)$ and ruff Philomachus pugnax. There are 17,000 nesting birds of 20 species including shelduck, greater black-backed gull Larus ichthyaetus, Mediterranean gull L. melanocephalus, herring gull L. argentatus, sandwich tern Sterna sandvicensis, little tern $S$. albifrons and Caspian tern S. caspia. It is one of the principal moulting sites in the USSR for mute swan Cygnus olor $(3,000-4,000)$ and shelduck $(2,000-3,000)$.

\section{Changes in Ecological Character None reported (1980).}

Management Practices The number of wardens in the hunting reserve has been increased and the site is being actively managed.

Scientific Research and Facilities Mid-winter counts of waterfowl have been carried out periodically since the 1960 s but there has been no systematic research programme.

Principal Reference Material The above information was taken from the USSR National Report prepared for the Conference on the Conservation of Wetlands of International Importance especially as Waterfowl Habitat held in Cagliari, Italy in November 1980. 
Supplemented by:

Carp, E. (1980). A Directory of Western Palearctic Wetlands. IUCN, Gland, Switzerland.

Sabinevskiy, B.V. and Sevastjanov, V.I. (1975). Distribution of waterfowl on the northwestern coast of the sea of Azov in Sivash and in Karkinitskiy and Dzarilgachskiy Bays of the Black Sea in January 1975. Transactions of the All-Union Conference on Bird Migration Part 1. Moscow.

\section{Karkinitski Bay}

Location $45^{\circ} 50^{\circ}-45^{\circ} 46^{\circ} \mathrm{N}, 33^{\circ} 22^{\prime}-33^{\circ} 47^{\circ} \mathrm{E}$. Situated in the north-west of the Crimea Peninsula opposite Sivash Bay wetland, in the Crimean District of the Ukranian SSR.

Area 37,300 ha

Degree of Protection The site is state owned and administered for the Gosagroprom of the Ukranian SSR. It contains the Karkinitski Zakaznik and a protected section of the Crimean (Krimskoye) zakaznik established in 1957, in which economic exploitation and recreational activities are prohibited. In the remaining area of the site, commercial fishing is regulated and recreational activities restricted to the seashore. Designated as a Ramsar site at the time of ratification on 11 October 1976.

Site Description Most of the site area comprises water less than $8 \mathrm{~m}$ deep to the north of the islands, and there is an extensive shallow coastal area $(0.8-1 \mathrm{~m})$. The coastline is indented with a number of small bays and several sand spits and islands within the main saltwater Karkinitski Bay including the Lebiaji Islands $100 \mathrm{ha}$ (of great ecological interest). Several small islands are formed by shellfish colonies. The hinterland is mountainous. The vegetation is typical of the steppe zone bordering the Black Sea. Coastal vegetation in the bay is predominantly reedbeds of Phragmites communis with halophytes and grasses on the salty soil. There are vast watermeadows of aquatic plants such as stoneworts Charophyta spp. and eelgrass Zostera marina, with a rich zoobenthos. The vegetation of the islands consists of halophytes, steppe vegetation and reeds.

International and National Importance The bay is important for waterfow'l in all seasons including up to 100,000 ducks (Anatidae) and waders (Charadriiformes) which pass through the area on their spring and autumn migrations. Spring flocks are dominated by whooper swan Cygnus cygnus, mute swan C. olor, greylag goose Anser anser and white-fronted goose A. albifrons. Autumn flocks are dominated by ruff Philomachus pugnax and sandpipers Calidris spp. The islands in the bay are the site of large seabird breeding colonies including herring gull Larus argentatus $(65,000-68,000$ pairs), Mediterranean gull L. melanocephalus (4,000-5,000 pairs), gull-billed tern Sterna nilotica (8,000-9,000 pairs), Caspian tern $S$. caspia (200-400 pairs), common tern $S$. hirundo (200-300 pairs), shelduck Tadorna tadorna (50 pairs) and red-breasted merganser Mergus serrator (50 pairs). There are specially protected colonies along the shore of little egret Egretta garzetta (50 pairs), great white egret $E$. alba (50 pairs), grey heron Ardea cinerea (100-150 pairs), squacco heron Ardeola ralloides (60 pairs) and glossy ibis Plegadis falcinellus. The bay is one of the most important summer moulting grounds for non-breeding mute swan Cygnus olor $(3-5,000)$. Over 50,000 birds winter in the area including whooper swan, sea ducks, freshwater ducks, coot Fulica atra and gulls.

\section{Changes in Ecological Character None reported (1980).}

Management Practices There are bird ringing and census programmes.

Scientific Research and Facilities Systematic studies are carried out by the research staff of the zakaznik. There are annual counts of moulting mute swan and shelduck. Hydrobiological investigations have been conducted in the Bay. The reserve participates in the international programme for colour-marking certain species of wild swan. 
Principal Reference Material The above information was taken from the USSR National Report prepared for the Conference on the Conservation of Wetlands of International Importance especially as Waterfowl Habitat held in Cagliari, Italy in November 1980. Supplemented by:

- Ardamatskaya, T.B. (1970). Wildfowl of the Ukranian Black Sea Coastal Region. Proc. Internat. Regional Meeting Conserv. Wild fowl Resources. Leningrad. Pp.67-69.

- Carp, E. (1980). A Directory of Western Palearctic Wetlands. IUCN, Gland, Switzerland.

- Kostin, Yu.V. (1961). Materials on ornithofauna of Lebiaji Islands and adjoining areas. Sbornik rabot po lesovodstvu i okhotovedeniyu, Vol.6, Simferopol. Pp.87-115.

\section{Intertidal Areas of the Dounai, and Yagorlits and Tendrov Bays.}

Location The designated wetland comprises separated areas. Dounai $45^{\circ} 25^{\prime}-45^{\circ} 30^{\prime} \mathrm{N}$, $29^{\circ} 32^{\prime}-29^{\circ} 40^{\prime} \mathrm{E}, 150 \mathrm{~km}$ south-west of Odessa near the Romanian border in Odessa District, and Yagorlits and Tendrov Bays $46^{\circ} 07^{\prime}-46^{\circ} 30^{\prime} \mathrm{N}, 31^{\circ} 49^{\prime}-32^{\circ} 22^{\prime} \mathrm{E}, 50-60 \mathrm{~km}$ south-west of Kherson and east of Odessa in Nikolayev and Kherson Districts. Both areas are situated in the Ukranian SSR.

Area 128,051ha (enlarged from 121,000ha in 1978): Dounai 14,851ha and Yagorlits and Tendrov Bays 113,200ha.

Degree of Protection The site is state owned and administered by the Gosagroprom of the Ukranian SSR and the Ukraine Academy of Science. The site contains (i)Dounaiskie plavni Zapovednik (14,851 ha) established in 1981 and (ii) Chernomorski Zapovednik $(50,000 \mathrm{ha})$ on the Black Sea coast established in 1927 with total protection and all exploitation and recreational activities prohibited; and Yagorlits Ornithological Refuge (30,300ha) in which all hunting is prohibited. The remaining area is under general protection, with exploitation of natural resources restricted. Designated as a Ramsar site at the time of ratification on 11 October 1976.

Site Description The Dounai (Danube) intertidal area is situated along the Black Sea near the main Dounai river mouth. This wetland area (including 4,600 ha water) comprises channels, alluvial islands, freshwater lakes and low sandy spits which enclose bays on the seaward side of the delta. The estuarine islands support lake and marsh vegetation composed mainly of reedbeds of Phragmites communis, Typha spp. and sedges Carex spp., with thickets of Salix sp. in drier areas. The waters are rich in aquatic and submerged vegetation with extensive Vallisneria spiralis stands, sea lettuce Salvinia natans, water chestnut Trapa natans and hornwort Ceratophyllaceae; zoo- and phyto-plankton; and fish. Dune and salt-tolerant plants grow on the sandy soils which are extending by acretion into the sea.

Yagorlits and Tendrov Bays: two extensive shallow saltwater lagoons (up to $6 \mathrm{~m}$ depth) separated from the Black Sea by narrow sandy spits and small islands. The vegetation of the low coast and islands is characterised by brackish and saltwater associations with a predominance of saltwort Salsola soda and marshgrass Puccinellia sp. On the steep sloping island shores kelp lies among sparse reedbeds of Phragmies communis. Behind the shore there is usually a strip of brackish marsh. Shallow water vegetation is characterised by large meadows of eelgrass Zostera sp. with tassel pondweed Ruppia spiralis and stoneworts Charophyta. The waters also support abundant benthos and fish including the small genus Cottus.

International and National Importance The wetland area is important for migrating, breeding, moulting and overwintering birds dependent on shallow waters. Spring and autumn migrants number several 100,000 including 20,000-30,000 geese including white-breasted goose Anser albifrons, greylag goose $A$. anser and red-breasted goose Branta ruficollis. Other birds include shelduck Tadorna tadorna, mallard Anas platyrhynchos, pintail A. acuta, tufted duck Aythya fuligula, greater scaup $A$. marila, red-crested pochard Netta rufina, mute swan Cygnus olor and whooper swan C. cygnus, ruff Philomachus pugnax, redshank Tringa totanus, black-tailed godwit Limosa limosa, Eurasian curlew Numenius arquata, 
whimbrel $N$. phaeopus, avocet Recurvirostra avosetta, black-winged stilt Himantopus himantopus, oystercatcher Haematopus ostralegus, woodcock Scolopax rusticola, snipe Gallinago gallinago, sandpipers Calidris spp. and divers Gavia spp. 200,000-350,000 pairs of gulls (Laridae), ducks (Anatidae) and sandpipers breed in the wetlands including Mediterranean gull Larus melanocephalus, slender-billed gull L. genei, sandwich tern Sterna sandvicensis, red-breasted merganser Mergus serrator, gadwall Anas strepera, white-eyed pochard Aythya nyroca, coot Fulica atra, shelduck, mallard, mute swan, redshank, avocet and a colony of herons including grey heron Ardea cinerea, great egret Egretta alba, little egret E. garzetta, glossy ibis Plegadis falcinellus and night heron Nycticorax nycticorax. White pelican Pelecanus onocrotalus, spoonbill Platalea leucorodia and the threatened Dalmatian pelican Pelecanus crispus nest on the Dounai tidal flats. The wetlands are a major moulting site for mute swan Cygnus olor (7-8,000). Overwintering birds include mute swan, greylag goose, red-breasted goose, mallard, whooper swan, Eurasian curlew, white-eyed pochard, coot, wigeon Anas penelope, teal $A$. crecca and pochard Aythya ferina.

Changes in Ecological Character None reported (1980).

Management Practices Reserve exploitation is controlled in accordance with the conservation requirements of the wetlands.

Scientific Research and Facilities The research staff of the reserve have been studying the area for many years. There are regular counts of wintering and nesting birds. The reserve participates in the international programme for colour marking of swans to study their distribution and movements.

Principal Reference Material The above information was taken from the USSR National Report prepared for the Conference on the Conservation of Wetlands of International Importance especially as Waterfowl Habitat held in Cagliari, Italy in November 1980. Supplemented by:

- Ardamatskaya, T.B. (1970). Wildfowl of the Ukranian Black Sea Coastal Region. Proc. Internat. Regional Meeting Conserv. Wildfowl Resources. Leningrad. Pp.67-69.

Carp, E. (1980). A Directory of Western Palearctic Wetlands. IUCN, Gland, Switzerland.

- Proceedings (1978). 50 years of the Chenomorski State Reserve. 197pp.

\section{Kourgal'dzhin and Tengiz Lakes}

Location $50^{\circ} 11^{\prime}-50^{\circ} 44^{\prime} \mathrm{N}, 68^{\circ} 37^{\prime}-69^{\circ} 43^{\prime} \mathrm{E}$. Situated north-east of the Aral Sea in Tselinograd District, northern Kazakhstan SSR.

Area 260,500 ha

Degree of Protection The site is state owned and administered by the Main Department of Zapovedniks and game management of the Kazakh SSR. It contains Kourgal'dzhin Zapovednik $(237,100 \mathrm{ha})$ established in 1958 with full protection and all activities including tourism prohibited; and a protection zone $(23,400 \mathrm{ha})$ in which hunting is restricted and exploitation of natural resources is controlled in accordance with conservation of the wetland as a waterfowl habitat. Designated as a Ramsar site at the time of ratification on 11 October 1976.

Site Description The two lakes lie at $300-400 \mathrm{~m}$ altitude in an extensive group of depressions. These contain shallow lakes ( $3-4 \mathrm{~m}$ depth) with no outflows and varied mineral composition (particularly sulphates and chlorides), and several waterbodies whose hydrological regime is determined by the amount of flooding, inflow from the Noura and Koulanou-Tpes rivers, sluices on the dams across the rivers and evaporation rates. Tengiz saltwater lake (156,000ha) is almost devoid of aquatic vegetation. The water level has fallen leaving vast mud and alluvial flats between the water and the original lake edge. The lake floor is covered with a thick layer of silt. Kourgal'dzhin Lake $(39,600 \mathrm{ha})$ comprises a network of deep water channels $(0.5-2.5 \mathrm{~m}$ depth) with varying degrees of salinity. It supports a rich aquatic vegetation, zoo- and phyto-plankton population and fish fauna. Reedbeds of Phragmites communis grow in the 
shallower waters and on the shores. The lakeside vegetation is bunch-grass steppe with the grasses Stipa lessingiana, Agropyron repens, Bromus inermis, Festuca sulcata and Calamagrostis epigeios and the flowering plants Pyrethrum achilleifolium, Spiraea hypericifolia, wormwoods Artemisia spp., Halocnemum strobilaceum and orache Atriplex cana. Mean January temperature is $-17^{\circ} \mathrm{C}$ and mean July temperature $20.5^{\circ} \mathrm{C}$, with 150 days below $0^{\circ} \mathrm{C}$. Annual precipitation is $250-300 \mathrm{~mm}$.

International and National Importance These lakes are of great importance as breeding, moulting and resting stations for wildfowl during their migration in the northern desert zone. The wetland is the main nesting site for $10-14,000$ pairs of greater flamingo Phoenicopterus ruber (listed in the USSR Red Data Book). The 20,000 other breeding birds include black-headed gull Larus ridibundis (2,000 pairs), common gull L. canus (800-900 pairs), greater black-backed gull L. ichthyaetus (350 pairs), common tern Sterna hirundo (1,500 pairs) and mute swan Cygnus olor (200 pairs in a summer population of 3,000 birds). Other non-breeding summer visitors include shelduck Tadorna tadorna, ruddy shelduck $T$. ferruginea and white-headed duck Oxyura leucocephala. The site is a moulting refuge for numerous non-breeding birds including greater flamingo $(9,000)$, mute swan $(3,000)$, and wigeon, pintail, gadwall, pochard and greylag goose (Anas penelope, A. acuta, A. strepara, Aythya ferina and Anser anser). Many thousands of birds (mainly wigeon and pintail) pass through the area on their spring and autumn migration.

Changes in Ecological Character In the past the lakeside areas were harvested for hay and some cultivation is still practised. The introduced muskrat Ondatra zibethicus has spread throughout the area.

\section{Management Practices No information}

Scientific Research and Facilities Studies have been made of the ecosystem and waterfowl populations. Laboratory facilities and boats are available.

Principal Reference Material The above information was taken from the USSR National Report prepared for the Conference on the Conservation of Wetlands of International Importance especially as Waterfowl Habitat held in Cagliari, Italy in November 1980.

- Andrusenko, N., Zhulii, V. (1978). Riches of the Kourgal'dzhin Zapovednik. Okhota $i$ okhotn. khozyaisivo, No.9, pp.2-4.

- Kovshar, A. (1982). Kourgal'dzhin zapovednik. In Zapovednoe delo v Kazakhstane, Alma-Ata. Pp.57-63.

\section{Lakes of the Lower Turgay and Irgiz}

Location $48^{\circ} 14^{\prime}-49^{\circ} 11^{\prime} \mathrm{N}, 61^{\circ} 53^{\prime}-62^{\circ} 30^{\prime} \mathrm{E}$. Situated near the town of Kouilis to the north-east of the Aral Sea, in Aktyubinsk District of Kazakhstan SSR.

\section{Area 348,000 ha}

Degree of Protection The site is state owned and administered by the Main Department of Zapovedniks and game management of the Kazakhstan SSR. It contains the Turgay Zapovednik $(348,000 \mathrm{ha})$. Hunting is prohibited in the whole area, and exploitation of natural resources is controlled in accordance with conservation of the wetland as a waterfowl habitat. In areas where agriculture is permitted, restrictions are planned to conserve waterfowl habitat. Commerical fishing is restricted, motorboats are prohibited and state purchasing of rushes Scirpus spp. harvested from the wetland has stopped. Designated as a Ramsar site at the time of ratification on 11 October 1976.

Site Description The wetland comprises a large group of lakes (some with no outflows) formed in depressions on a plateau dissected by a number of drainage channels (some of which are disused and in a state of disrepair). The lakes are shallow with a natural hydrological cycle of several years. The close proximity of the Kyzyl-Kum Desert and the large evaporative 
surface area of the waterbodies contribute towards the fluctuating waterlevels and result in many lakes and streams drying up completely in the hot dry summer, leaving only stagnant pools among the sandbanks. The irrigation of the plateau is dependent on the intensity of the seasonal floods and river inflow. The mineral content and concentration of the lake and river water varies from flowing freshwater in the hillside rivers to saline or brackish waters in closed depression lakes. The lakes on the floodplain of the Turgai river and tributaries are fringed by reedbeds of Phragmites communis, and sedge associations predominate in the floodplain meadows. The changing succession of vegetation reflects the periodic fluctuation in the water level of the lakes. The waters are highly productive providing a valuable food source for visiting wildfowl.

International and National Importance In favourable years up to 1.5 million migrating waterfowl and waders have been recorded including some 200,000 Anatidae such as greylag goose Anser anser, white-fronted goose A. albifrons, lesser white-fronted goose A. erythropus, the less common red-breasted goose Branta ruficollis, several thousand wigeon $A$. penelope and diving ducks such as mallard $A$. platyrhynchos, teal $A$. crecca, garganey $A$. querquedula, pintail $A$. acuta, pochard Aythya ferina and goldeneye Bucephala clangula. Other birds include Siberian crane Grus leucogeranus, white spoonbill Platalea leucorodia and great egret Egretta alba. There are up to 25,000 pairs of nesting birds including mute swan, shoveler, gadwall, tufted duck, shelduck, coot (Cygnus olor, Anas clypeata, A. strepera, A. fuligula, Tadorna tadorna, Fulica atra), teal and pochard. The wetland is a moulting site for several thousand birds including greylag goose, coot, greater flamingo Phoenicopterus ruber and dalmation pelican Pelicanus crispus.

Changes in Ecological Character The ecological conditions of the wetland are dependent on dry and wet seasons and years, and the balance easily is disturbed by variations in precipitation.

Management Practices Measures are being taken to improve conservation of the various habitats, particularly those important for birds.

Scientific Research and Facilities The biology and migration of the birds has been studied by ornithologists from the Zoological Institute of the Academy of Sciences of the Kazakhstan SSR.

Principal Reference Material The above information was taken from the USSR National Report prepared for the Conference on the Conservation of Wetlands of International Importance especially as Waterfowl Habitat held in Cagliari, Italy in November 1980.

- Berezovski, V. (1980). Spring migration of birds in the lower Turgai river. In Migrtsii ptits v Azii, (Bird migration in Asie), Dushanbe, pp.140-153.

\section{Issyk-kul Lake}

Location $42^{\circ} 09^{\circ}-42^{\circ} 45^{\circ} \mathrm{N}, 76^{\circ} 09^{\prime}-78^{\circ} 23^{\prime} \mathrm{E}$. Situated about $100 \mathrm{~km}$ due south of Alma Ata in Issyk-Kul District, Kirghiz SSR.

Area 629,800 ha

Degree of Protection The site is state owned and administered by the State Committee of Forestry of the Kirghiz SSR. The Issyk-kul Zapovednik (22,400ha) and protection zones include a considerable belt of land around the lakeshore. Commercial fishing is controlled. Designated as a Ramsar site at the time of ratification on 11 October 1976.

Site Description The lake is $182 \mathrm{~km}$ by $60 \mathrm{~km}$, with an average depth of $280 \mathrm{~m}$ (less in the east). It occupies a tectonic basin at $1,609 \mathrm{~m}$ altitude between the ranges of Kungei Alatau to the north and Terskei Alatau to the south. The lake is fed by over 80 streams and minor channels but has no outflow and the water is brackish and oligotrophic. Water temperature in winter never falls below $2.75^{\circ} \mathrm{C}$ so the lake does not freeze. There are hot springs at Aksu on the lakeshore where there is a health resort. The shallow waters support a rich submerged and 
floating vegetation of Charophyla, Potamogeton and Myriophyllus species, and an abundant zoobenthos with over 150 species of Mollusca, Oligochaetae, Gammaridae and Chironomidae, which are an important food source for visiting birds. Lake fish include zander Stizostedion lucioperce and introduced carp Cyprinus carpio.

International and National Importance The lake area is of primary importance as an overwintering site for wildfowl and for migrating birds. Overwintering numbers vary greatly depending on the severity of the winter, the main species being whooper swan Cygnus cygnus, mute swan $C$. olor, pochard Aythya ferina and coot Fulica atra. The main migrant is pintail Anas acuta. There are small nesting colonies of storks Ciconiidae.

Changes in Ecological Character There may be changes in run-off and inflow into the lake due to afforestation of the surrounding mountain slopes.

Management Practices There is a fishery on the lake for zander and introduced carp.

Scientific Research and Facilities The lake is important for limnological research, and there is a special research ship. There are regular counts of wintering birds.

Principal Reference Material The above information was taken from the USSR National Report prepared for the Conference on the Conservation of Wetlands of International Importance especially as Waterfowl Habitat held in Cagliari, Italy in November 1980.

- Baranov, I.V. (1961). Limnological types of lakes of the USSR. Hydrometeoizdat. Leningrad.

- Luther, H. and Rzoska, J. (1971). Project Aqua. A source book of inland waters proposed for conservation. IBP Handbook No.21.

- Proceedings of the Zapovednik Issyk-kul. (1976) Frunze, 124pp.

\section{Lake Khanka}

Location $44^{\circ} 32^{\prime}-45^{\circ} 14^{\prime} \mathrm{N}, 132^{\circ} 00^{\prime}-132^{\circ} 52^{\prime} \mathrm{E}$. Situated about $160 \mathrm{~km}$ north of Vladivostok in the Primorski District of the RSFSR, north of the Sea of Japan. The northern border coincides with the border with China which crosses the lake.

Area 310,000 ha

Degree of Protection The site is state owned and administered by the Main Department of Game Management and Zapovedniks by the RSFSR Council of Ministers of the USSR. It contains Khankaiski Zakaznik $(49,000 \mathrm{ha})$, in which exploitation of natural resources is strictly controlled and hunting, fishing, hay harvesting, burning and drainage prohibited. The remaining lake area is under general protection with fishing and other commerical activities permitted. Designated as a Ramsar site at the time of ratification on 11 October 1976.

Site Description The site includes part of an extensive lake in the basin of the Sungucha, one of the headwaters of the Ussuri river. The maximum depth of the lake is $10 \mathrm{~m}$, but the water level varies with changes in the prevailing wind and autumn inflows after heavy rains. Areas of the lake sheltered from the wind are dominated by aquatic vegetation mainly of Potamogeton spp. and vast expanses of Myriophyllus, Utricularia. Trapanatans, Nuphar, Mynphaceae and Ceratophyllum species occupy the bays. When the wetland is flooded, floating mats of peat rise to the surface in the southern area, and the sharp seasonal changes in the vegetation they support are dependent on the water level. There are extensive fringing reedbeds of Phragmites communis backed by flooded willow Salix purpurea thickets.

International and National Importance The lake contains relict plant species from the tertiary period, which are of great limnological interest. The wetland is of particular importance for migrating birds and as a summer moulting station. It lies on spring and autumn migration routes with $100,000-200,000$ ducks passing through the area including pintail Anas acuta (27,000-32,000), teal A. crecca $(41,000-50,000)$, mallard $A$. platyrhynchos $(14,000-16,000)$, 
falcated teal $A$. falcata $(7,000-9,000)$, spotbill duck $A$. poecilorhyncha $(4,500-7,000)$, wigeon $A$. penelope, Heude's parrotbill Paradoxornis heudei polivanovi, goldeneye Bucephala clangula (9,000-11,000) and tufted duck Aythya fuligula (9,000-11,000). The summer moulting population is dominated by mallard $(100,000)$, teal and coot Fulica atra. Cranes Grus japonensis and $G$. vipio are breeding here. The endangered Oriental white stork Ciconia ciconia boyciana and Japanese crested ibis Nipponia nippon have been recorded at this site, but there are no recent reports of their occurrence in the immediate vicinity.

Changes in Ecological Character Much of the area surrounding the lake is under rice cultivation. Commercial fisheries and lake navigation may disturb the relict aquatic species.

Management Practices Fishing and hunting are controlled. Measures are being taken to conserve habitats particularly important for birds.

Scientific Research and Facilities The area has been studied by biologists from the Far East Science Centre, Academy of Sciences of the USSR.

Principal Reference Material The above information was taken from the USSR National Report prepared for the Conference on the Conservation of Wetlands of International Importance especially as Waterfowl Habitat held in Cagliari, Italy in November 1980.

- Polivanova, N.N. (1971). The birds of the Khanka Lake (Hunting-game waterfowl and colony birds). Part 1. Proceedings of the reserve "Kedrovaya Pad", v.3. Vladivostok. 240pp. 


\section{Population $54,804,100(1983)$}

Summary of Wetland Situation With a coastline exceeding $7,000 \mathrm{~km}$, numerous offshore islands, a wide variety of freshwater habitats, and a temperate climate, the British Isles provide refuge for many species of waterfowl, particularly on passage and in winter. The richest areas are found in and bordering the intertidal zone. Strangford Lough in the Irish Sea, and the extensive tidal flats on the northern Irish Sea coasts, from the Solway to north Wales, and the coasts of the North Sea and English Channel are particularly important. The shallower coastal waters of northern Scotland and offshore islands are significant for the numbers of wintering sea-ducks. Farmland and the coastal grazing marshes of east and southern Scotland, as well as certain localities in England (Ribble, Wash, Severn), support in winter a sizeable proportion of the world population of several species of geese. These geese also depend on estuaries and inland wetlands for roosting.

The larger inland waters, which are ice-free in all but the most exceptional winters, complement the coastal sites. They include natural lakes such as Lough Neagh in Northern Ireland and Loch Leven in south-east Scotland, as well as freshwater marshes, man-made reservoirs and gravel pits.

Most of the areas of greatest importance for breeding waterfowl are in northern Scotland where human population pressures are less acute. Here, sea lochs, highland lakes and extensive tracts of peatland provide relatively undisturbed sites for both ducks and wading birds.

Over 100 wetlands of international importance have been identified in Great Britain and many are notified as Sites of Special Scientific Interest (SSSI). This should ensure that the Government's statutory advisor on nature conservation, the Nature Conservancy Council (NCC), is included in the planning consultation process and can draw attention to the likely ill effects of any proposed developments. Some key sites are owned by the NCC or Voluntary bodies such as the Royal Society for the Protection of Birds (RSPB). Other sites are safeguarded by management agreements.

Protected Areas Legislation Until recently, the principal legislation on nature conservation in Great Britain were: The National Parks and Access to the Countryside Act 1949; The Civic Amenities Act 1968; and The Town and Country Planning Act 1971. The Wildlife and Countryside Act 1981 brought together much of the previous legislation covering nature conservation, which provided enhanced protection for wildlife habitats and a number of species not previously safeguarded by law. National Nature Reserves (NNRs) are designated by declaration of the Nature Conservancy Council pursuant to a Nature Reserve Agreement and purchase or lease, whichever method is most appropriate. This land has the same immunity from development as any other land held by a Government Department. Local Nature Reserves (LNRs) are set up by a local Government Authority, in consultation with the Nature Conservancy Council. Sites of Special Scientific Interest (SSSIs) are areas notified by the Nature Conservancy Council to Local Planning Authorities as being of special interest. The Planning Authorities must consult the Council before giving permission to develop the sites. As a result of the 1981 Act, all SSSIs have to be renotified, work which is currently under way. In some cases where agreement has been reached with the owners, the land is managed for nature conservation purposes. More than 1,200 non-statutory reserves covering 68,000ha have been established chiefly by the Royal Society for the Protection of Birds, the Royal Society for Nature Conservation and the associated County Naturalists' Trusts. The Countryside Commission designates extensive areas of country as "National Parks" by reason of their natural beauty and opportunities for outdoor recreation, but ownership of the land and rights of landowners are not affected. There are several NNRs within national parks. Although not meeting IUCN criteria for National Parks, these areas have considerable social and scientific importance. The same applies to some of the properties acquired by the National 
Trust under specific Trust legislation; since these can be declared inalienable or not to be disposed of without the express sanction of Parliament, permanent preservation is assured although management policies of the Trust have not always given wildlife and the preservation of natural ecosystems priority. There is a separate Countryside Act for Scotland (1967) and although there are no national parks, the Countryside Commission for Scotland has designated 40 National Scenic Areas where greater planning control can be exercised to conserve areas with particular natural beauty.

Northern Ireland Two Orders-in Council passed in 1985, the Nature Conservation and Amenity Lands (Northern Ireland) Order and the Wildlife (Northern Ireland) Order, replace and expand earlier measures. The Department of the Environment for Northern Ireland has power to establish National Nature Reserves (NNRs) similar to those in Great Britain. The Department also designates Areas of Special Scientific Interest (ASSIs) which are virtually identical in substance to SSSIs in Great Britain. Wildlife Refuges may be established with the agreement of the landowner, giving protection from disturbance. The Department also has the power to establish National Parks, but none have been designated. Non-statutory nature reserves are established by the Forest Service of the Department of Agriculture and by voluntary bodies. The department has the opportunity to make financial provision by means of grant-in-aid to certain aspects of management on these reserves.

Protected Areas Administration Great Britain Responsibility for nature conservation is vested in the Nature Conservancy Council (which comes under the aegis of the Department of the Environment). Its functions are; (i) the establishment, maintenance and management of nature reserves; (ii) the provision of advice to government on the development and implementation of policies for or affecting nature conservation; (iii) the provision of advice and dissemination of knowledge about nature conservation; and (iv) the commissioning or support of relevant research. The Countryside Commission and the Countryside Commission for Scotland have an important role in the administration of many countryside areas. The Forestry Commission is the largest landowner in Britain, and has management interests in many areas of conservation value. Other responsible land owners include the National Trust, Local Authorities and the Ministry of Defence, as well as the RSNC, RSPB etc.

Northern Ireland The Department of the Environment for Northern Ireland is both the legislative and administrative body for nature and countryside conservation. It is advised by the Committee for Nature Conservation and by the Ulster Countryside Committee on both topics respectively. The Forest Service is part of the Department of Agriculture. Other responsible landowners are similar to those in Great Britain.

\section{Sites designated under the Convention}

Signature subject to ratification 6 September 1973. Finally ratified on 5 January 1976, with 13 sites listed at signature, six sites added 24 July 1981, six sites added 17 July 1985, three added 28 November 1985 and three added 25 September 1986.

Cors Fochno and Dyfi

Bridgwater Bay

Bure Marshes (Ranworth, Cockshoot and Hoveton Great Broads, and Woodbastwick Marshes)

Hickling Broad and Horsey Mere

Lindisfarne

Loch Druidibeg, Loch a'Machair and Loch Stilligary

Loch Leven

Loch Lomond

Lough Neagh and Lough Beg

Minsmere - Walberswick

North Norfolk Coast (Scolt Head, Holkham, Blakeney Point, and Cley and Salthouse Marshes)

Ouse Washes

Rannoch Moor

Cairngorm Lochs 
Loch of Lintrathen

Claish Moss

Silver Flowe

Abberton Reservoir

Rostherne Mere

The Dee Estuary

The Swale

Chesil Beach and the Fleet

Derwent Ings

Holburn Moss

Irthinghead Mires

Leighton Moss

Martin Mere

Alt Estuary

Loch of Skene

Loch Eye

Rockcliffe Marshes

Government body responsible for administration of the Convention

Department of the Environment, Tollgate House, Houlton Street, Bristol, BS2 9DJ

\section{Cors Fochno and Dyfi}

Location $52^{\circ} 31^{\prime} \mathrm{N}, 4^{\circ} 00^{\prime} \mathrm{W}$. Situated on the coast of central Wales, north-northeast of Aberystwyth in the counties of Dyfed, Gwynedd and Powys.

Area 2,497ha

Degree of Protection 2,095ha is a National Nature Reserve established in 1969 and extended since April 1980. The remainder is a Site of Special Scientific Interest (SSSI) under multiple ownership including the Royal Society for the Protection of Birds. 525ha of the national nature reserve is owned by the Nature Conservancy Council (NCC). The remainder is leased and managed by the NCC under the 1949 Act. Leases are due to be renewed in 1989 and 1998. The National Nature Reserve area was approved as a Biosphere Reserve in June 1976. Designated as a Ramsar site at the time of ratification in January 1976.

Site Description The Ramsar site has three components: the River Dyfi estuary, a sand dune system and part of the raised bog of Cors Fochno on the south side of the estuary. The estuary includes a full range of estuarine habitats with sand banks, mudflats, saltmarsh, river channels and creeks. The plant community of the saltmarsh has been modified by the introduction and spread of cordgrass Spartina anglica, a British hybrid form, but still retains considerable diversity. The dune system has a full complement of typical plant communities such as marram grass Ammophila arenaria, and Cors Fochno is an actively growing raised bog. Other plant communities include dwarf bog shrub with willow Salix sp., birch Betula sp., ling Calluna sp. and Phragmites australis reedbeds. The main faunistic interest is the waterfowl populations but there is also a very diverse invertebrate fauna in the estuary littoral zone. Cors Fochno is of considerable entomological value.

International and National Importance The estuary supports a migrant population of up to 2,500 waders, and a winter population of 4,000 Anatidae including about 2,000 wigeon Anas penelope and a small flock of about 60 Greenland white-fronted geese Anser albifrons flavirostris, the only one remaining in southern Britain. The central area of Cors Fochno contains the most extensive tract of unmodified lowland raised mire vegetation in Great Britain which is effectively buffered by a peripheral belt of modified raised mire communities. The mire is an important area for stratigraphical studies. The polecat Mustela putorius now scarce in Britain occurs in the dunes. 
Changes in Ecological Character Part of Cors Fochno has been subjected to drainage works for agricultural improvement completed in November 1981. A $1.3 \mathrm{~km}$ length of ditch has been cut across an area of peat cuttings and the resulting drainage extends $100 \mathrm{~m}$ back into the bog. After negotiations with the owner the NCC has now purchased this area (29ha) and remedial work to block the ditches and arrest the damaging effects of drainage operations has been completed. The 29 ha within the Ramsar Site was declared as part of the Dyfi NNR last year. In addition the surface communities of the mire suffer occasional outbreaks of fire. The dunes and sandy shores attract large numbers of holiday visitors and the risk of human erosion is a major problem. There is an information centre at the dunes.

Management Practices Rehabilitation work on areas damaged by human erosion is done on a rotational basis. Access is unrestricted except to Cors Fochno which is by permit only. The eastern third of the estuary, which includes part of the Ynyshir Reserve owned by the Royal Society for the Protection of Birds, is managed as a wildfowl refuge. Shooting at the western end of the estuary is controlled by a permit system.

Scientific Research and Facilities Past and current research projects concerning the history, structure and biology of the area by university workers. The reserve is being used increasingly for educational purposes by schools, colleges and universities.

Principal Reference Material The above information is taken from documents supplied by the Government of the United Kingdom for designation in 1976, for the Cagliari Conference in November 1980 and for the Groningen Meeting in 1984.

Supplemented by:

- Carp, E. (1980). A Directory of Western Palearctic Wetlands. IUCN, Gland, Switzerland.

\section{Bridgwater Bay}

Location $51^{\circ} 13^{\prime} \mathrm{N}, 3^{\circ} 04^{\prime} \mathrm{W}$. Adjoining the estuary of the River Parrett, about $9.5 \mathrm{~km}$ north of Bridgwater in the county of Somerset, England.

\section{Area $2,703 \mathrm{ha}$}

Degree of Protection The whole area is a National Nature Reserve established in 1954. Of this 36 ha is owned by the Nature Conservancy Council (NCC), part is leased from the Crown Estate Commissioners; the remainder is managed by the NCC under a Nature Reserve Agreement due for renewal in 1993 with the owners, the Wessex Water Authority. Designated as a Ramsar Site at the time of ratification on 5 January 1976.

Site Description The site includes extensive intertidal mudflats to the west of the River Parrett, $4 \mathrm{lha}$ of saltmarsh pasture, a $4.8 \mathrm{~km}$ strip of the river bank south from the mouth, and a $9 \mathrm{~km}$ stretch of the Huntspill River. An artificial waterway was built to help drain the Somerset Levels in the hinterland. The main habitats are mudflats, saltmarsh, shingle beach and sea wall. The principle botanical feature is the extensive sward of cord grass Spartina anglica. Over 100 species of flowering plants and over 200 species of birds mainly migrant species have been recorded.

International and National Importance The site was the second known European moulting ground for shelduck Tadorna tadorna (maximum 3,000). It is now the largest of at least 3 such sites in the British Isles. Average winter peaks are mallard Anas platyrhynchos 2,400 (maximum 4,000), teal A. crecca 900 (maximum 2,150), wigeon A. penelope 4,800 (maximum 10,000) and black-tailed godwit Limosa limosa islandica 1,500 (maximum 5,000); and in April-May there are 2,000 whimbrel Numenius phaeopus on passage. Stert Island, $1 \mathrm{~km}$ offshore, is a roosting ground for whimbrel and small numbers of white fronted geese, Anser albifrons. Notable flora include bulbous foxtail Alopecurus bulbosus (rare in Britain), the local Ray's knot grass Polygonum raii, and sea spurge Eurphorbia paralais. The site contains one of the largest areas in Britain of clay and silt flats. 
Changes in Ecological Character The major threat to the reserve at present is a nuclear power station proposed on the western margin of the site. This is not however expected to have any major lasting effect on the site. A Severn Barrage scheme is still under consideration, and could have serious deleterious effects on the Reserve if constructed.

Management Practices Shooting by permit is allowed in parts of the reserve. Some areas are open to the public.

Scientific Research and Facilities Regular counts are made of the numbers of waterfowl as part of the national contribution to the IWRB census. Research has been undertaken on wigeon feeding preferences aimed at providing information necessary for the management of the saltings. There have also been extensive studies of Spartina by the Nature Conservancy Council and studies by university workers on the coastal formation processes of erosion and accretion.

Principal Reference Material The above information is taken from the documents supplied by the Government of the United Kingdom for designation in 1976, for the Cagliari Conference in November 1980 and the Groningen Meeting in May 1984.

Supplemented by:

- Carp, E. (1980). A Directory of Western Palearctic Wetlands. IUCN, Gland, Switzerland. Additional references:

There are many scientific publications concerning the research carried out on the reserve in ornithology, botany and physiography.

- Cadwallader, D.A. and Morley, J.V. (1974). Further experiments on the management of saltings pasture for wigeon Anas penelope conservation at Bridgwater Bay National Nature Reserve, Somerset. J.Appl. Ecol. 11: 461-466.

- Morley, J.V. (1986). The birds of Bridgwater Bay. NCC internal report.

\section{Bure Marshes}

Location $52^{\circ} 41^{\prime} \mathrm{N}, 1^{\circ} 29^{\prime} \mathrm{E}$. Floodplain of the River Bure about $10 \mathrm{~km}$ north-east of Norwich in the county of Norfolk, England.

\section{Area 412 ha}

Degree of Protection Bure Marshes were declared a National Nature Reserve in 1958. Managed by the Nature Conservancy Council under Nature Reserve Agreements and a lease with four separate land owners. These Agreements are due for renewal in 2003 and 2004, and the lease in 1999. Designated as a Ramsar site at the time of ratification on 5 January 1976.

Site Description The reserve comprises most of the undrained fenland in the floodplain of the River Bure between Wroxham and Ranworth. The area is subject to small freshwater tidal changes and some salt water may reach the downstream river section and lakes (such as Ranworth) at high spring tides. There are four lakes or broads, thought to have been formed after extensive peat digging (prior to the 13th century) when a combination of change in climate and rise in sea level flooded the pits and they were abandoned. Sediment accumulation since the 13 th century has resulted in these broads being quite shallow with a water depth of 0.5 to $1.5 \mathrm{~m}$. Peat digging continued after the 13 th century but only shallow $80 \mathrm{~m}$ pits (turf ponds) were dug. Most of the surrounding fen was managed for reed, sedge and marsh hay harvesting, with channels (dykes) cut for access and transport, and this extensive exploitation diversified the habitats. These traditional activities have declined since the 1900 s and natural succession since has resulted in the invasion of turf ponds by fen vegetation and the transition from fen to fen woodland. Some of the dykes have silted up and become overgrown. The reserve still contains a wide variety of fenland communities ranging from aquatic and open fen habitats to mature alder Alnus spp. woodland. The vegetation is influenced by the alkaline nutrient-rich condition of the water. Dominant species of open fen are common reed Phragmites australis and great fen sedge Cladium mariscus, of ten associated with milk parsley Peucedanum palustris; sweet gale Myrica gale; and alder buckthorn Trangula alnus. 
Other widespread species include royal fern Osmundia regalis, marsh fern Thelypteris palustris, fibrous tussock sedge Carex appropinquata and cowbane Cicuta virosa. Aquatic plants include yellow water lily Nuphar lutea, pondweeds Potomageton spp. and water soldier Statiotes aloides. The rivers and broads contain coarse fish including pike Esox lucius, eel Anguilla anguilla and roach Rutilus rutilis. Other fauna include otter Lutra lutra, introduced South American coypu Myocaster coypus and a diverse bird community.

International and National Importance The site is part of one of Britain's most important wetland areas. The diverse habitats support a wide variety of breeding birds including great crested grebe Podiceps cristatus, gadwall Anas strepera, teal $A$. crecca and shoveler $A$. clypeata. There are also a few common tern Sterna hirundo and grey heron Ardea cinerea. Ranworth and Cockshoot Broad form an important refuge for wintering geese and ducks (Anatidae). In 1963 the winter population was $1,000-2,000$ but in 1984 there were only a few hundred. The area also supports a moderately strong breeding population of swallowtail butterfly Papilio machaon brittanica, a subspecies now confined to the fens and broads of East Anglia.

Changes in Ecological Character The Norfolk Broads is a very popular tourist area, and the River Bure adjoining the reserve carries an exceptionally heavy traffic of pleasure craft (up to 1,000 boats per day, of which $70-75 \%$ are motor hire craft). The wash from the boats is eroding the land that separates the broads from the river, and damaging the riverside reedbeds which provide shelter and nesting areas for birds. The River Bure is very eutrophicated, with high levels of phosphorus and nitrogen derived from sewage effluent and agricultural runoff. These nutrients have encouraged high algal productivity resulting in high sedimentation rates (about $1.0 \mathrm{~cm}$ per year) in the broads. Extensive reduction in the reedswamp area has been caused by boat damage, grazing by introduced coypu and waterfowl, and high nitrogen levels. There are regular outbreaks of avian botulism.

Management Practices The main management objective has been to maintain substantial areas of open fen, and to clear and maintain the dyke system. The upper phosphorus-rich sediment was removed from Cockshoot Broad, which had become very shallow due to sediment accumulation, and the broad was isolated by damming from the nutrient-rich River Bure in 1982. These works have produced an improvement in the ecology and water chemistry of the site, but, owing to heavy grazing by coot Fulica atra and other waterfowl, macrophytes were reintroduced to speed up the process of recovery. Boat traffic is prohibited on the broads in Bure Marshes National Nature Reserve and is subject to speed limits on the River Bure (governors are fitted to the engines of most hired boats). The reserve has a nature trail accessible only by boat at Hoveton Great Broad and a trail accessible by foot to Cockshoot Broad. Coypu are controlled by the Ministry of Agriculture, Fisheries and Food.

Scientific Research and Facilities Much of the work on the Broadland sequence of natural succession, alluvial stratigraphy of the broadland fens and the origin of the Norfolk Broads was carried out in the reserve. Recently completed or current work includes studies on water vole Arvicola amphibius, the ecology of the dykes, regression of marginal swamp communities and eutrophication studies at Hoveton Great Broad.

Principal Reference Material The above information is taken from the documents supplied by the Government of the United Kingdom for designation in 1976, and for the Cagliari Conference in November 1980.

Supplemented by:

- Broads Authority (1982). What Future for Broadland? Strategy and Management Plan for Broadland (draft). Broads Authority, Norwich.

- Carp, E. (1980). A Directory of Western Palearctic Wetlands. IUCN, Gland, Switzerland.

- Moss, B. (1983). The Norfolk Broadland: experiments in the restoration of a complex wetland. Biol. Rev. 58: 521-561.

- IUCN (1977). World Directory of National Parks and Protected Areas. IUCN, Morges, Switzerland. 


\section{Hickling Broad and Horsey Mere}

Location $52^{\circ} 45^{\prime} \mathrm{N}, 1^{\circ} 39^{\prime} \mathrm{E}$. Situated in the county of Norfolk, England. Hickling is about $20 \mathrm{~km}$ north-east of Norwich and Horsey is $3.5 \mathrm{~km}$ further east.

\section{Area 892 ha}

Degree of Protection A National Nature Reserve (487ha) which includes Hickling Broad was established in 1958. The reserve is owned by the Norfolk Naturalists Trust and a private landowner. The trust manages the privately owned land by agreement with the owner, and the whole is subject to a Nature Reserve Agreement with the Nature Conservancy Council. The remaining area is owned by the National Trust and managed as a nature reserve. Designated as a Ramsar Site at the time of ratification on 5 January 1976.

Site Description The area comprises four brackish shallow lakes: Hickling Broad, Heigham Sound, Horsey Mere and Martham Broad, and much of the marginal reedswamp and fen vegetation inside and outside the retaining floodbank. Like all the Norfolk Broads, these lakes are thought to have been formed after extensive peat digging (prior to the 13 th century) when a combination of change in climate and rise in sea level flooded the pits so that they were abandoned. The topography has been extensively modified since by drainage of the surrounding marshland and embankment of the broads and associated waterways. These broads are in direct connection with the River Thurne. The range of habitats includes reedswamp dominated by common reed Phragmites australis or lesser reedmace Typha angustifolia; sedge beds dominated by the great fen sedge Cladium mariscus; mixed communities of black bog rush Schoenus nigricans, tufted sedge Carex elata, milk parsley Peucedanum palustris, common valerian Valeriana officinalis and yellow loosestrife Lysimachia vulgaris; acidophilous communities containing crested buckler fern Dryopteris cristata, marsh cinquefoil Potentilla palustris, sharp-flowered rush Juncus acutiflorus, bogbean Menyanthes trifoliata, sphagnum mosses Sphagnum palustre and S. fimbriatum; fen carr comprising alder Alnus glutinosa, downy birch Betula pubescens and grey willow Salix cinerea; mowing or grazing marshes; and neglected grazing marshes in various stages of reversion to mixed fen. The aquatic communities have been degraded through eutrophication, but the rare holly-leaved niad Niajus mariana persists. Horsey Mere has more extensive submerged vegetation though it is less species-rich than Hickling Broad. Species include spiked water milfoil Myriophyllum spicatum, fennel pondweed Potomageton pectinatus and marestail Hippiuris vulgaris. Fauna is characteristic of the Norfolk Broads, and includes the introduced South American coypu Myocaster coypus. The area is renowned for birdlife.

International and National Importance The site is of outstanding importance for characteristic marshland birds, some of which are very uncommon in Great Britain and have their principal populations in Broadland. Breeding species include pochard Aythya ferina, bittern Botaurus stellaris, bearded tit Panurus biarmicus, gadwall Anas strepera, garganey $A$. querquedula (1 pair), little tern Sterna albifrons, marsh harrier Circus aeruginosus and water rail Rallus aquaticus. Occurring regularly are black-tailed godwit Limosa limosa, ruff Philomachus pugnax and spotted redshank Tringa erythropus. In winter the reserve attracts 3,000-4,000 Anatidae, notably mallard Anas platyrhynchos (1,250), teal A. crecca and shoveler $A$. clypeata. The area is one of the principal strongholds of the swallow-tail butterfly Papilio machaon brittanica, a sub-species now confined to the fens and broads of East Anglia. Plants include crested buckler fern, which, although frequent in Norfolk, is decreasing locally and is listed as vunerable in the British Red Data Book.

Changes in Ecological Character Water quality has been affected by nitrogen from agricultural runoff and phosphorus from sewage effluent, though, unlike the River Bure broads, some submerged plants have remained. There are no major sewage outfalls directly into these broads, but phosphorus may reach the area by movement upstream of effluent-laden water from the lower River Thurne or River Bure. In Hickling Broad an additional source of phosphorus is droppings from the large wintering population of black-headed gull Larus ridibundus. Aquatic plants are being damaged by boats passing too close or penetrating the marginal vegetation, and by the introduced coypu. Regular fish kills are caused by a dinoflagellate brackish water alga Prymmesium (which is stimulated by high nutrient levels). 
Drainage in the peaty catchment has resulted in the formation of acid water rich in particulate ferric compounds (ochre), with substantial quantities reaching Horsey Mere from drainage pumps at Brogave Mill and Eastfield Mill. A similiar problem at Martham has now been solved by re-siting the drainage pump downstream of the site.

Management Practices The water levels in the marshland are controlled to provide optimum conditions for birds throughout the year. Boating on the broads is unrestricted except at Martham, but a permit is required to visit the surrounding marshland. Reed and sedge are harvested commercially which contributes to the running costs of the reserve. Coypu are controlled by the Ministry of Agriculture, Fisheries and Food.

Scientific Research and Facilities Some of the work on the origin of the Norfolk Broads was carried out at Hickling. The site has also been used for research on the ecology of the swallowtail butterfly, and for studies on eutrophication. It is currently part of an investigation into the regression of marginal swamp communities throughout the broadland.

Principal Reference Material The above information is taken from the documents supplied by the Government of the United Kingdom for designation in 1976 and for the Cagliari Conference in November 1980.

Supplemented by:

- Broads Authority (1982). What Future for Broadland? Strategy and Management plan for broadland (draft). Broads Authority, Norwich.

- Carp, E. (1980). A Directory of Western Palearctic Wetlands. IUCN, Gland, Switzerland.

- Moss, B. (1983). The Norfolk Broadland: experiments in the restoration of a complex wetland. Biol. Rev. 521-561.

\section{Lindisfarne}

Location $55^{\circ} 41^{\prime} \mathrm{N}, 1^{\circ} 48^{\prime} \mathrm{W}$. On the coast, $15 \mathrm{~km}$ south-east of Berwick upon Tweed, adjoining and including part of Lindisfarne (Holy Island); in the county of Northumberland, England.

Area 3,278 ha

Degree of Protection Privately owned but managed under lease by the Nature Conservancy Council. Established as a National Nature Reserve in 1964, and extended in 1966, 1969 and 1974. The leases are due for renewal in 1985, 1986, 2014 and 2073.. It is included within a stretch of coast scheduled as an Area of Outstanding Natural Beauty. Designated as a Ramsar site at the time of ratification on 5 January 1976.

Site Description The reserve includes two large areas of intertidal sand and silt, smaller areas of saltmarsh, and a moderately lime-rich dune system with well developed base-rich slacks (hollow areas within dunes). There are also low sandstone cliffs and wave cut platforms with rock pools. The tidal flats carry notable populations of Enteromorpha spp., seaweed and eelgrass Zostera spp., but the saltmarsh has been heavily invaded by cord-grass Spartina anglica. The dunes support a particularly varied flora combining northern and southern elements, with notable orchid and bryophyte populations including some rare species in the dune slacks. The dunes have a cover of marram grass Ammophila arenaria. Vegetation in the slacks includes creeping willow Salix repens which is locally abundant, wintergreen Pyrola rotundifolia and curved sedge Carex maritima. The hybrid small reed Ammocalamagrostis baltica occurs on the dunes. The site supports significant waterfowl populations.

International and National Importance The large areas of tidal sand and silt flats support internationally important populations of waterfowl. Of primary interest is the winter population of about 35,000 Anatidae and 40,000 (maximum) waders. Wigeon Anas penelope have increased from 10,000 in winters $1966-68$ to 30,000 in 1978-79, whooper swan Cygnus cygnus formerly reached a peak in excess of 400 but now seldom exceed 150 , and pale-bellied Brent goose Branta bernicla hrota varies between 350 and 2,100 (maximum recorded in 1978-79). Waders include 10,000 knot Calidris canutus, 30,000 dunlin C. alpina and 4,000 
bar-tailed godwit Limosa lapponica. The flats are also fished by terns Sterna spp. when the tide is in. The dune slacks support a number of rare plant species including the coralroot orchid Corallorhiza trifida and dune helleborine Epipactis dunensis.

Changes in Ecological Character The growth of cord-grass is accelerating the rate of natural accretion and is also encroaching into areas of eelgrass which are important for wigeon, whooper swan and Brent goose. The introduced Australasian pirri-pirri burr Acaena novae-zealandae is widely distributed. There is considerable tourist pressure in summer.

Management Practices Areas of cord-grass are being treated with dalapon in order to halt encroachment into eelgrass areas. Another management project is dune stabilisation. Shooting is allowed in parts of the reserve by a maximum of 750 permit holders but the remaining areas are maintained as a sanctuary. Access on foot is unrestricted.

Scientific Research and Facilities Recent projects have included studies of the feeding ecology of ringed plover Charadrius hiaticula, grey plover Pluvialis squatarola, bar-tailed godwit and curlew Numenius arquata by the University of Durham, and assessment of the effects of hunting on the local concentration of birds. There are routine counts of waterfowl.

Principal Reference Material The above information is taken from documents supplied by the Government of the United Kingdom for designation in 1976, for the Cagliari Conference in November 1980, and for the Groningen Meeting in 1984.

Supplemented by:

- Carp, E. (1980). A Directory of Western Palearctic Wetlands. IUCN, Gland, Switzerland.

- IUCN (1977). World Directory of National Parks and Protected Areas. IUCN, Morges, Switzerland.

Additional references:

- Cartwright, R.A. and D.B. (1976). The Holy Island of Lindisfarne. David and Charles.

- Galliers, J.A. (1970). Geomorphology of Holy Island, Northumberland. Univ. of Newcastle upon Tyne Research Series 6.

- Perry R.A. (1946). Naturalist on Lindisfarne. Lindsay Drummond.

- Smith, P.C. and Evans, P.R. (1973). Studies of shorebirds at Lindisfarne, Northumberland: feeding, ecology and behaviour of the bar-tailed godwit. Wild fowl 24:135-139.

- Magnusson, M. (1984). Lindisfarne - The Cradle Island. Oriel Press (Routledge and Kegan Paul).

\section{Loch Druidibeg, Loch a'Machair and Loch Stilligary}

Location $57^{\circ} 21^{\prime} \mathrm{N}, 7^{\circ} 24^{\prime} \mathrm{W}$. Situated on the western seaboard of the Isle of South Uist, Western Isles, north-west Scotland.

Area 1,677 ha

Degree of Protection The whole area is a National Nature Reserve established in 1958. 1,030 ha of this area is owned by the Nature Conservancy Council. The remainder is managed under a Nature Reserve Agreement with the owners (renewal date 1987). The national nature reserve area was approved as a Biosphere Reserve in June 1976. Designated as a Ramsar site at the time of ratification on 5 January 1976.

Site Description The whole area is underlain by Lewisian gneiss bedrock. The eastern section is a flat, moorland basin and contains Loch Druidibeg which is an oligotrophic loch of 316 ha with average depth of $1.5 \mathrm{~m}$ (maximum $4.0 \mathrm{~m}$ ). The loch has a sandy bottom, deeply indented shoreline, and many islands. The western (seaward) section is raised beach or 'machair' where the bedrock has a mantle of old beach deposits consisting of marine calcareous shellsands. The lochs in this section, which include Loch a'Machair and Loch Stilligary, are eutrophic. Both lochs are about 40 ha in area with average depth of $1-2 \mathrm{~m}$ (maximum 3.0). Because of proximity to the sea, all the lochs have relatively high sodium chloride levels from salt-laden sea-spray. The eastern section has moorland vegetation with blanket bog, dwarf shrub heath and 
deciduous scrub woodlands on the loch islands. The largest British fern, the royal fern Osmanda regalis, is also found on the islands. The western section contains freshwater marsh, reedswamp, dune grasslands, dune slack mires and premanent pastureland. The lochs of the western section contain extensive beds of rooted aquatic vegetation including Characeae. The machair grasslands are rich in cultivated and uncultivated herbaceous species. The intertidal zone is mainly bare sand but larger stones bear short fucoid seaweeds. The reserve was primarily established for the greylag goose Anser anser breeding population. Fauna include golden eagle Aquila chrysaetos, otter Lutra lutra in Loch Druidibeg, and short-tailed vole Microtus agrestis. The grey seal Halichoerus grypus occurs offshore. The lochs and running waters contain the Atlantic salmon Salmo salar, both brown non-migratory and migratory trout Salmo trutta and the nine-spiked stickleback Pungitius pungitius. There are examples of brackish-water fauna in the lochs such as the mysid Neomysis integer and the amphipod Gammarus duebeni. Over 900 species of invertebrates have been identified, and the 'machair' lochs are particularly rich in zooplankton and benthos.

International and National Importance Loch Druidibeg regularly supports a substantial part of the native greylag goose breeding population in Britain. The geese also depend on the rich machair grasslands around Loch a'Machair and Loch Stilligary to rear their young. Some of the freshwater invertebrate species are uncommon or not found in the mainland. The machair lochs contain species of plants representative of shallow eutrophic lakes in the northern oceanic climate of north-west Scotland.

Changes in Ecological Character There is the possiblity of agricultural reseeding of moorland vegetation and of drainage improvements which could result in lower water levels in Loch Druidibeg. Wild red deer Cervus elaphus have been introduced by the owners to the area managed under a Nature Reserve Agreement. The effects of the deer on the woodland of the islands in Loch Druidibeg are being monitored. There is some predation on the local wildlife by domestic dogs and cats belonging to the crofters.

Management Practices The sandy machair grasslands contain plant communities modified by agriculture. Some of the area is permanent pasture that has been grazed for many centuries by cattle and sheep. Other parts including the ecotone between grassland and moorland are cultivated with oats, rye and potatoes. The moorland has been modified by fire and has extensive peat banks. The freshwaters are managed as a sea trout/salmon fishery, and wildfowling is allowed on the western section. Access to the eastern section of the reserve is restricted in the goose breeding season. Visitor pressure is generally quite low. The Nature Conservancy Council have established an experimental plantation of trees once native to this area. The management plan for the area is now under revision.

Scientific Research and Facilities Research projects include a study of the population dynamics of the greylag goose, and physical and botanical studies of the 'machair'.

Principal Reference Material The above information is taken from the documents supplied by the Government of the United Kingdom for designation in 1976 and for the Cagliari Conference in November 1980.

Supplemented by:

- Luther, H. and Rzoska, J. (1971). Project Aqua. IBP Handbook No. 21. Blackwell Scientific Publications.

Additional references:

- Newton, L. (1969). Greylag geese Anser anser at Loch Druidibeg. Wild fowl 20: 156.

\section{Loch Leven}

Location $56^{\circ} 13^{\prime} \mathrm{N}, 3^{\circ} 23^{\prime} \mathrm{W}$. Situated about $19 \mathrm{~km}$ south of Perth in the district of Perth and Kinross, Tayside region, south-east Scotland.

Area $1,597 \mathrm{ha}$ 
Degree of Protection Privately owned but declared a National Nature Reserve in 1964 under section 19 of the National Parks and Access to the Countryside Act 1949. Subject to a Nature Reserve Agreement with the Nature Conservancy Council. This agreement is due for renewal in 2004. Designated as a Ramsar site at the time of ratification on 5 January 1976.

Site Description A shallow loch of $13,350 \mathrm{sq} . \mathrm{km}$ at an altitude of $107 \mathrm{~m}$, with a maximum depth of $25 \mathrm{~m}$ and mean depth of $3.9 \mathrm{~m}$. The loch fills two kettle holes in glacial sand and till which overlie Devonian sandstone. It is very exposed to west and east, and subject to strong wave action. The Loch has partial or complete ice cover in most winters, though rarely complete cover for long periods. The shoreline is of sand or small stones, and $40 \%$ of the lake floor is covered with sand to $3 \mathrm{~m}$ depth, below which the sediment is mud. There are seven islands, the largest $32 \mathrm{ha}$ and second largest $2 \mathrm{ha}$. The loch is naturally base-rich, and subject to accelerated eutrophication due to high levels of phosphorous in sewage effluent and the increasing use of nitrate fertilisers in the catchment area (mainly arable and improved grassland). The high nutrient status of the loch has caused prolonged and dense algal blooms. The vegetation of the landward section of the reserve is old pine plantations, ungrazed grasslands and mesotrophic mire. There is an interesting range of ruderal species in the strand-line vegetation. Emergent vegetation is now confined to a few scattered areas, but sparse submerged macrophytes have shown considerable recovery since previous decline with fennel-leaved pondweed Potamageton pectinatus now dominant. Emergents include reed Phragmites australis, reedgrass Phalaris arundinacea and scattered common spike rush Eleocharis palustris. The fauna includes brown trout Salmo trutta, perch Perca fluviatilis, pike Esox lucius, three-spined stickleback Gasterosteus aculeatus, brook lamprey Lampetra planeri and many species of waterfowl.

International and National Importance Loch Leven's geographical position midway between the Firths of Forth and Tay at the focus of migration routes, and its rich and extensive feeding grounds and large size, are significant in making the loch the most valuable inland waterfowl lake in Great Britain. The loch has the largest numbers of breeding ducks in Britain, with over 500 pairs of mallard Anas platyrhynchos and tufted duck Aythya fuligula, and 50-60 pairs of gadwall Anas strepera. Also breeding here are 8,000 pairs of black-headed gull Larus ridibundus. The reserve is also an important moulting refuge and staging post on migration, with up to 15,000 pink-footed goose Anser brachyrynchus arriving in autumn. Wintering species include mallard, teal Anas crecca, pochard Aythya ferina, shoveler Anas clypeata, goldeneye Bucephala clangula, whooper swan Cygnus cygnus and greylag goose Anser anser. The loch is renowned for trout fishing, and some $20,000 \mathrm{~kg}$ are caught by anglers annually.

Changes in Ecological Character Although there was some improvement in the loch water (and recovery of submerged macrophytes) following controls on industrial effluent during the 1970 s, high levels of nutrients continue to enter the loch (mainly from domestic sewage and agricultural run-off). The increasing phosphorous inputs, and concentrations in the loch are the worst problem, causing loss of aquatic plants and species diversity, and contributing to erosion of exposed shorelines which have suffered die-back of emergent vegetation. The lagoon areas which are duckling nursery habitat are threatened by shoreline erosion. A feasibility study of control by gabioning was implemented by the NCC (1982-4) and resulted in nearly $2000 \mathrm{~m}$ of the east shore of the loch being protected by a gabion reef, $20-30 \mathrm{~m}$ offshore. A drop in the numbers of trout caught has led to a decision by the landowner to reopen the fish hatchery and restock the loch. A planning application for a helicopter landing pad on the boundary of the reserve has been refused. Helicopters using this pad would have flown out across part of the loch shore used by nesting duck and across flight lines used by wintering geese between their roosting and feeding areas. There may be future pressures from water abstraction, light industry and tourist/recreational activities.

Management Practices Access is restricted under byelaws and there are only three points of public access. Trout fishing by boat is permitted, under control of the landowner. In 1985-86 a major research contract was placed with the Institute of Terrestrial Ecology (Natural Environment Research Council). This was jointly funded by Tayside Regional Council (with financial assistance by EEC), the Nature Conservancy Council, and the Department of 
Agriculture and Fisheries for Scotland, and aims to provide a total phosphorus budget for Loch Leven. A preliminary report has been produced and discussed. It is hoped that these discussions will lead to Tayside Region installing phosphate stripping equipment at the sewage works.

Scientific Research and Facilities Loch Leven was the site of a major UK International Biological Programme (IBP) project on productivity and production processes in the food chain. This included projects on water circulation, nitrogen and phosphorus budgets, insecticides in fish, fluctuations in phytoplankton and benthic algae, macrophytes and duck population, biology and parasitology. Research is continuing on biotic fluctuations and related management problems, particularly a re-survey of aquatic macrophytes and utilisation of the water surface and shoreline by duckling broods.

Principal Reference Material The above information is taken from documents supplied by the Government of the United Kingdom for designation in 1976, for the Cagliari Conference in November 1980 and for the Groningen Meeting in 1984.

Supplemented by:

- Carp, E. (1980). A Directory of Western Palearctic Wetlands. IUCN, Gland, Switzerland.

- Luther, H. and Rzoska, J. (1971). Project Aqua. IBP Handbook No. 21. Blackwell Scientific Publications.

Additional references:

- Allison, A., Newton, I. and Campbell, C. (1974). Loch Leven National Nature Reserve: a study of waterfowl biology. WAGBI Chester.

- IBP (1974). The Loch Leven Project. Proc. Royal Soc. Edinburgh B 74: 1-450.

- Le Cren (Ed.) (1976). The productivity of freshwater communities. Phil. Trans. R. Soc. Lond. B 274: 359-374.

- Morgan, N.C. (1972). Productivity studies at Loch Leven (a shallow nutrient-rich lowland lake). In Kajak, Z. and Hilbricht-llkowska, A. (eds). Productivity problems of freshwaters. Warsaw-Krakow. Pp. 183-205.

- Munro, W.R. and Balman K.H. (1956). Observations on the spawning runs of brown trout in the South Queich, Loch Leven. Freshwater Salm. Fish. Res. 13:1-17.

- Newton, I. and Campbell, C.R.G. (1969). Geese at Loch Leven. Wild fowl 20: 156.

- Newton, I. and Campbell, C.R.G. (1975). Breeding of ducks at Loch Leven, Kinross. Wild fowl 26: 83-103.

\section{Loch Lomond}

Location $56^{\circ} 04^{\prime} \mathrm{N}, 4^{\circ} 35^{\prime} \mathrm{W}$. Situated in the south-east corner of Loch Lomond in Dumbarton and Stirlingshire districts, Strathclyde and Central region, southwest Scotland.

Area $253 \mathrm{ha}$

Degree of Protection The island of Inchcailloch within the site is owned by the Nature Conservancy Council and the remaining site area is privately owned and managed by the NCC under Nature Reserve Agreements (due for renewal in 1987 and 1991). The site is part of a national nature reserve of $416 \mathrm{ha}$ established in 1962 and extended in 1977. Designated as a Ramsar site at the time of ratification on 5 January 1976.

Site Description The site comprises five islands: Inchcailloch, Torrinch, Creinch, Clairinsh and the Aber Isle; part of the mainland shore; and marshy hinterland around the lower reaches of the River Endrick. The islands lie along the Highland Boundary Fault Line which is one of the major geological features of Scotland. The four larger islands have fine examples of semi-natural deciduous woodland with oak Quercus spp. dominant. Soil varies from acidic to base-rich with the acidic ground flora corresponding closely to a Vacciniumrich type. There are areas of alder carr, and species-rich zones around the shores of the islands. The shore portion comprises large areas of low-lying, regularly flooded wetlands, woodland fringes and rough pasture. The rough pasture covers at least half of the mainland area of the site, with scattered areas of greater botanical interest. The Ring Bog is a mesotrophic fen covered by a 
herb-rich flora, including sharp-flowered rush Juncus acutiflorus, with almost pure reed-canary grass Phalaris arundinacea in places. The slow-moving rivers and lagoons of the mainland are especially rich in aquatic invertebrates. The area is noted for waterfowl.

International and National Importance The area is a regionally important wintering refuge for waterfowl holding over 100 Greenland white-fronted geese Anser albifrons flavirostris and 3,000 (maximum) greylag geese Anser anser. In summer the area holds one of the largest inland breeding populations of shelduck Tadorna tadorna in Scotland, and a regionally important inland wader breeding population. The woodlands on the islands contain some of the highest recorded densities of breeding insectivorous birds in Britain. The shore wetlands contain several botanical rarities including eight-stamened waterwort Elatine hydropiper, thread rush Juncus filiformis and, at its only known locality in Britain, Scottish dock Rumex aquaticus.

Changes in Ecological Character The continuing apparent "drying out" of parts of the fen areas continues to give cause for concern. Colonisation of the area by shrub species is still occurring, particularly by willow Salix sp. This encroaching scrub is being cleared as it appears, but the underlying problem relating to changes in the hydrology of the area requires attention. The initial phases of a rehabilitation project have been completed with wide, deep canals having been dug around the periphery. This should enable the Nature Conservancy Council to pump "clean" water into the fen but keep polluted water out. Further phases are planned. There is some illegal shooting of waterfowl.

Management Practices Open grasslands are maintained by the use of domestic stock such as sheep and cattle, and annual cutting following flowering. Access to Inchcailloch, where there is a nature trail and camping site, is unrestricted, but access to the mainland portion is by permission of the reserve warden.

Scientific Research and Facilities Much research has been carried out on the fauna and flora including bird counts, vegetation mapping, land-use history (particularly of the islands), soils and geology. Universities are encouraged to carry out research on certain areas.

Principal Reference Material The above information is taken from the documents supplied by the Government of the United Kingdom for designation in 1976 and for the Cagliari Conference in November 1980.

Supplemented by:

- Duffey, E. (1982). National Parks and Reserves of Western Europe. Macdonald and Co., London

Additional references:

- Hunter, W.R. (1961). Annual variations in growth and diversity in natural populations of freshwater snails in the west of Scotland. Proc. Zoo. Soc. Lond. 136: 219-253.

- Idle, E.T. (1974). Botany. A natural history of Loch Lomond. Univeristy of Glasgow Press. Pp 24-35.

- Loch Lomond National Nature Reserve Management Plan and miscellaneous published and unpublished reports held by the Nature Conservancy Council, Dumbartonshire.

- Slack, H.D. (1957). Studies on Loch Lomond. Glasgow. 133pp.

\section{Lough Neagh and Lough Beg}

Location $54^{\circ} 40^{\prime} \mathrm{N}, 6^{\circ} 25^{\prime} \mathrm{W}$. Situated in the counties of Antrim, Londonderry, Tyrone, Armagh and Down in Northern Ireland.

Area 39,500 ha

Degree of Protection Lough Neagh and Lough Beg are Areas of Special Scientific Interest (ASSI). Lough Neagh ASSI contains the following National Nature Reserves (NNR) established under the Amenity Lands Act (Northern Ireland) 1965 and managed by the Department of the Environment: Randalstown Forest NNR owned by the Forest Service and managed by 
agreement; Farr's Bay NNR owned by Lord O'Neill (Shanes Castle) and managed by agreement; Rea's Wood Forest NNR owned by the Forest Service and managed by agreement; Oxford Island NNR owned by Craigavon Borough Council and managed by agreement; Lough Neagh Islands NNR (including most of the smaller islands) owned by Shaftsbury Estates and others and managed by agreement; and Annagariff and Mullenakill NNR owned and managed by the Department of the Environment. There are also two Wildfowl Refuges at Doss Bay and North-East Lough Neagh. Lough Neagh and Lough Beg are Category A sites on the Project MAR list. Designated as a Ramsar site at the time of ratification on 5 January 1976.

Site Description Lough Neagh is the largest lake in the British Isles covering some 38,300 ha and is connected to the sea through Lough Beg and the Lower Bann River. It is shallow with an average depth of less than $9 \mathrm{~m}$. Lough Beg covers $640 \mathrm{ha}$. The loughs lie in the western extension of the Bioland Valley of Central Scotland. The sedimentary basin which was formed in the Carboniferous period contains thick layers of Triassic, Rhaetic Liassic, Cretaceous and Tertiary rocks. Above this lies some $350 \mathrm{~m}$ thickness of Late Tertiary clays and sands. The vegetation around Lough Neagh is varied and includes mature woodland, scrub, fen, reed-swamp, water meadow and improved grassland. In the south away from the shore, are several peatland areas. Lough Beg to the north contains a diverse macrophyte flora. Lough Neagh is very eutrophic, with an extremely rich benthos (over 4,000 animals per square metre), nekton and plankton. The fauna contains two relicts from glacial times which are at the western end of their distribution: the pollan Coregonus lauaraetus and a freshwater shrimp Mysis relicta. Eel, brown trout, salmon and perch (Anguilla anguilla, Salmo trutta, Salmo salar and Perca fluviatilis are common and are exploited commercially. These fish and several bird species are dependant on the rich insect life on the lough, and particularly on the species of Chironomid midge which spend their larval stage on the lough bed. The otter Lutra lutra also occurs in this site.

International and National Importance The loughs and adjoining grasslands are important wintering and passage areas for Bewick's swan Cygnus columbianus bewickii (250-500), whooper swan C. cygnus (400-700), teal Anas crecca (1,500-2,000), pochard Aythya ferina (17,000 but 41,000 maximum in the recent past), tufted duck $A$. fuligula $(6,500-8,000$ but with up to 20,000 in the recent past), scaup $A$. marila $(600-1,200)$ and goldeneye Bucephala clangula (3000-5,000). The numbers of pochard constitute $4.9 \%$ of the northwest European population and tufted duck 1\%. Other waterfowl species are mute swan Cygnus olor (300-400), wigeon Anas penelope, mallard A. platyrhynchos, shoveler A. clypeata and coot Fulica atra. In the breeding season the shores and islands provide nesting sites for several species of duck as well as gulls, terns waders and probably the largest population of great crested grebe Podiceps cristatus in the British Isles. The fauna also includes many rare invertebrates. The eel population is of international importance. The site contains a number of plant species listed in the Red Data Book including eight-stamened waterwort Elatine hydropiper (rare), summer snowflake Leucojum aestivum (rare), Irish ladies-tresses Spiranthes romanzoffiana (rare), holy-grass Hierochloe odorata (rare) and penny royal Mentha pulegium (vunerable). Botanically important sites include the peatland areas to the south of Lough Neagh and also Lough Beg where diversity of macrophytes is unparalleled elsewhere in Northern Ireland.

Changes in Ecological Character The water regime of Lough Neagh has been greatly changed from the natural state. Originally it was subject to considerable rise in water level during winter resulting in extensive innundation of the surrounding land especially in the south. The seasonal variation of water level has now been greatly reduced and the lough level has been lowered several times (the latest in 1959). There are several wetlands on the boundary of Lough Neagh ASSI which were formerly flooded but which now appear to be separated from the lough by dry land. The major threat to Lough Neagh would be a continual increase of eutrophication. Land reclamation is a major threat especially scrub clearance which has resulted in degradation of some shoreline habitats. A way from the lough shore drainage is a threat to some of the smaller wetlands. Other problems include over-fishing, sand extraction, shooting pressure and scrub encroachment on some islands. 
Management Practices The Department of the Environment (Northern Ireland) has recently implemented a capital programme for phosphate removal at the ten large sewage treatment works in the Lough Neagh catchment. Habitat management for breeding waterfowl is carried out in Lough Neagh Islands NNR and North-East Lough Neagh Wildfowl Refuge. Shooting is prohibited in North-East Lough Neagh and Dross Bay Wildfowl Refuges and Oxford Island NNR, and in a series of voluntary refuges established by the Wildfowlers clubs.

Scientific Research and Facilities Monthly wildfowl counts were carried out between 1965 and 1969 by a voluntary club and were re-commenced under Department of the Environment (Northern Ireland) control in 1985. Intermittent total counts were made in the intervening years. The joint Departments of Agriculture and Environment Freshwater Biological Investigation Unit at Greenmount and the New University of Ulster Limnology Laboratory at Traad Point use Lough Neagh for most of their research.

Principal Reference Material The above information is taken from the documents supplied by the Government of the United Kingdom for designation in 1976 and for the Cagliari Conference in November 1980.

Supplemented by:

- Luther, H. and Rzoska, J. (1971). Project Aqua. IBP Handbook No. 21. Blackwell Scientific Publications.

Additional references:

- Anon. (1968). Lough Neagh, Northern Ireland. OECD Symposium on large lakes and impoundments, Sweden. Government of Northern Ireland.

- Dakin, W.J. and Latarche, M. (1913). The plankton of Lough Neagh. Proc. Roy. Irish Acad. B 30: 20-96.

- Edwards, C. (1958). Gammarids of Lough Neagh. Unpublished Thesis, Queens University, Belfast.

- Frost, W.E. (1950). The eel fisheries of the River Bann, Northern Ireland and observations on the age of silver eels. J. Com. Internat. L'explore Mer. XVI (3).

- Graham, T.R. (1970). The zooplankton of Lough Neagh 1968-69. Irish Nat. J. 16: 265-271.

- Macan, T.T. and Lund J.W.G. (1954). Records from some Irish Lakes. Part 1. Proc. Roy. Irish Acad. B 56: 135-137.

- Smith, R.V. (1977). Domestic and agricultural contributions to the imputs of phosporus and nitrogen to Lough Neagh. Water Research II: 433-459.

- Wood, R.B. and Gibson, C.E. (1973). Eutrophication and Lough Neagh Water. Research 7: 173-187.

\section{Minsmere-Walberswick}

Location $52^{\circ} 17^{\prime} \mathrm{N}, 1^{\circ} 37^{\prime} \mathrm{E}$. Situated on the Suffolk coast in England. Walberswick is $20 \mathrm{~km}$ south of Lowestoft. Minsmere is $3 \mathrm{~km}$ south of Dunwich.

Area 1,697ha

Degree of Protection Ownership is divided: the Nature Conservancy council manage 514ha of Walberswick as a NNR and in 1986 leased another 42 ha which will be included in the NNR. Walberswick was established as a National Nature Reserve in 1972, most of the reserve is managed by the Nature Conservancy Council under a Nature Reserve Agreement which is due for renewal in 1993 (the remainder being part leased and part owned by the Nature Conservancy Council). The Royal Society for the Protection of Birds (RSPB) own 588 ha at Minsmere which has had Nature Reserve status since 1948 and is a RSPB non-statutory reserve. The National Trust own and manage 85 ha at Dunwich Heath. The remaining 452 ha are in private ownership or owned by Walberswick Common Lands Charity. It is a Site of Special Scientific Interest and a Category A site on the Project MAB list. Designated as a Ramsar site at the time of ratification on 5 January 1976. 
Site Description Minsmere is a river valley that was drained and reclaimed as a grazing marsh in the 19th century but flooded in 1940 as a war-time defence measure. There are now extensive reedbeds, freshwater meres (lakes) and an area (16ha) of man-made brackish lagoons and islets known as the Scrape. The land slopes down from high ground at Westleton in the north to the Minsmere Valley in the south. The eastern boundary is protected from the North Sea by a shingle beach and clay embankment. The vegetation of the valley is dominated by common reed Phragmites australis. There is an expanding colony of marsh sowthistle Sonchus palustris but the marsh flora is poorly developed due to its recent origin. The higher ground has heathland comprising mainly heather Calluna vulgaris with bell heather Erica cinerea, bracken Pteridium aquilinum and gorse Ulex europaeus locally dominant and extensive woods of secondary origin with oak Quercus robur predominant but good representation of Scots pine Pinus sylvestris, silver birch Betula pendula and downy birch $B$. pubescens.

Walberswick, which is just north of Minsmere, consists of a gentle ridge between the tidal mudflats of the River Blythe to the north and extensive reedbeds and shallow meres of Westwood marshes to the south. The valleys were reclaimed for grazing but the river walls have either become derelict or have been breached for wartime defence so that the valleys have reverted to mudflats and reedbeds. There are extensive areas of acidic heathland on the high ground between the valleys, dominated by bracken with bell heather, gorse, broom Cytisus scoparius and grassheath of bent grass Agrostis sp. and sheep's fescue Festuca ovina. There is some carr woodland with some 19th century plantations of oak, Scots pine and silver/downy birch and also considerable natural regeneration on former heathland. The reedbeds are almost pure stands of common reed. The saltmarshes are dominated by sea purslane Halimione portulacoides with some sea aster Aster tripolium, sea lavender Limonium vulgare and glasswort Salicornia sp. The fauna of the site includes red deer Cervus elaphus and a diverse bird community. Adder Vipera berus and lizard Lacerta vivipara occur and over 250 species of Lepidoptera have been recorded.

International and National Importance The site is of prime ornithological importance with over 220 bird species recorded annually including 99 breeding species such as marsh harrier Circus aeruginosus, nightjar Caprimulgus europaeus, nightingale Luscina megarhynchos, bearded tit Panurus biarmicus, reed warbler Acrocephalus scirpaceus, sedge warbler A. schoenobaenus, cetti's warbler Cettia cettia, garganey Anas querquedula, Savi's warbler Locustella luscinioides, redstart Phoenicurus phoenicurus, bittern Botaurus stellaris, water rail Rallus aquaticus, gadwall Anas strepera, avocet Recurvirostra avosetta, common tern Sterna hirundo, little tern $S$. albifrons and sandwich tern $S$. sandvicensis. The site is an important staging point for migrant waterfowl particularly shelduck Tadorna tadorna of which there is a substantial breeding population, redshank Tringa totanus, black-tailed godwit Limosa limosa and dunlin Calidris alpina. There is a regular winter population of Bewick's swan Cygnus columbianus bewickii. The white-mantled wainscot moth Nonagria neurica, which is scarce in Britain, also occurs.

Changes in Ecological Character Encroachment by bracken and scrub is a problem both at Minsmere and Walberswick. This is being tackled by management.

Management Practices The Scrape at Minsmere requires intensive management: mainly removal of encroaching vegetation by handpulling, mowing and spraying (although input into this management technique is being reduced) and removal of silt. Sprays are also used to control reed and bracken. Invading birch on the heathland is removed. There was intensive ditching work in the reedbeds in 1980 . Waterlevels are carefully controlled to create optimum feeding conditions and prevent flooding after periods of heavy rain. Other management acvitities include control of the main pests: coypu Myocastor coypus, brown rat Raltus norvegicus and rabbit Oryctolagus cuniculus. At Walberswick the reeds are cut annually for thatching. Walberswick is partially open to the public, but access to Minsmere is by permit only and limited to six days per week from April to mid-September. The policy at Minsmere was to be reviewed late in 1986, but was likely to remain unchanged. There are two public hides overlooking the scrape which are open to the public every day. 
Scientific Research and Facilities Research at Minsmere is concentrated on survey and monitoring work, particularly of breeding birds such as avocet, black-headed gull Larus ridibundus, nightjar, bittern, little tern, common tern and marsh harrier. Surveys have included the aquatic macrophytes of the newly excavated ditches and the marine molluscs of Minsmere. Since 1983 MAFF have been doing ecological studies on eel populations at Walberswick.

Principal Reference Material The above information is taken from the documents supplied by the Government of the United Kingdom for designation in 1976 and for the Cagliari Conference in November 1980.

Supplemented by:

- Carp, E. (1980). A Directory of Western Palearctic Wetlands. IUCN, Gland, Switzerland.

- European Committee for the Conservation of Nature and Natural Resources (1982). Minsmere Nature Reserve, UK. Category A. Annual Report for 1981. Strasbourg 1982.

- IUCN (1977). World Directory of National Parks and Other Protected Areas. IUCN, Morges, Switzerland.

Additional references:

- Conder, P. (1964). Notes on the management of freshwater reed marsh of Minsmere and saltwater lagoons of Havergate Island, Suffolk, England. In Project MAR. Proceedings of the Conference on conservation and management of temperate, marshes, bogs and other wetlands held at Les Saintes-Maries-de-la-Mer 1962. IUCN Publ. New Series 3: 302-317. Morges, Switzerland.

- Regular reports in the RSPB Journal 'Birds' and occasional papers in 'British Birds'.

\section{North Norfolk Coast}

Location $52^{\circ} 30^{\prime} \mathrm{N}, 0^{\circ} 41^{\prime} \mathrm{E}$. East Anglia, England.

\section{Area $5,559 \mathrm{ha}$}

Degree of Protection The Ramsar site comprises four separate units: Scolt Head National Nature Reserve (737ha) established in 1954, owned by the National Trust and Norfolk Naturalists Trust and leased and managed by the Nature Conservancy Council; Holkham National Nature Reserve (3,953ha) established in 1967, part-managed by the NCC under a nature reserve agreement with the owners (due for renewal in 1988) and the remainder leased by the NCC from the Crown Estate Commissioners; Blakeney Point declared as a Site of Special Scientific Interest in 1954, owned and managed by the National Trust under the National Trust Act 1907; and Cley and Salthouse Marshes SSSI which includes the former Cley Marshes Statutory Bird Sanctuary established in 1966, managed by the Norfolk Naturalists Trust, now incorporated in the Notrh Norfolk Coast SSSI in February 1986 as a composite site of 7,200ha, the whole of which will extend the Ramsar site. 5,497ha of the area was approved as a Biosphere Reserve in June 1976. An area of 5559ha were designated as a Ramsar site at the time of ratification on 5 January 1976.

Site Description The site is mainly intertidal sand and mud, shingle, sand-dunes and salt marshes. It includes a shingle spit at Blakeney which forms the foundation for extensive ridges of sand-dunes and is of considerable physiographical interest. An offshore shingle bank at Scolt Head capped by sand-dunes contains a succession of saltmarshes of varying ages on the landward side and one of the largest saltmarshes in England at Holkham. Dune grassland is dominated by sand couch grass Elymus farctus, marram grass Ammophilia arenaria or sand sedge Carex arenaria depending on the height above high tide level and the degree of encroachment by fresh blown sand. On a dune area at Holkham, dense natural regeneration has occurred seaward to a plantation of Corsica pine Pinus nigra var. maritima. The pines were planted between 1853 and 1890 to assist stabilisation of the dunes. Holkham also contains a small area of deciduous woodland and large area of agricultural land (half arable/half pasture) derived from reclaimed saltmarsh. Maritime pasture at Cley and Salthouse Marshes includes jointed rush Juncus articulatus, silverweed Potentilla anserina, marsh foxtail Alopecurus geniculatus and annual beard-grass Polypogon monspeliensis - all plants of 
damp grazing areas. Shingle ridge colonists include shrubby seablite Suaeda vera, yellow-horned poppy Glaucium flavum, sea campion Silene maritima, stonecrop Sedum acre, curled dock Rumex crispus var triangulivalvis and birdsfoot trefoil Lotus corniculatus. Sea wormwood Artemisia maritima and purslane Halimione portulacoides occur in the transition zone between shingle and marsh. The saltmarsh succession is typified by glassworts Salicornia spp., sea aster Aster tripolium, sea lavender Limonium vulgare, purslane (particularly fringing creeks), saltmarsh grass Puccinellia maritima, thrift Armeria maritima and sea wormwood. The intertidal flats mainly comprise unvegetated sand and shingle. Some mud flats have seasonal growths of eel grass Zostera sp. and green algae Entermorpha spp. and Vaucheria spp. There are extensive reedbeds of Phragmites australis at Cley and Salthouse Marshes due to brackish conditions caused by a spring and freshwater drain. Also present are mud rush Juncus gerardi, Ranunculus baudottii, false foxsedge Carex otrubae, sea clubrush Scirpus maritimus, bur-reed Sparganium erectum and great reedmace Typha latifolia. The North Norfolk Coast is of great ornithological interest. Fauna also includes otter Lutra lutra, natterjack toad Bufo calamita and common lizard Lacerta vivipara. The red squirrel Sciurus vulgaris has not been reported since 1981. The mudflats and creeks have locally abundant concentrations of invertebrates which are important as a food source for waterfowl.

International and National Importance One of the largest breeding colonies (maximum 4,500 pairs) of sandwich tern Sterna sandvicensis in the United Kingdom occurs at Scolt Head and Blakeney Point, constituting about $1 / 12$ of the world population. Blakeney Point supports the largest colony of little tern Sterna albifrons in Western Europe. Other important breeding birds include common tern Sterna hirundo, bearded tit Panurus biarmicus, bittern Botaurus stellaris, marsh harrier Circus aeruginosus and avocet Recurvivostra avosetta. The geographical position of the North Norfolk Coast, and the wide range of habitats, make it particularly valuable for migratory birds including numerous waders and, in winter, large numbers of Brent goose Branta bernicla, and smaller numbers of pink-footed goose Anser brachyrhynchos and white-fronted goose Anser albifrons. The site is also of great importance for coastal physiography, and classic studies of the processes of the formation of shingle, sand-dune and salt-marsh systems. It is of international interest for the distinctive age series of marshes enclosed by shingle spit recurves, as well as a great variety of marsh development.

Changes in Ecological Character At Holkham the ecological character has been changed by the planting of Corsican pine and by reclamation of 700 ha of saltmarsh for agriculture during the 17-19th centuries. Much of the old creek patterns and flora have been destroyed by cultivation. An attempt to reclaim another area of saltmarsh failed, but the canalised creeks still remain. Blakeney and parts of the west Holkholm have intensive tourist use during July-September. At Cley and Salthouse Marshes the remains of several saltwater broads are being reduced by the inexorable landward movement of shingle during storms, and the construction of sea walls in the 17 th century has enabled part of the area to be grazed by cattle. At Blakeney a number of buildings have been constructed including a lifeboat house (now used for other purposes).

Management Practices The primary management objective is to allow the natural processes of physiographic evolution and vegetative succession to proceed with minimal interference. Positive management mainly concerns care and maintenance of the sand-dunes. Controlled flooding is practised over much of the bird sanctuary at Cley Marshes. Public access to Scolt is unrestricted except during the bird breeding season. Holkham has open access to all areas except farmland. Blakeney has unrestricted access except when the ternery is occupied (when visitors to this area must be accompanied by the warden). Some wildfowling is allowed at Cley and Salthouse Marshes and elswhere at Holkham and Scolt Head.

Scientific Research and Facilities The Nature Conservancy Council and many universities use the area for research, and there is a wide range of past and current ecological studies. The flora and fauna of Blakeney Point has been studied since 1920, and the physical geography of Scolt Head Island. 
Principal Reference Material The above information is taken from the documents supplied by the Government of the United Kingdom for designation in 1976 and for the Cagliari Conference in November 1980.

Supplemented by:

- IUCN (1977). World Directory of National Parks and Other Protected Areas. IUCN, Morges, Switzerland.

\section{Ouse Washes}

Location $52^{\circ} 30^{\circ} \mathrm{N}, 0^{\circ} 13^{\circ} \mathrm{E}$. The washes begin $17 \mathrm{~km}$ almost due north of Cambridge. The midway point is $7 \mathrm{~km}$ northwest of Ely. Situated in the counties of Cambridgeshire and Norfolk, England.

\section{Area $2,276 \mathrm{ha}$}

Degree of Protection 1,132.4ha is owned or leased by conservation agencies: Royal Society for the Protection of Birds 875 ha; Wildfowl Trust $313 \mathrm{ha}$; Cambridge and Isle of Ely Naturalist Trust Ltd 158ha; and Bedfordshire and Huntingdonshire Naturalist Trust 3.4 ha maintained as a non-statutory reserve. The remaining area is divided among a large number of private owners. 2,106ha are classified as a National Wildfowl Refuge and the whole area is a Site of Special Scientific Interest. Designated as a Ramsar site at the time of ratification on 5 January 1976.

Site Description The Ouse Washes comprise a stretch of grassland about $30 \mathrm{~km}$ long and $800 \mathrm{~m}$ wide lying between two canalised watercourses, the New and Old Bedford Rivers. These rivers receive run-off from a large area of eastern England and carry it across the intensively cultivated East Anglian Fenland which in places is below sea level. The rivers are embanked on the outer side only and the grassland between them is used as a flood-relief reservoir. The depth and duration of the flooding varies with rainfall and season, and this is reflected in the vegetation. The wetter areas are dominated by reed sweetgrass Glyceria maxima and floating sweetgrass $G$. fluitans, and the drier parts by reed canary-grass Phalaris arundinacea and bent grasses Agrostis spp. Spike rushes Eleocharis spp. and sedges Carex spp. are abundant and provide important food for waterfowl. The genera Juncus (rushes), Oenanthe (water dropwort) and Polygonum are well represented. The ditches carry a great variety of aquatic plants such as fringed water-lily Nymphoides peltata, water parsnip Sium Latifolium and all four species of duckweed Lemna. Although the washes are about $20 \mathrm{~km}$ from the sea, relicts of former marine flooding still occur such as sea aster Aster tripolium, wild celery Apium graveolens and sea rush Scirpus maritimus. Small stands of willow Salix spp. are also present. In the winter and spring the area attracts many species of waterfowl.

International and National Importance The Ouse Washes are of outstanding importance as the largest inland gathering for wildfowl in Britain. During winters 1975-84 the washes held peak numbers of about 30,000 Anatidae (maximum 62,400). Wigeon Anas penelope has reached an average level of 25,358 (maximum 42,500), teal $A$. crecca 3,182 (maximum 7,570), pintail A. acuta 1,342 (maximum 3,260) and Bewick's swan Cygnus columbianus bewickii 2,528 (maximum 5,227). The maximum numbers of other species recorded in the same period have been mallard Anas platyrhynchos 6,337, shoveler A. clypeata 685, pochard Aythya ferina 4,900, mute swan Cygmus olor 643 and whooper swan Cygnus cygnus 248. A further 14 species were present in small numbers. In the summer the washes attract many breeding birds particularly common snipe Gallinago gallinago, lapwing Vanellus vanellus and redshank Tringa totanus. The area also supports one of the few breeding colonies of black-tailed godwit Limosa limosa (20 pairs) in Britain, and is an occasional breeding site of ruff Philomachus pugnax. The washes are also important as the largest area of regularly flooded freshwater grazing marshland left in Britain. The marshes are rich botanically with $44 \%$ of British aquatic species occurring here.

Changes in Ecological Character Late spring and summer flooding, probably due to increased upstream drainage, is of detriment to bird breeding and prevents essential grazing. 
Management Practices The area is managed to provide optimum conditions for breeding and wintering waterfowl, and methods include controlled grazing, hay-cutting and, so far as possible, control of water levels. Shooting is restricted in places which are important primarily as breeding sites. The shooting rights over the area outside the refuges belong to the individual owners. Other management practices include the coppicing of willow to provide osier wands, and double ditching to provide secure nesting sites.

Scientific Research and Facilities Research includes detailed investigations of wildfowl and waders, a study of the colonisation of the area by black-tailed godwit, and conservation methods in relation to increased flooding, research into management problems, an aquatic plant survey and detailed research into the biology of the snipe.

Principal Reference Material The above information is taken from documents supplied by the Government of the United Kingdom for designation in 1976, for the Cagliari Conference in November 1980 and for the Groningen Meeting in 1984.

Supplemented by:

- Carp, E. (1980). A Directory of Western Palearctic Wetlands. IUCN, Gland, Switzerland. Additional references:

- Grose, M. and Allen, D. (1978). A survey of Ouse Washes water plants. R.S.P.B., Anglian Water Authority Report. $125 \mathrm{pp}$.

- Thomas, G.J. (1975). Ingested lead pellets in Ouse Washes water birds 1968-1973. Wild fowl 26: 43-48.

- Thomas, G.J. (1976). Habitat usage of wintering ducks at the Ouse Washes, England. Wild fowl 27.

- Thomas, G.J. (1978). Lead poisoning in wildfowl and ways of reducing it. International Waterfowl Research Bureau Bulletin 45: 27-31.

- Thomas, G.J. (1978). Breeding and feeding ecology of waterfowl at the Ouse Washes, England. PhD Thesis. Council for National Academic Awards. 293pp

\section{Rannoch Moor}

Location $56^{\circ} 39^{\prime} \mathrm{N}, 4^{\circ} 40^{\prime} \mathrm{W}$. Situated in Perth and Kinross District, Tayside Region in Scotland.

Area 1,499 ha

Degree of Protection Part of Rannoch Moor was established as a National Nature Reserve in 1958 and is owned by the Nature Conservancy Council. Designated as a Ramsar site at the time of ratification on 5 January 1976.

Site Description A glaciated low-lying area surrounded by uplands. The area has a complex relief characterised by morainic and granitic knolls, peat-filled depressions and numerous lochs of varying size. Temperate moist oceanic climate. Altitude $300-500 \mathrm{~m}$. On the broad flats and more gentle slopes blanket bog of the western type with deer sedge Trichophorum cespitosum (dominant), hare's tail cottongrass Eriophorum vaginatum and bog asphodel Narthecium ossifragum has developed. The water bogs are often drained by soaks, and where slight slopes or hollows occur there are patches of oligotrophic soligenous mire. Sometimes these seepage areas discharge into small peaty lochs with hydroseral swamps around their edges. The soligenous sites are commonly marked by an abundance of bottle sedge Carex rostrata, common sedge $C$. nigra, slender sedge $C$. lasiocarpa, mud sedge $C$. limosa, the rush Juncus bulbosus, greater bladderwort Utricularia vulgaris, intermediate bladderwort $U$. intermedia and lesser bladderwort $U$. minor, but those forming at the base of the moraines are dominated by purple moorgrass Molinia caerulea. The extent of marginal swamps and fen vegetation around the loch edges varies greatly, but typically there are open water communities dominated by sedge species, abundant bogbean Menyanthes trifoliata, common cottongrass Eriophorum angusifolium and sometimes waterlily $N y$ mphaea $\mathrm{sp}$. cf occidentalis, marsh 
cinquefoil Potentilla palustris and common reed Phragmites australis. The Carex swamp usually passes into a shoreward zone of spongy Sphagnum flats often with well developed pool-hummock systems. The fauna includes red deer Cervus elaphus and a number of typical moorland species.

International and National Importance The site is important for containing a diverse complex of northern oligotrophic mire types, and Rannoch Moor is the only known location in Britain for Rannoch rush Scheuchzeria palustris. This species was common in Britain at the time of flooding of bog surfaces at the opening of the sub-Atlantic period, but has disappeared from its few other known localities during the past hundred years or so. The moor supports some notable breeding birds including red grouse Lagopus 1 . scoticus, golden plover Pluvialis apricaria, greenshank Tringa nebularia, dunlin Calidris alpina, short-eared owl Asio flammeus and merlin Falco columbarius.

Changes in Ecological Character A planning application for the development of a fish farm on the edge of this site has been refused, but there may be further pressures for fish-farming and fishing in the area. There is potential risk of pollution from pesticides and fertilisers used on the extensive commercial forests adjacent to the reserve. Red deer numbers have recently declined due possibly to adjacent fencing of land for afforestation.

Management Practices Active management is considered inappropriate at this stage; management objectives aim to maintain the status quo of factors influencing the reserve.

Scientific Research and Facilities Research is mainly directed to the maintenance of the existing range of bog structure and vegetation. There is also research in a small fenced enclosure into the establishment of Scots pine Pinus sylvestris, birch Betula spp. and alder Alnus glutinosa together with hydrological research on the blanket bog.

Principal Reference Material The above information is taken from the documents supplied by the Government of the United Kingdom for designation in 1976 and for the Cagliari Conference in November 1980.

Additional references:

- McVean, D.N. and Ratcliffe, D.A. (1962). Plant communities of the Scottish Highlands. A study of Scottish mountain, moorland and forest vegetation. Monographs of the Nature Conservancy No. 1., London HMSO.

\section{Cairngorm Lochs}

Location $58^{\circ} 04^{\prime} \mathrm{N}, 3^{\circ} 47^{\prime} \mathrm{W}$. Situated in the districts of Moray, Kincardine and Deeside, Badenoch and Strathspey and Inverness of the Grampian and Highland regions, Scotland.

Area 179 ha

Degree of Protection The Cairngorm Lochs are privately owned but are subject to a Nature Reserve Agreement with the Nature Conservancy Council. The lochs are part of the Cairngorms National Nature Reserve $(25,949 \mathrm{ha})$ which was declared in 1954 . Designated as a Ramsar site in July 1981.

Site Description The lochs include Avon, Etchachan, Uaine, Einich and Coire and Lochain. The highest are corrie lakes at about $1,000 \mathrm{~m}$ and the larger glacial lakes occupy lower glens. The underlying rock is granite, and all the lochs are extremely oligotrophic. The shorelines comprise mainly ice-polished boulders. The lochs have a continuous ice cover from December to May in most winters.

International and National Importance These lochs are the highest standing waters in Britain and are of an Arctic-alpine nature. In winter specialised populations of phytoplankton and zooplankton develop below the ice. 
Changes in Ecological Character No information

Management Practices Access to the Cairngorm National Nature Reserve is unrestricted apart from visitors being asked to cooperate with the Nature Conservancy Council and estates during August, September and October when deer culling may be taking place.

\section{Scientific Research and Facilities No information}

Principal Reference Material The above information is taken from the document supplied by the Government of the United Kingdom for designation in 1981.

Supplemented by:

- Nature Conservancy Council (1981). National Nature Reserves in Scotland. Information Sheet No. 4.

\section{Loch of Lintrathen}

Location $56^{\circ} 41^{\prime} \mathrm{N}, 3^{\circ} 11^{\prime} \mathrm{W}$. Situated $11 \mathrm{~km}$ west of Kirriemuir in the district of Angus, Tayside region, Scotland.

\section{Area 218 ha}

Degree of Protection Loch Lintrathen is owned by Tayside Regional Council and is a Site of Special Scientific Interest. Part of the area is currently managed as a nature reserve by the Scottish Wildlife Trust - a voluntary conservation organisation. Designated as a Ramsar site in July 1981.

Site Description The loch occupies a glacial basin and is large and quite deep, having been deepened by being artificially dammed. It is used as a water supply reservoir and is oligotrophic/mesotrophic.

International and National Importance The loch is important for high numbers of greylag geese Anser anser with a winter average of 2,822 ( $3.1 \%$ of the UK and European population), and a peak count of $6,200(6.9 \%)$ during 1980-85. Other regularly occurring wildfowl species include mallard Anas platyrhynchos, teal $A$. crecca, wigeon $A$. penelope, shoveler $A$. clypeata, tufted duck Aythya fuligula, pochard A. ferina, goosander Mergus merganser and whooper swan Cygnus cygnus.

\section{Changes in Ecological Character None known.}

\section{Management Practices None known.}

Scientific Research and Facilities The Loch of Lintrathen was studied as part of the Survey of Freshwaters of Tayside (1981). A viewing hide is provided for members of the Scottish Wildlife Trust and is opened to the general public periodically in spring and autumn.

Principal Reference Material The above information is taken from the document supplied by the Government of the United Kingdom for designation in 1981.

Supplemented by:

- Maitland, P.S., Smith, I.R., James, D.H., East, K., Morris, K.H. and Lyle, A.A. (1981). The Freshwaters of Tayside. Institute of Terrestrial Ecology report to the Nature Conservancy Council.

- Scott, D.A. (1980). A preliminary inventory of wetlands of international importance for waterfowl in west Europe and north-west Africa. IWRB Special Publication No. 2. Glos, England. 


\section{Claish Moss}

Location $56^{\circ} 45^{\prime} \mathrm{N}, 5^{\circ} 44^{\prime} \mathrm{W}$. Situated in the district of Lochaber in western Scotland.

\section{Area 563ha}

Degree of Protection Claish Moss is owned by the Nature Conservancy Council and was declared a national nature reserve in 1979. The area was approved as a Biosphere Reserve in January 1977. Designated as a Ramsar site in July 1981.

Site Description The area represents a patterned raised mire typical of the hyper-oceanic climatic conditions of north west Scotland. The vegetation is typical of Sphagno-Trichophoreto-Eriophoretum (sphagnum moss - cotton grass) with well developed Rhacomitrium hummock facies. Many species characteristic of western blanket mire are present including purple moorgrass Molinia caerulea, the liverwort Pleurozia purpurea, the moss Campylopus atrovirens, many-stemmed spike-rush Eleocharis multicaulis, mud sedge Carex limosa, great sundew Drosera anglica and sweet gale Myrica gale. The fauna includes red deer Cervus elaphus, otter Lutra lutra, red grouse Lagopus $l$. scoticus and greenshank Tringa nebularia. The aquatic fauna includes eight species of dragonfly.

International and National Importance The site is an internationally important peatland. The large size and total scale of the raised mires is unparallelled in Britain. The brown beak-sedge Rhynchospora fusca, a plant of very restricted occurrence, is abundant in pools on some parts of the mire. Of particular importance is the community of sphagnum mosses, comprising 14 species, including several at the nortinern limit of their range. The site regularly supports a small population of wintering Greenland white-fronted geese Anser albifrons.

Changes in Ecological Character Although grazed by sheep until recently, the area has suffered little deterioration except by occasional uncontrolled fires which have resulted in some modification of the vegetation.

Management Practices Public access is restricted.

Scientific Research and Facilities The site has potential for research into stratigraphical and pollen analyses.

Principal Reference Material The above information is taken from the documents supplied by the Government of the United Kingdom for designation in 1981.

Supplemented by:

- Biosphere Reserve proposal sent to Unesco-MAB secretariat.

- Moore, P.D (1977). Stratigraphy and pollen analysis of Claish Moss. J. Ecol. 65: 375-397.

- Ratcliffe, D.A. (1977). A Nature Conservation Review. Cambridge University Press.

\section{Silver Flowe}

Location $55^{\circ} 07^{\prime} \mathrm{N}, 4^{\circ} 23^{\circ} \mathrm{W}$. Situated $17 \mathrm{~km}$ north of Newton Stewart in Wigtown and Stewartry districts, Dumfries and Galloway region, south-west Scotland.

Area $608 \mathrm{ha}$

Degree of Protection Owned by the Forestry Commission, but 200 ha is leased to the Nature Conservancy Council. 191ha of this was leased on 11 November 1955 for a term of 99 years and declared a National Nature Reserve in 1956. The remaining 9ha were leased on 11 November 1963 for a term of 91 years, but this area has not yet been declared. The site is part of the Silver Flowe - Merrick Kells Biosphere Reserve $(3,088 \mathrm{ha})$ which was approved by the MAB Bureau in June 1976. Designated as a Ramsar site in July 1981. 
Site Description The upland area at about $822 \mathrm{~m}$ is part of a glaciated plateau with extensive corries and well developed peri-glacial features. The broad glaciated valley at about $228 \mathrm{~m}$, containing the Silver Flowe, is floored with a series of patterned blanket mires exhibiting a complete gradation from discrete valley mire to blanket mire. The mire is dominated by deer grass/ cotton grass Trichophoreto-Eriophoretum with an oceanic element indicated by the abundance of the mosses Campylopus atrovirens and Sphagnum plumulosum, great sundew Drosera anglica and liverwort Pleurozia purpurea. The eastern slopes overlying granite support a sub-montane vegetation including Molinietum and damp Callunetum. The extensive north-facing cliffs support a few notable montane species. The fauna includes red deer Cervus elaphus and feral goats Capra hircus.

International and National Importance This series of patterned blanket mires constitutes the least disturbed and most varied extent of acid peatland in southern Scotland and is one of the most important systems of blanket mire in Britain. The considerable variety of surface pattern is remarkable, especially in view of the relatively small area of the series. The site is also of interest as the most southerly development of oceanic blanket mire vegetation. A few pairs of peregrine falcon Falco peregrinus and raven Corvus corax breed in the area. The blue dragonfly Aeschna caerulea occurs in the pools of the mire system.

Changes in Ecological Character The area has been grazed by sheep and burnt by man in the past, but is now largely undisturbed. Some past gravel extraction from rivers has taken place. There is extensive conifer afforestation outside the National Nature Reserve.

Management Practices Public access is restricted. A walkway has been constructed to allow research workers access to experimental plots with minimum disturbance to the mire surface.

Scientific Research and Facilities Much past and current research on the stratigraphy, hydrology and phytosociology of the mire systems. There has also been extensive research on the contact metamorphism of the granite aureole. Universities are encouraged to utilise the site for research.

Principal Reference Material The above information is taken from documents supplied by the United Kingdom Government for designation in 1981.

Supplemented by:

- Boatman, D.J. (1983). The Silver Flowe National Nature Reserve, Galloway, Scotland. J. Biogeogr. 10: 163-274.

- Carp, E. (1980). A Directory of Western Palearctic Wetlands. IUCN, Gland, Switzerland.

- IUCN (1977). World Directory of National Parks and Other Protected Areas. IUCN, Morges, Switzerland.

Additional references:

- Goode, D.A. (1970). Ecological studies on the Silver Flowe National Nature Reserve. PhD Thesis. University of Hull.

\section{Abberton Reservoir}

Location $51^{\circ} 49^{\prime} \mathrm{N}, 0^{\circ} 52^{\prime} \mathrm{W}$. Situated some $8 \mathrm{~km}$ south of Colchester in the county of Essex, England.

Area $1,228 \mathrm{ha}$

Degree of Protection Abberton Reservoir is owned by the Essex Water Company. 1,188ha is a bird sanctuary established under the Wild Birds (Abberton Reservoir Sanctuary) Order in 1967 and protected under the Protection of Birds Act 1954. The ieservoir is also notified as a Site of Special Scientific Interest and is included as a Category A wetland in the International MAR List. Designated as a Ramsar site in July 1981. 
Site Description Abberton is a permanent lowland reservoir of 485 ha with an average depth of $4.7 \mathrm{~m}$ (maximum about $16 \mathrm{~m}$ ) and water volume of approximately 23,000 million litres, some from the dammed Layer Brook, but most extracted from the River Stour and pumped $18 \mathrm{~km}$ to Abberton. The reservoir has been in use since 1941. The designated site includes all the open water and a surrounding area of land at least one field's distance from the shoreline. This encloses the entire catchment of the reservoir up to $30 \mathrm{~m}$ above sea level. The reservoir is bordered by farmland, and a proportion of the land inside the catchment must be maintained as grassland. The lake is divided by causeways into three basins: the largest (about $400 \mathrm{ha}$ ) has concrete banks, and the other two are fringed by a belt of greater reedmace Typha latifolia, reed canary grass Phalaris arundinacea and rushes Juncus spp. Summer draw-down exposes extensive mudflats in the two largest basins. The reservoir is highly eutrophic and subject to algal blooms. In the more natural sections there is a fairly typical invertebrate fauna for a eutrophic lake. A varied coarse-fish population is also present. The area is noted for waterfowl.

International and National Importance The reservoir is outstandingly important as an autumn arrival point and a wintering locality for migrant Anatidae including mute swan Cygnus olor which exceeds 500, coot Fulica atra up to 10,000, mallard Anas platyrhynchos 2,250 $(5,240)$, teal $A$. crecca $2,250(5,240)$, wigeon $A$. penelope $6,280(11,830)$, shoveler $A$. clypeata $450(850)$, pochard Aythya ferina $800 \quad(1,410)$, tufted duck A. fuligula $1,520(2,670)$ and goldeneye Bucephala clangula 485 (610) (first figure is average autumn winter peak, second figure in parenthesis is maximum peak for ten years up to 1986). It is an important moulting area for $2,270(4,000)$ pochard and $2,745(3,390)$ tufted duck. Also occurring at the site are smew Mergus albellus, goosander $M$. merganser, gadwall Anas strepera and pintail $A$. acuta. It is one of very few inland breeding sites for cormorants Phalocrocorax carbo (150 nests in 1986). The site is also the main waterfowl ringing station in Great Britain.

Changes in Ecological Character No water sports are allowed at present, but there is an increasing demand throughout southeast England for recreational facilities, especially sailing.

Management Practices Coarse fishing by permit at four points and a limited number of permits for bird-watching. There are no foot paths away from the public roads, and access to much of the periphery is strictly controlled.

Scientific Research and Facilities 2-3,000 duck and a large number of other species are ringed annually at a ringing station run in cooperation with the Wildfowl Trust. An intensive bird-ringing programme has been in operation since 1949 and by 1986 a total of 80,000 Anatidae had been ringed, including 36,000 teal and 30,000 mallard. A decoy is manned throughout the year. Ringing activities are published by the Wildfowl Trust. There is a substantial hide at Double Gates Bay (Layer-de-la-Haye).

Principal Reference Material The above information is taken from the documents supplied by the Government of the United Kingdom for designation in 1981.

Supplemented by:

- Duffey, E. (1982). National Parks and Reserves of Western Europe. Macdonald and Co., London

- Carp, E. (1980). A Directory of Western Palearctic Wetlands. IUCN, Gland, Switzerland.

- Scott, D.A. (1980). A preliminary inventory of wetlands of international importance for waterfowl in west Europe and north-west Africa. IWRB Special Publication No. 2.

Additional references:

- Wainwright, C.B. (1967). Results of wildfowl ringing at Abberton Reservoir, Essex 1949-1966. Wild fowl Trust 18th Annual Report. Pp. 28-35.

\section{Rostherne Mere}

Location $53^{\circ} 21^{\prime} \mathrm{N}, 2^{\circ} 23^{\prime} \mathrm{W}$. Situated $16 \mathrm{~km}$ southwest of the centre of Manchester in the county of Cheshire, England. 
Degree of Protection Rostherne Mere is part of a National Nature Reserve (NNR) established in 1961. The whole of the National Nature Reserve is notified as a Site of Special Scientific Interest (SSSI). The mere and some surrounding land is owned by the Nature Conservancy Council, but the NNR extends over a further 73 ha managed under a Nature Reserve Agreement with the private owner. At the request of the owner this 73 ha area is excluded from the site listed under the Ramsar Convention. Designated as a Ramsar site in July 1981.

Site Description The mere is situated in farmland despite the proximity of the Manchester conurbation. The site includes the mere and surrounding areas of marsh/woodland known as Old Hall Wood, Wood Bongs, Shaw Green Willows, Mere Covert, Gale Bog, Harpers Bank Wood, Boathouse Wood, Observatory Wood, about $280 \mathrm{~m}$ of the inlet stream and $450 \mathrm{~m}$ of the outlet, and a two metre strip of the surrounding farmland. The mere lies in a hollow surrounded by thick deposits of glacial drift overlying triassic marls and salt-beds. The shores shelve rapidly. Maximum depth is $30.4 \mathrm{~m}$, and about half the lake is over $15 \mathrm{~m}$ in depth. Reedbeds Phagmites australis encircle $50 \%$ of the mere, and beyond them tall fen vegetation grades into willow Salix spp. and alder Alnus glutinosus carr, and on drier ground to mixed deciduous woodland dominated by oak Quercus robur. The mere is calcareous and rich in minerals supporting very high phytoplankton populations (though the variety of species is relatively small). The site is also of some entomological interest.

International and National Importance Rostherne is a regional refuge used in winter by Anatidae as a daytime haven. Conditions are unsuitable for feeding due to the depth of water. The most abundant species in recent years have been pochard Aythya ferina (up to 2,000) and tufted duck $A$. fuligula (up to 1,500). Other species include mallard Anas platyrhynchos, teal $A$. crecca, wigeon $A$. penelope, shoveler $A$. clypeata and coot Fulica atra. Up to 20,000 gulls of the five common species use the mere for roosting. As well as being important to waterfowl the mere provides the only British record of the fish smelt Osmerus eperlanus in a freshwater locality, but this was in 1922 and it is probably now extinct in this area.

Changes in Ecological Character Three local sewage treatment plants discharge treated effluent into Rostherne Mere. These discharges are thought to be responsible for the major input of phosphates to the mere. The Nature Conservancy Council has asked the North West Water Authority to close these plants and to run the sewage into a main treatment works whose discharges do not affect Rostherne Mere's catchment. The Authority is apparently considering this proposal. Pollution by silage effluent is a recurrent problem which remains unresolved despite intervention by the Water Authority. Concern is also felt about the possibility of pesticide pollution from aerial spraying which is increasing locally, as well as fertiliser run-off into the mere.

Management Practices The reserve was established to maintain the mere as a strict wildlife refuge and to provide facilities for ornithology and freshwater biology research. A limited number of permits are issued to scientists with suitable projects. The woodlands are being managed to improve their general ecological interest.

Scientific Research and Facilities The mere is close to several centres of research, and work has been published on its chemistry, phytoplankton, organic geochemistry, zoopiankton, fish and benthos. Detailed bird records have been kept for at least 60 years. It is therefore one of the most thoroughly studied of the British lowland lakes. Three observation hides overlook the mere and further development of its educational potential is being considered.

Principal Reference Material The above information is taken from the documents supplied by the Government of the United Kingdom for designation in 1981 and for the Groningen Meeting in May 1984.

Supplemented by:

- Carp, E. (1980). A Directory of Western Palearctic Wetlands. IUCN, Gland, Switzerland.

- Luther, H. and Rzoska, J. (1971). Project Aqua. IBP Handbook No.21. Blackwell Scientific Publications. 
Additional references:

- Badsha, K.S. and Goldspink C.R. (1982). Preliminary observations on the heavy metal content of four species of freshwater fish in NW England. J. Fish Biol. 21: 251-267.

- Banks, J.W. (1970). Observations on the fish population of Rostherne Mere, Cheshire. Field Studies 3(2): 357-379.

- Ellison, N.F. and Chubb, J.C. (1968). The smelt of Rostherne Mere, Cheshire Lanes and Cheshire. Fauna Commiltee Publ. 53: 7-16.

- Gaskell, S.J. and Eglinton, G. (1976). Sterols of a contemporaty lacustrine sediment. Geochimica et Cosmochimica Acta 40: 1221-1228.

- Grimshaw, H.M. and Hudson, M.J. (1970). Some mineral nutrient studies of a lowland mere in Cheshire, England. Hydrobiologia 36:329-341.

- Harrison, R. and Rogers, D.A. (1977). The Birds of Rostherne Mere Naitonal Nature Reserve. Narure Conservancy Council, Banbury.

- Hincks, W.D. and Shaw, S. (1954). Faunal survey of Rostherne - insects, part 2. Mem. and Proc. Manchester Lit. and Phil. Soc. 96(9): 1-17.

- Livingstone, D. and Reynolds, C.S. (1981). Algal sedimentation in relation to phytoplankton periodicity in Rostherne Mere. Br. phycol. J. 16: 195-206.

- Pearsall, W.H. (1923). The phytoplankton of Rostherne Mere. Mem. and Proc. Manchester Lit. and Phil. Soc. 67(3): 45-55.

- Reynolds, C.S. (1978). Notes on the phytoplankton periodicity of Rostherne Mere, Chershire, 1967-1977. Br. Phycol. J. 13: 329-335.

- Reynolds, C.S. (1979). The limnology of the eutrophic meres of the Shropshire-Cheshire plain. Field Studies 5(1): 93-173.

- Tattersall, W.M. and Coward T.A. (1914). Faunal survey of Rostherne Mere I. Introduction and Methods. Mem. and Proc. Manch. Lit. and Phil. Soc. 58(8): 1-21..

- Walsh, B. (1965). An investigation of the bottom fauna of Rostherne Mere, Cheshire. PhD Thesis. University of Liverpool.

\section{The Dee Estuary}

Location $53^{\circ} 17^{\prime} \mathrm{N}, 3^{\circ} 05^{\prime} \mathrm{W}$. Situated between the Wirral peninsula and the North Wales coast in the counties of Clwyd (Wales), Cheshire and Merseyside, (England). 16km south-west of Liverpool.

Area 13,055 ha

Degree of Protection Originally notified as a Site of Special Scientific Interest (SSSI) in 1954 and renotified in 1983. Hilbre Island is managed as a Local Nature Reserve by Wirral Metropolitan Borough Council. The Royal Society for the Protection of Birds own 2,148ha at Gayton Sands. Designated as a Ramsar Site on 17 July 1985.

Site Description Large areas of intertidal sandflats and mud, with extensive saltmarshes at the head of the estuary and along the eastern coastline. The site includes the Hilbre islands: three small low lying sandstone islands lying about two kilometres from the extreme north-west corner of the Wirral peninsula from which they are cut off at high tide. The Hilbre islands support a neutral grassland vegetation with limited amounts of heath, and are a principal high-water roosting site for overwintering waders. The English side of the Dee has a very large saltmarsh system, much of it dominated by the introduced common cord grass Spartina anglica which is spreading at a considerable rate. Behind this community is a large area of lightly grazed mature marsh. Of particular interest is sea purslane Halimione portulacoides dominant over large sections, but which is scarce or absent on many west coast marshes as a result of heavy grazing by cattle or sheep. At Neston there is a gradual transition into brackish marsh domninated by common reed Phragmites communis, a type of community uncommon in England and Wales because of reclamation of the upper marsh.

Criteria for Inclusion 1(a), 1(b), 3(a) and 3(b) 
International and National Importance The Dee Estuary is one of the five most important estuaries in Britain for waders and wildfowl. It is a valuable staging post for migrating birds in both spring and autumn, and supports large numbers of waders throughout the winter. The birds feed on the rich invertebrate populations of the extensive intertidal alluvial sediments. The estuary supports internationally important concentrations of a number of waders including oystercatcher Haematopus ostralegus ( $2.6 \%$ of the European population), knot Calidris canutus (6.2\%), bar-tailed godwit Limosa lapponica (5.6\%) and redshank Tringa totanus (2.9\%). The maximum monthly count of wildfowl exceeded 20,000 in both $1984 / 85$ and $1983 / 84$, the most recent years with complete records. The most important species are pintail Anas acuta $(2.6 \%$ of the European population overwintering) and shelduck Tadorna tadorna (3.3\%). The Hilbre islands and the saltmarshes provide roosting areas for the waterfowl in the estuary, and breeding sites for a number of species. The saltmarshes in particular support breeding wader species including an especially large number of redshank. The seaweed covered rocks of Hilbre Island are of interest in supporting a small winter population of nurple sandpiper Calidris maritima, a species with a predominantly north-eastern distribution; as well as large flocks of dunlin Calidris alpina and knot. The presence of a large herd of grey seals Halichoerus grypus is of interest. These haul out on the West Hoyle Bank and represent $15 \%$ of the Welsh population. Other sea mammals occur occasionally: bottle-nosed and Risso's dolphin, common porpoise and killer whale may visit.

Changes in Ecological Character The eventual construction of a proposed bounded reservoir storage scheme would cause major changes. Their extent will depend on the location and shape of the reservoirs, and the uses to which the reclaimed land is put. Over the years, particularly on the Welsh side of the estuary, there has been considerable tipping onto the saltmarsh from the British Steel Corporation at Shotton, from the Central Electricity Generating Board at Connah's Quay, from Courtaulds at Flint and Greenfield, and from the National Coal Board at Point of Ayr. Much of this tipping has ceased or now occurs outside the SSSI boundary, with the exception of colliery spoil from Point of Ayr. Recent developments which could affect the SSSI include a proposed dock extension involving mudflat reclamation; increased drainage; intensification of grazing; channel deepening and groyne construction at Mostyn Dock; and new road developments like the Flint by-pass. Spartina anglica invasion threatens to destroy the normal saltmarsh succession and hasten the accretion of silt. The mosquito Aedes detritus breeds in massive numbers on the Cheshire saltmarsh and has caused a major problem in the Parkgate area. A programme of control using BTi is underway, but further drastic measures are being considered. Increased recreational pressure at West Kirby is forcing the waders to find alternative high tide roost sites from those traditionally used on the shoreline.

Management Practices The RSPB manages a nature reserve at Gayton Sands where wildfowling controls are exercised. The RSPB also have a licence for the land owned by the Welsh Water Authority and Haven Holidays at Point of Ayr, however, no management or wardening is undertaken here. Hilbre Island is managed as a Local Nature Reserve by Wirral Metropolitan Borough Council. The Deeside Naturalists' Society have a Nature Reserve Agreement with the Central Electricity Generating Board over land they own within the Dee estuary at Connah's Quat. The Dee Wildfowlers have shooting licences for much of the estuary, although they operate a system of sanctuary and shooting zones. Other management practices undertaken are permits to visit Reserves, Spartina control, control over dog walking and horse riding in some parts of the estuary, maintenance of existing grazing levels and wildfowling management.

Scientific Research and Facilities Detailed studies of the progress of saltmarsh formation and of the invasion of Spartina anglica have been made over the past 20 years, and this is now monitored by the Nature Conservancy Council. Research into the birds and invertebrates is established near Hilbre Island and Hilbre Bird Observatory undertakes large-scale ringing of waders. Liverpool Polytechnic has initiated a study of Calidris alpina. Studies of possible disturbance by wildfowling, and monitoring of wildfowl and wader populations are also being undertaken. 
Principal Reference Material The above information is taken from the documents supplied by the Government of the United Kingdom for designation in 1985.

Supplemented by:

- Carp, E. (Ed.) (1980). A Directory of Western Palearctic Wetlands. IUCN, Gland, Switzerland.

- Hywel-Davies, J. and Thom, V. (1984). The Macmillan Guide to Brilain's Nature Reserves. Macmillan, London

Additional references:

- Liverpool Bay Study Group papers and Dee Ins. Cons. Group list.

- Cragg, J.D. (ed.) (1982). Hilbre: The Cheshire Island. Hilbre Bird Observatory - annual reports.

- Ratcliffe, D.A. (Ed.) (1977). A Nature Conservation Review. Cambridge University Press.

\section{The Swale}

Location $51^{\circ} 22^{\prime} \mathrm{N}, 1^{\circ} 07^{\prime} \mathrm{W}$. On the north Kent coast, England.

Area 5,790ha

Degree of Protection The Swale is a Site of Special Scientific Interest (SSSI) notified in 1968 and renotified in 1984. There is a National Nature Reserve and a Local Nature Reserve within the site. The Royal Society for the Protection of Birds leases 282 ha and holds the shooting rights (not exercised) over 1,080ha. Designated as a Ramsar site on 17 July 1985.

Site Description The Swale includes the largest remaining areas of freshwater grazing marsh in Kent, and is representative of the estuarine habitats found on the north Kent coast. The habitats comprise chiefly mudflats, saltmarsh and freshwater grazing marsh, the latter being intersected by extensive dykes and fleets. Locally on the seaward side of the sea walls are smaller areas of harder substrates. Shingle below high water mark in places supports large mussel beds, which in turn attract different birds from those of the mudflats such as turnstone Arenaria interpres. There are several areas of shell, or shell sand beach, notably at Shellness on Sheppey and at Castle Coote west of Seasalter. These have an interesting calcareous flora, with plants charactersitic of both sand and shingle beaches such as: sea kale Crambe maritima, yellow horned poppy Glaucium flavum, marram grass Ammophila arenaria and sea rocket Cakile maritima. The grazing marsh complexes provide a variety of wetland and grassland habitats; the ditches and fleets contain a good range of aquatic plants including the natioally scarce brackish water-crowfoot Ranunculus baudottii and soft hornwort Ceratophyllum submersum. A range of ditch types are present on the Swale from freshwater to saline; the abundance of saline water dykes and their distinctive plant and invertebrate communities are especially characteristic of the Swale grazing marshes. The grassland habitats range from the damp muddy areas near the dykes, where characteristic plants include divided sedge Carex divisa and small goosefoot Chenopodium botryodes, to the dry seawalls and couterwall which support several rarities in addition to many widespread plants, such as: hogs fennel Peucedanum officinale, slender hare's-ear Bupleurum tenuissimum, sea clover Trifolium squamosum and sea barley Hordeum marinum, all of which are more abundant in the North Kent Marshes than elsewhere in Britain. Other less extensive habitats in the Swale include water-filled disused clay-pits, and small patches of scrub and woodland.

\section{Criteria for Inclusion $1(\mathrm{a}), 1(\mathrm{~b}), 1(\mathrm{c}), 1(\mathrm{e})$ and 2(a)}

International and National Importance Large numbers of waders and wildfowl use the area in winter, and during autumn and spring passage, and these are considered to be of national or international significance. Many of the birds utilise more than one habitat, some for example feed on the mudflats at low tide and then move up to roost on the saltmarsh or on fields inland of the sea wall. There is a substantial breeding population of Anatidae including garganey Anas querquedula, shoveler $A$. clypeata, tufted duck Aythya fuligula and pochard A. ferina; colonies of common tern Sterna hirundo and black-headed gull Larus ridibundus are established along the Swale. In winter the area holds a total of about 7,500 
Anatidae and 20,000 waders, with average peaks of 800 white-fronted goose Anser a. albifrons, 500 brent goose Branta b. bernicla, 900 shelduck T. tadorna and 5,000 wigeon Anas penelope. The concentrations of oystercatcher Haematopus ostralegus, grey plover Pluvialis squatarola, knot Calidris canutus, redshank Tringa totanus and curlew Numenius arquata are regarded as internationally important. Also breeding on the site are coot, moorhen, lapwing, teal, gadwall, mallard, ruff and black-tailed godwit (Fulica atra, Gallinula chloropus, Vanellus vanellus, Anas crecca, A. strepera, A. platyrhynchos, Philomachus pugnax and Limosa limosa) and occasional small numbers of pintail $A$. acuta. Where undisturbed, the shell sand beaches attract breeding ringed plover Charadrius hiaticula and little tern Sterna albifrons. As well as providing feeding and roosting places for many birds, the saltmarshes are extremely rich in invertebrates, over 350 species having been recorded; some of these, such as the polychaete worm Clymenella torquata are known from nowhere else in Britain. They are also of entomological interest especially for Coleoptera; and are the main British habitat of the scarce ground lackey moth Malacostoma castrensis. The saltmarshes are among the richest for plant life in Britain, including most of the British species of saltmarsh-grass Puccinellia and glasswort Salicornia, rarer plants include small cord-grass Spartina maritima and golden samphire Inula crithmoides.

Changes in Ecological Character The Swale is likely to be affected by increased disturbance, and by industrial pollution from sites outside the area. Some decrease in the populations of intertidal fauna has already been noted. The main recreational pressures in the Swale area are boating and water sports, wildfowling, bait digging and general recreation (walking, picnicking, bird watching).

Management Practices The site has been significantly reduced in extent along the north bank of the Swale. The primary aims should be to retain the grazing regime on the freshwater marshes and to control the disturbance caused by sailing and power boating on the Swale. High water levels are monitored in conjunction with the grazing regime. Parts of the site are managed as nature reserves by the RSPB, Nature Conservancy Council and Kent Trust for Nature Conservation.

Scientific Research and Facilities The rich invertebrate fauna makes the area an important research and teaching area for marine biology, especially from the London colleges. The populations of waterfowl and freshwater invertebrates have been monitored for many years.

Principal Reference Material The above information is taken from the documents supplied by the Government of the United Kingdom for designation on 17 July 1985.

Supplemented by:

- Carp, E. (Ed.) (1980). A Directory of Western Palearctic Wetlands. IUCN, Gland, Switzerland.

Additional references:

- Gilham, E.H. and Holmes, R.C. (1950). The Birds of the Norht Kent Marshes. London.

- Harrison, J.G. (1972). Wildfowl of the North Kent Marshes. WAGBI Conservation Publication.

- Hywel-Davies, J. and Thom, V. (1984). The Macmillan Guide to Britain's Nature Reserves. Macmillan, London

- Ratcliffe, D.A. (Ed.) (1977). A Nature Conservation Review. Cambridge University Press.

\section{Chesil Beach and the Fleet}

Location $50^{\circ} 36^{\prime} \mathrm{N}, 2^{\circ} 32^{\prime} \mathrm{W}$. Chesil Beach links the Isle of Portland to the mainland $5 \mathrm{~km}$ west of Weymouth, Dorset, England.

Area 763 ha

Degree of Protection Privately owned: the bed of the Fleet, two thirds of the Chesil Beach and much of the coastline at the western end belongs to one owner, the eastern coastland to numerous owners and the eastern end of the Beach to the Crown Estate Commissioners. The 
Fleet and Chesil Bank were notified as a Site of Special Scientific Interest in 1952 and also designated as an Area of Outstanding Natural Beauty. The Swannery at Abbotsbury has been designated a Statutory Bird Sanctuary. Designated as a Ramsar site on 17 July 1985.

Site Description Chesil Beach is a linear storm beach which is exceptional for its size (150-200m wide and $28 \mathrm{~km}$ long), systematic coarsening of pebbles eastwards, the variation in composition of the pebbles, and the extensive historical records of beach changes. To landward of the beach is the Fleet, a lagoon $13 \mathrm{~km}$ long, $75-900 \mathrm{~m}$ wide with a surface area of $4.9 \mathrm{sq} . \mathrm{km}$ at high tide. The water is mostly shallow, $1.5 \mathrm{~m}$ deep on average although it reaches $5 \mathrm{~m}$ in depth at the Narrows. It is open at the eastern end into Portland Harbour, giving rise to a tidal flow which decreases in height from approximately $2 \mathrm{~m}$ to almost nil midway along the lagoon, and to a salinity gradient which varies from marine at the eastern end to close to freshwater at the other. Sea water can also percolate through the bank. The bed of the lagoon is mostly composed of sand and silt, although in the vicinity of the Narrows it is very unusual, consisting of transitional patches of pebble, hard coralline rock and soft mud. The lagoon has extensive underwater meadows of eel-grasses Zostera noltii and $Z$. angustifolia, spiral tassel-weed Ruppia cirrhosa and beaked tassel-weed $R$. maritima particularly at the western end. The drift line is dominated in parts with shrubby sea-blite Suaeda fruticosa. The only woody plants are blackthorn Prunus spinosa, fen sallow Salix cinerea and Tamarix anglica. Sea campion Silene maritima and sea pea Lathyrus japonicus are abundant higher up on the Bank. In all, 167 flowering plants have been recorded on the shingle ridge, the margins of the Fleet, and the landward side of the Bank. On Chesil Beach, rare or nationally important populations of sea kale Crambe maritima, yellow-horned poppy Glaucum flavum and shrubby sea-blite Suaeda fruticosa also occur, and sea holly Eryngium maritinum, Portland spurge Euphorbia portlandica and little-robin Geranium purpureum (a Red Data Book species) are also present. The Fleet supports about 150 species of algae, and rarities include the filamentous green algae Cladophora battersia and $C$. retroflexa. The invertebrate fauna is varied and interesting and has been studied in detail.

\section{Criteria for Inclusion 1(a), 1(c), 1(d) and 2(c)}

International and National Importance The shingle provides nesting habitat for up to 100 pairs of little tern Sterna albifrons (about $5 \%$ of the British breeding population). It is also an important site for common tern $S$. hirundo and ringed plover Charadrius hiaticula (about 50 pairs). The Fleet is notable for the diversity of waders and wildfowl in winter. In particular it regularly supports at least $1 \%$ of the north-west European population of wigeon Anas penelope, with up to 7,500 birds being recorded in recent years. Good numbers of pochard, tufted duck, teal, pintail, mallard, shoveler and goldeneye (Aythya ferina, A. fuligula, Anas crecca, A. acuta, A. platyrhynchos, A. clypeata and Bucephala clangula) are also present. The site supports the largest resident mute swan Cygnus olor population in Britain (1,200+ birds with $60+$ breeding), which predominantly graze the Zostera beds. Numbers of over-wintering dark-bellied brent geese Branta bernicla now exceed 1,000. The Fleet is an important nursery ground for the bass Dicentrarchus labrax, and the goby Gobius couchii only occurs here, in Portland Harbour and the Helford River. The shingle is the only British locality for the scaly or wingless cricket Mogoplistes squamiger. It also supports at least three distinct and highly unusual mollusc associations. The looping snail Truncatella subcylindrica and a sea slug Tenellia adspersa are both only known from one other British site. Two other invertebrates present include the sponge Suberites massa and the burrowing anemone Scolanthes callimorphus, both which have only been found at two other British sites. Another rare anemone Nematostella vectensis is known only from a few other British sites and from nowhere else in Europe.

Changes in Ecological Character The appearance of Japanese seaweed Sargassum muticum in the Fleet over the past three years has caused concern but there are no obvious adverse ecological changes as yet. Replacement of Ferry Bridge and the creation of a new mouth to the Fleet, $50 \mathrm{~m}$ to the south, in 1984 may cause local redistribution of mud banks before the system is stable again. There is some concern over nutrient levels from adjoining agricultural land, but no obvious adverse effects are yet noticeable, and recreational use may become a threat in future. Despite excellent wardening and protection, tern numbers are experiencing some decline at present, perhaps part of a cyclical pattern affecting other south coast sites. 
Management Practices The landowners treat the western end of the beach as a private nature reserve. There is limited wildfowling under their control. The Abbotsbury Swannery and historic decoy are popular features with visitors and there is a permanent wardening staff. The shingle beach is wardened in summer to protect breeding tern colonies from disturbance and predators. A small sector of the Fleet and beach near the eastern end is leased to the Ministry of Defence and used by the adjoining bridging camp for training purposes.

Scientific Research and Facilities The area has been, and continues to be, the subject of detailed physiographic and biological studies.

Principal Reference Material The above information is taken from the documents supplied by the Government of the United Kingdom for designation on 17 July 1985.

Supplemented by:

- Carp, E. (Ed.) (1980). A Directory of Western Palearctic Wetlands. IUCN, Gland, Switzerland.

- Hywel-Davies, J. and Thom, V. (1984). The Macmillan Guide to Britain's Nature Reserves. Macmillan, London

Additional references:

- Bird, E.C.F. (1970). The physiography of the Fleet. Proc. Dorset Nat. Histo. Arch. Soc.

- Carr, A.P. (1971). Experiments on longshore transport and sorting of pebbles: Chesil Beach, England. Jour. Sedimentary Petrology 41:1084-1104

- Spencer, B.E. (1965). Survey of the Fleet, near Weymouth, Dorset (Dec. 1964). Mimeo., Min. Ag. Fish and Food, Conway.

- Whittaker, J.E. (1972). Recent brackish and marine Ostracoda from the Fleet and Weymouth Bay, Dorset: a study in ecology. Ph.D. thesis, Univ. of Averystwyth.

\section{Derwent Ings}

Location $53^{\circ} 50^{\prime} \mathrm{N}, 0^{\circ} 54^{\prime} \mathrm{W}$. Alongside the River Derwent between Sutton-upom-Derwent and Breighton in the counties of North Yorkshire and Humberside, England.

Area $783 \mathrm{ha}$

Degree of Protection This is a Site of Special Scientific Interest (SSSI). First notified in 1975. Extended in 1981, revision date 1982. Part of the site is a statutory Sanctuary under the Wild Birds (Wheldrake Ings Sanctuary) Order 1978, Statutory Instrument No. 1259. Designated as a Ramsar site on 17 July 1985.

Site Description The site comprises a series of floodlands alongside the River Derwent, with an excellent range of neutral alluvial grasslands. The character and species composition of the grasslands is mainly governed by the extent of winter flooding. In the wettest areas the vegetation is dominated by reed sweetgrass Glyceria maxima, reed canary-grass Phalaris arundinacea and slender tufted sedge Carex acuta, of ten associated with the rather local marsh stitchwort Stellaria palustris. On the drier areas where winter flooding is very infrequent, a species-rich community with grasses such as meadow foxtail Alopecurus pratensis, meadow fescue Festuca pratensis and timothy Phleum pratense occurs. Herbs include great burnet Sanguisorba officinalis, meadowsweet Filipendula ulmaria, common sorrel Rumex acetosa, pepper saxifrage Silaum silaus, common meadow-rue Thalictrum flavum, and important populations of the rare plant narrow-leaved water dropwort Oenanthe silaifolia.

International and National Importance The grasslands are important as a breeding habitat for a wide range of wetland bird species. In recent years up to fourteen species of wildfowl have bred. The site is nationally significant for shoveler Anas clypeata, supporting nearly $10 \%$ of the UK population (about 100 pairs). Other species include shelduck Tadorna tadorna, garganey Anas querquedula, mallard Anas platyrhynchos, teal Anas crecca, gadwall Anas strepera, pintail Anas acuta, pochard Aythya ferina and tufted duck Aythya fuligula. Breeding waders include curlew Numenius arquata, lapwing Vanellus vanellus, snipe Gallinago gallinago 
and redshank Tringa totanus, as well as smaller numbers of oystercatcher Haematopus ostralegus, common sandpiper Tringa hypoleucos and little ringed plover Charadrius dubius. In winter the Ings are of international importance, supporting populations of Bewick's swans Cygnus columbianus bewickii up to about 250), teal (up to 3000), and wigeon Anas penelope (up to 5,580), as well as significant numbers of mallard (up to 5,900), pochard (up to 3,115 ), tufted duck (up to 800 ), golden plover Pluvialis apricaria and lapwing. The Derwent also provides habitat for ottersLutra lutra, rare plants and 35 species of fish including burbot, trout, salmon grayling and barbel.

Changes in Ecological Character In the early 1980s grant aid was sought by an Internal Drainage Board for a pilot pump drainage scheme on one part of the Derwent Ings at North Duffield Carrs. This scheme would decrease the period of time over which water would stand on the Ings in spring. The request for grant aid was rejected by the Minister of Agriculture in November 1984. In 1984 the Yorkshire Derwent Trust Ltd, an organisation representing navigation interests, filed evidence in the High Court to try to prove existence of a public right of navigation upstream from Sutton to Malton. The High Court had yet to announce its decision in late 1986.

Management Practices Part of the site, Wheldrake Ings, is managed as a nature reserve by the Yorkshire Wildlife Trust Ltd. Maintenance of the botanical interest of the grasslands depends on the traditional management of hay cropping, which is often followed by late summer grazing by cattle or sheep.

\section{Scientific Research and Facilities No information}

Principal Reference Material The above information is taken from the documents supplied by the Government of the United Kingdom for designation on 17 July 1985.

Additional references:

- Hywel-Davies, J. and Thom, V. (1984). The Macmillan Guide to Britain's Nature Reserves. Macmillan, London

- Ratcliffe, D.A. (Ed.) (1977). A Nature Conservation Review. Cambridge University Press.

\section{Holburn Moss}

Location $55^{\circ} 37^{\prime} \mathrm{N}, 1^{\circ} 57^{\prime} \mathrm{W}$. In the county of Northumberland, England.

Area $22 \mathrm{ha}$

Degree of Protection The area is a Site of Special Scientific Interest (SSSI) first notified in 1964 and renotified in 1983. During the renotification ththe boundary of this site was reduced to exclude areas of moorland now afforested or of low biological interest. The area of wetland remains unaltered. Designated as a Ramsar site on 17 July 1985.

Site Description Holburn Lake was created in 1934 when the present outflow to the west was dammed. A large stand of great reedmace Typha latifolia grows on the island in the Lake, and a floating bog is present along its eastern shore. Several bogmosses Sphagnum spp. are found here including those of waterlogged hollows $S$. cuspidatum and those which favour the drier hummocks $S$. squarrosum, $S$. fimbriatum. Holburn Moss lies to the east of the lake, and is an example of mire at the dry end of the range of variation. The peat surface to the east is covered by the bogmoss Sphagnum papillosum growing under a thick mantle of ling Calluna vulgaris. Large, damp hollows which are colonised by $S$. cuspidatum and soft rush Juncus effusus are found throughout this area, and are an unusual feature in British mires. Cranberry Vaccinium oxycoccus and sundew Drosera rotundifolia are common around the drier edges of the hollow, growing with $S$. rubellum. The centre of the moss is dominated by cross-leaved heath Erica tetralix, with ling Calluna vulgaris, and common cotton-grass Eriophorum angustifolium occurring widely. The drier slopes to the west are covered with bracken Pteridium aquilinum and occasional gorse Ulex europaeus, which grow on 
the freely draining acidic soil. Bracken gives way to ling Calluna vulgaris and occasional bell heather Erica cinerea around Copsey Hill.

International and National Importance The area is of international importance as a major roost for greylag goose Anser anser of the Icelandic population, holding more than $1 \%$ of the north-west European population (upwards of 2000 birds). It is also regularly visited by large flocks of mallard Anas platyrhynchos, wigeon Anas penelope and teal Anas crecca and provides an inland roost for coastal wildfowl during unfavourable coastal weather conditions. There is a large breeding colony of up to 3,000 pairs of black-headed gulls Larus ridibundus. In addition, a few pairs of shelduck Tadorna tadorna, shoveler Anas clypeata and tufted duck Aythya fuligula regularly breed here.

Changes in Ecological Character Vegetation on the island has recently been suppressed by the impact of large numbers of greylag geese. This may reduce the availability of nest sites for the black-headed gulls.

Management Practices Grazing is excluded from the wetter areas of the Moss. There is occasional removal of pine seedlings from the Moss. There is also licensed collection of black-headed gulls eggs by the owner.

Scientific Research and Facilities Regular bird censuses are made during winter periods.

Principal Reference Material The above information is taken from the documents supplied by the Government of the United Kingdom for designation on 17 July 1985.

\section{Irthinghead Mires}

Location $55^{\circ} 04^{\prime} \mathrm{N} \quad 2^{\circ} 22^{\prime} \mathrm{W}$. Irthinghead Mires is a composite of seven sites: Gowany Knowe Moss, Felecia Moss, Coom Rigg Moss, Hummel Knowe Moss, Haining Head Moss, Grain Heads Moss and Butterburn Flow. The first six are in Northumberland, the last site is in Cumbria, in northern England.

Area Total 608ha; Gowany Knowe Moss 19.4 ha; Felecia Moss 33.47 ha; Grain Heads Moss 18.38ha; Coom Rigg Moss 39.6ha; Hummel Knowe Moss 59.35ha; Haining Head Moss 29.03ha; Butterburn Flow 409.3ha.

Degree of Protection Gowany Knowe Moss, Felecia Moss and Hummel Knowe Moss were each first notified as Sites of Special Scientific Interest (SSSIs) in 1969, Coom Rigg Moss in 1959, and Haining Head Moss in 1965. All were subsequently renotified in 1983. Grain Heads Moss was first notified as an SSSI in 1983, and is also a National Nature Reserve. Butterburn Flow was first notified as an SSSI in 1959/68, and renotified in 1982/84. Designated as a Ramsar Site on 17 July 1985.

Site Description Gowany Knowe Moss is a particularly fine example of the blanket mire vegetation which was once widespread in this area, but which has been reduced by afforestation to a series of isolated remnants. The domed surface of the mire is dominated by bog mosses Sphagnum magellenicum, $S$. papillosum, with cross-leaved heath Erica tetralix and ling Calluna vulgaris forming a sparse dwarf-shrub layer. Cranberry Vaccinium oxycoccus, bog rosemary Andromeda polifolia, bog asphodel Narthecium ossifragum, round-leaved sundew Drosera rotundifolia and cotton grass Eriuophorum angustifolium are common. A significant feature at the western end of the site is an extensive area of flushed or soligenous mire, which receives water flowing down the steeply sloping moss boundary from the south. This flushed area supports a different vegetation type, with slender sedge Carex lasiocarpa becoming locally dominant at its lower and richer (NW) end with 'brown moss' species and marsh cinquefoil Potentilla palustris also present. At a higher level in the seepage are Sphagnum recurvum, the carnation sedge Carex panicea, and the rarer bog sedge Carex limosa, with marsh horsetail Equisetum palustre, common cotton-grass Eriophorum angustifolium and the moss Polytrichum commune. The upper levels are occupied by Sphagnum 
auriculatum agg., with the bottle and common sedges Carex rostrata and $C$. nigra, and the herbs bogbean Menyanthes tirfoliata and common butterwort Pinguicula vulgaris.

Felecia Moss is an example of blanket mire which is now one of a small number of unplanted areas within the extensive Wark Forest. It is noted for its variety of bog-mosses Sphagnum papillosum, S. magellanicum, S. imbricatum, S. fuscum, S. cuspidatum and S. tenellum. In the wetter areas active growth of the bog-mosses produces an undulating surface of hummocks and hollows, the latter sometimes supporting temporay pools and here the great sundew Drosera anglica is especially frequent. Two pools near the centre of the site are of note for the abundance of Sphagnum subsecundum. Interspersed within the bog-moss lawn are ling Calluna vulgaris, crowberry Empetrum nigrum, common cottongrass Eriophorum angustifolium, hare's-tail cottongrass $E$. vaginatum, bog rosemary Andromeda polifolia, bog asphodel Narthecium ossifragum and round-leaved sundew Drosera rotundifolia.

Grain Heads Moss is a raised-mire dominated by bog-mosses Sphagnum spp., the remains of which are continuing to form peat, thus promoting active growth of the mire surface. The bog-mosses, principally S. magellanicum, S. uvellum. S. tenellum and S. papillosum form a continuous carpet, with $S$. cuspidatum growing in the wetter hollows; amongst the Sphagna there are abundant leafey liverworts. The remarkably undisturbed and natural condition of the mire surface over the greater part of the site is a feature identifying this as one of a series of internationally important mires. Upon the bog-moss carpet there is a sparse but even distribution of dwarf-shrubs which, as a consequence of the high water-table, are somewhat stunted in their growth. Cross-leaved heath Erica tetralix is particularly abundant, and bog rosemary Andromeda polifolia and cranberry Vaccinium oxycoccus are both common. The high water-table is further emphasized by the abundance of common cottongrass Eriophorum angustifolium, together with the herbs bog asphodel Narthecium ossifragum and sundew Drosera rotundifolia. On a central ridge the peat is thinner. Here, whilst the cover of the Sphagnum carpet is still continuous, ling Calluna vulgaris and hare's-tail cotton-grass $E$. vaginatum occur.

Coom Rigg Moss is an important site exemplyifying blanket mire and raised mire which has remained undamaged by grazing, burning, peat-cutting or drainage. A carpet of bog-mosses Sphagnum papillosum and $S$. magellanicum forms the active peat-forming surface. Widespread and generally abundant are heather Calluna vulgaris, hare's-tail cotton grass Eriophorum vaginatum, cross-leaved heath Erica tetralix and common cotton grass Eriophorum angustifolium. Also abundant on the moss surface are bog asphodel Narthecium ossifragum and the insectivorous round-leaved sundew Drosera rotundifolia. A series of mossy hummocks carries such species as Sphagnum imbricatum and $S$. fuscum, together with bilberry Vaccinium myrtillus, crowberry Empetrum nigrum and woolly hair moss Rhacomitrium lanuginosum. One open pool and several moss-filled hollows are present in the south-west portion of the site. At two separate locations the bog surface carries a depauperate growth of common reed Phragmites australis in a situation most unusual for this plant. This is thought to be a relic of the bog's formative stages when this species occupied wet hollows in the boulder clay substrate and initiated peat formation under fen conditions. Its persistence into the acid conditions of blanket bog is thus of great interest.

Hummel Knowe Moss is an example of raised and blanket mire formed by the accumulation of deep peat infilling first a lake and later the whole col between Hummel Knowe in the north and Hugh's Hill in the south. The maximum recorded peat depth is $10.7 \mathrm{~m}$. Whilst a small part of the site adjacent to Hummel Knowe itself comprises unafforested land within the extensive Wark Forest, it is separated by a fence and wall from the greater area which forms part of the extensive sheepwalk of Burndivot Common. As at Hainging Head Moss, the grazed moss surface is remarkably even, and consists of a carpet of various bog-mosses, notably Sphagnum papillosum and S. magellanicum, with little differentiation of hummock or hollow topography. Interspersed within this are common cottongrass Eriophorum angustifolium, hare's-tail cottongrass Eriophorum vaginatum, deer grass Trichophorum cespitosum, cross-leaved heath Erica tetralix, crowberry Empetrum nigrum and ling Calluna vulgaris, the latter being low growing as a result of the very wet conditions. Bog asphodel Narthecium ossifragum, bog rosemary Andromeda polifolia, cranberry Vaccinium oxycoccus and round-leaved sundew Drosera rotundifolia are abundant. Also recorded from this site are great 
sundew $D$. anglica, white beak sedge Rhynchospora alba and tall bog-sedge Carex paupercula. Peripheral areas have a greater preponderance of ling and cross-leaved heath, with occasional isolated patches of bottle sedge $C$. rostrata which may mark the position of former pools in the moss surface. The southern and eastern boundaries are marked by steeper slopes, and a change to acidic grassland with wavy hair-grass Deschampsia flexuosa. To the south-west is an area flushed by drainage water from Hugh's Hill and here there are tussocks of hare's-tail cottongrass with tormentil Potentilla erecta. At the base of the hills to the north and south is a marginal lagg with soft rush Juncus effusus and Sphagnum recurvum.

Haining Head Moss is an extended basin mire developed in a shallow depression between the headwaters of the rivers Irthing and North Tyne. The condition of the vegetation differs markedly to either side of a fence-line along the site's east-west axis, dividing it into a large northern sector which comprises part of an intensively grazed sheepwalk, and a relatively ungrazed smaller southern sector which is one of a small number of unplanted areas within the extensive Wark Forest. The southern sector was formerly crossed by four drainage ditches. These are now blocked, but their effect is still evident in the abundance of tall ling Calluna vulgaris, which dominates a hummocky carpet of bog-mosses Sphagnum magellanicum. $S$. papillosum, $S$. rubellum. Species associated with the ling include cranberry Vaccinium oxycoccus, bog rosemary Andromeda polifolia, bog asphodel Narthecium ossifragum, cross-leaved heath Erica tetralix and common cottongrass Eriophorum angustifolium. Between the bog-moss hummocks, tussocks of hare's-tail cottongrass $E$. vaginatum support cross-leaved heath and the mosses Pleurozium schreberi and Aulacomnium palustre. The site boundary in the southern sector has been reduced to conform with that of the adjacent plantation. In the northern sector, the effects of grazing, together with an absence of drainage, have resulted in a remarkably even-textured carpet of bog-mosses in contrast to the hummock-hollow structure of the southern sector. It consists of a mosaic of Sphagnum magellanicum, S. papillosum. $S$. tenellum, S. rubellum and $S$. cuspidalum. Growing among the bog-mossses, cross-leaved heath and common cottongrass are codominant and ling, in contrast to its abundance in the southern sector, occurs here only as extremely stunted individual stems. Associated species include cranberry, bog rosemary, bog asphodel and small scattered tussocks of deer-grass Trichophorum cespitosum and hare's-tial cottongrass.

Butterburn Flow is the most important blanket mire within England. The site lies $21 \mathrm{~km}$ north east of Bramton and abuts the Cumbria/Northumberland border at an altitude of $270 \mathrm{~m}$. The Flow represents a transition between hummock-hollow mire and true patterned mire typified by narrow ridges and open water pools. Similar transitional patterning is known at only three other sites in Britain and none are as undamaged as Butterburn. The Flow is noted for containing large, intact areas dominated by bog mosses Sphagnum spp. The bog moss dominated plant community forms a major component of the blanket mire vegetation of the Flow, to an extent now rarely seen in Britain. Constant species in the community are Sphagnum magellanicum, $S$. papillosum, cross-leaved heath Erica tetralix and cranberry Vaccinium axycoccos. The hydrological unit extends down to the river Irthing around most of the northern and eastern boundaries. The marginal band of grass- and rush-dominated vegeatation on the more mineral soils is included to protect the finely-balanced hydrology in the peat of the patterned mire. A number of local and rare mire species are present on Butterburn, notably tall bog sedge Carex magellanica, few-flowered sedge $C$. pauciflora and the bog mosses Sphagnum pulchrum and S. imbricatum. In addition, bog rosemary Andromeda polifolia is abundant and the vegetation has certain affinities with that of the Solway raised mires with the association of Sphagnum pulchrum and white-beak sedge Rhyncospora alba accompanying bog rosemary. Cloudberry Rubus chamaemorus occurs at an unusually low altitude for England.

International and National Importance Coom Rigg Moss - A rare spider Eboria caliginosa has been recorded at this site. Haining Head Moss - Rare plant species recorded from this sector include great sundew Drosera anglica, few-flowered sedge Carex pauciflora, tall bog-sedge $C$. paupercula and white-beak sedge Rhynchospora alba. Butterburn Flow - Seven species of wader are known to breed on the Flow, together with other moorland species.

Changes in Ecological Character Gowany Knowe Moss is grazed by cattle and sheep, but their effect is concentrated on the acidic grassland in the north and east portions and no 
disturbance of the mire surface is as yet apparent. The boundary of Felecia Moss has been reduced to conform with that of the plantation edge during the 1983 revision. (A subsidiary area formerly notified to the north west has been deleted.) Peripheral areas of Grain Heads Moss show signs of past disturbance and in the north of the site, in an area where hare's-tail cotton-grass is abundant, there is a small population of the unusual tall bog-sedge Carex paupercula. Some narrow drains across the southern part of the mire are marked by an increase in the height of the fringing ling, but they are becoming occluded by bog-mosses. Some erosion of the bog surface around the head of a former drain in Hummel Knowe Moss is apparent near the eastern boundary. In the northern sector of Haining Head Moss, the effects of grazing together with an absence of drainage have resulted in a remarkably even-textured carpet of bog-mosses in contrast to the hummock-hollow structure of the southern sector.

Management Practices Coom Rigg Moss and Grain Heads Moss are managed by the Nature Conservancy Council as National Nature Reserves.

\section{Scientific Research and Facilities No information}

Principal Reference Material The above information is taken from the documents supplied by the Government of the United Kingdom for designation on 17 July 1985.

Additional reference

- Ratcliffe, D.A. (Ed.) (1977). A Nature Conservation Review. Cambridge University Press.

\section{Leighton Moss}

Location $54^{\circ} 10^{\prime} \mathrm{N}, 2^{\circ} 47^{\circ} \mathrm{W}$. Situated between Warton Crag and Silverdale on the edge of Morecambe Bay in the Arnside-Silverdale Area of Outstanding Natural Beauty, Lancashire, England.

\section{Area $125 \mathrm{ha}$}

Degree of Protection Leighton Moss is a Site of Special Scientific Interest (SSSI). It was originally notified in 1951 as Storr's Moss and the boundary was revised by partial deletion at renotification. Most of the site is an RSPB reserve. Otters Lutra lutra and red squirrels Sciurus vulgaris, protected species listed on Schedule 5 of the above Act, are resident. Designated as a Ramsar site on 28 November 1985.

Site Description There are extensive areas of open water in the reedbeds, and areas of willow scrub and mixed fen vegetation. A typical and varied fen flora has developed in some parts, and this shows all stages of transition from open water to woodland. The reedbeds are important as a northern outpost of broadland-type avifauna, with nationally important breeding populations of bittern Botaurus stellaris (about 12 pairs, i.e. about $25 \%$ of the current British population) and bearded tit Panurus biarmicus (about 30 pairs), but the diversity of habitat supports a wide range of birds with over 65 species breeding regularly. These include important populations of pochard Aythya ferina (about 8 pairs) and shoveler Anas clypeata (about 15 pairs), a large population of reed warbler Acrocephalus scirpaceus (one of the most northerly colonies in Britain), sedge warbler $A$. schoenobaenus, grasshopper warbler Locustella naevia, water rail Rallus aquaticus and a wide range of waterfowl.

International and National Importance Leighton Moss is a site of outstanding ornithological importance. It contains the largest reedbed in North West England and the only large reedbed in Lancashire; the only other example of any significant size being the nearby Hawes Water Moss. The site also supports a variety of passage and wintering waterfowl and other birds, including nationally important numbers of teal (up to 1800), shoveler (up to 220), bittern 
(11-13 breeding pairs in 1977-82), bearded tit (20-40 breeding pairs in 1977-82) and gadwall (up to 35). The site is also of value for other fauna. It is one of the few places in Lancashire where otters regularly breed. Red squirrels, roe Dana dana and red deer Cerus elaphus occur, and a wide range of butterflies have been recorded from the site.

Changes in Ecological Character The site was originally an extensive peat moss which was drained and brought into agricultural use as arable land in the 19th Century. In 1917, following cessation of pumped drainage, the valley flooded with base-rich water from the surrounding limestone hills and soon developed into a Phragmites reedbed.

Management Practices In 1964 Leighton Moss became an RSPB reserve, and has since been managed to maintain and diversify the habitats of wetland birds.

Scientific Research and Facilities Monitoring of bird and butterfly populations are carried out; in particular, research into the management of reed beds for bird populations, the effects of scrub cutting on warbler populations and studies of bittern biology

Principal Reference Material The above information is taken from the documents supplied by the Government of the United Kingdom for designation on 28 November 1985.

Additional references:

- Ratcliffe, D.A. (Ed.) (1977). A Nature Conservation Review. Cambridge University Press.

\section{Martin Mere}

Location $53^{\circ} 35^{\prime} \mathrm{N}, 2^{\circ} 49^{\prime} \mathrm{W}$. Situated to the north of Burscough in Lancashire.

Area 119 ha

Degree of Protection Martin Mere was notified as a Site of Special Scientific Interest (SSSI) in 1979 and and renotified in 1984. The site boundary has been amended by minor corrections. The area has also been corrected as the acreage given on the 1979 notification was incorrect. This is a Wildfowl Trust Reserve, and was designated as a Ramsar site on 28 November 1985.

Site Description The Mere is a low-lying wetland complex of open-water, marsh and grassland habitats overlying deep peat. It is situated to the north of Burscough and occupies part of the site of the old Martin Mere which, prior to drainage, was probably the largest lake in Lancashire.

International and National Importance The principal interest of the site lies in the numbers of migrant birds which it supports during the winter months, with overall numbers of wildfowl regularly in excess of 10,000 and over 100 different species using the Mere as a wintering ground. Of particular importance are the wintering populations of pink-footed geese Anser brachyrhynchos (up to 18,000), teal Anas crecca (5,000-10,000), Bewick's swan Cygnus columbianus bewickii (up to 370 ) and pintail $A$. acuta $(1,000-3,700$ ) which, by representing more than $1 \%$ of their total NW European populations, reinforce the international status of this site. Martin Mere also supports nationally important numbers of gadwall Anas strepera and whooper swan Cygnus cygnus, with numbers regularly well in excess of $1 \%$ of the total British wintering population. Nationally important numbers of snipe Gallinago gallinago, lapwing Vanellus vanellus and black-tailed godwit Limosa limosa have been recorded, and the wintering flock of ruff Philomachus pugnax (250 on average) is believed to be the largest in Britain. Breeding birds total over 35 species, and include gadwall, mallard Anas platyrhynchos and snipe. In total, over 150 species of birds have been recorded at the site and this includes several unusual species, such as avocet Recurvirostra avosetta, lesser yellowlegs Tringa flavipes, marsh sandpiper T. stagnatilis and white-winged black tern Chlidonias leucopterus which have been recorded on passage. Martin Mere is, thus, of exceptional value for the 
wealth and diversity of its avifauna. Additional scientific interest is provided by the presence of two locally important plant species: water dropwort Oenanthe fistulosa, which is regionally scarce, and whorled caraway Carum verticillatum, found here in abundance in its only Lancashire locality (and one of very few sites in the north of England).

Changes in Ecological Character There has been an invasion of Bidens on the area known as Vinsons due to the management regime (flooding during winter), and presumably a change will also take place on Sunleys which was flooded for the first time during winter 1985/86. These changes are being monitored by the Nature Conservancy Council.

Management Practices Following acquisition by the Wildfowl Trust in 1974, the rough grazed pasture of a decade ago has been transformed by positive management techniques into a reserve of international importance for waterfowl.

Scientific Research and Facilities Monitoring of bird populations is carried out. There is also habitat monitoring by the Nature Conservancy Council.

Principal Reference Material The above information is taken from the documents supplied by the Government of the United Kingdom for designation on 28 November 1985.

\section{Alt Estuary}

Location $53^{\circ} 30^{\prime} \mathrm{N}, 3^{\circ} 10^{\prime} \mathrm{W}$. Located $3-4 \mathrm{~km}$ south-west of Formby, Merseyside, about $10 \mathrm{~km}$ north of Liverpool, England.

Area 1,160 ha

Degree of Protection The area designated as a Ramsar site lies within the Altcar Sand Dune and Foreshore Site of Special Scientific Interest (SSSI), notified in 1979 and renotified in 1983. Designated as a Ramsar site on 28 November 1985.

Site Description Salt marsh and reedbed are present on the east bank of the river Alt. The saltmarsh is characterised by the presence of common saltmarsh-grass, creeping bent, spearleaves orache Atriplex prostata, glasswort Salicornia europaea and sea arrow grass Triglochia maritima. Common cord-grass Spartina anglica is present in places. The reedbed is dominated by common reed Phragmites australis.

International and National Importance The Alt Estuary regularly supports more than 20,000 wintering waders (an average of over 35,000). The site supports in winter on average 25,700 knot Calidris canutus (over 7\% of the European wintering population), 560 sanderling $C$. alba (4\%) and 6,000 bar-tailed godwit Limosa lapponica (over 1\%). Over 3,000 pink-footed goose Anser brachyrhynchus (over 3\%) roost on the site at some stages of the winter. The site also provides roosts for many other species of wading birds and wildfowl including oystercatcher Haematopus ostralegus, grey plover Pluvialis squatarola, curlew Numenius arquata, redshank Tringa totanus, dunlin Calidris alpina and shelduck Anas clypeata.

Changes in Ecological Character Ongoing natural processes of erosion and accretion are modified by dredging activities in the Crosby channel leading to the Mersey and Liverpool docks. Other known threats to the ecological character and value include proposed coast protection works at Hightown adjacent to and within the Ramsar site, sewage dumping in Liverpool Bay, and possible increases in intensity of recreational uses.

Management Practices Informal public recreation (walking) occurs over 10\% of the area of the site. Boat moorings are present and sailing takes place in the Alt Estuary. Bait digging occurs but affects less than $0.5 \%$ of the area. There is also sporadic commercial shrimping of about $5 \%$ of the site. Shooting rights on this site are not excercised. 
Scientific Research and Facilities Research is carried out particularly in regard to coastal hydrological and sedimentological processes.

Principal Reference Material The above information is taken from the documents supplied by the Government of the United Kingdom for designation on 28 November 1985.

Additional reference:

- Ratcliffe, D.A. (Ed.) (1977). A Nature Conservation Review. Cambridge University Press.

\section{Loch of Skene}

Location $57^{\circ} 09^{\prime} \mathrm{N}, 2^{\circ} 20^{\prime} \mathrm{W}$. In Aberdeenshire, about $16 \mathrm{~km}$ west of Aberdeen, Scotland.

Area 125ha

Degree of Protection This has been a Site of Special Scientific Interest since 1971, renotified in 1982. Designated a Ramsar site on 25 September 1986.

Site Description The site includes all of the shallow Loch of Skene and a narrow strip along most of the shoreline, widening to about $15 \mathrm{~m}$ in the north-west corner. The submerged flora has been depleted by plankton blooms of blue-green algae caused by phosphorous enrichment. The fringing reedbed and birch-alder carr is, however, largely undisturbed. A regionally important range of breeding birds are present, with 69 species recorded.

International and National Importance There are nationally important concentrations of breeding and wintering wildfowl and gulls. It is an important breeding area for tufted duck Aythya fuligula (50-100 pairs). In winter, nationally important numbers of goosander Mergus merganser and goldeneye Bucephala clangula roost here, and regionally important numbers of mallard Anas platyrhynchos, teal A. crecca, wigeon $A$. penelope and pochard Aythya ferina also occur. In autumn it is a major roosting site for common gull Larus canus and large numbers of greylag goose Anser anser use the loch (peak: 4000-6500 birds). A number of uncommon plant species are present.

Changes in Ecological Character No information

Management Practices No information

Scientific Research and Facilities No information

Principal Reference Material The above information is taken from documents submitted by the Government of the United Kingdom for designation on 25 September 1986.

\section{Loch Eye}

Location $57^{\circ} 48^{\prime} \mathrm{N}, 3^{\circ} 56^{\prime} \mathrm{W}$. In the Moray Firth lowlands, Ross and Cromarty district, Scotland.

Area $195 \mathrm{ha}$

Degree of Protection The loch is a Site of Special Scientific Interest. Part of the site has been a statutory bird sanctuary since 1974. Designated a Ramsar site on 25 September 1986.

Site Description The site comprises a shallow inland loch about $2 \mathrm{~km}$ long and a narrow strip of shoreline around it. The water chemistry is such as to allow the presence of plant communities characteristic of both nutrient-rich and nutrient-poor communities, resulting in great species diversity. Plants cover about $90 \%$ oi the loch's bottom. The shore supports trees 
or fen and, at the eastern end, swamp with willow carr. The loch is not always free of ice in winter, which reduces bird populations during cold periods. There is a varied and rich invertebrate fauna.

International and National Importance This loch supports the greatest freshwater concentrations of wildfowl on the Highland mainland with large numbers of ducks and geese, particularly greylag goose Anser anser, of which over 30,000 have been recorded at one time. Large numbers of other species, some of which reach national significance in most winters, including mute swan Cygnus olor, whooper swan $C$. cygnus, wigeon Anas penelope, mallard A. platyrhnchos, teal A. crecca, and pochard Aythya ferina. The aquatic flora includes uncommon species and at least one national rarity.

\section{Changes in Ecological Character No information}

\section{Management Practices No information}

\section{Scientific Research and Facilities No information}

Principal Reference Material The above information is taken from documents submitted by the Government of the United Kingdom for designation on 25 September 1986.

\section{Rockcliffe Marshes}

Location $54^{\circ} 52^{\prime} \mathrm{N}, 3^{\circ} 30^{\prime} \mathrm{W}$. In northern Cumbria, England, $10 \mathrm{~km}$ north of Carlisle, on the border with Scotland. The site is in the estuary of the rivers Esk and Eden and adjacent to Burgh Marsh SSSI.

\section{Area 1,897 ha}

Degree of Protection The site has been a Site of Special Scientific Interest since 1954, and was renotified in 1984. Rockcliffe Marsh is within the Solway Firth Area of Outstanding Natural Beauty, and forms part of the Upper Solway Flats and Marshes proposed Special Protection Area. Designated a Ramsar site on 25 September 1986.

Site Description The site includes the area of coastal marshes formed between the mouths of the Rivers Eden and Esk at the head of the Solway Firth, bordered on three sides by mud and sand flats above the level of mean high water. There is a seawall on the landward side. The saltmarsh contains numerous creeks, and can be divided into an eastern landward part which is older, with soils which are frequently gravelly and rarely submerged, and a newer marsh of recently accreted sand. In recent years, accretion on the seaward edge has been rapid. The saltmarsh vegetation reflects the age and substrate type, with a well-represented sequence of communities. The seaward edge is typified by pioneer species, notably common saltmarsh grass Pucinellia maritima with some glasswort Salicornia europaea. The invasive cordgrass Spartina spp. is so far absent. Inland, there is a transition to extensive grassy saltmarsh dominated by red fescue Festuca rubra with abundant thrift Armeria maritima. Further inland the grass creeping bent Agrostis stolonifera becomes more prominent, together with saltmarsh rush Juncus gerardii, sea plantain Plantago maritima and various sedges. A number of other salt-tolerant plants (halophytes) are locally abundant in these grasslands, for example sea milkwort Glaux maritima, common sea lavender Limonium vulgare and sea arrowgrass Triglochin maritima. Parsley water-dropwort Oenanthe lachenalii and sea club rush Scirpus maritimus are found in the creeks, sometimes with sea aster Aster tripolium and common scurvy grass Cochleria of ficinalis towards the edges. Towards the sea wall at the eastern edge of the marsh the proportion of halophytes gradually decreases, leaving a sward dominated by bent and fescue grases with perennial species such as sea couch, Yorkshire fog, autumn hawkbit, white clover and even perennial rye-grass gaining importance. The grassland is grazed in summer by cattle and a few horses. 
International and National Importance The site supports large numbers of waterfowl, especially pink-footed goose Anser fabalis brachyrynchus (up to 4000 use the area in winter, about $50 \%$ of the Icelandic and Greenlandic populations) and barnacle goose Branta leucopsis (up to 3000 birds, $40 \%$ of the Svalbard population in winter and about 8000 birds, or $90 \%$ of this population, in spring). It regularly supports over 10,000 ducks, geese and swans; flocks of waders are numerous in winter. The Solway Firth as a whole supports very large numbers of wintering and passage wildfowl and waders, with the sand flats and marsh at Rockcliffe an important constituent. For the Solway as a whole, internationally important wintering populations include those of pink-footed goose, barnacle goose, oystercatcher Haematopus ostralegus and pintail Anas acuta, with sanderling Calidris alba in passage. It also supports large breeding populations of black-tailed godwit Limosa limosa, common tern Sterna hirundo and Arctic tern $S$. paradisaea. In a 1985 survey of 77 saltmarshes in Great Britain, part of the Rockcliffe Marshes held the highest density of breeding oystercatchers and the second highest density of all breeding waders combined. Oystercatcher, lapwing Vanellus vanellus and redshank Tringa totanus nests each number over 100, and there are consistently 10-20 ringed plover Charadrius hiaticula nests.

\section{Changes in Ecological Character No information}

Management Practices The marsh is managed for part of the year as a Nature Reserve by the Cumbria Trust for Nature Conservation.

Scientific Research and Facilities Bird populations have been studied, including winter censuses and nest counts.

Principal Reference Material The above information is taken from documents supplied by the Government of the United Kingdom for designation on 25 September 1986. 
Summary of Wetland Situation The vast size of this country, and the variety of geology, climate, soils and land use, results in a wide range of freshwater and marine wetlands. In the mid-1970s there were an estimated 40 million ha of wetland in the conterminous U.S. plus about 80 million ha in Alaska. Wetland makes up over $25 \%$ of the areas of the states of Alaska, Louisiana and Florida, but in most states this is under $5 \%$. The most abundant types are freshwater marshes and swamps, while estuaries make up about $5 \%$ of the total area. Over half of the wetlands in the conterminous U.S. present when the first settlers arrived have disappeared, mostly through drainage for farming and forestry or construction but also due to natural causes such as sea level rise. Since the mid-1950s, small gains have occurred in some habitat types, notably in lake area, which has increased by 566,000 ha through the construction of reservoirs; in coastal open waters a gain of 81,000 ha has occurred, largely due to flooding of coastal wetlands in Louisiana.

There are a number of major wetland regions in the U.S. Along the Atlantic coast, saltmarshes are important for breeding and wintering birds as well as forming stopovers for migrant waterfowl on the Atlantic Flyway. Chesapeake Bay is the largest estuary in the U.S. and a primary waterfowl wintering ground, particularly important for canvasback Aythya valisineria and whistling swan Cygnus columbianus, but populations have declined partly due to a decrease in the sea grass beds and water pollution. Southern Florida contains a vast area of palustrine wetlands, dominated by the Everglades, which are important breeding areas for ducks, herons, egrets, spoonbills and ibises. The bottomland forested wetlands of the lower Mississippi are prime overwintering grounds for many waterfowl, including 2.5 million mallard Anas platyrhynchos ( $85 \%$ of the North American population) and 4 million wood duck Aix sponsa; numerous fish also spawn here. Louisiana contains one third of the coastal marshes in the conterminous U.S., but this area is declining as sediment accretion is not keeping up with the rise in sea level due to a complex of natural and man-made factors.

Inland, wetlands are noted for waterfowl breeding, particularly the Prairie Pothole region of the Dakotas in the north-west, which extends into Canada, where at least 15 species of waterfowl nest. The forest and scrub lands of the North Carolina pocosins are also important for waterfowl. In the north-east, red maple swamps are the most abundant wetland types, and wood duck plus 45 other bird species nest there. Wetlands of Nebraska's Sandhills and Rainwater Basin area are important to waterfowl on the Central Flyway, including sandhill crane Grus canadensis pulla plus 2.5 million ducks in spring. However, reduction of wetland area has forced ducks and geese to concentrate into remaining wetlands, and populations have declined through disease and food shortages. However, legislation to strengthen protection of wetland sites was due to be introduced in 1984. In the arid and semi-arid west, riparian forested wetlands are important nesting areas and stopover sites for migrant birds, and provide shelter for certain mammals. However, this habitat has suffered greatly from conversion to cropland and overgrazing; in Arizona, dam construction poses the greatest threat.

Alaskan and other tundra wetlands are the primary breeding grounds for most North American waders. Nearly the entire Pacific Flyway population of the Canada goose Branta canadensis and white-fronted goose Anser albifrons nest in the Yukon-Kuskokwim delta, and the state is the most important breeding area for pintail Anas acuta in the U.S. Alaska's north slope wetlands are important as a summer range and calving area for caribou.

Hawaii's wetlands are particularly important for endangered birds incuding Hawaiian stilt Himantopus himantopus knudensi, Hawaiian coot Fulica americana alai, Hawaiian gallinule Gallinula chloropus sandvicensis and Hawaiian duck or koloa Anas wyvilliana. 
Protected Areas Legislation There is legislation concerning protection of wetlands at both state and federal level. The foundation of federal wetland regulations is Section 10 of the River and Harbor Act of 1899 and Section 404 of the Clean Water Act of 1977, which relate to the need for permits to carry out changes in wetland areas. Permits have to be obtained from the U.S. Army Corps of Engineers, although normal agricultural and silvicultural activities are exempt. However, changes in 1982 to Corps regulations reduced the federal government's role in protecting wetlands. This generated much controversy and prompted new proposals to increase federal protection of palustrine wetlands which are in danger of disappearing if legislation is not strengthened. Other important domestic legislation includes the Federal Land Policy and Management Act of 1976 which requires the inventory, assesment and planning of all federal lands including wetlands; the Fish and Wildlife Act of 1956; the Coastal Zone Management Act of 1972; the Endangered Species Act of 1973; the National Policy Act of 1969; and the Fish and Wildlife Improvement Act of 1978.

Acquisition of wetlands at federal level is associated mainly with the Fish and Wildlife Service's National Wildfowl Refuge System and the Soil Conservation Service's Water Bank Program. The Migratory Bird Conservation Act of 1929, the Migratory Bird Hunting and Conservation Stamp Act of 1934, the Pittman-Robertson Act of 1937 and the Land and Water Conservation Fund Act of 1965 provide the authority and/or funds to purchase wetlands. The Dingell-Johnson Act of 1950 also provides $75 \%$ of the cost of fish restoration and management projects. The Fish and Wildlife Service currently controls nearly 13 million ha of estuarine wetlands, most of which are in Alaska.

Since the 1960s, 24 states have passed laws to regulate wetland uses, although these relate mostly to estuarine wetlands along the seaboards and great lakes. However, wetland orders are authorised by the statutes of at least eight states to include inland sites but they are more difficult to enforce than coastal ones partly due to their less easily identifiable physical characteristics. Local regulation of wetland activities has also been adopted in some states, strengthened by the National Flood Insurance Program which requires local regulation of the 100 -year floodplain in order to qualify for federally subsidised flood insurance.

Protected Areas Administration The U.S. Fish and Wildlife Service is primarily responsible for wetland protection and its responsibility comes from the Fish and Wildlife Coordination Act 1958 and international treaties.

Sites designated under the Convention

Ratification on 18 December 1986 with four sites listed.

Ash Meadows National Wildlife Refuge (Alaska)

Edwin B. Forsythe National Wildlife Refuge (New Jersey)

Izembek National Wildlife Refuge (Alaska)

Okefenokee National Wildlife Refuge (Georgia and Florida)

Government body responsible for administration of the Convention

U.S. Department of Fish and Wildlife, Department of the Interior, Washington, D.C. 20240.

\section{Ash Meadows National Wildlife Refuge}

Location $36^{\circ} 21^{\prime}-36^{\circ} 30^{\prime} \mathrm{N}, 116^{\circ} 15^{\prime}-116^{\circ} 23^{\prime} \mathrm{W}$. In southern Nye county, south-western Nevada, about $145 \mathrm{~km}$ north-west of Las Vegas and $64 \mathrm{~km}$ east of Death Valley National Monument.

Area 9,509 ha

Degree of Protection Devil's Hole was designated a National Monument in 1952 and Ash Meadows National Wildlife Reserve formed in 1984; the whole area was designated a Ramsar site on 18 December 1986. The United States Government currently owns 8,899ha (about 94\%) of the total area, and is planning to acquire the remaining 610 ha of privately owned land. Of 
the federally owned land, 5,106ha are owned and managed by the U.S. Fish and Wildlife Service under the National Wildlife Refuge System; 3,794ha owned by the Bureau of Land Management are either co-managed with the Fish and Wildlife Service $(2,709 \mathrm{ha})$ or scheduled to be transferred to the Fish and Wildlife Service (1,085ha). A 16ha parcel, Devil's Hole National Monument, is owned by the National Park Service and co-managed with the Fish and Wildlife Service. Many of the threatened plant species are protected under Nevada State laws.

Site Description The site is part of the lowland plains area of the Amargosa Valley which altogether cover about 20,500 ha of desert uplands and spring-fed oases. They are within the Mojave Desert region of the basin and range physiographic province of the south-west United States. The underlying rocks are predominantly calcareous (limestone and dolomite) forming mountains and hills with associated bajadas (colluvial slopes), arroyos (washes) and wetland areas. Soils are extremely fine-textured sands, silts and clays, with slow internal drainage. The water table is near the surface over much of the area, and the soils are mostly saline, of ten with a salt crust at the surface. Surface pavement is generally well-developed, especially in the bajadas, and caliche, a carbonate hardpan, is common. The area slopes from elevations of about $960 \mathrm{~m}$ in the north-east to about $640 \mathrm{~m}$ in the south-west. There are over 30 springs, in three main groups: Devil's Hole $(732 \mathrm{~m})$, a series of small springs at about $710 \mathrm{~m}$, and many larger ones between $680 \mathrm{~m}$ and $707 \mathrm{~m}$. In pluvial times surface waters of Ash Meadows discharged into the Amargosa River System, but now flows from larger springs discharge into remnants of Carson Slough, a tributary of the Amargosa River, ard sink into desert soils or evaporate before leaving the meadows. Precipitation varies between $70 \mathrm{~mm}$ and $100 \mathrm{~mm}$ per annum, most falling in winter. Annual evapotranspiration generally exceeds $2,500 \mathrm{~mm}$. Over 200 species of vascular plant have been identified. A creosote bush Larrea tridentata vegetation community dominates the desert uplands of the region. Important co-dominants include bur-sage Ambrosia dumosa, desert thorn Lycium andersonii, hop-sage Grayia spinosa and shadscale Atriplex confertifolia. Seasonally wet meadows of salt grass Distychlis spicata are common, of ten in association with species of Atriplex and Suaeda, while the drier uplands are dominated by shadscale and Haplopappus acradenius. Within spring and seepage areas, where water comes to the surface from deep underground aquifers, many small streams, pools and wet meadows are conspicuous features, with scattered groves of trees dominated by velvet ash Fraxinus velutina var. coriacea (which gives Ash Meadows its name), screwbean Prosopis pubescens and mesquite $P$. juliflora. The shrub layer in these groves is predominantly Baccharis emoryi. Herbaceous vegetation around the springs is frequently dominated by Carex praegracilis, bulrushes Scirpus spp., spike rushes Eleocharis spp., salt grass and Anemopsis californica.

International and National Importance This site is a unique desert oasis providing habitat for at least 25 species of rare, endangered or unusual plants and animals, including many endemic to the area (and most being associated with wetland or aquatic habitats). The concentration of endemic species is greater than in any other land area of the United States, and second greatest in all of North America. At least four of the springs contain native fish, four of which are listed as endangered under the Endangered Species Act of 1973: Devil's Hole pupfish Cyprinodon diabolis, Warm Springs pupfish $C$. nevadensis pectoralis, Ash Meadows Amargosa pupfish $C$. nevadensis mionectes and Ash Meadows speckled dace Rhichthys osculus nevadensis. Three of these inhabit several springs and pools, though fewer than in historical times, but the Devil's Hole pupfish is restricted to a single limestone cave. Six plant species are listed as threatened species: Ash meadows blazing star Mentzelia leucophylla, Ash meadows milk-vetch Astragalus phoenix, Ash meadows sunray Enceliopsis nudicaulis var. corrugata, spring-loving centaury Centarium namophilum var. namophilum, Ash Meadows gumplant Grindelia fraxino-pratensis and Ash Meadows ivesia Ivesia eremica. The Amargosa niterwort Nitrophila mohavensis, the most localised of all the endemic plants in Ash Meadows, is listed as endangered. All of the aforementioned plants are endemic to Ash Meadows with the exception of Centaurium namophilum, which has historically been collected in a few other spring areas in the general region, though not in historical times. An aquatic bug, the endangered Ash Meadows naucroid Ambrysus amargosus, only occurs in a single spring. Two species of plants, one mammal, one insect and 12 snail species are being considered for listing and protection under the endangered species act. This area, particularly Carson Slough, was important historically for waterfowl, and there are plans to restore this function. At present, 
three reservoirs are used by modest numbers of ducks and geese in autumn and winter, particularly mallard Anas platyrhynchos, pintail $A$. acuta, green-winged teal $A$. crecca, cinnamon teal $A$. cyanoptera, canvasback $A$ thya valisineria and coot Fulica americana. Peak waterfowl numbers are usually between 2500 and 3500 birds.

Changes in Ecological Character Large-scale disturbance of Ash Meadows began in the early 1960s with marshland peat-mining, agricultural conversion of wetlands and uplands, alteration of spring systems for crop irrigation and cattle ranching purposes, and excessive groundwater pumping. Large herds of feral horses adversely affected spring morphology and plant populations. Exotic fish introductions have depleted native fish and aquatic invertebrate populations. There has also been disturbance from mining and off-road travel. Under present management as a wildlife refuge, no immediate threats of magnitude are anticipated. However, land use changes in the several privately-owned parcels of land within the refuge's boundaries could have adverse effects if these are not acquired by the federal government.

Management Practices The site is managed as a wetland, even though the wet areas occur within a desert ecosystem. Practices are in accordance with U.S. Fish and Wildlife Service National Wildlife Refuge System policies, and with the policies and goals of the endangered species and migratory waterfowl programmes. Primary objectives include prevention of endangerment and extinction through habitat restoration; conservation of migratory waterfowl and population enhancement; and the preservation of the full complement of native ecological and biological diversity. A recovery plan for the entire Ash Meadows ecosystem and its threatened species is nearly complete, and a refuge master planning process for habitat restoration and improvement has been initiated. The U.S. Government Bureau of Land Management is at present implementing a habitat management plan for lands owned or co-managed by them.

Water levels in three man-made reservoirs are manipulated to provide favourable water conditions for wintering and migratory waterfowl. The restoration of Carson Slough to its original wetland status and importance for waterfowl is being considered. Exotic species eradication is being actively undertaken by the Fish and Wildlife Service, Bureau of Land Management and Nevada Department of Wildlife, and includes removal of tamarisk Tamarix spp. and other alien plants, exotic fish and feral horses. Over 200 wild horses were removed from the refuge in 1985. Hunting of dove, quail and waterfowl and reservoir fishing of large-mouth bass are allowed on refuge lands, but are strictly controlled under federal and state regulations. There is close cooperation on several resource management issues between the various federal and state agencies involved.

Scientific Research and Facilities A number of significant studies have been conducted or are continuing, including research into the area's geology, groundwater hydrology, botany and relict fish and invertebrate populations. Institutions involved include the U.S. Department of the Interior (Fish and Wildlife Service, Geological Survey, National Park Service) as well as many universities. There are no research facilities located at the refuge.

Principal Reference Material The above information is taken from the 1984 and 1985 Annual Narrative Reports of the Desert National Wildlife Refuge Complex and Agency Review Draft (1986) of the Recovery Plan for the Endangered and Threatened Species of Ash Meadows, prepared by the U.S. Fish and Wildlife Service, Department of the Interior.

Additional references:

- Beatley, J.C. (1976). Vascular Plants of the Nevada Test Site and Central-Southern Nevada: ecologic and geographic distibutions. U.S. Energy Research and Development Administration. $308 \mathrm{pp}$.

- Beatley, J.C. (1977). Endangered Plant Species of the Nevada Test Site, Ash Meadows, and Central-Southern Nevada. U.S. Energy Research and Development Administration. Contract E(11-1)-2307.

- Sada, D.W. (1984). Land Protection Plan: Proposed Acquisition to Establish Ash Meadows National Wildlife Refuge, Nye County, Nevada. U.S. Department of the Interior, U.S. Fish and Wildlife Service, Portland, Oregon. 40pp. and appendices.

- Smith, G.R. (1978). Biogeography of intermountain fishes. Great Basin Naturalist Memoirs 2:17-42. 
- U.S. Fish and Wildife Service (1980). Devil's Hole Pupfish Recovery Plan. Unpubl. report, Portland, Oregon.

- Williams, J.E., Bowman, D.B., Brooks, J.E., Echelle, A.A., Edwards, R.J., Hendrickson, D.A. and Landye, J.J. (1985). Endangered aquatic ecosystems in North American deserts with a list of vanishing fishes of the region. Journal of the Arizona-Nevada Academy of Science 20:41-43.

- Winograd, I.J. and Thordarson, W. (1975). Hydrogeologic and Hydrochemical Framework, South-Central Great Basin, Nevada-California, with special reference to the Nevada Test Site. U.S. Geol. Survey Prof. paper 712-c. 126pp.

\section{Edwin B. Forsythe National Wildlife Refuge}

Location $\quad 39^{\circ} 26^{\prime}-39^{\circ} 46^{\prime} \mathrm{N}, 74^{\circ} 07^{\prime}-74^{\circ} 28^{\prime} \mathrm{W}$. In south-eastern New Jersey in Atlantic, Burlington and Ocean counties, approximately $96 \mathrm{~km}$ south-east of Philadelphia and $10 \mathrm{~km}$ north-west of Atlantic City.

Area 13,080ha; comprising two management units, formerly two separate refuges, Barnegat Division (4,358ha) and Brigantine Division (8,722ha).

Degree of Protection Owned by the Federal Government. The State of New Jersey retains certain rights on most of the tidal area below mean high tide, though primary jurisdiction on refuge tidal lands remains with the federal government. Forsythe NWR was established and renamed in 1984 through the merging of Brigantine NWR (established 1939) and Barnegat NWR (established 1964). The whole area was designated a Ramsar site on 18 December 1986. Under the Wilderness Act of 1964, 2,704ha (one fifth of the total refuge area) are designated and managed as wilderness, most of which is pristine saltmarsh. The refuge is managed by the Fish and Wildlife Service under the National Wildlife Refuge System.

Site Description The site is located along $29 \mathrm{~km}$ of coastline and comprises several separate units. It is bounded to the east by the Atlantic Ocean and by several shallow bays, which separate the mainland from offshore barrier beaches and spits: Great Bay, Little Bay, Grassy Bay, Barnegat Bay, Manahawkin Bay and Little Egg Harbour Bay. The coastal plain of New Jersey in this region consists of geologically recent beaches, swamps, dunes and marshes overlying gently sloping to near level unconsolidated beds of sand, gravel, clay and marl. Elevations vary from $2 \mathrm{~m}$ below to $15 \mathrm{~m}$ above above mean sea level, with an average elevation of $2 \mathrm{~m}$. Normal tidal amplitude is about $1.4 \mathrm{~m}$. The Mullica River, one of the major drainages in the region, traverses the refuge in Brigantine Division, and a number of smaller rivers flow into the shallow bays just eastward of the mainland refuge boundaries.

Regularly and irregularly-flooded saltmarshes and meadows cover about $80 \%$ of the refuge (about 10,500ha). The dominant vegetation in these areas is cordgrass Spartina alterniflora and/or saltmarsh hay $S$. patens. Bays and tidal flats are the next most extensive features, covering about $1,800 \mathrm{ha}$. The shallow tidal areas contain extensive beds of sea lettuce Ulva lactuta, eelgrass Zostera marina, and a marine alga, which are important foods for wintering birds, particularly brent geese Branta bernicla. Where freshwater exerts an influence, reed grass Phragmites australis, cattail Typha latifolia and bulrushes Scirpus spp. commonly occur. Upland vegetation is primarily pitch pine Pinus rigida, blackjack oak Quercus marilandica, holly Ilex opaca, scrub oak $Q$. ilicifolia and japanese honeysuckle Lonicera japonica. Bottomland swamps contain mostly red maple Acer rubrum with some Atlantic white cedar Chamaecyparis thyoides, sweetbay Magnolia virginiana and blackgum Nyssa sylvatica with a shrub layer of sweet pepperbush Clethra alnifolia, clammy azalea Rhododendron viscosum and blueberries Vaccinnium spp.. Parts of the upland areas are planted with wildlife food plants, cover plants and grasslands. Approximately $650 \mathrm{ha}$ of saltmarsh have been dyked off and converted to freshwater impoundments fed by upland runoff and precipitation, and these have had aquatic food plants introduced. The mud flats and tidal channels are rich in invertebrates and are commercially important for clams and oysters in particular. Little Beach 
Island and Holgate Wilderness Area contain mostly saltmarshes, sandy beaches and dunes, with typical barrier island landforms and vegetation, including Ammophila breviligulata and Myrica pensylvanica.

Over 289 species of birds have been observed on the refuge, and at least 200 are common. The main species are ducks, geese and marshbirds, including ten species of heron and 37 wader species. Clapper rails Rallus longirostris are abundant in the saltmarshes. There are gull and tern colonies, of ten extensive, in the sandy areas. About 38 mammals occur, including Eastern cottontail rabbit Sylvilagus floridanus, muskrat Ondatra zibethicus, racoon Procyon lotor and red fox Vulpes fulva. Eight amphibian and eleven reptile species inhabit the area, incluciing northern diamondback terrapin Malaclemys terrapin, which is prominent here.

International and National Importance Both of the component refuges were originally established for the protection and management of waterfowl in the Atlantic flyway, with special emphasis on brent geese and black duck Anas rubripes. Brent geese find their major protection on waterfowl refuges, wintering on a small section of coastline from Massachusetts to South Carolina. They are most abundant along the coast of New Jersey, where wintering populations at Forsythe NWR of ten swell to over 60,000 birds, nearly one third of the total winter population. Numbers of black duck and snow goose Anser caerulescens at times reach 60,000-70,000 birds. Other important migrants include mallard Anas platyrhynchos, gadwall $A$. strepera, American wigeon $A$. americana, common teal $A$. crecca, pintail $A$. acuta and Canada goose Branta canadensis. The area is also important for breeding waterfowl, including mallard, black duck, gadwall, blue-winged teal Anas discors and Canada goose, over 3,000 ducklings being produced annually.

Changes in Ecological Character There are no immediate threats to the refuge itself, but much of the adjacent marshlands and uplands are threatened by burgeoning human development and population growth. These increased development pressures could potentially have significant adverse impacts on both habitat and wildlife value through changes in water and air quality, loss of surrounding habitat and by direct disturbance. The eelgrass beds are nearly completely recovered from the devastating eelgrass blight of the 1930s.

Management Practices Major management practices are directed toward protecting and improving the wetland environment for waterfowl, particularly brent geese and black ducks, but also for other migrating and wintering birds and to maintain existing habitat to benefit rare or endangered plant and animal species. Over $2,700 \mathrm{ha}$ are managed as wilderness. Environmental education, wildlife-orientated recreation and scientific research are also primary management objectives. Hunting and trapping are strictly controlled in accordance with state and federal regulations. Other public uses are managed in the refuge, including saltwater fishing, clamming and crabbing, boating and wildlife observation. Open water marsh management by ditching and impounding is practised over large areas of the marshlands for mosquito control purposes, and for the creation of waterfowl habitat. Water levels are manipulated seasonally to form the most favourable conditions. Forest management consists of controlled burning and replanting, particularly with Atlantic white cedar in its historical habitat. Herbicides are used along dykes and impoundments to control weeds, particularly the reed Phragmites australis. Pest control includes water management, biological control and pesticides. Certain grasslands are regularly mowed to promote regrowth for deer and geese, and to improve nesting habitat for waterfowl. Upland areas are planted with perrenial grasses to supplement natural food plants.

Scientific Research and Facilities Research studies are encouraged on the refuge and have been conducted on a variety of subjects for many years. Some of the more recent investigations include: survival and habitat use of wintering black duck; areas overgrazed by snow geese; evaluation of open marsh water management and its effect on black duck and other bird populations; mating strategies and larval habitats of the greenhead fly Tabanus nigrovittatus; laughing gull Larus atricilla behaviour; air quality monitoring; and the effects of ground water withdrawal. 
Principal Reference Material The above information is taken primarily from the 1984 Annual Wildlife Narrative Reports of the Edwin B. Forsythe National Wildlife Refuge (Barnegat and Brigantine Divisions) and Refuge Leaflet 40 of the U.S. Fish and Wildlife Service, Department of the Interior.

Additional information:

- Leck, C. (1975). Birds of New Jersey. Rutgers University Press, New Brunswick, New Jersey. Pp.18-39.

- Lewis, J.V. and Kummel, H.B. (1915). The Geology of New Jersey. Geological Survey of New Jersey, Bull. 14. 146pp.

\section{Izembek National Wildlife Refuge}

Location $55^{\circ} 30^{\prime}-56^{\circ} 00^{\prime} \mathrm{N}, 162^{\circ} 07^{\prime}-163^{\circ} 15^{\prime} \mathrm{W}$. Near the extreme western tip of the Alaskan Peninsula, approximately $1,000 \mathrm{~km}$ south-west of Anchorage, between the Northern Pacific Ocean and the Bering Sea.

\section{Area 168,433 ha}

Degree of Protection Ownership is part federal and part state government. Izembek NWR, established in 1960, is federal-owned, managed by the Fish and Wildlife Service and comprises 128,337 ha of mainly terrestrial habitat. All of the site's tidelands, including Izembek Lagoon, cover about $39,000 \mathrm{ha}$, and are owned by the State of Alaska under the Tide and Submerged Lands Act. They were established in 1972 as the Izembek State Game Refuge, jointly managed by the Alaska Departments of Natural Resources and Fish and Game in cooperation with the Fish and Wildlife Service. In 1980, 121,410ha of lands within the NWR were officially designated as wilderness under the Alaska National Interest Lands Conservation Act. The whole area was designated a Ramsar site on 18 December 1986.

Site Description The site is about $77 \mathrm{~km}$ long and between $8 \mathrm{~km}$ and $40 \mathrm{~km}$ wide, and includes about 130,000 ha of upland, the reminder being intertidal areas and coastal lagoons, includind Izembek Lagoon, the largest of its type in Alaska. The geology of the area has been much influenced by volcanism, glaciation and marine deposition with rugged volcanic pinnacles rising to $1,800 \mathrm{~m}$, and glaciers on the mountainous parts of the refuge. Most of the site is, however, below $300 \mathrm{~m}$ in elevation and glacial till covers much of the lowlands. The valleys contain westward-flowing streams which cross a low, rolling tundra area with scattered freshwater lakes and ponds. The shallow, extremely acid tundra soils are susceptible to erosion. Izembek Lagoon is only three to four metres deep, and separated from the Bering Sea by offshore islands and spits of marine origin. Lagoon sediments are mostly sand and clay derived from of fshore shelf areas.

The area is treeless, with typical subarctic-alpine vegetation in the mountains. On lower slopes and along waterways are alders Alnus crispa and sparse growths of willows Salix spp. The glacial outwash and coastal plains are dominated by a mixture of low ericaceous shrubs and graminoid tundra, including crowberry Empetrum nigrum, mountain cranberry Vaccinium vitis-idaea, bluejoint grass Calamagrostis canadensis, cottongrass Eriophorum scheuchzeri, arctic willow and other willows; reindeer mosses Cladonia spp. and several species of Sphagnum moss. Wet meadows and marshes are dominated by beach ryegrass Elymus arenaria. Sedges Carex spp. border the lagoon. About $87 \%$ of the terrestrial habitat is characterised as wetlands, comprising 81,000 ha of moist tundra, 9,000 ha of wet sedge and grass marsh and 24,300 ha of pond, lake and riverine areas. An estimated $53 \%$ of Izembek Lagoon is vegetated with eelgrass Zostera marina, making it one of the largest eelgrass beds in the world. At least 142 species of bird and 23 of mammal are reported to be residents or migrants of the site, including large numbers of waterfowl and waders.

International and National Importance Izembek Lagoon and its vast eelgrass beds are of international importance to migratory birds, being the primary food of many geese and ducks. The site is particularly critical as a last staging post for many species of waterfowl and wader which make trans-oceanic flights to winter on the Pacific coast of the USA or on islands 
further south; the area is used by birds that nest and/or winter in countries along the Pacific Rim including the Soviet Union, Canada, Japan, Australia and Mexico, as well as the United States. The lagoon supports nearly the entire North American population of black brent goose Branta bernicla nigricans during spring and autumn migrations. In some years, substantial numbers (over 10,000) may overwinter in the lagoon. Additionally, tens of thousands of Taverner's Canada goose B. canadensis taverneri and emperor goose Anser canagicus migrate through the area, with moderate numbers of the latter overwintering. Whistling swan Cygnus C. columbianus are a key nesting waterfowl species on the refuge. Migrant populations of up to 300,000 dabbling ducks at a time use the area in spring and autumn migration periods: the most abundant ducks are pintail Anas acuta and mallard $A$. platyrhynchos. Others ocurring in fairly large numbers include gadwall $A$. strepera, common teal $A$. crecca and American wigeon A. americana. Wintering populations of Steller's eider Polysticta stelleri may approach 100,000 birds on Izembek and adjacent lagoons, a major portion of the population of this species. Other sea ducks wintering in abundance here are long-tailed duck, bufflehead, common goldeneye, greater scaup, common eider, king eider, black-winged scoter and white-winged scoter (Clangula hyemalis, Bucephala albeola. $B$. clangula, Aythya marila, Somateria mollissima, S. spectabilis, Melanitta nigra and $M$. fusca).

Important upland species include Alaskan brown bear Ursus arctos, barren ground caribou Rangifer tarandus, wolverine Gulo gulo, mink Mustela vison, willow ptarmigan Lagopus lagopus, river otter Lutra canadensis and grey wolf Canis lupus. Bald eagle Haliaeetus leucocephalus and Peregrine falcon Falco peregrinus pealei are year-round residents. The sand spits and barrier island beaches surrounding Izembek lagoon are haulout sites for harbor seals Phoca vitulina with up to 5000 present at one time. An estimated 500-1000 sea otters Enhydra lutris and 100 Steller's sea lions Eumetopias jubatis frequent the lagoon and nearby offshore areas for feeding and resting. Four species of pacific salmon Oncorhynchus spp. including sockeye, chinook, pink salmon and chum, enter the Pacific Ocean to spawn. Dolly Varden trout Salvelinus malma and rainbow trout Salmo gairdneri also inhabit many of the streams and lakes. A minimum of 39 species of fish use the are as migratory, spawning or nursery habitat.

Changes in Ecological Character The area surrounding Cold Bay (Refuge Headquaters) was badly abused during World War Two and many land scars are still in evidence. The remainder of the refuge is wilderness or relatively undisturbed except for some access roads. Hunting is the most common recreational use of the refuge, particularly waterfowl hunting around the lagoons and upland hunting of caribou and brown bear. Direct threats to the resources of Izembek Lagoon are generally not imminent and of low intensity. Recently there has been a substantial increase in petroleum development activities in adjacent offshore areas. The possibility of a major oil spill entering the lagoon or the construction of oil pipelines and support facilities in the area are viewed as potential threats. The Alaska Department of Natural Resources has closed Izembek lagoon to oil and gas leasing in order to protect its wildlife resources and ecological values. Aircraft overflights, primarily helcopters associated with offshore petroleum activities, are a potential threat to staging and wintering waterfowl.

Management Practices Management is directed towards the preservation of the natural environment for all native species of wildlife. Most of the area is managed by the Fish and Wildlife Service as a wilderness area. Hunting, fishing and trapping are allowable uses, but strictly controlled under state and federal regulations. Wildlife habitats are generally not manipulated. Except for erosion control, road maintenance and landscaping at refuge headquaters in Cold Bay, no land management is foreseen.

Scientific Research and Facilities Most research is carried out from refuge headquaters in Cold Bay. Ongoing projects include individual studies on seasonal movements, distribution and productivity of brown bear, caribou, black brent geese, emperor geese, tundra swan, steller's eider and other species. Researchers from the Institute of Marine Science of the University of Alaska have carried out studies since 1963 on the dynamics of the eelgrass beds in lzembek lagoon and other aspects of the ecology of the estuary. 
Principal Reference Material Most of the above information is taken from the 1983 and 1984 Annual Narrative Reports and 1969 Master Plan of Izembek National Wildlife Refuge, Cold Bay, Alaska, prepared by the U.S. Fish and Wildlife Service, U.S. Department of the Interior. Additional information from:

- Alaska Department of Fish and Game (1982). Alaska Dept. of Fish and Game Special Areas Program Document. Habitat Division, Alaska Dept. of Fish and Game. Anchorage, Alaska. $17 \mathrm{pp}$.

- Barsdate, R.J., Nebert, M. and McRoy, C.P. (1974). Lagoon contributions to sediments and water and the Bering Sea. Proc. of the Int. Symp. on Oceanography of the Bering Sea. $34 \mathrm{pp}$.

- Frost, K.J., Lowry, L.F. and Burns J.J. (1982). Distribution of marine mammals in the coastal zone of the Bering Sea during summer and autumn. Final report, Research Unit \#613. Contract \#NA 81 RAC 00050 . 188pp.

- McKinney, F. (1958). Waterfowl at Cold Bay, Alaska, with notes on the display of the black scoter. Wild fowl Trust Annu. Rep. 10: 133-140.

- McKinney, F. (1965). The spring behaviour of wild Steller's eiders. Condor 67:273-290.

- McRoy, C.P. (1966). The standing stock and ecology of eelgrass Zostera marina in Izembek Lagoon, Alaska. Unpubl. M.Sc. Thesis, Univ. of Washington. 138pp.

- McRoy, C.P. (1970). Standing stocks and other features of eelgrass Zostera marina populations on the coast of Alaska. J. Fish Res. Bd. of Canada 27:1811-1821.

- U.S.Dept of the Interior. (1985). The Bristol Bay regional management plan and final environmental impact statement Volume I. Bristol Bay Study Group and the Alaska Land Use Council. Anchorage, Alaska. $411 \mathrm{pp}$.

\section{Okefenokee National Wildlife Refuge}

Location $30^{\circ} 36^{\prime}-31^{\circ} 02^{\prime} \mathrm{N}, 82^{\circ} 09^{\prime}-82^{\circ} 31^{\prime} \mathrm{W}$. In the south-east of the state of Georgia in Ware, Charlton and Clinch counties, extending a short distance into Baker county in north-eastern Florida. The northern boundary is about $19 \mathrm{~km}$ south of Waycross, Georgia, and the eastern boundary about $64 \mathrm{~km}$ north-west of Jacksonville, Florida.

\section{Area 159,889 ha}

Degree of Protection The whole area is owned by the federal government. It was established by Executive Order in 1937 and is managed under the National Wildlife Refuge System by the Fish and Wildlife Service. The Okefenokee Wilderness Act of 1974 designated 143,260ha (nearly $90 \%$ of the refuge) as a wilderness area. The whole refuge is protected by numerous legislative acts. The refuge was designated as a Ramsar site on 18 December 1986.

Site Description The site is a vast low-lying natural wilderness area dominated by the peat bog swamp forests of Okefenokee Swamp, the second largest wetland in the United States. This swamp coves about 177,260 ha, of which nearly $85 \%$ is within the refuge boundaries. It occupies a huge saucer-shaped depression considered to have once been part of the ocean floor. The upland margin of the swamp varies in elevation from $39 \mathrm{~m}$ on the north-east side to $32 \mathrm{~m}$ above sea level on the south-west edge. The swamp is within the drainage divide between the Atlantic Ocean and the Gulf of Mexico. Inflows consist of several short streams which enter on the north-west side and drainage is sluggish towards the two outlets, the Suwannee River which is the larger and flows towards the Gulf of Mexico and St Mary's River, which flows into the Atlantic Ocean. Okefenokee is a mosaic of dense swamps, freshwater marshes, small lakes and ponds, upland islands and upland forests. Eight major habitat types and 20 plant communities have been identified, and about $94 \%$ of the refuge is classified as wetlands. Approximately $80 \%$ of its area is swamp forest of bald cypress Taxodium distichum, pond cypress $T$. ascendens, black gum Nyssa sylvatica, loblolly bay Gordonia lasianthus, swamp bay Persea palustris and sweet bay Magnolia virginiana.

Freshwater marshes, known locally as "prairies", are extensive shallow areas $0.3-1 \mathrm{~m}$ deep of open water with areas of luxurious aquatic plants. Characteristic plants include white water lily Nymphaea odorata, bladderworts Utricularia spp., golden club Orontium aquaticum, maiden 
cane Panicum hemilomon, Virginia chain-fern Woodwardia virginica, yellow pond lily Nuphar luteum, floating heart Nymphoides aquatica and various species of grasses and sedges. Scattered throughout the prairies are tree islands which are similar in floristic composition to the swamp vegetation and of ten contain thick beds of Sphagnum mosses and carnivorous plants. There are about 60 small lakes and ponds, generally less than $100 \mathrm{~m}$ wide, which have areas of open water or contain floating plants and are bordered by dense swamp underbrush.

About 50 sandy islands are present, totalling some 6,685 ha and these are dominated by longleaf pine Pinus palustris and slash pine $P$. elliotii. Upland pine forests adjacent to the swamplands cover about $6,155 \mathrm{ha}$, and consist mostly of longleaf and slash pine, loblolly pine $P$. taeda, pond pine $P$. serotina, sweet gum Liquidambar styraciflua and several oaks Quercus spp. Understorey plants include grasses, saw palmetto Serenoa repens and several species of ericaceous shrubs.

The swamp and surrounding pinelands are a fire-dependent ecosystem in which wild firez have historically preserved the unique mosaic of plant communities. The variety of habitats supports a high diversity and abundance of typical coastal plain vertebrates, including 233 species of birds, 48 mammals, 66 reptiles, 37 amphibians and 36 fish. Black bear Euarctos americanus and white-tailed deer Odocoileus virginianus both have fairly large, stable populations.

International and National Importance Okefenokee has particular value as a refuge for rare or endangered animals and plants. Residents protected under the U.S. Endangered Species Act are American alligator Alligator mississippiensis (one of the largest concentrations in the U.S., estimated at 12,000 individuals), Florida panther Felis concolor coryi (very rarely sighted), eastern indigo snake Drymarchon corais couperi and red-cockaded woodpecker Picoides borealis Migrant federally-protected species that visit the refuge on a regular or infrequent basis include Bachman's warbler Vermivora bachmanii bald eagle Haliaeetus leocucephalus and wood stork Mycteria americana. One of the last strongholds of the ivory-billed woodpecker Campephilus principalis was Okefenokee swamp, but no confirmed sighting has been made here since the 1930s.

Okefenokee was formerly of considerable importance as a wintering area for migratory waterfowl, even though the area is not within the major Atlantic flyway. Habitat change from open, grassy marshes to dense swamp shrublands may have contributed to its decline in significance. Peak wintering populations are estimated at 8,000-10,000 kirds, with wood ducks Aix sponsa predominating and good numbers of mallard Anas platyrhynchos, ring-necked duck Aythya collaris and common teal Anas crecca. Common residents include white ibis Eudocimus albus, great egret Casmerodinus albus, sandhill crane Grus canadensis, anhinga Anhinga anhinga and great blue heron Ardea herodias.

Changes in Ecological Character There is a potential threat from adjacent commercial timber lands where felling results in increased flows of water into the swamp which may carry pesticides, herbicides or other chemical pollutants. In the future there could also be air pollution from urban areas or disturbance from low flying aircraft, but these impacts have not been investigated. Unfavourable changes in habitat could result from fire suppression activities in the area, though in general, fire management has been used to improve and maintain favourable wildlife habitat.

Management Practices The Wilderness Area of the refuge is a sanctuary for plant and animal communities indigenous to the swamp, and is managed in accordance with the Fish and Wildlife Service National Wildlife Refuge System policies. Public use is permitted within the area, and consists primarily of limited duration camping at designated campsites, canoeing and boating along designated routes, wildlife observation, photography and fishing. There is emphasis on using the area as an outdoor classroom for students at all levels. Public access is limited to four points. Lands outside the wilderness area include 6,155ha of pine forests, where management includes prescribed burning to enhance pine forest upland habitat for the red-cockaded woodpecker and eastern indigo snake. Future management may include 
manipulation of water levels in conjunction with prescribed burning within the Okefenokee Swamp in an effort to perpetuate the numerous unique vegetation characteristics of the refuge; research is being done to investigate these possibilities.

Scientific Research and Facilities The University of Georgia has been involved in studies for over 12 years, and is currently investigating the feasibility of establishing a permanent research station on the refuge. Its Institute of Ecology is involved in a long-term study of the swamp's ecosystem to develop a basic knowledge of interspecies relationships and hydrology which will help in the assessment of long-term effects of natural and human disturbance. Other institutions have made short-term studies of endangered species, vegetation and geology.

Principal Reference Material The above information is taken largely from the 1984 Annual Narrative Report of the Okefenokee National Wildlife Refuge prepared by the Fish and Wildlife Service, U.S. Department of the Interior.

Additional references:

- Cohen, A.D., Casagrande, J.D., Andreko, M.J. and Best, G.R. (1984). The Okefenokee

Swamp: its Natural History, Geology and Geochemistry. Wetlands Surveys, Los Alamos, New Mexico.

- Cypert, E. (1961). The effects of fires in the Okefenokee Swamp in 1954 and 1955. American Midland Naturalist 66(2):485-503.

- Harper, R.M. (1909). Okefenokee Swamp. Popular Science Monthly 74:596-614.

- Wright, A.H. and Wright, A.A. (1932). The habitats and composition of the vegetation of Okefenokee Swamp, Georgia. Ecol. Monogr. 2:109-232. 


\section{URUGUAY}

Area $186,925 \mathrm{sq} . \mathrm{km}$

Population $2,864,000$ (1978).

Summary of Wetland Situation The country borders on the Atlantic Ocean (220km of coastline), the Rio de la Plata $(460 \mathrm{~km})$ and the Rio Uruguay $(480 \mathrm{~km})$. There are some 3500 sq. $\mathrm{km}$ of lakes, lagoons and dams, and some $3500-4000 \mathrm{sq}$. $\mathrm{km}$ of permanent and tempo-ary marshes, the largest being those situated in the east and northeast of the country. Overall, it has been estimated that wetlands make up about $3.6 \%$ of the territory of Uruguay. Of the 400 or so species of birds occurring in Uruguay, $175(44 \%)$ are aquatic or semi-aquatic; these belong mainly to the Siluriformes and Cypriniformes, and many are of commercial importance. All 36 species of amphibians known from Uruguay inhabit wetlands for at least a part of their life cycle, and several of the reptiles are dependent on wetlands, namely five species of freshwater turtle, three snakes and the caiman Caiman latirostris. The latter is now in danger of extinction in Uruguay. Of the mammals associated with wetlands, three are trapped for their fur and constitute important natural resources. These are the la plata otter Lutra platensis, coypu Myocastor coypus and capybara Hydrochoerus hydrochaeris.

Protected Areas Legislation Protection of all parks and forests is apparently based on the Forestry Law (13.723) of 16 November 1968. This defines national parks and fiscal forests. Various other categories are used in practice, however, including national monument and wildlife refuge, and there would appear to be a degree of overlap in their application.

Protected Areas Administration Decree 269/967 of 27 April 1967 incorporates the National Park Department into the Ministry of Agriculture (Ministerio da Ganaderia y Agricultura) under the title Direccion Forestal, Parques y Fauna. This Department is in charge of all the national parks, apart from Santa Teresa and San Miguel, which come under the Ministerio de Defensa Nacional. The Department has the right to expropriate lands, and to inspect and seize vehicles, instruments and arms employed in illicit activities.

\section{Sites designated under the Convention}

Accession 22 May 1984 with one site listed at accession.

Banados del Este y Franja Costera

Government body responsible for administration of the Convention

Direccion Forestal, Parques y Fauna, Ministerio de Ganaderia y Agricultura, Montevideo, Uruguay.

\section{Banados del Este y Franja Costera}

Location $32^{\circ}-35^{\circ} \mathrm{S}, 53^{\circ}-55^{\circ} \mathrm{W}$. In eastern Uruguay, on the Brazilian frontier.

Area 200,000 ha.

Degree of Protection 30\% state property; $70 \%$ privately owned. This area is said to contain some 30,500 ha in National Parks that are governed by law no. 9841 (4 July 1935) concerning the protection of flora and fauna. It is unclear to which areas this refers. Designated as a Biosphere Reserve on June 1976 and as a Ramsar site at the time of accession on 22 May 1984.

Site Description Four important rivers flow through Banados del Este into the Merim Lagoon; the Yaguaton, Tacuari, Olimar and San Luis. Grey panosol fields, normally under water, produce a great floral variety. The soils are peaty with high acidity. Annual average rainfall in the zone is $1,100 \mathrm{~mm}$, most abundant in winter, and the temperature ranges between $8^{\circ} \mathrm{C}$ and 
$28^{\circ} \mathrm{C}$. This is the only area in the country where the "butia" palms Butia yatay growing in these soils are protected. They form an almost pure association. Dominant in the herbaceous community are Cyperaceae, Juncaceae, Gramineae (Scirpus californicus, Typha spp., Zizaniopsis bonaerensis, Scirpus giganteus, etc.). There are also a variety of psammophilous plants and extensive stands of the conifer Pinus atlantica along the coast.

International and National Importance The indigenous fauna remains almost intact except that the marsh deer Blastocerus dichotomus is now locally extinct. There are large colonies of coypu Myocastor coypus and capybara Hydrochoerus hydrochoeris, while giant otter Pteronura brasilensis are less abundant. Perhaps more important, however, is the tremendous wealth of the avifauna, which includes species such as the red-legged seriema Caraima cristata, black-necked swan Cygnus melanocoryphus, Coscoroba swan Coscoroba coscoroba and muscovy duck Cairina moschata. In addition, this zone is one of the most important in the southern hemisphere for the study of migratory birds in their movements from north to south. Examples are the American golden plover Pluvialis dominica dominica from the Arctic, the albatross Diomedea sp., the petrels (Procellaridae) and the penguins (Spheniscidae).

Changes in Ecological Character The ecosystem is threatened with serious changes as stock raising gradually gives way to rice-growing. This has led to an attempt to dry the lake areas and alter the water levels in the flood zones. Uncontrolled tourism is also exerting increasing pressure. The implementation of a plan to channel the lagoons and marshes flowing into the sea would have irreversible consequences for the environment.

Management Practices A small technical staff is available for isolated studies. Among the basic problems, concerning which an ambitious plar. for research has been undertaken, the following may be mentioned: a) dry-season pastures for the development of stock raising; b) water regulation in periods of flooding and drought; c) control of bird migration and reintroduction of extinct species; d) epidemiological research into furuncular myiasis. All this ecological research is important for the countries in the temperate zone having wetlands.

Scientific Research and Facilities The whole area of the eastern marshes is provided with a good road network and accommodation facilities for groups of scientists working there.

\section{Principal Reference Material}

- Biosphere reserve nomination submitted to Unesco-MAB Secretariat.

- Instituto Nacional para la Preservacion del Medio Ambiente (1973). Informe sobre "Banados de Rocha".

- IUCN/ (1982). IUCN Directory of Neotropical Protected Areas. Tycooly, Dublin.

- Melendo, Mariano (1974). Informe Mision Espanola.

- Sombroek, W.G. (1969). Soil studies in the Merim Lagoon basin. 


\section{YUGOSLAVIA}

Area 255,834 sq.km

\section{Population $22,850,000(1983)$}

Summary of Wetland Situation Since the end of the War, the majority of the larger wetland complexes have been drained and put under cultivation or pastures. In several of the few wetlands that survive, suitable habitats for breeding waterfowl are seriously degraded, but conditions for roosting and wintering birds sometimes remain viable. Efforts are now being made to improve the situation for nesting birds, especially at sites which are still rich in species, and a number of reserves have been established since 1965. The Yugoslav Waterfowl Commission is also ensuring that adjacent feeding areas are included in reserves.

The Province of Vojvodina has a number of wetlands which at one time were among the finest in south-east Europe. Fishing and hunting have long been economically important activities, and the wetlands included many shallow lakes, ponds and marshes, and seasonally inundated plains and forests situated between the meanders of the Dunav (Danube), Theiss (Tisza) and Bega (Begej) rivers; belonging geographically to the great Pannonian plain. Between 1951 and 1970 five reserves of limnological, as well as zoological, importance were established in this area: Obedska bara (1,000ha), Ludosko Jezero (318ha), Vojtina Mlaka (50ha), Monostor (1,000ha) and Kozjak (44ha).

The Obedska bara and a sixth site, Carska bara, near the confluence of the Bega and Theiss rivers, are perhaps the best known areas. Their typical breeding birds are bittern (sporadic), little bittern (common), night-heron, squacco heron (nesting commonly in riparian forests), little egret (common), great white egret (breeding in small numbers), purple heron (large colonies in reedbeds), white stork (common but slowly declining), black stork (breeding in small numbers), glossy ibis (common in 19th century but now only in small numbers at Obedska Bara) and spoonbill (nesting in small numbers at Obedska Bara but no longer near Pancevo nor near Novi Sad; where formerly common). Several species of gulls and terns also nest when conditions are suitable.

In the Republic of Croatia several reserves were established between 1965 and 1970, of which Kopacki rit $(17,700 \mathrm{ha})$ for both limnological and zoological reasons is undoubtedly of international importance. The waterfowl which nest in the area include cormorant, greylag goose and both egrets.

Two reserves established in the Neretva delta serve to protect coastal saltmarshes of 1,200 and 700 ha in extent. The delta region is certainly one of the most important sites for waterfowl in the Adriatic coastlands. Its breeding birds include several grebes, pygmy cormorant, herons, mallard, garganey, ferruginous duck and rails. The marshes, wet meadows, saltpans and sandbanks of the whole delta/valley complex also provide suitable habitat for migrating and wintering birds, although hunting pressure is severe. Further inland, the Neretva river rises in, and flows through, the Republic of Bosnia and Hercegovina which has also established two reserves, Hutovo Blato (360ha) and Bardaca ( $700 \mathrm{ha}$ ), in a lake and marshland area to the east of the lower Neretva.

In the Republic of Montenegro, eleven glacial lakes on Durmitor mountain and another on Biogradska Gora have been included in the National Parks. The Yugoslav sector of the great Skadarsko jezero on the Albanian border is partly protected and contains a small colony of dalmation pelicans, and protection has also been given to some of the coastal wetlands and saltpans on the final $30 \mathrm{~km}$ of the Bojana river which forms the border with Albania before it enters the sea. 
The great lakes on the Albanian and Greek borders, Ohrid, Prespa and Dojran have been declared Natural Monuments, implying some general measure of protection for the landscape. Some areas around these lakes and also the marshes of the Crna river, a tributary of the Vardar and known as a past nesting-place of pelicans, have been proposed as nature reserves.

Little is known of the exact status of the wetlands of the Republic of Slovenia, but about 5,000 ha are protected as a nature reserve at Ljubljansko barje, and some 1,000 ha of mudflats and coastal wetland in the bay of Portoroz, in the north-west corner of the Istra Peninsula. Finally, in the Province of Kosovo some small lakes, gorges and springs, believed to be of considerable limnological and hydrographic interest, have been protected as landscape reserves; but the only waterfowl habitat known to be important, about 300 ha in the marshes of Radevo, is unprotected.

Protected Areas Legislation The principles of environmental conservation are embraced in the Constitution of 7 April 1963, where all natural resources are defined as social property (with the exception of private holdings up to 10ha). National parks can only be declared by the highest authority which is usually the Republic Assembly, under the law on Nature Protection, Article 27, Paragraph 1 (Norodne novine No. 53/76). National parks consist of a central strictly protected area surrounded by a less strictly protected zone. Each republic creates national parks and other protected areas under its own special laws within the national framework with nature reserves in Croatia declared under a decree for the Protection of Natural Rarity, for example, No. 221/48, and in Bosnia and Heiregovina by decision of the National Institute for the Protection of Historic Monuments and Natural Beauty. The legal texts covering national parks exercise control over forestry, hunting, fishing and certain agricultural works whilst in nature reserves all activities are strictly controlled.

Protected Areas Administration The Federal Republic is composed of six republics and two socialist autonomous provinces with the resulting wide variety of administrative bodies covering nature conservation. Protected area administration is based on a decentralized public authority structure with an institute for nature protection in each of the six republics. The parks are managed by public administrative bodies, the actual authority varying from republic to republic. The parks maybe managed by experimental farms under the Ministry of Agriculture, or by local self-administered committees or bodies under the Ministry of National Education or under a nature conservancy institute. Each national park must have by law its own administration, professional staff and funds for effective protection.

\section{Sites designated under the Convention}

Accession on 28 March 1977, with two sites listed at accession.

Nature Reserve Obedska Bara

Nature Reserve Ludasko Lake

\section{Government body responsible for administration of the Convention} No information.

\section{Nature Reserve Obedska Bara}

Location $44^{\circ} 43^{\prime} \mathrm{N}, 20^{\circ} 04^{\prime} \mathrm{E}$. Situated in the Commune of Pecinci in Srem Region, Vojvodina Province.

\section{Area $17,501 \mathrm{ha}$}

Degree of Protection The designated site contains three zones with different degree of protection: a Region of Particular Natural Beauty completely surrounding a Strict Nature Reserve and Scientific Research Reserve (combined area of SNR and SRR about 2,400ha). Designated as a Ramsar site in March 1977. 
Site Description The Strict Nature Reserve and Scientific Research Reserve are situated between the villages of Obriez and Kupinovo, and comprise part of an old meander of the River Sava and some of the enclosed land. The meander is now only connected to the river at medium and high water levels. The SNR comprises the north and east of the horse-shoe shaped meander, and the SRR includes part of the area enclosed by the meander and a portion of the meander near the village of Kupinovo. The Region of Particular Natural Beauty extends to the banks of the River Savo in the south, and to and including the villages of Ogar and Asanja in the north. Habitats include ponds, marshes, reedbeds, peatbogs and woodland.

International and National Importance The site has a wide range of habitats, and is repurted to be of great scientific, cultural and educational importance. It is important for breeding waterfowl including glossy ibis Plegadis falcinellus, white spoonbill Platalea leucorodia, bittern Botaurus stellaris (irregular), little bittern Ixobrychus minutus, night heron Nycticorax nycticorax, squacco heron Ardeola ralloides, purple heron Ardea purpurea, little egret Egretta grazetta, great white egret Egretta alba, white stork Ciconia ciconia and black stork Ciconia nigra.

Changes in Ecological Character It was reported at the Second European Meeting on Wildfowl Conservation in 1966 that there were possible plans for felling of the oak woodlands surrounding the site. The waterfowl are less numerous than in the mid-nineteenth century.

\section{Management Practices No information}

\section{Scientific Research and Facilities No information}

Principal Reference Material The above information is taken from maps and documents submitted by the Government of Yugoslavia at the time of ratification of the Ramsar Convention.

Supplemented by:

- Carp, E. (1980). A Directory of Western Palearctic Wetlands. IUCN, Gland, Switzerland.

- Proceedings of the Second European Meeting on Wildfowl Conservation (1966). Noordwijk ann Zee, Netherlands.

- Scott, D.A. (1980). A preliminary inventory of wetlands of international importance for waterfowl in west Europe and northwest Africa. IWRB Special Publication No. 2.

\section{Nature Reserve Ludasko Lake}

Location $46^{\circ} 04^{\prime} \mathrm{N}, 19^{\circ} 48^{\prime} \mathrm{E}$. Situated $12 \mathrm{~km}$ east of the town of Subotica in the region of Backa, Vojvodina Province.

\section{Area 593ha}

Degree of Protection Part of the northeast area of the lake and some surrounding land is a Strict Nature Reserve. The whole lake and a band of surrounding land (of varying width) is a regional park which in the northeast acts as an outer protective zone to the strict nature reserve. Designated as a Ramsar site in March 1977.

Site Description Ludasko Lake (221ha) lies in a north-south direction between the Danube and Tisa Rivers. The lake is about $5 \mathrm{~km}$ long, $2 \mathrm{~km}$ wide in the north but only about $200 \mathrm{~m}$ wide in the south. It is shallow and has extensive reedbeds. The area is a natural refuge for most types of waterfowl and many other water-associated fauna.

International and National Importance The lake is an important breeding area for many herons and egrets (Ardeidae) and white-headed duck Oxyura leucocephala. It is situated on a bird migration route used in various seasons, and is a wintering area for large numbers of waterfowl.

Changes in Ecological Character None reported (up to March 1977). 


\section{Yugoslavia}

Management Practices No information

Scientific Research and Facilities No information

Principal Reference Material The above information is taken from maps and documents submitted by the Government of Yugoslavia at the time of ratification of the Ramsar Convention. 
Abies, 42

Acacia, 25, 198, 321

Acacia arabica, 294

Acacia modesta, 289

Acacia nilotica, 178

Acacia tortilis raddiana, 247

Acaena novae-zealandae, 382

Acanthis hornemanni, 351

Accipiter badius, 293-4

Accipiter gentilis, 344

Accipiter nisus, 145, 244

Acer, 154

Acer negundo, 56

Acer rubrum, 420

Achillea asplensifolia, 171

Acrocephalus, 294

Acrocephalus arundinaceus, $43,47,244,335,342,344$

Acrocephalus arundinaceus orientalis, 242

Acrocephalus bistrigiceps, 241-2

Acrocephalus dumetorum, 214

Acrocephalus melanopogon, 244

Acrocephalus paludicola, 171

Acrocephalus palustris, 300,344

Acrocephalus schoenobaenus, 107, 300, 335, 341, 389, 410

Acrocephalus scirpaceus, $244,300,341,362,389,410$

Acroceras macrum, 321

Actitis macularia, 71

Aedes detritus, 401

Aegypius monachus, 294

Aeschna caerulea, 397

Agropyron, 58, 183, 232

Agropyron elongatum, 210

Agropyron junceiforme, 128

Agropyron repens, 370

Agrostis, 63, 389, 392

Agrostis stolonifera, 414

Agrostis tenuis, 203

Aira capillaris, 220

Aix sponsa, 52, 425

Ajaia ajaja, 251

Alauda arvensis, 169

Alburnus alburnus stumicae, 154

Alca torda, 88, 100, 102, 104, 303

Alcedo atthis, 2-3, 34, 47, 238, 264

Alcelaphus buselaphus, 316

Alces alces, 59, 301

Alces americana, 64

Alectoris barbara, 225

Alectoris chukar, 185

Alectoris rufa, 305

Alhagi, 196, 249

Alhagi pseudoalhagi, 365

Alisma plantago, 318

Alisma plantago-aquatica, 63,145

Alligator mississippiensis, 425

Allium suaveolens, 137

Alnus, $33,154,187,260,276,301,334,378$

Alnus crispa, 422

Alnus glutinosa, $102,113,158,259,299,301,380$, 394,399

Alnus japonica, 240

Alnus rubra, 63

Alopecurus alpinus, 69

Alopecurus bulbosus, 377

Alopecurus geniculatus, 390

Alopecurus pratensis, 405

Alopex lagopus, 66,174

Alopochen aegyptiacus, 315

Alosa fallax, 357

Althenia, 186

Amauromis phoenicurus, 294

Ambrosia dumosa, 418

Ambrysus amargosus, 418

Ambystoma dumieri dumieri, 250

Ambystoma lermaensis, 250

Ambystoma mexicanum, 250

Amirkelayeh Lake, 194
Ammi visnaga, $\mathbf{3 5 7}$

Ammocalamagrostis baltica, $\mathbf{3 8 1}$

Ammophila arenaria, $42,113,273,325,333,376,381$, 402

Ammophila breviligulata, 421

Ammophilia arenaria, 390

Amorpha fruticosa, 168,170

Amphibromus neesii, 16

Anabaena flos-aquae, 174

Anas, 95-8, 110, 167, 191-3, 196, 200, 296

Anas acuta, 2, 39, 41-2, 52, 65, 72, 78-9, 81-2, 84, $91,94,107-8,110,114,122,130,132,150,153,162$, $167,184-6,203,215-6,222,225-6,229-30,251,253$, $264,269,291,294,308,316,325,339,345,351$, $362-3,365,368,370-2,392,398,401,403-5,411$, $415,419,421,423$

Anas americana, 63, 65, 251, 421, 423

Anas angustirostris, $3,184,186,189,193,325-6,365$

Anas castanea, 17

Anas clypeata, $2,36,39,41-2,52,79,81-4,94-5$, $97,114,122,135,137,140,145,147,150,153,162$ $167,170-1,179,190,203,210,212,217,220,230$, $234,241,253,257,259,264,291,294,299,301,303$, $305,308,325-6,335,338-9,341,344,346,353,357$, $371,379-80,384,387,392,395,398-9,402,404,410$, 412

Anas crecca, 2-3, 37, 39, 43, 48, 52, 72, 79, 81-4 $93-4,96-7,99,129,131,134-5,137-9,143-5,147$ $150,153-4,168,171,179,184-5,190,203,209-10$, $215-9,223,225-6,229-30,232-3,253,257,261,264$, $277-9,290-1,294,303,305,325,335,338-9,341$, $343-4,346,348,351,353,357,363,365,369,371-2$, $377,379-80,384,387,392,395,398-9,403-5,411$, $413-4,419,421,423,425$

Anas cyanoptera, 419

Anas discors, 52-3, 71, 251, 421

Anas erythrorhyncha, 319

Anas falcata, 373

Anas gibberifrons, $13,28-30,272$

Anas penelope, 2-3, 37, 39, 79, 82-4, 88-9, 91, 93-4, $97,99,110,114,122,129,131,150,153,161-2,174$, $203,210,215,217-8,220,222,225-6,230,232,239$, $253,261,278,290-1,294,301,303,306,325,338-9$, $343,345-6,348,357,369-71,373,376-7,381,387$, $392,395,398-9,403-4,406,41 \mathrm{j}-4$

Anas platyrhynchos, 2-3, 39-42, 46, 48-9, 63, 78-9, 81-4, 88-90, 93-9, 104-7, 114, 118-9, 122, 135, 138, $140-1,144-5,151,153-4,158,162,164,166-8$, $170-1,184-5,190,203,209-12,215,218-20,222$, 225-8, 232-3, 235, 239, 244, 253, 258, 264, 277-80, $289-91,294,299-300,303,305,325-6,333,335,339$, $341,343,353,362-3,365,368,371-2,377,380,384$, $387,392,395,398-9,403-5,411,413-4,419,421$, 423,425

Anas poecilorhyncha, 239-40, 242, 291, 294, 373

Anas querquedula, $32,36,40-1,108,114,120,122$, $133,136,153,167-8,170-1,210-2,217,220,225-6$, $228,237,264,294,299-300,308,326,335,339,341$, $344,353,363,371,380,389,402,405$

Anas rhynchotis, 30,272

Anas rubripes, 52-3, 72, 421

Anas smithi, 315

Anas strepera, 2-3, 39, 42-3, 46, 72, 114, 120, 124, $136-7,139-41,143-4,164-5,167,174,179,203$ $210-2,228,230,253,260,264,291,294,299,301$, $303,325-6,338,341,343-4,353,362-3,369-70,371$, $379-80,384,389,398,403,405,411,421,423$

Anas superciliosa, 28-30, 272

Anas undulata, 315,319

Anastomus lamelligerus, 316

Anastomus oscitans, 176, 179

Andromeda polifolia, 206, 407-9

Anemopsis californica, 418

Angelica archangelica, $\mathbf{1 7 4}$

Angelica sylvestris, $168-70$

Anguilla anguilla, 214, 217, 219, 222, 225-6, 357 , 379,387

Anguilla australis schmidtii, 272 
Anguilla dieffenbachii, 272

Anhinga anhinga, 293, 308, 425

Anhinga melanogaster, 176, 179

Anser, 120-2, 167, 169, 186, 291-3

Anser albifrons, $32,37,39,49,61,68,91-2,107$, $118,129,131,147,153-4,166,170-1,210,230,258$, $300,335,367-8,371,377,391,403$

Anser albifrons flavirostris, 202-6, 376, 386

Anser anser, 32-3, 39-40, 46, 49, 79, 83-4, 90-1, 93, $98-9,104-5,121,129,131,150-1,153,165,167,169$, $171,183-4,189-90,193-4,203,224,253,261,264$, $296,299-301,305,325,340-1,343,357,361,363$, $365,367-8,370-1,383-4,386,395,407,413-4$

Anser brachyrhynchus, 37, 78-9, 81-4, 128-9, 203, $384,391,412$

Anser caerulescens, $61,67,69,421$

Anser caerulescens atlanticus, 52,66

Anser caerulescens caerulescens, 62-3,68

Anser canagicus, 423

Anser erythropus, 46, 166, 171, 183, 345, 349, 351, 371

Anser fabalis, $32,37,39-40,83,91-3,99,107-9$, $118,129,147,165-6,169,171,210,258,299-300$, $335-6,339,343-5,347,351$

Anser fabalis brachyrynchus, 415

Anser fabalis serrirostris, 242

Anser indicus, 286

Anser rossi, 67

Anseranas semipalmata, 9-10

Antechinus bellus, 9

Anthozanthum odoratus, 203

Anthriscus cerefolium, 168

Anthus campestris, 169

Anthus cervinus, 349-51

Anthus pratensis, 334

Anthus spinoletta littoralis, 85

Antilope cervicapra, 177-8

Aphanius dispar, 244

Aphanius fasciatus, 214, 357

Aphelia, 14

Aphydra, 267

Apium graveolens, 392

Apodemus sylvaticus, 174

Aquila chrysaetos, 107, 171, 298, 343-4, 349-51, 383

Aquila clanga, 179, 244, 293-4

Aquila heliaca, 32, 171, 179, 293-4

Aquila heliaca adalberti, 325

Aquila pomarina, 32, 154, 214, 298

Aquila rapax, 179, 293-4

Aquilla chrysaetos, 335

Aquilla heliaca, 151

Ardea, 34

Ardea alba, 220

Ardea cinerea, $33,40-1,47-8,89,110,135,140,147$, $150-2,155,165,167,170-1,197,215,219-20,232$, 236-7, 247, 259-60,264,286,289-91, 293-4, 296, $305-6,325,353,363,365,367,369,379$

Ardea goliath, $197,310,316,319$

Ardea herodias, 71, 425

Ardea novaehollandiae, 30, 272

Ardea pacifica, 30

Ardea purpurea, 3, 32, 47-8, 144, 151, 153, 157, 159, $162,164-5,167,169-71,189,210-2,214,219,225-9$, $232,237,244,259-60,291,293-4,305,308,319$, $325-6,363,431$

Ardeola grayii, 176, 197, 291, 293-4

Ardeola ralloides, $3,47,113,149,151-2,154,157-9$, $164,167-8,170-1,211-2,228,244,303,325,363-4$, 367,431

Arenaria ammophila, 317

Arenaria interpres, $26,38,87,93,99,102,104-5$, $130,247,261-2,272-3,330,340,402$

Arenicola maritima, 360

Aristida depressa, 289

Aristida junciformis, 321

Aristolochia clematitis, 168,170

Armeria maritima, 261, 391, 414

Armoracia macrocarpa, 171

Artemia salina, 185, 267

Artemisia, 186, 370
Artemisia fragrans, 364

Artemisia maritima, 48, 220, 391

Artemisia monogyna, 171

Arthrocnemum, 220, 247

Arthrocremum glaucum, 113, 235, 325

Arthrocueum peren, 158

Arvicola amphibius, $\mathbf{3 7 9}$

Asio flammeus, 171, 261, 338-9, 343, 350, 394

Asio otus, 259, 343

Asparagus albus, 219

Asperula rivalis, 168

Aster, 58, 333

Aster tripolium, $39,79,169,171,220,232,389$, $391-2,414$

Astragalus, 58, 186, 365

Astragalus phoenix, 418

Ateles paniscus, 330

Atherina mochon, 220, 222, 225-6

Atherina presbyter, 217

Atriplex, 222, 418

Atriplex cana, 370

Atriplex confertifolia, 418

Atriplex halimus, 220

Atriplex hastata, 39, 145

Atriplex litoralis, 171

Atriplex maritima, 261

Atriplex prostata, 412

Atriplex verruciferum, 190

Aucoumea klaineana, 116

Aulacomnium palustre, 409

Aulacomnium turigidum, 66

Avicennia, 197-9, 330

Avicennia africana, 247

Avicennia germinans, 251, 330

Avicennia nitida, 310

Avicennia officinalis, 286

Axis axis, 177

Aythya, 110, 191, 193, 196, 215, 362

Aythya affinis, 251

Aythya americana, 55, 71-2

Aythya collaris, 53, 71, 425

Aythya ferina, 2-3, 39, 42-3, 83-4, 91, 98, 106, 123, $135-9,141,143,146-7,150,153-4,161,164,167-8$, 170-1, 184, 190, 209-10, 212, 215-7, 219-20, 222, 225-6, 230, 257, 264, 290-1, 293-4, 299-300, 303, $325-7,335,339,341,344,346,352-3,357,362,365$, $369-72,380,384,387,392,395,398-9,402,404-5$, $410,413-4$

Aythya fuligula, 2, 39, 42-3, 84, 91, 93-9, 102, $104-6,119-20,136-7,139-44,147,167,174,179$, $203,209-10,219,226,232,235,241,257,264$, 289-91, 293-4, 299, 303, 335, 339, 341, 344, 352-3, $361,363,365,368,371,373,384,387,395,398-9$, $402,404-5,413$

Aythya marila, 83, 88, 90-1, 93-4, 97, 99, 103-5, 119, $174,203,241,300,337,348,368,387,423$

Aythya nyroca, $32,46,48,149,151,153,157,164$, $167-8,170-1,184,189,191,210,212,219,237,291$, $293-4,363,369$

Aythya valisineria, 55, 71, 419

Azolla, 10, 178

Baccharis emoryi, 418

Balaenoptera physalus, 247

Balanites aegyptiaca, 247, 308

Balanus, 360

Banksia dentata, 8

Barbus barbus, 357

Barringtonia acutangula, 10

Barringtonia racemosa, 321

Batis maritima, 330

Baumea articulata, 16

Baumera arthrophylla, 16

Betula, 42, 61, 64, 108, 134, 257, 334, 336, 348-50, $360,376,394$

Betula alba, 261

Betula glandulosa, 59

Betula papyrifera, 59

Betula pendula, 389

Betula pubescens, 174, 259-60, 301, 380, 389

Betula verrucosa, 301 
Bidens, 412

Bidens coronata, 70

Bidens tripartita, 145

Bison bison, 59,61

Biziura lobata, 23

Blastocerus dichotomus, 428

Blechnum spicant, 205

Bolboschoenus maritimus, 171

Bombina variegata pachypus, 218

Bombycilla garrulus, 349

Bos taurus, 10

Boselaphus tragocamelus, 178

Botanus stellaris, 32, 225-6

Botaurus lentiginosus, 71

Botaurus stellaris, $37,41,43,49,83,106,120,133$, $135,151,165,167,169-70,211-2,227-8,257$, $259-60,264,296,298,302,326,335,342-4,380,389$, $391,410,431$

Botaurus stellaris poiciloptilus, 272

Bowdleria punctata punctata, 272

Brachypodium phoenicoides, 113

Branta, 291-3

Branta bernicla, $66,79,107,110,128-9,203,249$, 261-2, 283, 336, 338, 391, 404, 420

Branta bernicla bernicla, 82, 87-90, 93, 97, 99, 403

Branta bernicla hrota, 67, 69, 202, 381

Branta bernicla nigricans, 67,423

Branta canadensis, $61-3,67-9,71-2,99,203,336$, $344,346,421$

Branta canadensis taverneri, 423

Branta leucopsis, $107,129,131,203,283-5,336,340$, 362,415

Branta ruficollis, $46,49,359,364,368,371$

Bromus, 183

Bromus inermis, 370

Bubalus bubalis, 10, 357

Bubo bubo, 107

Bubulcus ibis, 325, 364

Bucephala albeola, 423

Bucephala clangula, $65,79,82-4,88-9,91,93,96-7$, $99,119-20,137,140-4,146,167,203,229,241$, $277-8,300-1,339,346,352,362,365,371,373,384$, $387,398,404,413,423$

Bucephala islandica, 174

Bufo bufo spenosa, 218

Bufo calamita, 334, 391

Bufo viridis, 334

Bulbulcus ibis, 113, 303

Bulweria bulwerii, 304

Bupleurum tenuissimum, 402

Burhinus oedicnemus, $32,48,149,169-71,215,225$, 238,305

Butastur teesa, 294

Buteo buteo, 325,335

Buteo lagopus, 335, 344, 349

Buteo rufinus, 294

Butia yatay, 427

Butomus umbrellatus, 361

Caiman latirostris, $\quad 427$

Cairina moschata, 428

Cakile maritima, 402

Calamagrostis, 61

Calamagrostis canadensis, 61,422

Calamagrostis epigeios, 370

Calamagrostis langsdorffii, 240

Calamagrostis purpurea, 276

Calandrella brachydactyla hungarica, 171

Calatella punctata, 171

Calcarius lapponicus, 351

Calicotome spinosa, 219

Calidris, $303,367,369$

Calidris acuminata, 11, 272

Calidris alba, 38, 127-8, 244, 412, 415

Calidris alpina, $39,79,82-3,87,93,99,110,127-9$, $247,253,255,261-2,277-9,282,305-6,334-6,339$, $343,351,381,389,394,401,412$

Calidris alpina schinzii, $337-8,340$

Calidris canutus, 17, 53, 99, 127-8, 130, 247, 255, 261-2, 272-3, 282, 306,316, 381, 401, 403, 412

Calidris ferruginea, 49, 222, 234, 247, 346, 401
Calidris fuscicollis, 53

Calidris maritima, $85,282,349$

Calidris melanotos, 27, 272

Calidris minuta, $220,222,230,234,244,247,253$, 282,306

Calidris minutilla, 53

Calidris pusilla, 53,330

Calidris temminckii, 105, 244, 294, 345

Calidris tenuirostris, 17

Calligonum comosum, 247

Callinula chloropus, 244

Callitriche verna, 298

Callitris collumellaris, 8

Calluna, 205, 376

Calluna vulgaris, $42,134,205-6,333,389,406-9$

Calonectis diomedia, 303

Calotropis, 294

Caltha palustris, 41, 263

Cambarus diogenes, 55

Campephilus principalis, 425

Camphorosma, 184

Camphorosma annua, 168,171

Campylopus atrovirens, 206, 396-7

Canis aureus, 154, 177-8, 247, 364-5

Canis lupus, 59, 154, 157, 363, 365, 423

Capparis aphylla, 178

Capparis decidua, 247

Capra hircus, 397

Capreolus capreolus, 154, 301

Caprimulgus europaeus, 389

Caprimulgus ruficollis, 305

Carabus clathratus antonelli, 212

Caraima cristata, 428

Carassius carass, 240

Carcinus mediterraneus, 222

Carduelis spinus, 240

Caretta caretta, 247, 286, 310, 320

Carex, 43, 61, 80, 182, 184, 186-7, 190, 193, 195-6 $212,273,326,334,348,368,392,394,422$

Carex acuta, 341, 405

Carex appropinquata, 379

Carex aquatilis, 59

Carex arenaria, 390

Carex augustinowiczii, 240

Carex buxbaumii, 259

Carex caespitosa, 240

Carex caryophyllea, 215

Carex chordorrhiza, 66, 174

Carex diandra, 259

Carex distans, 261

Carex divisa, 402

Carex elata, 169,380

Carex elongata, 260

Carex gracilis, 301

Carex juncella, 276

Carex lasiocarpa, 259, 393, 407

Carex limosa, 393, 396, 408

Carex lyngbyei, 63,174

Carex magellanica, 409

Carex maritima, 381

Carex nigra, 393, 408

Carex otrubae, 391

Carex panicea, 206, 408

Carex paniculata, 260

Carex pauciflora, 409

Carex paupercula, 409-10

Carex praegracilis, 418

Carex rostrata, 174, 301, 393, 408-9

Carex schmidtii, 240

Carex stans, 66, 69

Carex vesicaria, 276

Carpha alpina, 272

Carpinus orientalis, 157

Carpodacus erythrinus, $336-7,341,344$

Carum verticillatum, 412

Casmerodius albus, 71, 425

Cassia italica, 247

Castor canadensis, $\quad 52,59$

Castor fiber, 113, 144, 301, 348

Casuarina, 294 
Catabrosa aquatica, 244

Catoptrophorus semipalmatus, 330

Centarium namophilum, 418

Centaurea prespana, 157

Centipeda minima, 15

Centrolepis aristata, 14

Centrolepis puluinata, 14

Cepphus grylle, 85-6, 90, 102, 104

Cerastium dubium, 171

Cerastoderma, 222

Ceratophyllum, 187, 225, 227, 364, 372

Ceratophyllum demersum, 167, 218

Ceratophyllum submersum, 402

Cereopsis novaehollandiae, 28

Cereus hexagonus, 330

Ceriops candoleana, 286

Cervus axis, 178

Cervus elaphus, 325, 334, 383, 389, 394, 396-7

Cervus porcinus, 178

Cervus unicolor, 178

Cettia, 294

Cettia cetti, 41, 389

Chaetomorpha, 214

Chalinolobus nigrogriseus rogersi, 9

Chamaecyparis thyoides, 420

Chara, 133, 177-8, 186, 210, 212, 260, 342

Chara aspera, 301

Chara fragilis, 301

Chara hispida, 326

Chara intermedia, 301

Chara stachymorpha, 314

Charadrius, 177

Charadrius alexandrinus, $40,48,130,149,151,166$, $169-71,183,186,196,215,220,222,225-6,234-5$, $244,253,261,269,290,292,294,305-6,326,334$

Charadrius bicinctus, 272,274

Charadrius dubius, $48,114,220,222,225-6,235,311$, 406

Charadrius hiaticula, 27, 40,94, 104-5, 114, 128, $130,247,253,261,282,305-6,311,333,351,382$, $403-4,415$

Charadrius leschenaultii, 27

Charadrius melodus, 55

Charadrius pallidus, 315

Charadrius pecuarius, 311,317

Charadrius pluvialis obscura, 272

Charadrius semipalmatus, 53,330

Charadrius vociferus, 71

Charetum acuteolatae, 298

Charetum asperae, 298

Charetum contrariae, 298

Charetum tomentosae, 298

Charophyta, $365,367,372$

Chelonia mydas, 9, 197, 247, 286, 310, 320

Chenolea diffusa, 317

Chenopodium botryodes, 402

Chenopodium vulvaria, 299

Chironomus islandicus, 174

Chlidonias hybrida, $30,47,152,171,183,188,211-2$, 228,292

Chlidonias leucopterus, 171, 294, 411

Chlidonias nigra, 47, 71-2, 131-3, 153, 157, 171, 211, $221,228,247,257,260,336,342-3$

Chrysanthemodes monilifera, 317

Chrysanthemum vulgare, 168

Ciconia, 34

Ciconia ciconia, 32-3, 40-1, 48, 146, 150, 155, 170-1, $193,305-6,325,395,431$

Ciconia ciconia boyciana, 373

Ciconia nigra, $33,48,168,171,214,296,300,302$, $315,357,431$

Cicuta virosa, 379

Ciprinidon calaritanus, 220

Circaetus gallicus, 154, 171, 179, 244, 294, 305, 325

Circus, 47

Circus aeruginosus, $39,41,43,48-9,78,83,98,106$, $157,212,215,219,222,225-7,237,259,261,264$, $269,292-4,298,326,336,338,341-4,346-7,362$, $380,389,391$

Circus cyaneus, $\quad 48,259,261,269,298,300,335,341$,
$343,346,351$

Circus macrourus, $48,293-4$

Circus pygargus, $48,215,225,227,238,261,269$, 300,305

Circus ranivorus, 319

Cirsium, 263

Cirsium furiens, 171

Cisticola juncidis brunniceps, 242

Cistoseira, 214

Cistus monspeliensis, 219

Cladium, 326

Cladium mariscus, $212,215,334,378,380$

Cladonia, 205, 422

Cladonia impexa, 206

Cladonia uncialis, 206

Cladophora, 177

Cladophora aegagropila, 174

Cladophora battersia, 404

Cladophora retroflexa, 404

Cladorhynchus leycocephalus, 23

Clamator glandarius, 113,215

Clangula hyemalis, $68-9,93,100,119,345,351,423$

Clareola pratincola, 244

Clarius lazera, 244

Clemmys guttata, 70

Clemys leprosa, 357

Clethra alnifolia, 420

Clymenella torquata, 403

Cochlearia officinalis, $39,69,414$

Cochlearius cochlearius, 251, 330

Colobus badius temmincki, 310

Connochaetes gnou, 316

Connochaetes taurinus, 116

Convulvulus arvensis, 168

Coracias garrulus, 113, 244

Corallorhiza trifida, 382

Coregonus, 137

Coregonus lauaraetus, 387

Cornulaca monacantha, 247

Cornus sanguinea, 168

Corophium volutator, $\mathbf{5 3}$

Corvus corax, 397

Coscoroba coscoroba, 428

Cottus, 368

Coturnix coturnix, 343

Crambe maritima, 402, 404

Crassula tillaea, 215

Crataegus, 183

Crataeva tapia, $\mathbf{3 3 0}$

Cressa cretica, 186, 220, 226

Crex crex, 147, 336, 343

Crocethia alba, 66

Crocodylus moreletii, 251

Crocodylus niloticus, 310,321

Crocodylus palustris, 294

Crocodylus porosus, 9-10

Culluna vulgaris, 408

Cupressus macrocarpa, 215

Cyanopica cyanus, 305

Cygnus, 183, 188, 195-6, 291-3, 299, 364

Cygnus atratus, 11-2, 14, 22, 28, 30, 272, 274

Cygnus colombianus, 65

Cygnus columbianus, $39,55,61,68,71,78-9,81-3$, $131-3,242,423$

Cygnus columbianus bewickii, 120, 193, 202-3, 298, $362,387,389,392,406,411$

Cygnus cygnus, 78-9, 81-4, 88, 90-1, 93-7, 99, 107, $109,119,121-2,132,174,202,241-2,277-8,339$, $350-1,362-3,365,367-8,372,381,384,387,392$, $395,411,414$

Cygnus melanocoryphus, 75, 428

Cygnus olor, 39, 46, 49, 79, 82-4, 88-90, 92-7, 99, $104,119,144,209,277,279,296-302,333,341$, $343-4,361,369,365-72,387,392,398,404,414$

Cymbopigon jwarancusa, 289

Cymbopigon shoenanthus, 289

Cymmodocea nodosa, 247

Cymodocea, 214

Cynodon, 183

Cyperus, 178, 187, 318 
Cyperus alterniflora, 294

Cyperus alternifolius, 293

Cyperus articulatus, 330

Cyperus fuscus, 43

Cyperus laevigatus, 243

Cyperus papyrus, 321

Cyprinodon diabolis, 418

Cyprinodon nevadensis, 418

Cyprinus carpio, 124, 140, 240, 363, 372

Dacrycarpus dacrydoides, 271

Dacrydium cupressinum, 272-3

Dactylis, 183

Dactylorhiza incarnata, $43,259,339$

Dama dama, 325, 336

Damaliscus dorcas phillipsi, 316

Danaus plexippus, 55

Dancus carota, 168,357

Dancus vulgare, 168

Daphinia longispina, 174

Daphne mezereum, 298

Decentrachus labrax, 226

Delphinus delphis, 247

Demostachya bipinnata, 288

Dendrocygna arcuata, 10

Dendrocygna autumnalis, 251

Dendrocygna bicolor, 308

Dendrocygna viduata, 308

Dermochelys coriacea, 9, 247, 251, 286, 320

Deschampsia cespitosa, 334

Deschampsia flexuosa, 409

Desmoschoenus spiralis, 274

Desmostachya bipinuata, 288-9

Dicentrarchus labrax, 214, 217, 222, 235, 357, 404

Diomedea, 428

Diospyrus natalensis, 321

Diplodus sargus, 217

Dipsacus laciniatus, 168

Distychlis, 58

Distychlis spicata, 418

Dodomaea viscosa, 273,289

Donatia novae-zelandiae, 272

Dreissenia polymorpha, 167,352

Drepanocladus revolvens, 66

Dromas ardeola, 197

Drosera, 206

Drosera anglica, 301, 396-7, 408-9

Drosera rotundifolia, 301, 406-9

Drymarchon corais couperi, 425

Dryocopus martius, 34

Dryopteris cristata, 43, 380

Dugong dugon, 9,320

Dunalia, 220

Dupetor flaricollis, 294

Eboria caliginosa, 409

Egretta, 28, 308

Egretta alba, 18, 30, 32, 46, 150-1, 154-5, 157, $161-2,165,167,169-71,196-7,222,289-91,294$, $330,357,363,367,369,371,431$

Egretta caerulea, 330

Egretta garzetta, 30, 47, 149, 151-2, 154-5, 157-9, $161-2,164,167,169-71,211-2,215,220,222-3,228$, $232-4,238,291,294,303,306,325-6,363-4,367$, 369,431

Egretta gularis, 197, 247, 286

Egretta intermedia, 29-30

Egretta picata, 10

Egretta thula, 71, 251, 330

Egretta tricolor, 330

Eichornia crassipes, 304

Elaeagnus, 58

Elanus caeruleus, 294, 305

Elaphe longissima, 154

Elaphe vulpina gloydi, 70

Elatine hydropiper, 386-7

Eleocharis, 392,418

Eleocharis dregeana, 321

Eleocharis multicaulis, 206, 396

Eleocharis mutata, 330

Eleocharis palustris, $171,244,384$

Elodea, 187
Elymus arenarius, $128,333,422$

Elymus farctus, 390

Elytrigia pungens, 39

Emberiza, 244

Emberiza pusilla, 350

Emberiza rustica, 350

Emberiza schoeniclus, 145, 241, 261, 334

Empetrum nigrum, 80, 206, 261, 408, 422

Emydoidea blandingi, 70

Emys orbicularis, 158, 211-2, 224, 228, 305

Enceliopsis nudicaulis, 418

Enhydra lutris, 423

Enteromorpha, 177, 225, 381, 391

Enteromorpha intestinalis, 185, 220, 235

Epilobium hirsutum, 244

Epipactis dunensis, 382

Epipactis palustris, 43, 301, 339, 353

Equisetum arvense, 168

Equisetum fluviatile, 346

Equisetum palustris, 49,408

Equus burchelli, 116, 316

Equus caballus, 116

Eragrostis, 309

Eretmochelys imbricata, 9, 247, 286, 320

Erica cinerea, 389,407

Erica tetralix, 42, 80, 134, 205-6, 333, 406-9

Erinaceus frontalis, 316

Eriophorum, 134, 205

Eriophorum angustifolium, 80, 206, 393, 407-9

Eriophorum gracile, 259

Eriophorum scheucheeri, 422

Eriophorum vaginatum, $66,393,408-9$

Erithacus, 241

Eryngium maritinum, 404

Erythrina glauca, 329

Esox lucius, 211, 228, 363, 379, 384

Euarctos americanus, 425

Eucalyptus, 8

Eucalyptus camaldulensis, $\quad 18-9,25$

Eucaly ptus largiflorens, 19

Eudocimus albus, 176, 251, 425

Eudocimus ruber, 330

Eudromia morinellus, 231

Eumeces latiscutatus, 240

Eumetopias jubatis, 423

Euphorbia, 294

Euphorbia balsamifera, 247

Euphorbia cauduciflora, 294

Euphorbia paralais, 377

Euphorbia portlandica, 404

Eurycercus lamellatus, 174

Euterpe oleracea, 330

Fagus, 154

Fagus sylvatica, 157

Falcaria vulgaris, 168

Falco cherrug, 171

Falco chicquera, 294

Falco columbarius, $261,349,394$

Falco naumanni, 225

Falco peregrinus, $59,61,65,108,171,179,261,294$, $302-3,316,338,357,397$

Falco peregrinus brookei, 225

Falco peregrinus pealei, 423

Falco rusticolus, $350-1$

Falco subbuteo, $145,325,344$

Falco tinnunculus, 225, 261, 294, 325

Falco vespertinus, 171

Felis bengalensis, 178

Felis catus, 154

Felis chaus, 178, 364

Felis concolor coryi, 425

Felis margarita, 247

Felis pardina, 325

Felis silvestris, 247, 325, 357

Felis viverrina, 178

Fennecus zerda, 247

Festuca, 183

Festuca anindinaceae, 63

Festuca ovina, 389

Festuca pratensis, $\mathbf{4 0 5}$ 


\section{Taxonomic Index}

Festuca pseudovina, 168, 170-1

Festuca rubra, 261, 414

Festuca sulcata, $\mathbf{3 7 0}$

Fesuca pseudovina, 166

Ficedula parva, 337

Ficus, 294

Ficus hippopotami, 321

Filipendula ulmaria, $\mathbf{4 0 5}$

Fontinalis hypnoides, 276

Fragilaria construens, 174

Frangula alnus, 259, 301

Fraterula arctica, 285

Fraxinus, 168, 171, 301

Fraxinus oxycarpa, 113, 212

Fraxinus pennsylvanica, 56

Fraxinus velutina, $\mathbf{4 1 8}$

Fregata, 265

Fregeta magnificans, 330

Fucus, 360

Fuirena, 321

Fulica, 249

Fulica americana, $71-2,249,419$

Fulica atra, 2-3,46, 48-9, 79, 83-4, 91, 93-7, 99, $106,119,138,140-4,147,150-1,153,155,160-1$, $168,170-1,184-5,188,190-3,195-6,200,209-12$, $215-7,219-20,222,225-30,232,235,242,253$, 290-1, 294, 298-9, 325-7, 333, 339, 341, 352-3, 357, $361,363-5,367,369,371-3,379,387,398-9,403$

Fulica cristata, $254,315,325$

Galium aparine, 168

Gallinago gallinago, $3,52,71,141,143,145,147$, $167,171,174,242,259,290,293,334,346,353,369$, $392,405,411$

Gallinago hardwickii, 240

Gallinago media, 344, 348-9

Gallinago solitaria japonica, 242

Gallinula chloropus, $2-3,46,48,71-2,219-20,222$, $225-7,235,242,291,294,333,341,403$

Gambusia affinis, 219

Gammarus duebeni, 383

Gasterosteus aculeatus, 174, 384

Gavia, 61, 369

Gavia arctica, $49,88,108,339$

Gavia stellata, $\mathbf{1 0 8}, \mathbf{3 3 9}, \mathbf{3 4 5}$

Gazella dorcas, 247

Gazella subgutturosa, 365

Gelochelidon nilotica, $48,113,131,157,210,223$, 230,247

Genetta genetta, 325,357

Gentiana pneumonanthe, 353

Geochelone pardalis babcocki, 316

Geranium purpureum, 404

Gladiolus italicus, 212

Gladiolus palustris, 137

Glareola pratincola, $48-9,113,149,151,157-8,169$, $171,183,191,210,222,225-6,230,232,235,305-6$

Glaucium flavum, 391, 402, 404

Glaux maritima, $39,41,79,333,414$

Glossostigma elatinoides, 273

Glyceria australis, 14

Glyceria fluitans, 392

Glyceria maxima, 392,405

Glycyrrhiza glabra, 363

Gnaphalium uliginosum, 299

Gobio uranoscopus elimeins, 158

Gobius, 226

Gobius couchii, 404

Gordonia lasianthus, 424

Gorilla gorilla gorilla, 116-7

Gracillaria, 177

Grampus griseus, 247

Grayia spinosa, 418

Grevillea pteridifolia, 8

Grindelia fraxino-pratensis, 418

Grus americana, $58-9,61$

Grus antigone, 179

Grus canadensis, $\quad 58, \mathbf{2 5 0}, 425$

Grus grus, $107,114,120-1,132-4,151,166,171,184$, $186,190,200,214,223,230,235,244,258,296,298$, $300,302,339,341,344,346$
Grus japonensis, 240,373

Grus leucogeranus, $176,179,371$

Grus monachus, 239

Grus vipio, 373

Gulo gulo, 349-50, 423

Gunnera arenaria, 273

Gymnadenia conopsea, 339

Gymnosporia roylaena, 289

Gyps bengalensis, 294

Gyps fulvus, 157, 294

Haematopus moquini, 317

Haematopus ostralegus, 40, 48, 89-90, 93-4, 104, $127-8,130,151,198-9,257,261-2,269,272,274$, $282,333,343,360,369,401,403,412,415$

Haematopus unicolor, 272, 274

Haliètor pygmeus, 49, 212

Haliaetus albicilla, $32,34,46,95,98,151,154$, $157,171,261,294,296,298-300,302,335,350,360$ $362-3,365$

Haliaeetus leucocephalus, $55,59,423,425$

Haliaeetus leucoryphus, 179, 294

Haliaeetus vocifer, 316

Haliastur indicus, 294

Halichoerus grypus, 88, 334, 383, 401

Halimione portulacoides, $220,225,389,391,400$

Halimium halimifolium, 325

Halocnemum, 184

Halocnemum portulacoidies, 220

Halocnemum strobilaceum, 190, 220, 222, 243, 365, 370

Halodule wrightii, 247

Halopeplis amlexicaulis, 243

Halostachys caspica, 365

Hammarbya paludosa, 42

Haplopappus acradenius, 418

Helichrysum paralium, 28

Heliotropium bacciferum, 247

Hemachatus haemachatus, 316

Herpestes edwardsi, 178

Herpestes ichneumon, 357

Hibiscus tiliaceus, 330

Hieraaetus fasciatus, $154,293,357$

Hieraaetus pennatus, 325,357

Hierochloe odorata, 387

Himantopus himantopus, $3,48,149,151,157,161$, $169-71,186,210,214-5,220,222-3,225,229-30$, $232-5,272,292,294,305-6,311,326-7,357,369$

Hippiuris vulgaris, 380

Hippocampus, 317

Hippolais, 294

Hippolais icterina, 136, 337

Hippophae rhamnoides, 203, 261

Hippopotomus amphibius, 321

Hippotragus, 311

Hippuris vulgaris, 66

Hirundo, 244

Hirundo rustica, 221

Histrionicus histrionicus, 174

Holcus lanatus, 63, 203

Hoplopterus spinosus, 153, 159

Hordeum, 58

Hordeum hystrix, 168, 171

Hordeum marinum, 220, 402

Hordeum maritimum, 357

Hucho perryi, 240

Hyaena hyaena, $177-8,247$

Hydra, 174

Hydrilla, 177-8

Hydrilla verticillata, $241,291,293-4$

Hydrocharis morus-ranae, 171, 212

Hydrochoerus hydrochoeris, 427-8

Hydrocotyle medicaginoides, 28

Hydrocotyle pterocarpa, 28

Hydrocotyle ranunculoides, 225, 227

Hydrocotyle volksmanni, $\mathbf{7 5}$

Hydrophasianus chirurgus, 291, 294

Hydroprogne caspia, 247, 272, 316

Hydroprogne tschegrava, 277

Hyla arborea, 154, 240

Hyphnum jutlandicum, 205 
Hypoxis hirsuta, 70

Hystrix cristata, 357, 365

Hystrix indica, 178

Ibis leucocepalus, 179

Ilex opaca, 420

Imperata cylindrica, 288

Inula britannica, 171

Inula crithmoides, 210, 220, 232, 403

Iphydrus carrarei, 212

Ipoma, 178

Ipomoea aquatica, 293-4

Iris pseudocorus, 49, 168, 170

Iris sibirica, 137

Ivesia eremica, 418

Ixobrychus, 362

Ixobrychus exilis, 71

Ixobrychus minutus, 29, 41, 43, 47, 49, 144, 150-1, $153,184,219,222,225-7,237-8,244,294,315,431$

Junais holoschoenus, 14

Juncus, 43, 75, 182, 184-5, 187, 194-6, 205, 222, 226 , $254,271,273,288,301,318,333,392,398$

Juncus acutiflorus, 380,386

Juneus acutus, 158, 244

Juncus arabicus, 244

Juncus articulatus, 291, 293-4, 390

Juncus bufonius, 244

Juncus bulbosus, 393

Juncus effusus, 406, 409

Juncus filiformis, 386

Juncus fontanesii, 244

Juncus gerardii, $79,244,261,391,414$

Juncus ingens, 18

Juncus kraussi, 317

Juncus maritimus, 218, 244, 273, 293, 333

Juncus sublatus, 220, 357

Juniperus, 254

Juniperus communis, 336

Juniperus exelsa, 157

Juniperus foetidissima, 157

Juniperus oxycedrus, 217,325

Juniperus phoenicea, 113, 215, 217, 325

Kentia ramsayi, 8

Kochia, 184

Lacerta viridis, 154

Lacerta vivipara, 389,391

Lagopus lagopus, 349, 394, 396, 423

Laguncularia, 330

Laguncularia racemosa, 251, 330

Lampetra planeri, 384

Lamprophis aurora, 316

Lamprothamnium papulosum, 210

Larix laricina, 59

Larrea tridentata, 418

Larus, 40, 91, 93, 95, 177

Larus argentatus, $85,90,100,102,104,108,114$, $128,185,210,220,222,225,232,236,261,289,292$, $294,303,333,353,360,366-7$

Larus atricilla, 251, 330, 421

Larus audouinii, 110, 220, 222, 324

Larus bulleri, 274

Larus canus, 89-90, 102, 104-5, 261-2, 334, 353, $360-1,370,413$

Larus dominicanus, 272,317

Larus fuscus, 85-6, 100,102, 104-5, 261

Larus genei, 158, 185, 189, 210, 220, 222, 230, 247, 311,369

Larus ichthyaetus, 292, 366, 370

Larus marinus, 86, 90, 102, 104, 108, 261-2

Larus melanocephalus, $38,40,151,158-9,170,210$, $353,366-7,369$

Larus minutus, $38,83,221,337,341,343,346-7$

Larus ridibundus, $3,40,79,85-6,88,94,106-7,109$, $114,131,133,135,141-2,144-5,165,168,170,222$, $225,235,257,259,262,292,294,298-9,301-2,336$, $340-1,343,353,361,370,380,384,390,402,407$

Lathyrus japonicus, 404

Lathyrus palustris, 11

Ledum groenlandicum, 59

Lemma minor, 346

Lemmus, 66
Lemna, $46,154,178,187,196,364,392$

Lemna gibba, 145, 244

Lepidochelys olivacea, $9,251,286,310,320$

Leptocarpus, 271

Leptocarpus simplex, 273

Leptocarpus spathaceus, 8

Leptospermum ericoides, 273

Leptospermum scoparium, 273

Lepus, 301

Lepus americanus, 59

Lepus nigricollis, 178

Lepus talai, 365

Leuciscus cephalus macedonicus, 154

Leucobryum glaucum, 206

Leucojum aestivum, $168,170,387$

Lilaeopsis orbiculatus, 273

Limicola, 166

Limicola falcinellus, $107-8,345-6,359-51$

Limnocryptes minimus, 344

Limnodromus griseus, 53,330

Limoniastrum monopetalum, 325

Limonium, 113, 317

Limonium carnosum, 190

Limonium gmelini, 169-71

Limonium scabrum, 317

Limonium vulgare, $40,225,389,391,414$

Limosa, 136, 303, 305

Limosa lapponica, $17,79,82,87,89,92,94-5,99$, $127-9,197-9,247,255,261-2,272-3,282,306,346$, $382,401,412$

Limosa limosa, $32,39,42,79,129,131-2,134,166-7$, 169-70, 203, 220, 234, 253, 257, 261, 269, 277-8, 311, $316,335-8,340,344,346,368,377,380,389,392$, $403,411,415$

Limosolla tenuifolia, 273

Liparis loeselii, 259

Liquidambar styraciflua, 425

Listera cordata, 205

Lithognathus mormyrus, 226

Littorina, 360

Locustella fluviatilis, $302,336,343$

Locustella lanceolata, 362

Locustella luscinioides, 259-60, 264, 326, 336, 389

Locustella naevia, 261, 336, 341, 344, 410

Lolium multiflorum, $\mathbf{3 5 7}$

Lolium perenne, 203

Lonicera japonica, 420

Lotus, 333

Lotus corniculatus, 391

Loxodonta africana, 116-7

Lupinus albus, 168

Lupinus arboreus, 273

Lupinus lutea, 168

Luscina svecica, $37,43,302$

Luscinia luscinia, 344

Luscinia megarhynchos, 136, 264, 389

Luscinia svecica, $32,46,214,221,300$

Lutra canadensis, 423

Lutra lutra, 41, 47, 154, 157-8, 171, 209-11, 214, $228,301,325,350,357,379,383,387,391,396,406$

Lutra perspicillata, 178

Lutra platensis, 427

Lycena dispar, 259

Lychnis flos-coculi, 169

Lycium andersonii, 418

Lycopus exaltatus, 171

Lymnaea pereger, 174

Lymnocryptes minimus, $107-9,339,350$

Lynx canadensis, 59

Lynx lynx, 157, 349-50

Lyrurus tetrix, 134

Lysimachia vulgaris, 380

Lythrum salicaria, 14-5

Lythrum virgatum, 171

Lythrym salicaria, 361

Macaca mulatta, 178

Macropus agilis agilis, 9

Maerus crassifolia, 247

Magnolia virginiana, 420, 424

Malaclemys terrapin, 421 


\section{Taxonomic Index}

Malacorhynchus membranaceus, 21

Malacostoma castrensis, 403

Marsilea quadrifolia, 171

Martes martes, 349

Matricaria chamomilla, $168,170-1$

Mauremys caspica, 305

Medicago marina, 113

Meesea triataria, 66

Melaleuca, 8, 10

Melaleuca oraria, 28

Melanitta, 65

Melanitta fusca, $82-3,87-90,92-4,105,109,282$, $345,348,360-1,423$

Melanitta nigra, $37-8,85,88-94,109,174,345,348$, 360,423

Meles meles, 325

Melilotus officinalis, 168

Mellivora capensis, 247

Mellivora indica, 365

Mentha arvensis, 361

Mentha pulegium, 387

Mentzelia leucophylla, $\mathbf{4 1 8}$

Menyanthes trifoliata, 259, 346, 380, 393, 408

Mephitis mephitis, 70

Mergus albellus, $98,107,109,132-3,135-6,193,196$, $346,351,398$

Mergus merganser, $79,81-2,84,88-90,96-7,99,120$, $135-6,139,146,278,301,333,343-4,352-3,361$, $395,398,413$

Mergus serrator, $82-3,84-5,87-9,91,93,96-7$, $104-5,110,119,122,174,183,215,229,333,360$, $362,367,369$

Merops apiaster, 113, 215, 225, 305

Merops superciliosus persicus, 244

Microtus agrestis, 383

Milvus migrans, 154, 157, 238, 294, 298, 305, 325

Milvus milvus, 325,335

Mimusops caffra, 321

Minuartia, 128

Mogoplistes squamiger, 404

Molinia, 205, 353

Molinia caerulea, 134, 205-6, 393, 396

Monachus monachus, 247

Monotheca buxifolia, 289

Motacilla flava, $334-5,338$

Mugil, 214, 219, 225

Mugil auratus, 222

Mugil capito, 217

Mugil cephalus, 217, 222, 235, 357

Mugil chelo, 217

Mugil ramada, $\mathbf{3 5 7}$

Mustela erminea, 41

Mustela nivalis, 240

Mustela putorius, 376

Mustela vison, $59,70,174,282,423$

Mycteria americana, 251, 425

Mycteria ibis, 316,319

Mycteria leucocephala, 176

Myocastor coypus, 157, 379-80, 389, 427-8

Myosotis scorpioides, 259

Myrica gale, 134, 259, 333, 378, 396

Myrica pensylvanica, 421

Myriophyllum, 72, 154, 187, 227, 273, 342, 364, 372

Myriophyllum muelleri, 14

Myriophyllum spicatum, 32, 113, 174, 220, 380

Myriophyllum verticillatum, 167, 218, 224

Myrtus communis, 215

Mysis relicta, 387

Mytilus galloprovincialis, 222

Naga, 178

Naia tripudians, 294

Najas, 177

Najas marina, 167, 301, 363

Najas minor, 293, 363

Nardus stricta, 206

Narthecium ossifragum, 205-6, 393, 407-9

Naumbergia thyrsiflora, 361

Nelumbo lutea, 70

Nelumbo nucifera, 241, 363

Nematostella vectensis, 404
Neomysis integer, 383

Neophema chrysogaster, 12, 22, 28

Neophocaena phocaenoides, 286

Neophron percnopterus, 157, 244, 294, 357

Nerita albicilla, 317

Nerium oleander, 357

Netta rufina, $36,46,120,137,140-1,143-4,161$, $190,196,209,219,225-6,260,291,294,298,301$, $305,325-6,353,363,365,368$

Nettapus coromandelianus, 179, 291, 294

Nettapus pulchellus, 10

Niajus mariana, 380

Nilumbium, 178

Nipponia nippon, 373

Nitella, 177

Nitraris retusa, 243

Nitrophila mohavensis, $\mathbf{4 1 8}$

Nonagria neurica, 389

Nottapus auritus, 316

Nucras taeniolata ornata, 316

Numenius arquata, $32,40,42,82,128-9,134,143$, $147,167,170,197-9,257,259,261-2,292,294,296$, $303,305,334,345,368,382,403,405,412$

Numenius arquta, 166

Numenius madagascariensis, 13, 17, 27, 272

Numenius minutus, 27

Numenius phaeopus, $37,42,166,170,247,272,311$, $330,348,369,377$

Numenius tenuirostris, 230, 253, 255

Nuphar, 260, 372

Nuphar advena, 70

Nuphar lutea, $157,166,361,379,425$

Nuphar pumila, 346

Nyctanassa violacea, 330

Nyctea scandiaca, 349

Nyctereutes procyonoides, 240

Nycticorax, 176, 214

Nycticorax caledonicus, $19,28,30$

Nycticorax nycticorax, $3,33,40,43,47-8,71,140$, $144,149,151-2,154-5,157-8,167,169-71,191$, $211-2,228,237-8,260,264,292-3,303,308,325-6$, $330,357,363-4,369,431$

Nymphaea, 154, 393

Nymphaea alba, 46-7, 157, 164, 166, 169, 171, 211-2, $228,361,363$

Nymphaea candida, 346

Nymphaea cristata, 178

Nymphaea lotus, 293-4

Nymphaea nouchatia, 178

Nymphaea odorata, 424

Nymphaea stellata, 178

Nymphaea tuberosa, 70

Nymphoides aquatica, 425

Nymphoides peltata, 157, 392

Nyssa sylvatica, 420,424

Obione pedunculata, 261

Oceanodroma castro, 304

Odocoileus virginianus, 425

Oenanthe, 392

Oenanthe aquatica, 157, 299

Oenanthe fistulosa, 412

Oenanthe lachenalii, $\mathbf{4 1 4}$

Oenanthe oenanthe, 261

Oenanthe silaifolia, -405

Olea europea, 215

Oncorhynchus, 423

Ondatra qibethicus, $47,59,64,70,301,370,421$

Orchis laxiflora, 212

Orcinus orca, 247

Oreaster reticulatus, 265

Oreochromis mossambicus, 314

Oreostylidium subulatum, 272

Oriolus oriolus, $136,337,343$

Orontium aquaticum, 424

Oryctolagus cuniculus, 85,389

Osmanda regalis, 383

Osmerus eperlanus, 399

Osmundia regalis, 379

Ostrea cuculata, 286

Ostrea discoides, 286 
Ostrea gryphoides, 286

Otis arabs, 308

Otis tarda, 32, 169, 171

Otis tetrix, 305

Ovis ammon gmelini, 185

Oxibos moschatus, 66

Oxyura australis, 20, 23

Oxyura jamaicensis, 71-2

Oxyura leucocephala, $3,155,169,183-4,190-1,196$, $225,227,286,290,325,357,365,370,431$

Pachydactylus capensis capensis, 316

Pagellus mormyrus, 235

Paliurus, 155

Pan troglodytes, 116-7

Pandanus, 8

Pandion haliaetus, $48,107,179,214,244,250,261$, $264,293-4,296,298,300,338,341,344,346,349$

Panicum, 309

Panicum hemitomon, 425

Panicum turgidum, 247

Pannisetum orientale, 289

Panthera pardus, 117, 179

Panurus biarmicus, 32, 46, 171, 210, 212, 260, 298, $300,302,326,342,380,389,391,410$

Papilio machaon brittanica, $379-80$

Paradoxornis heudei polivanovi, 373

Paradoxurus hermaphroditus, 178

Parkinsonia, 294

Parnassia palustris, 259

Paspalum, 309

Paspalum dilatatum, 318

Paspalum vaginatum, 310

Patiriella vivipara, 13

Pelagodroma marina, 304

Pelamis platurus, 320

Pelecanus, 177, 184, 265

Pelecanus conspicillatus, 28

Pelecanus crispus, 45-6, 48, 149, 153-5, 157, 160-2, $183-4,189-90,194,197,199,294,363,369,371$

Pelecanus erythorhynchos, 58

Pelecanus occidentalis, 249, 251

Pelecanus onocrotalus, $45,48,116,150,153-5,157$, $185,190,247-8,294,308,315-6,321,369$

Pelecanus philippensis, 179,286

Pelecanus rufescens, $310-1,316,321$

Pelomedusa subrufa, 314

Peltandra virginica, 70

Penaeus japonicus, 317

Pennantia corynbosa, 273

Perca, 137

Perca fluviatilis, $363,384,387$

Perdix perdix, 257

Pergularia tomentosa, 247

Perisoreus infaustus, 349

Pernis apivorus, 244

Persea palustris, 424

Peucedanum officinale, 402

Peucedanum palustris, 378,380

Phacochoerus aethiopicus, 308

Phagmites communis, 361

Phagmites karka, 288

Phalacrocorax, 2, 308

Phalacrocorax africanus, 247

Phalacrocorax aristotelis desmarestii, 225

Phalacrocorax auritus, 58

Phalacrocorax carbo, 39, 41, 49, 151, 154, 161, 179, $194,198-9,230,264,272,291,293-4,299,363,398$

Phalacrocorax carbo lucidus, 247

Phalacrocorax carbo sinensis, 33, 89-90, 94, 97, 127, $140,144,153,157,167,215,217,219-20,222,225$, $226,236,260$

Phalacrocorax fuscicollis, 179, 292

Phalacrocorax melanoleucos brevirostris, 272

Phalacrocorax niger, 179, 291, 293-4

Phalacrocorax olivaceous, 251

Phalacrocorax pygmaeus, 46, 150-1, 154, 160, 188, 364

Phalacrocorax varius, 22, 24

Phalaris arundinacea, $145,299,384,386,392,398,405$

Phalaropus lobatus, $108-9,174,345-8,350-1$

Phaliurus pannicus, 171
Phasianus colchicus, 257

Pheonicopterus ruber, 186

Phillyrea, 232

Phillyrea angustifolia, 113

Philomachus pugnax, 27, 39, 79, 83, 93, 99, 109, 131, $136,144,147,179,221,234,258,277-9,296,305$, $308,311,326,335-6,338-9,341,343,346,348,351$, $353,362,366-8,380,392,403,411$

Philoxerus vermicularis, 310

Phleum pratense, 203, 405

Phoca vitulina, $82,86,88,90,95,99,334,423$

Phocoena phocoena, 247

Phoeniconaias minor, 315,319

Phoenicopterus, 177

Phoenicopterus minor, 310-1, 321

Phoenicopterus ruber, 113, 153, 183-5, 189, 194 $196-8,220,222,225-6,234,236,247,249,251,253$, $265,267,290,294,303,305-6,310-1,314,319,321$, $325,327,330,356-7,359,364-5,370-1$

Phoenicurus moussieri, 357

Phoenicurus ochrurus, 244

Phoenicurus phoenicurus, 244, 389

Phoenix dactylifera, 198

Phormium, 271

Phormium tenax, 273

Phragmites, 42, 113, 129, 131, 133, 143, 154, 254 $306,342-3$

Phragmites australis, $41,43,156,314,317,334,338$, $341,376,378,380,384,389,391,394,399,408,420-1$

Phragmites communis, 32, 46-9, 56, 106-7, 113, 145, $149,152,155,158,164-6,168-71,183-8,190-2$ $194-6,200,203,210-2,214-5,218,222,226-8$, 231-2, 234, 240, 259-60,263,280,300-1, 318, 321, $326,344,346,357,363-5,367-9,371-2,400$

Phragmites isiaca, 220

Phragmites japonica, 241

Phragmites karka, 288, 291, 294

Phylloscopus, 294

Picea, 350

Picea abies, 360

Picea glauca, 59, 61

Picea mariana, 59, 61, 64

Picoides borealis, 425

Pinguicula vulgaris, 408

Pinus, 154, 349

Pinus atlantica, 428

Pinus banksiana, 59

Pinus elliotii, 425

Pinus nigra, 390

Pinus palustris, 425

Pinus pinaster, 303

Pinus pinea, 210, 305, 325, 350

Pinus rigida, 420

Pinus serotina, 425

Pinus sylvestris, $339,360,389,394$

Pinus taeda, 425

Pisidum, 174

Pistachio pistacia, 186

Pistacia altantica, 185

Pistacia lentiscus, 113, 215, 219

Plantago, 333

Plantago maritima, $166,171,220,414$

Plantago pauciflora, 299

Plantago schwarzenbergiana, $168,170-1$

Plantago tenuiflora, 168, 170-1

Platalea ajaja, 330

Platalea alba, 311, 319

Platalea flavipes, 18,30

Platalea leucorodia, $32,46,48,149,151,153-5,157$, $165,167-71,176,179,184-5,197,199,217,223,230$, $247,260-1,264,269,272,292,305-6,308,311,325$, $363,369,371,431$

Platalea regia, 30

Platanthera bifolia, 301

Platanus, 154-5

Plectropterus gambensis, $308,317,319$

Plegadis falcinellus, $30,46,48,71,149,151-2,157$, $184,191,211-2,217,223,225,228,294,319,357$, $363-4,367,369,431$

Pleurozia purpurea, 396-7 


\section{Taxonomic Index}

Pleuroxium schreberi, 109

Plocuna, 286

Pluvialis apricaria, $39,83-4,87,93-4,99,131,134$, $146-7,169,206,339,351,394,406$

Pluvialis dominica, 13, 26-7, 242, 272, 428

Pluvialis squatarola, 17, 53, 127-9, 247, 253, 255, $261-2,305,311,330,382,403,412$

Poa bulbosa, 365

Poa compressa, 63

Podiceps, 184, 194

Podiceps auritus, $108,174,339,344,346-7$

Podiceps cristatus, $2,13,38-9,41,48-9,106-7,135$, $142-4,147,171,184,188,193,196,209,211-2,215$, $219,225-6,228,232,259,264,289,291,294,302$ $335,352-3,361,379,387$

Podiceps grisegena, $46,49,160,165,170-1,240,301$, $339,342,346,362$

Podiceps nigricollis, $2,42,49,137-8,140,143,171$, $184,188,193,196,215,222,225-6,289-90,298,326$, 335,352

Podiceps poliocephalus, 13

Podilymbus podiceps, 71

Poecilogale albinucha, 247, 316

Poezana carolina, 71

Polygonum, 63, 392

Polygonum amphibium, 167, 299

Polygonum barbatum, 291, 294

Polygonum lapathifolium, 145, 168, 170

Polygonum persicaria, 145, 299

Polygonum raii, 377

Polygonum atrigosum, 14-5

Polypogon monspeliensis, 390

Polysiphonia, 177

Polysticta stelleri, 423

Polytrichum commune, 408

Pomatostomus temporalis, 28

Pontederia cordata, 70

Populus, 154-5, 168

Populus alba, 113, 158, 171, 212

Populus balsamifera, 59,61

Populus nigra, 171

Populus tremula, 261

Populus tremuloides, 59, 336

Porphyrio porphyrio, $3,188,219,222,225-7,235$, $272,291,294,306,325,364$

Porphyrula martinica, 222

Porzana fusca erythrothorax, 242

Porzana parva, 171, 237, 300, 343-4, 353

Porzana porzana, 42, 83, 133, 237, 300, 336, 338-9, $341,343-4,353$

Porzana pusilla, 169, 171, 184, 186, 244, 272

Porzana tabuensis, 272

Potamogeton, 2, 64, 72, 113, 133, 154, 177, 187, 212 $217,225,227,260,301,318,342,357,365,372,379$

Potamogeton communis, 225

Potamogeton crispus, 218, 364

Potamogeton filiformis, 174

Potamogeton gramineus, 301

Potamogeton lucens, 294, 301

Potamogeton pectinatus, $32,46,70,113,218,225$, $291,293-4,314,316,357,363-4,380,384$

Potamogeton perfoliatus, 167, 291, 294, 301, 363

Potentilla anserina, 390

Potentilla erecta, 206, 409

Potentilla fruticosa, 336

Potentilla palustris, $361,380,394,407$

Presbytis entellus, 178

Primula farinosa, 137

Procyon lotor, 70, 421

Prosopis, 288

Prosopis cineraria, 178

Prosopis juliflora, 418

Prosopis pubescens, 418

Prosopis spicigera, 294

Protonotaria citrea, 55

Prunus amygdalus, 186

Prunus spinosa, 404

Prymnesium, 380

Psammobates oculifer, 316

Pseudoraphis spinescens, 18
Pteridium aquilinum, $273,389,407$

Pterocarya fraxinifolia, 195

Pteronura brasilensis, 428

Pteropus alecto gouldii, 9

Puccinellia, 39, 333, 368, 403

Puccinellia limosa, 169, 171

Puccinellia maritima, 203, 261, 391, 414

Puffinus assimilis, 304

Puffinus tenuirostris, 17

Pungitius pungitius, 383

Punica, 183

Pyrethrum achilleifolium, 370

Pyrola rotundifolia, 381

Pyrrhocorax pyrrhocorax, 304

Pyrus, 154

Quercus, 42, 154-5, 157, 168, 301, 336, 385, 425

Quercus ilex, 215, 232

Quercus ilicifolia, 420

Quercus macrocarpa, 56

Quercus marilandica, 420

Quercus robur, $171,389,399$

Quercus suber, 305,325

Rallus aquaticus, $41,143,145,147,219-20,222$, $225-7,235,240,244,300,339,341,344,380,389,410$

Rallus elegans, 55,71

Rallus limicola, 71-2

Rallus longirostris, 421

Rana dalmatina, 212

Rana latastei, 212

Rana pipiens, 59,61

Rana ridibunda, 244, 357

Rangifer pearyi, 66

Rangifer tarandus, 59, 423

Ranunculus, 342

Ranunculus aquatilis, 49,171

Ranunculus baudottii, 391,402

Ranunculus lingua, 41, 361

Ranunculus ophioglossum, 357

Ranunculus pedatus, 171

Ranunculus sceleratus, 145

Ranunculus trichophyllus, 174

Rattus norvegicus, 85,389

Recurvirostra americana, 249

Recurvirostra avosetta, 32, 39-40, 48, 79, 82-4, 87, $89-91,93-5,97,110,113,128-9,131,150-1,153-4$ $159,166,169-71,186,191,210,220,222,225,230$, $233-4,253,261,269,303,305,311,319,326-7,334$ $337-8,340,369,389,391,411$

Remiz pendulinus, $32,34,113,212,296,335$

Rhacomitrium lanuginosum, 408

Rhamnus, 183

Rhichthys osculus nevadensis, 418

Rhizophora harrisonii, 310

Rhizophora mangle, 251, 310, 330

Rhizophora racemosa, 310

Rhododendron viscosum, 420

Rhodonessa caryophylacea, 176

Rhynchospora alba, 205-6, 409

Rhynchospora fusca, 396

Ribes, 183

Rissa tridactyla, 85-6

Romulea columnae, 215

Rorippa amphibia, 299

Rorippa islandica, 145

Rosa, 58

Rosa rugosa, 333

Rostratula benghalensis, 28, 293

Rubus, 183, 364

Rubus chamaemorus, 409

Rubus fruticosus, 274

Rubus spectabilis, 63

Rubus ursimus, 63

Rumex acetosa, 405

Rumex aquaticus, 386

Rumex crispus, 145,391

Rumex hydrolapathum, 299

Rumex maritimus, 299

Rumex obtusifolius, 145

Ruppia, 186, 255, 278, 314, 317, 365

Ruppia cirrhosa, 404 
Ruppia maritima, $113,203,225,235,404$

Ruppia spiralis, $113,210,215,220,225,368$

Ruppieta maritimae, 229

Rutilus rutilis, $\mathbf{3 7 9}$

Rynchops nigra, 330

Saccharum, 288, 293

Saccharum spontaneum, 289

Saggitaria, 187, 294

Sagittaria chilensis, 75

Sagittaria cuneata, 52

Sagittaria latifolia, 52

Sagittaria sagittifolia, 171

Salamandrella keyserlingii, 240

Salicornia, $10,79,182,188,210,214-5,222,226$, $229,234,261,273,308,314,317,325,333,389,391$, 403

Salicornia arabica, 357

Salicornia europaea, $40,203,235,261,278,412,414$

Salicornia fruticosa, $113,210,214,218,220,225$, 231-2, 235

Salicornia berbacea, 235

Salicornia senegalensis, 247

Salix, 41-3, 59, 63-4, 69, 154, 164, 166, 168, 183, $187,195,205,212,263,276,280,294,334,341,343$ $347,368,376,386,392,399,422$

Salix alba, 113, 157-8, 171, 299

Salix aurita, 299

Salix caprea, 195

Salix cinerea, 157, 261, 301, 380, 404

Salix fragilia, 157, 171, 299

Salix micans, 195

Salix nigiricans, 298

Salix pedicellata, 158

Salix pentandra, 301

Salix purpurea, 372

Salix repens, 381

Salix rosmarinifolia, 301

Salix triandra, 168, 171, 363

Salmo gairdneri, 423

Salmo salar, $174,383,387$

Salmo trutta, $174,272,383-4,387$

Salsola, 184, 190, 294

Salsola baryosma, 247

Salsola dendroides, 364

Salsola incanescens, 365

Salsola kali, 128

Salsola maritimus, 225

Salsola soda, 166, 168, 171, 210, 225, 235, 368

Salvadora, 294

Salvadora oleoides, 178

Salvadora persica, 178

Salvelinus alpinus, 174

Salvelinus malma, $\mathbf{4 2 3}$

Salvinia natans, $171,363-4,368$

Sambucus ebulus, 168,170

Sambucus nigra, 261

Samolus valerandi, 43

Sandelia capensis, 314

Sanguisorba officinalis, 169, 405

Sanguisorba tenuifolia, 240

Sarcocornia, 317

Sarcocornia decumbens, 317

Sarcocornia perennis, 317

Sargassum muticum, 404

Sarkidiornis melanotos, 179

Sarothamnus scoparius, 389

Saxicola rubetra, 334

Saxicola torquata, 241

Saxifraga caespitosa, 69

Scheucheeria palustris, 394

Schoenoplectus, 131, 154

Schoenus, 353

Schoenus nigricans, 205-6, 380

Scirpetium maritimae, 203

Scirpus, 52, 113, 131, 154, 187, 195, 226, 280, 325, $333,338,344,370,418,420$

Scirpus acutus, 70

Scirpus americanus, 52,63

Scirpus californicus, 75,428

Scirpus cespitosus, 205-6
Scirpus giganteus, 428

Scirpus lacustris, 260, 300-1, 357, 361

Scirpus littoralis, 243, 293-4

Scirpus maritimus, $215,218,225,244,357,391-2,414$

Scirpus maximus, 39

Scirpus montiuagus, 16

Scirpus pungens, 14

Scirpus tabernaemontani, $43,167,171,338$

Scirpus triducter, 263

Scirpus tuberosus, 294

Scirpus validus, 59,70

Sciurus vulgaris, 391

Scolanthes callimorphus, 404

Scolimus maculatus, 357

Scolochloa festucacea, 56

Scolopax rusticola, 369

Scorzonera cana, 171

Scylla serrata, 317

Sebaea albidiflora, 28

Sedicularis palustris, 361

Sedum acre, 391

Senecio, 75, 145

Serenoa repens, 425

Sesuvium portulacastrum, 310,330

Shepherdia canadensis, 59

Sideroxylon inerme, 314

Silaum silaus, 405

Silene maritima, 391, 404

Silvris glanis, 363

Simulium vittatum, 174

Sium latifolium, 212, 392

Solanum dulcamara, 145

Solea, 217

Solea solea, 222,357

Solidago, 58

Somateria mollissima, $38-9,69,85-94,100,102,104$, $127,130,261-2,269,282-5,333,338,340,360-1,423$

Somateria spectabilis, $66,68-9,423$

Sonchus palustris, 389

Sousa teuszii, 247,310

Spalax leucodon, 166

Sparganium, 70, 72, 363

Sparganium erectum, 391

Sparganium minimum, 298

Spartina, 53, 72, 218, 274, 377, 401, 414

Spartina alterniflora, 420

Spartina anglica, 376-7, 381, 400-1, 412

Spartina brasiliensis, 330

Spartina maritima, 403

Spartina patens, $\mathbf{4 2 0}$

Spartina pectinata, 70

Spartina townsendii, 128

Spartina versicolor, 218

Sparus auratus, 217, 222, 226, 235

Sphagnum, 206, 258, 394, 406, 408-9, 422, 425

Sphagnum auriculatum, 408

Sphagnum capillifolium, 205

Sphagnum cuspidatum, 406, 408-9

Sphagnum fuscum, 408

Sphagnum imbricatum, $380,406,408-9$

Sphagnum magellanicum, 407-9

Sphagnum palustre, 380

Sphagnum papillosum, 406-9

Sphagnum plumulosum, 397

Sphagnum pulchrum, 409

Sphagnum recurvum, 408-9

Sphagnum rubellum, 206, 406, 409

Sphagnum squarrosum, 406

Sphagnum subsecundum, 408

Sphagnum tenellum, 408-9

Sphagnum uvellum, 408

Spilornis cheela, 179

Spiraea hypericifolia, 370

Spiranthes romanzoffiana, 387

Spirogyra, 177

Sporobolus subtilis, 321

Sporobolus virginicus, 330

Stellaria palustris, 298, 405

Steno bredanensis, 247

Stercorarius longicaudus, 351 
Sterna, 91, 93, 177, 269, 382

Sterna albifrons, $38,48,90,93-5,130-1,151,157-8$, $161,183,204,210,220,222,224-6,229-30,232-6$, $238,261-2,306,311,334,337,340,366,380,389$, $391,403-4$

Sterna anaethetus, 247

Sterna arctica, 362

Sterna aurentia, 292, 294

Sterna balaenarum, 317

Sterna bergii, 17, 28

Sterna caspia, 17, 104-5, 210, 274, 315, 341, 361, $366-7$

Sterna forsteri, 55

Sterna hirundo, $40,48,71,88,104-5,120,127$, $130-1,144,149,151,157,170,186,191,204,210$ $222,232,236,238,247,257,261-2,353,367,370$, $379,389,391,402,404,415$

Sterna maxima, 247

Sterna nereis, 17,28

Sterna nigra, 259

Sterna nilotica, 151, 159, 222, 327, 367

Sterna paradisaea, $87,90,93,95,99,102,104-5$, $261-2,285,334,360,415$

Sterna sandvicensis, $2,38,79,82,85-6,88-9,93$, $97,110,127,130,151,157,210,261-2,269,334,340$, $366,369,389,391$

Sterna striata, 272

Stictonetta naevosa, 20,25

Stipa, 58

Stipa lessingiana, 370

Stipagrostis pungens, 247

Stizostedion lucioperce, 363,372

Stratiotes aloides, $164,166,171,300,379$

Streptopelia turtur, 145

Strombus gigas, 265

Sturnus unicolor, 305

Suaeda, 128, 186, 222, 226, 234, 333, 357, 418

Suaeda fruticosa, 247, 404

Suaeda maritima, 40,168,170-1, 210, 317

Suaeda pannonica, 171

Suaeda vera, 391

Suberites massa, 404

Succisia pratensis, 169

Sus scrofa, $10,113,116,178,244,301,325-6,363-5$

Sygnathus, 357

Sylvia, 244, 294

Sylvia nisoria, 337

Sylvilagus floridanus, 421

Symphoricarpos, 58

Symphoricarpos albus, 63

Synaptomys, 66

Syzygium cordatum, 321

Tabanus nigrovittatus, 421

Tachybaptus ruficollis, 2-3,40-1, 138-9, 154, 196, $219-20,225-7,232,240,242,290-1,294335,344,346$

Tadorna, 200

Tadorna ferruginea, $46,151,153,184-6,193,291,370$

Tadorna nebularia, 292

Tadorna orchropus, 292

Tadorna radjah, 10

Tadorna tadorna, $39-40,42,48,79,82-4,88,90$, $127-9,153,158,161,185-6,194,210,215,220,222$, $230,234,253,261-2,269,291,294,333,335,338$, $366-8,370-1,377,386,389,401,405$

Tadorna tadornoides, 13,28

Tadorna variegata, 272

Tamaris senegalensis, 308

Tamarix, 154, 183, 185-6, 190, 192, 196, 200, 226, $234,365,419$

Tamarix anglica, 404

Tamarix articulata, 288

Tamarix dioica, 288, 291, 293

Tamarix gallica, $\mathbf{3 2 6}$

Tamarix jampeana, 158

Tamarix jordanis, 243

Tamarix macrocarpa, 243

Tamias sibiricus, 240

Tanytarsus gracilentus, 174

Taxodium ascendens, 424

Taxodium distichum, 424
Tayassu, 116

Tenellia adspersa, 404

Terminalia sericea, 321

Testudo hermanni, 154,158

Tetragonia decumbens, 317

Tetrao tetrix, 296

Tetrao urogallis, 349

Tetraplodon urceolatus, 66

Tetrapteryx paradisea, 317

Thalasseus elegans, 251

Thalasseus maximus, 251

Thalassia testudium, 265

Thalictrum flavum, $\mathbf{4 0 5}$

Thelipteris palustris, 43, 379

Themeda trianda, 321

Thermopsis, 58

Thespesia populnea, 330

Threskiornis aethiopica, 18, 20, 22, 29, 189

Threskiornis melanocephalus, 179

Threskiornis spinicollis, 18, 20, 22, 29-30

Thymelaea hirsuta, 217

Tilapia aurea, 244

Tilapia zillii, 244

Tilia, 301

Tinca tinca, 211,228

Tomichia ventricosa, 314

Trangula alnus, 378

Trapa natans, $152,154,157,167,171,187,241$, $363-5,368,372$

Trichechus manatus, 330

Trichechus senegalensis, $117,308,310$

Trichilia emetica, 321

Trichophorum cespitosum, 393, 408-9

Trifolium angulatum, 171

Trifolium camperstre, 168

Trifolium cherleri, 215

Trifolium repens, 203

Trifolium squamosum, 402

Triglochin, 333

Triglochin maritima, 39, 412, 414

Triglochin palustris, 298

Triglochin procera, 16

Tring terek, 28

Tringa, 244

Tringa cinereus, 197

Tringa erythropus, $108-9,129,220,235,253,294$, $335,346,350-1,353,380$

Tringa flavipes, 330,411

Tringa glareola, $109,157,179,221,292,335,339$ $341,346,351$

Tringa hypoleucos, $136,179,242,406$

Tringa melanoleuca, 72,330

Tringa nebularia, $11,136,294,335,394,396$

Tringa ochropus, $136,179,290,294,341$

Tringa stagnatilis, 220, 222, 292, 411

Tringa totanus, $48,102,104-5,120,128-9,134,136$, $145,147,149,151,169-71,174,197,199,210,220$, $222,235,244,247,253,255,257,261-2,294,303$, $305-6,311,326,333-4,338-9,341,343,346,368$, $389,392,401,403,406,412,415$

Trionyx spiniferus, 70

Tristanian lactiflua, 8

Triturus cristatus, 154, 212

Triturus vulgaris, 154, 212

Tropidonotus tessalate, 244

Truncatella subcylindrica, 404

Tubifex tubifex, 174

Turdus naumanni, 240

Tursiops truneatus, 247

Typha, 46-7, 63, 70, 72, 133, 149, 154, 166, 183-4, $187,190,192,194-5,222,225-6,254,306,308,326$, $344,365,368,428$

Typha angustata, 178, 243,288, 291, 293-4

Typha angustifolia, $43,75,168,171,178,212,220$, $227,260,301,361,363,380$

Typha latifolia, $43,48,59,145,158,212,218,220$, $300-1,318,334,346,361,391,398,406,420$

Ulex europaeus, $274,389,407$

Ulmus, 113, 301

Ulmus procera, 212 
Ulva lactuca, 420

Uria aalge, $100,102,303$

Ursus americanus, 59

Ursus arctos, $157,349-50,423$

Ursus maritmus, 66

Urtica dioica, 145, 263

Utricularia, 372,424

Utricularia intermedia, 259, 393

Utricularia minor, 393

Utricularia vulgaris, 43, 212, 301, 393

Vaccinium, 385, 420

Vaccinium myrtillus, 205, 408

Vaccinium oxycoccos, 206, 406-9

Vaccinium vitis-idaea, 422

Valeriana officinalis, 380

Vallisneria, 178

Vallisneria spiralis, 363,368

Valonia, 214

Vanellis leucurvus, 186

Vanellus, 214

Vanellus cinereus, 152

Vanellus indicus, 291, 294

Vanellus leucurus, 196, 292, 294

Vanellus senegallus, $\mathbf{3 1 1}$

Vanellus spinosus, 244

Vanellus vanellus, 2-3, 48, 136, 144-5, 147, 151 $166-7,169-71,253,257,261,278-9,290,333-4,341$, $353,392,403,405,411,415$

Vaucheria, 391

Venerupis decussatus, 222

Vermivora bachmanii, 425

Veronica altissima, 70

Veronica anagalis, 299

Veronicastrum virginicum, 70

Vetiveria zizenoides, 179

Viburnum opulus, 261

Vicia cracca, 333

Villarsia exaltata, 15

Vipera berus, 389

Viverricula indica, 178

Vulpes bengalensis, 178

Vulpes fulva, 421

Vulpes rueppelli, 247

Vulpes vulpes, $90,240,282,301,325,363,365$

Wilsonia backhousei, 28

Wilsonia humilis, 13

Wilsonia rotundifolia, 14

Woodwardia virginica, 425

Xenopus laevis, 314

Xenorhynchus asiaticus, 10

Zannichellia palustria, 244, 357

Zizania latifolia, 241

Zizania palustris, $\mathbf{5 2}$

Zizaniopsis bonaerensis, 428

Zizyphus, 294

Zizyphus lotus, $\mathbf{3 5 7}$

Zizyphus mauritiana, 178

Zizyphus mucronata, 321

Zostera, 89, 214, 220, 273, 360, 364-5, 368, 381, 391, 404

Zostera angustifolia, 404

Zostera marina, 110, 278, 361, 367, 420, 422

Zostera noltii, 247, 404

Zosterion, 203 

